PEDRO HENRIQUE GONÇALVES DE OLIVEIRA RIBEIRO

\title{
ENTRE ECLUSAS E ESPELHOS: \\ A ESFERA PÚBLICA VISTA A PARTIR DE UMA LEITURA CRÍTICA DE NIKLAS LUHMANN E DE DEBATES CONTEMPORÂNEOS
}

Dissertação de Mestrado

Orientador: Prof. Titular Marcelo da Costa Pinto Neves

UNIVERSIDADE DE SÃO PAULO

FACULDADE DE DIREITO

SÃO PAULO

2012 
PEDRO HENRIQUE GONÇALVES DE OLIVEIRA RIBEIRO

\section{ENTRE ECLUSAS E ESPELHOS: \\ A ESFERA PÚBLICA VISTA A PARTIR DE UMA LEITURA CRÍTICA DE NIKLAS LUHMANN E DE DEBATES CONTEMPORÂNEOS}

Dissertação de Mestrado apresentada ao Programa de Pós-Graduação da FDUSP como requisito parcial à obtenção do grau de Mestre na área de concentração de Direito do Estado sob a orientação do Prof. Titular Marcelo da Costa Pinto Neves

UNIVERSIDADE DE SÃO PAULO

FACULDADE DE DIREITO

SÃO PAULO

2012 


\title{
FOLHA DE APROVAÇÃO
}

Pedro Henrique Gonçalves de Oliveira Ribeiro

ENTRE ECLUSAS E ESPELHOS:

\section{A ESFERA PÚBLICA VISTA A PARTIR DE UMA LEITURA CRÍTICA DE NIKLAS LUHMANN E DE DEBATES CONTEMPORÂNEOS}

\begin{abstract}
Dissertação de Mestrado apresentada ao Programa de Pós-Graduação da FDUSP como requisito parcial à obtenção do grau de Mestre área de concentração de Direito do Estado sob a orientação do Prof. Titular Marcelo da Costa Pinto Neves.
\end{abstract}

Área de concentração: Teoria Geral do Estado

\section{Banca Examinadora:}

$\operatorname{Prof}(\mathrm{a}) . \operatorname{Dr}(\mathrm{a})$.

Instituição:

Assinatura:

Prof (a). Dr (a).

Instituição:

Assinatura:

Prof (a). Dr (a).

Instituição:

Assinatura:

São Paulo, 
Ao meu pai, José Dirceu Ribeiro, meu verdadeiro Ibn Sina - como no livro que lemos juntos. Pela vontade constante de enxergar o que está além das montanhas e por me fazer ver mais longe. Pela doação para a academia e por trazer humanidade à medicina, ao conhecimento e à vida daqueles a sua volta. Pelo exemplo de superação e de luta pela vida - sua e dos outros.

À minha mãe, Maria Ângela Gonçalves de Oliveira Ribeiro, por ser meu suporte na vida, em seus momentos alegres e difíceis.

E à minha irmã Maria Júlia Gonçalves de Oliveira Ribeiro, pela amizade, carinho e aprendizados em conjunto. 


\section{AGRADECIMENTOS}

Ao Professor Marcelo Neves, pela pessoa e acadêmico que ele é. Pela generosidade, dedicação e pelo incansável trabalho que tanto nos inspira. Pelo apoio incrível que ele me dá - que muito me honra. Também à Elvira Gama Neves, pelo apoio e por me receber tão bem em sua casa, com grande alegria.

Ao Professor Orlando Villas Bôas Filho, a quem devo muita gratidão pelas discussões, ensinamentos, apoio e pela confiança depositada em mim. Com grande admiração e muita estima.

Ao Professor Adrian Gurza Lavalle, pelo trabalho e pelos excelentes cursos ministrados no DCP/USP. Pelos valiosos comentários e conversas sobre essa dissertação e pela presença em minha formação acadêmica.

Ao professor Frederic Vanderberg e à professora Cintia Hamlin, pelo belo trabalho realizado na ANPOCS. Pelo apoio, discussão e incentivos ao artigo que pude apresentar por lá - e que agora consta como anexo de minha dissertação.

À Fundação de Amparo à Pesquisa do Estado de São Paulo - FAPESP, que financiou e possibilitou esse estudo.

Ao Goethe Institut São Paulo e aos seus professores. Principalmente ao professor Marc Siemons, por seu inabalável esforço e inumana paciência em me fazer completar os exercícios e compreender a gramática do alemão - mesmo quando eu não lhe dava motivos para que isso parecesse possível.

Aos professores que contribuíram muito para minha formação e para essa dissertação, em especial professores Márcio Álves da Fonseca, Rodrigo Octávio Bróglia Mendes, Cassiano Terra Rodrigues, Guilherme Leite Gonçalves, Celso Fernandes Campilomgo, Rainer Schmidt e Maurizio Bach.

Aos estudantes do primeiro ano que cursaram TGE I e II com o professor Marcelo Neves, que muito me ensinaram e continuam a me ensinar quando nos encontramos pelos corredores. Com especial menção a Fernando Ramon e Lucas Fucci Amato, pesquisadores brilhantes.

Aos meus amigos Vinícius Poli, Paulo Maluf, Marina Lima e Octaviano Padonese. Pelo companheirismo, alegria e apoio nos trabalhos acadêmicos de monitoria e orientação. 
Ao meu grande amigo, professor e primo, Túlio de Oliveira Massoni. Pela amizade e pelo suporte na vida pessoal e acadêmica. Com muita gratidão e carinho.

Aos companheiros de grupos de estudos e de vida acadêmica, em especial Ramón Negócio e Maurício Palma Resende, pela grande amizade e incentivo, pelas discussões acadêmicas e pessoais feitas sempre com muita alegria. Ao José Gladston Viana Correia, pelos ensinamentos e aprendizados em conjunto. Ao Felipe Salvador, pelas valiosas críticas e discussões quando da leitura de trabalhos. À Priscilla Soares de Oliveira, pelo grande apoio ao meu trabalho e vida. A Douglas Elmanuer e Rafael Izaias, com admiração. A Marcos Paulo Silveira e Lucas Petroni, grandes amigos, pela presença em minha vida acadêmica.

Aos companheiros da Revista Brasileira de Estudos Constitucionais - RBEC, Diogo Rais, Paulo André Nassar, André Janjácomo Rosilho e Habacuque Sodré. Com especial menção a Pedro Buck, pela amizade, confiança e apoio ao meu trabalho e vida. E ao meu grande amigo Rubens Eduardo Glezer, a quem não tenho como expressar minha gratidão pela inabalável amizade, pelos bons momentos compartilhados, pelas conversas e pela presença importante em meus momentos alegres e difíceis.

À Gisela Mara Ferreira, por todo o carinho e apoio para mim e minha família. Com eterna gratidão.

Ao meu pai, José Dirceu Ribeiro, minha mãe, Maria Ângela G. de O. Ribeiro e minha irmã Maria Júlia G. de O. Ribeiro, pessoas a quem dedico essa dissertação. A eles, todo agradecimento é pouco.

Em especial, aos meus amigos e amigas, pelo incondicional carinho e amizade. Dentre tantos, especial menção a Arthur Villela, Samuel Friedman, Rafael Giovanelli, Marcos Schreiner, Fabiana Borin, Juliana Hereda, Helio Piovesan, Pedro Ivan, Mario Santin Frugiuele, Bárbara Cordovani, Lucas Pahl, Viviane Ornellas Cantarelli, Lucas Tozo, Luiza Testa, Marcelo Lombardi Garbellini, Gregory Valente, Felipe S. Garcia, Daniel Leite, Carolina Juliotti, Júlio Comparini e Guilherme Henrique G. Oliveira.

À Andreza Davidian, com amor. Pela parceria e forte presença emocional e efetiva neste trabalho e, sobretudo, por dar cores ao meu mundo. 
„Nicht, wenn die Wahrheit schmutzig ist, sondern wenn sie seicht ist, steigt der Erkennende ungern in ihr Wasser" Friedrich Nietzsche

"To reject one paradigm without simultaneously substituting another is to reject science itself." Thomas Kuhn

“(...) o melhor drama está no espectador e não no palco.” Machado de Assis

[na voz do "Bacharel Duarte"] 


\section{RESUMO}

O presente estudo trata do conceito de esfera pública (Öffentlichkeit) na sociedade moderna a partir da teoria social de Niklas Luhmann. Não se trata, contudo, de mera exegese. É certo que a teoria luhmanniana é utilizada como guia do argumento e como referencial teórico básico, mas sua utilização é feita através de uma abordagem interdisciplinar que visa a dialogar tanto com a "macro teoria" dominante acerca da esfera pública (de Jürgen Habermas) quanto com problemas teóricos levantados por teorias "de médio alcance" que, preocupadas com a pesquisa empírica, evidenciaram "problemas" e fenômenos contemporâneos que não parecem ser passíveis de enfrentamento pela teoria habermasiana. Por isso, os desenvolvimentos da teoria dos sistemas sobre o conceito de esfera pública enfrentarão dois momentos de tensão: no primeiro - Parte I do trabalho um enfrentamento teórico conceitual em face da teoria de Jürgen Habermas sobre a esfera pública, e no segundo - Parte II - com alguns problemas contemporâneos levantados para literatura atual: sua relação com o Estado e o sistema político, com os Tribunais Constitucionais, com os meios de comunicação em massa, com movimentos de protesto e com as pretensões de inclusão na sociedade mundial (Weltgesellschaft).

Palavras-chave: Esfera Pública, opinião pública, teoria dos sistemas, Niklas Luhmann, teoria do discurso, Jürgen Habermas. 


\begin{abstract}
This study concern the concept of the public sphere (Öffentlichkeit) of modern society in the social theory of Niklas Luhmann. It is not, however, an exegetic study. Niklas Luhmann's theory constitutes the main guide-line of this study and functions as its basal theoretical framework. Nevertheless, the arguments here presented are carried on by an interdisciplinary approach, in order to perform a dialog not only with the dominant theory of the modern public sphere (Jürgen Habermas), but also with theoretical problems raised by "middle range theories" which are concerned which empirical research; and with contemporary "problems" and "phenomena" that do not seem to be tacked properly by the habermasian theory. Therefore, the systems theory model of modern public sphere faces two moments of tension: In the first one - Part I - it faces Jürgen Habermas theory of the public sphere. In the second - Part II - contemporary problems and issues are addressed: the relation among the public sphere, the State and the political system; the mass communication system; protest movements and the inclusion claims carried on in the world society (Weltgesellschaft).
\end{abstract}

Keywords: Public sphere, public opinion, systems theory, Niklas Luhmann, discourse theory, Jürgen Habermas. 


\section{Sumário}

INTRODUÇÃO

1. Delimitação da abordagem do estudo: diversas formas de se pensar a esfera pública ............... 2

2. Mapeamento do campo da macrossociologia da Esfera Pública ............................................... 8

3. O "duplo teste" de um trabalho "teoricamente orientado" ....................................................... 12

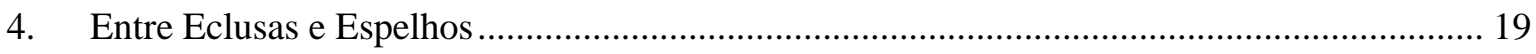

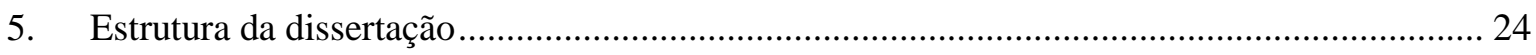

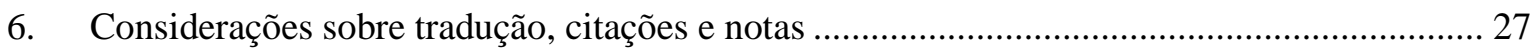

\section{PARTE I}

CAPÍTULO 1 - COM OS ÓCULOS DE LUHMANN .................................................................. 29

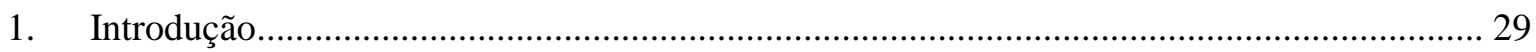

2. Por que e para que Luhmann? Breves alertas metodológicos e metateóricos .......................... 33

3. Uma incorporação "não-metafórica" e sem analogias da teoria (geral) dos sistemas ............. 45

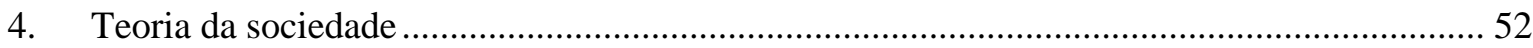

4.1 A "ambição da teoria": a necessidade de um novo paradigma na macrossociologia

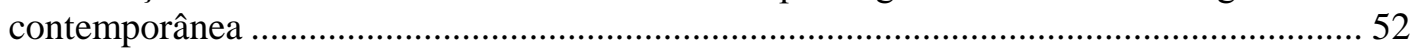

4.2 Obstáculos epistemológicos para o conceito de sociedade da teoria dos sistemas .............. 55

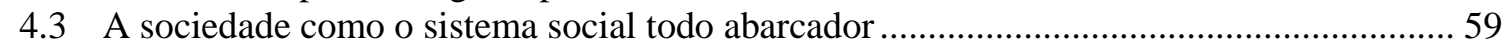

4.4 A evolução da sociedade moderna hipercomplexa e funcionalmente diferenciada ............. 63

4.5 Mudanças estruturais nos sistemas sociais: como sistemas mudam? ............................... 72

4.6 Os meios de comunicação simbolicamente generalizados............................................... 78

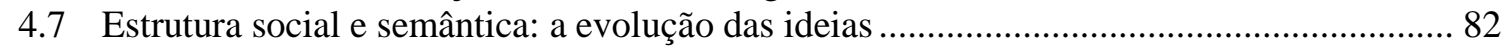

4.8 Construtivismo radical e observações de segunda ordem .................................................. 85

5. Funcionalismo radical e o modelo teórico de comparação entre sistemas funcionais .............91

5.1 A importância da análise funcional para a sociologia luhmanniana ................................... 91

5.2 Interação e organizações: outras diferenciações dos sistemas sociais ................................. 94

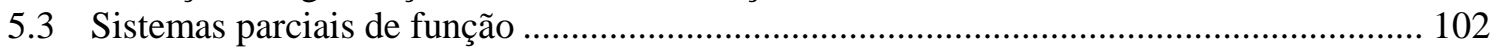

6. Conclusões parciais: consequências do quadro teórico luhmanniano para um conceito "negativo"

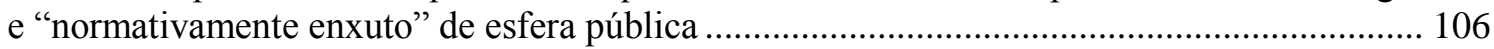

CAPÍTULO 2 - UMA FORMULAÇÃO NORMATIVA E SOCIOLÓGICA DA ESFERA PÚBLICA: O DESENVOLVIMENTO DO MODELO HABERMASIANO ........................... 108

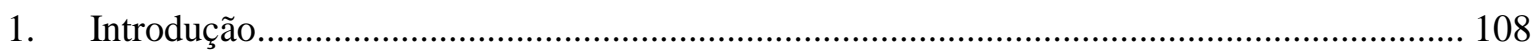

2. Uma sociologia da esfera pública burguesa: o modelo de 1961 .............................................. 110

2.1 Uma "história sociológica" da esfera pública no jovem Habermas ................................. 110 
2.2 Estrutura, função e ideologia da esfera pública burguesa

2.3 Mudança estrutural da esfera pública - as consequências da primeira abordagem de Habermas sobre a esfera pública

3. O conteúdo normativo da modernidade: o projeto teórico habermasiano

3.1 Por uma pragmática universal intersubjetiva: orientação para o entendimento e o consenso.

3.2 A tese da dupla integração social: sistemas e mundo da vida ........................................... 130

3.3 O Conteúdo normativo da modernidade: moral pós-convencional e evolução social ...... 134

3.4 A crise de legitimação do capitalismo tardio: enfrentando o desafio luhmanniano........... 137

3.5 A esfera pública pensada pela metáfora dos fluxos I: barragens democráticas de autocontenção da esfera pública

3.5.1 Esfera pública pluralista e a questão da "exclusão" .............................................. 142

3.5.2 Um posicionamento menos pessimista frente às mudanças estruturais da esfera pública .....

3.5.3 O modelo das "barragens democráticas" e do "cerceamento" da administração ..... 147

3.6 A esfera pública pensada como fluxo comunicativo II: a validade e a facticidade da esfera pública (1992).

3.6.1 Esfera pública em termos normativos: democracia deliberativa e soberania Popular "procedimental"

3.6.2 A facticidade da esfera pública: o papel da sociedade civil e da cultura política..... 157

4. Discussão e conclusões parciais: análises sociológicas da "virtualização" da esfera pública em Habermas.

\section{CAPÍTULO 3. A ESFERA PÚBLICA ENTRE AS TEORIAS DO DISCURSO E DOS} SISTEMAS

1. Introdução

2. A esfera pública como espelho da sociedade

2.1 Os sistemas jurídico e político na teoria dos sistemas ...................................................... 178

2.2 Os espelhos da sociedade e da política: esfera pública e opinião pública........................... 182

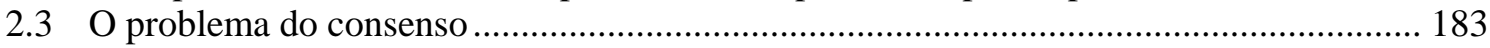

2.4 A função de "alarme" e de "caixa de ressonância"................................................................ 187

2.5 Implicações da "despolitização" da esfera pública .......................................................... 189

2.6 Legitimidade como fórmula de contingência da política e uma "questão desconfortável".

3. A sombra da exclusão social: o outro lado de uma esfera pública universalista em relação a discursos

3.1 Dois modelos de cidadania: status de direitos ou atitude política?.................................. 194

3.2 A diferença "Inclusão/Exclusão" e suas implicações para o conceito de cidadania .......... 198

3.3 Dois problemas "sociológicos": generalização de direitos e a falta da abordagem da "exclusão"

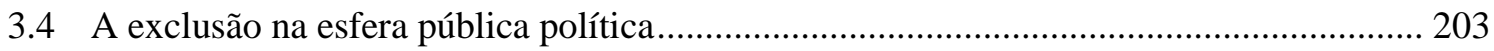

4. O modelo de Marcelo Neves: a esfera pública como arena do dissenso e a heterolegitimação do

Estado Constitucional de Direito

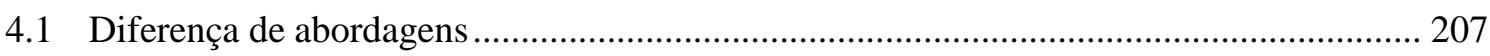

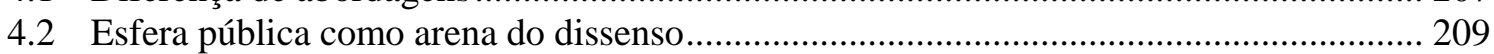

5. Problemas abertos levantados por teorias de médio alcance. Um exemplo das críticas aos modelos da sociedade civil 


\section{PARTE II}

\section{CAPÍTULO 4 - ESFERA PÚBLICA E SISTEMAS SOCIAIS: MEIOS DE COMUNICAÇÃO EM MASSA E A POLITIZAÇÃO DOS TRBUNAIS}

CONSTITUCIONAIS

1. Introdução

2. Os meios de comunicação em massa e a esfera pública.

2.1 Os meios de comunicação em massa pela teoria dos sistemas .......................................... 217

2.2 Meios de comunicação em massa e esfera pública ............................................................. 221

2.3 Conclusão parcial: esfera pública e os meios de comunicação em massa .......................... 223

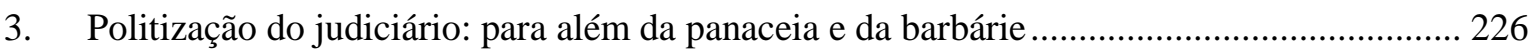

3.1 O judiciário entre a política e o direito - por meio da Constituição .................................. 227

3.2 Discussão e Conclusões parciais: a questão dos Tribunais Constitucionais ...................... 236

\section{CAPÌTULO 5 - MOVIMENTOS DE PROTESTO, ESFERA PÚBLICA MUNDIAL E} DIREITOS HUMANOS ...................................................................................................................... 240

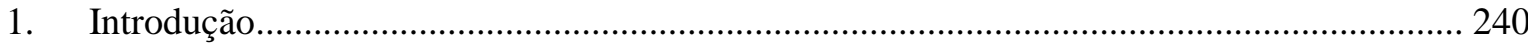

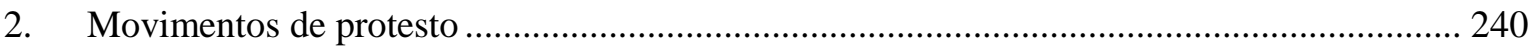

2.1 Elementos do debate contemporâneo sobre movimentos sociais........................................ 241

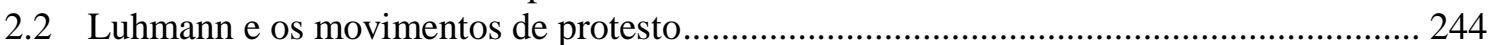

2.3 Conclusões parciais: movimentos de protesto na sociedade moderna .............................. 247

3. Esfera pública mundial: um novo espaço dos debates ........................................................... 251

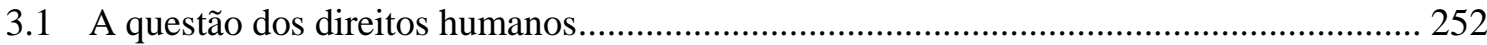

3.2 Conclusões parciais: a esfera pública mundial e escândalos na sociedade mundial .......... 254

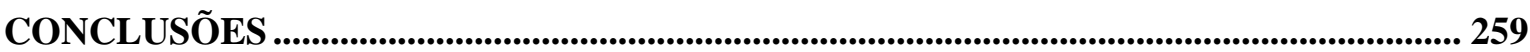

REFERÊNCIAS BIBLIOGRÁFICAS ............................................................................................ 264

ANEXO - LUHMANN "FORA DO LUGAR"? COMO A "CONDIÇÃO PERIFÉRICA" DA AMÉRICA LATINA IMPULSIONOU DESLOCAMENTOS E APRENDIZADOS NA TEORIA DOS SISTEMAS 276 


\section{INTRODUÇÃO}

O presente estudo trata do conceito de esfera pública (Öffentlichkeit) na sociedade moderna a partir da teoria social de Niklas Luhmann. Não se trata, contudo, de mera

exegese. É certo que a teoria luhmanniana é utilizada como guia do argumento e como referencial teórico básico, mas sua utilização é feita através de uma abordagem interdisciplinar que visa a dialogar tanto com a "macro teoria" dominante acerca da esfera pública (de Jürgen Habermas) quanto com problemas teóricos levantados por teorias "de médio alcance" que, preocupadas com a pesquisa empírica, evidenciaram "problemas" e fenômenos contemporâneos que não parecem ser passíveis de enfrentamento pela teoria habermasiana. Por isso, como veremos, os desenvolvimentos da teoria dos sistemas sobre o conceito de esfera pública enfrentarão dois momentos de tensão: no primeiro - Parte I do trabalho - um enfrentamento teórico conceitual em face da teoria de Jürgen Habermas sobre a esfera pública, e no segundo - Parte II - com alguns problemas contemporâneos levantados para literatura atual: sua relação com o Estado e o sistema político, com os Tribunais Constitucionais, com os meios de comunicação em massa, com movimentos de protesto e com as pretensões de inclusão na sociedade mundial (Weltgesellschaft).

Realizar tal movimento viabiliza momentos de reflexão que "irritam" a teoria dos sistemas de Luhmann: cabe, aqui, perguntar pela "utilidade" da teoria, ou seja, quais são seus ganhos e suas limitações ao tratar do tema da esfera pública tendo em vista os debates contemporâneos. Com isso, discussões acerca da consistência interna da teoria dos sistemas também poderão ser acessadas, resultando em um "duplo teste" para a teoria, ou seja: saber se, em primeiro lugar, ela pode iluminar discussões e temáticas contemporâneas acerca da esfera pública e, em segundo, se ela o faz de maneira consistente.

A tese defendida neste trabalho é que o paradigma da sociologia dos sistemas de Luhmann pode oferecer uma releitura do conceito de esfera pública que pode iluminar alguns "pontos cegos" apontados como "debilidades cognitivas" da teoria do discurso de Jürgen Habermas ao tratar do mesmo conceito. Ao defendê-la, contrapõem-se dois modelos abrangentes e abstratos de teoria social e se colocam problemas para ambos; exercendo sobre eles uma "tensão" a partir da discussão de questões contemporâneas tratadas pela literatura sobre esfera pública. 
Entretanto, antes de apresentar a estrutura do trabalho, faz-se necessário expor a abordagem metateórica que pauta o argumento e, com isso, apresentar a forma pela qual se contrapõem os modelos da esfera pública chamados de "modelo das eclusas" (Habermas) e de "modelo do espelho" (Luhmann).

\section{Delimitação da abordagem do estudo: diversas formas de se pensar a esfera pública}

O conceito de esfera pública (Öffentlichkeit) é objeto de grande interesse de diversos campos e disciplinas das ciências sociais, o que nos possibilita reconhecer uma ampla variedade de abordagens disponíveis e apontar para uma polissemia conceitual manifesta. Um conceito tão amplo como esse desenvolve distintas facetas e pode ser abordado por diversas maneiras, muitas delas inconciliáveis.

Em grossas linhas, a grande importância normativa atrelada à esfera pública pode ser considerada um grande impulsionador desse interesse multifacetado. Com efeito, sem pretender realizar aqui qualquer historiografia do referido conceito, é possível reconhecer que, em suas origens, à noção de uma esfera pública atrelava-se uma autopercepção moderna de valores como autonomia e autodeterminação política pelo princípio democrático, pelos quais a sociedade moderna poderia utilizar o esclarecimento racional para combater a opressão e a dominação. Portanto, tal conceito era concebido como um espaço público no qual ocorre o "uso público da razão", ao qual se vincula o conceito de "publicidade". Pode-se afirmar que ao conceito de esfera pública, ainda hoje, são vinculados quase que imediatamente conceitos como soberania popular, legitimação de sistemas políticos, conquista da autonomia e crítica à dominação. $\mathrm{O}$ caráter público, de “abertura", reconhecido pelo prefixo "Offen” do alemão, demonstra o caráter filosófico e político que tal conceito carrega - daí porque a tradução de Offentlichkeit geralmente os leva em conta, sendo o termo vertido como "publicidade”, “o público", "espaço público" ou, mais comumente, como "esfera pública". ${ }^{1}$ Tal conceito é carregado normativamente e traz consigo pretensões reivindicatórias características das comunicações políticas para dentro das discussões acadêmicas e teorias das ciências sociais. ${ }^{2}$

\footnotetext{
${ }^{1}$ STRUM, 1994, p. 161

${ }^{2}$ NEIDHARD, 1994, p. 8.
} 
Não obstante o termo ter sido abordado em estudos mais antigos, tanto em longa história de tradição alemã como em autores de língua inglesa, ${ }^{3}$ é possível afirmar que foi a reinterpretação do conceito desenvolvida por Jürgen Habermas, inicialmente em 1962 na obra Strukturwandel der Öffentlichkeit (Mudança Estrutural da Esfera Pública) que pautou os debates interdisciplinares contemporâneos em torno do conceito, em sua atual configuração. Nota-se, contudo, que as reformulações posteriores desenvolvidas por Habermas continuaram a incentivar debates e promover maiores discussões. Isso principalmente devido a dois textos: o "o prefácio da nova edição de 1990" da "Mudança Estrutural da Esfera Pública" (Vorwort zur Neuauflage 1990), no qual o autor faz diversas revisões teóricas sobre o conceito, e em sua obra Faktizität und Geltung: Beiträge zur Diskurstheorie des Rechts und des demokratischen Rechtsstaats em 1992 ("Facticidade e Validade" - ou "Direito e Democracia", na tradução para o Português).

Além dessa sua faceta filosófica - na realidade muito mais abrangente do que a versão alemã aqui aludida - o conceito foi objeto de diversos estudos no campo da teoria política, principalmente daqueles que buscam trabalhar o florescimento de uma esfera pública que consiga legitimar procedimentos democráticos ou melhorar a qualidade da democracia. Aqui, aponta-se para a vinculação necessária da esfera pública com direitos constitucionais e liberdades fundamentais garantidos por sistemas democráticos de Estados Constitucionais de Direito. ${ }^{4}$ Nesse sentido é seguro apontar que, de uma maneira geral, o conceito serve de base também para argumentos de cunho político institucional, relacionando-se com modelos de democracia em teorias democráticas.

A esses, somam-se estudos de caráter histórico e sociológico de "médio alcance" que tratam da gênese e condicionamentos da esfera pública moderna, de gênese ou de história do conceito ou de suas manifestações em determinadas regiões, voltando-se para as especificidades de determinada esfera pública política em um determinado país.

Enfim, a partir dessa breve exposição de abordagens possíveis no estudo da esfera pública, podemos concordar com Arthur Strum que, em seu artigo bibliográfico sobre Öffentlichkeit na edição especial da New German Critique sobre Niklas Luhmann, notou que o estudo deste conceito é marcado por abordagens "que empregam linguagens teóricas radicalmente diferentes, constituídas por vezes por pressupostos estruturais com divergências agudas". Isso, contudo, não implica a impossibilidade de um diálogo frutífero

\footnotetext{
${ }^{3}$ Cf. STRUM, 1994, p. 161.

${ }^{4}$ NEIDHARDT, 1994, p.8, além do modelo de NEVES, 2006, que será trabalhado no presente estudo.
} 
interdisciplinar, no qual cada campo possa por em cheque e reavaliar sua confiança em "pressupostos naturais e familiares". Neste sentido, "o teórico literário pode zombar da desatenção do historiador para detalhes textuais; uma historiadora pode se irritar com a aparente inabilidade do teórico literário em definir claramente seus termos e conceitos. Contudo, esse encontro pode se tornar frutífero se, em negação abstrata, a disciplina que fala através de seus agentes for posta de lado em favor de uma prontidão para se vivenciar o estranhamento conceitual". 5

Tendo em vista essa pluralidade de abordagens possíveis e adotando em parte a postura de abertura interdisciplinar inerente ao estudo deste tema, cabe precisar, desde já, a abordagem empregada no presente estudo. Isso, pois ainda que esse trabalho se paute pela redescrição teórica da esfera pública por meio da teoria social de Niklas Luhmann, são travadas discussões e embates teóricos com a filosofia de Jürgen Habermas e com alguns problemas indicados por teóricos políticos que - preocupados com a compreensão de fenômenos contemporâneos vinculados à esfera pública - apontam inconsistências e desafios para as teorias macrossociológicas e filosóficas acerca do conceito. Isso aponta para um diálogo interdisciplinar, cujas implicações serão mais bem exploradas no Capítulo 1 da dissertação.

Uma vez que o presente trabalho parte de considerações teóricas e epistemológicas, de cunho heurístico, a delimitação da abordagem e do objeto necessitam ser esclarecidos ou seja, é necessário precisar quais aspectos do conceito polissêmico “esfera pública” serão trabalhados e por qual maneira. Enfrentar essa questão nos leva à necessidade de uma introdução um pouco mais longa que o comum, o que se justifica em um trabalho estruturado na forma "dedutiva", ou seja, partindo antes da teoria do que do problema, seguindo suas implicações epistemológicas. Isso impõe delimitar o campo do debate, rejeitar abordagens paralelas possíveis em definições negativas e, então apresentar o caminho do argumento e seus objetivos.

Desde já é importante que se diga que o estudo não realiza qualquer historiografia de conceitos ou da gênese da esfera pública ou da constituição do espaço público burguês. Por esse motivo, não é trabalhada uma revisão ampla bibliográfica de abordagens teóricas,

${ }^{5}$ STRUM, 1994, p. 162. Em sentido semelhante, ao responder a diversos autores em uma publicação conjunta sobre o seu livro "Mudança estrutural da esfera pública", quase trinta anos depois, Jürgen Habermas reconhece diversos níveis de análise em sua obra, com implicações descritivas e normativas, e assevera: “(...) esses níveis são agora habitados por pessoas totalmente diferentes - eu quero dizer, pessoas que se movimentam em universos acadêmicos diferentes. Mesmo assim, nós podemos falar uns com os outros" (HABERMAS, 1994, p. 464). 
que são muitas. Não é a intenção realizar uma monografia panorâmica do assunto, mas investir em uma problematização teórica específica. Modelos teóricos clássicos e importantes que estudam o conceito, como os presentes em Hegel e Marx e aqueles que trabalham com modelos de sociedade civil e sua separação com o Estado e o mercado, por exemplo, estarão ausentes ou serão abordados de formas secundárias em algumas passagens.

Com isso, percebe-se que o presente estudo está inserido dentro de um campo teórico limitado: a teoria dos sistemas de Niklas Luhmann na descrição da esfera pública na sociedade moderna. Assim, fica claro que também não se trata de um estudo concreto vinculado a alguma esfera pública política específica, ou seja, de algum país ou história regional específica. Como busco demonstrar ao longo do trabalho, as maiores vantagens analíticas e heurísticas da sociologia luhmanniana são dadas por sua metodologia "radicalfuncionalista", que lhe permite realizar comparações abstratas - em termos de equivalentes funcionais - e desenvolver uma teoria que dê conta de amplo contingente de objetos e, assim, seja válida, em grande medida, para toda a sociedade moderna e suas esferas públicas políticas nacionais; além de acessar o tema de uma esfera pública mundial (Weltöffentlichkeit).

Não se trata, ainda, de desenvolver uma teoria geral da esfera pública moderna, buscando oferecer um conceito e um modelo fechado e último. O trabalho se debruça sobre as eventuais vantagens e limites comparativos da teoria luhmanniana frente aquela desenvolvida por Jürgen Habermas e frente a problemas contemporâneos. A contrapartida com Jürgen Habermas se justifica, por ser ela uma teoria social de grande alcance e exercer grande influência nos debates contemporâneos. Por isso, as diversas correntes e propostas das "chamadas teorias deliberativas da democracia" não serão abordadas, senão tangencialmente. ${ }^{6}$ Ademais, como foi dito acima, a tradição filosófica habermasiana prevalece nos estudos teóricos mais abrangentes sobre esfera pública. Por outro lado, é sabido que um dos objetivos da teoria de Niklas Luhmann é precisamente trazer os temas abstratos da teoria social de volta para a sociologia, que precisaria se atualizar. Deste modo, o "esforço de atualização" da teoria dos sistemas no âmbito dos estudos da esfera pública não poderia ser desvencilhado de uma contraposição à teoria dominante no campo,

\footnotetext{
${ }^{6}$ Agradeço ao Professor Adrian Gurza Lavalle por ressaltar esse ponto, indicar formas de redução das teorias analisadas e por apontar que essa distinção estava ausente no trabalho apresentado para a banca da qualificação.
} 
ainda mais se notarmos que a contraposição com a filosofia social de Habermas é algo constitutivo no desenvolvimento teórico da sociologia de Luhmann.

Ora, tal utilização do referencial teórico da teoria dos sistemas implica na recusa de se desenvolver um modelo normativo de esfera pública. Nota-se, pois, que também não é o foco deste trabalho investir em uma proposta de legitimação nem em um estudo das condições contemporâneas da consolidação e do estabelecimento de esferas públicas no contexto dos Estados de Direito e da sociedade mundial, tal qual Marcelo Neves realizou em modelo próprio. ${ }^{7}$ Antes, o ponto principal deste estudo é realizar um "teste teórico" da teoria luhmanniana em contraposição com o modelo habermasiano, este sim, de acentuado caráter normativo. Com Luhmann, não é possível desenvolver um modelo normativo, de condições ideais e de justificação da esfera pública, tal como o faz Habermas a partir da ideia de racionalização e legitimação do poder pela ação comunicativa, ao qual ele associa o processo discursivo de deliberação que requer uma cultura política desenvolvida e uma inclusão cidadã ativa e crítica.

Antes, a proposta aqui desenvolvida é a de reconhecer como a macrossociologia de Luhmann pode contribuir para o entendimento da função, do funcionamento e da estrutura da esfera pública na sociedade contemporânea funcionalmente diferenciada. Nesse sentido, o estudo assume um caráter "cognitivo" ou explicativo, buscando descrever teoricamente o fenômeno da esfera pública sem ter, neste momento, a pretensão de apresentar "prognoses críticas" ou terapêuticas, ou nas palavras de Luhmann: pelo "jogo entre crise e crítica", na "semântica da emancipação" dos "diagnósticos de sintomas e prognósticos de futuro". Assume-se a premissa luhmanniana de que a sociedade moderna supercomplexa e funcionalmente diferenciada clama por novos desenvolvimentos da teoria social abstrata, mas também se argumenta que novos desenvolvimentos e alterações reconhecidas nas discussões sobre esfera pública - e, portanto, pouco ou nada tematizados por Luhmann -

7 Agradeço ao Professor Orlando Villas Boas Filho e ao parecerista anônimo da FAPESP por ressaltarem a importância dessa diferenciação com o modelo de Marcelo Neves. Não se trata, portanto, de reproduzir o modelo desse autor (NEVES, 2006) em sua análise do conceito de Estado de Direito a partir das teorias de Luhmann e Habermas. Ainda que o modelo de Neves tenha influenciado consideravelmente esse trabalho, nota-se que sua preocupação central é trabalhada em teria prórpria e implica o desenvolvimento de um modelo de Estado de Direito e de uma esfera pública que funcione como heterolegitimação dessa ordem política (NEVES, 2009a). Daí a preocupação do autor em analisar as condições do Estado de Direito e da formação de uma esfera pública pluralista. Estas pretensões, ainda que abordadas no estudo, não são, aqui, o centro do argumento - mais voltado ao teste teórico de categorias luhmannianas para o enfrentamento de questões contemporâneas como os Tribunais Constitucionais, movimentos de protesto e a possibilidade do surgimento de uma esfera pública mundial, temas que foram abordados apenas tangencialmente por Neves e que, neste trabalho, são tratados por uma ótica diferente.

${ }^{8}$ LUHMANN, 1991, pp. 147-151; 2007a, pp. 885 e ss., 1996b, p. 73 e ss. 
podem de alguma forma iluminados pela teoria dos sistemas. Com isso não se acredita que a teoria dos sistemas possa ser útil ou relevante para estudos de médio alcance e de caráter empírico - que têm seus próprios pressupostos de compreensão aos quais a teoria dos sistemas não parece poder contribuir muito de forma direta, ou seja, sem mediações. O que se intenta fazer aqui é antes um esforço de atualização e problematização da teoria luhmanniana no contexto dos estudos da esfera pública.

Neste sentido, também está ausente nessa dissertação uma proposta institucional para o fomento da esfera pública. A discussão aqui realizada não se apoia na premissa normativa da valorização da esfera pública (ainda que seja possível e muito fácil defendela) nem tem como premissa explicativa central os vínculos normativos indisponíveis entre esfera pública e legitimidade democrática, ou entre esfera pública e boa governabilidade entendida como boas tomadas de decisão nas instituições democráticas. É claro que para ambos os autores existe uma conexão necessária entre a presença de uma esfera pública política e democracia, principalmente através do conceito de Estado Constitucional de Direito. Contudo, cumpre ressaltar que o presente estudo realiza antes um esforço de discussão e explicação teórica acerca de fenômenos contemporâneos relacionados à esfera pública pela teoria dos sistemas, valendo-se de problemas contemporâneos associados à esfera pública para "irritar" a sociologia de Luhmann. Problemas estes que, aliás, foram em grande parte levantados como críticas ao modelo habermasiano de esfera pública, utilizado aqui como contraponto teórico da discussão.

Além disso, ao partir de um autor funcionalista como Luhmann, que encara a sociedade como um sistema social que processa comunicações como seus elementos, os temas e abordagens vinculados a atores da esfera pública são parcialmente deslocados. Com isso, a descrição luhmanniana parte de outros pressupostos que não aqueles da teoria da ação e análise de tomada de decisões de atores sociais. Portanto, a ausência de confrontação frontal com tais modelos no cerne da argumentação é justificável, bem como a recusa de adentrar debates tais como aqueles que tratam da cidadania ativa, da educação cívica e de incentivos para a participação popular, ainda que possamos reconhecer a importância e a relevância desses estudos e discussões. 


\section{Mapeamento do campo da macrossociologia da Esfera Pública}

Enfim, determinado o enfoque do presente estudo, resta saber como ele se enquadra dentro do campo dos estudos macroteóricos sobre a esfera pública. Neste sentido é possível incluí-lo naquilo que podemos chamar de sociologia da esfera pública (Öffentlichkeitssoziologie) em sua faceta macrossociológica e contemporânea. Friedhelm Neidhardt apresenta uma interessante organização desse campo de estudos, afirmando que ele se constitui ao redor da questão de determinar a função ou as funções da esfera pública política (Funktionsbestimmungen politischer Öffenlichkeit). O autor nota que a questão com a qual a sociologia da esfera pública se depara já é tratada pela própria esfera pública, questão que vem à tona desde que a democracia começou a se estabelecer como padrão de dominação política. Segundo ele, a esfera pública pertence às provisões fundamentais (Grundausstattung) constitucionalmente asseguradas das democracias e a partir dessa ligação se desenvolvem funções políticas reivindicatórias que podem ser medidas pela própria esfera pública. Ainda, nota-se que "para além dos outros conceitos políticos, a esfera pública e a opinião pública (öffentliche Meinung) possuem, desde o início do Iluminismo (Aufklärung), grande carga normativa".9

Neidhardt desenvolve seu argumento ao introduzir um caderno especial da Kölner Zeitschrift für Soziologie und Sozialpsychologie intitulado "Öffentlichkeit, öffentliche Meinung, soziale Bewegungen” no qual diversos autores discorrem sobre o tema sob óticas teóricas diversas, a saber: abordagens empíricas centradas em atores da esfera pública e de movimentos protestos, teorias normativas de pré-condições da esfera pública "legítima" baseadas no modelo habermasiano e modelos sociológicos que perguntam pela função da esfera pública e abordam a teoria luhmanniana.

$\mathrm{O}$ autor reconhece que, apesar de diferenças teóricas consideráveis, é possível reconhecer, de maneira geral, que a esfera pública “aparece como um fórum de comunicação aberto para todos”. Nas arenas e estações de transmissão (Relaisstationen) desses fóruns encontram-se atores que põem em marcha (weitertragen) determinadas opiniões estruturadas ao redor de temas determinados. Nessas "galerias" reúne-se um contingente maior ou menor de observadores: o público (das Publikum). Sob condições determinadas, o processo de comunicação se foca em temas e concordâncias específicas nas manifestações de opinião (Meinungsäußerungen) reveladas nesses temas. No caso de

\footnotetext{
${ }^{9}$ NEIDHARDT, 1994 , p. 8.
} 
haver essa consonância de arenas, surge então a "opinião pública" (öffentliche Meinung), compreendida como a opinião dominante compreendida pelos atores da esfera pública e que pode ser percebida pelo público. O ponto relevante é notar que a opinião pública - que não se confunde de nenhuma maneira com a vontade da população (Bevölkerungsmeinung) - exerce uma pressão relativamente forte aos tomadores de decisão do sistema político. É possível também, nesse contexto, que essas comunicações se desenvolvam - novamente: "sob determinadas condições" - e se transformem em movimentos sociais ou de protesto, adquirindo a característica de organização e mobilização de grupos do público com a meta de acessar e disputar as arenas da esfera pública, a opinião pública e os processos políticos de decisão, influenciando-os a seu favor. ${ }^{10}$

Neidhardt parece ser bem sucedido ao demonstrar as peculiaridades da discussão do campo da sociologia da esfera pública. Aliás, seria importante precisar que este é um debate mais próximo da chamada "sociologia de grande alcance" ou macrossociologia, de caráter conceitual e abstrato. Existem diversos outros estudos sociológicos - como aqueles sobre movimentos sociais - que se valem de teorias de médio alcance e extensiva pesquisa empírica, cujo foco principal não é a discussão conceitual da esfera pública moderna e de sua adequação a uma teoria geral da sociedade. Estes estudos, necessários e bem vindos, são encarados por Neidhardt como frutíferos e necessários, mas penso que se enquadram em um campo de certa forma mais autônomo. Por isso, a discussão do presente trabalho se foca no embate teórico abstrato da sociologia da esfera pública a partir de dois modelos diferentes acerca da sociedade moderna: os modelos de Habermas e Luhmann.

O mapeamento de Neidhardt é importante não tanto pelas definições que ele oferece, ainda que nele podemos já diferenciar de forma bem sucedida alguns conceitos de forma geral para preparar o diálogo teórico que será realizado entre as teorias do discurso e dos sistemas. Mais do que isso, essa organização apresenta "pontos de contato" entre as teorias, ou seja, podemos retirar dela alguns "elementos-chave" da discussão do campo, certos aspectos fundamentais associados à noção de esfera pública que estruturam o campo e que, portanto, são úteis para essa introdução, a saber:

i) A busca da função e do caráter prestacional da esfera pública (política) para os sistemas democráticos modernos,

ii) seu caráter filosófico e normativo, ligado ao conceito de razão e emancipação que deitam suas raízes no Iluminismo. Disso resulta um modelo normativo que domina os

\footnotetext{
${ }^{10}$ NEIDHARDT, 1994, pp. 7-8.
} 
debates. Tal característica que pode ser reconhecida tanto nas próprias reinvindicações (Ansprüche) da esfera pública em sua discussão pública, quanto em discussões teóricas no âmbito das ciências sociais - em que são ressaltadas as "condições ideais" (e utópicas) da esfera pública e os requisitos que elas devem seguir para extração de seu potencial legitimador. Essa tradição é fortemente ligada ao modelo discursivo de Jürgen Habermas.

iii) O caráter de formação e processamento de opiniões públicas e de cristalização de temas e opiniões passíveis de serem observadas. Aqui, o principal ponto de destaque é relação com o sistema político. Disso se retira sua faceta de "institucionalização de temas"11 trazidos pelo "fórum" da esfera pública que podem servir como "caixa de ressonância" quando, ligados ao meio da opinião pública.

iv) Seu caráter manifestamente político, que visa a influenciar a tomada de decisões coletivamente vinculantes no centro do sistema político, ou, como se convencionou chamar na ciência política, da disputa e influência na "agenda setting" (formação e estipulação da agenda política).

Essas questões estruturam em grande medida os debates do campo da sociologia da esfera pública que aqui são abordadas pelos modelos de Habermas e Luhmann e servem de pano de fundo para o reconhecimento e a constituição do campo.

Em outro momento de bom mapeamento do debate, Neidhardt apresenta três linhas de funções atribuídas à esfera pública que continuam na pauta do debate, ainda que de forma latente. $\mathrm{O}$ autor argumenta que, de maneira geral, o modelo normativo clássico de esfera pública, desenvolvido por Amai Etzioni em 1969 em seu “Active Society” estaria já obsoleto, mas exerceria alguma influência para a sociologia contemporânea da esfera pública que criticaria este modelo de forma mais ou menos rigorosa, dependendo de sua variante teórica. Segundo esse modelo, a esfera pública seria um sistema comunicacional de processamento de temas e opiniões por em processos de input-throughput-output. Estes três níveis de processos se relacionam com três princípios e funções da esfera pública política:

A) a esfera pública deve ser aberta para todos os grupos sociais bem como para todos os temas e opiniões de relevância coletiva. Neste sentido, na medida em que é aberta, a esfera pública política satisfaz funções de transparência.

B) Os atores da esfera pública devem defender discursivamente seus temas e opiniões sob as pressões da argumentação e revidar considerações de outros discursos. Na

\footnotetext{
${ }^{11}$ NEIDHARDT, 1994, p.9.
} 
medida em que o princípio da discursividade é levado em conta, a esfera pública, pela comunicação pública (öffentliche kommunkation), presta funções de validação.

C) A comunicação pública operada pelos atores da esfera pública de forma discursiva gera a "opinião pública”, que o Público pode convincentemente perceber e aceitar. $\mathrm{Na}$ medida em que a opinião pública assume tal autoridade, ela oferece à democracia uma prestação de funções de orientação. ${ }^{12}$

Estas três funções da esfera pública, encarada de maneira normativa por Etzioni, parecem também estruturar os estudos teóricos sobre esfera pública e são abordas pelos modelos aqui trabalhados em releituras distintas.

Neidhardt opõe, então, dois modelos contemporâneos de esfera pública política, a saber, o "modelo do espelho" (Spiegelmodell) de Niklas Luhmann e o modelo discursivo de Jürgen Habermas - ao qual me refiro, no presente trabalho, também como o "modelo de eclusas" para contrapor a metáfora luhmanniana do espelho com a metáfora utilizada tardiamente por Habermas. Esta oposição é precisamente o ponto de partida teórico do presente trabalho, que se vale também da oposição destes dois modelos.

O caráter normativo do modelo discursivo habermasiano é bem apontado pelo autor, uma vez que ele pressupõe que as funções de uma esfera pública legítima apenas se concretizam quando diversos pressupostos normativos são satisfeitos e a esfera pública opera de maneira aberta, crítica, livre de opressão e cooptação em um processo discursivo de racionalidade comunicativa legitimando os processos políticos. Contudo, ao tratar do modelo do espelho - baseando-se ainda em textos mais antigos de Luhmann -, Neidthard apresenta algumas reservas. Ele ressalta que o enfoque principal luhmanniano estaria na função da transparência e na institucionalização de temas cristalizados politicamente na opinião pública, de modo que um ponto positivo do modelo seria atentar para as condições estruturais da sociedade moderna e como ela pode se observar através do meio da esfera pública. Em seguida, Neidhard argumenta que "[o] modelo discursivo contém as premissas básicas do modelo do espelho e vai além". ${ }^{13}$ Além disso, apesar de reconhecer que "condições estruturais da esfera pública" na sociedade moderna limitam seu desenvolvimento, ele sustenta que o modelo discursivo satisfaria funções heurísticas não fornecidas pelo modelo do espelho. ${ }^{14}$

\footnotetext{
${ }^{12}$ NEIDHARDT, 1994, pp. 8-9.

${ }^{13}$ NEIDHARDT, 1994, p. 10.

${ }^{14}$ NEIDHARDT, 1994, p.38.
} 
Não obstante o interessante mapeamento realizado por Neidhardt, discordo que a diferença entre estes modelos seja apenas uma de desenvolvimento e que o modelo do discurso "contenha as premissas básicas" do modelo do espelho. Pelo contrário, como argumento neste trabalho, tanto as premissas quanto as abordagens de ambos são diferentes e apresentam distintas consequências para a sociologia de grande alcance ou macrossociologia que trata da esfera pública. Isso implica sustentar que o modelo luhmanniano de esfera pública, inseparável de sua teoria geral da sociedade moderna, apresenta ganhos heurísticos importantes e fundamentalmente diferentes daqueles trazidos por Habermas. Se há uma diferença de ganho heurístico entre as teorias de Habermas e Luhmann, ela não parece ser facilmente reduzida em prol da teoria do discurso, como se uma teoria compreendesse a outra. Pelo contrário, pretendo demonstrar que a teoria luhmanniana traz consigo ganhos heurísticos frutíferos para o debate sobre o conceito de esfera pública na sociedade moderna. O que a teoria habermasiana permite fazer em contraposição à teoria luhmanniana, é desenvolver uma abordagem normativa e crítica e um programa para mudanças e alterações na sociedade. Isso, contudo, é algo amplamente reconhecido por ambos os autores - não sem a contraposição de críticas mútuas. ${ }^{15}$

\section{O "duplo teste" de um trabalho "teoricamente orientado"}

Uma vez que o presente trabalho tem o objetivo de apresentar eventuais possibilidades ou ganhos heurísticos do modelo luhmanniano de esfera pública, não parece ser possível centrar o debate apenas em questões abstratas de redescrição teórica. É necessário também que o modelo teórico seja "irritado" por questionamentos provenientes de debates concretos para testarmos, em alguma medida, se tal teoria se mantém coerente frente a problemas contemporâneos. Com isso, não se desconhece que teorias macrossociológicas são incapazes ou pouco afeitas a orientar pesquisas empíricas e à compreensão de fenômenos concretos e localizados histórica e regionalmente. A pergunta é antes por uma teoria sociológica abrangente que seja consistente e adequada para explicar os fenômenos contemporâneos no nível de abstração capaz de trabalhar com objetos tão amplos como a sociedade moderna mundial.

A questão, como vemos, parece tratar de uma "pergunta teórica" pautada antes pela consistência de explicações disponíveis do que uma "pergunta primariamente baseada

\footnotetext{
${ }^{15}$ Por exemplo, HABERMAS, 2000, pp. 489 e 492 e LUHMANN, 1998c. pp. 164 e ss.
} 
em um problema" e na compreensão de fenômenos bem determinados. Assim, uma vez que há implicações teóricas centrais e se trabalha no nível da consistência de uma teoria, o trabalho é estruturado de modo dedutivo tanto em sua exposição quanto na estrutura de sua argumentação.

Todavia, esse "movimento dedutivo" apresenta alguns cuidados e recebe muitas críticas pertinentes, principalmente daqueles pesquisadores vinculados à compreensão de fenômenos sociais que se baseiam em pesquisas empíricas e em teorias de médio alcance (middle range theories). ${ }^{16} \mathrm{O}$ risco que se corre é recair em explicações circulares ou tautológicas e "encaixar" o mundo em premissas teóricas, ou seja, encontrar no mundo as premissas teóricas que lá estavam como pressuposições, oferecendo pouco auxílio para compreensão de fenômenos sociais que seriam antes aludidos de forma seletiva apenas para confirmar a teoria pressuposta.

Ao discorrer sobre esse "perigo", Adrian Gurza Lavalle analisou o argumento do "ethos público" - "uma determinação cultural incontornável" - no âmbito do pensamento político brasileiro e nos ensaios sobre a identidade nacional como um "raciocínio circular tautológico" que gera "efeitos de explicação sem acréscimos quanto à compreensão dos problemas visados pela análise". ${ }^{17}$ Ele chega a considerar o raciocínio circular como um “obstáculo epistemológico", tal como formulado por Gaston Bachelar (e citado por Luhmann, diga-se de passagem), ou seja, uma "barreira do pensamento contra o próprio pensamento". 18

Em termos gerais, contudo, Lavalle apresenta uma diferenciação entre a “compreensão", definida como esforço voltado para a problematização, e a "explicação", encarada como momento de conformidade com as razões existentes. Após discutir diversas

\footnotetext{
${ }^{16}$ Robert Merton (1968, p. 51 e ss.) caracteriza as middle range theories como teorias que "objetivam a orientação de pesquisas empíricas". Para uma análise de como a teoria de Luhmann não seria uma "middle range theory", apesar de não haver citação direta do conceito de Merton, ver: TEUBNER, 1989.

${ }^{17}$ LAVALLE, 2004, p. 156. O autor trabalha também com outros problemas específicos da explicação pelo ethos, como a "definição pela ausência e anomalia". Em sentido semelhante, também relacionado com a questão do "ethos ibérico" de cunho culturalista, ver VILLAS BÔAS FILHO, 2009, esp. pp. 204 e ss e e 266 e ss.

${ }^{18}$ Em sua análise específica sobre o argumento do ethos público culturalista no pensamento político brasileiro encontramos uma passagem elucidativa: Na esteira do raciocínio circular "[p]ropõem-se como razões explicativas um conjunto de predicados que, na realidade, formam parte dos atributos pressupostos na definição do sujeito - o ethos -, pelo que o raciocínio discorre de maneira circular. A tautologia é sempre impecável: uma vez introduzido o ethos, seja como chave explicativa da configuração do espaço público no geral, seja perante algum problema mais específico, identificam-se os comportamentos já pressupostos no próprio ethos e de imediato produz-se a explicação, sem proveito para a compreensão, precisamente pela 'descoberta' da presença do ethos como substrato organizador das relações que definem a vida pública no país” (LAVALLE, 2004, p. 157).
} 
correntes sobre o assunto, ele se associa às teses epistemológicas de Hugo Zemelman e sustenta haver uma "relação paradoxal entre ambos os termos, pois para se aproximar da realidade de forma compreensiva é preciso renunciar, no primeiro momento, à tentação de explicar". ${ }^{19}$ Talvez seja possível argumentar também o oposto, que generalizações explicativas tendem a ser autorreferenciais, abstratas e mais distantes da "realidade" ou de sua compreensão mais imediata.

Por sua vez, Ian Shapiro reconhece semelhante problema no âmbito da ciência política, mas trata da questão de forma mais generalizada e radical. $\mathrm{O}$ autor reconhece uma tendência da disciplina em adotar estudos orientados pela teoria (theory driven) ou pelo método (method driven), que inviabilizariam a compreensão de problemas políticos e de estudos orientados por problemas (problem driven). Sem desconsiderar a importância da teoria para a criação de problemas de análise, a proposta do autor é que tanto a pesquisa empírica quanto as explicações teóricas deveriam ser orientadas por problemas. Os estudos orientados por métodos ou teorias incorreriam no provérbio que diz que "quando a única ferramenta que você tem é um martelo, tudo ao seu redor começa a se parecer com um prego". ${ }^{20}$ Assim, para o autor, os estudos orientados por teorias utilizariam problemas apenas como "artefatos" e o fariam de uma maneira trivial que apenas reforçaria a teoria pressuposta ao invés de iluminar um problema de análise. ${ }^{21}$ Ele propõe que a ciência deve se basear antes em estudos indutivos, pois ela deveria estar preocupada em primeira instância com produção de conhecimento válido e apenas secundariamente com proposição de generalizações, que só viriam em detrimento da pesquisa empírica. O autor rejeita até o que chamou de "divisão do trabalho" na ciência, em que teóricos positivos deveriam procurar por questões de generalização enquanto os pesquisadores empíricos enfrentam questões de validade (validity). ${ }^{22}$ Tal divisão do trabalho implicaria em uma fortificação das "patologias" da pesquisa orientada pela teoria.

Tendo em vista essas críticas, como evitar ou tentar mitigar os perigos de um estudo teórico dedutivo voltado para a análise da explicação luhmanniana do conceito de esfera pública? Veremos no Capítulo I que a teoria de Niklas Luhmann é manifestamente desenvolvida como uma teoria abstrata e "autorreferencial" claramente voltada para a

\footnotetext{
${ }^{19}$ LAVALLE, 2004, p. 205 (nota 37 do capítulo IV, referente à página 157).

${ }^{20}$ SHAPIRO, 2002, p. 597-598.

${ }^{21}$ SHAPIRO, 2002, p. 601.

${ }^{22}$ SHAPIRO, 2002, p. 605.
} 
explicação do fenômeno social como um todo. Ainda assim, o próprio autor entende que a teoria - mesmo que abstrata - deve fazer alguma referência à realidade, mesmo que pequena. Ora, o mero recurso à abstração da teoria não resolve a questão. A pergunta permanece: um trabalho estruturado dedutivamente como este, cujo cerne do argumento é teórico baseado na sociologia de Luhmann, incorre, então, necessariamente em raciocínio circular de redescrição do mundo sem iluminá-lo ${ }^{23}$ Ou melhor, apenas se vale do problema da esfera pública como artefato para a mera afirmação de seus pressupostos heurísticos ${ }^{24}$

A resposta é negativa se atentarmos para duas questões. Em primeiro lugar, vemos que a estrutura da primeira parte do trabalho, que lida com a teoria luhmanniana comparativamente à teoria de Jürgen Habermas e com comentadores do conceito de esfera pública desses modelos, já o afasta de uma pura exegese. Em segundo, a estruturação do argumento por problemas do debate contemporâneo na Parte II, serve tanto para ver quais são as possíveis questões acessíveis no tema pela teoria luhmanniana - como ela pode ou não "iluminar" questões - e, ao mesmo tempo, perguntar quais são seus pontos cegos, ou seja, seus limites frente a esses fenômenos.

Ainda assim, é incontornável que tal utilização "dedutiva" da teoria dos sistemas que pergunta por sua consistência teórica - caracteriza o presente estudo como "theory driven”. Ian Shapiro é convincente em sua argumentação quanto às preocupações com as pesquisas em ciência política. Realmente, uma divisão do trabalho acadêmico que separe teóricos e cientistas de maneira radical pode ser problemática para o desenvolvimento de ambos os lados. Contudo, ainda que consideremos juntamente com Lavalle o paradoxo entre "explicar" e "compreender", ou seja, que não haja uma saída de "síntese" entre os dois polos, isso não quer dizer que não haja possibilidade de irritação mútua entre eles. Daí ser útil o esforço de abordagem interdisciplinar que não se resume a uma divisão estéril do trabalho acadêmico, mas se constitui, antes, em um diálogo de mútua redescrição. ${ }^{25}$

\footnotetext{
${ }^{23}$ Agradeço as discussões da banca de qualificação que me incentivaram a ressaltar mais ainda esse ponto e a evitar algumas "armadilhas" do trabalho com uma teoria tão abstrata como a de Luhmann.

${ }^{24}$ Agradeço também a Felipe de Souza Salvador pelas inúmeras discussões sobre a (in)aplicabilidade da teoria dos sistemas à ciência política.

25 Marcelo Neves fala sobre a questão sob o termo de "comutação discursiva" e "tradução de linguagem" em estudos interdisciplinares. Para o autor não há interdisciplinaridade sem disciplinaridade, ou seja, para haver possibilidade de influências recíprocas, os pontos de vista e as abordagens disciplinares devem estar bem estabelecidos (NEVES, 2005b, p. 211).
} 
Aliás, como podemos ver no artigo anexo do presente estudo, a teoria dos sistemas - como qualquer outra em princípio -, por mais abstrata que seja, pode também se alterar e apresentar desenvolvimentos após receber críticas de natureza “empírica”. O oposto é mais visível: parece ser impossível que a discussão acadêmica e científica seja completamente "indutivista" e de nenhuma forma orientada por teorias. ${ }^{26}$ Existem influências e irritações mútuas, apesar de esforços de mediação serem necessários para explorá-las.

Com efeito, conforme notou Marcelo Neves, o fato de haver poucas aplicações da teoria dos sistemas a casos concretos decorre de ser ela muito complexa "exigindo uma dedicação quase integral", por haver pontos ainda em aberto e pelo "grau muito abstrato do artefato conceitual". ${ }^{27} \mathrm{O}$ reconhecimento de sua complexidade e abstração, contudo, não pode ser um argumento para sua não aplicação ou para sua completa rejeição. ${ }^{28} \mathrm{O}$ próprio Luhmann, em diversas passagens reconhece que sua teoria deve ser trabalhada e desenvolvida. Segundo ele, a teoria deve "ser um fator que possa gerar irritação para que outras pessoas possam movimentá-la e pensar por si próprias". ${ }^{29}$ Essa característica da teoria foi bem ressaltada por Marcelo Neves em uma entrevista transcrita em que ele afirma que "a teoria de Luhmann não é uma teoria de chegada, mas sim uma teoria de partida, aberta a novas incursões e alternativas". ${ }^{30}$

Ao enfrentar questionamentos atuais relacionados à esfera pública é possível fugir do problema do raciocínio circular se atentarmos para os limites e possibilidades da teoria em relação ao objeto de análise. Além disso, ao retirar da discussão as consequências que o debate leva para a teoria dos sistemas em sua consistência interna, não se recai em uma

${ }^{26}$ Karl Popper afirma que relação entre teoria e experimento não ocorre de forma simples e que seria um erro "supor que um experimentador procede assim para 'lançar luz sobre o trabalho do teórico' ou talvez para oferecer ao teórico base em que apoiar generalizações indutivas. Ao contrário, o teórico deve ter, muito antes, realizado o seu trabalho, ou, pelo menos, a parte mais importante deste trabalho: deve ter formulado, tão claramente quanto possível, sua pergunta". Daí a assertiva do autor de que "a ciência requer pontos de vista e problemas teóricos" (POPPER, 2006, p.113-115). Em seu artigo, contudo, Ian Shapiro tenta rebater esse argumento, se posicionando contra a tendência exacerbada de orientação por teoria na pesquisa em ciência política.

${ }^{27}$ NEVES, 2009c, p, 270.

${ }^{28}$ Sobre as críticas de que sua teria seria incompreensível, Luhmann argumenta: "Linguagem para poucos, compreensão para poucos: precisa ser assim? Não penso em nenhum princípio de exclusão e muito menos em uma linguagem elitista. Mas penso que se deve encarar sem concessões as necessidades da coisa e que a compreensibilidade não pode ser um princípio que impeça algo que é possível de ser dito" (LUHMANN, 2002b, p. 58).

${ }^{29}$ LUHMANN, 2009, p. 23. Essa resposta de Luhmann foi dada no contexto de uma entrevista na qual ele foi perguntado sobre a tentativa de ampliar a "esfera pública acadêmica de sua teoria" ( ... eine breitere akademische Öffentlichkeit), ao que Luhmann responde em inglês: That's not my problem. (LUHMANN, 2009, p. 21).

${ }^{30}$ NEVES, 2009c, p. 270. 
orientação teórica necessariamente negativa como discorre Shapiro. Isso, pois a abertura interdisciplinar que é necessária para o estudo do campo da sociologia da esfera pública que aludimos acima com Arthur Strum - traz irritações tanto para o campo de estudos como para a teoria dos sistemas. Afinal, não é suficiente se preocupar com os problemas se esquecermos o desenvolvimento de boas ferramentas teóricas. E o trabalho de desenvolver, ampliar e modificar a teoria luhmanniana parece ir por esse sentido.

Como escolher, então, questionamentos e problemas contemporâneos que podem trazer novos debates para a sociologia da esfera pública e aplicar tensão aos conceitos cristalizados que debatemos na macrossociologia, especialmente na teoria dos sistemas? Existem outras "mudanças estruturais" no funcionamento dos sistemas políticos e suas esferas públicas ocorridas após o início da década de 90 quando o debate teórico abstrato parece ter dado seus maiores e últimos saltos? Em caso positivo, quais são elas e como elas podem ser abordadas pela teoria?

Cumpre notar que as questões sobre as quais o campo se constituiu ganham atualmente novas colorações e novas perspectivas são abertas para a discussão. As discussões acadêmicas do campo parecem apontar para um conjunto determinado de questões relevantes levantadas tanto por coletâneas de debates quanto por estudos interessados na compreensão de problemas e fenômenos delimitados que parecem "fugir às regras" impostas pela teoria - em grande parte dominada pela influência habermasiana. Como veremos no Capítulo II, os problemas escolhidos para o trabalho ${ }^{31}$ foram em grande parte críticas levantadas em relação ao modelo habermasiano e a alguns estudos normativos dele decorrentes que trouxeram uma "grande esperança" no conceito de esfera pública, mas aos quais teria se seguido uma "grande decepção" - política e teórica. ${ }^{32}$

i) Em primeiro lugar, a importância dos meios de comunicação em massa, ressaltada no início das discussões como um dos fatores necessários para a gênese e a manutenção da esfera pública, pareceu perder um pouco de sua centralidade nos estudos atuais sobre esfera pública. ${ }^{33}$ Atualmente, entretanto, os recentes desenvolvimentos desse

${ }^{31}$ Com esse recorte também foi limitado o número de problemas enfrentados no presente trabalho quando da fase do exame de qualificação. Agradeço aqui aos Professores Adrian Gurza Lavalle e Orlando Villas Bôas Filho pela indicação que tornou o estudo mais enxuto e mais denso.

32 Essa grande decepção é baseada, como bem formulou Evelina Dagninio, em notar que após a "grande expectativa" teórica depositada nas experiências associativas sucedeu a "inexorável constatação de seu fracasso.” (DAGNINO, 2002b, pp.371 e 388-9).

${ }^{33}$ Em seu estudo de 1962, Habermas discorre como a transformação dos meios de comunicação em massa - que no início era vista com bons olhos na gênese da esfera pública -, passou a exercer funções de manipulação em uma sociedade de consumo. Contudo, em 1990, o autor trata do tema reconhecendo efeitos 
sistema social parecem permitir novas abordagens e despontar como um ponto de contato relevante com fortes implicações para a esfera pública.

ii) Juntamente com eles, encontramos um renovado interesse da academia pela discussão dos chamados (mais?) "novos movimentos sociais", com seus "novíssimos" atores e organizações, instituições e atuação no âmbito global, ${ }^{34}$ o que parece apontar para questões relevantes da relação entre movimentos sociais e a esfera pública contemporânea.

iii) Além disso, o "caráter defensivo" da esfera pública política, sustentado como fator normativo de autonomia da sociedade civil frente aos media do poder (Estado e poder administrativo) e dinheiro (sistema econômico) parece ser um pouco mitigado por novas formas de organização da representação "de advocacy", bem como por conselhos e organizações que se inserem no corpo estatal. Some-se a isso que o enfoque dos estudos sobre a esfera pública usualmente são centrados em sua influência nos processos de tomada de decisão no poder legislativo. Isso parece ser um enfoque restrito, uma vez que questões de políticas públicas vinculadas ao Executivo podem também ser tematizadas e debatidas no fórum da esfera pública. Ainda, e mais importante que isso, a literatura contemporânea tende a apontar para a questão da judicialização da política nas últimas décadas, com protagonismos de Tribunais Constitucionais e sua jurisdição constitucional, algo que é objeto de mobilizações de protesto e de discussões públicas nos meios de comunicação em massa e na esfera pública.

iv) Por fim, é possível reconhecer um movimento na academia que desloca seus interesses para o nível mundial da sociedade contemporânea, entendida ela mesma como uma sociedade mundial (Weltgesellschaft). Com isso, em um contexto de chamada "crise do Estado" - ou crise do "Estado de Bem Estar" -, estudos e questões acerca da esfera pública mundial (Weltöffentlichkeit) e esperanças quanto à possibilidade de uma inclusão mundial por meio dessa esfera pública global ganham destaque.

contraditórios dos meios de comunicação de massa eletrônica e, portanto, afastando-se de sua posição inicial mais pessimista (HABERMAS, 1990, p, 49). Tal reconhecimento foi observado por Luhmann, que ressalta a importância do tema (LUHMANN, 1998c, p.172) Contudo, em ambos os casos o tema não foi trabalhado de forma central, pelo menos não a partir da teoria luhmanniana acerca dos meios de comunicação em massa.

34 Nesse sentido, Maria da Gloria Gohn fala que "[n]este novo século novíssimos sujeitos sociopolíticos e culturais entraram em cena, como os movimentos sociais globais, anti ou alterglobalização, movimentos transnacionais, entidades civis modernas, fóruns, conselhos e câmaras de participação", com diversidade de temas e com impacto que "tem alterado a forma e as estruturas do associativismo da sociedade civil e suas relações com o Estado" (GOHN, 2010, pp. 11-12). 
Essas quatro questões contemporâneas levantadas se destacam como pontos centrais de debates em aberto no campo da teoria da esfera pública. O objetivo deste trabalho é enfrentá-las através da lente teórica da teoria dos sistemas de Niklas Luhmann.

Ao enfrentá-lo, abre-se a possibilidade da realização de um "duplo teste" para a sociologia luhmanniana, a saber: saber se ela pode contribuir para o campo de estudos da esfera pública em seus problemas atuais e apontar questionamentos e problematizações inovadoras. Por outro lado, simultaneamente, é possível também perguntar pela consistência interna da teoria ao enfrentar problemas atuais que ela não se propôs a enfrentar - pelo menos não de forma central. É essa pergunta por "limites e possibilidades" 35 da teoria de Luhmann que pauta o argumento do trabalho.

Por esse motivo o trabalho é dividido em duas partes. Na primeira parte, a parte teórica, o conceito de esfera pública é trabalhado a partir de uma perspectiva luhmanniana a partir de tensionamentos com a teoria do discurso e com desenvolvimento de comentadores. Na Parte II, encarregada da discussão de problemas atuais da esfera pública contemporânea, as considerações teóricas levantas na Parte I são testadas em relação aos problemas teóricos levantados pelos estudos atuais sobre a esfera pública.

\section{Entre Eclusas e Espelhos}

O título do trabalho, "Entre eclusas e espelhos" se refere a metáforas utilizadas por Habermas e Luhmann, respectivamente, para descrever a esfera pública. Importante dizer que, a rigor, a metáfora luhmanniana do espelho se refere mais diretamente à opinião pública no sistema político. ${ }^{36}$ Como veremos com calma no Capítulo III, no qual essa oposição será aprofundada, a metáfora do espelho é utilizada para descrever uma instância interna do sistema que aparece para ele - em suas autodescrições - como se estivesse "fora dele”, mas não está, pois faz parte de seus processamentos. Daí Luhmann chamar essa instância de "ambiente interno" de um referido sistema. Textualmente, a metáfora é utilizada para se referir à "opinião pública" (öffentliche Meinung) em relação específica com o subsistema político. Segundo o funcionalismo luhmanniano todos os sistemas de

\footnotetext{
${ }^{35}$ A ideia, aqui, é parafraseada BACHUR, 2010, livro decorrente de sua tese de doutorado cujo título inicial era "Distanciamento e crítica: limites e possibilidades da teoria dos sistemas de Niklas Luhmann".

${ }^{36}$ LUHMANN, 2000a, p. 286 e 1999b, p. 86 e ss.
} 
mesma natureza ${ }^{37}$ apresentam estruturas equivalentes. Portanto, a metáfora do espelho em si não é privilégio desse subsistema social. Ela pode ser utilizada para outros deles, como ocorre, por exemplo, no caso do "mercado", mencionado como o ambiente interno da economia, ao qual, consequentemente, Luhmann também atribui metaforicamente uma função de "espelho".

Mesmo assim - e isso talvez já seja sintomático da nota política que o conceito de esfera pública assume na academia -, diversos autores, como o supracitado Neidhart, sustentam que Luhmann teria desenvolvido um "modelo do espelho" para a esfera pública. Isso, a rigor, não está equivocado. É certo que o conceito luhmanniano de esfera pública é mais amplo do que o de opinião pública, mas ainda assim ele está relacionado com a viabilização de uma observação de segunda ordem, ou seja, uma reflexão; uma característica própria de espelhos. A esfera pública da sociedade - o sistema social mais abrangente - é encarada pelo autor como seu âmbito interno de toda a sociedade, pelo qual todos os outros sistemas sociais parciais podem se observar. A metáfora não é, então, específica do sistema político, cujo "espelho" propriamente dito, vale repisar, é a opinião pública, o âmbito que realmente adquire relevância política. Esse âmbito da comunicação social encarado como esfera pública, contudo, por se tratar do ambiente interno de toda a sociedade é encarada por ela como se fosse "externo"- daí porque a possibilidade de que críticas à sociedade sejam nela elaboradas.

Essa breve apresentação da formulação sistêmica do conceito de esfera pública, que é devidamente aprofundada no Capítulo III, chama a atenção por sua abstração e por seu caráter restrito ou "enxuto". Todavia, o que mais nos interessa nesta introdução é ressaltar que Luhmann trabalha com uma faceta "menos política", ou melhor, menos voltada para noções de direção e controle (Steuerung) - ou seja, vinculada à "agência" social e ao direcionamento da ação coletiva -, destacando antes suas funções de permitir observações mútuas entre diversos sistemas sociais (e não apenas sistemas funcionais, mas também sistemas organizacionais e interativos). Isso se relaciona com o fato de que a teoria dos sistemas considera que a descrição da sociedade moderna centrada na política é uma descrição "vétero europeia", o que também se aplicaria para sua descrição como sociedade econômica. Isso, pois a sociedade moderna se caracterizaria pela diferenciação funcional

\footnotetext{
${ }^{37}$ Um equívoco bastante comum é atribuir à teoria dos sistemas luhmanniana a pecha de que ela apenas trataria de sistemas sociais funcionais. Adiante-se que os sistemas sociais - cuja sociedade é o sistema mais abrangente - podem ter diversas naturezas distintas, ou, em termos luhmannianos, se estruturam em três níveis diversos - sistemas de função, sistemas de organização e sistemas de interação - além dos movimentos de protesto que teriam um estatuto próprio.
} 
(horizontal), com diversos subsistemas sociais autônomos e autorreferenciais sem haver prevalência ou dominação entre eles. Com um conceito mais "enxuto" e menos direcionado ao centro do sistema político, a esfera pública da sociedade para Luhmann é encarada como um âmbito de comunicações não organizada sistemicamente tal qual são os sistemas de função. Daí porque questões como costumes, preconceitos, "modos de vida", etc. também podem ser temas vinculados na esfera pública. A esfera pública é encarada antes como um espaço da publicidade (como oposta ao segredo) por meio do qual a sociedade pode se observar (como se estivesse olhando de fora) e se criticar.

Esse é o ponto chave da abordagem luhmanniana da esfera pública. Ela é condizente com sua teoria de uma sociedade policontextural e funcionalmente diferenciada. A partir dela é possível discorrer como a esfera pública da sociedade se relaciona com os diversos subsistemas sociais e como ela adquire relevância para eles. $\mathrm{O}$ ponto central que podemos acessar a partir da teoria de Luhmann é evidenciar as funções sociais da esfera pública e sua relação com os sistemas funcionais autopoiéticos. Ainda assim - e talvez exatamente por isso - seu conceito de esfera pública é muito reduzido, sendo quase que definido "negativamente" em relação à sua teoria do funcionamento dos sistemas sociais de função.

Por outro lado, o modo "tradicional" de se pensar a esfera pública, ao qual Habermas apresenta grandes contribuições em duas formulações consideravelmente distintas (a primeira na década de 1960 e a segunda no início da década de 1990), tende a destacar a influência que a esfera pública pode exercer na política organizada sistemicamente. O modelo se volta mais para a descrição de fluxos e contrafluxos de processos comunicativos. Essa sua descrição de "fluxos" implica o desenvolvimento teórico da tese dupla integração da sociedade. ${ }^{38}$

Se levarmos em conta as alterações no modelo habermasiano da esfera pública na década de 1990, vemos que o conceito é abordado com mais rigor a partir da tese da dupla integração da sociedade, ou da divisão analítica entre "sistemas" (da economia e do poder

38 Sobre a mudança dos paradigmas habermasianos sobre a esfera pública em que haveria uma "virtualização da publicidade" (ou virtualização da esfera pública) em que o autor teria redescrito o termo como um "fluxo comunicativo", ver LAVALLE, 2002; onde o autor afirma que as alterações na teoria habermasiana teriam uma dupla face, por um lado, um ganho teórico e normativo de abstração, mas, por outro, tais conquistas teriam imposto o "ônus de despir a categoria de seus componentes sociologicamente mais ricos, aparando-lhes suas implicações analíticas mais críticas” (p.65). O próprio Habermas reconhece essas questões e discute como lidar com as questões da difícil relação entre um projeto que seja mais histórico e específico (característica mais acentuada no trabalho de 1961) e abstrações de cunho teórico mais abstrato (nas obras 1990 e 1992). Para uma discussão, ver os debates nas "considerações finais" em HABERMAS, 1994, pp 470-471. 
administrativo) e "mundo da vida" (Lebenswelt); opondo, portando, integração social gerada no mundo da vida à integração sistêmica dos mercados e do poder burocrático administrativo.

É precisamente no contexto de seus desenvolvimentos teóricos tardios mais amplos que Habermas realiza grandes revisões e propõe um "quadro teórico modificado" em 1990 ao tratar da esfera pública. Como veremos no trabalho, Habermas é tributário do diagnóstico luhmanniano de ser a sociedade moderna marcada pela hipercomplexidade e por sistemas sociais funcionalmente diferenciados. Daí o reconhecimento do autor de que os sistemas são incontornáveis e têm uma "lógica própria" de funcionamento. ${ }^{39}$ Não obstante, suas teorizações normativas se voltam para propor modelos de influência entre estes âmbitos de integração da sociedade. Com efeito, o conceito de esfera pública é central nessa proposta. Nela, a noção de fluxo comunicativo e central.

Em suas considerações em 1961 e 1990, pode-se afirmar que Habermas desenvolveu um modelo "defensivo" de esfera pública, visando a manter sua autonomia e buscar evitar uma "colonização do mundo da vida pela lógica dos sistemas". Esse modelo é conhecido como o modelo do "sitiamento" ou modelo do "cerco", uma vez que Habermas afirma que os discursos processados na esfera pública não podem governar nem substituir a lógica interna da administração política e burocrática, mas apenas impactá-la por procedimentos que retirem dela sua legitimação, ou seja, por uma lógica que opere "como um sitiamento" (no original: ... “im Modus der Belagerung” einwirkt). ${ }^{40}$ A metáfora do autor baseada em fluxos comunicativos já começa a ser desenhada quando ele fala que, tendo em vista a impossibilidade de se substituir as lógicas sistêmicas do mercado e da burocracia em sociedades complexas, a questão se torna uma de equilíbrio de "formas de integração social" - e não de mera separação de poderes -, sendo a meta da democracia radical erguer uma barragem ou represa contra a invasão de imperativos sistêmicos no mundo da vida. ${ }^{41}$

\footnotetext{
${ }^{39}$ Por agora cabe apenas uma referência de seu debate com Nancy Fraser em que ele reconhece que mercados e poderes administrativos são facetas necessárias (ou incontornáveis) da vida em sociedades complexas e argumenta: “ [e]u não acredito que possa haver nenhum tipo de revolução em sociedades que têm tamanho grau de complexidade; de qualquer forma, nós não podemos voltar no tempo, inobstante todos os antimovimentos românticos (romantist antimovements). Para os acadêmicos, a revolução é uma noção do século 19”. (HABERMAS, 1994, p. 469). manner"”.

${ }^{40}$ HABERMAS, 1990, p. 44. A tradução do inglês é "it achieves impact on this logic 'in a siegelike

${ }^{41}$ HABERMAS, 1990, p. 36 (no original, o autor fala que a meta da democracia radical seria ,(...) die demokratische Eindämmung der kolonialisierenden Übergriffe der Systemimperative auf lebensweltliche Bereiche" ).
} 
Posteriormente, em 1992, respondendo às críticas de que seu modelo de esfera pública seria muito defensivo ou conservador (tanto em 1962 quanto em 1990), Habermas desenvolve um modelo mais "ofensivo" de esfera pública. A alusão aos fluxos comunicativos se mantém - e com ela a referência metafórica ao fluxo de águas de rios. Agora, entretanto, a metáfora da represa ou da barragem dá lugar à metáfora das "eclusas" ou "comportas" (Schleusen). ${ }^{42}$ Habermas trabalha com uma noção de um mundo da vida organizado por meio de uma grande rede de associações livres na sociedade civil que, na luta da esfera pública política pela formação de uma opinião pública poderiam influenciar o poder administrativo burocrático, ou melhor, poderiam traduzir poder comunicativo em poder burocrático. Aqui o caráter de "represa" ganha uma adição ofensiva: não se trata mais apenas de "segurar" o fluxo da colonização do mundo da vida por imperativos sistêmicos, mas gerar um momento de "contrafluxo" de poder comunicativo adquirido pela deliberação pública legítima que -por meio de processamentos na esfera pública - em redes associativas, associações, conversas em círculos literários, etc. - adquire intensidade suficiente, adentra os procedimentos políticos - administrativos e burocráticos - e os altera, os direciona e, em última instância, os "legitima", racionalizando o poder, "transformando o poder administrativo em poder comunicativo". É esse adensamento que caminha ao centro do poder político e passa pelas comportas ou eclusas do sistema político que Habermas atribui a nota central de sua teoria da esfera pública política. ${ }^{43}$

Temos, então, duas abordagens altamente abstratas sobre o conceito de esfera pública, levadas a cabo por dois autores que utilizam suas teorias da sociedade para explicá-lo, de modo que é possível afirmar que as descrições de ambos são indissociáveis de seus pressupostos teóricos abrangentes. Isso nos permite uma discussão teórica mais ampla que lide com dois grandes arcabouços teóricos tidos como duas das mais importantes teorias da sociedade moderna. Portanto, o debate sobre suas abordagens ao conceito que o presente trabalho propõe é travado no pano de fundo de dessas teorias.

As discussões teóricas com tamanha carga conceitual, contudo, poderiam deixar um trabalho cujo objeto é lidar com descrições contemporâneas da esfera pública se perder em discussões terminológicas. É por esse motivo que, ainda que a primeira parte se volte para considerações altamente teóricas de ambos os modelos e apresente as críticas mútuas entre

${ }^{42}$ HABERMAS, 2003c, p. 90, tendo o tradutor escolhido o termo "comportas". [no original, p.434]. Por sua vez, Jorge Adriano Lubenow utiliza o termo "eclusas" (LUBENOW, 2007). No decorrer do trabalho utilizo os dois termos de forma indistinta.

${ }^{43}$ HABERMAS, 2003c, pp. 90 e ss. 
eles, a segunda parte do estudo visa a desenvolver discussões que os utilizem e mobilizem, de forma a reconhecer seus limites e possibilidades.

Ainda que se ressalte, aqui, a importância de se tratar da esfera pública com um elemento teórico que reconheça seu caráter reflexivo - de "espelho"; parece ainda inegável que algum grau de influência política seja também visível, ou seja, o reconhecimento de que a esfera pública política exerce uma função de contrafluxo comunicativo direcionado ao centro do sistema político. É essa tensão entre as funções da esfera pública pensada como espelho e como contrafluxo que atravessa as comportas do poder político que guiará as análises desse estudo. As discussões são, então, travadas sob o pano de fundo dessas duas descrições paradigmáticas: entre eclusas e espelhos.

\section{Estrutura da dissertação}

Como vimos, a dissertação se estrutura em duas partes e um anexo. Na Parte I, que compreende os três primeiros capítulos, será desenvolvida a discussão teórica do conceito de esfera pública. Na Parte II, nos capítulos quatro e cinco, são discutidos temas contemporâneos sobre o assunto sob o pano de fundo das conclusões teóricas desenvolvidas no capítulo três no final da primeira parte do trabalho.

Com efeito, no âmbito de uma dissertação apresentada para um programa de mestrado, a formação teórica é importante. Daí o fato de a primeira parte ser mais extensa, com alguma consideração sobre os modelos teóricos de Habermas e Luhmann.

(I) No primeiro capítulo, apresentam-se alguns pressupostos da teoria social de Niklas Luhmann necessários para as discussões posteriores, trabalhando alguns elementos básicos de sua teoria da sociedade e sua incorporação da teoria dos sistemas. Não obstante o caráter introdutório deste capítulo, dispensável para leitores já iniciados em teoria dos sistemas, será desenvolvido um argumento sobre o "modo de aplicação" da teoria luhmanniana no presente estudo, ou seja, suas implicações epistemológicas. Nele, o método do funcionalismo radical e a abrangência da teoria social luhmanniana são destacados, servindo como pressuposto argumentativo de debates travados nos capítulos terceiro, quarto e quinto. Apresenta-se "a lente teórica" da sociologia de Luhmann pela qual a esfera pública será descrita.

(II) Em seguida, trata-se da colocação do problema da pesquisa e de sua descrição a partir da teoria de Jürgen Habermas. Para isso, em um primeiro momento, são expostas algumas linhas gerais do pensamento habermasiano para, posteriormente, apresentar sua 
teoria da esfera pública, com enfoque para seus textos de 1990 e 1992. Após essa exposição são apontados alguns "problemas" ou "gargalos" da teoria do discurso em abordar problemas contemporâneos da esfera pública por estudos que reconhecem algumas “dificuldades cognitivas" do modelo. É seguro dizer que a teoria habermasiana influenciou diversos estudos sobre o potencial emancipador da esfera pública e da "nova sociedade civil" de cidadania ativa na década de 1990. Entretanto, estudos posteriores apontaram problemas de diversas sortes nessa abordagem, tida como demasiadamente normativa. Esses problemas servirão de guia para encontrar pontos chave de tensão no modelo habermasiano da esfera pública e quais são as questões abertas para o debate. Isso é relevante tanto para a discussão teórica seguinte, a partir de uma releitura do debate a partir da teoria dos sistemas que seja direcionada para enfrentar as objeções levantadas contra a teoria habermasiana, quanto para preparação da Parte II do trabalho, em que questões mais substantivas serão analisadas.

(III) No terceiro capítulo apresenta-se propriamente a descrição da esfera pública a partir da teoria dos sistemas. Para isso é necessário um primeiro momento de explicação do funcionamento dos sistemas jurídico e político, bem como os conceitos de Estado Constitucional de direito e Estado de bem estar em Luhmann. Em seguida trabalha-se o conceito luhmanniano de esfera pública propriamente dito. Então, no final do capítulo, é realizada uma discussão comparativa com os problemas levantados no capítulo 2, a partir da qual o conceito luhmanniano é tensionado e aprofundado. Neste momento serão trabalhados estudos de comentadores da questão da esfera pública, com destaque para Marcelo Neves e Rudolf Stichweh.

(IV) O quarto capítulo inaugura a Parte II do trabalho. Nele são discutidas as consequências da mudança paradigmática na descrição da esfera pública a partir do modelo luhmanniano para debates atuais. O conceito delineado no capítulo terceiro, portanto, enfrenta diretamente os temas levantados no capítulo segundo, mas não mais por uma perspectiva teórica e sim pelo enfrentamento de fenômenos contemporâneos "novos". Em um primeiro momento, a questão da mídia (ou meios de comunicação em massa) é trabalhada a partir da descrição luhmanniana do funcionamento desse sistema. Em seguida, debate-se aa chamada "judicialização da política", em que tribunais constitucionais ganham proeminência no cenário público.

(V) O último capítulo apresenta, primeiro, a teoria luhmanniana dos movimentos sociais - ou movimentos de protesto - e sua relação com a esfera pública de uma sociedade 
complexa e funcionalmente diferenciada e discute, em seguida a o debate sobre a esfera pública mundial. Ele merece um espaço próprio de discussão devido ao grande interesse contemporâneo da academia - principalmente de origem alemã, onde os modelos de Habermas e Luhmann exercem maior influência.

(VI) Por fim, apresentam-se as conclusões do trabalho são expostas em espaço autônomo.

A escolha por anexar um artigo autônomo ao final da dissertação se justifica por diversos motivos. Em primeiro lugar, o artigo é um produto de diversas discussões com o orientador e em grupos de estudos e da apresentação de um trabalho no $35^{\circ}$ encontro da ANPOCS. Com efeito, os objetivos do mestrado não são apenas aquele do desenvolvimento de uma tese inovadora, mas também da discussão e do incentivo para a produção científica. Dessa forma, o anexo foi também um produto dos estudos da dissertação e pareceu ser pertinente introduzi-lo no corpo final do trabalho. Cumpre notar também que esse artigo compreendia um capítulo da dissertação no documento apresentado na banca de qualificação. Contudo, sugestões pertinentes da banca apontaram que ele detinha uma lógica interna própria e poderia se afastar do tema, motivo pelo qual ele foi radicalmente reestruturado e retirado do corpo da dissertação. Por fim, o artigo apresenta diversos "pontos de contato" com a dissertação. Em primeiro lugar, ele sustenta que a teoria dos sistemas pode "aprender" e se alterar a partir de debates empíricos, tese apresentada na introdução da dissertação e que justifica sua divisão em duas partes. Em segundo lugar, o debate sobre modos de inclusão na sociedade mundial moderna é diretamente relacionado com as discussões realizadas no capítulo 5. Com efeito, trabalhase uma sessão em que se analisam os pontos de contato entre o artigo anexo e a dissertação.

Cada capítulo conta com uma introdução e apresentação própria além de uma "conclusão parcial" ao seu final. A introdução dos capítulos apresenta a estrutura do argumento desenvolvido e apresenta os itens subsequentes. As conclusões parciais não são redutíveis a meros resumos do quer se discutiu no capítulo, mas envolvem discussões e argumentos relacionados com a hipótese de trabalho e com os capítulos anteriores e subsequentes. 


\section{Considerações sobre tradução, citações e notas}

As citações foram feitas no sistema "ano/data" para possibilitar maior número de referências. A escolha por um maior número de referências se justifica para possibilitar ao leitor maior chance de encontrar os trechos específicos citados e orientar suas pesquisas. Isso se justifica em um trabalho conceitual no qual a indicação do trecho específico onde se encontra a definição é necessária. Com isso, permite-se que o leitor possa questionar as interpretações adotadas comparando-as com os trechos citados por este estudo de maneira mais independente, podendo criticá-lo com maior praticidade. Como pesquisador principiante, considero que as referências em nota de rodapé auxiliam muito a pesquisa dos leitores. Por este motivo, esta dissertação traz um número considerável delas. Para tentar simplificar a leitura, evitando-se a "poluição visual", preferiu-se o modelo de citação referido, utilizando notas de rodapé.

As "ênfases" em itálico de trechos citados são sempre do original, salvo quando indico "ênfase adicionada" após a citação. Nas referências bibliográficas encontradas ao final do trabalho, as obras de Niklas Luhmann contam com indicação da data da publicação original entre colchetes, quando se utiliza versão traduzida.

Em todo o trabalho realizo a tradução livre de textos de língua estrangeira, citando a página do trecho citado ou parafraseado na versão lida. Por isso, se não há indicação, a tradução é sempre minha e livre. Esta escolha é pautada para tentar facilitar a leitura. Isso tem o problema de prováveis trechos que faltem com clareza ou precisão na tradução, principalmente quando vertidos do alemão.

No decorrer do trabalho, diversas obras em alemão foram trabalhas e citadas, contudo, não houve possibilidade de ler todas as obras no original. O curso de alemão se iniciou junto com o mestrado, em março de 2010. Por esse motivo, não há uma consistência na citação entre obras em alemão e em outras línguas, principalmente de textos de Niklas Luhmann, referência teórica central no trabalho. A regra geral é que, por óbvio, as obras sem tradução disponível foram lidas no original. Ainda assim, a leitura comparada de trechos relevantes de textos traduzidos com as obras na língua original auxiliaram a compreensão de alguns trechos, daí a possibilidade de apresentar algumas questões terminológicas entre parentes. Quando esse foi o caso, a referência do original consta na bibliografia.

Considerando que o trabalho é feito no âmbito abstrato e conceitual e lida com diversas posições de autores diferentes - principalmente no Capítulo III - julguei que uma 
redação em primeira pessoa do singular pudesse tornar a compreensão mais fácil e auxiliar a diferenciação de posições argumentativas e teóricas. Entretanto, o uso deste estilo de linguagem será mínimo, resguardado para momentos de argumentação em que é necessário distinguir o posicionamento do trabalho daquele de comentadores ou autores. Ainda que tal escolha seja heterodoxa na linguagem acadêmica, ela parece tornar a diferenciação de posicionamentos mais clara e facilitar o mapeamento de argumentos. Além disso, há precedentes da utilização deste estilo tanto em novas tendências acadêmicas quanto em publicações decorrentes de teses defendias na Universidade de São Paulo. 


\section{PARTE I}

\section{CAPÍTULO 1 - COM OS ÓCULOS DE LUHMANN}

\section{Introdução}

Ao se referir aos óculos ou às "lentes" de Luhmann ${ }^{44}$ busco apontar para o objetivo central deste capítulo, a saber: incorporar e compreender o referencial luhmanniano e seus objetivos principais para munir as discussões teóricas futuras que utilizarão o referencial teórico geral de Niklas Luhmann para discutir o conceito de esfera pública e os desafios deixados abertos para a macrossociologia no enfrentamento deste conceito. Daí a pergunta guia que abre este capítulo no item seguinte: "por que - e para quê - Luhmann”? Com este enfoque, trato de demonstrar as premissas e algumas linhas gerais de uma teoria recheada de pressupostos e axiomas, "difíceis de aceitar" e cujo "custo de entrada" é alto. Para isso, um momento preliminar de apresentação da linguagem teórica e dos objetivos metateóricos da teoria é indispensável. Além disso, sendo essa teoria uma teoria "grande" e com diversos pressupostos - como expresso pelas metáforas do "labirinto" e da "construção chanfrada"-, é necessário apresentá-la com cautela e demonstrar os pontos pelos quais ela pode se reestruturar e se redescrever após críticas e enfrentamentos de novos problemas. Aliás, o artigo anexo dessa dissertação mostra precisamente isso: que a teoria dos sistemas de Niklas Luhmann tem grande capacidade de se alterar com base em seus pressupostos gerais, revendo posições pontuais a partir de seus próprios conceitos. ${ }^{45}$ Luhmann sempre foi capaz de aprimorar e realizar "emendas" em sua teoria. Isso foi continuado por diversos comentadores, que vêm capacidade de realizar alterações aplicando variações da teoria nos mais desenvolvimentos nos mais diversos campos da dimensão social. Ao fazer isso, contudo, um esforço de adequação interna e de debate e reestruturação interna da coerência da teoria sempre é realizado: não são alterações desinteressadas que tomam o que foi tido

${ }^{44}$ A formulação é emprestada de forma livre do título "Pelos Óculos de Luhmann" que consta de recente obra coletânea sobre aplicações da teoria dos sistemas aos desafios da política e do direito na América Latina e na sociedade mundial.: Peter Birie, Mathias Dewey, e Aldo Mascareño (orgs). (2012) Durch Luhmanns Brille: Herausforderungen an Politik und Recht in Lateinamerika und in der Weltgesellschaft. Wiesbaden : Springen Fachmedien (obra não citada nas referências bibliográficas, pois cito apenas o título aqui).

45 Trata-se de se realizar um "trabalho de precisão conceitual" adequado para uma teoria abrangente da sociedade. Luhmann se insurge contra o descuido (carelessness) relativo a questões conceituais (LUHMANN, 1995b, p. xxxvii. "Instead of a Preface to the English Edition: On the Concepts 'Subject' and 'Action"'). 
antes com irrelevante - não se realizam alterações indiferentes à construção geral da teoria, ao seu passado, operando "sem pena nem glória". ${ }^{46}$ Isso impede interpretações e aplicações dogmáticas da teoria, precisamente o que busco me afastar neste trabalho.

De maneira clara, Marcelo Neves atesta essa característica de capacidade de alteração teórica interna realizada conjuntamente com um contínuo trabalho de consistência interna e conceitual da sociologia luhmanniana quando assevera: "[q]uando os luhmannianos dogmáticos superestimavam o conceito de legitimação procedimental, Luhmann passou a trabalhar com o conceito de autopoiese. Quando se superestimava a autopoiese, ele começou a dar ênfase à questão dos paradoxos. E quando os dogmáticos afirmavam, como Luhmann, que os direitos humanos não têm sentido, a não ser como direitos fundamentais constitucionalmente positivados, Luhmann, em face dos graves problemas de exclusão e de opressão no plano global, passou a sustentar que 'a crescente atenção para a violação dos direitos humanos constitui um dos indicadores mais importantes de um direito da sociedade mundial"".47

Ao demonstrar algumas das ideias básicas do autor, não pretendo uma introdução ou panorama exaustivo. Isso não seria possível nem desejável. O que se pretende é tratar dos pressupostos básicos que serão mobilizados de maneira livre nos capítulos da Parte II; nos quais há aplicação e discussão de conceitos e axiomas da teoria dos sistemas. Isso se justifica em um argumento de duas partes. Em primeiro lugar, sustento que a teoria geral de Luhmann é pressuposto para quaisquer de suas aplicações. Sua descrição da esfera pública é indissociável, portanto, de sua sociologia abrangente. Daí o "custo" de se trabalhar com Luhmann. Seu referencial é pesado, mas, se compreendermos os motivos pelos quais ele desenvolveu tamanho "monumento teórico", podemos perceber quais são seus eventuais frutos e ganhos heurísticos. Ademais, em um segundo momento do argumento, sabemos que Luhmann escreveu pouquíssimo sobre a esfera pública; tendo dela uma compreensão "quase negativa" em sua teoria. Isso, contudo, não é um problema de escolha do autor, pois, exatamente por se ligar com diversos pressupostos teóricos, Luhmann pôde desenvolver uma teoria sobre a esfera pública que é de extrema relevância para o debate sociológico hoje. Contudo, isso nos trás o ônus de - necessariamente abordar seu conceito de esfera pública à luz de outros de seus conceitos e discussões.

Com isso, dei preferência à sua teoria abrangente da sociedade e a algumas considerações metateóricas que o distanciam de teorias normativas - principalmente da

${ }^{46}$ Cf. termo cunhado por LAVALLE, 2003. Veremos essa formulação no Capítulo 2.

${ }^{47}$ NEVES, 2009c, p.273. 
tese da dupla integração da sociedade, como ocorre no modelo habermasiano. Ao assim proceder, preferi utilizar textos do próprio autor, evitando comentadores e glossários. A escolha buscou tanto marcar a pesquisa bibliográfica quanto tornar o argumento mais enxuto e passível de crítica por citar textos apenas de Niklas Luhmann. O uso de comentadores será guardado para diferenças de modelos de esfera pública que se valem de abordagens mais ou menos baseadas na sociologia Luhmanniana, ou seja, nos capítulos 3, 4 e 5. Contudo, isso não foi suficiente para deixar o capítulo curto, de modo que este primeiro capítulo é consideravelmente mais extenso que os demais. Isso se justifica por ser ele de caráter introdutório, de apresentação de definições e pressupostos teóricos. Seu objetivo é retirar o "peso conceitual" dos capítulos seguintes que poderão, então, se valer de axiomas e conceitos de maneira crítica sem necessidade de retomá-los, enfocando a discussão. A necessidade de lidar de forma conceitual com uma teoria tão cheia de pressupostos como é a de Luhmann fez com que este capítulo - que trata basicamente de definições - fosse mais longo e contasse com diversas e longas passagens citadas. Não parece ser interessante parafrasear apresentações de conceitos centrais da uma teoria, o que me levou a preferir, em diversos momentos, citações literais de definições do autor - ainda que longas.

Dei preferência para a teoria da sociedade de Luhmann. Apresento neste capítulo alguns conceitos que vão além do que normalmente se costuma atribuir à Luhmann; como se sua teoria fosse apenas uma dos sistemas de função autopoiéticos. Ao contrário, como se verá neste trabalho, a discussão sobre esfera pública implica mobilizar outras questões da teoria Luhmanniana.

Ao confrontar o modelo habermasiano de esfera pública que prevê "fluxos" comunicativos (modelo do "sitiamento" e das "eclusas"); é necessário demonstrar, em primeiro lugar, como Luhmann desenvolve um modelo único de integração social; sem haver possibilidade de interferência "de fora" da sociedade. Isso implica a necessidade de apresentar tanto sua noção da sociedade como sistema social todo abarcador quanto sua descrição da sociedade moderna como sendo policontextural. Ademais, por tratar a esfera pública de "mudanças na sociedade", a teoria da evolução em Luhmann precisa ser mais detalhadamente esboçada - o que implica explicar o funcionamento dos sistemas parciais da sociedade e a maneira pela qual eles se alteram e evoluem; ou sejam, lidam com questões estruturais da sociedade. Logo, são indispensáveis explanações sobre expectativas sociais (estrutura da sociedade) e do trato da "dupla contingencia". Ainda, 
lidar com a questão da esfera pública implica lidar com questões que envolvem interações e organizações - além dos com movimentos de protestos. Conceitos como "cultura política”, interações em bares, salões e círculos literários (como veremos no capítulo 2) são argumentos usualmente mobilizados para o tratamento da esfera pública. Por isso, é necessário desenvolver como Luhmann trata com estas questões de sistemas sociais que não são sistemas parciais de função. No mesmo sentido, algumas discussões metateóricas principalmente sobre o funcionalismo radical de Luhmann e a maneira pela qual o autor busca desenvolver uma teoria abrangente da sociedade pelo construtivismo radical sem "normativismo" - são indispensáveis ao se tratar de opor um modelo funcamentalmente normativo tal como o de Habermas com um modelo sociológico "cínico" (como dizem os comentadores) desenvolvido por Luhmann. Isso se relaciona questão de que a esfera pública, em si, é tratada pela tradição crítica de inspiração habermasiana de forma "legitimadora", passível de gerar uma crítica emancipadora de racionalização do poder e de combate à dominação. Por isso, algumas questões de se saber como a sociedade se altera para Luhmann (que foca antes a "morfogênese" do que a mudança radical ou revolucionária) são trabalhadas, ainda que a questão específica da comunicação da "negação da sociedade" seja deixada para o Capítulo 4, onde se discutirão os movimentos de protesto. Por fim, demonstrar claramente como Luhmann enxerga a modernidade e como se operam ideias e valores ("na evolução das ideias") será de extrema valia para os debates futuros, não apenas por contrapor ao modelo habermasiano de modernidade (de forte caráter normativo), como também para demonstrar como houve certa incorporação de pressupostos luhmannianos em alguns pontos da teoria habermasiana - discussões centrais para compreendermos os modelos de esfera pública desses dois autores.

Por estes motivos, o presente capítulo se estrutura da seguinte forma: (i) após esta introdução, (ii) o item 2 apresenta alguns objetivos e problemas característicos da teoria luhmanniana, buscando demonstrar os problemas pelos quais a teoria se estruturou. Tratase de considerações metateóricas que buscam demonstrar quais são os "ganhos" da teoria luhmanniana - e para onde eles podem ser dirigidos. Por óbvio, isso já deixa implícito que a teoria tem seus "pontos cegos" e, portanto, pode ser inútil para responder outros problemas ou questões formuladas de maneira diferente. (iii) $\mathrm{O}$ terceiro item é mais curto e trata de alguns pressupostos da teoria geral dos sistemas, principalmente dos desenvolvimentos das teorias dos sistemas autopoiéticos, para preparar o item posterior. (iv) Nele, o item mais longo do trabalho, é esboçada a teoria da sociedade luhmanniana, 
com ênfase em sua teoria da evolução da sociedade (e das ideias/semântica), além de caracterização da sociedade moderna. (v) Por fim, o quinto e último item discorrerá sobre a "metodologia" da sociologia Luhmanniana (tomada quase uma epistemologia): o funcionalismo radical. A partir dessa exposição é que se apresenta como Luhmann, por meio de sua análise funcional, pôde tratar de sistemas funcionais factualmente tão diferentes e heterogêneos apontando para estruturas e semelhanças e comparando-as. (vi) Ao final, são apresentadas as conclusões parciais do capítulo.

\section{Por que e para que Luhmann? Breves alertas metodológicos e metateóricos}

Uma pesquisa teórica interdisciplinar sobre o conceito de esfera pública e seu relacionamento com os sistemas político e jurídico na sociedade moderna a partir da teoria social de Niklas Luhmann é, necessariamente, um estudo abstrato - algo necessário para a teoria dos sistemas ${ }^{48}$. Não obstante, alguns estudos empíricos e de "médio alcance" serão abordados, principalmente devido ao esforço deste trabalho de - após delinear um conceito de esfera pública e de Estado de Direito e apontar as vantagens de tal conceituação - enfrentar debates contemporâneos interdisciplinares pertinentes ao tema. Portanto, além das discussões internas aos círculos luhmannianos de pesquisa, este estudo analisará questões postas por áreas como a teoria do Estado, teoria democrática, sociologia política etc. Temas tais como a influência da esfera pública em sistemas sociais, a "esfera pública do direito", a politização do judiciário, a formação de uma esfera pública internacional em uma sociedade civil internacional, a existência de novos movimentos sociais e "nova cidadania”, a mudança das relações entre Estado e sociedade civil, a permeabilidade do Estado para organizações da sociedade civil, o relacionamento esfera pública com os meios de comunicação em massa, novas formas de representação etc., serão trabalhados a partir do referencial teórico base e dos conceitos delimitados nos três primeiros capítulos.

Contudo, esse não é o final do argumento. O ponto de partida é também o ponto de chegada. Pretende-se aqui a realização de um movimento duplo: (i) primeiramente, realizase uma análise da problemática da esfera pública e de seu relacionamento com os sistemas sociais a partir da sociologia de Luhmann.. O enfoque, aqui, é o debate sobre um "fenômeno", uma problemática, no qual se propõe que a teoria social luhmanniana pode contribuir significativamente. (ii) $\mathrm{O}$ segundo momento, consiste em uma reflexão de como

\footnotetext{
${ }^{48}$ LUHMANN, 2005b, p 12 e ss.
} 
este movimento levanta questões relevantes para o desenvolvimento da pesquisa em teoria dos sistemas. Este momento reflexivo implica um retorno "crítico" 49 à teoria, trabalhando como o debate realizado pode apontar para problemas da teoria que merecem aprofundamento e discussão em um movimento que busca trazer à tona novas questões internas à teoria dos sistemas, ou novos posicionamentos em debates correntes.

Esse "duplo proceder" parte da premissa de que a teoria social de Niklas Luhmann apresenta um potencial de debate importante, que ultrapassa a restrição de "estudos de exegese". Luhmann pretende a criação de uma "teoria universal" do social, mesmo que não seja ela exclusiva. ${ }^{50}$ Para trabalhar a teoria sociológica "em crise" ${ }^{, 51}$ e dar-lhe unidade em um nível de abstração elevado, Luhmann desenvolve uma teoria complexa que visa a refletir a complexidade da sociedade moderna que busca descrever. ${ }^{52}$

Isso pode passar despercebido nos usos da teoria dos sistemas. A complexidade da teoria, com elementos provenientes de áreas pouco conhecidas no campo sociológico, muitas vezes é compreendida como característica que a torna "(inutilmente) complicada". 53 Por outro lado, pode ocorrer que, devido à sua "complicação" e referências teóricas incomuns, a teoria dos sistemas seja utilizada por seus comentadores de forma dogmática e não problematizada, sem adentrar debates sociológicos e de problemáticas teóricas relevantes, o que tornaria as análises luhmannianas excessivamente herméticas, exegéticas e com caráter (meramente) didático, ${ }^{54}$ como já notou muito bem João Paulo Bachur. ${ }^{55}$

Ora, uma das características mais instigantes da teoria dos sistemas é precisamente sua capacidade de inovar na discussão de temas mais abstratos da teoria social. Luhmann pode ser considerado "excêntrico" devido ao fato de que diversos elementos de sua teoria provêm de áreas incomuns ao campo sociológico. Todavia, as questões nas quais sua teoria apresenta contribuições radicais estão longe de ser incomuns. Ao contrário, Luhmann promove uma discussão direta com a maneira pela qual a sociologia responde suas questões mais abstratas, sempre com a preocupação de desenhar uma teoria que trabalhe com a questão da unificação do campo da sociologia. ${ }^{56}$

\footnotetext{
49 Aqui não se trata de teoria crítica da sociedade, mas antes um momento de reflexão e distanciamento da teoria (ver LUHMANN, 2005b, p.16).

${ }^{50}$ LUHMANN, 1995b, p. Xlvii e ss.

${ }^{51}$ LUHMANN, 1995b, p xlv, 2006, p, 11.

${ }^{52}$ LUHMANN, 1995b, p xlix-1.

${ }^{53}$ BOBBIO, 2007, p. 112.

${ }^{54}$ Não se desmerece a importância de abordagens didáticas aqui, muito pelo contrário. Contudo, notase que elas não devem ser a única preocupação dos estudiosos da teoria luhmanniana.

${ }_{55}$ BACHUR, 2010, p. 28 e ss.

${ }^{56}$ Ver LUHMANN, 1981b, p.195 e ss.
} 
Essa constatação, somada ao já mencionado caráter de "teoria universal (e não exclusiva) do social", permite reconhecer o potencial da teoria luhmanniana de não apenas criar uma análise abrangente - e uma descrição teórica, portanto - quase que "ponto-aponto" de todos os temas "abstratos" de ciência social, mas também de impulsionar discussões de teoria social em diversas perspectivas - e não apenas perspectivas luhmannianas, nem mesmo apenas em sociologia "geral". Notar isso é de destacada importância para os objetivos desta pesquisa, dentre os quais se encontra a tentativa de contribuir para a progressão do debate teórico com a "abertura" de novas questões. Partese, então, da premissa de que não apenas a teoria dos sistemas pode contribuir muito para o debate sobre a noção de esfera pública e seus temas conexos, mas também que o enfrentamento deste tema pode trazer questões relevantes para a teoria dos sistemas. É por isso que este trabalho realiza um "duplo teste" da teoria dos sistemas, discutindo se (a) ela pode contribuir para a discussão sobre a esfera pública, e (b) se ela resiste a este enfrentamento sem necessidades de revisão ou de maiores discussões internas à teoria.

A escolha do campo em que este duplo teste é realizado, por sua vez, não é inocente. As discussões sobre esfera pública configuram um campo consolidado (ainda que plural) e permeado por teorias críticas e emancipadoras da democracia e do Estado, além de contar com diversas pesquisas empíricas orientadas por estas teorias ou por outras teorias de médio alcance. A grande variedade de temas de análise vinculados às pesquisas sobre esfera pública permitem uma gama de abordagens diversas do tema: crise do Estado, movimentos sociais ou de protesto, participação da "mídia" ou meios de comunicação em massa, relacionamento com a política, influências no direito, apenas para citar alguns exemplos. Além disso, encontram-se aí diversas disputas conceituais de termos cujo uso passou por um processo notável de ampliação de significado nas décadas de 1980 e 1990, tais como sociedade civil, esfera pública, opinião pública, cidadania, participação, representação política, movimentos sociais, associações civis, grupos de interesse etc.

Essa pluralidade de abordagens e de disputas conceituais, por si só, já constituem um atrativo para uma teoria com pretensões tais como as da teoria dos sistemas. Entretanto, o que torna este campo mais interessante para a realização deste exercício de "duplo teste" é o fato de que ele é rico em críticas à teoria dos sistemas, seja por uma questão de perspectiva - por sua incapacidade de permitir análises primariamente normativas ou críticas no sentido de emancipação social -, seja por divergências na descrição de questões sobre a esfera pública ou sobre as noções de Estado de Direito, de política e de direito. A 
provocação (além o exercício de aprendizado teórico) que se pretende é, portanto, a de "tensionar" a teoria luhmanniana precisamente em um dos campos em que ela parece ser menos frutífera e mais criticável.

Isso parece ser particularmente interessante, pois, como este estudo pretende demonstrar, a pretensão legitimação da mudança social que é própria das teorias críticas e dos debates de teorias da democracia que têm caráter primariamente normativo, tende a gerar, por óbvio, "leituras normativas" da teoria dos sistemas. Isso é algo extremamente válido e necessário a partir da perspectivas destas teorias, orientadas para justificações de determinados modelos de democracia e de propostas de emancipação social. Não se nega aqui, de maneira alguma, a importância de tais movimentos teóricos.

Contudo, cabe notar que estas leituras - válidas e muito importantes, convém repetir - deixam de reconhecer a ênfase abstrata mais interessante da teoria de Luhmann e tendem a criticá-la por justificar modelos de democracia determinados, o que ela manifestamente se julga incapaz de fazer. Do ponto de vista da teoria democrática, sugerese por vezes que Luhmann defenderia normativamente uma concepção democracia elitista, agonista e estática. ${ }^{57}$ Do ponto de vista da teoria do direito e da dogmática jurídica, uma leitura semelhante permite a utilização da teoria dos sistemas para se justificar determinados modelos de Estado e, inclusive, posições dogmáticas acerca de quem deveria ou não ser incluído como "sujeito de direito" em determinado Estado. ${ }^{58}$ Ambas as visões, portanto, enquadram a teoria dos sistemas em uma lente normativa, o que parece ser, no mínimo, algo pouco frutífero se partirmos do ponto de vista da teoria dos sistemas. ${ }^{59}$

${ }^{57}$ P. ex. URBINATI E WARREN, 2008, p. 392, que desenham a figura de "democratas 'realistas' e 'elitistas' no estilo de Schumpeter e Luhmann", denotando com o termo 'democratas' (democrats) uma nota normativa carregada.

${ }^{58}$ Este é o caso de Gunter Jakobs em sua teoria do direito penal do inimigo, a que se atribui influência da sociologia de Niklas Luhmann. Para uma provocação crítica do uso da teoria dos sistemas como ratio decidendi para justificar tomadas de posições dogmáticas, ver CORREIA E RIBEIRO, 2011.

${ }^{59} \mathrm{O}$ mesmo ocorre com críticas que fazem leituras descritivas de teorias primariamente normativas. Logo, análises que visam refutar teorias normativas apenas por realizarem elas análises "demasiadamente normativas" (ou até romantizadas) com "baixo potencial explicativo" poderiam incorrer no mesmo problema. Em certa medida, apesar do cuidado dispensado a esta questão, pode-se reconhecer que tal simplificação será inevitável neste trabalho, principalmente quando forem apresentadas algumas críticas pontuais às teorias do discurso nos capítulos 3, 4 e 5. O argumento básico é que, não obstante este "problema irreconciliável" de perspectiva entre teorias normativas e positivas, os debates e as discussões que irritem uma e outra são, por sua vez, muito frutíferos; mesmo que não seja possível uma "síntese superadora" do debate. Pode-se afirmar, em consonância com Adrian Gurza Lavalle (comunicação pessoal em aula), que as teorias normativas apresentam primariamente pretensão de legitimação e buscam ter plausibilidade, algo de natureza distinta de teorias positivas ou descritivas que trabalham primariamente com questões explicativas e cognitivas. 
As teorias primariamente normativas são, neste sentido delimitado, irreconciliáveis com teorias primariamente descritivas. ${ }^{60}$ Cada uma tem seus "pontos cegos", por assim dizer, havendo grande possibilidade de utilização de modelos (injustamente) simplificados de teorias de perspectiva diversa. Porém, o debate é importante e parece salutar para a discussão em todas as perspectivas e em suas "zonas de penumbra", ainda que uma síntese final pareça ser impossível. ${ }^{61}$ Este alerta metateórico é importante para este estudo de modo que alguns mal-entendidos sejam evitados. Este cuidado do presente trabalho em proceder destacando níveis de análise e perspectivas metodológicas é necessário para que não se pense que se busca aqui um "modelo institucional" ou ainda uma proposta do que “deve ser" a esfera pública. A pretensão de legitimar modelos de democracia, quaisquer que sejam eles, é ausente neste estudo. Talvez por seu caráter "inicial” em sede de uma dissertação de mestrado, ou mesmo pela sua circunscrição em uma teoria tal qual a de Luhmann, este movimento seja impossível. Contudo, é muito importante ressaltar, mais uma vez, que outras perspectivas são possíveis.

Somado ao problema da perspectiva metodológica descrito acima encontramos um problema de nível de observação que com ele se confunde. Cabe perguntarmos, como sempre alerta Luhmann, pela questão da posição da observação.

Tratamos brevemente de como a teoria democrática e a dogmática jurídica fazem leituras da teoria dos sistemas para lidar com questões que ela mesma afirma ser incapaz de tratar. Ambas estão ligadas a um plano em que a auto-observação do sistema choca-se com hetero-observações desse mesmo sistema. Enfim, pode-se sustentar que elas o fazem a partir de uma auto-observação do sistema - uma observação de primeira ordem, - uma vez que estão ligadas a problemas funcionais específicos de cada um de seus sistemas. Em primeiro lugar, teorias da democracia precisam trabalhar com conceitos normativos de democracia, seja conceitualmente, seja em caráter normativo mais forte, já que um modelo de democracia mostra-se necessário para ser contraposto a modelos autocráticos, devendo ele ser defensável teoricamente. Ao mesmo tempo, busca-se, portanto, um conceito de democracia que seja "melhor", "mais defensável” e mais legítimo. Toda discussão acerca

${ }^{60}$ É claro que não existem teorias puramente descritivas nem puramente normativas. Existem preocupações primárias de ambos os lados. Sempre há a necessidade da descrição de algo ao qual se apresenta um prognóstico de mudança frente a algum critério contrafactual. Por outro lado, é possível afirmar que descrições da sociedade dificilmente escapam de "efeitos colaterais normativos" (agradeço aqui a contribuição de Marcelo Neves em comunicação pessoal).

${ }^{61}$ Niklas Luhmann tem uma abordagem incisiva da questão, afirmando que a pergunta de saber se uma teoria é "crítica" ou "afirmativa" é uma interpretação (Darstellung) Frankfurtiana. Para o autor a teoria dos sistemas não persegue de maneira central nenhuma ideia normativa ou idealizada, mas, apesar disso, ela é crítica (LUHMANN, 2005b, p. 16). 
do modelo de democracia passa por uma questão de legitimidade democrática deste modelo. Neste sentido, poderíamos pensar que a teoria democrática encontra-se no nível mais abstrato de autodescrição do sistema político ${ }^{62}$ (moderno e democrático).

Por seu turno, análises de dogmática jurídica não podem criticar a validade abstrata do ordenamento jurídico de referência e estão vinculadas à questão da decidibilidade dos tribunais, para os quais exercem função de prover critérios de decisão, organizando e pondo em relação os programas do sistema. Elas orientam os tribunais a decidirem todo tipo de questões, traduzindo pressões e demandas sociais sempre em termos jurídicos. Assim, a dogmática jurídica encontra-se, portanto, no nível de autodescrição mais abstrato do sistema jurídico ${ }^{63}$. Ali ela serve de ponto de referência para o sistema, pois, em sua "fronteira", ela encontra-se na tensão entre adequação social e consistência jurídica, entre a pretensão de autonomia do sistema jurídico e a irritações de outros sistemas para a adequação do direito às suas pretensões. Este paradoxo é constitutivo do direito, sistema que deve ao mesmo tempo ser adequado à sociedade nas pretensões desta por prestações jurídicas sem, contudo, perder sua identidade e autonomia. Esta questão aparece para o sistema como uma questão de justiça. Uma comunicação jurídica, uma decisão, que faça interpretações "legalistas" de maneira rígida e seguindo os ditames da segurança jurídica e da autonomia do sistema - elementos que dão ao sistema sua identidade -, poderá ser considera injusta do ponto de vista de pretensões dos sistemas sociais que se encontram no ambiente do sistema jurídico. Ao contrário, um sistema que sempre se adéqua aos ditames que as pressões por adequação social lhe impõem, perde seu caráter normativo ${ }^{64}$ e com isso sua identidade, e passa a tomar decisões que podem ser consideradas injustas, por serem não-isonômicas, não jurídicas, e carecerem de caráter jurídico, perdendo consistência na tomada de decisões jurídicas, ${ }^{65}$ - ou sua "justiça formal".

Interessante notar que as descrições de legitimidade e justiça luhmannianas têm o mesmo status em sua teoria da sociedade, a saber: são termos referentes às fórmulas de contingência do sistema político e jurídico, respectivamente. ${ }^{66}$ Ora, tanto as teorias

\footnotetext{
${ }^{62}$ Importante precisar que Luhmann não afirma isso. A análise, neste ponto, é minha.

${ }^{63}$ LUHMANN, 1983c, esp. pp. 95 e ss e 109 e ss. Para um discussão, ver CORREIA e RIBEIRO, 2011.

${ }^{64}$ LUHMANN, 1983c, esp pp. 109 e ss.

${ }^{65}$ LUHMANN, 2005a, p.289.

${ }^{66}$ Abordo o conceito de fórmula de contingência com maior precisão no Capítulo 3. As fórmulas de contingências põem o sistema em movimento de forma paradoxal, uma vez que os sistemas parciais se identificam pela busca da solução de um problema que lhes é inalcançável. É o caso da justiça no direito, da escassez na economia e da legitimidade na política, por exemplo (LUHMANN, 1983c).
} 
democráticas (que se preocupam com a legitimidade de modelos de democracia), quanto preocupações primariamente jurídicas e dogmáticas (que se vinculem com a questão da justiça no âmbito do direito), estão mais proximamente ligas às autodescrições dos sistemas político e jurídico, respectivamente. ${ }^{67}$ Este trabalho, inserido na perspectiva da teoria dos sistemas, não está orientado primariamente por nenhuma destas questões, pelo menos não por uma observação de primeira ordem tais quais as realizadas pela teoria democrática e pela dogmática jurídica. A intenção aqui é realizar uma observação de segunda ordem. Reconhecer isso não é, de forma alguma, afirmar que se faz uma descrição "melhor" ou "mais próxima da realidade". Observações de segunda ordem não "auxiliam" o funcionamento dos sistemas parciais. Elas não são primariamente programas da política, não orientam o código "governo/oposição"; nem do direito em seu "lícito/ilícito", nem no funcionamento da arte na atribuição "belo/feio". ${ }^{68} \mathrm{O}$ intuito deste alerta é antes o de precisar a perspectiva da qual se parte no estudo.

Este esforço aqui realizado busca delimitar a perspectiva da dissertação. Um estudo interdisciplinar, como o que aqui se apresenta, pode gerar muita confusão caso sua perspectiva não seja bem estabelecida e diferenciada. Como bem ressalta Marcelo Neves, a disciplinaridade é uma condição da interdisciplinaridade. ${ }^{69}$ Caso a abordagem de um estudo desta sorte não seja bem delimitada, incorre-se no risco do "ecletismo". ${ }^{70}$ Portanto, na busca de se evitar o "ecletismo inconsistente", alguma unidade é necessária. Essa unidade pode decorrer de características do campo adotado, de uma disciplina ou mesmo da problemática escolhida.

\footnotetext{
${ }^{67}$ Esta aproximação da teoria democrática com a questão da legitimidade, circunscrevendo-a no nível mais abstrato do sistema político é uma tentativa do presente trabalho de aproximar o argumento que Luhmann desenvolve sobre a dogmática jurídica e o sistema jurídico. Da mesma forma que a dogmática jurídica seria diferente da teoria do direito, a teoria democrática estaria em outro nível de observação da teoria política mais abrangente. Nota-se, não obstante essa semelhança no nível de observação, que a dogmática jurídica parece estar muito mais operacionalmente vinculada ao sistema jurídico do que a teoria democrática para o sistema político.

${ }^{68}$ De maneira interessante e expressa, Luhmann afirma que sua teoria não pretende auxiliar o julgamento ou a criação de obras de arte. Ele afirma não oferecer uma teoria da arte que seja útil neste sentido. Todavia, "isso não exclui a possibilidade de que o sistema da arte, em suas próprias operações, pode se beneficiar de um esforço teórico de clarificar o contexto e a contingência da arte de uma perspectiva social-teorética. Saber tal transposição de insights pode ser realizada e quais tipos de mal-entendidos podem contribuir para seu sucesso deverá ser decidido dentro do próprio sistema da arte, uma vez que "ter sucesso" pode apenas significar ter sucesso como obra de arte" (LUHMANN, 2000b, p. 3). O que ocorrem são "irritações" recíprocas, devendo a teoria social ser irritada pela arte - mas com sua prova sendo produzida pela ciência. Isso vale para a observação sociológica dos outros sistemas parciais da sociedade (Para um argumento semelhante no sistema jurídico, ver CORREIA E RIBEIRO, 2011.).

${ }^{69}$ NEVES, 2005a, p. 211.

70 Para uma definição do ecletismo como "uso de conceitos fora de seus respectivos esquemas conceituais e sistemas teóricos, alterando seus significados”, ver OLIVEIRA FILHO, 1995, p 263.
} 
A unidade buscada neste trabalho não parte, pois, da disciplinariedade proveniente da Teoria (geral) do Estado, mas trata-se antes de estudo interdisciplinar de teoria sociológica de questões pertinentes à teoria do Estado - ou de um estudo de sociologia do Estado, se assim se quiser. A questão da unidade da sociologia ${ }^{71}$ é colocada em termos muito abstratos pela "superteoria",72 dos sistemas. Luhmann sustenta que é uma problemática $^{73}$ (Problemstellung) que constitui a unidade da sociologia como teoria social: a pergunta sobre a possibilidade do social, ou "como a ordem social é possível". ${ }^{74} \mathrm{~A}$ colocação desta unidade em um âmbito tão abstrato ou macrossosiológico ${ }^{75}$ é interessante para um estudo interdisciplinar como este, pois permite a "entrada" das análises sociológicas em uma gama enorme de discussões e temas. Portanto, a "unidade guia" da presente pesquisa constitui-se no nível da teoria (sociológica dos sistemas) e da metodologia (do funcionalismo radical). ${ }^{76}$

Entender este ponto, que a abordagem da questão da esfera pública será compreendida a partir de uma teoria da sociedade abrangente, é muito importante para se evitar alguns equívocos comuns. Em primeiro lugar, cumpre notar que Luhmann não é um teórico da política, nem do direito, ${ }^{77}$ nem do Estado. ${ }^{78}$ Isso não quer dizer que ele careça de

${ }^{71}$ Luhmann afirma que têm dificuldade de indicar a unidade de seus objetos, e trata do problema de designar a unidade do objeto das disciplinas com um conceito científico (LUHMANN, 1997a, p.75).

72 LUHMANN, 1995b, p, 4, onde Luhmann afirma que as superteorias seriam teorias com pretensão de universalidade (ou seja, de incluir a si própria e seus oponentes).

${ }^{73}$ Para distinção entre problema e problemática ver RIBEIRO, 2009a, p. 34, nota 60.

${ }^{74}$ LUHMANN, 1981b, p. 195, em que o problema constituinte da disciplinaridade sociológica como "teoria do social" não se caracteriza porque a palavra "social" é delimitada em seu conteúdo semântico, mas antes porque ela se relaciona sobretudo com a possibilidade da socialidade (Möglichkeit von Sozialität). Isso vincula-se não apenas com a diferenciação da ciência na sociedade moderna, mas também com o fato de que "tão logo uma disciplina não é mais constituída sobre objetos (ou sobre uma forma de pensar relacionada a objetos - Gegenstandsarten), nem mais sobre um corte do mundo real, mas antes constitui-se sobre uma problemática (Problemstellung), ganha ela caráter universal.(...) Unidade, universalidade e delimitação requerem um determinado estilo reflexivo, em que relaciona a problemática de volta sobre si mesmo (auf sie selbst zurückbezieht)" (idem,p. 196).

75 Ao trabalhar sobre o sistema pedagógico da sociedade, Luhmann se enquadra dentro do campo "macrossociológico" de forma textual para se diferenciar de teorias específicas da pedagogia (LUHMANN, 2002a, p. 13).

${ }^{76}$ Luhmann afirma que o funcionalismo não é apenas uma metodologia, mas chega a obter o status de uma Epistemologia ou "clama por ser uma epistemologia" (LUHMANN, 1995b, p. 57).

${ }^{77} \mathrm{O}$ autor deixa isso claro em diversos momentos. A corrente afirmação de que Luhmann seria um "sociólogo do direito" parece desconhecer o ponto fundamental da abordagem luhmanniana como uma teoria abrangente da sociedade. Isso é expresso já no prefácio de sua obra mais compreensiva sobre o direito, "O Direito da Sociedade", em que Luhmann afirma que o contexto de suas investigações é o de uma teoria da sociedade e não "o de uma determinada seção de uma sociologia especial que obtém seu nome graças às seções das sociedades que se fazem na sociologia ou em cursos que as separem”. A seleção de sua descrição do direito é uma parte constitutiva da teoria sociológica (LUHMANN, 2005a, p. 57).

${ }^{78}$ Marcelo Neves e Rüdiger Voigt (NEVES E VOIGT, 2007b, p.9) sustentam que a "teoria dos sistemas de Niklas Luhmann não se trata estritamente de uma teoria do Estado, mas antes de uma teoria da sociedade, a saber, uma teoria da sociedade mundial (Weltgesellschaft). No entanto, existe em Luhmann uma compreensão acerca do Estado (Staatsverständnis), de acordo com a qual não há espaço para a tese liberal da 
uma compreensão e de uma descrição destes âmbitos da sociedade, mas antes que estas descrições devem ser compreendidas no contexto de sua teoria da sociedade. Para compreender a abordagem luhmanniana destes fenômenos sociais, é importante notar sua estratégia de abstração. A abstração é - "seja para o bem ou seja para o mal" -, uma estratégia de redução de complexidade, além de ser uma "necessidade epistemológica" para a teoria dos sistemas. ${ }^{79}$ Ela lida com problemas específicos da construção de teorias. Isso fica claro em uma perspectiva funcionalista que baseia suas análises no par oposição "problema/solução do problema" 80 para a descrição do funcionamento da sociedade e de seus sistemas. Levar a perspectiva funcionalista luhmanniana a sério, destacando suas principais características, é outro pressuposto metodológico necessário para as discussões deste estudo.

Com isso fica claro que uma apresentação geral ou introdutória da sociologia de Niklas Luhmann se faz necessária para embasar o presente estudo. Entretanto, cumpre notar que uma teoria complexa como a luhmanniana apresenta algumas dificuldades de apresentação, principalmente por ser uma teoria "não-linear".

Luhmann desenvolve uma teoria "policêntrica (e conseqüentemente policontextural) em um mundo e em uma sociedade concebidos acentricamente". Sua teoria não é apenas uma estrita correspondência ponto-a-ponto entre "conceito e realidade", de modo que a teoria desenvolve complexidade própria adequada para organizar a obtenção de conhecimento. Neste processo, "por um lado, uma referência à realidade precisa ser salvaguardada. Por outro, entretanto, a ciência, especialmente a sociologia, não deve permitir ser enganada $\left(\right.$ duped $\left.^{81}\right)$ pela realidade. Visto dessa forma, a abstração é uma necessidade epistemológica". ${ }^{82}$ Portanto, sua teoria é marcadamente nãolinear e sem centro. Luhmann compara o desenho de sua teoria a um labirinto, em detrimento de uma "estrada para o pôr do sol". 83

Este "caráter labiríntico" ganhou espaço nos comentadores da teoria luhmanniana. João Paulo Bachur, por exemplo, apresenta sua provocativa versão da metáfora do labirinto, alertando para a questão de que alguns comentadores "vagam indefinidamente pelas galerias conceituais que compõem o labirinto" sem notar que Luhmann não apenas

separação do Estado e da sociedade". Os autores apresentam, então, três concepções de Estado desenvolvidas por Luhmann em momentos diferentes.

${ }^{79}$ LUHMANN, 1995b, p, li.

${ }^{80}$ LUHMANN 1995b, p. li.

${ }^{81} \mathrm{O}$ texto foi lido em sua tradução para o Inglês.

${ }^{82}$ LUHMANN, 1995b, p.li

${ }^{83}$ LUHMANN, 1995b, p. lii. 
pretende a "reconceitualização da tradição sociológica e [que] sua teoria de sistemas não é mero catálogo conceitual. [Mas que] [s]eu propósito é inteiramente outro. Na verdade, nosso autor se ocupa da questão crucial da teoria sociológica, a saber: como a ordem social é possível?". 84 Também é o caso de Ignacio Izuzquiza que, como muitos, compara o "o esforço do conceito" de Hegel ao proceder teórico conceitual abstrato de Luhmann. Izuzquiza argumenta que Luhmann desenvolve uma "crítica escandalosa" à tradição sociológica, ${ }^{85}$ utilizando linguagem abstrata e conceitual para tratar da "abstração da novidade". Com isso, ele sustenta que a sociologia luhmanniana "obriga a pensar o novo, seu próprio tempo" e recorda que o excessivo respeito [aos clássicos] pode se caracterizar como um freio ao pensamento. Este "compromisso com o dinamismo" faria com que Luhmann "jogasse luz" sobre o objeto, a sociedade, apontando para "temores ocultos", o que faria de Luhmann "um profeta odiado". Para o autor, Luhmann teria transformado os "antigos labirintos de perdição" da sociologia clássica em "labirintos de cristal", "[1]abirintos onde seque existindo a possibilidade de se perder, mas em qe a estrutura da perdição é, cada vez mais, transparente. Isto é um labirinto de cristal: o labirinto perde, mas o cristal permite ver porque existe a perdição". ${ }^{86}$

Por sua vez, é interessante notar o posicionamento de Orlando Villas Bôas Filho que traz a metáfora da "construção chanfrada" como uma outra possibilidade de se descrever esse caráter labiríntico para a teoria dos sistemas. Com ela temos uma metáfora que trabalha de modo mais específico a estrutura interna de construção intrincada da teoria luhmanniana, ressaltando sua faceta de "múltiplas entradas" de forma bem sucedida. Villas Bôas Filho afirma que o pensamento luhmanniano, "inovador e multifacetado", implicaria em uma "construção entalhada de tal maneira que cada faceta sua permitiria ver, ainda que de modo fugaz e nebuloso, o seu todo". 87

O próprio Luhmann reconhece essa faceta múltipla de sua teoria, que poderia ser acessada por diversas "portas" diferentes, quando afirma: "[a] teoria da sociedade que tenho em mente poderia ser escrita a partir da teoria dos sistemas, ou da teoria da evolução,

\footnotetext{
${ }^{84}$ BACHUR, 2010. p. 28-29.

${ }^{85} \mathrm{E}$ argumenta que "somente quem sinta dor pelas consequências a que Luhmann chega poderá entender esta ruptura” (IZUZQUIZA, 2008).

${ }^{86}$ IZUZQUIZA, 2008, pp. 303-316.

${ }^{87}$ VILLAS-BÔAS FILHO, 2006, p. 257-258. Aqui, o autor alude a uma das "antologias críticas literárias" de Jean-Paul Satre, que teria se referido à obra do poeta Francis Ponge como uma apresentação de construções chanfradas. Por cada faceta poder-se-ia ver o objeto por inteiro, mas, a cada vez, por um outro ponto de vista. É a partir desta alusão que Villas-Bôas Filho apresenta sua interessante metáfora da teoria luhmanniana, trabalhando nesta obra a questão do paradoxo da auto-referência como uma via de acesso ao universo teórico (mas não como a única possível).
} 
ou da teoria da comunicação, ou a parir de teorias sobre o sentido e a auto-referência. Cada entrada, cada início, é onerado com pressuposições não explicitáveis, e por conta disso ela seria muito pouco compreensível para quem apenas lesse o texto seqüencialmente. O leitor pode verificar se as orações estão gramaticalmente corretas, mas não pode perseguir as opções da teoria, as quais estão no seu fundamento" 88

Reconhecer essa "estrutura chanfrada" da teoria parece ser muito frutífero para uma explanação tal qual a que é realizada neste capítulo. Isso, pois ela deixa clara a nãolinearidade da teoria, bem como sua necessidade de integração interna, juntamente com seu caráter multifacetado que opera como uma rede interligada de conceitos abstratos. ${ }^{89}$

Em seu curso de introdução à teoria da sociedade (Einführung in die Theorie der Gesellschaft), Luhmann apresenta sua intenção ("fácil de formular, mas difícil de realizar"): sua ideia é que uma teoria da sociedade moderna é necessária e essa sua obra ${ }^{90}$ tentará por tal teoria em movimento. Luhmann apresenta, aqui, um "mapa dual" de sua teoria da sociedade combinando dois aspectos: (i) uma perspectiva "histórica", na descrição da sociedade como "moderna" (em oposição à tradicional), ${ }^{91}$ e (ii) uma perspectiva interdisciplinar abstrata, usualmente marcada com a palavra-chave "teoria dos sistemas". Estes dois aspectos abstratos, em relação de interdependência, parecem oferecer uma boa entrada para a teoria de Luhmann para os fins do presente trabalho, que pretende analisar a questão da esfera pública na sociedade moderna complexa.

Ao tomarmos este "mapa dual" apresentado por Luhmann, temos que o "aspecto histórico" - cujo termo é um pouco vago - trata na verdade da abordagem luhmanniana sobre a sociedade moderna, e suas especificidades. Por outro lado, o aspecto conceitualabstrato parte de uma adaptação de elementos da teoria dos sistemas para a sociologia. Além destas duas "facetas", encontramos uma terceira que também é relevante para este estudo: a teoria do funcionamento dos sistemas (parciais) funcionais da sociedade.

No prefácio de seu livro (“A arte da sociedade" - Die Kunst der Gesellschaft ${ }^{92}$ ), Luhmann sustenta que sua teoria da sociedade pressupõe "duas abordagens, assumindo que: (1) o sistema como um todo é operativamente fechado na base da comunicação, e que

\footnotetext{
${ }^{88}$ LUHMANN, 2002b, p. 55.

${ }^{89}$ LUHMANN, 2005b, p.14., onde Luhmann refere-se a não-linearidade de sua teoria como uma "rede" (Netzwerk) sempre com a introdução de conceitos abstratos e novas diferenças.

${ }^{90}$ Trata-se de um curso - Vorlesung - transcrito em livro.

${ }^{91}$ LUHMANN, 2005b, pp.11-12. A distinção "sociedade moderna/sociedade tradicional" não indica qual a especificidade da sociedade moderna, sendo necessários outros desenvolvimentos. Veremos isso com a teoria da "evolução da sociedade" em Luhmann.

92 Aqui citado em sua tradução para o Inglês: “Art as a social system” (LUHMANN, 2000b).
} 
(2) os sistemas funcionais emergindo dentro da sociedade conformam-se ao princípio do fechamento operativo, incorporando-o, e, portanto, irão exibir estruturas comparáveis apesar de diferenças factuais entre eles". ${ }^{93}$ Desta maneira, "a unidade da sociedade não é buscada em demandas ético-políticas, mas antes na emergência de condições comparáveis em sistemas tão diversos como a religião e a economia monetária; a ciência e a arte; as relações íntimas e a política - não obstante as extremas diferenças entre as funções e os modos operacionais destes sistemas". ${ }^{94}$ Como já havia dito Luhmann na obra que serve de "introdução" às pesquisas dos sistemas parciais da sociedade: "uma teoria deve tornar comparações possíveis". 95

No presente estudo, considerando o caráter de "construção chanfrada" da rede de conceitos abstratos da teoria luhmanniana, qual a "faceta" que funcionará como porta de entrada para a teoria? Como o objeto do estudo é o conceito de esfera pública e sua relação específica com os sistemas político e jurídico, parece interessante centrar as análises na teoria da sociedade luhmanniana e sua evolução, em termos gerais. Para isso, como pressuposto básico e sumário, é necessário trabalhar anteriormente os pressupostos que o autor trouxe da teoria geral dos sistemas e, por fim, partir para sua descrição dos sistemas funcionais da sociedade e suas estruturas comparáveis ${ }^{96}$. Com isso, as comparações entre estes sistemas ficarão mais claras e mais embasadas. Prefiro uma análise "dedutiva" a uma "indutiva", pois argumento que análises "setoriais" de uma teoria complexa e interligada como é a Luhmann podem perder de vista suas considerações teóricas mais relevantes e gerais. A mera descrição de sistemas parciais me parece indissociável das pretensões teóricas mais abrangentes de sua teoria. Isso é ainda mais relevante quando o objeto de estudo implica trabalhar o relacionamento de diversos subsistemas parciais - como é o caso

${ }^{93}$ LUHMANN, 2000b, p.1., onde o autor atenta para a necessidade da análise de "sistemas funcionais tomados individualmente".

${ }^{94}$ LUHMANN, 2000b, p.2.

95 LUHMANN, 1995b, p. xlv. (ênfase adicionada). Esta obra, Social Systems foi originalmente publicada como Soziale Systeme em 1984. Luhmann afirmou expressamente que ela funciona também como uma introdução aos estudos dos sistemas parciais da sociedade (in LUHMANN, 2000b, p.2).

${ }^{96}$ Outras "entradas" seriam possíveis. Isso pode ser visto nos felizes exemplos a seguir. A escolha de Orlando Villas Bôas Filho de lidar com a questão epistemológica do paradoxo da auto-referencialidade na teoria de Luhmann se debruça sobre uma faceta interessante para comparações de cunho filosóficoepistemológico da auto-referência trabalhadas com outros autores, como Foucault e Habermas. (VILLAS BÔAS FILHO, 2006). Este caminho também é apontado por TEUBNER (1989a). Por seu turno, Marcelo Neves parte em um estudo da dicotomia "tradição/modernidade" para tratar da positivação do direito e do conceito de "Constituição" na teoria dos sistemas (NEVES, 1992), e, em outro estudo, parte da teoria da complexidade luhmanniana, juntamente com a evolução da sociedade, para tratar do modelo de Estado de Direito do autor (NEVES, 2006). Esta faceta apontada por Marcelo Neves possibilita a discussão de questões abrangentes da teoria (como a teoria da complexidade) usualmente deixadas de lado pelos debates mais circunscritos à descrição do sistema jurídico. 
do estudo da esfera pública que lida com os sistemas político, jurídico e dos meios de comunicação em massa de forma mais direta.

\section{Uma incorporação "não-metafórica" e sem analogias da teoria (geral) dos sistemas}

Niklas Luhmann promoveu uma grande empreitada interdisciplinar para estabelecer um "novo paradigma" na sociologia de grande alcance com a intenção de realizar uma "revolução científica" no sentido de Thomas Kuhn. Ao fazê-lo, o autor procurou redescrever as diversas discussões da macrossociologia a partir da incorporação de pressupostos de um campo estudos - também ele interdisciplinar - chamado de "teoria dos sistemas" e, assim, Luhmann desenvolveu a sua versão da "teoria dos sistemas sociais". 97 É por meio dessa construção interdisciplinar que Luhmann sustenta que pode contribuir para a discussão sociológica abrangente "em crise". Sua proposta teórica, portanto, foi desenvolver um novo modelo que "tomou emprestado" desenvolvimentos teóricos bem sucedidos realizados por outras disciplinas, especificamente pela teoria de sistemas autorreferências e autopoiéticos. ${ }^{98}$

Com efeito, tal incorporação de desenvolvimentos do campo interdisciplinar chamado de "teoria (geral) dos sistemas" não se trata de mera "analogia", "nem de uma transposição, mesmo que metafórica, de modelos de máquinas ou modelos de organismos". ${ }^{99}$ Sua pretensão não é de se criar uma teoria geral dos sistemas. O autor exclui "a analogia direta (extremamente controversa) entre sistemas sociais e organismos ou máquinas", recusando "o atalho da analogia" e tomando o caminho mais longo da generalização e reespecificação. ${ }^{100}$ Aliás, Luhmann afirma que, a rigor, sua teoria não

${ }^{97}$ LUHMANN, 1995b, p.1. Luhmann afirma " a teoria geral dos sistemas sociais reivindica abarcar todos os tópicos potenciais da sociologia, incluindo até a sociedade como a inclusão de todos os contatos possíveis; e, nesse sentido, reivindica ser uma teoria sociológica universal. Tal reivindicação universal é um princípio seletivo. Ele significa que se aceitam corpos de pensamento, ideias e críticas apenas e na medida em que ele os torna seu próprio princípio. Isso perpassa o solo de controvérsias sociológicas clássicas: tais como estática versus dinâmica, estrutura versus processo, sistema versus conflito, monólogo versus diálogo, ou, projetado dentro do próprio objeto, sociedade versus comunidade, trabalho versus interação" (LUHMANN, 1995b, p. 15).

${ }^{98}$ LUHMANN, 1995b, p. xlix.

${ }^{99}$ LUHMANN, 1997b,.p p. 60-61.

${ }^{100}$ LUHMANN, 1995b, p. 14. Luhmann afirma que, apensar de que seu edifício teórico ser rotulado de teoria dos sistemas, "isso não significa que ele tenha sido desenvolvido exclusivamente com o conceito de sistema (LUHMANN, 1995b, p. xxxvii - "Instead of a Preface to the English Edition: On the Concepts 'Subject' and 'Action'”. 
precisaria ser chamada de "teoria dos sistemas". ${ }^{101}$ Com isso, se retira que não é possível meramente "aplicar" a teoria geral dos sistemas à sociedade. Luhmann realiza grandes adaptações e desenvolvimentos próprios de uma teoria social independente. É por esse motivo que é possível se falar em uma "sociologia luhmanniana", que abordaremos no item a seguir, que, por ser o mais importante centro de sua teoria, será mais desenvolvido e um pouco mais extenso. Ao proceder dessa maneira, evitamos recair no perigo de enfatizar apenas os pressupostos teóricos abstratos da teoria e não seus axiomas centrais de caráter sociológico.

Luhmann trabalha com os desenvolvimentos da teoria geral dos sistemas ao apontar para um desenvolvimento no campo que se afasta do tratamento de "sistemas abertos" e passa a os encarar como "sistemas fechados" e autorreferenciais. A ideia de sistemas abertos era dominante na década de 1950, principalmente a partir de desenvolvimentos da termodinâmica. A pergunta característica do campo - como é possível uma ordem contra a entropia? Ou como a negentropia é possível a partir da entropia? - deixou de ser respondida pelo esquema "input-output" e passou a se pautar pela diferença "sistema/ambiente". Com isso, o enfoque se deslocou para a manutenção de fronteiras. A teoria dos sistemas abertos, entretanto, encarava estas fronteiras como "permeáveis" que permitiam a transmissão de elementos, como energia, por exemplo. ${ }^{102}$

Em desenvolvimentos posteriores, além do "avanço" da diferença sistema/ambiente (System/Umwelt), o campo passou a compreender os sistemas como fechados operativamente, ou seja, sistemas autorreferenciais que operam a partir de seus próprios elementos, não havendo transmissão de elementos para fora de suas fronteiras. Exemplos desse desenvolvimento são variados. Luhmann destaca os estudos sobre a "linguagem própria do cérebro", cuja operação elétrica peculiar compensava o não contato com o ambiente com o aumento da sua complexidade própria e internamente constituída; estudos sobre "maquinas não-triviais" - complexas e imprevisíveis -, cujo funcionamento não pode ser reduzido ao esquema de "input-output"; estudos sobre a cibernética de segunda ordem que questionam a imputação de causalidade e a substituem pela pergunta da "perspectiva do observador"; estudos de Humberto Maturana e Francisco Varela que caracterizavam os seres vivos como sistemas autopoiéticos, uma vez que uma "célula produz seus próprios

101 LUHMANN, 1995b, p. xlix. Todavia, Luhmann faz uma ressalva: “[c]aso se queira manter constante os outros aspectos da teoria e eliminar o conceito de sistema, haveria a necessidade de se encontrar algo que fosse capaz de cumprir as suas funções e tomar seu lugar dentro da teoria. E isso seria algo muito parecido com o conceito de sistema".

${ }^{102}$ LUHMANN, 1997b, p .62. 
elementos através da rede de seus próprios elementos"; e, por fim, estudos de neurobiologia cognitiva de interdependência entre sistema e ambiente sem que haja transmissão entre os dois. ${ }^{103}$

Luhmann, então, se vale desses desenvolvimentos para desenvolver sua teoria dos sistemas sociais, caracterizando-a como parte integrante da teoria geral dos sistemas. $\mathrm{O}$ enfoque do trabalho, como ele expressamente afirma, não é reconhecer as semelhanças entre eles, mas antes desenvolver as especificidades dos sistemas sociais "não físicos". 104 Nesse sentido, o reconhecimento da diferenciação de sistemas é essencial. Com efeito, Luhmann nota que desde seu estabelecimento a sociologia tem se ocupado da diferenciação. ${ }^{105}$ A noção de diferenciação luhmanniana, contudo, é diferenciação sistêmica. Luhmann afirma que, com isso, trabalha-se a oposição sistema/ambiente: "quando desta maneira se origina um sistema social, falaremos de diferenciação em referência ao que, como consequência da diferenciação, aparece como ambiente. (...) Não obstante isso, a diferenciação pode também acontecer no interior de sistemas já formados. Queremos designar como diferenciação dos sistemas unicamente a este caso ou - se se quer sublinhar a distinção da qual temos falado - como diferenciação interna do sistema correspondente. (...) Em outras palavras, a diferenciação sistêmica gera ambientes internos no sistema". ${ }^{106}$ Contudo, Luhmann afirma que "a diferenciação não é decomposição de um 'todo' em 'partes', nem em sentido de decomposição conceitual (divisio) nem no sentido de divisão real (partitio). O esquema todo/partes tem sua origem na tradição europeia antiga e se fosse aplicado aqui não se apreenderia o ponto decisivo. Diferenciação sistêmica não significa decompor o todo em partes nem, em consequência - considerado neste nível - , que este consista apenas de partes e suas 'relações'. Antes, cada sistemaparcial reconstrói ao sistema total - ao qual pertence e co-realiza - através de uma diferença própria (específica do sistema-parcial) de sistema/ambiente".

Para isso, ele argumenta que o ponto de partida para toda a teoria dos sistemas - que rejeita tanto o paradigma das "partes e do todo" quanto o paradigma "sujeito/objeto" - é a diferença entre sistema (System) e ambiente (Umwelt). ${ }^{107}$ Luhmann parte do conceito de forma de George Spencer-Brown para demonstrar que uma forma é sempre uma forma de dois lados, um conceito necessariamente relacional. Sempre que se indica um lado (mark)

\footnotetext{
${ }^{103}$ LUHMANN, 1997b, pp. 63-67.

${ }^{104}$ LUHMANN, 1995b, p. 14.

${ }^{105}$ LUHMANN, 2007a, p. 471.

${ }^{106}$ LUHMANN, 2007a, 473.

${ }^{107}$ LUHMANN, 1995b, pp. 16 e ss.
} 
por meio de uma distinção, deixa-se um lado não marcado (unmarked space). Portanto, uma "forma" tem necessariamente dois lados e uma configuração lógica autorreferencial e, assim, a unidade da forma - que marca um lado interno e um externo - não pode ser reduzida a nenhum deles, sendo ela a própria diferença. ${ }^{108}$ É, portanto, a diferença "sistema/ambiente" em si mesma considerada que é o conceito analítico chave para a teoria dos sistemas, e não apenas o sistema como o lado interno: a referência é sempre a relação entre sistema e ambiente. ${ }^{109}$

O conceito de ambiente (Umwelt) não deve ser confundido com a noção de "(meio) ambiente", tal qual na linguagem da ecologia. Mais importante, nota-se que o ambiente não deve ser compreendido como categoria residual, mas, ao contrário, a teoria compreende que a relação com o ambiente é constitutiva para a formação sistêmica. Nesse sentido, o termo "ambiente" não tem apenas importância "acessória", nem o sistema é tido como algo primário ou de "essência". Ademais, o ambiente não importa apenas para "preservar" o sistema ou lhe suprir de energia e informação. Isso, pois para a teoria de sistemas autorreferenciais, "um ambiente é, antes, um pressuposto para a identidade do sistema, pois a identidade só é possível a partir da diferença”. Isso leva a teoria dos sistemas a "desontologizar" objeitos, se abstendo tanto de implicações normativas quanto de qualquer "reificação" da realidade. Isso ocorre, vale a pena reforçar, pois "o sistema não é mais relevante que o ambiente tanto ontológica como analiticamente: ambos são o que são em referência mútua". ${ }^{110}$

Além disso, utilizar analiticamente a diferença sistema/ambiente não implica em "separar a realidade em dois". Mesmo se pressuponha que "existam sistemas" na realidade, ${ }^{111}$ tal existência não é ontológica; implicando a necessidade de se perguntar pela observação como "manejo da diferença". ${ }^{112}$ Assim, ainda que haja como pressuposto uma realidade subjacente à diferença sistema/ambiente, elas não são operacionalizadas pela diferença. Luhmann, ao esclarecer essa questão, dá o exemplo referente aos sistemas sociais afirmando que como condições de possibilidade para sua existência são necessárias realidades físicas, químicas, orgânicas e psíquicas, mas nenhuma delas capacita a formação de elementos manejados dentro do sistema - são para ele seu ambiente. Dessa forma, o

\footnotetext{
${ }^{108}$ LUHMANN, 2007a, pp. 41 e ss.

${ }^{109}$ LUHMANN, 1995b, p. 170.

${ }^{110}$ LUHMANN, 1995b, p. 177. Isso, pois não há hierarquia entre sistema e ambiente (LUHMANN, 2007a, p. 43).

${ }_{111}^{11}$ LUHMANN, 1995b, p. 2.
${ }^{112}$ LUHMANN, 1995b, p. 178.
} 
sistema químico de células é ambiente para o cérebro e a consciência de uma pessoa é ambiente para o sistema social: nenhuma decomposição de processos neurofisiológicos poderia alcançar cada célula individualmente como seus elementos e "nenhuma decomposição de processos sociais poderia chegar às consciências". ${ }^{113}$ Chega-se à conclusão de que o ambiente é uma situação sempre relacionada a um sistema. Cada sistema se destaca de seu ambiente e, portanto, o ambiente de cada sistema é diferente.

Por essa diferença, vemos que se trata de abordar o mundo pela diferenciação de sistemas de seus ambientes. Isso desloca a pergunta "ontológica" de sujeitos e objetos para a pergunta pela manutenção de sistemas e suas fronteiras, pois "a manutenção de fronteiras é manutenção do sistema". ${ }^{114}$ Tais fronteiras são traçadas pela assimetria de complexidade entre o sistema e o ambiente: "cada sistema deve se manter em relação à esmagadora complexidade de seu ambiente e, caso ele seja bem sucedido, tornará o ambiente de todos os outros sistemas mais complexo". ${ }^{115}$ Desse modo, o sistema adquire certa "liberdade" a partir da autonomia de sua autorregulação indiferente em relação ao seu ambiente. Logo, "pode-se descrever a diferenciação de um sistema como um aumento de sua sensibilidade para aquilo que foi determinado (o que é capaz de ser conectado internamente) e um aumento da insensibilidade para todo o resto - ou seja, dependência e independência ao mesmo tempo". ${ }^{116}$ Ao se diferenciar, o sistema passa a operar de forma fechada no tocante às suas operações, selecionando um ambiente específico; de modo que ocorra a formação de estruturas sem correspondência ponto-a-ponto com o ambiente; e que, por fim, resulte, no nível da reflexão, que o sistema determine sua identidade em contraste com todo o restante. ${ }^{117}$ Isso o leva à diferenciação interna e a um processo de reprodução autorreferencial ou autopoiética. ${ }^{118}$

É precisamente para tratar dessa reprodução autorreferencial ${ }^{119}$ que Luhmann se vale do conceito de "autopoiése" (autopoiesis) desenvolvido pelos biólogos Maturana e

${ }^{113}$ LUHMANN, 1995b, p. 179

${ }^{114}$ LUHMANN, 1995b, p. 17.

${ }^{115}$ LUHMANN, 1995b, p. 182

${ }^{116}$ LUHMANN, 1995b, p. 183.

117 LUHMANN, 1995b, p. 184

${ }^{118}$ LUHMANN, 1995b, p. 188. A diferenciação interna resulta do processo de reprodução autopoiética. "A conexão entre reprodução e diferenciação se torna compreensível se a reprodução é tomada não como a replicação do idêntico ou do quase-idêntico, (...) mas antes como uma nova constituição de eventos que podem ser conectados. Reprodução sempre implica a reprodução da possibilidade de reprodução". (LUHMANN, 1995b, p. 189).

119 Pode-se denominar um sistema de auto-referencial "se ele próprio constitue os elementos que o compõe como unidades funcionais e ele faz referência à essa autoconstituição por meio de todas as relações entre esses elementos, continuamente reproduzindo sua auto-constituição dessa forma. Neste sentido, sistemas auto-referenciais operam necessariamente por auto contato" (LUHMANN, 1995b, p. 33). 
Varela. ${ }^{120}$ Autopoiése significa a reprodução de um sistema por meio de seus próprios elementos - reprodução do sistema pelo próprio sistema. Por esse motivo, sistemas sociais (re)produzem sempre comunicações, nunca "células, macromoléculas ou ideias". ${ }^{121}$ Com isso, a reprodução de sistemas autopoiéticos é também encarada de forma autorreferencial, o que tem grande relação com o fato de serem esses sistemas "fechados operativamente".

O fechamento operativo implica que as operações do sistema ocorrem dentro de suas fronteiras, sem contato com o ambiente - ou apenas com "ilusão de contato". O exemplo do funcionamento do cérebro é sempre utilizado por Luhmann. Ainda que um sistema seja fechado operativamente, isso não implica que ele não possa ser irritado por outros sistemas em seu ambiente. Além disso, devido ao fato de que sistemas sociais (bem como os psíquicos) operam no meio sentido, eles têm a capacidade de observar outros sistemas, pelo que Luhmann afirmar que tais sistemas contam com um momento de abertura cognitiva. ${ }^{122}$ Portanto, a tese da abertura cognitiva não contradiz o postulado do fechamento operativo dos sistemas autopoiéticos. Ainda assim - mesmo com a ênfase em sistemas operacionalmente fechados que conectam suas operações com certa indiferença operacional com o ambiente -, “não se nega nem a realidade nem a relevância causal do ambiente. De outra maneira não seria possível falar em diferença, de processo de diferenciação etc.". 123

O fechamento operacional traz como consequência que o sistema fique determinado à auto-organização. Suas próprias estruturas podem constituir-se e transformar-se unicamente mediante operações próprias. Luhmann dá o exemplo da comunicação, afirmando que ela só pode se modificar com pela própria comunicação "e não de forma imediata com o fogo, com terremotos, com as radiações espaciais ou com as prestações

${ }^{120}$ Os biólogos, insatisfeitos com o termo "organização circular" para caracterizar a unidade de sistemas vivos como uma unidade, desenvolveram um "descrição linguística completa" que representasse bem a principal faceta da organização dos seres vivos, a saber: a autonomia. Humberto Maturana relata ter inventado a palavra autopoiése (autopoiesis) para resolver o problema: "[e]sta era uma palavra sem uma história, uma palavra que poderia significar o que ocorre na dinâmica da autonomia própria dos sistemas vivos". (MATURANA e VARELA, 1980, p. xvii). Por isso, auto (próprio) + poiesis (produção) = autopoiesis. Busca-se significar a faceta de autonomia de sistemas que se produzem a si mesmos por meio de seus próprios elementos.

${ }^{121}$ LUHMANN, 1995b, p. 35.

${ }^{122}$ LUHMANN, 1995b, pp. 34 e ss.

${ }^{123}$ LUHMANN, 2005a, p. 507. Este é um ponto importante que não pode passar despercebido sob pena de se atribuir à Luhmann (conscientemente ou não) um caráter de uma "sociologia estática". Neste sentido, no mesmo trecho, Luhmann continua: O fechamento operativo significa unicamente que a autopoiese do sistema somente pode ser efetuada com operações próprias. E também, o inverso: que o sistema não pode operar em seu ambiente, tampouco possui ele [sistema] a capacidade vincular-se ao seu ambiente através de operações próprias. 
perceptivas de uma consciência particular". ${ }^{124}$ Todavia, se este é o caso, "como é possível que um sistema se relacione com seu ambiente quando ele não pode realizar nenhum contato com ele?". 125

Para Luhmann, a teoria dos sistemas precisa responder esta "pergunta difícil" (que haveria sido nem colocada pelas conceituações humanistas e regionalistas da sociedade): “a resposta a uma pergunta difícil é um conceito difícil”, reconhece. Luhmann busca este "conceito difícil" também em nos biólogos Maturana e Varela. ${ }^{126}$ A resposta encontrada está no conceito de acoplamento estrutural. Os acoplamentos estruturais, diz Luhmann, restringem o campo das possíveis estruturas com as que um sistema pode realizar sua autopoiese. Os acoplamentos estruturais permitem haver uma "relação ortogonal" entre sistemas autopoiéticos. Com isso, irritações e influências recíprocas são realizadas entre dois sistemas, sem haver trocas diretas um com o outro. A noção de acoplamento estrutural é feita em distinção aos acoplamentos operativos (acoplamento de operação com operação) $)^{127}$ e também para delimitar as causalidades em cursos que ignoram os limites do sistema. ${ }^{128} \mathrm{O}$ conceito de acoplamento estrutural ficará mais claro quando tratarmos da Constituição como acoplamento estrutural entre os sistemas político e jurídico.

O que devemos retirar dessas considerações é que Luhmann incorpora tais desenvolvimentos da teoria geral dos sistemas para sua análise dos sistemas sociais e da sociedade como um sistema social que abarca todos os outros, como veremos a seguir. Com isso, a teoria dos sistemas, por sua abstração, torna comparações possíveis. Contudo, tais comparações devem ser restritas ao mesmo tipo de sistemas, ou melhor, ao mesmo nível. O autor argumenta que a comparação entre sistemas sociais e sistemas biológicos é profundamente perniciosa para a sociologia, por não reconhecer as especificidades de cada tipo de sistema - por exemplo, a questão dos sistemas sociais operarem com o meio do sentido. Ainda assim, nem a comparação entre sistemas psíquicos ou sistemas de

${ }^{124}$ LUHMANN, 2007a. p. 67.

${ }^{125}$ LUHMANN, 2007a, p72.

${ }^{126}$ Os biólogos apresentam a definição: “ACOPLAMENTO (DE UNIDADES): quando a condução de duas ou mais unidades ocorre de tal forma que o condução de cada uma é uma função da condução de outras". (MATURANA, e VARELA, 1980, p. 136 - "glossário”).

${ }^{127}$ A rigor, o "acoplamento estrutural se complementa com o acoplamento operativo". Luhmann nos dá um exemplo de acoplamento operativo, ou seja, acoplamento entre operações de sistemas que não chegam no nível da estabilização de estruturas: "deste modo, um médico pode atestar uma doença por escrito e dar um documento a um paciente para que ele o leve para o patrão. (...) Os acoplamentos operativos não podem realocar os acoplamentos estruturais. Eles os pressupõem. Mas eles se condensam e atualizam as irritações recíprocas e desta maneira permitem uma aquisição mais rápida e melhor coordenada das informações nos sistemas participantes." (LUHMANN, 2007a, p.625).

${ }^{128}$ LUHMANN, 2005a, p. 507-508. 
consciências e sistemas sociais seria possível. Aliás, Luhmann apresenta três níveis da sociedade: interações (ou sistemas de interação); organizações (ou sistemas de organização) e sistemas sociais ou sociedades. ${ }^{129}$ Comparações entre estes níveis também deverão ser levadas com cautela. Apenas se pode afirmar que todos são sistemas. ${ }^{130}$ Veremos esses níveis com mais calma no item 4. Por hora, o que importa saber é como Luhmann se vale desses desenvolvimentos para construir sua teoria.

\section{Teoria da sociedade}

\subsection{A "ambição da teoria": a necessidade de um novo paradigma na macrossociologia contemporânea}

Vimos que Luhmann reconhece uma crise da teoria sociológica abstrata. Segundo o autor é sintomático que a percepção da necessidade de uma nova teoria abrangente da sociedade teria surgido numa discussão com Jürgen Habermas ${ }^{131}$. Para ele, a macrossociologia estaria presa na exegese dos autores clássicos, perdendo sua capacidade de explicação de fenômenos sociais contemporâneos. ${ }^{132} \mathrm{O}$ cenário da sociologia seria marcado pela falta de uma "teoria da sociedade moderna". 133

Por isso, seu projeto de pesquisa é ambicioso. Quando o autor entrou na Universidade de Bielefeld fundada em 1969, ele apresentou seu programa de pesquisa que consistia em construir uma teoria da sociedade: "[t]empo estimado: trinta anos; custo do projeto, nenhum". Ao publicar em 1997 seu "A Sociedade da Sociedade" (Die Gesellschaft der Gesellschaft) ele afirmou: "[q]uanto à duração, as dificuldades do projeto foram estimadas realisticamente". ${ }^{134}$

${ }^{129}$ Luhmann (1995b, p. 2) apresenta um diagrama da disposição da teoria dos sistemas, como vemos abaixo:

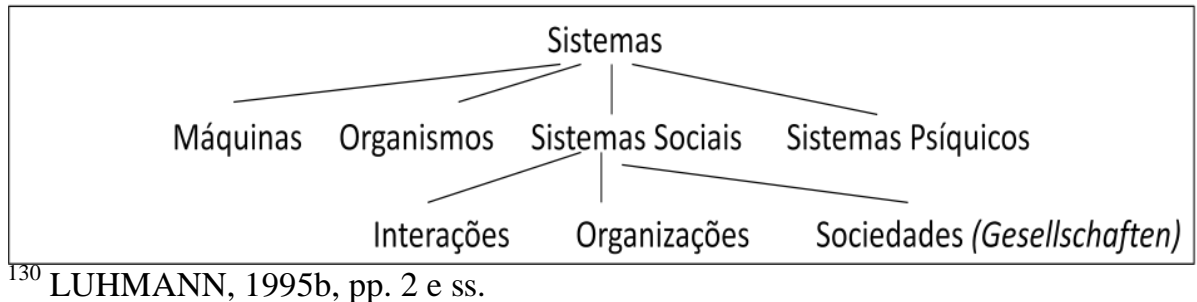

131 LUHMANN 2007a, p.1.

${ }^{132}$ LUHMANN, 2007a, pp. 7 e ss.

${ }^{133}$ LUHMANN, 2007a, p. 910.

${ }^{134}$ LUHMANN, 2007a, p. 1 
Luhmann pretendeu realizar construção teórica "radical", no sentido de que ela se afastava dos pressupostos teóricos cristalizados no debate anterior e promovia uma revisão ampla de pressupostos da disciplina sociológica. Importante notar que tal radicalidade não é encarada de do ponto de vista político, mas como forte mudança paradigmática na sociologia. $\mathrm{O}$ autor argumenta que "uma teoria conceitual da sociedade meticulosamente construída seria muito mais radical e muito mais desconfortante em seus efeitos do que as críticas de foco reduzido - como ao capitalismo, por exemplo - poderiam sequer imaginar."135

Para isso o autor precisava apresentar uma revisão dos clássicos da sociologia, os quais seriam citados quase que em forma de "culto", mas haviam desenvolvido suas teorias já há muito tempo "antigas" e, portanto, incapazes de encarar novos fenômenos da sociedade, como, por exemplo, o desenvolvimento dos meios de comunicação, o reconhecimento da sociedade mundial, questões que atravessam a ordem estatal, questões ecológicas etc. ${ }^{136}$ A tradição sociológica abstrata estaria, portanto, desatualizada, restando apenas realizar uma "exegese dos clássicos". Para Luhmann, "depois dos clássicos, e portanto desde quase 100 anos, a sociologia não mostrou progressos dignos de menção na teoria da sociedade". ${ }^{137}$

Luhmann argumenta que a tradição sociológica não teria levado em conta os problemas de abstração de uma teoria da sociedade circular que só pode se comunicar dentro do sistema da sociedade, ou seja, que reconhecesse sua relação circular com seu objeto. Para o autor, a questão da (unidade) da distinção indivíduo/sociedade não teria sido levada a cabo de maneira satisfatória. Desse modo, as descrições da vida social do ser humano teriam sido há muito marcadas por ideias para as quais "a realidade tal como

135 LUHMANN, 1996a, p.200. Para o autor, as teorias da dominação, dentre elas o marxismo, careceriam atualmente de radicalidade - não política, por óbvio, mas de radicalidade teórica que questionasse o pressuposto de uma determinação meramente econômica da sociedade. (LUHMANN, 1990, p. 28). Não obstante, quando perguntado por um "exemplo" de intelectualidade tal qual ele havia desenhado ao longo de uma entrevista, ele respondeu: "eu aponto Karl Marx" [Ich Nehme Karl Marx]. Luhmann vê a teoria de Karl Marx, como uma "construção genial" (geniale theoretische Konstruktion) que trabalha com elementos muito heterogênios". (LUHMANN, 1987, p. 26-27). Sobre o "potencial radical" do pensamento Luhmanniano ver: MOELLERS, 2006, pp. ix, 3 e ss. ; e 2011, "prefácio".

${ }^{136}$ Em tal culto aos clássicos, os fenômenos sociais contemporâneos que deveriam irritar a sociologia de grande alcance "ficam entregues a uma literatice sociológica ou também aos movimentos sociais. Modas intelectuais (...) são acompanhadas de perto, mas não deixam nenhum rastro no desenvolvimento da teoria sociológica. Falta uma teoria da sociedade que seja pelo menos de algum modo adequada" (LUHMANN, 1997b, p. 60)

${ }^{137}$ LUHMANN, 2007a, p.8. Cumpre notar que Luhmann circunscreve essa falta de desenvolvimentos ao âmbito mais abrangente da teoria da sociedade e reconhece que "[e]videntemente, a sociologia conseguiu diversos avanços nos campos da metodologia e teoria, sobretudo na acumulação de conhecimento empírico, mas não desenvolveu uma descrição da sociedade como um todo" (idem, p. 9) 
apresentada não era suficiente". Isso teria se passado na "velha tradição europeia" (Alteuropäische ${ }^{138}$ ) com seu ethos de perfeição do homem, mas também seria válido para a Europa moderna e para o Iluminismo com sua "dupla deidade de razão e crítica". Isso se manteria também no século XX, em que haveria uma "consciência de insatisfação (pode-se pensar em Husserl ou Habermas) vinculada à ideia de modernidade". Entretanto, para ele a sociedade apresenta causa problemas a si mesma que são independentes da intenção de melhorá-la em vista de ideias como maior solidariedade, emancipação, comunicação racional, integração social, etc.

O que Luhmann reconhece como problemático é que as "ferramentas teóricas" utilizadas para responder as questões abstratas da descrição da sociedade moderna (tais como ação, razão, subjetividade, consenso, dominação etc.) já estariam por demais desgastadas e apresentariam baixo potencial explicativo-cognitivo atual. Seriam "conceitos europeus obsoletos" (Alteuropäische Begriffe). Decorre daí sua busca por uma nova teoria da sociedade e por novos pressupostos teóricos.

Em sentido contrário, Luhmann afirma que a sociologia teria que compreender sua relação com a sociedade como uma relação de "aprendizagem e não de ensino". Para isso, “[o] mais sensível é apontar para a imensa complexidade da sociedade e a falta de uma metodologia adequada que seja capaz de tratar os sistemas altamente complexos e diferenciados - capaz, portanto, de tratar da chamada 'complexidade organizada". ${ }^{139}$ Esse é o ponto central da teoria luhmanniana: a sociedade moderna se caracterizaria por ser uma sociedade hipercomplexa, sem a possibilidade de utilização de conceitos totalizantes e "externos" tais como o conceito de razão. Sua teoria da sociedade objetiva enfrentar essa questão.

${ }^{138}$ O termo é de difícil tradução e aponta - de maneira vaga - para uma tradição europeia da ciência social frente a qual Luhmann quer se distanciar. Seria uma tradição "velha" ou "obsoleta" com grande continuidade no pensamento ocidental. A ela o autor atribui diversas características diversas, dentre as quais a prevalência de uma abordagem fundamente normativa na construção de teorias sociais - e com ela a utilização de conceitos do Iluminismo como razão, sujeito e crítica -, o enfoque em valores compartilhados e na "integração social" para a definição do social, a definição da sociedade como um todo por meio de teorias centradas na política (ou na economia política), além de pressupostos teóricos baseados na teoria da ação.

${ }^{139}$ LUHMANN, 2007a, p.8-10 


\subsection{Obstáculos epistemológicos para o conceito de sociedade da teoria dos sistemas}

Considerando que a descrição da sociedade estaria carregada com conceitos normativos, Luhmann contra-argumenta com o postulado de que a sociologia se refere à realidade social tal qual ela de fato existe e, portanto, "as perguntas normativas deveriam se desenvolver a partir dessa realidade, ou seja, não devem fornecer à sociedade conceitos sociológicos ideais". Isso o leva a se afastar tanto da tradição da "sociologia crítica" quanto do segmento denominado de "investigação empírica". ${ }^{140}$ Tal afastamento o leva a construir um "conceito de sociedade radicalmente antihumanista, radicalmente antirregionalista e radicalmente construtivista". ${ }^{141}$

Neste sentido, Luhmann desenvolve o que chamou de uma teoria "autológica"142 e "sociocêntrica" de sociedade, como veremos a seguir quando tratarmos de seu conceito de sociedade como o "sistema social todo abarcador". Um conceito assim formulado poderia acessar aquilo que ele considera ser as características fundamentais da sociedade moderna: o aumento da complexidade social e a consequente diferenciação funcional da sociedade. A dificuldade que a sociologia teria para reconhecer estas características definidoras é então atribuída a "obstáculos epistemológicos" conforme exposto por Gaston Bachelar e já visto por nós na introdução deste estudo. Segundo Luhmann, tais obstáculos “impedem uma adequada análise científica e promovem expectativas impossíveis de se satisfazer."143

Eles consistiriam em quatro pressupostos que se relacionam e se mantêm reciprocamente:

“(i) Que a sociedade é constituída por homens concretos e por relações entre seres humanos.

(ii) Que, por consequência, a sociedade se estabelece - ou pelo menos se integra através do consenso dos seres humanos, da concordância de suas opiniões e da complementaridade de seus objetivos.

(iii) Que as sociedades são unidades regionais, territorialmente delimitadas, pelo que se infere que o Brasil é uma sociedade distinta da Tailândia; os Estados Unidos são

\footnotetext{
${ }^{140}$ LUHMANN, 2007a, p.21

${ }^{141}$ LUHMANN, 2007, p. 20

${ }^{142}$ LUHMANN, 2007a, p.05,

${ }^{143}$ LUHMANN, 2007a, p.11
} 
uma sociedade distinta do que até há pouco nós chamávamos de União Soviética, e também que o Uruguai é uma sociedade distinta do Paraguai

(iv) E que, portanto, as sociedades podem observar-se desde o exterior como grupos de seres humanos". 144

Enquanto os três primeiros "obstáculos epistemológicos" impediriam o desenvolvimento de um conceito de sociedade adequado, o quarto é deixado sem comentários. Com efeito, é possível relacioná-lo a questões epistemológicas relacionadas à da teoria dos sistemas. Por isso, ele será tratado em item apartado, juntamente com exposição do construtivismo radical da sociologia luhmanniana. Por sua vez, trabalhar o conceito de sociedade de Luhmann por meio dos três obstáculos iniciais nos permite conceber de maneira clara o desenho da teoria da sociedade de Luhmann. Daí a importância de apresentá-los antes de discutir sua definição positiva do conceito.

O primeiro obstáculo, denominado de "preconceito humanista", estaria vinculado com uma tentativa de se explicar a sociedade por meio da "especificidade" humana. Isso implicaria descrever, em um primeiro momento o homem em oposição aos animais ${ }^{145}$ apoiando-se em diversas distinções (como razão, entendimento, vontade, imaginação, emoção, etc.). Essa busca pelo conceito humano na distinção ser humano/animal faria parte da "autodescrição humanística" da "semântica da antiga Europa". ${ }^{146}$ Após a metade do século XVIII, este problema foi trabalhado pela sociologia a partir da relação individuo/sociedade. Contudo, Luhmann afirma que esta tentativa ontológica de se definir "o humano" ocorreu por meio de conceitos "tradicionais" (como razão); que compreendiam a sociedade como soma de indivíduos ou de relações entre indivíduos. ${ }^{147}$

Um conceito "autológico e sociocêntrico" como o de Luhmann considera a sociedade como um sistema operativamente fechado, cujas operações não podem ser

${ }^{144}$ LUHMANN, 2007, pp. 11-12

${ }^{145}$ LUHMANN, 2007a., p. 13. e 1998a; p 215.

146 Contudo, Luhmann adverte: “[e]sse humanismo originário deve se distinguir daquele de novas versões do humanismo pelas quais se busca compreender idealisticamente os problemas da sociedade moderna e que, depois, (aproximadamente cem anos mais tarde) se denomina de "neohumanismo". Esta versão é tão vistosamente nova [à época] que Foucault pôde afirmar que o homem teria sido descoberto na segunda metade do século XVIII. De qualquer modo, hoje o ser humano já não é a sociedade; ou é antes um ideal que seve se manter como aproximação para ela, ou como um artefato" (LUHMANN, 2007a, p. 741 ênfase adicionada).

${ }^{147}$ LUHMANN, 2007a, p. 12 e ss.; 2005b, pp. 33 e ss. Por esse motivo, Luhmann se opõe a pensar a sociedade a partir do esquema "parte/todo", como se os indivíduos fossem partes constitutivas da sociedade, e argumenta: "Sempre foi requerido que partes sejam homogêneas em relação ao todo. Quartos - e não tijolos - são chamados de parte de uma casa; capítulos - e não letras do alfabeto - são conceituados como partes de um livro. Contudo, seres humanos individuais ainda contam como partes da sociedade. Dificilmente há qualquer critério teoricamente comprovado para dar conta dessa homogeneidade (...)". (LUHMANN, 1995b, p.7) 
reduzidas aos indivíduos, suas ações ou seus valores. Já vimos os conceitos de autopoiése e de fechamento operacional. Por agora é suficiente notar que Luhmann afirma que a sociedade se diferencia de seu ambiente e os indivíduos estão em seu ambiente. Com efeito, ao fazer isso, Luhmann não recai em "conservadorismo" ou em uma prescrição normativa de se desejar uma sociedade "tecnicista" ou "desumanizada". ${ }^{148}$ Antes, o que se quer dizer é que as análises do funcionamento e do operar da sociedade não podem ser reduzidas às operações humanas. ${ }^{149}$

No tocante ao "segundo obstáculo", Luhmann argumenta que a teoria social buscou descrever a sociedade a partir das relações entre os seres humanos, mais especificamente em relações como partilha de valores, consenso ou solidariedade. Enquanto nos séculos XVII e XVIII imperavam as teorias do contrato social, no século XIX foram introduzidos os conceitos de solidariedade e integração. Com o século $\mathrm{XX}$ e o advento das teorias sociológicas clássicas a teoria sociológica se volta para o conceito de ação social, para teorias da conduta e para teorias da solidariedade. ${ }^{150}$

O primeiro problema reconhecido por Luhmann, é que vincular o conceito de sociedade ao conceito de consenso e de solidariedade deixa de fora da sociedade a questão do dissenso, do conflito e da conduta desviante. Além disso, a pressuposição de que os indivíduos "materializam a sociedade mediante sua conduta" apresentaria uma implicação problemática: ainda que se trabalhe com a hipótese de que problemas estruturais da sociedade poderiam expressar-se como condutas individuais desviadas suscetíveis de

${ }^{148}$ Luhmann afirma que a colocação do homem no ambiente da sociedade não implica em sua desvalorização. Ao contrário, encarar analiticamente a humanidade "fora" da sociedade poderia colocá-la em uma condição autônoma com um tratamento mais adequado. Ainda, Luhmann chega a sustentar que, não bastasse isso, algumas "representações sobre os homens" (representações humanas) provenientes de referências externas têm servido para "endurecer assimetrias de papéis". Como exemplo são citados "a ideologia da raça e a distinção entre elegidos e malditos, a doutrina prescrita pelo socialismo e o que significam para os norte-americanos a ideologia melting pot e o American way of life.". (LUHMANN, 1998a, p.228). O pressuposto, aqui, é que tanto a sociedade quanto os homens podem se apresentar problemas mútuos. Para o autor, "[s]e o homem for tomado como parte da sociedade, a teoria da diferenciação teria que ser desenhada como teoria da classificação de seres humanos - seja por estratos sociais, por nações, por etnias ou por grupos. Todavia, isso entraria em clara oposição com o conceito de direitos humanos e em especial com o conceito de igualdade. Tal 'humanismo' fracassaria frente suas próprias ideias. Assim, não há outra possibilidade senão considerar o homem por inteiro - de corpo e alma - como parte do ambiente da sociedade". (LUHMANN, 2007a, p.16). Além disso, como afirma Luhmann, afirmar que as pessoas pertencem ao ambiente da sociedade "não contém uma avaliação da importância das pessoas seja para si ou para outros. Tal postulado apenas revê a pressuposição superestimada implícita no conceito de sujeito, a saber, a tese de que a consciência é o sujeito de tudo. O ambiente, e não o 'sujeito' 'subjaz' os sistemas sociais - (...).(LUHMANN, 1995b, p.178)

149 Segundo ele: “A sociedade não vive. Tampouco poderá ser levado a sério sustentar que os processos neurofisiológicos do cérebro seriam equivalentes a processos sociais, uma vez que eles não são sequer acessíveis à consciência”. (LUHMANN, 2007a, p 13).

${ }^{150}$ LUHMANN, 2007a, pp.13-14 
pesquisa empírica e comprovem estatisticamente estes "nexos", uma pergunta central permanece: como os indivíduos chegam a manifestar (ou a não manifestar) os sintomas das patologias sociais? Luhmann afirma que esta resposta não foi dada pela sociologia clássica. $^{151}$

Ora, ao discorrer sobre o terceiro obstáculo, o autor argumenta que: "no caso do conceito de sociedade referido ao ser humano se inclui por demais; no caso do conceito referido ao território se inclui pouco. Em ambos os casos, permanecer ligado a concepções tão inúteis poderia estar vinculado ao fato de se querer poder observar a sociedade desde fora". ${ }^{152} \mathrm{O}$ conceito territorial de sociedade deixaria de reconhecer as interdependências de alcance mundial que acontecem na sociedade moderna. Para ele, se ignorarmos que a sociedade moderna é antes um sistema em que comunicações e diversos sistemas parciais operam e comunicam sem respeitar fronteiras políticas, "estaríamos obrigados a voltar a um conceito de sociedade definido pela dominação, ou pela nostalgia de uma ideia de cultura. Então, seria necessário subordinar o conceito de sociedade a limites estatais definidos arbitrariamente ou se basear em unidade linguística (...) de uma 'cultura' regional". 153

Luhmann encara, então, a sociedade como o sistema mais abrangente da sociedade, ou seja, o sistema único da sociedade no interior do qual todos os outros sistemas sociais parciais operam. Frente a essa objeção Luhmann desenvolve o conceito de sociedade mundial (Weltgesellschaft). Para o autor, a semântica antiga fornecia uma autodescrição haverem "vários mundos", pois havia profundas diferenças regionais significativas em sociedades tradicionais organizadas hierarquicamente. Contudo, com o aumento de interrelações entre as diversas regiões do globo terrestre, com o desenvolvimento de meios de comunicação e tecnologias, com a mundialização de sistemas sociais - principalmente os da ciência, economia e arte - e principalmente a partir da estruturação da sociedade moderna pela diferenciação por sistemas de função (e portanto não territoriais), ${ }^{154}$ seria possível pensar a sociedade como um sistema de referência comum, ou melhor, como um mundo que "é a totalidade do que para cada sistema significa a diferença

${ }^{151}$ LUHMANN, 2007a, p. 15

${ }^{152}$ LUHMANN, 2007a, p. 18.

${ }^{153}$ LUHMANN, 2007, p. 18

${ }^{154}$ A exceção é o sistema político, e com ele o direito, ambos diferenciados regionalmente vinculados à forma do Estado. Todos os demais sistemas funcionais operam independentemente de limites temporais (LUHMANN, 2007a, p.125) 
sistema/ambiente". ${ }^{155} \mathrm{O}$ mais importante é notar que Luhmann, em sua abordagem radical funcionalista, encara a sociedade como um sistema que opera comunicações. Ora, atualmente é seguro afirmar que na modernidade o horizonte de referência pelo qual os processos comunicativos ocorrem não são limitados por fronteiras - seja em operações científicas, na arte, nos meios de comunicação em massa, nas operações de mercado econômico, etc. -, de modo que seria possível até se falar em uma "simultaneidade temporal" das operações, ainda que existam fusos horários diferentes. ${ }^{156}$

Além disso, Luhmann atenta para o fato de que diversos problemas e configurações atuais (como é o caso do problema ambiental e a configuração da ciência moderna) não mais podem ser pensados em termos de segmentações regionais ou locais. Assim, ao invés de tratar desta questão sob a rubrica de "globalização" ou sob a pecha de "pósmodernidade", o autor postula que a sociedade não seria um conjunto de sistemas sociais, mas antes ela (a sociedade) é que consistiria um sistema global. ${ }^{157}$ Conceber a sociedade mundial moderna como "um horizonte e um mundo comum" para todos os sistemas sociais é condizente com sua teoria que encara essa sociedade como sendo primariamente definida pela diferenciação funcional. Com isso, a sociedade complexa não pode mais ser explicada ou descrita seja a partir de "cosmovisões" hierárquivas religiosas de mundo - como ocorria em sociedades pré-modernas - seja a partir da descrição de um subsistema social determinado - o que marcaria a tradição sociológica que tenderia a descrever a sociedade como "sociedade política" ou "sociedade econômica". Uma sociedade complexa e funcionalmente diferenciada, como vimos acima, não tem um princípio "top-down" de organização, mas antes se organiza por um padrão policontextural múltiplo. O conceito de sociedade mundial é utilizado com mais rigor no Capítulo $\mathrm{V}$ e no artigo anexo desse estudo.

\subsection{A sociedade como o sistema social todo abarcador}

Até aqui trabalhamos apenas com definições primariamente "negativas" do conceito de sociedade na sociologia luhmanniana. De maneira propositiva, Luhmann descreve a sociedade como o "sistema social todo abarcador" (unfassendes

\footnotetext{
${ }^{155}$ LUHMANN, 2007a, pp 108-115

${ }^{156}$ LUHMANN, 2007a, p. 112 e ss.

${ }^{157}$ LUHMANN, 1997c, p. 67,
} 
Sozialsystem $)^{158}$ que inclui a si mesmo e todos os demais sistemas sociais”. Para Luhmann, a sociologia deveria ter um conceito para a unidade de tudo o que é social - "a totalidade de relações sociais, processos, ações ou comunicações". É para esse isso que se utiliza o conceito de sociedade. ${ }^{159}$ Ao tratar do conceito, Luhmann reconhece que ele estaria ligado à "velha tradição europeia", uma vez que já em Aristóteles poder-se-ia encontrar a definição da comunidade da vida citadina como a mais importante comunidade, que inclui a todas as outras". No entanto, sua proposta é dede uma nova descrição (uma redescrição) de seus axiomas fundamentais"

Vimos as implicações de se definir a sociedade como um sistema quando analisamos a incorporação luhmanniana da teoria geral dos sistemas acima. A definição de sociedade foi pensada por uma "forma de dois lados": sistema/ambiente (System/Umwelt), que se torna relevante para diferenciar um sistema determinado. Todavia, essa definição proveniente da teoria geral dos sistemas não é suficiente para o desenvolvimento do conceito de sociedade em Luhmann, o que nos leva a perguntar pela "peculiaridade" ou especificidade do "sistema sociedade" (sozialer System). Luhmann apresenta, então, um "mapa" de três distintos planos da análise da sociedade: ${ }^{161}$

(1) A teoria geral dos sistemas - e, nela, a incorporação luhmanniana dos sistemas autopoiéticos

(2) A teoria dos sistemas sociais.

(3) A teoria do sistema sociedade como um caso particular da teoria dos sistemas sociais.

Tratemos da relação da sociedade com os outros sistemas sociais. Nota-se, que é precisamente o reconhecimento da sociedade como o "sistema social todo abarcador" o que demonstra sua peculiaridade como sistema social: ele é um sistema que "inclui a si mesmo e ao mesmo tempo todos os outros". Como veremos, no primeiro plano de análise, todos os sistemas autopoiéticos são operativamente fechados e apenas cognitivamente abertos, ou seja, eles se diferenciam de seus ambientes respectivos por meio de suas

${ }^{158}$ Esse termo significa o "sistema que tudo abarca", ou melhor, que abarca os outros sistemas sociais. A tradução para o espanhol é "Sistema social omniabarcador", e no inglês encontrei "all-encompassing social system". Outra tradução bem sucedida e possível seria aquela oferecida por Marcelo Neves, como "sistema social mais abrangente" (p.ex. NEVES, 2007, p. 74 nota 82). Luhmann afirma que a sociedade é o sistema social todo abarcador "que inclui tudo o que é social e, portanto, não admite um ambiente social" (LUHMANN, 1995b, p. 408)

${ }^{159}$ LUHMANN, 1995b, p.408

${ }^{160}$ LUHMANN, 2007a, p. 55

${ }^{161}$ Com efeito, eles não se confundem com os três níveis ou tipos de sistemas sociais: sociedade, interações e organizações que vimos anteriormente e cujas implicações serão desenvolvidas no item 5, abaixo. 
operações - não há contato ou transferência operativa entre um sistema e seu ambiente. Esses sistemas operam apenas com os elementos que eles mesmos produzem. Em um segundo plano, veremos que um sistema pode se diferenciar também internamente, podendo ocorrer, inclusive, a formação de outros sistemas em seu interior. Tomemos isso como dado por ora. A partir dessas considerações pode se concluir que a sociedade é um sistema único e diferenciado internamente em diversos subsistemas sociais - cada qual também autopoiético.

Qual a característica definidora, então, de todos os sistemas sociais? ${ }^{162}$ Vimos que Luhmann não define a sociedade por conceitos clássicos de ação, consenso ou partilha de valores. Para o autor, a "menor unidade de sistemas sociais", seu "elemento" é $a$ comunicação. Isso vale para todos os sistemas sociais, que são "subsistemas" ou sistemas parciais da sociedade. ${ }^{163}$ A comunicação é tida como a única operação genuinamente social, pois irredutível à consciência e, ainda que pressuponha um grande concurso delas, não pode ser reduzida a uma consciência coletiva, voltada ao bem comum ou explicada pelo "consenso generalizado" e pela concordância generalizada. ${ }^{164}$

Conceituar a sociedade como um sistema cujos elementos constitutivos são comunicações implica um distanciamento da teoria sociológica clássica do século XX compreendida como teoria da ação. Para Luhmann, tal tradição não compreende de forma suficiente a relação entre "ação" e socialidade (Sozialität). O âmbito do social não pode ser encarado pelo conceito de ação, de modo que a socialidade "não é um caso especial de ação; ao contrário, a ação é que é constituída dentro de sistemas sociais por meio de comunicações e atribuições como uma redução de complexidade, como uma autosimplificação indispensável do sistema". ${ }^{165}$ Entender a sociedade como um sistema autopoiético prescreve que "o processo fundamental pelo qual os sistemas sociais produzem seus elementos apenas pode ser a comunicação". O autor sustenta que ainda que mesmo que o conceito de comunicação não possa ser separado a rigor da comunicação, eles podem ser distinguidos analiticamente. Assim, o processo elementar constitutivo do domínio social é a comunicação. Contudo, para poder dirigir a si mesmo, o processo é reduzido, decomposto em ações. ${ }^{166}$ Por isso, a busca por um conceito de sociedade deve

162 Ou seja, da sociedade e de seus sistemas parciais, sejam eles funcionais, de organização ou de interação.

${ }^{163}$ LUHMANN, 2007a, p.56

${ }^{164}$ LUHMANN, 2007a, p. 57 e ss

${ }^{165}$ LUHMANN, 1995b, p.137

${ }^{166}$ LUHMANN, 1995b, p. 138 -139 
levar em conta "a unidade que em última análise compreenda um sistema social e cujas inter-relações o sistema pode se distinguir de seu ambiente". É uma questão de "constituição do sistema", daí porque Luhmann sustenta que "a comunicação é a unidade elementar da auto constituição [dos sistemas sociais]; e a ação é a unidade elementar da auto-observação e da auto-descrição [dos sistemas sociais]." ${ }^{\text {167 }}$

Isso vai ao encontro de sua teoria que analisa a sociedade como um sistema autopoiético, ou seja, que opera por um processo de auto-referência composto por elementos (eventos) que se referem a si mesmos por incluir a sua conexão com outros elementos do mesmo processo. Disso se retira que não pode haver um correlato ambiental para a comunicação, uma vez que "não há correspondência da unidade da comunicação em nada no ambiente. ${ }^{168}$ Portanto a comunicação necessariamente opera por meio da diferenciação." Neste sentido, a comunicação apresenta o contexto conectivo para comunicações futuras: comunicação se liga com comunicação, o que fecha o ciclo autopoiético de um sistema diferenciado. ${ }^{169}$

Ao reforçar que a sociedade o sistema que abarca todos os sistemas sociais, Luhmann argumenta que "distinções como economia e sociedade, direito e sociedade, escola e sociedade são desconcertantes (...). Elas transmitem a ideia de que os componentes da distinção se excluem mutuamente, quando, na verdade, a economia, o

${ }^{167}$ LUHMANN, 1995b, p. 175.

168 Por este motivo, a "sociedade como sistema social omniabarcador não conhece sistemas sociais além de suas fronteiras e, por conseguinte, não pode observar-se deste fora. Os sistemas psíquicos, evidentemente, podem observar a sociedade desde fora, mas socialmente isso permanece sem consequências e não se comunica - é dizer: a observação não se efetua no sistema social.” (LUHMANN, 2007a, p. 63 ênfase adicionada)

${ }^{169}$ LUHMANN, 1995b, p. 144. O conceito de comunicação, em si, não é relevante para o presente trabalho. Cabe apenas referir aqui que Luhmann se afasta dos modelos comunicacionais que trabalham com a metáfora da "transmissão" ("Übertragung") seja de informações (Informationen) ou de mensagens (Nachrichten), por serem esses modelos por demais ontológicos ao pressuporem que "o emissor transmite algo que o receptor adquire", Esses modelos seriam "modelo duais" na medida em que trabalhariam com posições rígidas entre um emissor e um receptor da comunicação, de modo que o transmissor seja o foco das análises. (idem, p.139). Ao partir do conceito de sentido (Sinnbegriff), o autor afirma ser a comunicação uma ocorrência seletiva (a escolha de um referencial "deixando outras coisas de fora"). Seu modelo é, portanto, o de um processo trifásico, sendo a comunicação a síntese dessas três seleções. Primeiro, a informação (Information) é uma seleção em um repertório de possibilidades de referência. Ainda, é necessário escolher um comportamento (Verhalten). A diferença entre a informação e o comportamento de expressar uma mensagem (Mitteilungsverhalten) abre a possibilidade de que ambos os polos da comunicação - encarados por Luhmann por formas flexíveis e não fixas: "alter" e "ego" - interpretem essa relação de sentido. Daí a importância da compreensão (Verständniss) para o conceito de comunicação, de modo que a comunicação só se completa com a compreensão. O que é importante notar aqui é que a este conceito de comunicação como a síntese de três seleções - informação (Information) mensagem (ou ato de comunicar - Mitteilung) e compreensão (Verständniss) - Luhmann atribui a importância de "antecipações sobre antecipações" entre ego e alter no polo comunicacional, daí a importância de "expectativas". (idem, pp. 143-147) Esse tema será trabalhado por nós no item separado para a noção de "estrutura" e "mudanças estruturais" na teoria dos sistemas. 
direito, a escola, etc. não podem ser pensados fora da sociedade, mas apenas como sua realização. Tratar-se-ia, segundo ele, a do mesmo "sem-sentido" de se distinguir mulheres e seres humanos". 170

\subsection{A evolução da sociedade moderna hipercomplexa e funcionalmente diferenciada}

Vimos no item anterior como a teoria dos sistemas concebe a sociedade como um sistema diferenciado todo abarcador. Esse conceito "formal", contudo, ainda não explica as especificidades da sociedade moderna, nem como ela se diferencia, se estrutura internamente e se altera em processos dinâmicos. Para lidar com essas questões, a sociologia luhmanniana vincula à sua descrição da sociedade moderna um contexto de "hipercomplexidade", o que, em última análise, levaria esse sistema a se diferenciar funcionalmente. Isso é relacionado com a formação de sistemas. Resta-nos, agora, desenvolver a relação entre a teoria da diferenciação e a teoria da complexidade na teoria dos sistemas.

Adiante-se que um sistema se constitui como tal quando se diferencia de seu ambiente determinado (Diferenciação = Ausdifferenzierung). A diferenciação é um conceito central na teoria dos sistemas. Contudo parte-se de uma correlação (Zusammenhang) entre diferenciação sistêmica (Systemdifferenzierung) e complexidade para se explicar como sistemas são formados e evoluem - e por correlação não quer dizer que os conceitos denotem o mesmo sentido. ${ }^{171}$

Complexidade não deve ser confundida com complicação. ${ }^{172}$ Luhmann apresenta uma definição inicial do conceito de complexidade ao notar que o mundo apresenta ao homem uma multiplicidade de experiências e ações possíveis em contraposição ao seu limitado potencial em termos de percepção, assimilação, ação atual e consciente. Portanto, "[c]ada experiência concreta apresenta um conteúdo evidente que remete a outras possibilidades que são ao mesmo tempo complexas e contingentes. Com complexidade queremos dizer que sempre existem mais possibilidades do que se pode realizar. Por contingência entendemos o fato de que as possibilidades apontadas para as demais experiências poderiam ser diferentes das esperadas; (...) Em termos práticos, complexidade

\footnotetext{
${ }^{170}$ LUHMANN, 2007a, p. 65

${ }^{171}$ LUHMANN, 1980a, p.21

${ }^{172}$ LUHMANN, 2007a, p. 108
} 
significa seleção forçada, e contingência significa perigo de desapontamento e necessidade de assumir-se riscos". ${ }^{173}$

Essa relação fica mais clara em definições mais abrangentes e mais técnicas apresentada pelo autor. Em primeiro lugar, nota-se que complexidade "não é uma operação, nem algo que se um sistema execute ou que ocorra dentro dele, sendo antes um conceito de observação e de descrição". ${ }^{174}$ O ponto que Luhmann ressalta é que para haver criação ou formação de sistemas (Systembildung) é necessário haver assimetria de complexidade entre o sistema e o ambiente. Daí ele falar em correlação ou "coevolução" entre a complexidade do ambiente e a complexidade do sistema - uma vez que a complexidade de ambos aumenta de forma correlacionada. ${ }^{175}$ Podemos denominar a complexidade do ambiente de complexidade não-estruturada, não organizada ou indeterminada, ${ }^{176}$ e complexidade do sistema de complexidade sistêmica, estrutural, determinada ou organizada - ou seja, complexidade construída ou organizada pelo sistema.

Para entender essa questão é necessário trabalhar a diferença sistema/ambiente a partir de uma outra diferença: "elemento/relação". Nota-se que, da mesma forma que não há sistemas sem ambiente, não há elementos sem relação ou sem enlaces relacionais. ${ }^{177} \mathrm{Ou}$ seja, uma unidade de análise é considerada complexa "na medida em que possua vários elementos e os ligue através de várias relações". ${ }^{178}$

Os elementos são a menor unidade de um sistema. Vimos que nos sistemas sociais essa unidade é a comunicação. Portanto, um elemento é constituído como unidade apenas pelo sistema que os alista como um elemento utilizado em suas relações - ou seja, são elementos apenas para o sistema que os emprega como unidade. ${ }^{179}$ Ilustrativamente, para a teoria dos sistemas, os elementos da sociedade são comunicações, os elementos dos sistemas psíquicos são pensamentos e os elementos de sistemas biológicos são células.

Por sua vez, é a partir da relação entre elementos que o conceito de condicionamento pode surgir. Com efeito, os sistemas não são meras relações entre elementos, uma vez que as conexões entre relações também devem ser reguladas de alguma forma. É precisamente essa regulação que assume a forma de condicionamento (condições de possibilidade) e, por isso, assume maior complexidade. Esse

\footnotetext{
${ }^{173}$ LUHMANN, 1983a, p. 45-46

${ }^{174}$ LUHMANN, 2007a, p. 101

${ }^{175}$ LUHMANN, 2007a, p. 106.

${ }^{176}$ LUHMANN, 2007a, p. 100; 1995b, p. li

${ }^{177}$ LUHMANN, 1995b, p. 20

${ }^{178}$ LUHMANN, 2007a, p. 102

${ }^{179}$ LUHMANN, 1995b, p. 22
} 
condicionamento recíproco entre relações servem como "restrições" (Einschränkungen “constraints") ao funcionamento do sistema. ${ }^{180}$

Assim, é possível introduzir o conceito de complexidade a partir da definição de elemento e relação, o que permite não apenas aplicar o conceito de complexidade não apenas aos sistemas - e, portanto, ao "ambiente", "mundo" -, mas também enriquecer a análises de teoria dos sistemas. Nesse sentido, "complexidade organizada [complexidade sistêmica] só pode ocorrer por meio da formação de sistemas, pois 'complexidade organizada' não significa nada mais do que complexidade com relações seletivas entre seus elementos". ${ }^{181}$ - O sistema é obrigado a restringir possibilidades, a e reduzir processar a contingência e a complexidade do mundo. Ele é obrigado, então a fazer seleções e, ao fazêlo, torna-se mais complexo. Vejamos isso com mais calma, uma vez que esse processo é fundamental para a teoria da evolução de Luhmann.

Percebemos, então, que "diferenciação sistêmica" e "complexidade" são duas formas de se abordar a "decomposição" de um sistema: "[u]ma delas objetiva a formação de subsistemas (ou, mais precisamente, relações internas entre sistema e ambiente) dentro do sistema. A outra decompõe o sistema em elementos e relações. Na primeira, quartos compõem uma casa; na segunda, tijolos, pregos, feixes, etc., são o que o compõem. $O$ primeiro tipo de decomposição é levado a cabo por uma teoria da diferenciação sistêmica. O segundo resulta em uma teoria da complexidade sistêmica. É essa distinção que torna a afirmação de que a complexidade sistêmica aumenta com um aumento na diferenciação ou com uma mudança na forma de diferenciação seja uma assertiva significativa e não tautológica". ${ }^{182}$

Daí a importância do conceito de complexidade para a teoria da evolução de Luhmann. Isso, pois o autor argumenta que, geralmente, “a evolução somente é possível quando existe um grau suficiente de complexidade sistema-ambiente, e, neste sentido, a evolução é a co-evolução entre sistemas e ambientes". ${ }^{183}$ Ora, argumenta Luhmann, "quando ocorre um aumento no número de elementos que devem ser unidos em um sistema ou perante um sistema (como seu ambiente), chegamos rapidamente a um limiar no qual não é mais possível relacionar cada elemento com todos os outros". ${ }^{184}$

\footnotetext{
${ }^{180}$ LUHMANN, 1995b, p. 23

${ }^{181}$ LUHMANN, 1995b, p. 24. (ênfases adicionadas)

${ }^{182}$ LUHMANN, 1995b, p. 21. (ênfases adicionadas)

${ }^{183}$ LUHMANN, 1995b, p. 26

${ }^{184}$ LUHMANN, 1995b, p. 24
} 
$\mathrm{Na}$ esteira dessas considerações, fica fácil visualizar a relação entre a teoria da diferenciação e a teoria da complexidade: tanto a diferenciação de sistema aumenta a complexidade do ambiente (pois ele é o ambiente de outros sistemas) como o aumento da complexidade do ambiente pressiona o sistema a realizar seleções e, portanto aumenta também sua complexidade. Esse catalítico de reforço mútuo levou Luhmann a afirmar que "[o] impulso e o regulador da evolução é o hiato de complexidade entre o sistema e o ambiente". 185

Tanto a diferenciação de um sistema de seu ambiente (Ausdifferenzierung) quanto a diferenciação interna ${ }^{186}$ de um sistema em subsistemas (Differenzierung) aumentam a complexidade e reforçam as condições para a formação de novos sistemas. Neste sentido, "a diferenciação sistêmica é um promotor de complexidade e um impulsionador (Anstoß) para a construção de ordens emergentes". ${ }^{187}$

Enfim, dessas considerações se retira que transformação de complexidade desestruturada em complexidade estruturada - uma operação de seleção e redução (paradoxal) de complexidade ${ }^{188}$ - força o sistema a "realizar seleções", aumentando sua capacidade seletiva (ou seus condicionamentos de seleções) para responder ao aumento da complexidade de seu ambiente. Isso invariavelmente o leva obter um maior grau de complexidade estruturada. Em outras palavras, a inferioridade do sistema em termos de complexidade "deve ser contrabalanceada por estratégias de seleção. A complexidade do próprio sistema já exerce sobre ele pressão seletiva (Selektionszwang). ${ }^{189}$ Por sua vez ordem escolhida pelos sistemas para relacionar seus elementos resulta da diferença em complexidade entre ele e seu ambiente". ${ }^{190}$

Luhmann aplica esse modelo evolutivo da análise dos sistemas e análise da complexidade à sua teoria da evolução da sociedade. Por isso - e isso é importante que se diga - a pergunta sobre a evolução social na teoria dos sistemas é uma pergunta sem caráter

${ }^{185}$ LUHMANN, 1983a,p. 172. (Ênfase adicionada).

186 "Um sistema é diferenciado quando ele constrói sistemas parciais em si mesmo, o que significa repetir a construção sistêmica (Systembildung) em si mesmo e criar novamente a diferença entre sistema e ambiente (agora, ambiente interno). Pela diferenciação interna, portanto, o sistema se multiplica, em que ele se repete a si mesmo como repetição da diferença de sistema parcial e ambiente interno em um ambiente externo." (LUHMANN, 1980a, p.21).

${ }^{187}$ LUHMANN, 1980a, p. 21

${ }^{188}$ Uma vez que só complexidade pode reduzir complexidade (LUHMANN, 1995b, p.26)

${ }^{189}$ LUHMANN, 2007a, p. 335. Ver NEVES, 2006, pp 1-11; 1 e ss. A tradução deste termo encontra algumas variações. Conforme Marcelo Neves, Selektionszwang pode ser traduzida como "necessidade de seleção" (e 'necessita di selezione'); "coacción de seleción" (e“being forced to select' ) e "pressão seletiva"; sendo que Neves adota o último. (NEVES, 2006, p. X). Por sua vez, João Paulo Bachur escolhe o termo "pressão por seleção" BACHUR, 2010.

${ }^{190}$ LUHMANN, 1995b, 25-26. 
teleológico ou valorativo. Não há a possibilidade de previsões evolutivas, uma vez que ela não segue caminhos ou "fins determinados". Luhmann mantém como seus pressupostos o "acaso e a contingência", como seria de se esperar em sua teoria da complexidade. Portanto não há aproximação possível da teoria da evolução de Luhmann nem com teorias historicistas, de teoria da história nem de "darwinismo social" ou "ecologia humana".

Em Luhmann, a pergunta sobre a evolução da sociedade é antes uma pergunta pela "negentropia" do social e suas alterações - em outras palavras, pela "morfogênese da complexidade". O que guia as análises é a pergunta sobre o improvável surgimento de ordens que se auto sustentam - e por isso são negentrópicas - e por sua alteração. ${ }^{191}$ Aplicada à sociedade a pergunta se volta, então, para a análise do estabelecimento e da reprodução de suas estruturas. Só haverá evolução quando houver mudança na estrutura da sociedade. Veremos que o argumento luhmanniano sobre a evolução implica precisamente isso, com o aumento de complexidade, a sociedade se estruturou por formas distintas de diferenciação ao longo do tempo.

O conceito luhmanniano evolução é pautado por processos de variação, seleção $e$ reestabilização de estruturas. Com isso se ressalta o caráter central da pergunta evolutiva sobre como é possível a "ordem" se forme a partir do "ruído"; ou como expressado pelas teorias evolutivas iniciais, como ocorre o surgimento das formas essenciais e das substâncias a partir do acidental"' 192

Para Luhmann, os recentes desenvolvimentos da teoria da evolução - após seu início com Darwin - têm ocorrido sua pela aproximação com a teoria dos sistemas. A diferença principal se dá pela maneira pela qual se pensa a "adaptação". Para Luhmann, a evolução não é determinada pelo ambiente, como ele afirma ocorrer na teoria darwinista, segundo a qual os "desvios" (variações) são selecionados pelo ambiente ("seleção natural"). Para Luhmann, em oposição, tanto a seleção quanto a variação são sistêmicos

Por isso, o autor reforça o caráter sistêmico da evolução - ou em palavras mais precisas: "[d]o ponto de vista teórico sistêmico, variação e seleção são entendidas como 'sub-dinâmicas do sistema complexo""193. Por isso, não se trata de conceber que "a evolução deva produzir a adaptação do sistema ao ambiente, mas antes é necessário pressupor a adaptabilidade (do sistema ao ambiente) como uma espécie de condição prévia

${ }^{191}$ Para o autor, a evolução transforma a baixa probabilidade do surgimento de sistemas em uma alta probabilidade de preservação (LUHMANN, 2007a, p.326).

${ }^{192}$ LUHMANN, 2007a, p. 335.

${ }^{193}$ LUHMANN, 2007a, p. 340. 
de possibilidade". ${ }^{194}$ Enfim, se aplicarmos o que discutimos anteriormente aqui, temos que o conceito de adaptação - quando lido pela interação recíproca entre análise de sistemas e análise de complexidade - nos leva a reconhecer que "sistemas complexos devem se adaptar não apenas aos seus ambientes, mas também às suas próprias complexidades". ${ }^{195}$

As fases da evolução social, quando lidas pela teoria dos sistemas, se apresentam da seguinte maneira: (1) através da variação se modificam os elementos do sistema - no caso dos sistemas sociais, as comunicações. A variação consiste em uma reprodução desviante de elementos por elementos do sistema. Ou seja, ela consiste em uma comunicação inesperada, surpreendente. (2) Por seu turno, a seleção se refere às estruturas do sistema, ou seja, as expectativas que guiam a comunicação. Com base na comunicação desviante, a seleção elege as referências de sentido que tenham valor de formar estruturas, idôneas para o uso repetido, capazes de construir e condensar expectativas. Portanto, a seleção rejeita aquelas novidades que não aparentam ser aptas para servir de estruturas ou para dar rumo à comunicação posterior - seja atribuindo o desvio às circunstâncias, abandonando-as ao esquecimento, ou rechaçando-as explicitamente. (3) Por fim, a reestabilização se refere ao estado em que o sistema que está evoluindo se encontra a realização uma seleção que resultou positiva ou negativa. Aqui se trata, sobretudo, do próprio sistema mesmo da sociedade em relação com seu ambiente." 196

Essas são as linhas básicas da teoria da evolução da teoria dos sistemas. Quando elas são aplicadas à teoria da sociedade desenvolvida por Luhmann, chega-se ao conceito de uma sociedade moderna diferenciada funcionalmente. Esse é o elemento "histórico" do "mapa dual" dito por Luhmann: sua teoria da evolução social é uma teoria da "variação, seleção e reestabilização" das formas pelas quais a sociedade se estrutura - ou, mais precisamente de diferentes formas de diferenciação ao longo da história da sociedade. É por meio da análise das formas de diferenciação social que Luhmann desenvolve seu conceito de sociedade moderna funcionalmente diferenciada (em oposição às sociedades pré-modernas diferenciadas por outros critérios). Note-se que essa passagem da prémodernidade para a modernidade não compreende uma sequencia de etapas de desenvolvimento. São antes formas distintas pelas quais a sociedade se estruturou. É a aqui que a teoria da complexidade de Luhmann desempenha um papel importante.

${ }^{194}$ LUHMANN, 2007a, p. 341. Por esse motivo é que ele se afasta do "darwinismo social", pois não há relação com a "seleção natural" (LUHMANN, 2007a, p.444 e 555).

${ }^{195}$ LUHMANN, 1995b, p. 31.

${ }^{196}$ LUHMANN, 2007a, pp.358-359. 
O tema da "diferenciação" é clássico na sociologia e encontra nela diversas formulações. Todavia, o núcleo abstrato do argumento é o mesmo: a sociedade precisa se diferenciar para manter sua coesão sob condições de auto grau de crescimento. ${ }^{197}$ Ora, quanto maior for a complexidade, maior será a diferenciação. Quando há evolução, a forma de se diferenciar se reestrutura. ${ }^{198}$ Luhmann apresenta as formas de diferenciação na história da evolução social da seguinte maneira:

A. Diferenciação segmentária, caracterizada pela igualdade dos sistemas parciais da sociedade - sistemas que se distinguem ou a partir da descendência ou a partir das comunidades habitacionais, ou ainda a partir da combinação de ambos os critérios.

B. Diferenciação segundo centro e periferia: Neste caso já aqui se admite um caso de desigualdade que transpõe o princípio da segmentação e, portanto, prevê uma pluralidade de segmentos em ambos os lados da nova forma. Aparece a distinção de centros de distinção quando dentro de uma estrutura tribal ocorrem centros que somente podem ser ocupados por famílias distintas.

C. Diferenciação estratificada: é caracterizada pela desigualdade de hierarquia dos sistemas parciais. Esta forma também tem sua estrutura em uma distinção de pares, i.e., a distinção entre nobreza e povo comum. Aqui Luhmann se refere às hierarquias estáveis tais quais o sistema de casta na índia o a ordem estamental medieval tardia.

D. Diferenciação funcional: caracterizada tanto pela desigualdade como pela igualdade dos sistemas parciais. Os sistemas de funções são iguais em sua desigualdade. Aqui percebemos sua renúncia em assumir qualquer prioridade da sociedade total em suas relações recíprocas. Aqui não existe nem uma igualdade única (como no caso centro/periferia), nem uma forma de sociedade total para relacionar transitivamente todas as desigualdades, evitando relações até então circulares. Precisamente estas relações são agora completamente típicas e normais". ${ }^{199}$

Já vimos o que o conceito de diferenciação (ou diferenciação interna) se refere à formação de sistemas dentro de um sistema - ou melhor, em ${ }^{200}$ seu "ambiente interno". Contudo, Luhmann aborda a pergunta da evolução da sociedade por suas formas de diferenciação não apenas por ser este um conceito importante para a teoria dos sistemas, mas também por argumentar que o conceito de diferenciação é mais plausível

${ }^{197}$ LUHMANN, 2007a, p. 472.

${ }^{198}$ É importante repisar que não se tratam "sequências ou etapas de desenvolvimento", muito menos de etapas cronológicas.

${ }^{199}$ LUHMANN, Niklas. La sociedad de la sociedad. (op. cit.), p.485-486.

${ }^{200}$ LUHMANN, 2007a, p. 473. 
analiticamente para explicar a sociedade por não precisar de uma "coordenação" abrangente para operar. Isso implica um deslocamento do autor das análises da integração social como instrumento analítico para explicar como a sociedade se estrutura e evolui. A pergunta não se dirige, portanto, às formas de integração social em sua variação histórica, mas às suas formas de diferenciação.

A tradição europeia velha encara o conceito de integração prevendo "a ordenação coordenada na totalidade do todo". ${ }^{201}$ A esse conceito seriam ligados conceitos normativos de valores e solidariedade e clamar atitudes que o correspondam. Contudo, quando "as sociedades se tornam mais complexas, qualquer conceito normativo que exija integração (o a aprove) encontra crescente resistência". Isso levaria a um enfoque que se foca primariamente no rechaço da sociedade pela esperança de integração. Em outra palavra, a ênfase na ruptura seria limitada, uma vez que atribui primazia explicativa para uma maior quantidade de "nãos" do que os "sins". 202

A explicação luhmanniana de integração social como redução dos graus de liberdade dos sistemas parciais será mais bem abordada nos capítulos 3 e 4 do trabalho. Por agora, adiante-se que essas restrições aos sistemas parciais "não ocorre no ambiente externo da sociedade, mas em seu ambiente interno”, admitindo. Daí a importância de se discutir tal tema ao tratar do conceito de esfera pública. Ressalte-se, apenas, que o conceito luhmanniano de integração não é carregado normativamente e não obedece a nenhuma "instância central" coordenadora ou ontológica. Seu enfoque é apenas operativo, ou seja, voltado ao enlace de comunicações, de modo que não se requer consenso algum. Nesse sentido, Luhmann admite que não há uma distribuição em todos os sistemas funcionais das operações sociais, havendo, portanto, comunicação não operada pelos sistemas funcionais. ${ }^{203}$ Portanto, "[t]ambém uma sociedade altamente diferenciada conhece muita interação "livre". 204

Voltemos então ao conceito de diferenciação social e como ele pôde servir de critério para a classificação evolutiva da sociedade. Após rejeitar a explicação da evolução por formas de integração social, o autor reconhece que a riqueza histórica das sociedades pré-modernas e a diversidade de suas variações empíricas faz com que classificações

${ }^{201}$ LUHMANN, 2007a, p. 476

${ }^{202}$ LUHMANN, 2007a, p. 478.

${ }^{203}$ Luhmann assevera: "resultaria em um quadro sumamente parcial se descrevêssemos a sociedade moderna somente como um conjunto de sistemas funcionais autônomos. (...). A objeção que se coloca contra isso é que em algum lugar e de alguma maneira deve ocorrer a 'integração'.” (LUHMANN, 2007a, p. 615).

${ }^{204}$ LUHMANN, 2007a, p. 478-479 e p. 474. 
históricas fracassem. Por esse motivo ele utiliza o conceito de formas de diferenciação social. ${ }^{205}$ Nota-se que o processo de diferenciação pode se ativar espontaneamente - como resultado da evolução - e então induzir transformações estruturais. ${ }^{206}$.

Com isso em mente, Luhmann reconhece na evolução da sociedade uma mudança em suas estruturas de diferenciação. Ao lidar com níveis de complexidade cada vez mais altos, no curso da evolução posterior da sociedade, a função evolutiva de reestabilização se transfere cada vez mais aos sistemas parciais da sociedade. ${ }^{207}$ Essa "mudança estrutural" de forma de organizar pode ser marcada, grosso modo, por uma passagem de princípios organizativos estruturais integradores ou "top-down" para princípios mais flexíveis. Isso leva os sistemas sociais a se estruturar em relação à funções que eles prestam para a sociedade como um todo.

Com isso, Luhmann rejeita o princípio organizativo da hierarquia para caracterização da estrutura da sociedade moderna, uma vez que ele seria demasiado centralizador e simplificador. Luhmann trabalha com a noção de que os sistemas parciais são funcionais. A orientação e estruturação por funções auxiliam que esses sistemas parciais em sua auto-descrição e identidade, além de tornar possível que eles trabalhem com sua complexidade de forma mais elevada. ${ }^{208}$ Enfim, a função é encarada como um processo "cego" de variação e seleção. Por isso, "é um mecanismo morfogenético e criativo, que examina eventos por meio de sua função e ocasionalmente resolve o problema funcional ao adquirir "aquisições evolutivas" bem sucedidas. ${ }^{209}$

O postulado da diferenciação funcional é o que caracteriza a sociedade moderna para o autor. ${ }^{210}$ Essa forma de diferenciação foi uma "mudança estrutural" da sociedade que nos habilita a indicar e delimitar a sociedade moderna. É por orientar-se a uma função - ou seja, orientar-se a um problema e à sua resolução - que as estruturas rígidas de uma organização "hierárquica ou integradora" são quebradas, permitindo que os sistemas parciais se diferenciem de forma autopoiética e podem aumentar significativamente sua complexidade organizada. Portanto, por indicar a diferenciação funcional como a nota característica da sociedade moderna, Luhmann a descreve como sendo heterárquica - ou seja, marcada pela "igualdade" de sistemas sociais parciais ou de função. Logo, é por

\footnotetext{
${ }^{205}$ LUHMANN, 2007a, p. 482.

${ }^{206}$ LUHMANN, 2007a, p.474.

${ }^{207}$ LUHMANN, 2007a, pp.358-359.

${ }^{208}$ LUHMANN, 1995b, p. 299.

${ }^{209}$ LUHMANN, 1995b, p. 303.

${ }^{210}$ LUHMANN, 2007a, p.589.
} 
existirem "vários contextos parciais autopiéticos" na sociedade que Luhmann atribui a ela o caráter de ser "policontextural" e desconhecer "centros ou vértices".

Duas ressalvas são necessárias. Em primeiro lugar, apenas o fato de os sistemas sociais se orientarem por uma função não é o suficiente para que eles se fechem de modo autopoiético. Ainda será necessário que eles se dirijam à prestação de suas funções de forma estruturada e redundante, o que será explicado no item 5 pela necessidade de um código binário e a subsequente diferença entre "código e programação". ${ }^{211}$ A segunda ressalva postula que, ao contrário do que pode parecer, reconhecer que os sistemas parciais realizam funções em prol do sistema social todo abarcador - ao que se atribui o termo de prestação -, Luhmann não apresenta uma estrutura necessária da sociedade a partir dessas funções - tal como o fazia Parsons. Isso não implica de modo algum, nem em expectativa de "equilíbrio social" nem de "preservação do sistema da sociedade". A teoria de Luhmann não é uma teoria da manutenção da ordem. ${ }^{212}$ Esta questão ficará mais clara quando tratarmos, em termos gerais, do funcionalismo radical de Luhmann.

\subsection{Mudanças estruturais nos sistemas sociais: como sistemas mudam?}

Na teoria dos sistemas, o estudo das "mudanças estruturais" de sistemas sociais é indissociável do estudo do surgimento desses sistemas. Há mudança quando estruturas se alteram - porque sistemas complexos são dinâmicos e "não-triviais", sendo que conseguem operar em níveis de variação extremamente elevados, com mudanças s e pequenas que não alteram sua estrutura.

Para entender o conceito de estrutura da sociedade - as expectativas sociais devemos compreender a abordagem de Luhmann do conceito de dupla contingência na formação dos sistemas sociais. Uma explicação mais detida sobre os tipos de expectativas sociais - a cognitiva e a normativa - será desenvolvida no capítulo 3.

A explicação da formação da sociedade pela dupla contingência não é nova na sociologia. Contudo, sua formulação foi enquadrada na teoria da ação - principalmente em Parsons. A sociedade surgiria para "resolver o problema da dupla contingência". Como sabemos, Luhmann não se vale de um "shared simbolic system" ou de qualquer outro

\footnotetext{
${ }^{211}$ LUHMANN, 2007a, p.591-593.

${ }^{212}$ LUHMANN, 2007a, pp. .590 e ss.
} 
conceito integrativo ou consensual para teorizar como o problema da dupla contingência é solucionado pela sociedade ${ }^{213}$.

Como vimos, tanto os sistemas psíquicos quanto os sociais são ligados ao meio do sentido. O estudo da dupla contingência, segundo Luhmann, auxilia a teoria dos sistemas sociais a explicitar (ainda mais) a diferença entre indivíduo e sociedade. ${ }^{214}$ Isso, pois a dupla contingência pressupõe observações mútuas e expectativas mútuas (expectativas sobre expectativas) entre sistemas psíquicos inacessíveis uns para os outros. Essas expectativas são, portanto, formuladas socialmente.

Vejamos o conceito com maior vagar. Sistemas psíquicos são inacessíveis uns para os outros $^{215}$. Fundamentalmente, a situação dos sistemas de consciência se estabelece da seguinte forma: trata-se de duas caixas-pretas. Cada um "determina seu comportamento por opções auto-referenciais complexas dentro de suas próprias fronteiras (...). [E, além disso,] [c]ada um assume isso também do outro". ${ }^{216}$ Isso gera uma pressão por agir, pois observações e expectativas mutualmente referidas - em uma grande cadeira crescente e nunca solucionável - resulta em grandes níveis de complexidade. ${ }^{217}$

É essa complexidade gerada por estruturas de expectativas que restringem (constrain) a emergência de novas ordens, ou seja, a formação de novos sistemas. Estas "restrições sistêmicas da formação de sistemas" são as estruturas dos sistemas sociais, formadas por expectativas, portanto. A absorção de incerteza desempenhada ou prestada pelos sistemas é, portanto, uma estabilização de expectativas - e não de comportamentos, como a teoria da ação formulara a questão. ${ }^{218}$

Ao formular a questão da dupla contingência em termos de expectativas, Luhmann afirma ser possível aplicar o conceito na análise de sistemas sociais. Isso implica também a formação de fronteiras temporais. Nas palavras de Luhmann: “[u]m comportamento

${ }^{213}$ LUHMANN, 1995b, p. 103-104.

${ }^{214}$ LUHMANN, 1995b, p. 105-108.

215 Isso, pois ninguém pode saber o que o outro pensa e espera diretamente, ou seja por pensamentos. Ainda que se comunique o que está pensando, e portanto processe elementos no sistema sociedade, o problema da inacessibilidade das consciências permanece: a comunicação pode ser insincera ou mentirosa, pode haver falhas no entendimento, desconfiança, dificuldade de formulação, etc. Vermos que a linguagem como acoplamento estrutural entre consciências e sociedade - torna as comunicações sociais um sistema de interface entre consciências, não operando com elas. A sociedade é ainda diferenciada (Ausdiferenziert) dos sistemas de consciência.

${ }^{216}$ LUHMANN, 1995b, p.109.

${ }^{217}$ As observações e interpretações mútuas são complexas. Em palavras de Luhmann, “cada lado pode distinguir entre seu ambiente (mundo) e os sistemas com seus respectivos ambientes em seu ambiente [externo, mundo] (LUHMANN, 1995b, p.113).

${ }^{218}$ LUHMANN, 1995b, p 110 - 114. Note-se que essa necessidade de estabilização de expectativas não se confunde com a função do direito de estabilizar expectativas normativas, como veremos posteriormente. 
motivado apenas de maneira autista por uma pessoa individual continuará, mesmo se outras pessoas entrarem ou saírem do campo de mútua percepção. A experiência da dupla contingência, em contraste, permite e chega até a compelir uma meta-perspectiva que fornece às sequencias comportamentais fronteiras temporais, a saber, que disciplinam comportamentos ao fornecer a ele uma estrutura periódica (...). Portanto, o problema da dupla contingência tem as propriedades de um fator auto-catalítico: sem ser 'consumido', ele possibilita a construção de estruturas em um novo nível de ordenamento (...).,219

É assim que Luhmann explica como sistemas sociais se destacam da realidade psíquica química e orgânica. Neste sentido, sistemas psíquicos, no sistema social, se tornam pessoas, ou seja, "uma colagem de expectativas que funcionam como ponto de referência para seleções futuras dentro do sistema". ${ }^{220}$ Neste sentido, as pessoas não são sistemas, ${ }^{221}$ mas uma forma que serve ao acoplamento estrutural entre sistemas psíquicos e sociais. Elas funcionam, portanto, como "endereços comunicacionais". ${ }^{222}$ Juntamente com as pessoas (forma que serve o acoplamento estrutural), Luhmann concebe a linguagem como o meio fundamental da comunicação, que, por sua vez, também serve ao acoplamento dos sistemas de consciência aos sistemas sociais ${ }^{223}$

Voltemos à questão da dupla contingência sistêmica e sua relevância para o estudo das mudanças estruturais dos sistemas sociais. Nota-se, portanto, que ao tratar da formação de sistemas sociais de tal maneira, pela vinculação do problema da dupla contingência, o autor não pressupõe que o mundo está em ordem e depois persegue abordagem de 'problemas sociais' em relação a ameaças a estabilidade por desvios, desenvolvimentos exponenciais ou criminalidadade. Para Luhmann, "o que está em questão não é um interesse de reconhecer e curar - nem de preservar - o que existe, mas antes e acima de tudo por um interesse analítico: quebrar a ilusão da normalidade (...)". ${ }^{224}$ Nesse sentido, para a teoria dos sistemas sociais, são problemas que operam como agentes catalíticos factualmente efetivos da vida social. Isso tem amplas consequências teóricas, pois a teoria que se estrutura a partir daí encara a realidade como flutuante e "auto-fundacional" (selfgrounding). Mais importante que isso, conclui-se que a teoria não pode fundamentar a

\footnotetext{
${ }^{219}$ LUHMANN, 1995b, p.120.

${ }^{220}$ LUHMANN, 1995b, p.127.

${ }^{221}$ LUHMANN, 1998b, p. 232.

${ }^{222}$ LUHMANN, 1998b, pp. 243-244.

${ }^{223}$ LUHMANN, 2007a, pp 158 e ss.

${ }^{224}$ LUHMANN, 1995b, p.114.
} 
manutenção da ordem social nem na natureza, nem em normas ou valores que são válidos a priori". 225

A partir desse quadro teórico, Luhmann pode aprofundar a dimensão temporal dos sistemas em eventos/estruturas e argumenta que, "quando se percebe que estruturas sociais são estruturas de expectativas, pode-se ligar esse avanço teórico com a teoria dos sistemas". Postula-se que "expectativas (Erwartungen) emergem ao restringir âmbitos de possibilidade (Möglichkeitsspielraums). Em última análise, elas não são nada além dessas restrições". ${ }^{226}$ Assim, expectativas incluem mecanismos de redução de complexidade. A estrutura de expectativas equaliza uma multiplicidade de ocorrências heterogêneas pelo reconhecimento de seu desapontamento, que, por sua vez, indica linhas de ação possíveis. ${ }^{227}$ Entende-se que as estruturas de expectativas englobam uma interrelação de expectativas mais ou menos seguras de que algo pode acontecer. Com isso, além das questões de desapontamento, expectativas também podem ser a fonte de conflitos, tema que trataremos no capítulo $3 .^{228}$

Luhmann argumenta, então, que após definir que as estruturas dos sistemas sociais são formadas por expectativas é possível acessar a questão "de quais estruturas tiveram a chance de ser escolhidas e provaram seu valor no curso da evolução". ${ }^{229}$ Novamente, a resposta de Luhmann é aquela que ressalta a importância da diferenciação funcional da sociedade, agora lida por uma ótica da formação estrutural de sistemas. ${ }^{230}$

Como vimos anteriormente, as diferentes formas de diferenciação da sociedade implicam estruturas sociais diferentes. Vimos que a hierarquia - mais vinculada a uma ordem social estratificada - foi considerada como um princípio estrutural demasiado rígido para a sociedade moderna. Com efeito, a hierarquia é um princípio estrutural que não deixa aberta a possibilidade de alternativas a si, sendo, portanto, "funcionalmente insubstituível”. 231 Já a orientação por função "é em si mesmo uma contingência já formulada, ou seja, a equivalência formulada entre solução de problemas e a possibilidade de sua substituição ou troca: se algo não funciona mais, algo diferente irá". Assim, há menos pressão exercida para a conformação, tal qual com a hierarquia, uma vez que "o

${ }^{225}$ LUHMANN, 1995b, p. 123.

${ }^{226}$ LUHMANN, 1995b, p. 292.

${ }^{227}$ LUHMANN, 1995b, p. 293. Veremos esse ponto com maior vagar quando tratarmos do sistema jurídico da sociedade moderna ao distinguir expectativas normativas de expectativas cognitivas.

${ }^{228}$ LUHMANN, 1995 b, p. 307.

${ }^{229}$ LUHMANN, 1995b, p. 298.

${ }^{230}$ LUHMANN, 1995b, pp. 299 e ss.

${ }^{231}$ LUHMANN, 1995b, p. 338. 
acesso a alternativas possíveis é canalizado por estruturas que são orientadas por funções". Isso não elimina as hierarquias, mas as tornas passíveis de críticas de um ponto de vista funcional. Enfim, os sistemas funcionalmente orientados estimulam o criticismo porque sua unidade reside no princípio de que todas suas figuras podem ser substituídas sob certas condições. ${ }^{232}$ Em outras palavras, qualquer solução que é orientada a resolver um problema não consegue se manter como necessária, uma vez que a demonstração de alternativas à resolução desse problema podem se colocar e superar a solução anterior.

O ponto que Luhmann retira dessas considerações tão abstratas é que teorias voltadas para a explicação da mudança em sociedades hierárquicas não dariam conta de explicar as mudanças estruturais de uma sociedade funcionalmente diferenciada. Isso valeria para modelos de sistemas hierárquicos tais quais modelos de "dominação"233

Isso, pois para o autor, os sistemas orientados por função ao "funcionalizar" o que esta latente inclui sua própria ordem. Em outras palavras, as contingências que se apresentam perante os sistemas sociais devem ser, necessariamente, ou expelidas para seu ambiente ou trabalhadas dentro do sistema. De maneira provocativa, Luhmann afirma que essa pretensão de trazer à tona ou esclarecer o que está "latente", "secreto" ou "oculto" foi tratada pelo Esclarecimento (Aufklärung) na problematização crítica da faculdade de razão, tanto por teorias da virtude quanto por teorias do século XIX na busca por uma instância contra factual que fundamentasse a consciência da contingência. Luhmann se opõe a essa tradição afirmando desenvolver um esclarecimento sociológico (soziologische Aufklärung) faz com que estruturas e funções latentes se tornem manifestas. ${ }^{234}$

Essa consideração tem uma grande implicação na teoria da mudança social em Luhmann. Para o autor, só há mudança social quando há mudança em estruturas. Isso, pois ainda que os elementos de um sistema não possam se alterar, é possível que as relações entre eles sejam alteráveis e reversíveis. É no nível das expectativas, e não da ação, que um sistema pode aprender dissolver o que esta estabelecido e se adaptar à mudanças externas e internas. $^{235}$

Isso tem implicações para a teoria da mudança social e para as explicações de como elas acontecem. Luhmann argumenta não haver uma teoria unificada sociológica para a mudança social. Haveriam apenas diversas explicações bem sucedidas. Dentre elas, ele

\footnotetext{
${ }^{232}$ LUHMANN, 1995b, p. 339.

${ }^{233}$ LUHMANN, 1995b, p. 340.

${ }^{234}$ LUHMANN, 1995b, pp. 340-343.

${ }^{235}$ LUHMANN, 1995b, pp. 344-345.
} 
destaca que usualmente "se trabalha com contradições estruturais e conflito sob a hipótese de que sistemas desestabilizados por essas contradições tendem para mudanças estruturais. Além disso, existe no século XIX a herança de uma teoria da evolução que se aplica apenas a sistemas sociais e não a todos os sistemas sociais, bem como a teoria présociológica da mudança paradoxal, que sustenta haver um aumento na satisfação de desejos, bem estar, e sucesso de forma desproporcional, o que também aumenta a insatisfação e consequentemente leva à mudança estrutural”. Outras teorias encontrariam os maiores estímulos de mudança social na própria estrutura simbólica da sociedade como, por exemplo, a religião. O argumento de Luhmann é que todas essas tentativas são demasiadamente reducionistas e tentam compreender a tipologia da mudança do ponto de vista de suas causas e enriquecer seus modelos com uma constelação de condições históricas - descrevendo as mudanças estruturais, portanto, como processos históricos. ${ }^{236}$

A teoria dos sistemas pretende responder a esta questão por criar uma teoria que lide tanto com a mudança quanto com a manutenção social. O motivo para isso seria que mudanças estruturais pressupõem auto-manutenção. Disso se segue que "mudança $e$ preservação não podem ser explicadas por teorias diferentes (talvez 'progressivas', por um lado, e 'conservadoras', por outro), e que toda teoria deve sempre lidar com os dois conceitos". ${ }^{237}$ Para Luhmann, a sociedade é uma ordem "auto-substitutiva, uma vez que tudo a ser alterado ou substituído em relação a ela deve ser feito dentro dela". ${ }^{238}$ Esse é um ponto importante para nossas discussões com o modelo habermasiano de esfera pública.

Segundo a sociologia luhmanniana, mudanças estruturais - para se caracterizarem como tais - devem ser "persuasivas" e formar novas expectativas ou dar novos sentidos às expectativas existentes. ${ }^{239}$ Para que isso ocorra, o sistema precisa mobilizar suas próprias operações e estruturas e processar sua "auto-mudança" por meio de seu funcionamento autopoietico. Logo, "não há nenhuma intervenção causal do ambiente no sistema sem a cooperação desse sistema (...). Essa é a forma e a condição para toda adaptação". Sem a cooperação do sistema, restaria ao ambiente a possibilidade de meramente destruir a reprodução autopoiética. ${ }^{240}$ Ao proceder dessa forma, a teoria dos sistemas poderia

\footnotetext{
${ }^{236}$ LUHMANN, 1995b, pp. 346-347.

${ }^{237}$ LUHMANN, 1995b, pp. 347.

${ }^{238}$ LUHMANN, 1995b, p. 409.

${ }^{239}$ LUHMANN, 1995b, pp. 348 e 352.

${ }^{240}$ LUHMANN, 1995b, p. 350.
} 
oferecer uma teoria unificada da mudança social e evitaria recair no problema de "superestimar eventos como causas da mudança". 241

Por fim, ao ressaltar o postulado da "morfogênese" - que afirma que toda mudança é uma "auto-mudança" de um sistema, caso contrário haveria sua destruição -, Luhmann reconhece que, "apesar de ser possível encontrar frequentemente ações dirigidas a metas e mudanças estruturais intencionais e planejadas, até recentemente sequencias de mudanças estruturais teleologicamente concebidas eram muito raras". ${ }^{242}$ Para Luhmann, o planejamento da sociedade complexa funcionalmente diferenciada é de difícil controle e direcionamento, principalmente se pensarmos em teorias que veem a sociedade a partir do sistema política, inclusive as teorias da modernização. Isso resultaria em uma "advertência" para a sociologia. Uma vez considerado que mudanças sociais são primariamente "incontroladas", a sociologia deveria prestar mais atenção à observação de processos morfogênicos do que a eventos históricos. ${ }^{243}$

Estas questões ficarão mais claras quando tratarmos da abordagem luhmanniana da contradição e conflito no capítulo 3, ao discorrer sobre os movimentos de protesto.

\subsection{Os meios de comunicação simbolicamente generalizados}

Outro tema relevante para a teoria da evolução da sociedade em Luhmann é a distinção meio/forma e sua caracterização dos meios de difusão e meios de consecução ou - meios de comunicação simbolicamente generalizados.

Como vimos, segundo essa teoria, sistemas sociais autopoiéticos precisam “enlaçar” comunicações com outras comunicações futuras - estimuladas pela própria comunicação inicial - criando relações. Se cada enlace desse operar - de uma comunicação com outra - acontecesse de modo aleatório ou deixado ao azar, não haveria comunicação. Isso, explica Luhmann, pois "deve haver probabilidades que orientem a expectativa". A questão perquirida por Luhmann é aquela de saber como a comunicação pode superar a "improbabilidade" de seu proceder. Em outras palavras, como algo tão improvável como a comunicação pode ocorrer de forma tão corriqueira e se manter, uma vez que há tantos requisitos para sua manutenção? ${ }^{244}$

${ }^{241}$ LUHMANN, 1995b, p. 353.

${ }^{242}$ LUHMANN, 1995b, p.356.

${ }^{243}$ LUHMANN, 1995b, p. 356.

${ }^{244}$ LUHMANN, 2007a, p. 145. Novamente, vemos aqui o estilo luhmanniano de formular suas perguntas pelo questionamento dos motivos da negentropia e pela exposição das ilusões da normalidade. 
A discussão sobre a distinção meio/forma é empregada pela teoria dos sistemas para substituir as teorias da comunicação por "transmissão". Para Luhmann, não há transmissão de comunicação - muito menos "razão"245 como ordem superior. A comunicação ocorre por meio de sistemas sociais e a única ordem superior é o sistema sociedade como sistema de referência. ${ }^{246}$

Postula-se, então, que os sistemas de comunicação se constituem a si mesmos mediante a distinção meio/forma: "quando falamos de meios de comunicação pontuamos sempre o emprego operativo da diferença entre substrato medial e forma". ${ }^{247}$ Luhmann define esses conceitos pela diferença "acoplamento frouxo/acoplamento firme" dos elementos. Disso se retira que os meios realizam um acoplamento frouxo entre seus elementos, e as formas o fazem de forma firme e estável. Por esse motivo que é possível criar diversas formas em um meio. ${ }^{248}$

A diferença substrato medial/forma é importante para haver enlace entre comunicações. ${ }^{249} \mathrm{E}$ isso ocorre de duas maneiras, em dois "tipos" de meios. Em primeiro lugar, Luhmann discorre sobre os meios de difusão como aqueles que tratam do alcance da redundância social. Os meios de difusão determinam e ampliam o círculo de receptores da comunicação. Os exemplos principais oferecidos são a escrita, a imprensa e a comunicação eletrônica. Tais alterações nos meios de comunicação de difusão da comunicação foram extremamente relevantes para a evolução da sociedade - dentre outros motivos, por mudar a relação entre presentes e a temporalidade da comunicação social. ${ }^{250}$

O desenvolvimento dos meios de difusão tem uma grande importância para a teoria da evolução da sociedade para Luhmann. Esse ponto é muito importante para nossa discussão, pois será abordado quando tratarmos da questão do sistema dos meios de comunicação em massa (grosseiramente entendido como “mídia”) e sua relevância para a esfera pública.

Segundo Luhmann, o processo evolutivo dos meios de difusão (que vai da invenção da escrita até os modernos meios eletrônicos) resulta em algumas tendências evolutivas

${ }^{245}$ Luhmann sustenta que "diferentemente do postulado pela teoria da 'ação comunicativa' de Jürgen Habermas, nós nos livramos de incluir pretensões de racionalidade no conceito de comunicação; e sustentamos unicamente a existência de um contexto relacional entre capacidade de imposição e fugacidade temporal da forma. Os meios de comunicação - assim como o conceito de sistema ou de evolução - não prejudicam em direção da racionalidade" (LUHMANN, 2007a, p. 153).

${ }^{246}$ LUHMANN, 2007a, p. 148-149.

${ }^{247}$ LUHMANN, 2007a, p. 149 Luhmann fornece alguns exemplos de meios, como a luz, o ar e os campos magnéticos. Por sua vez, as formas podem se formar sobre esses substratos mediais.

${ }^{248}$ LUHMANN, 2007a, p. 151-153.

${ }^{249}$ LUHMANN, 2007a, p. 154.

${ }^{250}$ LUHMANN, 2007a, p. 155. 
importantes que se podem resumir naquela "que vai de uma ordem hierárquica para uma ordem heterárquica que renuncia a integração espacial das operações da sociedade". ${ }^{251}$

$\mathrm{O}$ autor argumenta que os meios de difusão trabalham paralelamente à organização hierárquica e realizam sua deslegitimação - ou melhor, apresentam um projeto alternativo. Isso, pois a hierarquia se assemelha à estrutura de uma pirâmide, na qual os princípios organizativos vão "de cima para baixo" a partir de um vértice. As heterarquias, ao contrário, se baseiam em uma série de contatos imediatos que observam e discriminam-se mutuamente. Luhmann se refere à questão da censura e da sobredeterminação dos meios de difusão por princípios políticos em burocracias como na China e Coreia do Norte. O autor afirma que, nessas empreitadas, "o fracasso é inevitável. A multiplicidade de obras impressas em diversos territórios e o rápido aumento de complexidade no conteúdo da comunicação impressa obriga, em último caso, a todas as hierarquias - inclusive a da política e a do direito - a fazer as pazes com uma sociedade que comunica primariamente de forma heterárquica. Desde o século XVIII esta circunstância se celebra como predomínio da 'opinião pública' - que em termos de diferenciação significa a passagem para a diferenciação por funções. ${ }^{252}$

Com esse desenvolvimento dos meios de difusão, a sociedade tenderia a ensaiar novos "valores próprios" que prometem estabilidade sob condições de heterarquia e de observação de segunda ordem. As seleções dos meios de difusão "poderiam ter aqui uma importância decisiva, já que pelo menos são compatíveis com uma ordem heterárquica da comunicação". 253

Ademais, com a evolução desses meios, ocorre a renúncia da "integração espacial”, ou seja, de que para que comunicações aconteçam seja necessário que pessoas estejam presentes em locais determinados com suas condições concretas. Luhmann argumenta: “[s]e no século XVIII a integração da sociedade se entrega à 'opinião pública', é possível encontrar aí, em última análise, uma renúncia à integração espacial - senão à integração enquanto tal. Isso, porque 'público' não quer dizer outra coisa senão deixar livre a entrada a qualquer pessoa (renúncia do controle do acesso), ou seja, indeterminação estrutural da integração espacial". 254

\footnotetext{
${ }^{251}$ LUHMANN, 2007a, p. 242.

${ }^{252}$ LUHMANN, 2007a, pp. 242-243.

${ }^{253}$ LUHMANN, 2007a, pp. 243.

${ }^{254}$ LUHMANN, 2007a, p. 244.
} 
Por sua vez, os meios de consecução - mais bem definidos como meios de comunicação simbolicamente generalizados - oferecem um nexo condicionamento e motivação. Estes meios têm grande importância para os enlaces comunicativos operados nos sistemas sociais. Isso ocorre, pois os meios de comunicação simbolicamente generalizados fazem com que expectativas de aceitação se "sintonizem". Em outras palavras, esses meios conseguem fazer com que comunicações determinadas tenham maior chance de serem aceitas - sem a necessidade de discussão ou consenso. Luhmann argumenta que é mais fácil se aceitar uma troca ou um pagamento quando se oferece dinheiro, ou obedecer a uma ordem por meio da violência estatal ou pela força do poder. Portanto, ao se institucionalizar, estes meios de comunicação simbolicamente generalizados amplia-se “o âmbito de 'não-rechaço' da comunicação - rechaço esse muito provável quando se impulsiona a comunicação a ir mais além do âmbito dos presentes". Daí Luhmann pegar o termo emprestado de Parsons e definir esses meios como persuasivos intrínsecos. Portanto, a sociedade se serve da formação de "meios especiais" para reduzir a contingência e vincular o condicionamento da motivação, ou seja, se serve dos meios de comunicação simbolicamente generalizados. ${ }^{255}$

Os meios de comunicação simbolicamente generalizados têm tamanha relevância para a teoria da sociedade de Luhmann, pois eles respondem à questão de saber como é possível ordem social sem referência à condições normativas, tais como direito natural, contrato social e moral do consenso. Essa é a diferença do uso do conceito por Parsons que trabalhava com a noção de "valores simbólicos compartilhados" e Luhmann, que não enxerga a necessidade de haver tal partilha de valores. ${ }^{256}$

Ao invés de se apoiar analiticamente na moral e na partilha de valores como explicação da coesão social, Luhmann se desloca a explicação para os meios de comunicação simbolicamente generalizados. Seu caráter "simbólico" dota as operações comunicacionais de maior perspectiva de aceitação, transformando "de maneira assombrosa as probabilidades do não em probabilidades de sim”. Esses meios coordenam seleções e alcançam um acoplamento firme apelas mediante a forma específica do respectivo meio, como por exemplo, "provas de amor, teorias, leis e preços". Eles funcionam de forma generalizada, pois podem abarcar diversas situações distintas ao ligar expectativas às operações de sistemas sociais autopoiéticos. ${ }^{257}$

\footnotetext{
${ }^{255}$ LUHMANN, 2007a, pp. 156-157.

${ }^{256}$ LUHMANN, 2007a, p. 245.

${ }^{257}$ LUHMANN, 2007a, p. 248.
} 
Isso fica mais claro quando Luhmann argumenta que, no processo de evolução, esses meios se concentram em "problemas-guia" para o seu desenvolvimento: verdade, amor, poder/direito e propriedade/dinheiro. ${ }^{258} \mathrm{Ou}$ seja, eles se ligam a uma função. Além disso, esses meios se diferenciam e apresentam relevância para as estruturas (expectativas). Eles são funcionalmente equivalentes entre si, mas cada um deles se especifica em uma função determinada e toma prevalência nela (se universaliza) - ou seja, nenhum outro meio de comunicação está disponível para aquela questão específica. Dessa forma, os meios de comunicação simbolicamente generalizados coordenam comunicações na estrutura das expectativas sociais, no âmbito do "agir e vivenciar" dos polos comunicativos ego e alter. $^{259}$

Luhmann apresenta uma correlação tabelada para demonstrar como os meios de comunicação simbolicamente generalizados conseguem obter essa característica de "universalismo e especificidade" em diferentes "âmbitos do agir e vivenciar". É dessa forma que ele apresenta os principais meios de comunicação simbolicamente generalizados: (1) âmbito de relação entre vivência de alter e vivência de ego: verdade $e$ valores. (2) âmbito de vivência de alter e agir de ego: amor, (3) âmbito do agir de alter e de vivência de ego: propriedade/dinheiro e arte. (4) âmbito do agir de alter e agir de ego: poder/dinheiro. ${ }^{260}$

$\mathrm{O}$ argumento dos meios de comunicação simbolicamente generalizados tem um importante peso analítico para "fechar" o argumento Luhmanniano de se explicar a sociedade sem a referência a valores, moral ou consensos. Com ele se fecha sua teoria da evolução da sociedade. Contudo, uma questão importante permanece aberta: seria possível falar em evoluções correlatas na sociedade - principalmente evolução de ideias? Esse é o tema do próximo item.

\subsection{Estrutura social e semântica: a evolução das ideias}

$\mathrm{O}$ argumento de que a sociedade complexa funcionalmente diferenciada é de difícil controle e planejamento traz consigo diversas objeções. Não seriam as ideias e as autodescrições da sociedade algo utilizado frequentemente por atores e pessoas para a alteração da sociedade? Ideias como o humanismo, democracia, etc. não poderiam ser

\footnotetext{
${ }^{258}$ LUHMANN, 2007a, p. 257.

${ }^{259}$ LUHMANN, 2007a, pp 258 e ss.

${ }^{260}$ LUHMANN, 2007a, p. 261.
} 
contrapostas aos sistemas para alterá-lo por pressões vindas "de fora"? Não poderíamos falar em uma evolução das ideias que alterasse a sociedade?

Luhmann discorre sobre essa possibilidade. Ele argumenta que a evolução da sociedade - da estrutura do sistema social, conforme exposto acima - não é o único processo evolutivo relevante para a sociedade, ou seja, não há uma evolução societal singular. Luhmann sustenta que esse não é o caso, pois há também outros processos evolutivos na sociedade, a saber: a evolução de ideias (de autodescrições ou semânticas) ${ }^{261}$ e a evolução dos sistemas parciais. Contudo, ao reconhecer isso, Luhmann reforça essas evoluções ocorrem todas dentro da sociedade e, por isso, são coevoluções.

Ao tratar da evolução particular das ideias, Luhmann introduz a diferença entre operação e observação: a forma com que a sociedade opera (estrutura social) é assimétrica em relação à forma pela qual ela se auto-descreve (semântica). ${ }^{262}$ Essa assimetria "produz efeitos na morfogênese" da construção evolutiva e na diversificação e desmontagem de estruturas. Notam-se assimetrias no nível semântico entre resultados evolutivos e suas descrições, de modo que ambas tenham "tempos" diversos. Isso fica evidente quando reconhecemos incongruências temporais entre a evolução estrutural dos sistemas e a evolução semântica quando presenciamos "ideias que surgem antes de plasmar-se em contextos de diferenciação". ${ }^{263}$

Luhmann atribui a evolução das ideias ao desenvolvimento dos meios de comunicação de difusão, principalmente a escrita. O que é relevante ressaltarmos, aqui, é que com esses desenvolvimentos semânticos possibilitou maior grau de comunicações críticas. ${ }^{264}$ Contudo, esse "potencial crítico" da semântica não deve ser levado como o fio condutor da análise, pois, como afirma Luhmann, "a evolução das ideias sempre resulta em semânticas históricas. Ela se torna dependente (...) de estruturas sociais predeterminadas pela forma dominante de diferenciação sistêmica correspondente. (...) As inovações devem ser introduzidas de acordo com ela [realidade ou estrutura social] e não contra ela". ${ }^{265}$ Admiti-se, ainda, que cada sistema funcional da sociedade possa ter sua própria história

${ }^{261}$ LUHMANN, 1980a, esp. pp. 19 e ss para a noção de que a semântica como autodescrição da sociedade torna possível a evolução de ideias (Ideenevolution) e pp. 34 e ss; para uma descrição de como a noção de semântica se relaciona com a teoria da complexidade (distinção elemento/relação) e a teoria da diferenciação (sistema/ambiente).

${ }^{262}$ LUHMANN, 2007a, pp. 424-425. E assevera: “(....) como resultado da diferença entre operação e observação, devem distinguir estruturas respectivas: as estruturas da diferenciação dos sistemas, e as estruturas semânticas que identificam, retém, recordam ou deixam cair no esquecimento o sentido digno de ser conservado".

${ }^{263}$ LUHMANN, 2007a, pp. 426-427.

${ }^{264}$ LUHMANN, 2007a, p. 430.

${ }^{265}$ LUHMANN, 2007a, p. 434. 
das ideias, mas isso requer um estudo interno de cada sistema especificamente considerado. Luhmann ressalta que, no conjunto da sociedade, só se pode falar em uma evolução geral das ideias. ${ }^{266}$

É necessário reforçar que tal descrição de coevoluções não significa haver total independência entre elas, mas antes uma assimetria, principalmente de ordem temporal. Além disso, da mesma maneira que não há um telos, uma direção e um resultado melhor/pior na evolução da estrutura social, não há nada dessa sorte na evolução das ideias. Elas são sempre correlatas à estrutura social que a permite surgir, pois como autodescrição, ela é indissociável das operações que observa. Assim, "[a] evolução das ideias pode ganhar potencial crítico ou inovador partindo da lógica de suas próprias determinações e com ela resultar em 'preadaptative advances'. Ou também pode seguir as suas próprias tradições ainda que - desde há muito tempo - sejam obsoletas, como por exemplo a ideia (que se sustenta tenazmente na 'sociedade burguesa' com esperança de ascensão) de que se vive em uma sociedade estratificadas com transições lineares entre "abaixo" e "acima". 267

As mesmas considerações gerais valem para a evolução dos sistemas parciais. Ainda que Luhmann reconheça que não há muita literatura sobre o tema e que a semântica de cada sistema funcional da sociedade é vinculada à sua estruturação, o autor observa que "[a]s evoluções dos sistemas parciais começam unicamente com a diferenciação funcional do sistema da sociedade, porque apenas com essa forma de diferenciação se alcança - no plano dos sistemas parciais - essa combinação de fechamento operacional e elevada complexidade própria; a qual oferece suporte suficiente para a diferenciação de funções evolutivas". Cada evolução própria desses sistemas parciais seria possibilitada pelo fechamento possibilitado pelos códigos binários desses sistemas. ${ }^{268}$

Novamente, não há a presença de um componente teleológico, finalístico ou valorativo na evolução dos sistemas parciais. Mais do que isso, não há uma evolução conjunta desses sistemas em uma direção comum. Por esse motivo, Luhmann afirma que "é necessário abandonar a ideia predominava após Segunda Guerra Mundial nas investigações sobre a modernização, ou seja, a ideia de que as tendências da modernização nos diversos sistemas funcionais, digamos: democracia política, economia monetária dirigida pelo mercado, Estado de direito, investigação científica sem impedimentos

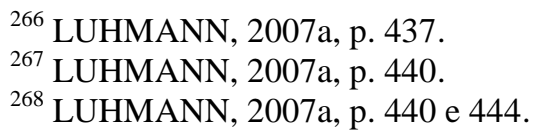


dogmáticos, meios de massa sem censura, escolaridade de toda a população conforme as suas capacidades individuais, etc., desencadeariam um impulso de desenvolvimento em que as realizações dos sistemas funcionais particulares se apoiariam e afirmariam mutuamente." 269

\subsection{Construtivismo radical e observações de segunda ordem}

A cibernética de segunda ordem e o construtivismo social radical também apresentam importância central na sociologia luhmanniana. Não é o momento para trabalharmos, aqui, as implicações que esses deslocamentos apresentam para a sociologia, principalmente para a teoria do conhecimento, mas antes tratá-los a partir da teoria social de Luhmann. Aliás, esses desenvolvimentos do construtivismo radical são utilizados pelo autor para "combater" o "quarto obstáculo epistemológico", que afirma ser possível que a sociedade "se observe (e se critique)" de fora. Além disso, as considerações luhmannianas, aqui, são em grande parte contrapostas às formulações de teorias críticas e normativas, o que é extremamente relevante para nossos debates posteriores sobre o conceito de esfera pública.

Vimos que o conceito antihumanista e antirregionalista de sociedade desenvolvido pela autor parte de investigações que "não negam que haja seres humanos e tampouco ignoram as grandes diferenças que marcam as condições de vida em diferentes regiões do globo terrestre. São investigações que apenas se recusam a deduzir destes fatos um critério para definir o conceito de sociedade e determinar os limites que determinam tal objeto. Contudo, é precisamente por meio dessa renúncia que se ganha a possibilidade de perceber - como autoprestação da sociedade - os padrões normativos e valorativos das relações entre os indivíduos. Por exemplo, os direitos humanos ou as normas com as quais se conquista o entendimento na comunicação no sentido de Habermas e, finalmente, as atitudes perante os diferentes graus de desenvolvimento das diversas regiões; sem que nada disso seja admitido como ideias reguladoras ou componentes do conceito de comunicação". ${ }^{270}$ Com isso, vimos que inexiste pretensão normativa de primeira ordem na teoria luhmanniana e, ainda que ela possa tratar de valores (como no caso das autodescrições semânticas da sociedade), eles são antes explicados pela teoria social e vinculados à estrutura social em questão.

\footnotetext{
${ }^{269}$ LUHMANN, 2007a, p. 449.

${ }^{270}$ LUHMANN 2007a, p. 20.
} 
O ponto de partida axiomático para compreendermos o "construtivismo radical" luhmanniano e notar que um sistema social - e naturamente a sociedade de um modo especial, - "pode se observar simultânea ou sucessivamente de maneiras muito diversas diríamos 'policontexturais'. Não existe então, nenhuma coação por parte do objeto par integrar as auto-observações: o sistema faz o que faz". ${ }^{271}$ Portanto, para o autor, a sociedade como sistema social todo abarcador não conhece sistemas sociais para além de suas fronteiras e, por conseguinte, não pode se observar de fora. Evidentemente, os sistemas psíquicos podem observar a sociedade de fora, "mas socialmente isso fica sem consequências se não é comunicado, ou seja,se a observação não se efetua no sistema social. Em outras palavras: a sociedade constitui o caso extremo de auto-observação policontextural de um sistema constrangido à auto-observação sem poder atuar como se fosse um objeto sobre o qual se procede a uma opinião correta, (...) "No caso da sociedade, não existe nenhuma descrição externa com respeito à qual podem haver as correções - por mais que literatos e sociólogos se esforcem em obter uma posição assim". ${ }^{272}$ Em outras palavras, "a rejeição do sujeito pela teoria dos sistemas está relacionada com a noção de que o mundo não é aquilo que pode ser descrito a partir de um [único] ponto. A última tentativa neste sentido foi a teoria do sujeito. (...) Tudo o que é formulado como sociedade, recai na grade (Raster) da percepção funcional, sendo, portanto, relevante politicamente, cientificamente, juridicamente, teologicamente, pedagogicamente, e assim por diante". ${ }^{273}$

Com isso, como veremos no Capítulo 3, as descrições da sociedade centradas na política e na economia são deslocadas por Luhmann, que afirma não ser possível nem descrever nem planejar a sociedade moderna hiplecomplexa, policontextural e funcionalmente diferenciada. O que, então, restaria para a sociologia?

Para o autor, a rejeição do "preconceito humanista" e a "descentração radical do sujeito" possibilitam uma análise mais clara de como a crise sociológica está sendo repensada dentro da própria sociologia. Luhmann sustenta que a sociologia tem abordado seu objeto-problema basicamente de duas maneiras, a maneira positivista (com a tradição baseada em Emile Durkheim) e a maneira crítica (iniciada com o pensamento de Karl Marx). Neste sentido, o autor afirma: “[o] resultado foi que, como uma ciência empírica, a sociologia estava interessada em estruturas latentes, enquanto como teoria crítica, ela tem apontado que a realidade social não é aquilo que parece ser. Portanto, todas as tentativas de

\footnotetext{
${ }^{271}$ LUHMANN, 2007a, p. 62.

${ }^{272}$ LUHMANN, 2007a, p. 63.

${ }^{273}$ LUHMANN, 1996b, p. 72.
} 
se construir uma teoria da sociedade unificada na base da distinção crítica/positivista obrigatoriamente levavam ao paradoxo de se tratar aparência e realidade; ou estruturas latentes e estruturas manifestas, como uma e a mesma coisa. Esta situação está agora mudando de uma maneira radical, a qual ainda deve ser apreciada pela sociologia. Eu estou me referindo a recentes discussões interdisciplinares sobre teorias de sistemas autoreferenciais, sistemas de fechamento autopoiético, cibernética de segunda ordem de sistemas observantes, e epistemologia construtivista e processamento de informações. Podemos nos valer destas recentes discussões no objetivo de entender a sociedade como um sistema auto-observante (auto-referencial) que define sua própria identidade, enquanto, ao mesmo tempo, deixar um "espaço livre" ( "unmarked space”) para a possibilidade de descrever a sociedade de formas bem diferentes"

Esta crise que teoria sociológica traz consigo - a dicotomia entre positivismo e teoria crítica - não seria o leitmotive da crise atual que afeta sociologia. Luhmann reconhece que a tensão principal da sociologia é similar a este antigo debate, e consiste em responder ao mesmo tempo "Qual é o caso?" e "O que existe por trás?” (Was ist der Fall? Was steckt dahinter?) - trata-se ainda do par-oposição realidade / aparência. Este paradoxo parecia complicar a explicação sociológica, uma vez que a unidade do campo científico da sociologia parecia prejudicada: a identidade da sociologia parecia se perder entre duas polaridades; "a separação de nossas duas questões (...) tornou mais fácil que a sociologia evitasse considerar acerca de sua própria identidade”. Luhmann, em método caro a sua teoria dos sistemas, parte do paradoxo de se encontrar a identidade da sociologia através de uma distinção. Para o autor, paradoxos se tornam produtivos se substituídos por distinções (que poderão indicar os dois lados do paradoxo).

Para resolver o problema de se criar uma ponte entre a explicação das estruturas latentes e fatos manifestos com unidade de campo na sociologia, Luhmann afirma que outras áreas do conhecimento (como matemática, física, biologia, linguística e filosofia) também se perguntam acerca do que acontece no (e com o) mundo quando ele contém um observador. ${ }^{275}$ É a partir do conceito de observador (e da pergunta por sua posição) que Luhmann poderá elaborar seu "construtivismo radical". Com o paradoxo da autoreferência, qualquer realidade (conhecimento) é uma construção do mundo no mundo. $\mathrm{O}$ auto argumenta: “[é] claro, o construtivismo deve manter as distinções entre auto-

\footnotetext{
${ }^{274}$ LUHMANN, 1994, p. 126.

${ }^{275}$ LUHMANN, 1994, p. 130.
} 
referência e referências externas, conceitos e objetos, ou verdades analíticas e sintéticas. Contudo, estas são vistas como nada mais que distinções internas que estruturam as operações do conhecimento. Elas nunca podem deixar o sistema que as utiliza para construir o mundo",276

O papel do observador em distinguir o mundo e referir-se a si mesmo como um observador é inseparável da ideia de distinção. Um observador só pode perceber-se como tal ao distinguir-se de "outro". Assim, argumenta Luhmann, "observadores reais observam o mundo real no mundo. Portanto, observadores devem ser observáveis por outros observadores, e assim por diante. O observador, então, é a rede de observações observantes, ou comunicação. Comunicação também acontece no mundo real". ${ }^{277}$

O que é importante reter aqui é que o desafio de tentar "dar unidade" à teoria sociológica pressupõe deslocar a relação entre sujeito e objeto na sociologia. Ora, Luhmann argumenta: quem observa a sociedade? Esta é uma questão importante. Para a teoria dos sistemas não existe nenhum observador externo à sociedade (como poderiam ser "Deus" ou o "indivíduo" como consciência autônoma). A "filosofia do conhecimento" baseada no sujeito foi suplantada pela teoria da auto-referencialidade. Logo, é a própria sociedade que observa a si mesmo. Desta forma, valendo-se da lógica de duplo valor da cibernética (two-vallued logic) e do conceito de distinção de George Spencer Brown; Luhmann afirma que um observador, para indicar uma parte de uma distinção (um lado de um círculo, por exemplo) deve "marcar" um lado da distinção (indicar) deixando o outro lado "não-marcado" (unmarked space). Ao fazer esta distinção, o próprio observador se mantém invisível e se torna também um unmarked space. O observador se distingue daquilo que ele está observando ${ }^{278}$. Desta forma, apenas a sociedade pode observar a sociedade. ${ }^{279}$ (ela não pode ser observada por algo fora dela, como pela natureza, ou pela consciência psíquica de um indivíduo).

Ademais, na sociedade moderna, não existe mais uma "cosmovisão" hierárquica que determina a observação da sociedade. Na modernidade, a sociedade se observa por diversos sistemas sociais autopoiéticos (ou subsistemas sociais). Não existe um observador

\footnotetext{
276 LUHMANN, 1994, pp. 130-131.

${ }^{277}$ LUHMANN, 1994, p. 132.

${ }^{278}$ Luhmann argumenta que "isto significa que a sociedade pode descrever-se apenas se distinguindo daquilo que não é sociedade. Ao mesmo tempo, esta auto-descrição é a operação de uma parte da sociedade que, por sua vez, também se distingue do que quer que esteja sendo descrito. Ou seja, qualquer auto-discrição da sociedade cria dois unmarked spaces: aquilo que não é sociedade (em termos da teoria sistêmica: o ambiente), e aquilo que produz a descrição dentro da sociedade (LUHMANN, 1994, p. 133).
}

${ }^{279}$ LUHMANN, 1994, p. 132-133. 
totalizante da sociedade ${ }^{280}$. Por isso, a sociologia se enquadra como parte de um subsistema social (ciência) que tenta descrever a sociedade. E isso gera uma situação paradoxal. Nas palavras de Luhmann: "em todos os casos, a sociologia somente existe no interior da sociedade, não fora dela. Para ser mais preciso, a sociologia só pode existir na sociedade enquanto uma disciplina científica. Ela não tem nenhum outro modo de ser. Este fato explica a dupla perspectiva da sociedade. Como uma ciência, a sociologia se volta aos fatos. Se ela quer apreender sobre a realizada que se encontra por trás dos fatos, a referência externa é a sociedade mesma. Isto é, a diferença entre estas duas questões é uma diferença nas referências externas da sociologia. A Sociologia não pode se desvencilhar de seu caráter científico nem de seu caráter social. Ela é uma ciência do sistema social e um sistema social da ciência. Para deixar estas questões ainda mais complexas, temos que a sociologia, como um sistema social e como ciência, é também um observador interno de qualquer sistema que ela participa." 281

Vários sistemas da sociedade observam a própria sociedade; mesmo que não o fazendo em sua totalidade ${ }^{282}$. Uma sociologia que reconheça isso poderá se tornar um observador das observações dos outros sistemas sociais. Além disso, quando associada com o construtivismo radical, ela compreende que cada observação deve ter um ponto cego. Este "algo que está atrás da observação" é tradicionalmente conhecido como latência. No entanto, não se trata de uma latência estrutural como algum tipo de área ontológica escondida, mas latência operacional que distingue isto- e não outra coisa. ${ }^{283}$

O ponto principal é que Luhmann sustenta que a teoria de sistemas autopoiéticos quebra com a tradição sociológica. Ela responde às duas perguntas de uma forma diferente: "Qual é o caso? Resposta: é o que está sendo observado, incluindo a observação dos observadores. Por sua vez, a resposta da teoria para a questão, o que está por trás dos fatos? é: aquilo que a observação falha em observar. ${ }^{284}$

${ }^{280}$ LUHMANN, 1994, p. 135.

${ }^{281}$ LUHMANN, 1994, p. 133.

${ }^{282}$ Luhmann fala da tentativa da mídia de massa - mass mídia - em fazer uma descrição geral da sociedade. Contudo, ela o faz através dos códigos operacionais informarion/non-information, ou ainda news/not news. Ela se baseia no senso comum (common knoledge) para tal. Nesta tentativa, ela demonstra um ponto de vista diferente de outras esferas e (mesmo quando faz meta-jornalismo) ela se mantém invisível em sua distinção, não podendo ser (como nenhum subsistema social pode ser) um observador privilegiado da sociedade. Na verdade, Luhmann (em consonância com Gotthard Gunther) afirma que a os subsistemas sociais têm maior capacidade de reflexão que a sociedade em sua totalidade. (LUHMANN, 1994, p. 133135). Veremos a questão da mídia e suas pretensões de "semântica" dominante da sociedade no Capítulo 4.

${ }^{283}$ LUHMANN, 1994, p. 136.

${ }^{284}$ LUHMANN, 1994, p. 136 e ss. 
É frente à questão dessa latência que a tradição teria vinculado conceitos "transcendentais" como razão, sujeito e crítica. Também "a autonomização do homem pela 'ética discursiva' luta contra esse problema, mas o faz retirando-se para o terreno muito inseguro da linguística, para poder salvar do desastre do sujeito transcendental pelo menos algum conceito normativo de racionalidade". ${ }^{285}$ Luhmann coloca sua teoria no lugar, e, segundo ele, "nada atrás dela”. Isso, pois “[e]m primeiro lugar a própria teoria é o quadro do mundo (Weltbild), não há nada mais atrás dela. Por outro lado, penso que seria necessário abandonar sugestões da tradição europeia velha ou nova de orientação por mudanças, pois a excitação desnecessária em busca de causas, diagnósticos e terapias não estão no nível da realidade". ${ }^{286}$

É importante notar que, para Luhmann, não há como se estabelecer um “objeto" específico ao se estudar a sociedade. Isso ocorre, é impossível descrever a sociedade fora dela; ou seja, a partir de uma observação externa. Qualquer "tentativa de descrever a sociedade faz uso de comunicação, ativa relações sociais e se expõe à observação na sociedade. Então, como quer que se pretenda definir o objeto, a definição mesma é já uma das operações do objeto: ao realizar o descrito, a descrição se descreve também a si mesma." 287 Em outras palavras, podemos pensar que qualquer tentativa de descrever a sociedade irá ser - ela mesma - interna à sociedade. Desta forma, por exemplo, uma teoria sociológica de explicação da sociedade (inclusive a de Luhmann, como ele mesmo reconhece) implicará mobilizar o sistema científico em um campo teórico específico, seus problemas, programas e teóricos; por outro lado, a divulgação da teoria implicará a redação e venda de livros; ainda, a receptividade ou não desta descrição pelos pares sociólogos pode gerar prestígio para o autor da teoria; artigos científicos e reportagens podem ser redigidos sobre esta descrição, etc. A "teoria somente pode comunicar-se dentro do sistema social", afirma Luhmann.

Isso nos leva à importante distinção luhmanniana entre "observação de primeira ordem" e "observação de segunda ordem". Para o autor, os sistemas de comunicação não sabem que as comunicações fazem contato unicamente com outras comunicações. Os sistemas operam, por conseguinte, "sob a ilusão de contato com o ambiente - no sentido de que apenas observam que observam e como observam. As experiências de resistência e de não-arbitrariedade de resultados da operação se registram como se fossem algo externo -

\footnotetext{
${ }^{285}$ LUHMANN, 1998a, p. 229.

${ }^{286}$ LUHMANN, 1996b, pp.72-73.

${ }^{287}$ LUHMANN, 2007a, p.1.
} 
proporcionando, assim, um mundo ao qual há que se adaptar" ${ }^{288}$ E argumenta: "[e]sta condição pode ao menos se fazer visível e, na observação de segunda ordem, é possível se suspender (aufheben) sem que se renuncie totalmente à observação de primeira ordem, já que no último término da observação se segunda ordem se deve observar a um observador. Por isso, quando se descobre a ilusão da realidade, isso segue sendo um fato dentro do mundo real. Vê-se que o sol "sai" - e não se pode ver de outra maneira, apesar de que se sabe que isso é um erro. Em outras palavras: no plano da observação de primeira ordem, que nunca se abandona por completo, não se pode distinguir entre realidade e ilusão de realidade". 289

De maneira geral, acompanhando Luhmann, o que se retira dessa discussão é que, do ponto de vista cognitivo, a possibilidade de uma concepção de mundo ontológica (ontologischen Weltkonzeption) - em um conceito forte de realidade - parece ter cedido espaço para teorias que lidam com a "observação de segunda ordem”. Isso teria grandes implicações mateteóricas para a sociologia. Nas palavras de Luhmann, o "jogo entre crise e crítica", na "semântica da emancipação" dos "diagnósticos de sintomas e prognósticos de futuro" 290 teria sido superado e transcendido ( "aufgehoben werden") e o "esclarecimento sociológico" teria trazido a sociologia de volta para o lugar que ela pertence, a saber: ao sistema da ciência observando outros sistemas sociais. Ao invés reconhecer "crises e patologias" perante modelos normativos, Luhmann afirma que a sociologia deveria explicar os fenômenos sociais como resultado de efeitos sociais e da estrutura social em si. $^{291}$

\section{Funcionalismo radical e o modelo teórico de comparação entre sistemas funcionais}

\subsection{A importância da análise funcional para a sociologia luhmanniana}

Juntamente com a teoria sistêmica e o seu "construtivismo epistemológico", 292 Niklas Luhmann desenvolve uma metodologia que podemos chamar de "funcionalismo radical". Afirma-se que Luhmann desenvolve um "funcionalismo radical", pois ele se

${ }^{288}$ LUHMANN, 2007a, p. 67.

${ }^{289}$ LUHMANN, 2007a, p. 67.

${ }^{290}$ LUHMANN, 1991, pp. 147-151; 2007, pp. 885 e ss., 1996c, p. 73 e ss.

${ }^{291}$ LUHMANN, 1991, pp. 150-151.

${ }^{292}$ Ver, neste sentido, TEUBNER, 1989, esp pp. 730 e 737 ss., em que o autor discorre sobre o construtivismo social radical de Luhmann. 
afasta do estrutural-funcionalismo (Strukturfunktionalismus ou Bestandsfunktonalismus) de Talcott Parsons; ${ }^{293}$ que trabalhava com estruturas fixas que prestariam funções aos sistemas sociais. Por sua vez, o funcionalismo (functional analysis) luhmanniano não se refere a estruturas, mas consiste em uma técnica teórica que analisa forma não-ontológica a operação de "problemas e solução de problemas", colocando em relação a oposição "problemas/solução destes problemas". 294

Luhmann argumenta que já com semântica do século XVIII, ao lidar com as questões da "morte e do tempo", a sociedade produzia conhecimento sobre si mesmo e (fora dela) buscando, por um, lado conhecimento de todas as variabilidades históricas de formas e, por outro lado, conhecimentos fundamentais deliberados. Em outras palavras, "[h]istoricismo e funcionalismo surgem ao mesmo tempo e dependem um do outro. $\mathrm{O}$ funcionalismo garante ao historicismo a não arbitrariedade (Nichtbeliebigkeit) da variação. $^{295}$ A análise funcional trata do processamento teórico da historicização e funcionalização (Historisierung und Funktionalisierung). Com isso, a pretensão funcionalista busca explicar as variações e a manutenção de eventos e processos sociais sem se valer de ferramentas explicativas baseadas em crises de legitimidade (Legitimationskrise). Para Luhmann, a teoria funcionalista "não-revolucionária" da sociedade, capaz de refletir sobre si mesma, é possível e consegue dar conta desta questão. $^{296}$

Ao utilizar a análise funcional, ${ }^{297}$ Luhmann dá preferência à formulação de problemas e manifestamente toma um cuidado meticuloso para "se evidar determinações estruturais da teoria”. O método da análise funcional é desenhado para a obtenção de informação (além de certo caráter de "explicação", ao qual Luhmann procura se afastar um pouco, afirmando que isso dependeria do peso e da abordagem dada ao funcionalismo. Com efeito, o caráter explicativo de sua teoria está mais vinculado à teoria dos sistemas). O funcionalismo radical regula e especifica as condições sob "as quais as diferenças fazem diferença". Em outras palavras, Luhmann está preocupado com um "horizonte específico do mundo da vida (Lebenswelt) ${ }^{298}$ que é estabelecido com propósitos específicos e que

${ }^{293}$ LUHMANN, 2006, pp. 12, 13 e ss.

${ }^{294}$ LUHMANN, 1995b, pp. 52 e ss.

${ }^{295}$ LUHMANN, 1980a, p. 9.

${ }^{296}$ LUHMANN, 1980a, p. 11.

${ }^{297}$ No presente trabalho uso "análise funcional" e "funcionalismo radical" como sinônimos.

${ }^{298}$ O termo, aqui, é utilizado de maneira ampla, sem referência ao termo utilizado por Habermas. Luhmann parece querer indicar o âmbito de experiências humanas e sociais no sentido abrangente, ou melhor, determinar nele o âmbito específico com o qual sua teoria trabalha de forma central. 
subjuga tudo que normalmente ocorre no processamento de informação (...) em condições específicas e lhes concedem determinada forma". Neste sentido, a análise funcional é uma técnica teórica. Tal técnica teria uma maior afinidade com "interesses epistemológicos" ligados a conceitos caros à teoria luhmanniana, como "complexidade, contingência e seleção".299

A análise funcional, portanto, se vale de relações para compreender "o que está presente como contingente e o que é diferente como comparável". A relação entre problemas e suas soluções não é tomada isoladamente, mas serve como um fio guia na busca por equivalências funcionais. Assim, a análise funcional é frutífera na medida em que o valor explicativo de seus resultados dependem da possibilidade de especificação da relação entre problemas e suas possíveis soluções. Portanto, o "insight" do funcionalismo radical reside em, por assim dizer, causalidades transversais (athwart causalities na tradução para o inglês): ou seja, na comparação. ${ }^{300}$

Em última análise, então, o método funcional é um método comparativo, uma vez que ele relaciona algo sob um ponto de vista de um problema a fim de ser capaz de relacioná-lo com outras soluções. ${ }^{301}$ Não há preocupação com unidades possuindo propriedades específicas, cuja permanência ou impermanência está em questão. Ao contrário, a análise funcional "indica uma intenção para comparar, uma expansão da contingência, uma perspectiva para a observação". ${ }^{302}$

Novamente, vale repisar que o funcionalismo luhmanniano não é de caráter estrutural, ou seja, que prevê estruturas necessárias para a manutenção funcional da sociedade. Antes, o problema de Luhmann é analisar o processamento da complexidade, "e não a manutenção de continuidades”. Enfim, Luhmann afirma ser a análise funcional tão importante para sua teoria, que "ela clama por ser uma epistemologia". ${ }^{303}$ Ainda que o autor reconheça que não há garantias absolutas de que a análise funcional resultará em maior ganho de conhecimento, existe uma pista que aponta neste sentido. Quanto mais suas análises se mantêm em situações e fatos mais e mais heterogêneos que as confirmam, é possível atribuir maior chance de que sejam verdadeiras: “[p]ortanto, seu funcionamento

\footnotetext{
${ }^{299}$ LUHMANN, 1995b, p. 52.

${ }^{300}$ LUHMANN, 1995b, p.53.

${ }^{301}$ LUHMANN, 1995b, p. 54.

${ }^{302}$ LUHMANN, 1995b, p. 55.

${ }^{303}$ LUHMANN, 1995b, p. 57.
} 
apesar de grande heterogeneidade é, em si mesmo, uma espécie de prova" e um "indicador válido de verdade". 304

Com isso, estamos munidos dos elementos necessários para saber como Luhmann pode desenvolver uma teoria geral de sistemas sociais e comparar sistemas funcionaistão diferentes quanto o direito, a ciência, a medicina, a arte, a política, e o sistema pedagógico. Antes de tratar os sistemas parciais de função, é necessário apresentar em algumas linhas introdutórias os outros "níveis" da sociedade: a interação e as organizações. Os "movimentos de protesto" - a forma pela qual Luhmann denomina os movimentos sociais - têm lugar específico em sua teoria e não podem ser reduzidos a nenhum dos três níveis da sociedade (portanto, nem a interações, nem a organizações nem a sistemas parciais). Trataremos dessa questão no Capítulo 3 dessa dissertação.

\subsection{Interação e organizações: outras diferenciações dos sistemas sociais}

Estamos, agora, munidos das linhas gerais da teoria dos sistemas de Luhmann e da importância que a análise funcional desempenha para sua sociologia. É a partir dela que o autor pode desenvolver análises comparativas funcionalistas e abstratas e tratar de sistemas parciais de função os mais diversos. Contudo, notar que a sociedade é funcionalmente diferenciada e conta com sistemas parciais funcionais não esgota as possibilidades de aplicação da sociologia luhmanniana aos sistemas sociais. Como vimos, o autor trabalha com três níveis na análise dos sistemas sociais: (i) interações; (ii) organizações e (iii) sociedades - ou sociedade moderna diferenciada em sistemas de função. ${ }^{305}$ Pela diferenciação da sociedade encontramos subsistemas de função em relação de igualdade entre si - ou seja, sem haver prevalência ou sobredeterminação funcional de uns sobre outros. Todavia, com isso não se esgotam "as diferenciações sistêmicas que podem ser observadas na sociedade". Existem outras formas que tratam da questão da dupla contingência. Por isso, Luhmann desenvolve os conceitos de sistemas de interação e sistemas de organização. ${ }^{306}$

Niklas Luhmann argumenta que a diferenciação entre interação e sociedade não havia sido levada às suas últimas consequências pela sociologia, seja por reduzir um termo ao outro - como no interacionismo simbólico - ou ela "tese fracassada" de se separar a

\footnotetext{
${ }^{304}$ LUHMANN, 1995b, p. 58

${ }^{305}$ Como vimos acima, cf. LUHMANN, 1995b, p.2

${ }^{306}$ LUHMANN, 2007a, pp. 643-644
} 
sociedade - como sociedade civil ou societas civilis - do Estado e da política. Isso, para o autor, é algo necessário para o estudo de sociedades complexas, nas quais a interação não desempenha um papel tão proeminente na estruturação da sociedade como ocorria com sociedades simples. ${ }^{307}$

Já vimos o conceito de Luhmann de sociedade como o sistema social todo abarcador e, por isso, já está implícito que todas as interações sociais ocorrem na sociedade e - apesar de serem termos distintos -, que sociedade e interação pressupõem-se mutuamente, sendo, ambos - a sociedade e as interações - tipos diferentes de sistemas sociais $^{308}$. Luhmann afirma que "as grandes formas dos sistemas parciais ${ }^{309}$ da sociedade flutuam em um mar de pequenos sistemas que continuamente se formam e se desfazem. Não há formação de sistemas parciais, nem forma de diferenciação sistêmica da sociedade que domine em tamanho grau a formação de sistemas sociais que eles somente possam se efetuar dentro dos sistemas primários [sistemas de função] do sistema sociedade. Aqui se encontram precisamente as chamadas relações de 'interface' entre os sistemas funcionais que utilizam interações e organizações (...)".310

Luhmann argumenta que, no tocante às interações, a tradição da sociologia geralmente aponta para contatos imediatos entre seres humanos - mediante encontros diários e pequenos - com a finalidade de crítica à sociedade. Realmente, a "sociedade parece determinar nosso destino de tal maneira que não pode ser configurada nem modificada mediante contatos entre seres humanos. Frequentemente se encontram análises - ainda que tratem de evitar matizes de crítica societal - que partem da distinção entre relações sociais diretas e indiretas". Contudo, isso não basta: "mesmo os encontros mais minúsculos de tipo pessoal e impessoal - desde que haja comunicação - realizam a

${ }^{307}$ LUHMANN, 1995b, pp. 406-408

${ }^{308}$ LUHMANN, 1995b, p. 416. Portanto, "a sociedade não é possível sem interação, nem a interação sem a sociedade; todavia, ambos os tipos de sistema não se fundem. Ao contrário, eles são indispensáveis um ao outro em sua diferença". (LUHMANN, 1995b, p. 417). Isso, pois a relação entre sociedade e interação pressupõe um contínuo de realidade social - comunicações, de forma que a interação não sai da dimensão social e não se forma para além de seus limites, mas em seu interior. Ela "[r]ealiza a sociedade, mas de maneira que dentro dela se produzem limites entre sistema específico de interação e seu ambiente interno da sociedade" (LUHMANN, 2007a, p. 647) Não se trata, também, de inferir que a sociedade seria algo abstrato e a interação concreto, como se a última concretizasse a primeira. Luhmann assevera que "seria falso assumir que a sociedade é composta de operações abstratas e a interação de operações concretas (comunicações, ações). A sociedade inclui a interação. A diferença entre elas não é a distinção entre tipos de ação societal versus interacional. Ao contrário, essa diferença estrutura o domínio indiferenciado de operações elementares, adicionando uma capacidade de abstração que não poderia ser desenvolvida apenas pela interação. (LUHMANN, 1995b, p. 422)

${ }^{309}$ Sistemas parciais, subsistemas, sistemas funcionais ou sistemas de função são utilizados como sinônimos neste trabalho para indicar os subsistemas sociais funcionalmente diferenciados da sociedade moderna como arte, direito, medicina, educação ou sistema pedagógico, política, economia, etc.

${ }^{310}$ LUHMANN, 2007a, p. 644 
sociedade. ${ }^{311}$ Luhmann desenvolve o conceito de interação para descrever o "contato entre os presentes" na sociedade moderna, que tem uma "forma própria de operar" e se formam quando se utiliza a presença de pessoas para responder ao problema da dupla contingência. ${ }^{312}$ As interações formam episódios e, ao contrário da sociedade, elas têm início e fim, circunscrevendo uma limitação temporal de formas diversas - Luhmann dá exemplo das aulas nas escolas. Precisamente por implicar episódios, as interações pressupõem uma sociedade que não seja episódica e garanta o substrato social para as interações. ${ }^{313}$ Além disso, nas interações, a sociedade "se autoriza ao isolamento e indiferença" e pode se auto-observar. ${ }^{314}$ Por fim, as interações dentro da dimensão social, ao lidar com expectativas e com coparticipes de comunicação que adquirem individualidade e se movimentam nas interações, as interações produzem "espaços de liberdade $e$ delimitações, e, precisamente neste sentido, produzem integração". Com isso, a sociedade "também ganha" com a diferenciação das interações. ${ }^{315}$

As interações são sistemas sociais que não adquirem o caráter de sistemas funcionais, pois são momentâneas e episódicas, desenvolvendo estruturas relacionadas com pessoas e papeis sociais na mutua percepção em situações de trato com a dupla contingência. Nota-se que a diferença presente/ausente não é uma diferença de natureza ontológica; tratando-se antes de uma diferença de observações de auto-referência e heteroreferência. ${ }^{316}$ Daí porque falar que a escrita, ao tornar possível a relação entre ausentes, teve grande influência no desenvolvimento das relações de interação na sociedade moderna.

O que nos é interessante reter das considerações de Luhmann sobre as interações é que, enquanto em sociedades "pré-modernas" ou "mais antigas", a trama entre interação e ambiente interno da sociedade estava fortemente entrelaçada, na sociedade moderna "essa rede cai”. É por isso que relações de troca e competição, cooperação e conflito - quando realizadas na base da interação, entre presentes e episódicamente - transformam-se em relações sociais "em certa medida sem consideração social alguma", 317 ou seja, sem serem processadas pelos sistemas sociais parciais. Seja como for, em sociedades complexas, apresenta-se a impossibilidade de se exercer influência sobre o que de fato ocorre a cada

\footnotetext{
${ }^{311}$ LUHMANN, 2007a, p. 645

${ }^{312}$ LUHMANN, 2007a, p. 645

${ }^{313}$ LUHMANN, 2007a, p. 648

${ }^{314}$ LUHMANN, 2007a, p. 648

${ }^{315}$ LUHMANN, 2007a, p.649

${ }^{316}$ LUHMANN, 2007a, pp. 646 e ss.

${ }^{317}$ LUHMANN, 2007a, p. 654
} 
momento, e "tanto mais ilusória é a fé de que tal influência poderia ocorrer sob a forma de interação conduzida de forma racional (mediante diálogo e busca por acordos recíprocos entre interlocutores acessíveis)".318

Vejamos essa questão com mais calma. Luhmann sustenta que mudanças estruturais na sociedade afetam os sistemas de interações. Neste sentido, quanto mais complexo o ambiente, mais heterogêneos os sistemas de interação. Em termos evolutivos, nota-se que em sistemas sociais tradicionais tinham muita dependência de interações e papeis sociais, principalmente em sociedades estratificadas. Com a transição para a sociedade moderna essa ordem se dissolve. Com isso, ocorre um "enfraquecimento da possibilidade de alistar interações como uma fonte de solidariedade societal". Devido à maior diferenciação entre sistema social e sistemas de interação, as formas de interação passam a exibir grande indiferença para as com os "não-participantes" se tornaram bem sucedidas. Isso vale principalmente para a troca e para o conflito. ${ }^{319} \mathrm{Com}$ isso, Luhmann afirma que a "indiferença" em relação aos papeis e aos não participantes é que caracterizam as relações de interação na sociedade moderna. ${ }^{320}$ É por essa indiferença com o outro que se caminhou para uma maior diferenciação entre sociedade e sistemas de interação. Aliás, Luhmann argumenta não ser um acidente que "a sociedade burguesa do século XIX se compreendia primariamente como a regulação da troca e do conflito, como economia e Estado (...)".321

Expliquemos essa diferença com maior vagar. Luhmann postula que a diferença entre sociedade e interação se vincula a desenvolvimentos históricos. Segundo ele, nenhuma sociedade se confunde com interações, mas as sociedades primitivas são formadas de uma maneira muito próxima à interação. Seus subsistemas apenas eram formados de formas segmentárias com referências a interações concentradas (famílias, comunidades regionais, assentamentos). Quando ocorre a formação de cidades, a diferença entre "interações transitórias e sociedade torna-se visível para os participantes, e as famílias e com elas a diferenciação segmentária recedem para importância secundária”. ${ }^{322}$ Relações de interação - como amizade e códigos de conduta - passaram, por um tempo,

${ }^{318}$ LUHMANN, 2007a, p. 655

${ }^{319}$ LUHMANN, 1995b, p. 421

${ }^{320}$ Para uma análise de como essa indiferença no tratamento dos outros pode ser lida em uma "sociologia do outro" da sociedade moderna, ao opor o conceito luhmanniano de "indiferença" com os conceitos normativamente carregados de solidariedade - de forma aberta à discussão - ver o artigo de STICHWEH, (2004) - "Strangers in World Society: Indifference and Minimal Sympathy.

${ }^{321}$ LUHMANN, 1995b, p. 422

${ }^{322}$ LUHMANN, 1995b, p. 424 
apenas a ser relevante nos estratos superiores na época em que se dividia a sociedade pela "nobreza". A partir da Revolução Francesa, entretanto, a diferença entre sociedade e interação se torna "espetacularmente aparente". Os eventos não podem mais ser controlados ou remetidos às interações. Dessa forma, "a sociedade moderna, mais do que qualquer outra antes dela, separa sua formação de sistemas de possibilidades de interação. (...) Por isso, ela permite uma grande gama de atividades que são ocasionais, sem função societal, 'cotidianas', e sem localização ambígua, devendo ser vividas de forma mais ou menos trivial, uma vez que elas não mais podem ser conectadas com a semântica desenvolvida pela reflexão nas funções e nos meios de comunicação simbolicamente generalizados da ciência, economia, política, intimidde, arte e assim por diante. ${ }^{323}$

Com isso, a compreensão da sociedade moderna deveria reconhecer certo "desacoplamento" de nexos interacionais (ou interativos). Ainda que na sociedade moderna seja possível uma maior variedade de sistemas de interação auto-regulados, eles se tornam menos relevantes do ponto de vista dos sistemas parciais da sociedade: "[m]enos e menos é possível contar com a solução de problemas socialmente relevantes que partam da interação: por exemplo, contar com a presença física para a obtenção de consensos ou para prevenir atividades não-controladas. Imaginar que seria possível solucionar ou mesmo atenuar problemas na inter-coordenação de sistemas funcionais diversos (ciência e política, economia e educação, ciência e religião) trazendo participantes em discussão uns com os outros seria pura ilusão. Portanto, surge um abismo entre as sequências de interações que os indivíduos vivenciam - que são acessíveis e compreensíveis para eles - e a complexidade do sistema social, que eles não podem compreender e cujas consequências não podem ser influenciáveis, muito menos controláveis. Isso vale não apenas para as interações de 'pessoas comuns', mas em princípio para toda e qualquer interação, até aquela dos líderes do "novo corporativismo"". ${ }^{324}$ Com efeito, na sociedade moderna, segundo essa perspectiva luhmanniana, não é possível conceber a sociedade como interação nem conceber como adequadas teorias que concebem a sociedade como "comércio, intercâmbio, contratos, dança, correntes, teatro ou discurso". 325

Por sua vez, as organizações são definidas como um fenômeno universal presente em todas as sociedades, mas que se vincula à uma "aquisição evolutiva" que pressupõe um

\footnotetext{
${ }^{323}$ LUHMANN, 1995b, p. 425

${ }^{324}$ LUHMANN, 1995b, p. 426

${ }^{325}$ LUHMANN, 1995b, p. 430
} 
alto grau de desenvolvimento. ${ }^{326}$ Também as organizações pressupõem a sociedade. Entretanto, elas se relacionam de modo específicos com os sistemas funcionais autopiéticos, pois possibilitam interdependências sociais compatíveis com o fechamento operacional dos subsistemas. Assim como a sociedade e a interação, as organizações também são uma forma do trato com a dupla contingência. Elas lidam com expectativas e são orientadas para a tomada de decisões. Para fazê-lo, as organizações desenvolvem uma maneira de atuar que se vincula com uma regra de inclusão/exclusão, ou melhor, com "o status de membro" (Mitgliedschaft / membership/membrecía). Estar filiado a organizações implica decisões sobre o status social necessário de membro - que é formado e perdido por meio de decisões. ${ }^{327}$ É esse status de membro (Mitgliedschaft) que caracteriza o lado interno da forma das organizações, que interessa ao sistema e que tem maiores consequências. $\mathrm{O}$ mundo exterior permanece disperso enquanto o lado interior da forma adquire coerência e intefração. Neste sentido, uma vez que "a qualidade de membro se baseia em decisões e a conduta seguinte dos membros-em-condições-de-decidir depende dessa qualidade de membro, é possível caracterizar as organizações como sistemas autopoiéticos sobre a base operativa da comunicação de decisões. Elas produzem decisões a partir de decisões e, neste sentido, são sistemas operativamente fechados. (...) Seria possível afirmar que um sistema-de-decisões vive em vista de decisões posteriores de determinação autoproduzidas". ${ }^{328}$ As organizações vinculam decisões (em um contexto decisional que "produz decisões mediante decisões prévias), adotando uma forma autopoiética de operar e reduzir a contingência e a incerteza do futuro com uma rede de decisões que permite absorver a incerteza indeterminada de eventos futuros com recurso a certezas "autoproduzidas". Para isso, ela trata com a solução de problemas com suas estruturas de premissas de decisão ${ }^{329}$

Com essa "autopoiese especial", as organizações têm uma característica específica: "a possibilidade de se comunicar com sistemas em seu ambiente. Elas constituem o único tipo de sistema social que dispõe dessa possibilidade (...) Esse 'comunicar-se para fora' pressupõe a autopoiése sobre a base de decisões ${ }^{330}$ Isso, contudo, não contradiz a tese do fechamento operacional, uma vez que organizações se comunicam preferencialmente com

\footnotetext{
${ }^{326}$ LUHMANN, 2007a, p. 655

${ }^{327}$ LUHMANN, 2007a, p. 657

${ }^{328}$ LUHMANN, 2007a, p. 658

${ }^{329}$ LUHMANN, 2007a, esp. pp 660 e 661.

${ }^{330}$ LUHMANN, 2007a, p. 661
} 
outras organizações - sistemas de decisão com sistemas de decisão, portanto. Sempre se tratam de decisões.

A sociedade moderna, por sua vez, não pode ser encarada como uma grande organização ou corporação - algo que seria mais próximo de estruturas de sociedades prémodernas. Na modernidade, diversas organizações podem organizar enormes quantidades de interações entre si, sincronizando-as pelas premissas de decisão das quais dispõem; com a atribuição de papeis sociais e com suas regras de inclusão. ${ }^{331}$

A tradição sociológica teria tratado as organizações de forma ambígua, sem se deter na unidade do conceito, de modo que, por vezes, se refere de modo positivo às organizações quando se trata da satisfação de necessidades e das prestações que elas oferecem, contudo, quando se quer ressaltar suas características negativas, se utiliza o termo "burocracia". Enfim, ainda que existam organizações voluntárias e que não precisam se ligar a sistemas parciais específicos, “ é inegável que a maioria das maiores e mais importantes organizações se formam dentro dos sistemas funcionais e, desta maneira, assumem o primado funcional correspondente. Neste sentido é possível distinguir organizações econômicas, estatais e outras organizações políticas, sistemas escolares, organizações científicas, jurídicas e legislativas. ${ }^{332}$

Todavia, ainda que as organizações possam desempenhar um papel relevante para a orientação funcional de sistemas parciais, elas não se confundem com eles. Nenhuma organização pode atrair para si todas as operações de um sistema [funcional] e executá-las como operações próprias: "[s]empre há educação fora das escolas e universidades. Também os trâmites médicos não têm lugar só em hospitais. A enorme organização política denominada de Estado produz precisamente o efeito de que existem atividades políticas referidas ao Estado que não se desempenham como decisões estatais. (...)”. Enfim, ao se ligar a um sistema parcial, as organizações são sistemas fechados e autônomos, mas assumem o primado da função do respectivo sistema funcional e se ligam ao seu código operativo binário. Assim as organizações se identificam como tribunais, bancos, escolas. O ponto relevante, é que as organizações ativam uma distinção posterior à distinção do código binário, a saber: a distinção dos programas (decisões). ${ }^{333}$ Veremos a importância dos programas logo a seguir. Por agora, é necessário apenas notar que as organizações não são instâncias de mera "implementação" dos sistemas. Ressalta-se que as

\footnotetext{
${ }^{331}$ LUHMANN, 2007a, pp. 663 e ss.

${ }^{332}$ LUHMANN, 2007a, p. 666-667

${ }^{333}$ LUHMANN, 2007a, p. 667
} 
comunicações são o único sistema que pode se comunicar com seu ambiente. Neste sentido, organizações dotam os sistemas funcionais com a "capacidade de comunicação externa" (sempre na autopoiese da sociedade, ou seja, na comunicação). ${ }^{334}$

Enquanto os sistemas de função consideram - a princípio - uma inclusão generalizada (acesso a todos em princípio), as organizações operam com uma lógica de exclusão: elas excluem todos menos os membros elegidos de maneira altamente seletiva. As organizações operam a diferença inclusão/exclusão nos sistemas funcionais. Aliás, Luhmann argumenta que, no que toca o sistema político, quando se fala de "civil society, citizenship e sociedade de cidadãos", trata-se de um impulso dirigido contra a organização política, ou sejam "que prevê uma participação na vida pública sem o pertencimento à organizações". ${ }^{335}$ Novamente, Luhmann ataca as teorias que apresentam uma divisão entre "Estado e Sociedade". Essas teorias não dariam conta de compreender a relação entre organizações e sistemas funcionais. Para Luhmann, no lugar de uma concepção hierárquica entre sistemas funcionais e organizações, cabe tratar de um conceito de rede. Para o autor, “[a]s organizações desenvolvem uma dinâmica própria que é assumida pelo sistema funcional mediante procedimentos de observação de segunda ordem; tudo isso sob a condição de estar se reatualizando permanentemente, por exemplo, na forma do mercado, da opinião pública, de publicações científicas ou de textos jurídicos (...)". ${ }^{336}$ Essas estruturas de auto-observação, dentre elas a opinião pública referente ao sistema político, serão muito importantes em nossas discussões futuras.

Além da questão das interações e das organizações, Luhmann também discorre sobre os movimentos de protesto e outras formas de se lidar com a questão da inclusão/exclusão, dentre elas as chamadas "redes de inclusão" - formas que também tratam com a questão da dupla contingência e não podem ser reduzidas ao esquema geral de sua divisão da sociedade. Estas questões, contudo, serão mais trabalhadas em momentos próximos de argumentos nos capítulos 4 (movimentos de protesto); 3 e 5 (mecanismos de inclusão e redes de inclusão e sociedade mundial). Por isso, deixei estas questões mais pontuais de sua teoria para esses capítulos, me atendo às explanações de caráter mais geral neste capítulo.

\footnotetext{
${ }^{334}$ LUHMANN, 2007a, p. 667-668

${ }^{335}$ LUHMANN, 2007a, p. 669-670. Ênfase adicionada.

${ }^{336}$ LUHMANN, 2007a, p. 671
} 


\subsection{Sistemas parciais de função}

Tratamos bastante da diferenciação funcional dos sistemas parciais da sociedade. Com efeito, o funcionalismo radical luhmanniano aplicado à análise desses sistemas julga ser apropriado para possibilitar análises de sistemas de tal maneira abstrata que pode tratar de suas "equivalências funcionais". Sua empreitada fica muito clara quando de suas considerações sobre o sistema da arte. $\mathrm{O}$ autor afirma que o sistema da sociedade cataliza a formação de subsistemas que "dominam a face da sociedade". Pela análise funcional, eles são tratados como "comparáveis". Nas palavras do autor, "[e]m um domínio tal como a arte (assim como do direito, da política, e assim por diante), nós descobrimos não traços únicos da arte, mas facetas que podem ser encontradas, mutatis mutandis, também em outros sistemas funcionais”. Isso implica a mudança de uma perspectiva de primeira ordem para uma da observação de segunda ordem. Assim, a arte participa da sociedade se diferenciando como um sistema social, de modo a se submeter ao modo operativamente fechado característico de todos os sistemas parciais. Ao serem esses sistemas objeto da análise funcional, não há preocupação primária com problemas de causalidade. No caso da arte, não se busca analisar "a influência da arte na sociedade e da sociedade na arte (essas são questões de importância secundária)". No mesmo sentido, Luhmann argumenta que não advoga no sentido de uma atitude que postule a o dever de se afirmar e protegera autonomia da arte. Para ele, "[a] arte moderna é automa em seu sentido operativo. Ninguém mais faz o que ela faz". 337

Luhmann relembra que ao se perguntar pela função de um sistema, não se está perquirindo o propósito de ações ou instituições. Ao contrário dos propósitos, "a função não serve a orientação de observações de primeira ordem. (...) Uma operação não precisa conhecer sua função." Novamente, o ponto central é que a função é "um foco para a comparação". Ela marca um problema e busca soluções para ele. Se a análise funcional, como vimos, é um método de observação de segunda ordem que pode ser aplicado a qualquer problema em princípio, essa "arbitrariedade é reduzida quando o observador seleciona um sistema de referência". Nesse sentido, vale a pena repisar, novamente encontramos a diferença entre operação e observação e entre observação de primeira

\footnotetext{
${ }^{337}$ LUHMANN, 2000b, pp. 133-134. Ênfase adicionada.
} 
ordem (como o sistema observa suas operações) e observação de segunda ordem (no caso, do sistema científico em relação a outros sistemas sociais). ${ }^{338}$

É por esse motivo que Luhmann julga ser possível desenvolver estudos sobre sistemas sociais específicos. Por isso, o autor escreveu uma série de monografias sobre sistemas funcionais específicos, sobre a economia, o direito, a religião, a política, a ciência, a arte, o sistema pedagógico, o sistema da intimidade e do amor e os meios de comunicação em massa - algum deles compilados após sua morte - uma vez que o autor, frente a uma doença terminal que o acometia no último ano de sua vida, dedicou grande parte do seu tempo para terminar sua "obra mais abrangente" - "A Sociedade da Sociedade" - deixou algumas obras incompletas. ${ }^{339}$

Ao referir a estas obras, não se quer ressaltar uma questão biográfica ou de caminho intelectual, ${ }^{340}$ mas de demonstrar um projeto luhmanniano de desenvolver uma série de trabalhos que lidam com sistemas funcionais individuais ao aplicar sua teria geral da sociedade ao enfocaras estruturas comparáveis desses sistemas que persistem para além de suas diferenças factuais. Com isso, Luhmann desenvolve uma "observação de segunda ordem" e não visa a contribuir de forma interna a eles; ou seja, não há implicações de ser um crítico de arte, de apresentar propostas políticas, de desenvolver doutrinas jurídicas ou teoremas econômicos. Com isso, vemos que todos os elementos da teoria social de Luhmann confluem para a descrição radicalmente funcional de sistemas parciais sem a utilização de elementos normativos, integrativos ou de solidariedade. ${ }^{341}$ Vejamos, de maneira rápida, como isso é feito.

Já vimos que a sociedade funcionalmente diferenciada se orienta por funções e a "tarefa" de exercê-las (a questão da prestação dessas funções) é executada por sistemas parciais da sociedade moderna. A “diferenciação funcional se caracteriza, pois, que cada função que participa do esquema de diferenciação (não são necessariamente todas!) apenas podem ser operadas (bedient wird) em um sistema parcial da sociedade. De outra maneira essa forma de diferenciação não é realizada". ${ }^{342}$

\footnotetext{
${ }^{338}$ LUHMANN, 200b, pp. 135-139

339 Sobre esta questão, ver a elucidativa "Nota do Editor" de autoria de Andreas Kieserling na obra publicada após a morte de Luhmann intitulada "A Religião da Sociedade" (LUHMANN, 2007b, pp. 309310)

${ }^{340}$ Em entrevista, Luhmann pergunta a quem interessaria uma biografia de um autor - e da sua vida. Para o autor, "quando alguém precisa disso [biografias] para entender o que eu escrevi, então eu escrevi mal [a minha teoria]" (LUHMANN, 1987, p. 19)

${ }^{341}$ Ver, dentre outros LUHMANN, 2000b, pp. i e ss.

${ }^{342}$ LUHMANN, 2000a, 76-77. Isso apontaria para a "singularidade notável" da sociedade moderna, reconhecida por uma "comparação histórico-social", ou seja, a diferenciação da socieade em subsistemas
} 
A sociedade, precisamente por ser diferenciada em sistemas parciais autopoiéticos, se caracteriza por conter sistemas autorreferenciais e autônomos que não se sobrepõem uns aos outros de forma destrutiva ou de sobre determinação. Cada sistema presta uma função para a sociedade. Neste sentido, ilustrativamente, vemos que o sistema político tem a função de tomar decisões coletivamente vinculantes, ${ }^{343}$ o jurídico de "estabilizar as expectativas cognitivas de forma congruente", 344 o sistema científico de gerar conhecimento novo, ${ }^{345}$ a arte de integrar a percepção na rede comunicativa da sociedade, ${ }^{346}$ e assim por diante.

Além disso, alguns desses sistemas se associam a meios de comunicação simbolicamente generalizados específicos. É o caso da política ao poder, da economia ao dinheiro, da ciência à verdade, a intimidade ao amor, etc. Isso não implica que não haja comunicações orientadas a esses meios fora desses sistemas parciais, mas antes implica uma vinculação de sistemas específicos.

Para que os sistemas parciais sejam "fechados operativamente", eles se vinculam a um código binário - no estilo "sim/não" ou "positivo/negativo" - que os possibilitam exercer sua função de maneira operativamente fechada. Com isso, o sistema pode operar e com base em um código fundamental binário que organiza as comunicações. Portanto, o sistema econômico opera em referência ao código "ter/não-ter" ou "propriedade/nãopropriedade"; o sistema jurídico em referência ao código "lícito/ilícito; a ciência ao código "verdade/falsidade"; a arte ao código "belo/feio", os meios de comunicação em massa ao código "notícia/não-notícia" ou informação/não-inormação; a religião com o código "transcendência/imanência", a política ao código "poder/não-poder" e, em democracias contemporâneas "governo/oposição"; o sistema de saúde ao código saudável/doente, e assim por diante. Com efeito, a codificação binária não é suficiente para que haja a caracterização de um sistema funcional autopoiético, daí porque haver comunicações não estruturadas sistemicamente que se valem de um código binário, como é o caso da moral e seu código "desprezo/consideração" que, contudo, não conta com programas congruentemente generalizados e com estruturação sistêmica.

funcionais de tal maneira que a "diferenciação dos sistemas se oriente em cada acaso a uma função". (LUHMANN, 1996c, p. 246)

${ }^{343}$ LUHMANN, 2000a, esp. pp. 87 e ss.

${ }^{344}$ LUHMANN, 2005a, pp. 183 e ss;

${ }^{345}$ LUHMANN, 1996c, p. 246 e ss.

${ }^{346}$ LUHMANN, 2000b, p. 141 e ss 
Isso nos leva à outra diferença relevante para os sistemas funcionais: a diferença entre programação e codificação. Um código binário é tautológico por definição e, portanto, não pode se manter isoladamente. Outra diferença é necessária para guiar a diferença binária para seu lado positivo ou negativo. Isso é feito pelos programas, que se relacionam com os códigos (normalmente pelas organizações centrais dos sistemas) e os orientam. O centro dos sistemas funcionais são caracterizados pelo "loccus" de seu fechamento operacional propriamente dito. É o "lugar" onde ocorre o fechamento pelo código binário. Os programas provém da periferia do sistema. Exemplos são diversos, no caso do sistema jurídico, a dogmática, a legislação, os contratos, etc. servem de programas para que os tribunais (no centro do sistema) decidam sobre o código "lícito/ilícito"; no mesmo sentido, partidos políticos programam o código "governo/oposição" na política e teorias e experimentos empíricos programam o código da ciência. ${ }^{347}$

Se no centro dos sistemas ocorre o fechamento operacional, na periferia ocorrem as comunicações do sistema menos fechadas e mais suscetíveis a irritações de outros sistemas. Dentre as formas de irritação, destacamos os acoplamentos estruturais, já ressaltados por nós. Esses acoplamentos criam relações ortogonais de irritações mútuas entre sistemas e estão nas periferias dos sistemas. Como exemplo, podemos citar a Constituição como acoplamento entre política e direito, a Universidade entre ciência e política, a tributação entre política e economia, os contratos e as propriedades como acoplamento entre o direito e a economia. Ainda assim, existem organizações que podem ser extremamente relevantes para dois sistemas, como caso dos Tribunais Constitucionais para a política e para o direito e o caso já citado das Universidades, que servem até de acoplamento estrutural entre ciência e sistema pedagógico. ${ }^{348}$

Além disso, ainda no tocante à relação dos sistemas com seus ambientes; vemos que cada sistema apresenta uma "fórmula de contingência" que o faz continuar a seguir operações de forma que nunca chegará a resolver a contingência proposta. Já vimos com certo vagar essa questão no item 2 deste capítulo quando tratamos da questão da "justiça" para o direito (entre consistência jurídica e adequação social) e da "legitimidade" para a política. O mesmo poderia ser dito para a questão da "escassez" no tocante à economia.

Enfim, seja como for, estas questões ficarão mais clara nos capítulos 3 e 4, em que análises mais detidas de alguns sistemas funcionais - em especial os sistemas jurídico,

${ }^{347}$ Veremos essas questões com mais calma no que toca aos sistemas político, jurídico e do sistema dos meios de comunicação em massa nos Capítulos 3 e 4 .

${ }^{348} \mathrm{O}$ mesmo vale para esta questão, elas serão encaradas de forma mais detida nos capítulos seguintes. 
político e dos meios de comunicação em massa - serão desenvolvidas. Por agora, resta compreender, de maneira geral, como Luhmann desenvolve uma estrutura radical funcionalista de análise de equivalentes funcionais entre sistemas funcionais tão diversos entre si do ponto de vista factual.

\section{Conclusões parciais: consequências do quadro teórico luhmanniano para um conceito "negativo" e "normativamente enxuto" de esfera pública}

São poucas as conclusões parciais as quais chegamos após um capítulo de pressupostos teóricos. Trabalhar com calma as suas implicações já seria desenvolver uma discussão, o que será feito com maior vagar no capítulo 3. Não se trata também de resumir as definições já esboçadas acima.

O que é possível adiantar é o reconhecimento de alguns pontos teóricos e metateóricos centrais que serão acessados posteriormente nas discussões seguintes. Em primeiro lugar, vimos os motivos que levaram Luhmann à construção de sua teoria da sociedade. Com isso, percebe-se que sua teoria é frutífera para questões abstratas e teóricas e questões da unidade da disciplina, mas que sua teoria não tem grandes aportes empíricos nem normativos. Isso se opõe à maneira pela qual se estruturou o debate do conceito de esfera pública, tal como delineado na introdução.

A teoria luhmanianna, ao pretender descrever a "sociedade em sua unidade", desenvolveu uma teoria que pergunta tanto pela sua manutenção quanto pela sua mudança. Em análise funcional radical, ela desenvolveu uma explicação teórica para variações históricas de sistemas sociais. Nesse caminho, Luhmann cunhou um conceito autológico de sociedade, no qual não é possível nem dirigir a sociedade por um sistema parcial, nem é possível "agir sobre" a sociedade como se ações e comunicações estivessem "fora dela". Ao contrário de Habermas, não há uma tese da divisão entre "mundo da vida e sistemas" como veremos com mais calma nos dois capítulos seguintes tanto por parte de Habermas quanto de Luhmann. Para Luhmann, existem fluxos comunicacionais na sociedade, mas eles não têm "um sentido" - não há que se falar de influxos e resistências mútuas, em "sitiamento" ou "influxo que ultrapasse comportas ou eclusas". Isso fica claro pela maneira pela qual o autor se opõe às teorias da sociedade civil que opõem "sociedade" ao Estado (ou sociedade, Estado e Mercado - se ficarmos com os modelos tripartites). ${ }^{349}$

${ }^{349}$ Neste sentido, ver COHEN e ARATO, 1992, esp. pp. 299 e ss e 421 e ss. 
Ao desenvolver uma teoria "não orientada pela crítica" ou diagnósticos e prognoses de mudanças, sem se valer de "consenso, razão e sujeito"; Luhmann busca indicar mecanismos de funcionamento e (auto)alterações da sociedade em mudanças estruturais. Ao demonstrar como as ideias evoluem - e o fazem em "co-evolução com a estrutura social" - Luhmann antes "explica" valores sociais ligados à opinião pública, democracia e direitos humanos e trabalha com as condições de possibilidade para seu surgimento, do que os utiliza como premissa valorativa para realizar análise. Com isso, como veremos, as diferenças ente o modelo do autor e de Jürgen Habermas são ainda mais ressaltadas. Veremos que isso implicará uma diferença radical na maneira de se tratar da inclusão política e da cidadania.

Ainda que o mérito de Luhmann de chamar a atenção para o funcionamento da sociedade complexa tenha sido inclusive notado e incorporado por Habermas - que passa a tratar o mercado e a política como "indispensáveis" em sociedades complexas; Luhmann também tem explicações teóricas para interações e organizações, usualmente mobilizadas para fazer crítica à sociedade. Também ao discorrer sobre esses modelos teóricos, como vimos, Luhmann se distancia da crítica social e desenvolve argumentos próprios e consistentes com sua teoria.

Enfim, ao vestirmos os "óculos de Luhmann", vemos um mundo complexo, de difícil coordenação e improvável (impossível?) direcionamento e controle por um sistema social determinado, onde instâncias de influências externas à sociedade não são possíveis senão como ilusão. Sua definição de esfera pública se encaixa neste modelo de forma quase que negativa. A teoria de Luhmann parece ser útil por demonstrar como a esfera pública pode (ou não) tornar-se relevante para diversos sistemas parciais da sociedade. Daí porque falo que sua definição é quase negativa: ela encara a esfera pública como um ambiente interno de toda a sociedade; com comunicações desestruturadas. Contudo, com os óculos de Luhmann, será possível analisar como a esfera pública - como estrutura e em suas implicações semânticas - pode se relacionar com o funcionamento da sociedade funcionalmente diferenciada, com seus sistemas autopoiéticos; com as interações e com algumas organizações centrais na sociedade. 


\section{CAPÍTULO 2 - UMA FORMULAÇÃO NORMATIVA E SOCIOLÓGICA DA ESFERA PÚBLICA: O DESENVOLVIMENTO DO MODELO HABERMASIANO}

\section{Introdução}

Se o conceito de esfera pública em Niklas Luhmann é relacionado de forma quase "negativa" em sua teoria da sociedade, para Habermas, vale o oposto, uma vez que o conceito desempenha um papel central em sua teoria abrangente e possibilita que Habermas vincule seus postulados normativos da teoria do discurso e da evolução moral da sociedade moderna "pós-convencional" com estruturas "fáticas" na sociedade moderna. Assim, o conceito de esfera pública é elemento fundamental para "fechar" o argumento habermasiano de sua concepção deliberativa da democracia e, com isso, pensar um modelo de legitimação nos Estados Constitucionais de Direito.

Neste processo, Habermas estabelece um diálogo crítico direto com a teoria luhmanniana e, apesar de ser consideravelmente influenciado por problemas levantados por ela, o autor apresenta suas discordâncias por meio de sua teoria do desacoplamento entre sistemas e mundo da vida - e dos fluxos e contrafluxos de processos comunicacionais entre um e outro. Ao fazer isso, Habermas realiza um movimento de profunda abstração conceitual, o que permite comparações mais precisas com a teoria de Luhmann e suas considerações sobre a esfera pública. Com efeito, Habermas enfrenta a teoria luhmanniana no "polo sociológico" de sua teoria abrangente que, por sua vez, vincula pretensões normativas a uma teoria da sociedade.

Ao apresentar o desenvolvimento do conceito de esfera pública habermasiano pelas lentes de sua teoria geral, torna-se possível realizar uma discussão teórica mais próxima da construção luhmanniana, opondo as duas teorias em suas concepções de modernidade, descrições da sociedade, dos sistemas políticos e jurídico, das instituições do capitalismo moderno, etc., e ter maior espaço para desenvolver a oposição entre os dois modelos dos autores do conceito de esfera pública.

Esse capítulo, entretanto, assim como no capítulo anterior, não se resume à mera "exposição", uma vez que me posiciono no sentido de sustentar algumas "teses" interpretativas que me parecem importantes para as discussões posteriores. Em suma, defendo existir uma indissociabilidade entre a teoria geral de Habermas e seus escritos 
políticos, ${ }^{350}$ de modo que a tese da dupla integração da sociedade e do mundo da vida ainda desempenha um papel fundamental nos últimos escritos ditos "políticos" do autor ou pelo menos até sua formulação do conceito de esfera pública em 1992. Com isso, sustento também que é precisamente pelo conceito de esfera pública e de democracia deliberativa que Habermas chega ao momento "mais sociológico" dentro de seu projeto normativo de teoria do discurso (ou seja, após a "virada linguística" em sua teoria), enfrentando, então, a questão da tensão entre "facticidade e validade".

Neste sentido, defendo aqui que ainda que Habermas tenha realizado um movimento de "virtualização" da esfera pública por meio de seus pressupostos filosóficos e teóricos mais abstratos, isso não implicou em um afastamento sociológico do autor, mas, ao contrário, argumento que a segunda formulação habermasiana do conceito nos anos iniciais da década de 1990 se constituiu precisamente em uma tentativa do autor de concretizar seus pressupostos normativos desenvolvidos em sua teoria do discurso no âmbito da facticidade social. O que ocorreu na verdade parece ter sido um movimento de alteração de nível de abstração teórica e mudança de pressupostos metodológicos ou "metateóricos", uma vez que Habermas se afasta do historicismo, da teoria de classes e da crítica da ideologia presentes na primeira formulação do conceito, em 1961. Com isso, diversos pressupostos "sociológicos" presentes em sua primeira formulação não foram necessariamente "abandonados", mas traduzidos dentro de um novo contexto teórico que, aliás, foi muito influenciado pela teoria dos sistemas de Luhmann. É claro, isso não ocorre sem consequências importantes - que serão analisadas no decorrer do capítulo.

O presente capítulo se estrutura a partir desenvolvimento do autor sobre o conceito de esfera pública. Assim, (i) após essa introdução, (ii) discuto a primeira formulação de Habermas sobre a esfera pública em sua obra "Mudança estrutural da esfera pública" de 1961; (iii) para depois apresentar os desenvolvimentos teóricos do autor tanto de seu modelo normativo quanto de sua teoria social. (iv) Então, apresento a formulação do conceito de esfera pública entendida por meio da noção metafórica de "fluxos comunicacionais" desenvolvida por Habermas, a saber, as metáforas da "barragem democrática" e dos influxos comunicativos que atravessam as comportas (eclusas) do centro sistema político-administrativo. Neste momento, ressaltarei os elementos que julgo

${ }^{350}$ Por esse motivo, assim como fiz no capítulo anterior que trata da teoria luhmanniana, preferi o enfrentamento direto com os textos do autor, deixando as referências de comentadores para contextos secundários. 
serem essenciais para os debates dos próximos capítulos. (v) Ao final, apresento uma breve discussão e as conclusões parciais do capítulo.

\section{Uma sociologia da esfera pública burguesa: o modelo de 1961}

\subsection{Uma "história sociológica" da esfera pública no jovem Habermas}

Como vimos na introdução deste trabalho, a obra Strukturwandel der Öffentlichkeit de Jürgen Habermas exerceu grande influência na constituição da sociologia da esfera pública. Neste sentido, é necessário demonstrar alguns argumentos centrais de Habermas nesse trabalho. Cumpre notar que autor reformulou seu conceito de esfera pública radicalmente após 1990 - dentre vários motivos para isso, o principal foi a mudança de sua própria teoria, em sua "virada comunicativa" após 1981 e suas teses sobre a legitimação do capitalismo tardio já em 1973. Mesmo assim, trabalhar a forma pela qual Habermas abordou o tema em 1961 é elucidativo por diversos motivos, seja pela formulação já normativa do assunto, por pressupostos sociológicos presentes já em sua primeira formulação, além do próprio tratamento do objeto da "esfera pública burguesa", a gênese estrutura e sua "decadência". Já encontramos, nessa obra, alguns conceitos e vinculações fundamentais, como opinião pública, mídia e imprensa e estrutura de Estados (no conceito de Estado de Direito).

O objetivo dessa obra de Habermas consiste em analisar o "tipo" de "esfera pública burguesa". Assim como fizemos na introdução da dissertação, Habermas atenta para o caráter interdisciplinar do conceito, e, ao reconhecer que "a esfera pública burguesa" não pode ser estudada por uma só disciplina, mas ser explorada no "vasto campo outrora imputado à política”. Habermas afirma proceder simultaneamente de forma sociológica e histórica. Isso, pois, por um lado, a "esfera pública burguesa" é concebida com uma categoria de época - indissociável do desenvolvimento da sociedade burguesa - e, portanto, não poderia ser abstraída em um tipo ideal e aplicado de maneira indiscriminada em situações históricas quaisquer. Por outro lado, apesar dessa vinculação histórica, Habermas se distancia do historicismo rigoroso por ter ele pouca capacidade de abstração". 351

Habermas ressalta que seus estudos limitam-se à estrutura e à função do modelo liberal da esfera pública, "à sua origem e evolução". A escolha desse tipo específico de

${ }^{351}$ HABERMAS, 2003a, p.10. 
esfera pública - a burguesa -, se justificaria por ter sido ele o modelo que adquiriu dominância na sociedade. ${ }^{352}$

Habermas discorre, então, sobre a dificuldade de conceituação da esfera pública, anunciando uma "multiplicidade de significados correntes" do senso comum, válida tanto para o termo "público" [aqui, como adjetivo] quanto para o termo "esfera pública". As disciplinas das ciências sociais estariam impossibilitadas de dar um conceito mais preciso. O autor realiza algumas explanações sobre o conceito do que é público ( "öffentliche”). De início, ele afirma que "públicos" são "eventos acessíveis a qualquer um" - ressaltando a característica da acessibilidade como algo público. Além disso, "público" também pode se referir a algo do Estado, como cargo público ou edifício público, por exemplo. Por fim, Habermas discorre também sobre o conceito de reconhecimento público ou recepção pública, ligado à representação, boa sociedade ou a obtenção de renome. ${ }^{353}$ É suficiente notar que, para ele, o emprego mais comum do adjetivo "público" seria referente a "uma opinião pública, de uma esfera pública revoltada ou bem indignada ou informada, significados estes correlatos a público, publicidade, publicar. O sujeito dessa esfera pública é o público enquanto portador da opinião pública; à sua função crítica é que se refere a 'publicidade' (Publizität) como, por exemplo, o caráter público dos debates judiciais". ${ }^{354}$

Nota-se que um conceito de oposição ao poder político já começa a ser delineado por Habermas. Isso, pois o autor afirma que "a própria 'esfera pública' (Öffentlichkeit) se apresenta como uma esfera (Sphäre $\left.{ }^{355}\right)$ : o âmbito do que é setor público contrapõe-se ao privado. Muitas vezes ele aparece simplesmente como a esfera da opinião pública que se contrapõe diretamente ao poder público". 356 Para desenvolver essa análise - e discorrer sobre o potencial emancipador, crítico e de combate à dominação presentes na esfera pública, Habermas precisa trabalhar com as estruturas da esfera pública e sua relação com o que chama de sociedade burguesa.

Neste sentido, Habermas faz uma distinção de "tipos" da esfera pública, dentre elas a plebeia, a helênica, a antiga e a moderna ou burguesa. Em suma, a esfera pública helênica

${ }^{352}$ HABERMAS, 2003a, pp.9-11

${ }^{353}$ HABERMAS, 2003a

${ }^{354}$ HABERMAS, 2003a, p. 14

355 Daí porque preferi a tradução de Öffentlichkeit como esfera pública, seguindo a maioria das traduções para o português e para o inglês. Mantive "Publicidade" para os momentos em que Habermas utiliza o termo de origem latina "Publizität". Para uma concepção alternativa, que traduz "Öffentlichkeit" como publicidade (burguesa), ver LAVALLE, 2002.

${ }^{356}$ HABERMAS, 2003a, PP. 14-15 
traria a contraposição ao déspota doméstico e numa esfera pública, "num reino de liberdade e continuidade" na qual os melhores se destacariam, haveria espaço para a livre distinção honorífica entre cidadãos que transitariam como "iguais entre iguais" na busca pela virtude. ${ }^{357}$ Com a esfera pública no direito romano,por sua vez, teria havido uma separação entre sociedade civil e o Estado moderno. Ademais,a Idade Média teria se caracterizado por uma indistinção mais radical entre público e privado nas relações de servidão e nobreza (vassalagem). Este tipo de esfera pública, da Idade Média, se refere à obtenção de um status que represente uma hierarquia e se apresente como a “corporificação de um poder superior",. 358

O ponto central de Habermas é que, com o desenvolvimento das esferas públicas no caminho para a modernidade, surge também o lado privado. "Privat" teria o sentido de "ser excluído", de ser privado do aparelho do Estado. Portanto, surge um modelo do "público" (das Publikum e "the public", ou seja, substantivado e não como adjetivo) como uma antítese ao poder. Esse momento histórico marca o surgimento de uma esfera (da sociedade burguesa), genuíno setor da autonomia privada, que há de se contrapor ao Estado". 359

O que Habermas busca é a gênese da esfera pública burguesa, pois o autor vê nela um potencial de racionalização do poder e crítica do poder administrativo. Neste sentido, para ocorrer a gênese da esfera pública burguesa, foram necessárias diversas mudanças sociais vinculadas à esfera privada da economia burguesa e sua regulação- como a intensificação das trocas em livre-intercâmbio de mercadorias em uma espécie de "feira permanente". 360

Junto com o surgimento propriamente dito da esfera privada autônoma, Habermas atribui também ao momento da passagem para a modernidade e à ascensão da burguesia o

${ }^{357} \mathrm{O}$ autor faz, todavia, uma ressalva: “[n]ão é a formação social que lhe é subjacente, mas o próprio modelo ideológico é que se manteve ao longo dos séculos a sua continuidade [sic], uma continuidade exatamente nos termos da história das ideias" (HABERMAS, 2003a, p.16)

${ }^{358}$ HABERMAS, 2003a, pp 15-24

${ }^{359}$ HABERMAS, 2003a, p. 25

${ }^{360}$ HABERMAS, 2003a, 25-31 e pp. 35 e ss. Nota-se que essas regras de circulação são reguladas pelo poder político. Habermas fala em uma rede horizontal de dependências econômicas que, em princípio, não se deixam mais ordenar nas relações verticais de dependência do sistema feudal. Some-se a isso a intensificação das trocas de informações (juntamente com as trocas de mercadoria). Logo após o sistema de cartas e correios (ainda sem caráter rigorosamente público por lhe faltar o caráter de ampla acessibilidade), desenvolve-se uma forte imprensa, com notícias, publicidade e uso pelo poder administrativo no diário oficial. Habermas destaca aqui o caráter administrativo e financeiro do Estado moderno. Neste sentido, é possível falar que "[e]sta camada 'burguesa' é o autêntico sustentáculo do público, que, desde o início, é um público que lê". 
marco do surgimento de outra "esfera": a esfera do poder (político) administrativo. Em suas palavras, a "redução da representatividade pública que ocorre com a mediação das autoridades estamentais através dos senhores feudais cede espaço para uma outra esfera, que é ligada à expressão esfera pública no sentido moderno: a esfera do poder público. Esta se objetiva numa administração permanente e no exercício permanente. Assim, à permanência dos contatos, o intercâmbio de mercadorias e de notícias (bolsa, imprensa) corresponde agora uma atividade estatal continuada. O poder público se consolida em algo antitético". 361

Habermas trata aqui do poder administrativo, da burocracia, onde o adjetivo "público" é sinônimo de "estatal" e de funcionamento regular e de autoridades impostas de acordo com competências em um aparelho munido do monopólio da utilização legítima do uso da força. E é como contrapeso a essa autoridade e ao mercado que se constitui a sociedade civil burguesa.

Neste sentido, o autor pode ressaltar o caráter de tensão entre a esfera pública e a esfera administrativa. Compreende-se, pois, o "publicum como o correlato abstrato do poder público". Assim, o público da esfera pública burguesa que então nascia "acaba por revelar-se conscientemente como um antagonista" precisamente na vinculação entre crítica na esfera pública e autonomia na esfera privada. ${ }^{362}$ É nesse contexto que Habermas concebe o surgimento de um "público pensante que julga"; que se movimenta em vista de uma esfera pública que, indubitavelmente, tinha sido considerada uma esfera do poder público, mas que agora se dissociava deste como o fórum para onde se dirigiam as pessoas privadas a fim de obrigar o poder público a se legitimar perante a opinião pública. ${ }^{363}$

Ainda que caráter de oposição da esfera pública frente ao poder político administrativo seja enfatizado, não há, contudo, uma separação radical entre a esfera pública e a esfera privada, uma vez que são "pessoas privadas” que se contrapõem ao poder administrativo e o fazem por meio de um espaço de discussão, um fórum, onde exercem a função crítica de um público esclarecido. Veremos que Habermas apresenta isso

${ }^{361}$ HABERMAS, 2003a, p. 31

${ }^{362}$ HABERMAS, 2003a, p. 39. Segundo o autor, é em função das intervenções públicas na economia doméstica privatizada que se constitui, finalmente, "uma esfera crítica: quando há falta de trigo, é por meio de um decreto que se pró́be o consumo de pão às sextas feiras. Já que, por um lado, um setor privado delimita nitidamente a sociedade em relação ao poder público, mas, por outro, eleva a produção da vida acima dos limites do poder doméstico privado, fazendo dela algo de interesse público, a referida zona 'crítica' também no sentido de que exige a crítica de um público pensante

${ }^{363}$ HABERMAS, 2003a, p.40. ênfase adicionada 
como uma contradição da esfera pública burguesa. Antes, porém, vejamos as instituições dessa esfera pública burguesa e aquilo que Habermas chamou de sua "mudança estrutural".

\subsection{Estrutura, função e ideologia da esfera pública burguesa}

Para Habermas, a esfera pública burguesa, então, clama por ser regulamentada pela autoridade, mas atua diretamente contra ela "a fim de discutir com ela as leis gerais da troca na esfera fundamentalmente privada, mas publicamente relevante" das leis do intercâmbio de mercadorias. O autor ressalta seu caráter de contestação do poder e atribui a ela forte caráter crítico. Ele argumenta que os burgueses, como pessoas privadas, "não governam" e, por isso, as suas reivindicações não se dirigem apenas contra a concentração de um poder que deveria ser "compartilhado"; "muito mais, eles atacam o próprio princípio de dominação vigente. O princípio de controle que o público burguês contrapõe a esta dominação - ou seja, a esfera pública - quer modificar a dominação enquanto tal”.

Ademais, Habermas retira da forma de contestação do poder conclusões importantes. Segundo ele, o fórum da esfera pública opera suas discussões por um meio peculiar e inovador do ponto de vista histórico, ou seja, inexistente em nenhuma das outras esferas públicas, a saber: a racionalização pública. (öffentliche Räsonnement). Com isso, há um "apelo à razão" na argumentação da esfera pública, ao qual Habermas dá forte importância normativa, supondo que, caso fosse possível levar acabo tal reivindicação argumentativa em todas suas consequências, seria possível chegarmos a "algo mais do que uma mera mudança na base de legitimação de uma dominação que, em princípio, se mantém". 364

Essa superestimação que Habermas faz do potencial da esfera pública burguesa foi muito criticada. Ainda que ele tenha reconhecido que esse potencial não foi levado a cabo pelas contradições da esfera pública burguesa (encarada como ideologia), o reconhecimento de que ele superestimou esse potencial em 1961 gerou importantes deslocamentos em sua retomada do conceito na década de $1990 .{ }^{365}$

Enfim, argumenta Habermas, com a "polarização entre Estado e sociedade" e o aumento do campo tensional entre eles, a esfera pública passa a assumir funções políticas. $\mathrm{O}$ autor discorre sobre como espaços privados, e mais especificamente espaços culturais,

\footnotetext{
${ }^{364}$ HABERMAS, 2003a, pp. 42-43

${ }^{365}$ Neste sentido, ver HABERMAS, 1994.
} 
puderam ser "tornados públicos". Habermas argumenta que a esfera privada incluiria a sociedade civil (setor de troca de mercadorias e de trabalho social) e o espaço íntimo da pequena família (incluindo, aqui, a "intelectualidade burguesa"). Seria precisamente a "esfera pública literária” ou cultural - reunida em seus "clubes", "cafés", "salões" e atuante na imprensa - que intermediaria o setor privado e o setor público e possibilitaria o surgimento de uma esfera pública política. Em suas palavras: "[a] esfera privada compreende a sociedade civil burguesa em sentido mais restrito, portanto o setor da troca de mercadorias e do trabalho social; a família, com sua esfera íntima, está aí inserida. A esfera pública política provém da literária; ela intermedia, através da opinião pública o Estado e as necessidades da sociedade". 366

A argumentação nestes ambientes da esfera literária, afirma Habermas, ocorre pelo “raciocínio público" característicos das cidades que não seriam apenas o centro econômico vital da sociedade burguesa, mas também "a antítese política e cultural à 'corte"”. A esfera literária burguesa, que encontra suas instituições nos "cofee-houses, nos salons e nas comunidades de comensais", desenvolve suas conversações em "aberta crítica" ao poder e "rebentam a ponte existente entre a forma que restava de uma sociedade decadente, a corte, e a forma primeira de uma nova: a esfera pública burguesa". 367

Segundo Habermas, é possível atribuir a essas "instituições da esfera literária" grande importância na emergência da esfera pública burguesa, pois seriam precisamente elas que permitiriam a intermediação entre as esferas privada e pública do mundo burguês. Isso ocorre, segundo Habermas, pois ainda que estes espaços - salões, cafés, comunidades de comensais - sejam muito heterogêneos, "todos tendem sempre a organizar (...) a

${ }^{366}$ HABERMAS, 2003a, pp. 44-46. Habermas associa à família burguesa a institucionalização de um tipo de privacidade ligado ao público. Nele, o isolamento da esfera da pequena-família patriarcal teria passado pela construção de uma subjetividade familiar mais exacerbada e na ligação dessa esfera - onde o homem está solto de suas relações políticas e econômicas, é só o "humano" sem ser pessoa privada nem pública - com a esfera pública. A esfera familiar permitiria uma "autonomia" sem determinação do mercado ou da economia, e por isso, não é privada, a rigor, mas "íntima"; onde ocorreriam relações puramente humanas. A subjetividade do indivíduo ganharia força e daria substrato para o surgimento do espaço público de indivíduos. (HABERMAS, 2003a, pp. 60 - 68) A família teria, contudo, "caráter ambíguo". Enquanto tanto na esfera pública quanto na privada se imbricam em públicos de pessoas privadas (baseadas na propriedade), na esfera da família burguesa se realiza no âmbito do "amor, na liberdade, na cultura - em suma: enquanto humanidade". Enquanto o mercado é o cerne da vida privada, a esfera da família constitui a esfera íntima. Sua ambivalência recai no fato que Habermas atribui ser a família tanto "um agente da sociedade" quanto também "de certo modo a antecipada emancipação da sociedade". Ela expressa a dualidade do homem burguês: proprietário de bens e ser "humano entre seres humanos"; "bourgeois e homme" (HABERMAS, 2003a, pp. 72-73

${ }^{367}$ HABERMAS, 2003a, p. 45 
discussão permanente entre pessoas privadas". Para fazerem isso, eles dispõem de uma série de critérios institucionais em comum.

Em primeiro lugar, segundo o autor, há neles uma exigência de uma "sociabilidade comum", que implica uma "paridade de status" entre os participantes discursivos. Tal "paridade" implica que a autoridade do argumento se mantém contra a hierarquia social (e opera independentemente dela). Os homens privados ("Les hommes, private gentlemen, Privatleute") não têm a capacidade de fala e de discussão decorrentes de cargos públicos ou da condição de nobreza, tal como ocorre na esfera pública representativa. ${ }^{368} \mathrm{~A}$ discussão é, então, levada a cabo "entre iguais". Em segundo lugar, a discussão num público cultural tido como paritário, pressupõe a problematização de setores que até então não eram questionáveis. A problematização e o questionamento do "universal", ou seja, de todo ou qualquer tema, passa a ser acessível pelo público literato e não mais aos políticos, artistas e filósofos. Em terceiro lugar, no contexto do processo de transformação da cultura na "forma mercadoria" - que é típico da sociedade burguesa - resultaria no "não fechamento do público". Isso, pois o público, ainda que restrito, nunca poderia se fechar completamente, uma vez que estaria inserido em outro público maior. Habermas apresenta aqui a distinção entre o "público de vanguarda" ou "público literato" e o "grande público" ou "público de espectadores". O grande público se formaria difusamente fora das instituições do público (“de vanguarda”) e incorporaria até as grandes massas rurais e citadinas. Entre estes públicos haveria uma relação, por vezes, de representação, na qual o público de vanguarda, apesar de se diferenciar do grande público de massa de espectadores, "reivindica aparecer de algum modo como seu porta-voz, talvez até como seu educador. Aparecer em seu nome e até mesmo representá-lo - eis a nova configuração da representação burguesa". 369

${ }^{368}$ HABERMAS, 2003a, pp.51-52. Habermas chega a afirmar que, nesses espaços, "também relações de dependência econômica não deveriam ser, em princípio, eficazes; leis do mercado estão aí suspensas, tanto quanto as do Estado". E apresenta uma ressalva: "[n]ão que se deva crer que, com os cafés, os salões e as associações tal concepção de 'público' tenha sido efetivamente concretizada; mas, com eles, ela foi institucionalizada enquanto idéia e, com isso,colocada como reivindicação objetiva e, nessa medida, ainda que não tenha se tornado realidade, foi, no entanto, eficaz". Vemos nesta passagem a importância normativa que Habermas dá ao conceito de esfera pública, ao qual, ainda que o autor reconheça "contradições", atribua "caráter ideologia" e lamente uma "mudança estrutural" fática, seria possível retirar dele diversos postulados normativos para uma teoria crítica da sociedade moderna. O ponto que entra em questão, e que será formulado de maneira muito diversa a partir da 1990, é como encarar o problema da "dominação econômica" neste modelo.

${ }^{369}$ HABERMAS, 2003a, pp. 51-53 
O argumento central de Habermas é que, quando o público se constitui de "indivíduos conscientizados" ele apropria a esfera pública controlada pelas autoridades políticas e a "transforma numa esfera em que a crítica se exerce contra o poder de Estado" e se realiza como uma refuncionalização ou desfuncionalização (Umfunktionierung) da esfera pública literária, tornando-a pública. A relação com a esfera privada e íntima, para Habermas, é central para caracterizar a esfera pública burguesa e seu caráter moderno. A esfera pública burguesa se diferenciaria das outras por deslocar as tarefas políticas para as "tarefas mais propriamente civis de uma sociedade que debate publicamente (para garantir a troca de mercadorias). A tarefa política da esfera política burguesa é a regulamentação da sociedade civil (em oposição à res pública)". Daí porque Habermas atribui à esfera pública burguesa o "caráter privado polêmico" ou "polêmico racionalista". Ela operaria uma "inversão da soberania", se contrapondo ao "segredo baseado na vontade do soberano" pela "publicidade (Publizität) com base na razão". Enfim, a consciência política articulada na esfera pública burguesa exige leis genéricas e abstratas e busca auto-afirmação, ou seja, "afirmar a opinião pública como única fonte legítima das leis".370

Habermas analisa, então, o caso inglês (e os correlatos francês e alemão como “correlatos continentais europeus") para demonstrar a institucionalização e a aquisição de funções políticas da esfera pública burguesa. Retiremos desses comentários "históricos" as linhas gerais do argumento. O autor argumenta que a esfera pública burguesa adquiriu funções políticas ao se construir como um "novo fórum" politicamente ativo com participação do público, debates e argumentação públicos (pelo raciocínio público), incorporando a imprensa e o jornalismo crítico. Com isso, o público se torna consciente das funções de controle político. A institucionalização de partidos políticos e a possibilidade das minorias de se "refugiar" na esfera pública também fortalecem sua instituição. O "pensamento do público como comentarista crítico" passa a não ser mais exclusividade do parlamento e se intensifica a opinião pública ("Public opinion" “öffentliche Meinung”). Segundo Habermas, “[a] opinião pública se forma na luta dos argumentos em torno de algo, não sem crítica, na aprovação ou rejeição, seja ela ingênua ou plebiscitariamente manipulada, em relação a pessoas, através do common sense". ${ }^{371}$

\footnotetext{
${ }^{370}$ HABERMAS, 2003a, pp. 68-71

${ }^{371}$ HABERMAS, 2003a, pp. 75-85
} 
Em todos os casos, ainda que em momentos diferentes, ${ }^{372}$ o "público que raciocina politicamente" buscou formas de institucionalizar suas tendências críticas, o que perpassa a existência de um jornalismo crítico, de uma "assembleia dos estados", de reuniões da burguesia, do surgimento de "clubes partidários", da publicidade dos atos estatais; enfim, o que se estava em busca era de uma institucionalização da esfera pública e de sua "regulamentação jurídica". 373

Habermas discorre sobre a institucionalização de direitos fundamentais e liberdades públicas tanto em tratados internacionais como a Declaração dos Direitos do Homem e do Cidadão de 1789 quanto em Constituições de diversos países em direitos fundamentais. Com isso, Habermas atribui à esfera pública uma consequência institucional relevante. Para ele, na esteira desse processo, a esfera pública burguesa se torna “diretamente o princípio organizatório dos Estados de Direito burgueses com a forma de governo parlamentar". 374

Habermas discorre, então, sobre contradições na institucionalização da esfera pública e, então, apresenta suas críticas. Para o autor, o sistema de autorregulação do mercado pela livre concorrência pressupunha a inexistência de intervenções extraeconômicas na "promessa" de que ele funcionaria na produção de bem estar que respeitasse o critério de justiça da eficiência individual; operando em uma sociedade livre de poder e dominação. A ela seriam vinculadas garantias jurídicas que protegessem sua autonomia e sua previsibilidade. Para isso, o Estado de Direito burguês necessitaria de leis gerais e abstratas. Com efeito, para Habermas, “o Estado de Direito não garantiria já per se uma legislação de acordo com as necessidades do intercâmbio burguês. Só com a própria competência legislativa é que o público das pessoas privadas conquista essa certeza. O Estado de Direito enquanto Estado burguês estabelece a esfera pública atuando

${ }^{372} \mathrm{Na}$ França, por exemplo, os requisitos institucionais teriam acontecido "de uma só vez" com a Revolução, enquanto na Inglaterra foram sendo sedimentados com críticas do público frente à monarquia e ao parlamento.

\footnotetext{
${ }^{373}$ HABERMAS, 2003a, pp. 85-89
}

${ }^{374}$ HABERMAS, 2003a, pp. 89-93. Isso, sempre lembrando o caráter sociológico da esfera pública de ligar a esfera privada à esfera política, pois a "esfera pública com atuação política passa a ter o status normativo de um órgão de automediação da sociedade burguesa com um poder estatal que corresponda às suas necessidades. O pressuposto social dessa esfera pública "desenvolvida" é um mercado tendencialmente liberado, que faz da troca na esfera da reprodução social, à medida do possível, um assunto particular das pessoas privadas entre si, completando assim, finalmente, a privatização da sociedade burguesa". Habermas afirma que as instituições de direito civil e o princípio de "igualdade dos donos de mercadoria no mercado" é estendido para "as pessoas cultas na esfera pública". É por esse motivo que Habermas dá tanta ênfase ao conceito de Estado de Direito burguês, pois é apenas nele que a "sociedade burguesa enquanto esfera privada" se emancipa. (HABERMAS, 2003a, pp. 93-95 e 99.) 
politicamente como órgão do Estado para assegurar institucionalmente o vínculo entre lei e opinião pública". 375

A contradição que Habermas reconhece na institucionalização da esfera pública se enquadra no conceito de lei, que implica tanto uma imposição de força e de uma vontade, por um lado, e um conceito baseado na razão, por outro. Segundo Habermas, a "hegemonia" da esfera pública, de acordo com sua própria concepção, é uma ordem em que a própria dominação se dissolve tornando a "voluntas" uma "ratio" "que se produz na concorrência pública dos argumentos privados como consenso sobre o praticamente necessário no interesse geral". 376

A grande contradição vista por Habermas é que a esfera pública burguesa se baseia em uma esfera privada que se pretende neutra de dominação, mas não é. O autor argumenta que a esfera pública se tornou um "princípio organizatório" do Estado, sendo que a opinião pública e os debates na esfera pública influenciam os debates parlamentares e os processos judiciais pelo princípio da publicidade. Com isso, as normas constitucionais que se referem à esfera pública burguesa no Estado de Direito seriam "fundadas num modelo de sociedade civil que não correspondem de jeito nenhum". Seriam apenas "tendências sociais", mas apenas tendências; uma vez que a autonomia era garantida através da propriedade e contava com as formações culturais e educacionais de um público que, na verdade, se constitui em uma pequena minoria (grande e pequena burguesia). Portanto, Habermas assevera que "a esfera pública se rege e cai com o princípio de acesso a todos", uma vez que a exclusão de certos grupos da esfera pública a tornaria não apenas incompleta, mas obstaria sua própria caracterização. O "critério de admissão" na esfera pública, a propriedade, demonstraria sua composição contraditória. Ele segue a estrutura da sociedade civil e requer um "homem culto e proprietário". ${ }^{377}$ Com isso, Habermas afirma haver uma "homogeneidade de classe" na esfera pública burguesa: "o interesse de classe é a base da opinião pública". ${ }^{378}$

${ }^{375}$ HABERMAS, 2003a, pp. 100-103

${ }^{376}$ HABERMAS, 2003a, pp. 102-103

${ }^{377}$ Habermas argumenta que esses seriam pressupostos de três naturezas: o pressuposto econômico (livre concorrência); o pressuposto sociológico (a existência de uma sociedade de pequenos produtores) e o pressuposto teórico (previsão da autorregulação de um mercado livre de crises e eficiente alocação de capacidades). Só havendo estes pressupostos que seria possível adquirir o status de proprietário e, com ele, possibilitar o status "homem" (público).

${ }^{378}$ HABERMAS, 2003a, pp. 106-109 e pp. 134-135 
A partir dessa crítica à contradição da esfera pública burguesa, Habermas pôde formular a noção de esfera pública como ideologia. Para isso, o autor postula que o autoentendimento da função da esfera pública (sua "ideia”) burguesa se cristalizou no topos da “opinião pública". O autor reconhece uma "longa história do conceito", que ganha seus contornos centrais como uma opinião obtida através de uma discussão crítica na esfera pública e que clama por afirmar a autonomia da sociedade civil em relação ao Estado. Ademais, ela buscaria exercer uma racionalização do poder político, controlando-o socialmente. ${ }^{379}$

Essa "ideia" da opinião pública formada na esfera pública politicamente ativa é vinculada por Habermas a seus traços liberais e ao seu ideário iluminista. Seria possível apontar, ainda com reservas, para uma "dialética" da esfera pública e apontar a ideia de esfera pública como ideologia. Habermas o faz apoiando-se em Hegel e Marx. O argumento central é que esfera pública excluiria o proletariado - que se definiria apenas negativamente frente à burguesia. A esfera pública burguesa, regulada pelo Estado de Direito burguês, prestaria auxílio às pessoas privadas e, quando deveria traduzir a "dominação em razão", na verdade, se confunde com a sociedade civil - onde há dominação. A ideologia da opinião pública como legitimador do Estado de Direito esconderia, portanto, seu caráter de "máscara do interesse de classe burguês", como afirmou Marx. Ela esconderia as relações de poder dentro das relações entre as pessoas, como nas relações entre proprietários e assalariados. ${ }^{380}$

Com isso, a partir do século XIX, a "dialética” da esfera pública se manifesta. Com a entrada de outros grupos nas argumentações da esfera pública - que não dispunham de propriedade e nem estava ligados à base da autonomia privada - forçam a estrutura da esfera pública a se alterar. Com a entrada da massa dos não-proprietários, a esfera pública vem a se tornar "democraticamente revolucionada" e não mais corresponderia à manutenção de interesses de classe. Isso, contudo, do ponto de vista marxista, dependeria também da "socialização dos meios de produção". Se isso fosse levado a cabo, "a esfera pública deviria, então, poder realizar a sério o que ela sempre já prometera: a racionalização da dominação política como uma dominação de homens sobre homens". ${ }^{381}$

\footnotetext{
${ }^{379}$ HABERMAS, 2003a, pp. 116-120

${ }^{380}$ HABERMAS, 2003a, pp. 145-151.

${ }^{381}$ HABERMAS, 2003a, pp. 152-153
} 
As "esperanças socialistas" sobre a esfera pública, contudo, não se concretizaram e "a ampliação dos direitos de igualdade política para todas as classes sociais ocorreu no âmbito dessa mesma sociedade de classes”. A esfera pública 'ampliada' não levou fundamentalmente à superação daquela base sobre a qual o público das pessoas privadas tinha inicialmente intencionado algo como uma "soberania da opinião pública". Por outro lado, a dialética da esfera pública estaria "tão manifesta" que, segundo Habermas, os teóricos do liberalismo passaram a concebê-la de forma ambígua, festejando-a e condenando-a simultaneamente.$^{382}$

Habermas sustenta que mesmo cem anos após o período áureo do liberalismo, em um capitalismo que pouco a pouco se 'organiza", a relação originária entre esfera pública e esfera privada se dissolve e os contornos da esfera pública burguesa se decompõem. Habermas, então, se posiciona no debate. Segundo ele, nem a "ideia" nem a "denúncia de ideologia" da esfera pública - nem o modelo liberal, nem o modelo socialista do conceito seriam "adequados para o diagnóstico de uma dimensão pública que flutua entre ambas as constelações estilizadas no modelo". Neste sentido, a dimensão pública da sociedade penetraria esferas cada vez mais extensas da sociedade e, ao mesmo tempo, perderia a sua função política, deixando-se submeter os fatos tornados públicos ao controle de um público crítico".

\subsection{Mudança estrutural da esfera pública - as consequências da primeira abordagem de Habermas sobre a esfera pública}

Ao considerar os modelos socialista e liberal de esfera pública como inadequados, Habermas trabalha com mudanças na estrutura social da esfera pública que teriam tido consequências arrebatadoras no esvaziamento de sua função política, discursiva e crítica. Esse diagnóstico acompanha a constatação da perda da base social da esfera pública em uma "interpenetração entre esfera pública e setor privado", resultando em uma esfera pública que se amplia consideravelmente, mas perde sua força e sua função política e crítica.

O autor argumenta que teria ocorrido uma privatização da sociedade e, com ela, a distinção entre Estado e sociedade, necessária para a constituição da esfera pública burguesa, teria se dispersado. O intervencionismo do Estado na economia e na esfera social

${ }^{382}$ HABERMAS, 2003a, pp. 155-157. 
teria levado a transferências de competências para entidades privadas resultando na dialética de "uma socialização do Estado" simultânea a uma "estatização da sociedade". $\mathrm{Na}$ esteira dessas considerações, Habermas reconhece diversas mudanças nas relações entre os setores públicos e privados. Neste cenário, ganham força os interesses privados coletivos" e a estrutura de barganha e negociação frente o Estado.

Com isso, esses interesses se vinculariam à "manutenção de um equilíbrio do sistema que não p[oderia] mais ser assegurado através do mercado-livre". Nesse sentido, à concentração do capital seguiu-se um crescente de intervencionismo estatal. As "novas funções" do Estado Social - de estruturação; de planejamento econômico e de investimentos no controle do ciclo econômico; de promover legislação social protegendo e indenizando os grupos mais fracos com prestações de serviços públicos e de previdências privadas - demonstram esse processo. ${ }^{383}$

Além disso, Habermas argumenta ter havido também um processo de "decadência" da esfera literária dando lugar ao "setor pseudo-público ou aparentemente privado do consumismo cultural". ${ }^{384}$ A esfera literária, contudo, teria avançado no âmbito do consumo e se tornado "apolítica" e inserida no ciclo de produção. Com isso, ela se tornaria incapaz "de construir um mundo emancipado do que é imediatamente necessário à vida". ${ }^{385}$ Sem a interiorização característica da esfera íntima não haveria mais "a garantia institucional para uma individuação da pessoa de acordo com o modelo da "ética protestante"”. Por outro lado,não se apresentavam caminhos para a formação de uma "ética política" necessária

${ }^{383}$ HABERMAS, 2003a, pp. 169-177. Ademais, Com a "estatização da sociedade" - e o correlato processo de alterações na esfera íntima da família- Habermas afirma que o "público se transforma em massa" em uma citadina "cada vez mais complicada" de modo que não lhe possa ser pública. Para Habermas, enquanto o trabalho passa a obter um caráter público, a família perde sua função tal qual a exercia pela família patriarcal pequeno burguesa de formação da intimidade. Isso, pois, dentre outros motivos, a socialização passa a ser realizada em maior escala por instâncias "extra-familiais", principalmente no contexto da vida urbana das grandes cidades. Com essa alteração da instituição da família, também teria ocorrido o desaparecimento do salão, das salas de recepção, e do suporte de individualidade e criação de formas de intimidade necessárias para a esfera pública. A intimidade passa a ser realizada apenas como lazer (entendido negativamente como tempo de não-trabalho) ou "sob holofotes", o que assume "tendencial,ente o espaço daquela esfera pública literária que, outrora, era a referência da subjetividade formada na esfera íntima da família burguesa”. (HABERMAS, 2003a, pp. 189-189)

384 Neste momento da argumentação é possível afirmar que Habermas atribuía grande potencial normativo à esfera pública burguesa e, consequentemente à esfera literária como seu requisito fundamental. Isso, pois para o autor, "a cultura burguesa não era mera ideologia", uma vez que "o raciocínio das pessoas privadas nos salões, clubes e associações de leitura não estava subordinado de modo imediato ao ciclo da produção e do consumo, ao ditame da necessidade existencial, porque, no sentido grego de uma emancipação das necessidades existenciais básicas, possuía muito mais um caráter político também em sua forma meramente literária".

${ }^{385}$ HABERMAS, 2003a, p. 190 
para a construção de um público tal qual o necessário para a esfera pública burguesa e suas ideias. $^{386}$

Com o diagnóstico da passagem "do público pensador de cultura" ao "público consumidor de cultura", Habermas apresenta um cenário no qual os salões e as reuniões de discussão perdem importância para o lazer que, por sua vez, não precisa de discussões, em um âmbito de diversão no qual o público perde seu caráter crítico para ser mero consumidor de lazer. Com o aumento do acesso e com a massificação na ampliação da esfera pública, ela termina por perder seu caráter político e dá lugar à "acessibilidade psicológica", inclusive sem necessidade de educação formal ${ }^{387}$, o que a afasta de seu caráter público. $^{388}$

Nem a imprensa e os meios de comunicação em massa (mídia) escapariam desse problema do consumismo cultural. As revistas e jornais teriam perdido seu caráter de jornalismo crítico e dado lugar as notícias de lazer escolhidas por "tomadas de posição da redação" que cederiam espaço para informações e reportagens tomadas em decisões internas a "agências noticiosas" por seu próprios critérios e seleção de notícias". Habermas estende esse cenário para o que chama de "os novos mídias" de sua época - incluindo o rádio, o cinema e a televisão - gerando uma "ilusão" de esfera pública em que o leitorreceptor não consegue se distanciar criticamente daquilo que recebe de informação. ${ }^{389} \mathrm{Com}$ isso, a decadência da esfera pública literária cede frente a um "público" de grande massa de consumidores em meio a uma comunicação pública, também ela, de massa. ${ }^{390}$

Em geral, o cenário reconhecido por Habermas é um de uma alteração do modelo de esfera pública burguesa que contava com "uma esfera pública das pessoas privadas reunidas num público [e] que fazia a mediação entre o Estado e as necessidades da

${ }^{386}$ HABERMAS, 2003a, p. 191-192

387 HABERMAS, 2003a, p. 196, onde o autor afirma : "[à] medida em que a cultura se torna mercadoria, e isso não só por sua forma, mas também por seu conteúdo, ela se aliena àqueles momentos cuja recepção exigem uma certa escolarização".

${ }^{388}$ HABERMAS, 2003a, 193-200

${ }^{389}$ HABERMAS, 2003a, pp. 201- 203

390 HABERMAS, 2003ca p. 207. Além disso, Habermas afirma que a imprensa teria se postulado criticamente contrária à censura em épocas em que a esfera pública burguesa se construía, lutando por liberdade de expressão - e por isso não podia apenas trabalhar com "notícias e informações", adotando uma abordagem crítica. Contudo, com o estabelecimento do Estado burguês de Direito e com a legalização da esfera pública politicamente ativa, a imprensa "se alivia das pressões sobre a liberdade de opinião" e pode "abandonar sua posição polêmica e assumir as chances de lucro de uma empresa comercial". Ocorreria uma inversão no papel da imprensa, que não mais intermediaria e reforçaria o raciocínio das pessoas privadas, mas passaria a cunhá-lo através dos meios de comunicação em massa (HABERMAS, 2003a, p. 216-221) 
sociedade". Com a imbricação do setor público e privado, teria surgido uma "esfera social politizada" sem intermédio de pessoas que pensam politicamente. Com isso, Habermas admite que o "público midiatizado" (das mediatisiert Publikum) no interior de uma esfera pública imensamente ampliada é mais citado e com maior frequência para fins de aclamação pública. Todavia, ele estaria mais distante dos processos de exercício de poder e da distribuição do poder que a racionalização deles mal pode ser ainda estimulada através do princípio da publicidade, "do tornar público". 391

Com a cultura consumista e a propaganda dos meios de comunicação em massa despolitizados, com tomada de centralidade de associações de interesse coletivo e a pressão por mera aclamação do "público como massa"; a formação de uma opinião pública consciente e crítica ficou severamente obstada. Segundo Habermas, surgem antes "consensos fabricados" que nada têm em comum com a opinião pública formada "após um laborioso processo de recíproco esclarecimento (Aufklärung)" que servisse de base para uma "concordância racional de opiniões em concorrência aberta. ${ }^{392}$ As pretensões de formação do raciocínio público perdem, com isso, lugar para as negociações de "pressões e contrapressões" no "equilíbrio precário de uma constelação de forças entre aparelho de Estado e grupos de interesses" em um modelo caracterizado como sendo de "barganha". 393 Neste cenário, a opinião pública não mais abarca um contínuo de discussão e passa a ser encarada como opinião pré-fabricada (ou opinião não-pública), sendo “medida" apenas pelo comportamento eleitoral da população. ${ }^{394}$

Do ponto de vista da organização do poder, a passagem do Estado liberal de Direito para o Estado da social-democracia é encarada por Habermas antes como um contínuo do que uma ruptura. A questão é que o Estado social-democrata de Direito se vê obrigado a estruturar as relações sociais e tornar-se o portador da ordem social por meio de intervenções estatais. Passa, portanto, a atuar com garantias materiais e não mais informais

${ }^{391}$ HABERMAS, 2003a, p. 212

${ }^{392}$ HABERMAS, 2003a, p. 228

${ }^{393}$ HABERMAS, 2003a, p. 232 Habermas atribui a esse processo o diagnóstico de um deslocamento de competências do poder legislativo para um mundo de relações entre setores administrativos sem passar pelo processo institucionalizado da esfera pública política. Para o autor, associações e partidos continuam a ser fundamentalmente instituições privadas (HABERMAS, 2003c, p. 233) Ademais, Habermas afirma que esse modelo de barganha se expressaria no parlamento, em um caráter de "assembleia de facções" que a democracia representativa "parlamentar-burocrata" teria assumido, de modo que não seria o caso de se afirmar, pelo "princípio da publicidade", a existência de um parlamento deliberativo; mas antes um caráter negocial do parlamento-burocrata (HABERMAS, 2003c, pp. 238-241)

${ }^{394}$ HABERMAS, 2003c, pp. 246 ess. 
para tal, uma vez que ele deve ser um Estado "produtor, repartidor, distributivo, que não deixa por conta dos indivíduos a sua situação social, mas vem ajudá-los através de garantias". ${ }^{395} \mathrm{O}$ autor reconhece uma tendência efetiva no sentido de se retirar a força da esfera pública enquanto princípio, o que perpassa o Estado social democrata, seus direitos fundamentas e o aumento de sua burocracia e órgãos sociais; e assevera: sob essas condições, as pessoas privadas somente poderão participar de modo efetivo "através dos canais da esfera pública intrapartidária e intrínseca às associações, num processo de comunicação pública à base de uma 'publicidade' posta em ação para o intercâmbio das organizações com o Estado e delas entre si”. 396

Ainda assim, Habermas reconhece duas tendências divergentes da esfera pública social-democrata: por um lado, como configuração decadente da esfera pública burguesa, ela dá espaço para uma publicidade manipulativa; por outro, como continuação do Estado Liberal, ele também se "fixa no mandamento de uma esfera pública politicamente ativa, em decorrência da qual o público mediatizado por organizações deveria colocar em movimento, através delas mesmas, um processo crítico de comunicação pública”. Essa esfera pública burguesa tinha como pressuposto reduzir os conflitos estruturas de interesse e as decisões burocráticas a um número mínimo. Isso geraria problemas para o Estado social-democrata, com sua crescente burocratização e uso da razão pública apenas no interior do aparelho burocrático do Estado, dos partidos e das associações de interesse. ${ }^{397}$ Assim, com a pluralização de interesses, ficaria difícil trabalhar consensos possíveis em uma noção de interesse geral. Mesmo com essas considerações, Habermas afirma que ainda haveria possibilidades de se reforçar a tendência de uma esfera pública politicamente ativa. Da mesma forma que as duas tendências da esfera pública social-democrata estariam em tensão, os conceitos de "opinião pública crítica" e uma "opinião pública manipulada" também estariam em conflito e serviriam de "termômetro de um processo de democratização na sociedade industrial organizada como social democracia". ${ }^{398}$

\footnotetext{
${ }^{395}$ HABERMAS, 2003a, pp. 262-263

${ }^{396}$ HABERMAS, 2003a, p. 269. Ênfases omitidas

${ }^{397}$ HABERMAS, 2003a, pp. 270-271

${ }^{398}$ HABEMRAS, 2003a, p. 283.
} 


\section{O conteúdo normativo da modernidade: o projeto teórico habermasiano}

Para compreendermos a abordagem habermasiana da esfera pública compreendida "entre facticidade e validade", em sua última formulação, é necessário compreender como Habermas desenvolve seu programa teórico entre um modelo normativo de teoria vinculado e uma teoria da sociedade moderna. ${ }^{399}$ Nesse desenvolvimento, Habermas retira grande potencial normativo da sociedade moderna no sentido de sua autonomização e capacidade de autorregulação, o que o leva a desenvolver um modelo de evolução moral da sociedade "pós-convencional" e afirmar que o potencial da modernidade não teria ainda se esgotado - sendo ela um "projeto inconcluso". Habermas critica aqueles que seriam céticos sobre o conceito de racionalidade moderno, sejam eles pós-estruturalistas, teóricos críticos ou seguidores da teoria dos sistemas tal como formulada por Luhmann. ${ }^{400}$ Todos eles fariam uma "crítica limitada" do conceito de razão, desconsiderando o potencial racional "não-instrumental" da razão comunicativa. Segundo Habermas, a modernidade consiste também em um processo que ganhou certa autonomização e, a partir da "crítica à tradição" e da quebra das estruturas hierárquicas tradicionais, pôde "extrair de si mesma a sua normatividade. A modernidade vê-se referida a si mesma, sem a possibilidade de apelar para subterfúgios. Isso explica a suscetibilidade da sua autocompreensão, a dinâmica das tentativas de 'afirmar-se' a si mesma, que prosseguem sem descanso até os nossos dias". Em sua consciência histórica moderna, afirma Habermas, a autocompreensão da sociedade deixa de lado o passado e passa a se abrir para o futuro. A renovação contínua e termos como "progresso", "emancipação", revolução, etc., passam a figurar a consciência histórica da modernidade, que tende a se autonomizar. ${ }^{401}$

Podemos dizer que a sociedade moderna, em sua autoconsciência, considera sua autonomia frente ao passado, fundamentando-se em si mesma. Aqui, o reconhecimento do "Iluminismo" como uma dos pilares desta "identidade e auto-consciência histórica" será uma marco central que, contudo não teria levado suas consequências até o fim por desconsiderar o caráter comunicativo da razão; sendo passível de uma "reconstrução crítica" dos potenciais do Esclarecimento (Aufklärung).

399 De maneira diferente, e com comparação à teoria de Michel Foucault, desenvolvi em trabalho anterior (RIBEIRO, 2009b) alguns desses argumentos para analisar "três momentos" críticos à concepção de legitimidade do direito dos autores referidos.

\footnotetext{
${ }^{400}$ Neste sentido, ver: HABERMAS, 2000.

401 Ver HABERMAS, 2000, esp. p. 12 e ss.
} 
O "projeto" moderno iluminista, em sua primeira formulação, pode ser bem expresso por Kant, a quem considera haver certo grau de continuidade de pensamento. Ao buscar responder a pergunta "O que é Esclarecimento?", Kant trata do processo de autonomia via o Esclarecimento, na saída do homem de "seu estado de minoridade". Em outras palavras, primeiro elemento do projeto iluminista que podemos reconhecer em Kant é a autonomia pela razão. Em segundo lugar, a liberdade propiciada pela autonomia racional que levaria a uma nova reforma do pensamento e da auto-determinação. Encontrase, aqui, a ideia de uso público e livre da razão feito em espaço público, no qual o que está em consideração é a argumentação, não a obediência. O terceiro elemento que podemos retirar deste texto de Kant é sua noção do esclarecimento como processo. Por isso não vivíamos em uma época esclarecida, mas em uma época de esclarecimento. ${ }^{402}$

É precisamente esta ideia de "emancipação" pela razão como pensada pelo iluminismo (esclarecimento) que será posta em cheque por grande parte da teoria crítica do século XX (principalmente a partir da sua segunda metade); pelas teorias pósestruturalistas e pós-modernas e pela teoria dos sistemas que, como vimos, abandona o conceito de racionalidade como "europeu velho". ${ }^{403}$ Habermas, entretanto, tendo em vista que a modernidade se autonomiza e cria as condições de sua identidade ${ }^{404}$, busca precisamente na reconstrução das estruturas normativas da modernidade ${ }^{405}$ a possibilidade de uma crítica universalista por meio da razão comunicativa, "recuperando" o potencial emancipatório da razão. Neste sentido, grande parte de seu percurso na obra $O$ Discurso Filosófico da Modernidade se estrutura em rebater as críticas radicais da razão, afirmando que elas apenas se voltam a uma faceta da razão, da razão que "desconsidera seus próprios fundamentos". ${ }^{406}$ Segundo ele, "a crítica radical da razão paga um alto preço pela despedida da modernidade". 407

Habermas tem uma dupla faceta metateórica para construir esse argumento no decorrer de sua obra: um postulado normativo de "reconstrução crítica da razão" por meio de sua teoria do discurso $e$ uma teoria social que, ao mesmo tempo, ancore seus postulados normativos em uma evolução moral "pós-convencional” da sociedade. Por isso, é possível

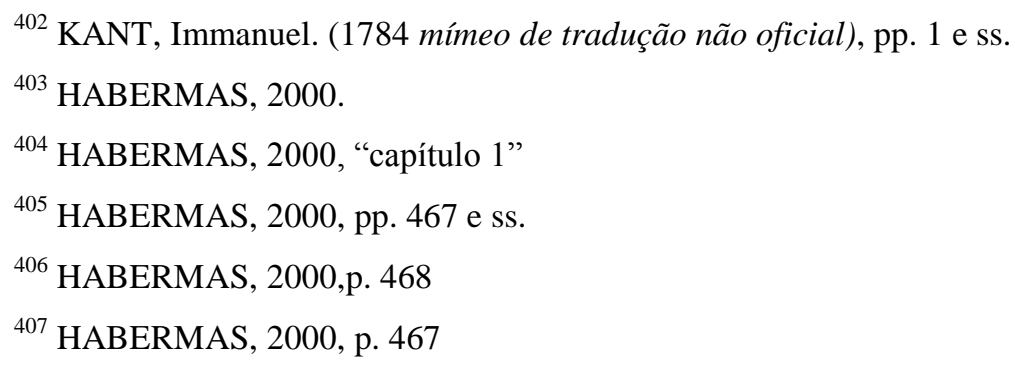


acompanhar Oliver Voirol em sua afirmação de que, de certa maneira Habermas ainda se conectaria com a tradição "Escola de Frankfurt" da dialética da razão inaugurada por Hegel que, a partir da crítica da modernidade, mostrava suas ambivalências e contradições. Assim, esta tradição faria uma espécie de crítica normativa que visava partir da normatividade da sociedade empírica, afirmando não necessitar de ancoragem "extratéorica".

Voirol argumenta: "Habermas está em sintonia com esta tradição: sua abordagem da sociedade contemporânea permite identificar um interesse na emancipação que não se dá por meio de uma abstração teórica pura, mas que apresenta forte grau de efetividade prática. A crítica se opera, então, em face de uma modernidade e a uma sociedade 'autênticas', constituindo-se no núcleo da sociedade. A ancoragem normativa da crítica reside, em Habermas, no potencial inter-humano do ouvir através da comunicação potencial este que é ameaçado pelas tendências funcionais das sociedades capitalistas modernas. É na medida em que ela supõe uma comunicação livre de dominação que a interação linguística comporta um potencial de utopia imanente. A crítica, então, não é arbitrária, uma vez que pode representar o ponto de vista prático a partir do qual ela submete as situações problemáticas dos tempos atuais à denunciação. Ao formalizar as condições universais da comunicação social, Habermas combina a esta crítica uma dimensão transcendental à qual é associada a pragmática universal - que visa dar conta das regras em uso na comunicação quotidiana e estruturam toda a situação de fala. Habermas faz um esforço de juntar os dois modelos de críticas, o transcendental e o imanente, e de os combinar. (...) Deste modo, a crítica normativa visa identificar explicitamente, em dado momento, as formas de experiências ou as formas de vida como portadoras de uma sociabilidade que incorpora uma visão emancipatória suscetível de se implantar; e é à partir desta ancoragem que a abordagem analítica se enche com os processos em curso, formulando um diagnóstico do mundo presente por submeter a críticas os mecanismos de destruição e dominação". 408

\footnotetext{
${ }^{408}$ VOIROL, Olivier. (2006), p. 12.0 Por não ter conhecimentos suficientemente seguros do francês, , cabe aqui abrir uma exceção e transcrever o trecho original: « Habermas se s'inscrit dans le droit fil de cette tradition : son approche de la société contemporaine permet d'identifier un intérêt à l'émancipation qui ne soit pas une pure abstraction théorique mais qui présente in fort degré d'effectivité pratique. La critique s'opère alors face à une modernité et d'une socialité «authentiques », constituant le noyau même de la société. L'ancrage normatif de la critique réside chez Habermas dans le potentiel interhumain de l'entende au moyen da la communication, potentiel qui est menacé par les tendances fonctionnelles des sociétés capitalistes modernes. C'est dans la mesure où elle suppose une communication exempte de domination que l'interaction langagière comporte un potentiel d'utopie immanente. La critique n'est alors pas arbitraire car elle permet de rendre compte du point de vue pratique à partir duquel elle soumet les évolutions
} 


\subsection{Por uma pragmática universal intersubjetiva: orientação para o entendimento e o consenso}

Ao realizar sua crítica à teoria do conhecimento, Jürgen Habermas parte do paradigma da "virada linguística". No entanto, a teoria do discurso apresenta um "elemento adicional" às teorias da guinada linguística, o que levou Thomas McCarthy a cunhar o termo de uma guinada social em cima da guinada linguística. ${ }^{409}$

Para tal, Habermas critica a filosofia do conhecimento de Kant, com suas categorias "transcendentais apriorísticas", 410 argumentando que ele teria feito "renuncias precipitadas" ao conceito da "constituição da experiência" e a um tratamento explícito do conceito da realidade. ${ }^{411}$ Habermas, portanto, substitui o conceito "solipsista" do sujeito transcendental kantiano pela análise da validade universal (intersubjetiva) dos "pressupostos comunicacionais universais e gerais" entendidos como pressupostos de um processo argumentativo com pretensão de validade. Critica-se o caráter apriorístico das categorias do sujeito transcendental e, com elas, a perda da capacidade de compreender as “experiências comunicativas" que ocorrem quando um ouvinte participa de um processo comunicativo com um falante: as categorias de pensamento, para Habermas, não são $a$ priori, mas socialmente (e intersubjetivamente) constituídas através da comunicação. ${ }^{412}$ Desta forma, a situação de "possibilidade de compreensão mútua" substitui a noção de "objeto de possível experiência". Isto significa que esta possibilidade de compreensão mútua pressupõe uma orientação para o entendimento. A partir desta crítica “epistemológica", Habermas pode vislumbrar um novo tipo de "ação social” que se orienta

problématiques du temps présent à lá dénonciation. En formalisant les conditions universelles de la communication sociale, Habermas combine à cette critique une dimension transcendantale à laquelle est associée la pragmatique universelle. - que vise rendre comte des règles en usage dans la communication courante et qui structure toute situation de parole. Habermas s'este efforcé de faire tenir ensemble les deux modèles de critique, transcendantal et immanent, de les combiner. (...) La critique normative vise donc à identifier explicitement, à un moment donné, des formes d'expériences ou des formes de vie comme porteuses d'une socialité incorporant un visée émancipatoire susceptible de se déployer davantage ; et c'es à partir de cet ancrage que la démarche analytique se penche sur les processus en cours, formule un diagnostique du monde présent pour soumettre à la critique les mécanismes de destruction et de domination».

${ }^{409}$ Cf. McCARTHY, 1981, p. 91, onde o autor afirma que "[O livro de Jürgen Habermas denominado de] Knowledge and Human Interests demonstra a necessidade de se realizar uma nova guinada, uma 'guinada social', no caminho de uma teoria do conhecimento adequada.".

$$
\begin{aligned}
& { }^{410} \text { HABERMAS, 1996, p. } 39 \\
& { }^{411} \text { HABERMAS, 1996, p.42 } \\
& { }^{412} \text { HABERMAS, 1996, p, } 42 \text { e ss. }
\end{aligned}
$$


para o entendimento comum e, portanto, parte de um pressuposto de "expectativa de consenso." Isso implicará uma nova forma de se pensar a racionalidade - "a racionalidade do agir comunicativo".

\subsection{A tese da dupla integração social: sistemas e mundo da vida}

Primeiramente, é importante precisar o conceito de mundo da vida como o horizonte no qual os agentes comunicativos movimentam-se; horizonte este que é o próprio pano de fundo do agir comunicativo. Como argumenta Marcelo Neves, "o conceito de mundo da vida reproduz-se mediante a ação comunicativa, orientada para o entendimento do intersubjetivo. (...) Portanto, é possível no modelo habermasiano conceituar o mundo da vida como a moldura simbólica de referência da ação comunicativa". ${ }^{413}$ Segundo seu conceito de 'colonização do mundo da vida', a "economia e política como sistemas autoregulados invadem destrutivamente o mundo da vida, perturbando-lhe os processos de reprodução, e, assim, ameaçando a manutenção de seus componentes". ${ }^{414}$ Ou ainda mais precisamente, "fala-se então de colonização interior do mundo da vida: 'a tese da colonização do interior' afirma que os subsistemas economia e Estado, em face do crescimento capitalista, tornam-se mais complexos e invadem sempre mais profundamente a reprodução simbólica do mundo da vida'..."415

Habermas, assim como Weber e Lukács, percebe que a modernidade implica em diferenciação de "esferas de valor" (Weber) e em uma racionalidade sistêmica fragmentária que "reifica" relações sociais (Lukács). Na verdade, Habermas dialoga com Niklas Luhmann e com sua teoria de sistemas autopoiéticos. Jürgen Habermas não rejeita nem o diagnóstico da "reificação", tampouco o da prevalência da racionalidade instrumental no capitalismo moderno. O autor argumenta, antes, que não é apenas a racionalidade instrumental (que ele também denomina de sistêmica, referindo-se aos meios "media" sistêmicos "dinheiro" e "poder") que existe na modernidade, mas também racionalidade comunicativa. Isso permite a oposição entre o "agir-com-relação-a-fins" e o "agir comunicativo". Desta forma, desvela-se tanto uma nova explicação da modernidade como uma nova possibilidade de emancipação.

\footnotetext{
${ }^{413}$ NEVES, 2006, p.68

${ }^{414}$ NEVES, 2006, p.75

${ }^{415}$ NEVES, 1994, p.257.
} 
Habermas é conhecido como um "teórico do duplo enfoque". Ou seja, quando se pergunta acerca de como uma sociedade moderna complexa, que não se sustenta mais por vínculos tradicionais e hierárquicos, mantendo-se integrada, Habermas chega a uma resposta dupla: por meio de sistemas (reprodução material) e pelo mundo da vida (que apresenta três funções de reprodução "social”, podemos dizer).

Nota-se, com efeito, que Habermas também trabalha com uma oposição entre sociedades "pré-modernas", que chama de tradicionais, e sociedade moderna. Nas primeiras, as tradicionais, um conjunto de valores religiosos ou míticos são compartilhados pelos membros da comunidade formando uma cosmovisão que serve de referência para a ação e um modo de vida compartilhado, havendo unidade política e religiosa. Por seu turno, a sociedade moderna é encarada por Habermas como complexa, impondo, assim, uma pluralidade de "eticidades" e concepções de mundo. Portanto, para manter uma sociedade complexa integrada, são necessários mecanismos de coordenação de ação mais abstratos, como sistemas político e econômico (pelos media poder e dinheiro). ${ }^{416}$ Aqui, então, vemos que Habermas trata a sociedade moderna como dividida entre sistemas (reprodução material - coordenação estratégica especializada de integração social) e mundo da vida (Lebenswelt) (no qual ocorre a reprodução social da sociedade).

Habermas considera que esta análise do mundo da vida tem por objeto "apreender as estruturas que se apresentam como invariantes frente às cunhagens históricas dos mundos da vida e das formas de vida particulares". ${ }^{417}$ Isso, pois é no plano do mundo da vida que os agentes comunicativos se movimentam, sendo este mundo da vida simultaneamente o horizonte e o pano de fundo das manifestações comunicativas; a delimitação do espaço-tempo e um sistema de referência. Ele abarca o agir comunicativo que, por sua vez, "pode ser compreendido como um processo circular no qual o ator é as duas coisas ao mesmo tempo: ele é o iniciador, que domina as situações por meio de ações imputáveis; ao mesmo tempo, ele é também o produto das tradições nas quais se encontra; dos grupos solidários aos quais pertence e dos processos de socialização nos quais se cria”. Neste sentido, o agir comunicativo é sustentado por um mundo da vida que não somente forma o contexto para os processos de entendimento mútuo, mas também fornece os recursos para isso. O mundo da vida comum em cada caso oferece uma provisão de

\footnotetext{
${ }^{416}$ NOBRE, 2008, p. 15 e ss. Ver também, NEVES, 2006, esp. pp. 53 e ss. E 67 e ss.

${ }^{417}$ HABERMAS, 1987, pp. 169-170
} 
obviedades culturais donde os participantes da comunicação tiram seus esforços de interpretação, os modelos de exegese consentidos". 418

Desta forma, o mundo da vida fornece o contexto da situação das ações e os recursos para que a referência a "algo no mundo" possa ser feita. Ou seja, nele não encontramos apenas os "consensos ingênuos mais fundamentais da interação humana que permitem nossa comunicação partilhada", mas também os recursos para que possamos nos referir a algo no mundo. Por isso, o mundo da vida engloba os "três mundos" da ação (objetivo, social e subjetivo) ${ }^{419}$, de modo que os agentes comunicativos se movem sempre dentro de seu horizonte (sem poder dele sair) e podem se referir a algo como "algo intersubjetivo".

Nas palavras de Habermas, "as estruturas do mundo da vida fixam as formas de intersubjetividade do entendimento possível. (...) Os participantes da comunicação devem a elas a sua posição extramundana frente ao intramundano sobre a qual podem entender-se. O mundo da vida é, por assim dizer, o lugar transcendental no qual falante e ouvinte se encontram; onde podem requerer reciprocamente a pretensão de que suas emissões concordem com o mundo (com o mundo objetivo, com o mundo subjetivo e com o mundo social), e em que podem criticar e exibir os fundamentos destas pretensões de validade, resolver seus dissentimentos e chegar a um acordo." ${ }^{420}$

Desta forma, é no mundo da vida ocorre a reprodução social da sociedade (a reprodução material se dá pela funcionalidade de meios de coordenação sistêmicos : os mídia dinheiro e poder dos sistemas econômico e político). No entanto, olhando mais de perto, vemos que o mundo da vida é tripartido. Seus componentes estruturais são a (i) cultura, a (ii) sociedade ("integração", pode-se dizer ${ }^{421}$ ) e a (iii) personalidade. Respectivamente, os processos de reprodução ("funções") são a reprodução cultural, a integração social e socialização. ${ }^{422}$

${ }^{418}$ HABERMAS, 2003d, p166.

${ }^{419}$ HABERMAS, 1987, p.171

${ }^{420}$ HABERMAS, 1987. P, 179

${ }^{421}$ A escolha pelo termo "integração" ao invés de sociedade é baseada em sugestão do Prof. Adrian Gurza Lavalle, conforme aula ministrada no departamento de Ciência Política da FFLCH-USP.

${ }^{422}$ HABERMAS, 1987, p. 207-208. A diferenciação interna ao mundo da vida entre estas três funções (processos de reprodução social) "leva anexa" consigo uma diferenciação entre forma e conteúdo. Assim, acompanhando Habermas de perto, temos que no plano da cultura, os núcleos de tradição que garantem a identidade se separam dos conteúdos concretos das imagens míticas do mundo e se reduzem a elementos formais de concepção de mundo tais como conceitos e concepções de mundo, pressupostos da comunicação, procedimentos argumentativos, valores fundamentais abstratos, etc. No plano da sociedade (integração), cristalizam-se princípios universais. Nas sociedades modernas se implantam princípios jurídicos e morais que 
Habermas, então, deixa muito claro que a reprodução da sociedade pelo mundo da vida (integração social) não dá conta de mantê-la integrada. Ora, argumenta, "se entendermos a integração da sociedade exclusivamente como integração social estamos optando por uma estratégia conceitual que, como temos visto, parte da ação comunicativa e concebe a sociedade como mundo da vida". ${ }^{423}$ Mas sociedade não é (apenas) mundo da vida. Habermas não discorda que na sociedade moderna capitalista existe o que chamou de "razão funcionalista", tipo genérico com o qual Habermas engloba quase a totalidade das críticas da Razão iluminista tida como formal, excessiva, normalizadora, disciplinadora e controladora de relações sociais. Habermas, então, reconhece que grande parte da reprodução social (integração material) não é feita pelo mundo da vida, mas sim pelos sistemas, que por sua vez possuem capacidade muito mais elevada de coordenação social. Nas sociedades complexas, ocorre a diferenciação funcional de sistemas parciais de redução de complexidade. O argumento habermasiano entende a "evolução social como um processo de diferenciação de segunda ordem: ao qual ao aumentar a complexidade de um e a racionalidade do outro, sistema e mundo da vida não apenas se diferenciam internamente como sistema e mundo da vida, mas também, se diferenciam simultaneamente um do outro". Neste sentido, com o progressivo aumento de complexidade da sociedade moderna, sistemas autônomos começam a se diferenciar do mundo da vida e ocorre o "desacoplamento entre sistemas e mundo da vida". ${ }^{424}$ Habermas decompõe o âmbito sistêmico da reprodução social nos sistemas econômico e político (ou burocrático-administrativo) que operam os media de coordenação dinheiro e poder, respectivamente. Estes meios "não comunicativos" estão desacoplados do mundo da vida.

O que é mais importante notar é que Habermas reconhece que a ampliação do âmbito sistêmico de maneira excessiva se assemelharia a uma "patologia da razão", uma patologia moderna. A razão formal, técnica e normalizadora dos sistemas teria sua função concretizada no mercado e na organização do poder. Habermas concorda com Luhmann que as sociedades modernas complexas - que não contam com uma cosmovisão, uma tradição homogênea e nem com uma organização hierarquizada - precisaram desenvolver meios sistêmicos para se manterem. O que Habermas concebe como um diagnóstico

cada vez estão menos recortados por medidas de forma de vida concretas. No plano do sistema da personalidade, as estruturas cognitivas adquiridas no processo de socialização se emancipam cada vez mais dos conteúdos de saber cultural com que inicialmente estavam agregadas no "pensamento concreto".

${ }^{423}$ HABERMAS, 1987, p. 213

${ }^{424}$ HABERMAS, 1987. p.216-217. 
("patológico") da modernidade é um cenário no qual esta "racionalidade sistêmica" se expande por demais e "coloniza" o mundo da vida.

Com esse modelo da dupla integração social, não apenas a colonização do mundo da vida pelo sistema é possível, mas também o contrário: a influência pode se dar no sentido oposto e o poder comunicativo pode se "transformar" em poder administrativo (sistêmico). É por este motivo que Habermas irá, em sua obra mais tardia, buscar a possibilidade de se pensar esta transformação no/pelo direito no contexto da democracia deliberativa apoiada em uma esfera pública autônoma e ativa. Neste momento, para demonstrar precisamente como a esfera pública se insere nesse contexto, Habermas lança mão de metáforas relativas "a fluxos comunicativos", se valendo de termos como "barragens" e "comportas", conforme veremos abaixo.

\subsection{O Conteúdo normativo da modernidade: moral pós-convencional e evolução social}

Habermas pretende fazer uma teoria crítica da sociedade que não seja "externa a ela", mas cujo "o conteúdo normativo" seja extraído da própria modernidade em sua autodescrição. ${ }^{425}$ Assim, afirma Habermas, a diferença entre descrição e normatividade, entre facticidade e normatividade, entre teoria positiva e teoria normativa, fica muito mais fluída e de difícil demarcação.

Neste sentido, Habermas argumenta que "o ponto de vista moral já se encontra implícito na constituição sócio-ontológica da prática pública da argumentação, compreendendo as complexas relações de reconhecimento mútuo que participantes do discurso racional 'devem' aceitar". ${ }^{426}$ Esta afirmação de Habermas deixa claro sua tentativa de buscar na "ontologia social" - não em princípios morais ou "teorias abstratas da justiça - a forma da normatividade (moralidade) moderna.

Habermas realiza uma "crítica" de natureza reconstrutiva ${ }^{427}$ que relaciona o conteúdo normativo da modernidade, procurando demonstrar como uma identidade

${ }^{425}$ Cf. defendido em HABERMAS, 2000.

${ }^{426}$ HABERMAS, 1995, p. 127

427 Reconstrução significa "que uma teoria é desmontada e recomposta de modo novo, a fim de melhor atingir a meta que ela própria se fixou: esse é o modo normal (...) de se comportar diante de uma teoria que, sob diversos aspectos, carece de revisão, mas cujo potencial de estímulo não chegou ainda a se esgotar". 
universalista pode ser pensada em uma sociedade complexa na qual mecanismos de poder são mais difusos e fluídos. Desse modo, sua teoria da comunicação, usualmente enfrentada no âmbito da filosofia e da ética discursiva, pode ser reconstruída por uma teoria da evolução social. ${ }^{428}$ Portanto, para possibilitar a crítica da sociedade, seria necessário reconstruir pressupostos e procedimentos comunicativos gerais para a justificação de normas e valores.

Ele desenvolve, então, uma relação entre a sociogênese e a teoria da ontogênese ao partir do pressuposto de que a psicologia cognoscitiva do desenvolvimento (no nível do indivíduo, da ontogênese) chegou a conclusões que apontam para diversos "níveis de consciência moral" descritos, em suma, como pré-convencionais, convencionais e pósconvencionais. ${ }^{429}$ Para Habermas, "os mesmos modelos se repetem na evolução social das ideias morais e jurídicas”. Neste sentido, ele passa a investigar as estruturas de racionalidade também em terrenos empírica ou conceitualmente até agora pouco estudados: os terrenos de desenvolvimento do Eu e da evolução das imagens do mundo, por um lado, e, por outro, das identidades do Eu e do grupo.

$\mathrm{O}$ autor desenvolve a ideia de que sujeito e objeto se constituem reciprocamente, e que o sujeito só pode se tornar consciente de si mesmo em relação com - e na construção de - um mundo objetivo. ${ }^{430}$ Habermas parte de uma extensa reconstrução dos "estágios do desenvolvimento do eu" no sentido da obtenção de capacidade de crítica universalista que se dirige, inclusive, para a crítica de convenções sociais.

Ao apresentar uma homologia com o desenvolvimento do "eu" desenvolvido pela psicologia cognitivista, ${ }^{431}$, Habermas isola um aspecto central do desenvolvimento do "Eu"

${ }^{428}$ HABERMAS, 1983, pp. 11 e ss.

${ }^{429}$ Isso tudo baseado na ligação da "consciência moral com o agir comunicativo" com um caminho evolutivo no sentido de princípios universalista, Para esse desenvolvimento, além da obra supracitada, ver sua incorporação dos modelos da psicologia evolucionaista de Piaget e do modelo de desenvolvimento moral de Kohlberg pela ótica da "teoria discursiva da ética" in: HABERMAS, 2003d, pp. 143 e ss.

${ }^{430}$ HABERMAS, 1983, pp15-16

${ }^{431}$ HABERMAS, 1983, pp.16-17. Segundo ela, o "Eu" se reconhece (ao reconhecer o mundo e os outros) em estágios: (a) simbiótico, [primeiro ano de vida] no qual não há diferença entre si e mundo; entre sujeito e objeto, e a criança não reconhece nem seu corpo físico (b) egocêntrico, [fase sensorial e préoperativa] estágio em que se reconhece a existência física, mas não se diferencia a natureza do social; de modo que a criança é incapaz de reconhecer situações independentemente de seu próprio ponto de vista (c) sociocêntrico-objetivista, [perto do sétimo ano de vida] no qual o Eu compreende normatividades e regularidades do mundo; possibilitando-o a distinguir coisas de eventos manipuláveis, por um lado, e, por outro, sujeitos compreensíveis da ação; e (d), por fim, universalista, quando o Eu torna-se reflexivo. Esta fase é associada à adolescência, quando o(a) jovem se liberta do dogmatismo e pode deixar de aceitar as pretensões de validade contidas em afirmações e normas. Ele pode tanto transcender o objetivismo de uma 
- "a consciência moral" - e analisa o esquema de L. Kohlberg que define seis estágios de desenvolvimento ("racionalmente reconstrutíveis") da consciência moral. ${ }^{432}$

No nível pré-convencional, a criança é capaz de responder a regras culturais interpretando noções de "bom" e de "mau", mas a interpretação aqui se dá em termos das consequências físicas ou hedonistas da ação (punição, troca de favores, etc,). No "estágio 1", a orientação se dá por meio de punição e de obediência; no "estágio 2", a orientação é instrumental-relativista: a ação justa satisfaz os próprios carecimento e apenas ocasionalmente a dos outros, uma vez que as relações são instrumentais, sem estarem presentes noções de justiça e lealdade.

Por sua vez, o nível convencional permite que seja avaliável pelo seu direito intrínseco o fato de se satisfazer as expectativas de grupo circundantes (como família, por exemplo). Não é mais apenas a conformação às expectativas pessoais e à ordem social, mas de lealdade em face dela. No "Estágio 3" ocorre a concordância interpessoal ou a orientação "bom moço - moça bem comportada" - em conformidade com as imagens estereotipadas de comportamento "natural" ou da maioria. O "Estágio 4" se caracteriza pela orientação pela "lei e ordem", havendo orientação no sentido da autoridade, dos papéis fixos e da manutenção da ordem social, sendo o comportamento justo aquele que cumpre seu dever.

O nível pós-convencional (autônomo ou fundado em princípios), “caracteriza-se por haver um claro esforço no sentido de definir os valores e princípios morais que têm validade e aplicação independentemente da autoridade dos grupos ou das pessoas que os sustentam e do fato de que o próprio indivíduo se identifique ou não com tais grupos". Assim, no "Estágio 5", encontra-se a orientação legalista social-contratual. Nela, a ação justa tende a ter acentos utilitários e a ser definida em termos de direitos individuais. Já se encontra presente, neste estágio, o relativismo de valores pessoais. O resultado é uma acentuação do 'ponto de vista legal', mas com uma insistência na possibilidade de mudar a lei em função de considerações racionais de utilidade social. Finalmente, no "Estágio 6" temos a orientação no sentido de princípios éticos universais. Aqui, "o justo é definido pela decisão tomada pela consciência de acordo com princípios éticos autonomamente escolhidos, os quais apelam à compreensibilidade lógica, à universalidade e à consciência.

natureza dada, quanto romper o sociocentrismo de um ordenamento superado entendendo (e por vezes criticando) as normas existentes como meras convenções, se vistas à luz de princípios.

${ }^{432}$ HABERMAS, 1983 , p. 55 
Esses princípios são abstratos e éticos ("a regra de ouro, o imperativo categórico"); não são regras morais concretas, mas princípios universais de justiça, de reciprocidade, de igualdade, dos direitos humanos e do respeito pela dignidade dos seres humanos como pessoas individuais". 433

Com este processo, Habermas acredita ter encontrado uma forma de se juntar sua teoria do discurso (que possibilita a crítica transformando os "consensos ingênuos" do mundo da vida em consensos discursivos) com uma teoria do desenvolvimento e da evolução social que aponta para uma pragmática universal ética na reconstrução filosófica da "ética universal da linguagem". ${ }^{434}$ É daí que Habermas retira que a "sociogênese repete a ontogênese", chegando ao conceito de sociedades pós-convencionais que podem criticar suas instituições. Por isso, o próximo passo teórico seria desenvolver mecanismos pelos quais estas sociedades podem fazer isso, ou seja, a pergunta de como seria possível que sociedades complexas caminhassem no sentido de uma moral pós-convencional. Aqui, após esse longo percurso, a nova formulação habermasiana do conceito de esfera pública desempenhará um papel central.

\subsection{A crise de legitimação do capitalismo tardio: enfrentando o desafio luhmanniano}

Em “Crise de Legitimação do Capitalismo Tardio", Habermas discute a lógica da crise de legitimidade de instituições modernas e, para isso, diferencia seu conceito de legitimidade - mais carregado normativamente - do conceito de legitimidade funcional. Habermas demonstra que sua principal preocupação é trabalhar a relação da legitimidade com a noção de verdade. Habermas se opõe, portanto, às concepções "decisionistas" de legitimidade (tradição que o autor afirma vir de Carl Schimitt até Niklas Luhmann) que respondem a este problema ressaltando a necessidade de se aduzir razões constitucionais por meio de procedimentos formais para legitimar sanções. Esta concepção seria a concepção de "positividade do direito" coadunada com a "legitimação pelo procedimento" no pensamento luhmanniano.

433 Todo este quadro é reproduzido de HABERMAS, 1983, p. 55. (que, por sua vez, o reproduz de KOHLBERG, Lawrence. "From Is to Ought"in MISCHEL, T. (Ed.) Cognitive development and Epistemology, Nova Iorque, 1971, pp. 151-236.

${ }^{434}$ HABERMAS, 1983, p. 68 
A esta concepção decisionista (ou auto-referencial, no caso de Luhmann), Habermas contrapõe a posição de que o positivismo legal requer um "consenso geral racional valorativo para se legitimar". Habermas admite, contudo, que em sociedades complexas (Luhmann) com esferas de valores irredutíveis (Weber), tal tese se torna insustentável, ao que Habermas propõe recorrer às normas fundamentais do discurso racional, que pressupomos em qualquer discurso.

Portanto, Habermas irá trabalhar a relação entre questões práticas e verdade para fundamentar sua pragmática universal. Para isso, Habermas se vale da força da argumentação num processo de conhecimento que utiliza argumentos substanciais. Isso implica em um processo argumentativo capaz de fornecer fundamentos racionais para pretensões de validade. Para Habermas, se o debate com argumentos substanciais em atos de fala for pensado em condições ideais específicas, ${ }^{435}$ ocorrerá um consenso necessário que será reflexo da "vontade racional" discursiva: "o interesse é comum, porque o consenso livre de constrangimento permite apenas o que todos podem querer". ${ }^{436}$ Aqui, vemos que Habermas consegue unir o elemento "universal" à sua "pragmática" e afirma que com isso ele resolve os dilemas do decisionismo com a capacidade de generalização dos interesses. Logo, o problema do pluralismo de interesses irredutíveis (proposto por Weber) se dissolve, e se torna possível pensarmos em um procedimento de universalização que possibilita a generalização de interesses a partir de um procedimento intersubjetivo discursivo orientado pelo entendimento. Com efeito, apenas uma ética cognitiva discursiva (que se baseia no desenvolvimento de uma moral universalista pós-convencional) não precisaria de princípios externos, fundamentando-se intersubjetivamente em normas discursivas.

Habermas se volta, então, contra as tentativas "de supressão" da formação de vontade democrática e de interesses generalizados e rejeita as concepções "de acordo entre partes" ou de "negociações de barganha" (e mesmo de classes) por considerá-los projetos de "anti-iluminismo" que não resolveriam o problema da legitimação do capitalismo tardio. Em uma perspectiva marcadamente normativa, Habermas afirma que sua intenção é a de se pensar uma gênese normativa genuína - e acordos não lhe são suficientes, ainda que

${ }^{435}$ As pretensões de validade constituem um objeto exclusivo do discurso, nele os participantes têm igual oportunidade de participação em contribuições livres, não há força externa que restrinja os argumentos; e, por fim, que o único motivo buscado é o da busca cooperativa da verdade (HABERMAS, 2002, p 136). Estas são as "condições ideais" que levariam a um consenso. Daí a ligação entre "verdade" e "legitimidade".

${ }^{436}$ HABERMAS, 2002, p.137. Ênfase adicionada. 
ele reconheça que "pseudo-acordos" sejam uma forma importante de legitimidade "formal" em sociedades complexas.

Habermas relembra que a função dos sistemas é a de "evitar o caos". O reconhecimento das contingências e da expansiva complexidade social tornaria necessário um correspondente aumento de complexidade interna de sistemas sociais funcionalmente diferenciados - como postula Luhmann. Neste contexto, uma justificação social seria de difícil verificação. Aqui surgem teorias de (a) pessimismo cultural (Nietzsche) ou de (b) teorias minimalistas da democracia (no retrocesso democrático na teoria política); (c) teorias da crítica da razão e de fim do indivíduo como em Horkheimer e Adorno. Realmente, este contexto parecia recair em uma gritante "crise de humanidade" e em uma crise de legitimação no seio do capitalismo moderno.

Para enfrentar essa "crise" de legitimação, Habermas postula uma "questão-guia:" como as decisões coletivamente vinculantes seriam decididas na organização social através da formação discursiva de vontade, sob condições discursivas ideais, com adequado conhecimento das condições limitantes $e$ dos imperativos funcionais da sociedade?. ${ }^{437}$

Enfim, para Habermas, após o autor considerar estarem refutadas as teorias empiricistas e decisionistas; bem como as tentativas de explicação da legitimidade por acordo e por interesses, abre-se a possibilidade de que as questões práticas e políticas possam ser tratadas discursivamente. Falta apenas saber como isso pode ser feito. Para isso é que Habermas desenvolve seu conceito de democracia deliberativa, cujo conceito “sociológico" central é a esfera pública ativa.

Para trabalhar este contexto em sua defesa de uma legitimação discursiva do Estado de Direito para responder à crise da legitimidade, Habermas acompanha Luhmann em seu reconhecimento da necessidade de levar em conta o aumento da complexidade social e enfrenta, novamente, a tese luhmanniana da autolegitimação do sistema político. ${ }^{438}$

Para o autor, o desafio imposto pela teoria social de Luhmann é decisivo. Ele afirma categoricamente: "[a]té mesmo aqueles que, seguindo Lukács, se atêm ao conceito de reificação, concordam cada vez mais com seus adversários na descrição que [estes últimos] fazem; cada vez mais sentem-se impressionados com a impotência dos sujeitos em face dos processos circulares, não influenciáveis, dos sistemas auto-referenciais. Já

\footnotetext{
${ }^{437}$ HABERMAS, 2002, p.143

${ }^{438}$ HABERMAS, 2002, pp. 160-173
} 
pouco importa se uma acusa como totalidade negativa o que o outro festeja como cristalização, ou se um denuncia como coisificação o que o outro define tecnocraticamente como lei objetiva. Essa tendência do diagnóstico do tempo presente proposto pela teoria social conflui há décadas para um ponto que o funcionalismo sistêmico transformará em sua pointe: faz os próprios sujeitos se decomporem em sistemas. O funcionalismo sistêmico sela tacitamente o 'fim do indivíduo', que Adorno ainda circunscrevera com uma dialética negativa e conjurara como um destino auto-inflingido. (...) $\mathrm{O}$ estado de barbárie que Marx prognosticara no caso de fracasso da práxis revolucionária é caracterizado por uma completa subsunção do mundo da vida sob os imperativos de um processo de valorização desconectado dos valores de uso e do trabalho concreto". 439

O mais interessante notar é que, a rigor, Habermas não tenta apresentar uma real contraposição positiva ao arrebatador diagnóstico Luhmanniano; mas antes apresenta uma crítica afirmando que sua teoria "cínica" impediria a formação de uma crítica à sociedade. E argumenta: “[a] teoria de Luhmann, hoje incomparável sob o aspecto de sua força de conceitualização, de sua imaginação teórica e de sua capacidade de elaboração, desperta, em todo caso, dúvidas na questão de saber se o preço de seu 'ganho de abstração' não seria demasiado alto. O triturador incansável da reconceitualização elimina, como resíduo indigesto, o mundo da vida 'subcomplexo' - ou seja, justamente o domínio de fenômenos que atrai o interesse de uma teoria social que ainda não demoliu todas as pontes com as experiências de crise pré-científicas".

Então, como vimos, Habermas utilizará sua divisão da sociedade em sistemas e mundo da vida para tentar contrapor o diagnóstico luhmanniano; encarando-o como uma descrição parcial da sociedade que desconsidera a importância do âmbito cotidiano de linguagem ordinária do mundo da vida que possibilita a criação do agir comunicativo. Por esse motivo, Habermas une sua teoria do discurso e do reconhecimento do desenvolvimento moral no sentido de uma moral pós-convencional universalista com pretensões de legitimação do capitalismo tardio. A questão a ser enfrentada, então, é saber como isso poderia ser feito; ou seja, como este âmbito sistêmico "desacoplado do mundo da vida" poderia ser influenciado; evitando-se que ele invada o mundo da vida e o colonize. Para isso, Habermas tem que aprofundar sua teoria "sociológica" das democracias contemporâneas e apontar como estes processos seriam possíveis e, além

${ }^{439}$ HABERMAS, 2000 ,p.488-489 
disso, como eles seriam plausíveis. Neste sentido, o autor retorna ao conceito de esfera pública com esta pergunta em mente.

\subsection{A esfera pública pensada pela metáfora dos fluxos I: barragens democráticas de autocontenção da esfera pública}

Após quase trinta anos da publicação de "Mudança Estrutural da Esfera Pública", Jürgen Habermas disse ter ficado tentado a alterar consideravelmente as passagens e realizar emendas no livro original. Contudo, frente à impraticabilidade de tal tarefa, o autor preferiu desenvolver um prefácio específico à edição de 1990 explicitando as releituras e alterações. Ademais, a relevância dada ao tema da esfera pública teria sido reestabelecida no contexto de uma revolução que se "desvelava frente aos nossos olhos" na década de 1990 na Europa central e do leste, motivo pelo qual a obra teve recepção nos EUA com tradução em 1989. ${ }^{440}$ O prefácio, em suma, é motivado por três motivos: (i) "a pesquisa e os problemas teóricos são agora radicalmente diferentes do que eles eram no final da década de 1950 e 1960, quando da publicação original do estudo”. (ii) Ademais, Habermas sustenta que o "contexto extracientífico (Außerwissenschaftliche Kontext) que modela o horizonte de experiência - do qual a pesquisa científica social deriva sua perspectiva" também haveria mudado. Por fim, (iii) sua própria teoria também se alterou, “ainda que menos em seus fundamentos encarados de maneira ampla (Grundzügen) do que em seu grau de sua complexidade". 441

O mais interessante para essa dissertação é o último tópico. Além disso, Habermas afirma que seu foco no prefácio se volta para as possíveis contribuições para o estudo de novas questões relevantes da teoria da democracia, adequando suas considerações à sua teoria do discurso e à democracia contemporânea. Vemos que o foco central é a pergunta pelas condições da produção de poder e solidariedade comunicativa em "sociedades complexas" funcionalmente diferenciadas, onde os imperativos sistêmicos colonizam o mundo da vida. Aqui, sua teoria da ação comunicativa (teoria do discurso) serve de base para apontar a esfera pública como um lócus privilegiado para isso. Sua versão da teoria deliberativa da democracia é, então, inserida no modelo para adequar a noção de esfera pública às "sociedades complexas". Com isso, Habermas realiza uma grande alteração

\footnotetext{
${ }^{440}$ HABERMAS, 1990, p. 11.

${ }^{441}$ HABERMAS, 1990, p. 12
} 
conceitual e se afasta da concepção historicamente delimitada, baseada em análises de classe e base sociais em um contexto marcado pela teoria crítica da sociedade, para o desenvolvimento de um modelo processual de democracia e de uma esfera pública política pensada como fluxos comunicacionais.

\subsubsection{Esfera pública pluralista e a questão da "exclusão"}

Habermas argumenta que em 1961 o objetivo era derivar o "tipo ideal" da esfera pública burguesa do contexto histórico do Reino Unido, França e Alemanha nos séculos XVIII e XIX. Habermas não deixa de reconhecer seus "déficits" empíricos e a necessidade de utilizar literatura secundária. ${ }^{442}$ Em termos mais gerais para o que nos interessa aqui, Habermas trata da objeção de sua descrição "por demais estilizada" da esfera pública burguesa, que levaria para uma idealização injustificada envolvendo uma ênfase mais do que exagerada nos aspectos de racionalização de uma comunicação pública cuja base é a leitura e se pauta pela conversação (Gesprächen fokussierten).

Habermas argumenta que seria equivocado falar, como ele fez em 1961, em uma única esfera pública, ainda quando assumimos que exista certa homogeneidade do público burguês. Contudo, para ele, a diferença de classe seria subjacente a todas as outras diferenciações e seria, portanto, a mesma nas diversas esferas públicas, podendo ser a base comum para um "consenso adquirível, pelo menos em princípio". A questão principal ressaltada por Habermas é que, "para além de introduzir uma diferenciação interna do público burguês - o que poderia ser acomodado dentro do meu modelo por meio de um foco orientado para detalhes - surge um quadro diferente se desde o começo se admite a coexistência de esferas públicas que competem entre si e se leva em consideração a dinâmica desses processos de comunicação que são excluídos da esfera pública". ${ }^{443}$ Habermas discute aqui a questão da esfera pública plebeia como exemplo. Ainda que ela seja uma variante que tenha competido com a esfera pública burguesa historicamente, ela teria tido a esfera pública burguesa como modelo (Vorbild) e não seria nada mais que do que uma mera variante, uma vez que ela desenvolve o potencial emancipatório da esfera pública burguesa em um novo contexto social. A esfera pública plebeia é, por assim dizer,

\footnotetext{
${ }^{442}$ HABERMAS, 1990, p. 13

${ }^{443}$ HABERMAS, 1990 , p. 15
} 
uma esfera pública burguesa cujas precondições sociais foram nulificadas. Com isso, Habermas justifica seu enfoque na esfera pública burguesa.

Ainda assim, Habermas reconhece que a exclusão de estratos sociais inferiores política e culturalmente mobilizados promove uma "pluralização da esfera pública" no processo de sua emergência. Ao lado da esfera pública hegemônica, e interconectada com ela, uma esfera pública plebeia assume forma. $\mathrm{O}$ autor reconhece, entretanto, que a cultura popular (Volkskultur) não era apenas um "eco passivo da cultura dominante", mas também uma "revolta violenta que se estruturava em um contraprojeto em relação ao mundo hierárquico da dominação" por meio de uma dinâmica interna própria. Para o autor, existem na esfera pública "mecanismos de exclusão" que reprimem, mas não deixam de fazer aparecer "contraprojetos". 444

O reconhecimento dessa pluralidade, mesmo na gênese da esfera pública burguesa, deveu-se a diversas críticas, dentre elas várias provenientes da teoria feminista, que afirmam que Habermas não tomaria conhecimento, por exemplo, das dominações e mecanismos de exclusão internas à esfera pública burguesa ou de discursos que seriam excluídos de "esfera pública hegemônica". Esse reconhecimento foi importante para Habermas "adequar" sua teoria aos novos movimentos sociais e suas manifestações, uma vez que eles não são homogêneos (marcados por relações "transclassistas"). Isso o impeliu a conceber a esfera pública de forma "menos homogênea" e abandonar os pressupostos de "totalidade" e de análise de luta de classes, tal como utilizados em 1961. Habermas reconhece que não apenas as mulheres eram excluídas da esfera pública burguesa, mas também trabalhadores, camponeses e "povo". Todos aqueles que faltavam com “independência” e propriedade eram negados de adentrar a esfera pública.

$\mathrm{O}$ autor admite que a mudança no relacionamento entre esfera privada e pública no curso da expansão do direito democrático de participação e da compensação do Estado de bem-estar em relação às desvantagens específicas de classe descrita por ele em 1961 não levou em conta que essa mudança estrutural da esfera pública ocorreu sem afetar o caráter patriarcal da sociedade como um todo. À igualdade de direitos civis e políticos não se seguiu uma igualdade de gênero. No tocante à gênese da esfera pública burguesa, isso demonstra que ela teria sido constituída por um "gênero específico". ${ }^{445}$ Contudo, ainda que Habermas reconheça essas críticas, ele não deixa de atribuir ainda forte potencial de

\footnotetext{
${ }^{444}$ HABERMAS, 1990, p 15-18

${ }^{445}$ HABERMAS, 1990, p. 18-19
} 
emancipação no discurso universalista da esfera pública, que possibilitaria a comunicação dos discursos na esfera pública com "aqueles que estão fora dela", não sendo, a rigor, um discurso hegemônico. ${ }^{446}$ Em formulação em obra posterior, em 1992, Habermas chega a admitir que "esferas públicas parciais" se constituem por mecanismos de exclusão, mas ressalta que esferas públicas não podem "se cristalizar na forma de organização ou sistema", o que o leva a crer que não existe nela "nenhuma regra de exclusão sem cláusula de suspensão". Dessa forma, existem na esfera pública em geral "direitos à inclusão e à igualdade ilimitada" que impedem mecanismos de exclusão típicos dos "discursos foucaultianos". Habermas reafirma o potencial de autotransformação interna da esfera pública, garantido pela sua formatação "universalista" na "inclusão de todos os membros de uma sociedade". ${ }^{447}$

Enfim, a caracterização habermasiana da institucionalização contraditória da esfera pública de 1961 é revisada no sentido de reconhecer que teria sido formulada de modo demasiadamente rígido. Habermas, então, abandona o contraste de idealização histórica, por assim dizer, entre uma "esfera política inicial (que teria durado até o século XIX) e uma esfera pública de massas de Estados de bem estar, que teria sido subvertida pelo poder", retirando-lhe a "áurea de contraste entre um passado idealisticamente glorificado e um presente distorcido". O reconhecimento de tal "equívoco" por Habermas, contudo, "não falsifica o desenho maior do processo de transformação apresentado". ${ }^{448}$

Considero que a questão da "exclusão" na esfera pública, contudo, ainda parece ser um ponto frágil na teoria habermasiana, como veremos no capítulo 3, quando analisarmos os conceitos de "inclusão" e cidadania de Habermas e Luhmann.

446 Afirma o autor: “ [e]ssa consideração convincente [da exclusão das mulheres] não despreza os direitos de inclusão irrestrita e igualdade, que são partes integrantes da auto-interpretação da esfera pública liberal, mas antes apelam para elas. Foucault considera que as regras formativas de um discurso hegemônico são mecanismos de exclusão que constituem seus "outros" respectivos. Nesses casos, não há comunicação entre aqueles que estão dentro e aqueles que estão fora. Aqueles que participam no discurso não dividem uma linguagem comum com os outros protestantes. É assim que pode conceber o relacionamento entre esfera pública representativa de dominação tradicional e a contracultura popular desvalorizada: as pessoas eram forçadas a mover e se expressar num universo diferente e outro. Nesse sistema, portanto, cultura e contracultura eram de tal forma interligados que encontrava aceitação com o outro. A esfera pública burguesa, em contraste, é articulada em discursos que promovem áreas de base comum não apenas para o movimento trabalhista, mas também para o outro excluído, ou seja, o movimento feminista. O contato entre esses movimentos, por seu turno, transformou esses discursos e as estruturas da esfera pública por dentro. Desde o começo, os discursos universalistas da esfera pública burguesa já eram baseados em premissas autorreferenciais; elas não permaneceram incólumes a um criticismo vindo de dentro, pois elas se diferem dos discursos foucaultianos por seu potencial de auto-transformação" (HABERMAS, 1990, p. 20).

${ }^{447}$ HABERMAS, 2003c, p. 107-108. Ênfase adicionada.

${ }^{448}$ HABERMAS, 1990, pp. 21 e ss. 


\subsubsection{Um posicionamento menos pessimista frente às mudanças estruturais da esfera pública}

As análises da mudança estrutural da esfera pública realizadas por Habermas em 1961 e que levaram em conta mudanças no Estado e na economia, por um lado, e nas relações entre esfera privada e esfera pública, por outro, sofreram radicais reformulações a partir de 1990, em grande parte pelo reconhecimento da emergência, por diferenciação (Ausdifferenzierung), de uma economia controlada pelo mercado. Isso, como veremos, terá grandes consequências para a teoria do autor, tanto na revisão de teses de 1961 quanto na formulação da noção de democracia deliberativa. Antes, Habermas estava interessado em analisar o potencial de autorregulação da esfera pública e suas repercussões no Estado de Direito em suas análises da societalização do Estado e da estatização da sociedade. Habermas reconhece diversas fraquezas neste seu argumento. ${ }^{449}$

Em suas análises, Habermas considerava a sociedade civil (bürgerliche Gesellschaft) como sendo uma esfera completamente privada e contraposta à autoridade pública ou governamental, incluindo tanto a economia quanto a esfera íntima e propriamente civil. Contudo, o autor abandona a análise de caráter holístico - com suas "fraquezas" de pretensões de totalidade - e assevera que "uma sociedade diferenciada funcionalmente não pode ser analisada de forma adequada por conceitos holísticos de sociedade". A queda do socialismo de Estado ajudaria a confirmar que "um sistema econômico moderno e regulado por mercado não pode ser alterado ou desligado conforme se queira seja por meio de mecanismos monetários ou envolvendo poder administrativo e tomadas de decisões democráticas sem que sua capacidade de desempenho seja ameaçada." Ademais, as experiências contemporâneas com um Estado de bem-Estar levado aos seus limites, segundo Habermas, "teriam nos sensibilizado para os fenômenos da burocratização e juridificação (Verrechtlichung ${ }^{450}$ )". Esses dois "efeitos patológicos" seriam resultado da intervenção do Estado em esferas de atividade estruturadas de uma maneira tal que torna o modo jurídico administrativo de regulação inapropriado". ${ }^{451}$

\footnotetext{
${ }^{449}$ HABERMAS, 1990, pp.23-24

$450 \mathrm{Na}$ versão em Inglês [citada na bibliografia ao lado da original], "Verrechtlichung" [Bürokratisierungs- und Verrechtlichungsphänomene] é traduzido como “intrusive legalism”. (p.435). O termo "juridificação" é traduzido cf. NEVES, 2006, p. 108-209, onde Neves relatar ser a "juridificação" uma forma de colonização do mundo da vida pelos sistemas. Para uma discussão sobre o debate da "juridificação versus a desjuridificação", a partir do qual se debate a expansão e especialização do direito, ver pp. 229 e ss.

${ }^{451}$ HABERMAS, 1990, pp. 26-27.
} 
Outra revisão realizada pelo autor em 1990 é a de sua tese sobre o comportamento do público de massas como clientes. Em 1961 Habermas trabalhou com a oposição de um princípio crítico de publicidade em oposição à publicidade (opinião nãa-pública) com a noção de uma esfera pública infiltrada pela mídia em massa. Apesar dessa posição ter sido considerada muito simplista, como veremos, Habermas não deixa de afirmar que com a inserção dos meios eletrônicos da mídia de massa, um aumento da relevância da propaganda e do entretenimento e o colapso da lógica liberal de vida associativa confirmaram algumas das tendências que o autor analisou em 1961, em uma arena influenciada pela mídia eletrônica com propósitos de manipulação, que tornou a esfera pública infiltrada por poder. A "batalha”, aqui, não é apenas por influência, mas pelo controle de fluxos comunicativos que afetam o comportamento. A distinção apresentada por Habermas em 1961 entre processos comunicativos críticos, autorregulados, interligados horizontalmente, de caráter inclusivo que se assemelha ao comunicativo, por um lado, e funções manipulativas que se dirigem à manipulação de consumidores, eleitores e clientes, por outro, é abandonada. Isso pois, ainda que Habermas continue com a descrição ampla da "mudança estrutural da esfera pública em suas linhas gerais", sua análise do comportamento público é rejeitada. Isso, não apenas devido ao fato de ter sido Habermas muito influenciado pela teoria da cultura de massa de T. Adorno, de não haverem estudos e problemas vinculados à televisão e influência da mídia na época, mas principalmente, do ponto de vista teórico, por faltar-lhe o conceito de "cultura política", importante para seus desenvolvimentos teóricos após 1990. Habermas argumenta ter sido pessimista, e que seu "diagnóstico unilinear de um desenvolvimento de um público politicamente ativo para um público retraído para uma privacidade deletéria - ou seja, um movimento de públicos debatedores de cultura para públicos consumidores de cultura - é muito simplista". O autor afirma que o motivo para isso era que, na época, ele era muito pessimista em relação aos "poderes de resistência" especialmente em relação ao "potencial crítico de um público de massas pluralístico e internamente diferenciado que, aos poucos, começava a se desvencilhar dos limites de classe". ${ }^{452}$

A última revisão que o autor realiza em sua "teoria da mudança estrutural da esfera pública”, antes de entrar nas consequências das mudanças teóricas que o desenvolvimento de seu pensamento traz para o conceito, implica rever algumas das considerações de idealização de um tipo histórico de esfera pública e enfrentar as questões de como o

${ }^{452}$ HABERMAS, 1990 , pp. 28-30 
princípio da esfera pública política pode ser concretizado em democracias de massa em sociedades complexas.

No último capítulo de 1961, Habermas tenta juntar o diagnóstico da decadência e quebra da esfera pública liberal com o aspecto normativo de uma visão radical da democracia que busca tomar em seu favor a imbricação entre Estado e sociedade. Ainda que ele tenha desenvolvido dois conceitos de opinião pública que eram conflitantes entre si, isso não teria sido suficiente para distinguir processos de comunicação pública genuína daqueles processos comunicativos subvertidos pelo poder. Em 1961, o autor afirma que não conseguia vislumbrar "nenhum outro veículo de publicidade crítica que não as associações de interesse e os partidos políticos, ambos democratizados internamente". Tal conclusão era derivada do reconhecimento de uma tendência para uma sociedade organizada, na qual não mais indivíduos, mas coletividades organizadas em uma esfera pública policêntrica competiam pelo consentimento de massas passivas para adquirir um balanço de poder entre elas. Habermas esta aqui demonstrando suas críticas ao chamado "pluralismo de interesses irreconciliáveis", o qual associa com a teoria liberal da política. Do ponto de vista normativo, o pluralismo estava preparado para admitir a opinião pública como uma restrição imposta ao poder, mas, de forma alguma, elas consideravam-na como um meio para o potencial de racionalização do poder. ${ }^{453}$

\subsubsection{O modelo das "barragens democráticas" e do "cerceamento" da administração}

Ainda que tais revisões tenham sido feitas, Habermas continua acreditando que as democracias de massa e os Estados de Bem-Estar social apenas podem satisfazer suas funções políticas se seguirem o mandato da esfera pública. A intenção é, ainda, demonstrar como é possível em nosso tipo de sociedade que o público coloque em movimento um processo crítico de comunicação pública. Isso implica trazer contribuições de uma teoria da democracia e resolver o problema do surgimento de um interesse geral em um cenário de pluralismo. Vimos seu afastamento das bases teóricas de crítica da ideologia e da idealização de um tipo histórico de esfera pública (a burguesa). ${ }^{454}$ Habermas afirma, então,

\footnotetext{
453 HABERMAS, 1990, pp. 31-32

${ }^{454}$ Para o autor, quando os ideais burgueses são levados em conta e a razão se torna cínica, a "crítica ideológica se torna estéril”.
} 
que seria possível levar a crítica da sociedade para um nível mais profundo, trazendo a "teoria da ação comunicativa" para o primeiro plano, uma vez que ela traria à luz o potencial racional intrínseco às práticas cotidianas. Ao fazer isso, a teoria abre caminho para uma ciência social que proceda reconstrutivamente e possa identificar o espectro de processos de racionalização societal e cultural de forma ampla e, portanto, encontrá-los, inclusive, antes do marco da modernidade. O que Habermas quer dizer com isso é que, com sua teoria abrangente, ele pode buscar potenciais normativos que não mais sejam restritos à formação de uma esfera pública específica de uma época. ${ }^{455}$

Com isso, temos uma mudança muito importante na teoria habermasiana. As implicações normativas não são mais retiradas de fenômenos históricos ou da "esfera pública burguesa", mas de questões teóricas vinculadas pelo autor. Aqui é o enquadramento teórico de Habermas que apresenta as grandes linhas explicativas. Com isso, o autor realiza um salto de abstração incorporando a teoria da sociedade e sua teoria normativa a ela vinculada para redescrever a esfera pública. Dessa forma, a partir desse ganho de abstração, nos moldes que vimos anteriormente, Habermas apresenta uma teoria que lida com questões de uma sociedade complexa diferenciada funcionalmente, o que nos dá a possibilidade de discutir suas conclusões com aquelas de Niklas Luhmann.

Voltando ao prefácio de 1990, agora com essas considerações em mente, foi possível notar que Habermas sentiu a necessidade de trazer suas considerações sobre a esfera pública para o contexto de sua teoria ampla. O autor afirma que a presunção de que a sociedade como um todo poderia ser concebida como uma associação ampla que "dirija a si própria via os meios do direito e do poder político se tornou inteiramente implausível tendo em vista o alto nível de complexidade das sociedades funcionalmente diferenciadas". A influência de Luhmann, aqui, é clara. Isso levou Habermas a admitir diferença de um âmbito separado da manutenção de fronteiras sistêmicas (o mundo da vida) já em 1973 com a referida obra e, com ela, fazer surgir o modelo geral de sua "Teoria da Ação comunicativa" (1981) com seu conceito bipartido (zweistufige Konzept) da sociedade como mundo da vida e sistema. E assevera que as implicações para o seu conceito de sociedade foram consideráveis.

$\mathrm{Na}$ esteira dessas considerações, Habermas passou a considerar tanto o Estado quanto a economia como campos de ação sistemicamente integrados que, portanto, não poderiam ser transformados democraticamente "por dentro", ou seja, seria impossível que

${ }^{455}$ HABERMAS, 1990 , p. 34 
seu modo de operação fosse alterado para um modo "político" sem danificar suas lógicas sistêmicas próprias e capacidade de funcionamento. Habermas, então, apresenta em uma passagem central para seu conceito de esfera pública: “(...) a democratização radical agora objetiva uma mudança de forças dentro de uma 'separação de poderes' que ela mesma tem de ser mantida em princípio. O novo equilíbrio a ser buscado não é um equilíbrio entre poderes do Estado, mas entre diferentes formas de integração societal. O objetivo não é a superação (Aufhebung) do sistema econômico e do sistema burocrático de dominação, ambos com vidas próprias, mas antes erigir uma barragem democrática (die demokratische Eindämung $)^{456}$ contra a invasão colonizadora de imperativos sistêmicos em áreas do mundo da vida". Desse modo, uma mudança no sentido radical democrático no processo de legitimação se guia por um novo equilíbrio das forças de integração societal de modo que o poder social integrativo da solidariedade (a força produtiva de comunicação) possa prevalecer sobre os poderes das duas outras formas de controle, a saber, o dinheiro e o poder administrativo, e, com isso, afirmar as demandas de validade (Geltung) orientadas do mundo da vida". 457

Habermas argumenta que o poder social integrativo da ação comunicativa tem seu lugar nas formas de vida (Lebensformen) e mundos da vida (Lebenswelten) interconectados com tradições e interesses da esfera da "eticidade" (Späre der "Sittlichkeit"). Essas energias comunicativas geradoras de solidariedade, contudo, não são carregadas para dentro de procedimentos democráticos, pois não há um âmbito homogêneo de convicções compartilhadas nem de interesse de classe. Por esse motivo, Habermas desenvolve suas noções de racionalidade comunicativa em um contexto intersubjetivo. Assim, a "esfera pública política" é o conceito adequado que denota todas aquelas condições de comunicação sob as quais pode surgir uma forma discursiva da formação de opinião e vontade por parte de um público composto por cidadãos do Estado. É por isso que ele é apropriado como o conceito fundamental de uma "teoria da democracia cujo intuito é normativo". Neste sentido, sua versão da democracia deliberativa busca justificação nos termos e condições pelos quais a associação procede por meio da argumentação pública e pelo raciocínio público entre cidadãos iguais. Os cidadãos dividem o cometimento com a resolução de problemas de escolha coletiva por meio de raciocínio público e consideram

${ }^{456}$ A versão em inglês fala de "democratic dam" (p.444). Poderíamos também falar em "represas democráticas".

${ }^{457}$ HABERMAS, 1990, p. 36. Ênfases adicionadas. 
suas instituições fundamentais como legitimas na medida em que elas estabelecem um enquadramento para deliberação pública livre. Assim, Habermas afirma que o conceito de democracia deliberativa "confia" (vertraut auf) na mobilização política e na força de produção comunicativa. ${ }^{458}$

A questão frente à qual Habermas se coloca é demonstrar como questões sociais capazes de gerar conflito podem ser abertas para a regulação racional, ou seja, regulação do interesse comum de todos os envolvidos. Neste sentido, a teoria postula que o engajamento na argumentação pública é a melhor meio para se obter tal formação racional de vontade. Como vimos, Habermas sustenta que sua teoria do discurso fornece elementos para a universalização de princípios e axiomas morais. Sua abordagem discursiva enxerga a troca de argumentos como sendo o procedimento mais adequado para resolver questões morais e práticas. Isso não se limita em apenas derivar princípios gerais de moralidade de precondições pragmáticas indispensáveis de todos os debates racionais, mas também por ancorar a validade de normas "na possibilidade de um acordo (Zustimung) racionalmente fundamentado por parte de todos aqueles que poderiam ser afetados". Habermas vincula as questões políticas a questões morais e afirma que a teoria política deve perguntar pela “institucionalização de práticas do debate público racional”. Essa ligação entre questões políticas (que lidam com questões empíricas) e questões morais serve de argumento para afirmar que a teoria do discurso abre a possibilidade de "ligar considerações normativas a considerações empíricas e sociológicas. No âmbito dessas analises, e principalmente no que toca à esfera pública, a abordagem da teoria do discurso teria a "vantagem de ser capaz de especificar as precondições da comunicação que devem ser satisfeitas a nas várias formas de debates racionais (...) se o seus resultados puderem ser presumidos como racionais". 459

No que toca à esfera pública, a questão que resta ser abordada é saber como seria plausível ocorrer tais elementos normativos de uma formação discursiva de opinião em democracias de massa e no contexto do Estado de Bem Estar. A questão se volta para o problema de conseguir extrair normas generalizáveis que transcendam interesses particulares. Se no jusnaturalismo isso era justificado pela coerção estatal e pela teoria liberal (de Kant, principalmente), pelo controle moral do poder pelo império da lei; Habermas sugere levar a questão mais longe ao postular que, para haver legitimidade, deve

\footnotetext{
${ }^{458}$ HABERMAS, 1990 , p. 37-39.

${ }^{459}$ HABERMAS, 1990, pp. 39-41. Ênfases adicionadas.
} 
haver geração e aplicação de programas legislativos dentro de parâmetros do debate racional. Com isso, a meta é institucionalização de procedimentos jurídicos que garantam a satisfação das precondições de comunicação necessárias para debates e negociações livres e justas. Novamente, o ponto central é que essas precondições ideais demandam a completa inclusão de todos aqueles afetados, equidade entre eles, interação livre e fácil sem restrição de tópicos, etc. ${ }^{460}$

Com esse princípio normativo discursivo, além da possibilidade de se testar a legitimidade de instituições existentes, é possível introduzir novas instituições contrárias à tendência da transformação de cidadãos em clientes. Para isso, seria necessário também estudar os fatores que condicionam os cidadãos a uma mentalidade de seguidores apolíticos, que os previna de refletir e os faça seguir apenas seus interesses imediatos; ou seja, um estudo dos mecanismos que "alienam cidadãos do processo político em democracias constituídas como Estados de bem-estar".

Chegamos, enfim, ao momento central do argumento. Habermas não circunscreve o conteúdo normativo de seu conceito de democracia apenas ao âmbito institucional. Muito pelo contrário, as instituições e a formação de opinião “corporativamente organizada" só atingem esse objetivo se permanecerem permeáveis aos valores, tópicos, contribuições e argumentos que flutuam livremente nas comunicações de seu entorno (umgebenden politischen Kommunikation). Isso deve ser facilitado pela Constituição, mas não organizado por ela. $\mathrm{O}$ que Habermas tem em mente é uma inter-relação entre "a formação política de vontade constitucionalmente instituída e fluxos espontâneos de comunicação não-subvertidas pelo poder que ocorrem dentro de uma esfera pública que não é orientada para a tomada de decisão, mas pela descoberta e pela resolução de problemas, sendo, neste sentido, não-organizada". E arremata: "Se ainda há uma aplicação realista da ideia de soberania do povo em sociedades altamente complexas, ela é indissociável de entendimentos concretos que tomam forma em membros de uma sociedade que tomam decisões coletivas conjuntamente, com participação e presença física”. ${ }^{461}$

Habermas desenvolve, então, um conceito "procedimental" de soberania popular, pautado nas formas demandantes de comunicação "sem sujeito" que regulam o fluxo de formação de opinião política e as legitimam com presunção de racionalidade prática. Essa "soberania popular tornada em um fluxo de comunicação" vem à tona no poder de

\footnotetext{
${ }^{460}$ HABERMAS, 1990 , p. 41

${ }^{461}$ HABERMAS, 1990, p. 43
} 
discursos públicos que revelam tópicos de relevância para a sociedade, interpretam valores, contribuem para a resolução de problemas, e geram "boas razões" para a política. Com efeito, Habermas afirma não desconhecer que estas opiniões devem tomar forma de decisões democráticas por órgãos institucionais tomadores de decisão, mas afirma que "os discursos não governam". Isso implica, mais uma vez, ressaltar que o poder comunicativo não pode substituir a administração, mas apenas influenciá-la. Ele o faz pela "retirada de legitimação". Em suma, o poder comunicativo, não podendo substituir a lógica interna das burocracias, “impacta sua lógica 'pelo modo do sitiamento' ('in modus der Belagerung')”; ou na forma de um "cerco". ${ }^{462}$ Esse é o "caráter defensivo" do modelo habermasiano de esfera pública, pois visa a "cercar" o poder administrativo e "sitiá-lo", atuando pela retirada de legitimidade.

Por fim, cabe tratar de um tema importante para a abordagem habermasiana sobre a esfera pública: sua "redescoberta da sociedade civil" e a importância atribuída à "cultura política" em suas análises. Habermas afirma que, para compreender a formação de opinião em esferas públicas, é necessário compreender a tendência racionalização do mundo da vida. Isso, pois, em suas palavras, “uma esfera pública que funciona politicamente requer mais do que garantias institucionais do Estado Constitucional; ela também precisa do suporte (Entgegenkommen $)^{463}$ de tradições culturais e de padrões de socialização; de uma cultura política de um povo acostumado à liberdade". Daí sua fala de que a rubrica atual da questão da esfera pública pode ser pensada pela "redescoberta da sociedade civil". Para isso, não bastaria apenas "a referência global do espírito de 'suporte' de mundos da vida diferenciados (ausdifferenzierter Lebenswelten) de seu potencial para a reflexão crítica". Habermas pretende deixar estes termos mais concretos com a referência a uma "cultura política liberal" enraizada em motivos e orientações valorativas que provê o solo para comunicações públicas espontâneas. ${ }^{464}$

Para compreender essa questão, e vinculá-la com "categorias sociológicas", Habermas redescreve a chamada "vida associativa" pelo conceito de sociedade civil Zivilgesellschaft. Aqui Habermas apresenta uma diferença entre dois termos que tanto em inglês quanto em português são vertidos da mesma forma, ou seja, como "sociedade civil": Zivilgesellschaft e bürgerliche Gesellschaft ou societas civilis. A diferença consiste em

\footnotetext{
${ }^{462}$ HABERMAS, 1990 p. 44. A tradução em inglês fala em “in a siegelike manner".

${ }^{463} \mathrm{Na}$ tradução para o inglês fala-se de "supportive spirit" (p.453)

${ }^{464}$ HABERMAS, 1990, p. 45
} 
notar que o conceito "redescoberto" de sociedade civil (Zivilgesellschaft) não mais inclui a esfera da economia, do trabalho e do capital e, portanto, se difere da "societas civilis" burguesa. Habermas argumenta que o "núcleo institucional da 'sociedade civil' (Zivilgesellschaft) se constitui de uniões voluntárias fora do âmbito do Estado e da economia e vão (para dar alguns exemplos sem ordem predeterminada) desde igrejas, associações culturais, e academias, a passam por mídias independentes, associações culturais, sociedades de debate, grupos de cidadãos engajados, (...) e vão até associações ocupacionais, partidos políticos, sindicatos laborais e "instituições alternativas". ${ }^{465}$

Essas associações "de formação de opinião" se manteriam em oposição aos sistemas, se opondo ao Estado e, neste sentido, impactariam a administração sem se fundirem com o Estado. Por isso elas se seriam distintas de partidos políticos, por exemplo. Esse impacto seria exercido diretamente na comunicação pública ou ao "advogar" projetos alternativos à "sabedoria tradicional", mesmo porque "o caráter programático de suas atividades pode estabelecer exemplos por meio dos quais elas contribuem implicitamente para a discussão pública." 466

Habermas relaciona a redescoberta da sociedade civil às reações à aniquilação totalitária da esfera pública política em regimes totalitários. Esse "exemplo histórico" que seria quase um experimento "social em ampla escala", principalmente no caso das repúblicas pós-soviéticas no leste europeu, teria demonstrado para o autor que "esferas públicas autônomas" poderiam ser construídas - e ocupar um lugar proeminente - na sociedade civil. Isso, pois os precursores desse movimento teriam sido associações voluntárias. Nas sociedades de tipo ocidental, contudo, essas associações são estabelecidas dentro do enquadramento institucional do Estado Democrático Constitucional, com problemáticas próprias, das quais Habermas destaca a questão de saber em que medida uma esfera pública dominada pela mídia de massa provê uma chance realística para que os membros da sociedade civil possam filtrar influências dos poderes econômico e político de forma crítica e inovadora. ${ }^{467}$

Ao final, Habermas altera seu posicionamento pessimista em relação aos efeitos da mídia em relação à esfera pública política. $\mathrm{O}$ autor discorre sobre o eventual "efeito infeccioso" de transmissão, principalmente pela televisão e pela transmissão de imagens de

\footnotetext{
${ }^{465}$ HABERMAS, 1990, pp. 45-46

${ }^{466}$ HABERMAS, 1990, p. 46

${ }^{467}$ HABERMAS, 1990, pp. 47-48
} 
massas mobilizadas. Habermas aponta para "efeitos contraditórios" da mídia de massa. Ainda que a mídia tenha efeitos de desdiferenciação (Entdifferenzierung) e desestruturação no mundo da vida provocados pela omnipresença eletrônica de eventos e que isso afete a auto percepção da social; esse processo caminha junto com uma plurificação de formas de vida, de remoção de barreiras e de individualização. Enfim, Habermas afirma estar convencido da existência de "uma natureza ambivalente do potencial democrático de uma esfera pública cuja infraestrutura é marcada pelas restrições crescentemente seletivas impostas pelos meios de comunicação de massa". Ao final, Habermas afirma que se fosse redescrever seu trabalho de 1961 sobre a esfera pública, teria sido menos pessimista. ${ }^{468}$.

\subsection{A esfera pública pensada como fluxo comunicativo II: a validade e a facticidade da esfera pública (1992)}

\subsubsection{Esfera pública em termos normativos: democracia deliberativa e soberania Popular "procedimental"}

A formulação última e mais desenvolvida de Habermas sobre o conceito de esfera pública foi trabalhada com mais rigor em 1992 em sua obra Faktizität und Geltung. Beiträge zur Diskursetheorie des Rechts und des demokratischen Rechtsstaats (publicado em português como "Direito e Democracia: entre facticidade e validade"). Nela a noção de esfera pública é refinada a partir de um modelo de circulação e contra circulação do poder. O autor busca enfrentar as teorias sociológicas que seriam "cínicas" frente à plausibilidade de uma esfera pública tal como ele quer analisar. Ao buscar um chão sociológico mais concreto para seus conceitos normativos, por assim dizer, Habermas desenvolve análises sobre as condições da esfera pública na sociedade complexa e busca adequar seu conceito de democracia deliberativa para desenvolver um modelo ainda mais ousado de esfera pública política no contexto de Estados Constitucionais de Direito. De maneira relevante para essa dissertação, Habermas apresenta diversas críticas ao modelo da teoria dos sistemas e seu enfrentamento prepara o debate para o próximo capítulo desse estudo.

${ }^{468}$ HABERMAS, 1990, pp. 49-50. Em sua obra de 1992, que analisaremos abaixo, Habermas retoma a questão da mídia, e, ao mesmo tempo em que ele reforça sua análise de seus "condicionamentos internos" em "estratégias da elaboração da informação" orientadas por tecnicidades e pela mistura entre "informação e entretenimento" que resultariam na despolitização pública, o autor afirma "serem claras" as tendências de reação frente a ela, com, por exemplo, códigos de conduta jornalística que expressariam a intenção de serem os meios de comunicação em massa "mandatários de um público esclarecido", "devendo imitar a justiça" e se legitimar perante esse público. (HABERMAS, 2003c, pp. 110-112). 
No apêndice denominado "Soberania popular como procedimento" (originalmente publicado em 1988), ${ }^{469}$ Habermas se contrapõe, novamente, às teorias "anti-iluministas" pós-modernas e aos pós-estruturalistas tentando trabalhar uma possibilidade de se recuperar a "força normativa da Revolução Francesa". Para isso, ele coloca a centralidade do Estado Democrático de Direito como o único candidato capaz de afirmar sua atualidade, uma vez a que democracia e os direitos formariam "o núcleo universalista do Estado constitucional". ${ }^{470}$ Para Habermas, a "consciência revolucionária é o berço de uma nova mentalidade" e dá espaço para um "novo conceito" da prática política, de um "novo começo" e de uma "nova" ideia de legitimidade. A de fundamentação da política pelo discurso racional se daria neste contexto de "novo começo" e "abertura para o futuro" no contexto da modernidade. Esta consciência revolucionária seria relacionada com a noção de "vida digna do homem" e, principalmente, com o princípio de autodeterminação e de vontade soberana do povo.

Contudo, como recuperar este ideal em sociedades pluralistas e extremamente complexas? Essa questão tão criticada em teorias republicanas baseadas em questões de "virtude popular" é enfrentada por Habermas no contexto de "sociedades complexas diferenciadas" pelo conceito já explorado por nós de soberania procedimental do povo na democracia deliberativa. Cabe, agora, uma análise mais detida desse argumento.

Depois de trabalhar as tensões entre igualdade e liberdade e entre socialismo e liberalismo - além da variante do anarquismo -, Habermas reconhece que uma variante importante em todas elas era a defesa contra "a expansão do Estado como poder administrativo de um sistema que se propaga a si mesmo e adquire autonomia em relação às fontes democráticas de sua legitimação".

Como vimos, Habermas já considera impossível - como queriam os anarquistas - a existência de uma sociedade moderna completamente integrada a partir de associações, prescindindo o mercado e o poder administrativo. $\mathrm{O}$ autor insiste, entretanto, na possibilidade de contraposição deste contexto sistêmico com base na sociedade civil. Com efeito, Habermas sustenta que a construção de uma esfera pública não organizada e não programada para tomar decisões poderia vir no sentido de se responder às falhas do argumento anarquista sem deixar de reconhecer a necessidade de sistemas administrativo e político em sociedades modernas complexas. Então, Habermas pensa em um a esfera

\footnotetext{
${ }^{469}$ HABERMAS, 2003c, pp. 249-278

${ }^{470}$ HABERMAS, 2003c, p. 252
} 
pública que funcione como conceito normativo, pelo qual associações livres formam os pontos de uma rede comunicacional nascida do entrelaçamento de esferas públicas autônomas.

Disso retira-se a consequência de que a noção de soberania do povo se torna dessubstancializada. Quando tratadas intersubjetivamente como formas de comunicação destituídas de sujeito, a soberania popular pode retornar como um conceito analítico. A racionalização do mundo da vida pelas esferas públicas informais, portanto, gera influxos na esfera pública formal sistêmica de produção de decisões vinculantes por meio de procedimentos democráticos. $^{471}$

Habermas, no capítulo "Política deliberativa - um conceito procedimental de democracia" $" 772$ - ao tratar de sua concepção de democracia deliberativa como uma superação de liberalismo e do republicanismo ${ }^{473}$, argumenta que a questão da formação de vontade não mais se dá por meio de uma "sobrecarga normativa de cidadãos virtuosos", mas antes pela deliberação. Ele analisa a questão de que o Estado democrático de Direito não pode ser descrito adequadamente sem se levar em conta a dimensão da validade do direito, da "força legitimadora da gênese democrática do direito" nem a "necessidade de legitimação". 474

${ }^{471}$ HABERMAS, 2003c, p 275: "Vimos que os procedimentos democráticos introduzidos no Estado de direito poderiam provocar resultados racionais na mentida em que a formação de opinião entre as corporações parlamentares continuasse sensível aos resultados de uma formação informal da opinião resultante de esferas públicas autônomas e que se forma a sua volta". Aqui, o conceito de esfera pública não é realista, mas poderia "ser preenchido no momento em que surgissem associações formadoras de opinião, capazes de cristalizar ao seu redor esferas públicas autônomas que liberam, modificam e filtram criticamente o leque de temas, valores e argumentos canalizados através dos meios de comunicação de massa, das associações e dos partidos"

${ }^{472}$ HABERMAS, 2003c, pp. 9-56

473 Para uma análise de como a teoria deliberativa seria distinta tanto do liberalismo quando do republicanismo dentro da teoria da democracia, ver o conhecido artigo "Três modelos normativos de democracia" (HABERMAS, 2007, pp. 277-292). Jürgen Habermas desenvolve uma teoria da ação comunicativa que implica a possibilidade de um "agir racional orientado para o entendimento". Neste sentido, em um processo de argumentação racional em condições ideais; haveria a possibilidade de se chegar ao consenso pro meio de uma argumentação discursiva que chegasse ao argumento moralmente preferível e mais sustentável. A diferença deste autor é que ele introduziu a importante ferramenta teórico-epistemológica da intersubjetividade. Resta notar, apenas, que no texto em questão, Habermas aponta o modelo liberal e republicano de democracia. O liberal teria o sentido de programar o Estado para ir ao encontro de fim privados do mercado; ligando o aparato da administração a este fim (sistema econômico e político). Por sua vez, a concepção republicana concebe a política como um relação de solidariedade pelo bem comum, concebendo um cidadão ativo e político. As vantagens de sua teoria deliberativa se dariam no sentido de extirpar o caráter utópico do republicanismo em derivar seu modelo de virtudes de cidadãos. A saída da intersubjetividade da ação comunicativa resolveria este problema para Habermas. É pelo processo ideal de deliberação que Habermas pode oferecer seu critério de democracia.

${ }^{474}$ Ver também, nesse sentido, HABERMAS, 2003b, esp. pp. 48 e ss e pp. 116-139 
Assim, após rejeitar as dimensões empiristas da legitimidade, Habermas discute sua teoria do processo democrático a partir do modelo pelo qual a teoria do discurso analisa o procedimento "ideal" para a deliberação e a tomada de decisão. Habermas está interessado em realizar um "influxo normativo" (ou uma compreensão de política que permita pensar este influxo) direcionado contra o poder expansivo da administração do Estado. Esta compreensão, portanto, não concebe o Estado como "representante da sociedade" e permite que o fluxo comunicacional que serpenteia na formação pública da vontade passe a influenciar o poder administrativo. Aqui, a esfera pública forma uma "rede ampla de sensores" que reagem à pressão de situações problemáticas da sociedade.

O mais interessante notar aqui, é que com seu conceito de democracia deliberativa em processos racionais discursivos orientados ao consenso chegariam a resultados legítimos se os procedimentos constitucionais seguissem, simultaneamente, pressupostos de oportunidade de participação e não-existência de coação. Aqui, sua noção de direito é central, ${ }^{475}$ uma vez que, para Habermas, a "autodeterminação" é um valor frente aos imperativos sistêmicos. Com efeito, o influxo de poder comunicativo no sistema político não pode ser feito diretamente. Para isso, seria necessário um mecanismo que "traduza" a linguagem não-sistemica em linguagem sistêmica. Esse é o papel do Direito, que é ambiguamente fundamentado no mundo da vida (na autonomia discursiva da produção de normas pelos próprios sujeitos afetados) e no sistema administrativo. Ora, argumenta Habermas, se os procedimentos forem feitos de maneira a cumprir as condições da teoria comunicativa, o que importa serão seus resultados. Mais importante ainda, procedimentos são elementos possíveis de serem lidos pelo sistema, o que possibilitaria sua absorção pelo sistema (político) administrativo. ${ }^{476}$

\subsubsection{A facticidade da esfera pública: o papel da sociedade civil e da cultura política}

Habermas, então, enfrenta as objeções "sociológicas" de sua teoria da esfera pública com maior rigor e desenvolve seu modelo final no capítulo intitulado "O papel da sociedade civil e da esfera pública política", onde o autor nuança e refina as bases sociológicas de seu modelo de esfera pública, lidando com problemas de "facticidade", na

\footnotetext{
${ }^{475}$ HABERMAS, 2003c, p. 23

${ }^{476}$ Cf. HABERMAS, 2003c, pp. 9-56
} 
tentativa de vincular teoria normativa e teoria social abrangente. Com isso, após considerar ter justificado seus aportes normativos, Habermas enfrenta teorias sociológicas para lidar com questões de plausibilidade da possibilidade de se concretização de uma esfera pública ativa, ligada a um mundo da vida racionalizado que seja capaz de fornecer legitimação no âmbito dos Estados Constitucionais de Direito em sociedades complexas funcionalmente diferenciadas e plurais do ponto de vista moral. Para isso, o autor tem que desenvolver um modelo "centrípeto" do poder que possibilite que o poder comunicativo se contraponha ao poder burocrático-administrativo e sustente que isso seja plausível ou "factível".

Habermas ataca, então, a sociologia "sóbria, quiçá cínica" do processo político que teria dissolvido o conteúdo idealista das teorias normativas, especialmente das teorias da democracia. Essa linha sociológica tenderia ao diagnóstico de reconhecer a autonomia do poder administrativo frente à sociedade e, por valer-se de "conceitos empiricistas" de poder, subestimaria a possibilidade de se tratar do poder comunicativo. Com conceitos empiricistas de poder, estas teorias explicariam a circulação do poder por formas institucionais e por lógicas internas do funcionamento institucional, quando muito, por meio da teoria das elites ou o pluralismo de interesses de organizações (auto)interessadas. ${ }^{477}$

Habermas ataca o argumento da "autonomização" da administração (política) ${ }^{478}$ ao afirmar que, já após os anos 60, a avaliação do sistema administrativo deveria ser mais contida, tanto por não mais se poder considerar que os sistemas administrativos poderiam planejar a sociedade, que atuariam de forma mais "reativa" sem a capacidade de prever crises (déficit de operacionalidade ou de regulação, por assim dizer), quanto por necessitarem da busca por legitimação na opinião pública e na esfera pública para se legitimarem (déficit de legitimação). Neste cenário, os partidos "temem" a perda de legitimação "pelas vozes do protesto" e daqueles que não são eleitores. Habermas

\footnotetext{
${ }^{477}$ HABERMAS, 2003c, pp. 57-61
}

478 Até o momento utilizei a denominação de "sistema administrativo" cunhada por Habermas sem maiores esclarecimentos. Pode-se depreender que o conceito engloba o sistema político estritamente considerado, ou seja, institucional ou "formal", com o Estado, parlamento e suas instituições. Esse é o âmbito sistêmico de reprodução social que se pauta pelo medium "poder" - tal qual o sistema econômico ou da economia de mercado se reproduz pelo medium do "dinheiro". Note-se que Habermas subtrai o termo comum "político", visando, com isso, ressaltar o caráter sistêmico e auto-regulado do sistema administrativo para poder opor a ele o caráter "político" - normativamente carregado - da esfera pública autônoma com pretensões de autorregulação. 
arremata: "[d]éficits de legitimação e regulação favorecem uma espécie de incrementalismo muito próximo do quietismo". ${ }^{479}$

Habermas afirma que as teorias sociológicas "cínicas" se bifurcariam na teoria econômica da democracia (principalmente com John Elster), que não trataremos aqui, e a teoria dos sistemas (com base em Niklas Luhmann e em H Willke em sua obra Ironie des Staates). ${ }^{480}$ Para Habermas, a teoria dos sistemas eliminaria os traços normativos do modelos de análise da democracia e se limitaria essencialmente aos problemas de regulação de um sistema político declaro autônomo. Ambas realizariam uma "terapia do emagrecimento normativo" da democracia.

No tocante à teoria dos sistemas, Habermas afirma que ela teria abandonado o nível dos sujeitos - sejam eles encarados como indivíduos ou como coletividades - e trabalharia apenas com um conceito de sociedade como uma "rede de sistemas parciais autônomos" que se fecham uns em relação aos outros de modo que a "interação entre tais sistemas não depend[a] mais das intenções ou dos interesses de atores participantes", mas apenas de seis modos de operação próprios e determinados internamente. Para Habermas, por um lado, a teoria dos sistemas abandona um conceito sociedade hierárquico e centrado no Estado, mas, por outro, retorna à centralidade do Estado ao atribuir a "formação política da vontade e da opinião, dominada pela concorrência entre os partidos, a um público de cidadãos e de clientes incorporados ao sistema político, porém desligados das raízes que os prendem ao mundo da vida, isto é, a [sic] sociedade civil, a [sic] cultura política e a [sic] socialização". 481

Habermas se refere à noção luhmanniana de "contra circulação oficial do poder" entre administração, processo legislativo e público ${ }^{482}$ e um contexto no qual "a complexidade social faz com que os pesos se desloquem em favor de um flux "centrífugo", de tal sorte que a pergunta: 'como é possível, em tais circunstâncias, a responsabilidade

${ }^{479}$ HABERMAS, 2003c, p. 61

480 Habermas assevera: “A história dos princípios 'realistas' conduz, de um lado, a uma teoria econômica da democracia, que pretende nos ensinar algo sobre as características instrumentais da formação democrática da vontade; de outro lado, a uma teoria dos sistemas, que quer provar a impotêncica dessa formação. Ambos os princípios operam com conceitos de poder insensíveis à relevância empírica da constituição do poder do Estado de direito, porque não focalizam o nexo constitutivo que existe entre direito e poder político" (HABERMAS, 2003c, p. 65. Ênfase adicionada)

481 HABERMAS, 2003c, pp. 61-64. A tradução deveria ter utilizado a crase para o correto entendimento da sentença; raízes que os prendem ao mundo da vida, à sociedade civil, à cultura política e à socialização.

${ }^{482} \mathrm{O}$ modelo luhmanniano da circulação de poder no sistema político é apresentado no Capítulo 3 , infra. 
política?' perde o seu sentido". Portanto, a teoria dos sistemas teria expelido qualquer resquício de normatividade e se tornado insensível em relação aos freios normativos contidos no fluxo de poder regulado pelo Estado de direito. $\mathrm{O}$ autor reconhece que a teoria dos sistemas teria contribuído para apontar o diagnóstico do solapamento do processo democrático por imperativos sistêmico-funcionais, mas argumenta que ela seria incapaz de criar qualquer modelo novo de teoria da democracia ao tratar com o paradigma de sistemas fechados e autônomos. ${ }^{483}$ Habermas assevera que o "ganho realístico" dessa teoria teria um "problema colateral inquietante", pois o sistema político autorregulado por seus códigos e sem comunicação com os outros, em uma espécie de "autismo" do "encapsulamento autopoiético", seria incapaz de integrar a sociedade em seu todo. ${ }^{484}$

Habermas formula que a "teoria dos sistemas não é levada necessariamente a negar a existência dos fenômenos de um poder comunicativo gerado no interior do complexo parlamentar - nem de uma influência adquirida na esfera pública; contudo suas descrições desses fenômenos são de tal tipo que os desmascaram a fortiori como impotência do poder comunicativo. Nessa visão, o sistema político pode prescindir das fontes autônomas do direito legítimo, após a positivação completa deste último”. O sistema político fechado em si mesmo e independente é ligado ao sistema do direito do qual retira a garantia de legalidade e retira dele tudo o que precisa de legitimação. Habermas postula que "[e]ssa imagem luhmanniana de autolegitimação de uma política ancorada no aparelho do Estado começa a apresentar rachaduras a partir do momento em que o princípio da teoria do sistema é confrontado com a tarefa de 'pensar a teoria do Estado na perspectiva de uma sociedade eticamente responsável e responsável pela ética'", 485

Para desenvolver seu argumento em oposição a estas teorias "cínicas", principalmente à teoria dos sistemas, Habermas argumenta que a "integração de uma sociedade altamente complexa não se efetua através de um sistema paternalista que ignora

${ }^{483}$ HABERMAS, 2003c, p. 64. Sem pretender adiantar a discussão, nota-se que na introdução dessa dissertação argumentei que a teoria dos sistemas não poderia ser vista como uma teoria da democracia e não apresenta, mesmo, frutos neste sentido. Neste ponto, há que se concordar com Habermas, ainda que de forma restrita, uma vez que o autor postula essa problemática do ponto de vista de seus interesses normativos para a democracia, enquanto eu tentei demonstrar a questão de um ponto de vista metateórico e de construção (e objetivos) da teoria.

${ }^{484}$ HABERMAS, 2003c, p. 65

${ }^{485}$ HABERMAS, 2003c, p. 73. Veremos a questão da legitimidade do sistema político na teoria luhmanniana no capítulo seguinte, no qual apresentarei o argumento da "autolegitimação" do sistema político acoplado estruturalmente ao sistema jurídico por meio da Constituição (e pelos processos recíprocos de prestações mútuas da "legitimação pelo procedimento" e "positivação do direito") juntamente com a discussão da legitimidade como "fórmula de contingência" do sistema político para enfrentar esta questão levantada por Habermas. 
o poder comunicativo do público de cidadãos" e que sistemas fechados "não conseguem encontrar por si mesmos a linguagem comum necessária para a percepção e a articulação de medidas e aspectos relevantes para a sociedade como um todo". O argumento "sociológico" habermasiano é que, para haver isso, seria necessário valer-se da linguagem comum situada abaixo do limiar de diferenciação dos códigos especializados. Essa linguagem, afirma Habermas, circula em toda a sociedade, "sendo utilizada nas redes periféricas da esfera pública política e no complexo parlamentar para o tratamento de problemas que atingem a sociedade como um todo. Por essa razão, a política e o direito não podem ser entendidos como sistemas autopoieticamente fechados". Após realizar essa crítica, Habermas apresenta seu modelo, iniciando o argumento afirmando que o "sistema político, estruturado no Estado de direito, diferencia-se internamente em domínios do poder administrativo e comunicativo permanecendo-se aberto ao mundo da vida. Pois a formação institucionalizada da opinião e da vontade precisa abastecer-se nos contextos comunicacionais informais da esfera pública, nas associações e na esfera privada. Isso tudo porque o sistema de ação político está embutido em contextos do mundo da vida", o que implica, para o autor, que sociedades funcionalmente diferenciadas não se esgotam, de maneira nenhuma, numa variedade de sistemas auto-referenciais fechados. Nesse sentido, Habermas reforça a importância das realizações da "linguagem comum multifuncional" e sustenta que ela é o "medium do agir orientado pelo entendimento, através do qual o mundo da vida se reproduz e os próprios componentes do mundo da vida se entrelaçam entre si". 486

Desse modo, o conjunto do mundo da vida é compreendido como uma rede de ações comunicativas coordenadas legitimamente, abrangendo também coletividades, associações e organizações especializadas. Para Habermas, apenas alguns desses "sistemas de ação funcionalmente especializados" se tornam independentes em relação ao mundo da vida; ganhando códigos próprios, como na economia, por exemplo. Entretanto, o caso do direito é tido como especial, pois a regulação jurídica permitiria "a linguagem do direito" a

${ }^{486}$ HABERMAS, 2003c, p. 84-85. Habermas chega a falar que "em domínios altamente organizados, o sistema científico e educacional adquire um sentido próprio que eles opõem às intervenções diretas do Estado; esse sentido, porém, não deriva de um código próprio ou de um medium de regulação, análogo ao dinheiro, mas da lógica de seus questionamentos específicos". A rigor, como já vimos, a teoria dos sistemas não concebe apenas sistemas funcionais, como outros sistemas e comunicações sociais não organizadas sistemicamente, como a moral e a esfera pública, por exemplo. No caso do sistema científico, como vimos, Luhmann o encara como um sistema social com código próprio (verdade/falsidade) e com um meio de comunicação simbolicamente generalizado "tal como o dinheiro" é para a economia, a saber: o meio "verdade". Devemos ter em mente que, para Habermas, só existem dois sistemas, o econômico e o (burocrático) administrativo. 
revestir as comunicações do mundo da vida com formas também assumidas pelos códigos especializados dos sistemas de ação e vice versa: “"’[s]em esse transformador, a linguagem comum não poderia circular por toda a sociedade". 487 Essa é a formulação "sociológica" que permite a Habermas unir os âmbitos da validade (normativo) e o âmbito da facticidade (âmbito social) e cunhar sua formulação do direito, com caráter ambíguo entre sistema e mundo da vida, como transformador ou "tradutor" entre as linguagens ordinária e sistêmica para, assim, atribuir caráter normativo a um direito "legítimo" produzido pela democracia deliberativa, ou seja, que leve em conta as demandas de uma esfera pública ativa. Para reconhecer um âmbito "comunicativo", vinculado à autorregulação pelo direito, Habermas precisa desenvolver seu conceito de esfera pública, sem o qual o direito ficaria apenas no plano sistêmico administrativo.

Para isso, o autor desenvolve um modelo de circulação do poder político no Estado de direito que, de certa forma, se contrapõe ao modelo luhmanniano. Habermas, então, divide o sistema político em dois âmbitos. ${ }^{488}$ Seu núcleo ou centro seria formado pelos complexos institucionais da administração (incluindo o governo), pelo judiciário e pela formação democrática da opinião e da vontade (incluindo as corporações parlamentares, eleições políticas, concorrência entre os partidos, etc.). O complexo administrativo teria maior capacidade de ação, enquanto o parlamentar seria mais aberto para tematização de problemas sociais. Ainda assim, o centro do sistema, com suas "rotinas" teria dificuldade para inserir inovações e gerar alterações em seus procedimentos. Daí a necessidade de uma periferia interna - com instituições dotadas "de diferentes tipos de direitos e autoadministração ou de funções estatais delegadas. (...) (universidades, sistemas de seguros, representações de corporações, câmaras, associações beneficentes, fundações, etc.)" - e também de uma periferia externa, na qual Habermas desenvolve seu conceito de esfera pública. Nesta periferia externa, encontrar-se-iam "associações formadoras de opinião, especializadas em temas e contribuições e, em geral em exercer influência pública", fazendo parte da "infra-estrutura civil de uma esfera pública" que através de seus "fluxos comunicacionais diferenciados e interligados" forma o "verdadeiro contexto periférico". 489

A partir dessa distinção, o modelo de "eclusas" (ou “comportas") de Habermas ganha uma especificação teórica relevante, a saber, como o poder comunicativo

${ }^{487}$ HABERMAS, 2003c, p. 86

${ }^{488}$ Habermas é muito influenciado pela obra "Die Integration moderner Gesellschaft" de Bernhard Peters nesta divisão do sistema político e na descrição das "comportas"

${ }^{489}$ HABERMAS, 2003c, pp. 87-88 
"influenciaria" o "poder administrativo". Habermas incorpora a discussão da esfera pública que atravessa as comportas do sistema administrativo por um modelo de contracorrente de circulação do poder. Note-se que, aqui, não se trata mais de uma posição de mera autocontenção, do imperativo de se construir "barragens" contra a colonização do mundo da vida, mas de inverter o fluxo oficial do poder, rompendo com as comportas administrativas e influenciando o sistema administrativo. Neste sentido, o centro seria constituído por um sistema de comportas a ser atravessado por diversos processos, mas ele só poderia controlar a regulação e dinâmica desses processos até certo ponto. Disso se retira uma ideia de democracia que "traduz em termos sociológicos a teoria do discurso" pela qual os processos políticos de formação de vontade têm um status periférico. Em outras palavras, as decisões impositivas do sistema, para serem legítimas, "têm que ser reguladas por fluxos comunicacionais que partem da periferia e atravessam as comportas dos procedimentos próprios à democracia e ao Estado de direito". 490

O modelo não é, contudo, um modelo de total oposição ou incompatibilidade entre os dois fluxos ou dois modos de circulação do poder. Para Habermas, as comunicações "no sentido contrário" contribuem também para o "ciclo oficial”, reduzindo sua complexidade e apresentando possibilidades de mudanças nas rotinas e padrões estabelecidos dos tribunais e burocracias. Neste sentido, inclusive do ponto de vista operacional, seria decisivo que tais rotinas se mantivessem abertas aos "impulsos renovadores oriundos da periferia". 491

Portanto, a esfera pública vista por esse modelo contribuiria para a busca de soluções, principalmente em momentos de crise. Segundo o modelo, ao se crescer a atenção na esfera pública para situações de deslegitimação ou crise, são desencadeadas controvérsias e a pressão da esfera pública consegue "forçar um modo extraordinário de elaboração de problemas" que "atualiza a sensibilidade do Estado de Direito em relação às responsabilidades políticas reguladas juridicamente". Portanto, em processos "normais", em casos de conflitos estabelecidos, são os parlamentos e os tribunais que limitam o espaço de decisão de uma administração orientada para fins programáticos próprios.

Contudo, para Habermas, eles não dispõem da capacidade de "transformar casos em conflito" por terem pouca sensibilidade para problemas latentes e quase nenhuma iniciativa para uma elaboração dramática bem sucedida de novos problemas. Isso, contudo,

\footnotetext{
${ }^{490}$ HABERMAS, 2003c, pp. 88-89

${ }^{491}$ HABERMAS, 2003c, p. 89
} 
seria possível no âmbito da esfera pública quando ela, a partir da periferia do sistema político, fosse capaz de "farejar problemas" latentes de integração social formuláveis politicamente, “identificá-los, tematizá-los e introduzi-los no sistema político, passando pelas comportas do complexo parlamentar (ou dos tribunais), fazendo com que o modo rotineiro seja quebrado". Para que a periferia seja capaz de fazer isso, seria necessário que redes de comunicação pública não institucionalizadas possibilitassem processos de formação pública mais ou menos espontâneas. Habermas tem em mente esferas públicas capazes de ressonância que funcionem como um "sistema de alarme dotado de sensores na especializados, porém sensíveis no âmbito de toda a sociedade”.

Entretanto, para que elas possam ressoar ou "ecoar problemas políticos", elas dependeriam de uma ancoragem em associações da sociedade civil, de uma introdução em padrões liberais da socialização e da cultura política, enfim, de "um mundo da vida racionalizado". O autor argumenta que essa "espontaneidade social" não poderia ser criada ou regulada juridicamente (ainda que possam ser incentivadas), suas condições se encontrariam dentro de contextos do mundo da vida. É por esse argumento que Habermas reforça, mais uma vez, a importância da sociedade civil e da cultura política. ${ }^{492}$

Habermas chama a atenção, aqui, para a questão da formação de agenda, ressaltando a pergunta pelo "sujeito" que coloca os temas na ordem do dia. Seguindo sua teoria da democracia deliberativa e seu modelo de circulação e contra-circulação do poder, há três "caminhos que levam a temas novos e politicamente relevantes": no primeiro deles, no modelo de circulação oficial de poder, a iniciativa é do poder político-administrativo e as discussões são levadas a cabo em suas instituições. No segundo caso, a iniciativa é também desse sistema, mas seus agentes são obrigados a mobilizar a esfera pública e obter apoio do público. Só no terceiro caso é que iniciativa pertenceria à esfera pública e a atores fora do sistema político pela "utilização da esfera política mobilizada, isto é, pela opinião pública". Esse tipo de formação da agenda ("agenda setting”) se baseia no argumento de que seria "plausível assumir que os atores da sociedade civil, até agora negligenciados, podem tomar um papel ativo e pleno de consequências”, o que permitiria inverter a direção do fluxo convencional do poder. Essa possibilidade se daria, pois essa esfera pública ancorada em experiências do mundo da vida teria maior sensibilidade para novos problemas; lançados por "intelectuais, pessoas envolvidas, profissionais radicais,

${ }^{492}$ HABERMAS, 2003c, p. 90-91 
'advogados autoproclamados' etc. em um sentido centrípeto caminhando ao núcleo do poder administrativo. ${ }^{493}$

Após todo esse percurso, Habermas apresenta uma definição nuançada de esfera pública, distinguindo-a de instituições e organizações e descrevendo-a como "uma rede adequada para a comunicação de conteúdos, tomadas de posição e opiniões; nela os fluxos comunicacionais são filtrados e sintetizados a ponto de se condensarem em opiniões públicas enfeixadas em temas específicos. Do mesmo modo que o mundo da vida tomado globalmente, a esfera pública se reproduz através do agir comunicativo, implicando apenas o domínio de uma linguagem natural: ela está em sintonia com a compreensibilidade geral da prática comunicativa cotidiana”. Neste sentido, ela não se especializa na direção de nenhum sistema funcional e, por isso, "quando abrange questões politicamente relevantes, ela deixa ao cargo do sistema político a elaboração especializada. A esfera pública constitui principalmente uma estrutura comunicacional do agir orientado pelo entendimento a qual tem a ver com o espaço social gerado no agir comunicativo, não com as funções nem com os conteúdos da comunicação cotidiana". ${ }^{494}$

Este caráter "espacial" da esfera pública, entendido como substrato social plausível para ancorar o "agir comunicativo" permite a Habermas descrever a esfera pública também por meio de "metáforas arquitetônicas", uma vez que ele permitiria trazer essas condições de fala para o grande público em espaços como "foros", "palcos", “arenas”, etc. Contudo, aqui, Habermas tende a acentuar o papel da mídia em poder ampliar esses espaços de "fórum" para além do público fisicamente presente. ${ }^{495}$ Importante notar que, segundo Habermas, é possível haver uma "especialização" da esfera pública em diversas arenas. Isso, pois ela é encarada como uma "rede supercomplexa que se ramifica espacialmente num sem número de arenas internacionais, nacionais regionais, comunais e subculturais, que se sobrepõem umas às outras e se articula objetivamente de acordo com pontos de vistas funcionais, temas, círculos polítcos etc., assumindo a forma de esferas públicas mais ou menos especializadas, porém acessíveis a um público de leigos. ${ }^{496}$

${ }^{493}$ HABERMAS, 2003c, pp. 113-116

${ }^{494}$ HABERMAS, 2003c, p. 92-93. Isso, pois Habermas ressalta que o agir comunicativo depende de situações ideais de fala em um espaço compartilhado intersubjetivamente em que participantes assumem obrigações ilocucionárias.

${ }^{495}$ HABERMAS, 2003c, p. 93

${ }^{496}$ HABERMAS, 2003c, p. 107. Ênfase adicionada. 
No âmbito desses espaços, manifestações se transformam em temas e em "tomadas de posição pró ou contra em forma de opiniões focalizadas". É nesse momento que surge a “opinião pública”, que, para Habermas, não se confunde com somatório de opiniões pessoais, mas se caracteriza pela a elaboração "racional" de propostas e argumentos em um contexto de ampla circulação de mensagens que "assegura, certamente, uma inclusão suficiente dos participantes". Apesar de opinião pública seu conceito ser abstrato, a "qualidade" desse tipo de opinião, tal como formulada por Habermas, seria passível de se tornar uma "grandeza empírica" na medida em que ela se mede pelas qualidades procedimentais de seu processo de formação. Neste sentido, se houve uma legitimação procedimental da formação da opinião, seus resultados são presumidos como racionais. ${ }^{497}$

Ao tratar do público que se mobiliza no interior da esfera pública, Habermas o conceitua como o grupo dos sujeitos privados que tem que ser convencido "através de contribuições compreensíveis e interessantes sobre temas que eles sentem como relevantes". Eles se dividiriam em dois grupos: o primeiro, seria caracterizado por tentativas de influência "através" da esfera pública, mas por meio de "pressões não públicas”. Esse seria o caso de grupos de interesse que se ocupariam a esfera pública já constituída para se aproveitar dela em agir estratégico voltado ao convencimento para seus interesses. Isso ocorre, pois os atores do público "aproveitador" não têm controles sistêmicos; uma vez que "opinião" pode ser manipulada, mas não comprada (imperativos econômicos) nem imposta à força (imperativos burocrático-administrativos). Esse público se caracterizaria por grupos de interesse ancorados em sistemas de funções. Em oposição a ele, Habermas afirma existir o público "nativo"498 que participa da reprodução da esfera pública, auxiliando que ela se reproduza a partir de si mesma e se configure como "estrutura autônoma" antes de ser utilizada pelo outro grupo, ou seja, por "atores que agem estrategicamente". 499

497 HABERMAS, 2003c, p. 93-95. No mesmo sentido, ainda que o conceito de democracia deliberativa se baseie no agir comunicativo orientado pelo entendimento e pelo consenso em condições ideais de fala que resultariam, em última análise, nos "melhores argumentos"; a sua legitimação não ocorre do ponto de vista substantivo, mas pelo ponto de vista procedimental da presunção de racionalidade substantiva desses processos e discursos, mas sim no nível processual de um espaço aberto a todos que se interessarem pudessem participar. Daí haver resultados presumidamente racionais em processo a fortiori, e não atribuição de racionalidade de resultados.

498 A mesma distinção é utilizada por Habermas para distinguir atores e movimentos sociais "nativos" e "aproveitadores" atuando na esfera pública (HABERMAS, 2003c, p. 109).

${ }^{499}$ HABERMAS, 2003c, p. 96-97 
O público se constitui no "substrato" para o cumprimento das funções da esfera pública de captar os problemas da sociedade, uma vez que "a esfera pública política tem que se formar a partir dos contextos comunicacionais das pessoas virtualmente atingidas". Aqui, Habermas afirma que tal suporte do público é concretizado pelo "recrutamento da totalidade das pessoas privadas" que "em suas vozes díspares e variadas" - em um mundo da vida perpassado por "biografias privadas" e possuidor de "antenas" - identificaria problemas sociais por se deslocar em um âmbito intermediário no qual haveria uma união entre "cidadãos do Estado" (titulares da esfera publica política) e "membros da sociedade" (pois são também trabalhadores e consumidores e exercem "papéis sociais" e podem perceber "as falhas correspondentes dos sistemas de prestação"). Desse modo, experiências privadas se entrelaçam em um mundo da vida comum. Nesse sentido, "a orientação pelo entendimento, que prevalece na prática cotidiana, continua valendo também para uma comunicação entre estranhos, que se desenvolve em esferas públicas complexas e ramificadas, envolvendo amplas distâncias", Com isso, não há isolamento entre esfera privada e pública, uma vez que o "limiar entre esfera privada e esfera pública" não é definida por relações fixas, mas por condições de comunicação modificadas. ${ }^{500} \mathrm{O}$ mais importante notar, aqui, é o caráter que a esfera pública assume de "estrutura intermediária de que faz a mediação entre o sistema político, de um lado, e os setores privados do mundo da vida e sistema de ação especializado em termos de funções, por outro". ${ }^{501}$

Além disso, Habermas reforça sua tese sobre a importância da sociedade civil desenvolvidas no prefácio de 1990 e afirma que, além dela não mais incluir a economia, o núcleo institucional da sociedade civil redescoberta (e não mais burguesa) passa a ser compreendido como "formado por associações e organizações livres; não estatais e não econômicas, as quais ancoram as estruturas de comunicação da esfera pública nos componentes sociais do mundo da vida. A sociedade civil compõe-se de movimentos, organizações e associações, os quais captam os ecos dos problemas sociais que ressoam nas esferas privadas condensam-nos e os transmitem, a seguir, para a esfera pública política. O núcleo da sociedade civil forma uma espécie de associação que institucionaliza os discursos capazes de solucionar problemas, transformando-os em questões de interesse geral no quadro das esferas públicas". 502

${ }^{500}$ HABERMAS, 2003c, p. 98

${ }^{501}$ HABERMAS, 2003c, p. 107

502 HABERMAS, 2003c, p.99. Habermas deixa claro a importância dada - sociológica e normativamente - ao conceito de sociedade civil, quando afirma que ele parte da ideia de que "os processos 
Habermas se refere ao trabalho de Cohen e Arato para afirmar que a sociedade civil não se identifica nem com o Estado, nem com a economia, nem com outros sistemas funcionais, "pois permanece vinculada aos núcleos privados do mundo da vida". Isso, segundo Habermas, é garantido pelo apoio dos "direitos fundamentais" (como liberdade de opinião, reunião, associação, imprensa, etc.), o que auxilia a possibilitar que a sociedade civil propicie a formação de "um nexo estreito entre cidadania autônoma e esfera privada". 503

Ressalte-se que apenas a estrutura institucional não é o suficiente, havendo a necessidade de uma "sociedade de sujeitos privados viva e atuante" em um caráter autoreferencial da prática comunicacional da sociedade civil. Habermas, então, adere explicitamente ao conceito de "dual politics" de Cohen e Arato ao afirmar que a sociedade civil teria uma dupla-orientação: exercer influência direta no sistema político, porém, ao mesmo tempo, se interessar pela estabilização e ampliação da própria sociedade civil e da esfera pública. ${ }^{504}$ Ainda seguindo Cohen e Arato, Habermas ressalta que esse caráter dual se apresentaria também nos "novos" movimentos sociais. Do ponto de vista ofensivo, eles lançariam temas para a sociedade, definindo problemas e buscando suas soluções, valendose de argumentos "a fim de produzir uma atmosfera consensual capaz de modificar os parâmetros legais de formação de vontade". "Defensivamente", em sua "autocontenção", esses movimentos tentariam preservar certas estruturas da associação e da esfera pública, construir contra-esferas públicas, solidificar identidades coletivas e ganhar novos espaços na forma de direitos mais amplos". No contexto de uma sociedade funcionalmente diferenciada, estes "movimentos oriundos da sociedade civil" renunciariam as aspirações de uma sociedade auto-organizada em sua totalidade. ${ }^{505}$ Como atores "nativos" da esfera pública, eles têm que produzir as características que os identificam, passando por fases de auto-identificação e autolegitimação, reproduzindo a "dual politics" da sociedade civil. ${ }^{506}$

públicos de comunicação são tanto mais isentos de distorções quanto mais estiverem entregues a uma sociedade civil oriunda do mundo da vida”. (HABERMAS, 2003c, p. 107)

${ }^{503}$ HABERMAS, 2003c, p. 100-101. O autor afirma que isso fica muito evidente quando de sua negação em sociedades totalitárias que invade a base privada da esfera pública que desintegram a estrutura comunicativa cotidiana, destruindo as condições vitais de solidariedade e de iniciativa. Portanto, o cenário seria o de uma destruição da racionalidade comunicativa "tanto nos contextos públicos de entendimento, quanto nos privados". (HABERMAS, 2003c, p. 102).

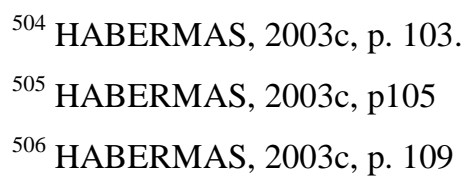

${ }^{504}$ HABERMAS, 2003c, p. 103.

${ }^{505}$ HABERMAS, 2003c, p105

${ }^{506}$ HABERMAS, 2003c, p. 109 


\section{Discussão e conclusões parciais: análises sociológicas da "virtualização" da esfera pública em Habermas}

O desenvolvimento habermasiano do conceito de esfera pública influenciou diversos trabalhos e correntes. Ele forneceu um enquadramento normativo para teorias críticas e propositivas como vertentes dos "novos movimentos sociais" e da "nova sociedade civil", influenciou teorias da democracia e das teorias da justiça por meio de sua ideia de democracia deliberativa, encontrou respaldo em algumas auto-descrições de movimentos sociais, etc. Juntamente a isso, diversas críticas foram formuladas. Por um lado, autores e pesquisadores vinculados à compreensão de fenômenos políticos criticaram o "excesso de abstração" da reformulação habermasiana, afirmando não ter ela "referência empírica determinável" ou ser "empobrecida" do ponto de vista sociológico devido a seu grande peso normativo. ${ }^{507}$ Além disso, enquanto alguns apresentaram críticas do ponto de vista teórico normativo do autor, ${ }^{508}$ outros atacaram sua formulação "sociológica" do conceito. ${ }^{509}$ No entanto, como vimos, esse "aumento de abstração" da teoria habermasiana - e sua tentativa de formular "por meio de uma teoria social" a concretude de seus pressupostos normativos da teoria do discurso - nos possibilitará trazer a discussão para o âmbito da teoria dos sistemas.

Adrian Gurza Lavalle demonstra bem esse processo de abstração do conceito na teoria habermasiana ao falar que Habermas teria realizado uma "virtualização da esfera pública". ${ }^{510}$ Entretanto, Lavalle argumenta que essa mudança teria o ônus de "despir a categoria de seus componentes sociologicamente mais ricos, aparando-lhe suas

${ }^{507}$ Destaco aqui LAVALLE, 2002. Além disso, críticas semelhantes poderiam ser desenvolvidas para incorporações do modelo habermasiano em vertentes como a "nova sociedade civil" (cf. LAVALLE, 1999 e 2003).

${ }^{508}$ Jorge Adriano Lubenow argumenta que não estaria claro se a esfera pública política seria apenas relevante em momentos de "crise" ou se ela também teria uma "estrutura latente". Ademais, os "mecanismos de transformação" do poder comunicativo em poder administrativo, bem como a relação entre "esfera pública "fraca" e "forte" não estariam, também eles, muito claros no modelo habermasiano, havendo "uma distância ou um desprendimento dos processos informais do mundo da vida e da sociedade civil das instâncias formais de tomada de decisão, o que acarretaria um "déficit estrutural" da esfera pública deliberativa, o que faz com que as reivindicações e as ações alternativas, ou seja, uma crítica prática, permaneçam restritas e limitadas” (LUBENOW, 2007, pp. 114-117).

${ }^{509}$ Destaco, aqui, a obra de Marcelo Neves (NEVES, 2006) que realiza uma "releitura sistêmica" da teoria do discurso. (Sobre essa releitura de Neves, ver também: VILLAS BÔAS FILHO, 2008). Veremos o modelo de Neves no capítulo seguinte

510 Como vimos, Lavalle traduz o termo Öffentlichkeit por publicidade. Ao me referir, aqui, aos argumentos de Lavalle, tomei a liberdade de substituir sua denominação de publicidade para esfera pública para manter a coerência terminológica interna dessa dissertação. Quando de citações, coloco o termo esfera pública entre colchetes. 
implicações analíticas mais críticas”. Segundo esse argumento, a partir da incorporação de pressupostos teóricos cada vez mais abstratos, a teoria habermasiana teria levado a esfera pública a ser redefinida em "termos de fluxos comunicativos espontâneos, abandonando, pela abstração do conceito, qualquer pressuposto empírico - notadamente a existência de um suporte institucional consolidado". 511

Lavalle argumenta que "a chave" do revigoramento da esfera pública reside na "arquitetura dual de sociedade" e na relação entre ambos os níveis. O autor afirma que "[n]a trajetória de tal especificação ocorreu um deslocamento progressivo da publicidade [esfera pública] como fenômeno histórico abrangente, que envolveu instituições políticas e de comunicação, associações civis e a vida pública de uma pujante camada de livres proprietários, para a publicidade [esfera pública] como constructo abstrato e altamente estilizado, cuja nota distintiva é tão-só a confluência de fluxos comunicativos oriundos do mundo da vida. Sob suas feições mais abstratas, de rede tecida ao sabor da espontaneidade social e da emergência de consensos, a publicidade [esfera pública] condensa seus significados como virtualidade comunicativa indeterminada, embora sujeita aos limites do mundo da vida quanto à capacidade de criação e reapropriação de sentidos. Nesse percurso, dimensões problemáticas do espaço público moderno como o perfil das instituições políticas e do Estado ou as tendências dos meios de comunicação, pesadamente presentes no diagnóstico de 1962, permanecem à margem dos novos contornos do conceito - sem dúvida mais universal e preciso, embora sociologicamente empobrecido". 512

Mesmo quando aceitamos a tese da "virtualização da esfera pública" no decorrer das obras de Habermas, é possível reconhecer algumas "relações" entre suas teses de 1961 com aquelas desenvolvidas em 1990 e 1992. A grande mudança foi aquela em que Habermas abandona seus pressupostos teóricos explicativos do historicismo holista, da teoria de classes, da crítica "ideológica" à cultura de massas e da vinculação da esfera pública ao seu caráter burguês e caminha para questões mais "funcionais", que perguntam sobre a função ou as "funções" da esfera pública na sociedade moderna duplamente integrada por sistemas e mundo da vida. Isso vai de encontro ao que chamei, com apoio em Neidhardt, da questão central que constitui a sociologia abrangente da esfera pública.

Assim, a pergunta se desloca para o reconhecimento do "substrato social" que ancorado em um mundo da vida organizado em associações "espontâneas" da sociedade

\footnotetext{
${ }^{511}$ LAVALLE, 2002, p. 70.

${ }^{512}$ LAVALLE, 2002, pp. 81-82.
} 
civil e em uma cultura política ativa - seria capaz de abarcar formas de solidariedade social e direcionar o fluxo comunicativo de poder em sentido "centrípeto", possibilitando-o a romper as comportas do núcleo do sistema administrativo em sociedades complexas funcionalmente diferenciadas e a legitimar as tomadas de decisões coletivamente vinculantes por meio da democracia deliberativa. Com isso, a relação da esfera pública política com as instituições do Estado Constitucional (social-democrata) de Direito é ressaltada. Isso é feito pela tese de que, além do contraponto normativo de influxo comunicativo, a esfera pública exerceria funções políticas relacionadas às prestações funcionais do sistema administrativo. Neste sentido, a esfera pública atuaria "captando problemas" na periferia do sistema político, além de servir de "caixa de ressonância" que tematiza problemas não "captáveis" pelas rotinas rígidas e invariáveis do núcleo do sistema administrativo em um processo de "formação de agenda" que passa pela discussão e pelo raciocínio público nas arenas e "fóruns" que ela abarca.

Portanto, ainda que Habermas tenha realizado uma "virtualização da esfera pública", a necessidade de "ancoragem social" dos argumentos normativos do autor não desapareceu, mas antes se "transmutou" pelos desenvolvimentos teóricos posteriores do autor, conforme tentei demonstrar acima. Parece-me que, a rigor, ele não realizou, necessariamente, um movimento de "empobrecimento sociológico", mas precisamente o oposto disso: buscou enfrentar teorias sociológicas para ancorar os pressupostos normativos de sua teoria do discurso na "facticidade do social". Lavalle tem razão ao afirmar que sua teoria se distancia de formulações sociológicas concretas e, com isso, se torna infrutífera para pensar relações concretas com instituições políticas. Esse é, na verdade, o núcleo de seu argumento. Todavia, me parece que Habermas não realizou um afastamento sociológico em si, mas antes realizou uma mudança de "nível de abstração" em sua teoria social, trocando seus pressupostos metateóricos. É certo que isso implica que a utilidade da teoria habermasiana para a análise de contextos históricos e de contextos institucionais específicos fica empobrecida.

Entretanto, ainda me parece ser possível olhar além dessa questão e trazer o debate para o âmbito da sociologia abstrata, no qual a teoria de Luhmann se insere; ressaltando os processos "sociológicos" com os quais Habermas tenta ancorar sua teoria abrangente após 1990 em suas considerações sobre o conceito de esfera pública. Disso não decorre a refutação da tese da "virtualização", mas implica em deslocar a ênfase do "nível de abstração" para outro "mecanismo" que a explique, a saber, o argumento "utópico" de 
"duplicação da realidade" com o argumento "reconstrutivo" das "condições ideais do discurso". ${ }^{513}$ Como pretendo demonstrar abaixo, Habermas apresenta uma continuidade de argumentos sociológicos acerca da esfera pública que perpassa as obras de 1961 e da década de 1990, ainda que o seu enquadramento teórico seja consideravelmente alterado.

Com isso, como dito na introdução, não se desconhece que teorias abstratas não conseguem "iluminar" de forma direta a "formulação de problemas". Contudo, é possível sustentar que há uma relação entre elas e que teorias podem "apreender" com problemas levantados por teorias de médio alcance e por problemas empíricos. ${ }^{514}$ Veremos isso com a teoria habermasiana no capítulo 3 , ao que se seguirá uma discussão teórica em contraposição com a teoria de Luhmann - cujo "enfrentamento" com problemas de teorias de médio alcance e "problemas empíricos" está reservado para os capítulos 4 e 5 . Antes disso é necessário ressaltar aqui quais são as implicações "sociológicas" da teoria habermasiana da esfera pública, preparando o seu enfrentamento direto com a teoria dos sistemas de Luhmann.

Em primeiro lugar, Habermas não abandona por completo a análise das relações entre esfera privada e esfera pública após 1990. Assim, ainda há a necessidade de conceber uma esfera pública que intermedeie uma vinculação com a esfera privada. Para isso, Habermas abandona a noção de família, de intimidade burguesa, de esfera privada autônoma baseada na propriedade (1961), mas redescreve essa questão no sentido de uma sociedade civil com forte caráter associativo. O caráter de "igualdade de membros" da esfera privada autônoma (1961) ganha um "equivalente funcional teórico" pela "igualdade de partes nas condições ideais do discurso". A relação entre esfera privada de "conjunto de proprietários" e esfera pública burguesa em 1961 é também substituída, após 1992, pelo elemento da relação entre "cidadãos do Estado" e "membros da sociedade", descolando-se de suas restrições de classe.

Neste sentido, a noção de autonomia privada ainda é analisada. Em sua primeira formulação, Habermas considerava a sociedade civil (bürgerlische Gesellschaft) englobando o espaço da economia e do trabalho, e, com isso, admitindo a existência de dominação em seu interior. Na década de 1990, seu conceito de sociedade civil (Zivilgesellschaft) ganha força e passa a ser considerado como um âmbito de produção de "solidariedade" vinculado ao mundo da vida, devendo ser "protegido" pelas barragens

\footnotetext{
${ }^{513}$ Para essa argumentação, ver LUHMANN, 1998c. Desenvolvo esta análise no Capítulo 3, a seguir.

${ }^{514}$ Ver, neste sentido, o artigo anexo deste estudo.
} 
democráticas contra a colonização pelos imperativos sistêmicos. ${ }^{515}$ Ele desenvolve, então, um modelo de auto-contenção da sociedade civil e parece ser muito menos crítico em relação a ela do que ele o foi em 1961. O aporte normativo que Habermas atribui à sociedade civil aumenta quando, em 1992, ele desenvolve um modelo mais "ofensivo" e aponta a sociedade civil como o espaço no qual ocorre a mobilização "espontânea" de associações e movimentos sociais, resultando em uma "racionalização do mundo da vida".

Note-se que Habermas se afasta de suas crenças na necessidade de "homogeneidade de classe" para desenvolver um conceito de uma esfera pública plural - que conta com "públicos" e "contra públicos" formados em "vozes díspares”. Não é mais necessária uma homogeneidade de classe, mas antes um "entrelaçamento de biografias formulado de forma privada" que possibilite um "horizonte comum de mundos da vida". Habermas não incorre, com isso, no conceito de "pluralismo de interesses" no sentido liberal do termo, que prevê um equilíbrio de forças auto interessadas. O autor toma o cuidado de diferenciar seu conceito de "esfera pública plural" do "pluralismo de interesses"; uma vez que a esfera pública amplamente considerada (abrangendo todas as arenas de esferas públicas e contraesferas públicas parciais) seria plural no sentido de ser, a princípio, "acessível” a todos. Por sua teoria do discurso ele recai na universalização de consensos formados em condições ideais frente às quais se pode presumir racionalidade. Assim, a função de "generalização e homogenização de interesses" - explicada em 1961 pelo conceito de interesse de classe - é substituída pelo intrincado conceito de universalização discursiva em condições ideais, na qual "o consenso" é encarado como o resultado necessário em uma esfera pública inclusiva, aberta a todos os "afetados potenciais". Dessa forma, o "caráter universalista" e pluralista da esfera pública pautada por discursos "inclusivos" não seria "hegemônico" tal como era o caso da esfera pública burguesa e, assim, se diferenciaria dos "discursos excludentes" conforme propostos por Foucault.

Esse ponto merece um comentário. Habermas abandona um elemento crítico às “exclusões" da esfera pública burguesa, presente em 1961, quando o autor "denunciava" a "dialética manifesta" na exclusão de grupos sociais na esfera pública burguesa, por exemplo, trabalhadores, os não proprietários e as mulheres. Habermas deixa de considerar,

515 O caráter de autonomia, de distinção frente ao poder político (Estado) também se mantém. Na primeira formulação, Habermas falava que os burgueses enquanto sujeitos privados e públicos estavam preocupados com sua esfera privada e não interessados em adentrar o poder político: "burgueses não governam", afirmou Habermas. No mesmo sentido, com a tese de que os sistemas administrativo e econômico seriam indispensáveis em sociedades complexas, Habermas afirma, na década de 1990, que ela se mantém distinta do âmbito sistêmico e não visa a sua substituição. A frase é semelhante: "discursos não governam". 
assim, o problema da exclusão na esfera pública. Contudo, como veremos em minha crítica no capítulo seguinte, esse caráter de "inclusão geral" apresenta problemas para a teoria habermasiana. Isso, tanto do ponto de vista normativo - pois, como o autor havia afirmado em 1961, uma esfera pública "não universalista" perderia seu caráter de esfera pública quanto do ponto de vista "sociológico", uma vez que é seguro afirmar que há amplos "setores de exclusão" na sociedade (mundial) que impedem que grande parte do "público" seja incluído, ainda que formalmente, nas discussões da esfera pública. Mais do que isso, Habermas não aborda a questão dos setores excluídos das prestações do sistema político e jurídico quando trata de seu conceito de esfera pública includente. A não tematização da exclusão na esfera pública não permite a Habermas desenvolver um correlato de "mecanismos de inclusão política" - seja ela vista do ponto de vista das prestações dos sistemas político-administrativo e jurídico, seja do ponto de vista da inclusão na esfera pública. Na verdade, isso aponta para outro elemento frágil de sua teoria: a tese da "espontaneidade" do surgimento de atores na esfera pública, sem demonstrar como isso é feito.

Em segundo lugar, a esfera literária - que na obra de 1961 dava as bases para a formação do "público de vanguarda" e para as condições do exercício do "raciocínio público"- perde espaço para o pressuposto de uma "cultura política ativa" em uma esfera política mobilizada e com forte caráter associativo. As oposições antes lidas pela crítica da ideologia da cultura de massas (público versus clientes) são substituídas pela distinção decorrente de sua teoria do discurso entre "públicos aproveitadores", que agem estrategicamente, e "públicos nativos" que agem comunicativamente (orientados pelo entendimento). Nesse contexto, a tentativa de Habermas de escapar - por meio de seu conceito de soberania do povo como procedimento - do dilema do republicanismo, que dependia do pesado pressuposto de uma "virtude cidadã", parece não ser totalmente bem sucedida dentro de seu referencial teórico que visa a enfrentar as condições de uma sociedade complexa. Essa conclusão é permitida, pois, como vimos acima, seu modelo se apoia na existência de uma "cultura política ativa". Mais do que isso, Habermas argumenta que o conceito de democracia deliberativa "confia" na mobilização política e na produção "espontânea" de forças comunicativas nas associações da sociedade civil. Isso não parece bem claro em seu modelo teórico, não apenas por se basear na frágil tese da "espontaneidade" das formações comunicativas da sociedade civil, mas, como bem 
argumentou Jorge Lubenow, ${ }^{516}$ por ser o conceito de esfera pública um conceito necessariamente ativo, sem haver possibilidade de sua existência "em repouso", o que pouco fala de sua manutenção em estados de latência.

Ainda, é possível estabelecer uma correlação entre as teses do jovem Habermas sobre a esfera pública burguesa no contexto institucional do Estado de bem estar com seu modelo tardio de esfera pública no Estado Constitucional de Direito. Enquanto num primeiro momento Habermas era "pessimista" em relação às possibilidades da constituição de uma esfera pública no Estado de bem estar "garantista", no qual ele só conseguia imaginar a formação de espaços públicos no interior de instituições estatais, propondo sua democratização interna; ele parece reconhecer uma vinculação mais forte entre o âmbito institucional dos Estados Constitucionais de Direito e a esfera pública por meio da formação discursiva da vontade e pelo enfoque nas prestações de legitimação e de funções políticas de tematização de problemas por parte da esfera pública.

Outra mudança de posicionamento é aquele em relação à mídia, que após 1990 passou a ser "ambíguo" do ponto de vista de sua teoria democrática. Seu "status" na teoria habermasiana, contudo, não é ainda bem claro. O autor chega a admitir certas possibilidades de que a esfera pública se valha desses meios para si; mas concebe também uma mídia que opera por seus próprios interesses de redação e pela fusão entre entretenimento e informação. Não fica claro o caráter ambíguo da mídia, se ela está mais inserida no âmbito do mundo da vida ou dos sistemas, se ela é um meio, ou como ela transita entre os dois. Com efeito, o "direito" e seu caráter de tradutor entre linguagem cotidiana e linguagem sistêmica parece ter uma descrição bem delimitada, o que não ocorre com as considerações de Habermas sobre a mídia.

Enfim, o ponto central a se ressaltar aqui é que Habermas utiliza sua tese da dupla integração da sociedade em sistemas e mundo da vida para enquadrar a teoria da esfera pública. Contudo, essa necessidade de se opor contextos "legítimos e ilegítimos", por assim dizer, já estava, de certa forma, presente nas considerações de 1961. Isso se explica pelo caráter normativo da teoria do autor. Ilustrativamente, vemos que já em 1961 Habermas procurava opor "cidadãos" a "clientes"; "ideia" a "ideologia"; "opinião pública" a “opinião não pública”, etc. Na década de 1990 sua teoria fica mais precisa e as oposições são feitas decorrentes de suas incorporações teóricas: "público nativo" a "público aproveitador", "poder comunicativo" a "poder administrativo", "circulação" e "contra

${ }^{516}$ Cf. LUBENOW, 2007 e nota de rodapé acima. 
circulação do poder", etc. No contexto de sua última formulação acerca da esfera pública, ao se vincular aos conceitos dos pressupostos comunicativos do discurso, Habermas parece "carregar" muito o conceito de esfera pública com "orientações para o entendimento", “inclusão generalizada" e "formação de consensos" a partir do melhor argumento. Isso parece subestimar a existência de discursos, pretensões, pressões e formulações vinculadas na esfera pública que sejam provenientes de atores auto-interessados e de sistemas sociais em seus públicos especializados. ${ }^{517}$ Isso sobrecarrega suas considerações a partir de uma divisão analítica entre mundo da vida e sistemas; com a qual Luhmann não trabalha.

A presente discussão parcial teve o intuito de preparar as bases da discussão sociológica que se segue. Não há aqui o esgotamento da discussão, mas o realce do caráter mais "sociológico" (ainda que abstrato) da teoria habermasiana da esfera pública. Por esse enfoque, afasto-me das discussões filosóficas, éticas, pautadas pela teoria democrática ou por teorias de justiça - todas passíveis de serem acessadas no amplo monumento teórico habermasiano. Com efeito, trabalhar com duas teorias tão abstratas quanto a de Habermas e Luhmann, me parece, é mais frutífero quando se aborda a teoria social de ambos, realizadas em um nível de abstração congruente e com debates diretos.

${ }^{517}$ Veremos a questão da sobrecarga conceitual e normativa do mundo da vida no capítulo seguinte, acompanhando Marcelo Neves. 


\section{CAPÍTULO 3. A ESFERA PÚBLICA ENTRE AS TEORIAS DO DISCURSO E DOS SISTEMAS}

\section{Introdução}

Após o longo percurso exegético e dissertativo de apresentar as linhas gerais das teorias abrangentes da sociedade de Luhmann e Habermas, este capítulo terceiro inicia a parte argumentativa da dissertação, cujo teor será mais voltado à discussão de argumentos do que à explicação detalhada de pressupostos teóricos. Por ser de caráter argumentativo, não é necessário delimitar um momento especificamente voltado para as conclusões parciais.

Cabe a este capítulo desenvolver as "tensões mútuas" presentes na descrição da esfera pública em teorias abstratas tão distintas que, cada qual a sua maneira, exercem considerável influência em estudos e desenvolvimentos no âmbito da sociologia política contemporânea. Neste sentido, são discutidas as consequências que os modelos das "eclusas" e "dos espelhos" têm para o campo específico da sociologia de grande alcance da esfera pública. Ao assim proceder, são analisados os espaços de "luzes" e "sombras" de cada teoria, ou seja, seus limites e possibilidades na descrição teórica de um fenômeno plural e multifacetado, rico em abordagens possíveis como é a esfera pública moderna. Desta forma, cada teoria consegue "iluminar" problemas determinados, sem escapar de apresentar "pontos cegos" em relação a outros. Entretanto, a perspectiva que adoto como central neste trabalho, como discutido na introdução, é pautada pela teoria dos sistemas de Niklas Luhmann. É precisamente por trabalhar também alguns pontos cegos e eventuais problemas da teoria luhmanniana, além de buscar desenvolver algumas "linhas de interpretação da obra do autor", 518 que este trabalho pode ser considerado uma "leitura crítica de Niklas Luhmann".

O enfrentamento de críticas mútuas entre os modelos será atravessado por algumas "teses" que desenvolvo a partir da discussão, cujos principais argumentos que tento sustentar se pautam pelo reconhecimento que o modelo habermasiano, ao trabalhar ótica de uma distinção analiticamente muito rígida entre sistemas e mundo da vida - que a mim não parece ter suporte na estrutura da sociedade moderna -, realiza uma "politização excessiva"

518 Coforme se verá neste capítulo, tento sustentar ser possível uma interpretação da teoria luhmanniana que leve a questão da "inclusão/exclusão" mais a fundo e a sério; sustentando que a teoria do autor apresenta diversas mudanças e problemáticas internas ao tratar dessa questão em suas obras tardias. 
e uma "idealização excessiva" da esfera pública. Com isso, argumento que seu modelo encontra algumas dificuldades para explicação de contextos comunicativos presentes na esfera pública que não podem ser explicados pela sua tese da sua "autocontenção", nem seriam redutíveis ao âmbito político orientado para a influência de decisões no núcleo do sistema administrativo. Por outro lado, a "idealização" do conceito faz com que o modelo enxergue a "inclusão" política de forma excessivamente normativa e "ativa" por meio de uma abordagem simplista de "inclusão generalizada" que não leva em consideração o problema da "sombra lógica da exclusão" e, por consequência, é incapaz de trabalhar com conceitos de inclusão dos cidadãos nas prestações dos sistemas sociais.

O capítulo se estrutura da seguinte forma: (i) após esta introdução, (ii) apresento alguns elementos dos conceitos de direito e política em Luhmann, demonstrando suas diferenças com o modelo habermasiano. Então, com esses elementos em mente, discuto o modelo luhmanniano de esfera pública para (iii) desenvolver uma crítica da forma pela qual o modelo habermasiano discute a questão da inclusão político jurídica, ressaltando a problemática da "inclusão/exclusão" tal como formulada por Luhmann. (iv) Posteriormente, discuto o modelo de esfera pública pluralista de Marcelo Neves como um modelo autônomo que trabalha com questões centrais para a discussão dos argumentos aqui desenvolvidos. (v) Para preparar as discussões "aplicadas" que se seguem nos capítulos posteriores, discuto algumas críticas levantadas por teorias de médio alcance à teoria habermasiana.

\section{A esfera pública como espelho da sociedade}

\subsection{Os sistemas jurídico e político na teoria dos sistemas}

Niklas Luhmann compreende o direito moderno a partir de sua teoria social, ${ }^{519}$ encarando-o como um sistema funcional autopoiético que opera pelo código binário lícito/ilícito (Recht/Unrecht), ${ }^{520}$ contando com os tribunais (sistemas organizacionais) em seu centro ${ }^{521}$ - o "lugar" no qual o corre seu fechamento autopoiético e sua formação de identidade. Por sua vez, os programas do direito se encontram na periferia do sistema, ${ }^{522}$

\footnotetext{
${ }^{519}$ LUHMANN, 2005a, p. 57.

${ }^{520}$ LUHMANN, 2005a, pp. 128 e ss e 227 e ss.

${ }^{521}$ LUHMANN, 2005a, pp. 359 e ss.

${ }^{522}$ LUHMANN, 2005a, pp. 507 e ss.
} 
junto com outras comunicações jurídicas. É por meio da periferia do sistema que o direito "se abre cognitivamente" para irritações de outros sistemas, ${ }^{523}$ servindo como um "filtro" que amortece as irritações externas.

No contexto moderno do aumento de complexidade, Luhmann descreve a função social do direito moderno como "a generalização congruente ${ }^{524}$ de expectativas normativas", ${ }^{525}$ recusando-se a trabalhar com um conceito de coerção. O autor postula que, com o aumento da complexidade social, o direito moderno passa a ser caracterizado por seu processo de "positivação",526 e argumenta que a "validade" do direito não é mais extraída de âmbitos externos (como a moral, a cosmovisão ou a religião), mas ancorada em seu próprio funcionamento autorreferencial. Contudo, para poder fazer isso, o sistema jurídico recorre à legislação, ${ }^{527}$ uma prestação do sistema político que dá validade para o sistema jurídico permitindo o seu fechamento. ${ }^{528}$ Para Luhmann, o direito moderno em sua positividade possibilitou que a política utilizasse do processo jurídico como forma de obter sua legitimação (pelos procedimentos juridicamente disponibilizados). ${ }^{529}$ Ainda que ambos sejam sistemas autopoiéticos, grosso modo, a política retira sua legitimidade procedimental com "auxílio" do direito; enquanto o direito consegue sua validade com o "auxílio" do sistema político. A positividade do direito moderno, portanto, está estritamente conectada com a legitimação pelo procedimento do sistema político moderno, em uma relação de

523 Os programas condicionam a atribuição de valor negativo ou positivo para comunicações jurídicas orientando as decisões dos Tribunais. Os programas estão ligados à abertura cognitiva do sistema, onde as irritações provenientes de seu ambiente - e se outros sistemas parciais da sociedade - são mais intensas. No caso do sistema jurídico, de forma simplista e exemplificativa, encontramos programas tais como legislação (política), dogmática jurídica (ciência) e contratos (economia).

${ }^{524}$ LUHMANN, 1983a, p.109 e ss.

${ }^{525}$ Já vimos o conceito de expectativas no Capítulo 1. Resta lembrar que expectativas cognitivas são aquelas que, no caso de desapontamentos, são adaptadas à realidade. Por sua vez, as expectativas normativas "não são abandonadas se alguém as transgride". LUHMANN, 1983a, p.57 ess. Daí porque Luhmann falar que $O$ Direito não é primariamente um ordenamento coativo, mas sim um alívio para as expectativas" (1983a, 115).

\footnotetext{
${ }^{526}$ LUHMANN, 1983a, pp. 237 e ss;

${ }^{527}$ LUHMANN, 1983a, p.227-8.
}

${ }^{528}$ Note-se que o conceito sociológico de "positivação do direito" não se confunde com "direito positivo". Ademais, reconhecer que o direito se vincula ao processo legislativo não implica, de forma alguma, que ele seja mais rígido ou insensível às pressões por adequação social. Ao contrário, uma das principais características do direito moderno é sua "mutabilidade". Isso fica claro quando Luhmann analisa a questão da evolução do direito e contrapõe o exemplo do "direito natural”, mais rídico a mudanças.

${ }^{529}$ LUHMANN, 1980b, esp. pp. 119 e ss. 
contraprestação entre os sistemas. Esses sistemas estão acoplados estruturalmente por meio da Constituição, compreendida como uma "conquista evolutiva da sociedade". 530

No tocante ao sistema político, Luhmann se afasta de conceitos de oposição entre "política e sociedade" ou entre "política e economia" que conceitual o sistema político como por oposição seja à sociedade burguesa (Bürgerlichgesellschaft) ou à sociedade civil (Zivilgesellschaft). ${ }^{531}$ Ao invés disso, o autor se volta para a análise da diferenciação do poder político, ou seja, pela transformação e concentração do poder $^{532}$ em poder político. Assim, Luhmann encara o poder (Macht) como o meio de comunicação simbolicamente generalizado do sistema político. Enquanto em sociedades pré-modernas o poder era organizado de maneira hierárquica, na sociedade moderna estruturada de forma heterárquica ele passa a lidar com o a vinculação da "opinião pública" (offentliche Meinung) em seus processos de decisão. ${ }^{533}$. Aliás, como vimos no Capítulo 1 , o surgimento da opinião pública é explicado por Luhmann no contexto da evolução dos meios de comunicação da sociedade funcional moderna "que se comunica de forma heterárquica". 534

O autor postula que os sistemas políticos modernos têm a função de tomar decisões coletivamente vinculantes. ${ }^{535}$ Eles operam pelo código da política "poder/ não poder" que, por sua vez, sofreria uma recodificação nos sistemas políticos democráticos e se constituiria pelo código "governo/oposição". ${ }^{536}$ Luhmann encara a política como um sistema fechado e autorreferencial, como vimos, o que o leva a afirmar a tese de que os problemas de "legitimação" de seus procedimentos são problemas internamente formulados por ele. Sistemas políticos modernos - não mais organizados pelo princípio da

${ }^{530}$ LUHMANN, 2005a, pp. 152 e ss e 519 e ss., 2000, pp. 390 e ss.

${ }^{531}$ LUHMANN, 2000. pp, 7-12; e 116 e ss. Luhmann descreve que a compreensão usual da política como centro dirigente da sociedade seria orientada por um entendimento "europeu velho" e pré-moderno que não engendrava uma distinção específica entre política e sociedade ou entre Estado e sociedade. Em uma história das ideias da palavra "política", Luhmann pôde notar que a sociedade descreveu sua unidade como sociedade política - ou seja, guiada politicamente - e logo depois pela economia, como sociedade econômica. Ambas as descrições não seriam adequadas à sociedade moderna diferenciada funcionalmente.

$532 \mathrm{O}$ poder existe também difuso na sociedade em diversos de seus âmbitos. Luhmann não nega isso, mas afirma que ele adquire uma forma específica no sistema político, exercendo formas "parasitárias" em outros sistemas. (LUHMANN, 2000, p. 69).

${ }^{533}$ LUHMANN, 2000, p. 71.

${ }^{534}$ LUHMANN, 2007a, pp. 242-243.

${ }^{535}$ LUHMANN, 2000, p. 84.

${ }^{536}$ LUHMANN, 2000, 86 e ss. e 111 e ss. 
hierarquia - são estruturados pela na diferenciação tripartite entre política (politics ${ }^{537}$ ), administração e público. ${ }^{538}$ Com isso, o sistema perde sua forma "cima-baixo" para adotar uma dinâmica cíclica: “o público influencia a política por meio de eleições políticas. A política coloca os limites e prioridades para as decisões administrativas. A administração usa as decisões para se vincular ao público que, por sua vez, pode "reagir às decisões por meio de eleições políticas ou outras formas de expressão". ${ }^{539}$ Contudo, após se estabilizar, este ciclo induziria também a contracirculação do poder: a política não se desvincula dos programas da administração, que pauta suas atividades. A política, com a ajuda de organizações partidárias, sugere ao público quais programas ele deve votar e quais os motivos para isso. Por sua vez, o público exerce sua influência na administração por diversos canais tais como grupos de interesse e apelos emocionais". Luhmann ressalta que tal "contraciclo" do poder só aparece como "ilegítimo" se ainda pensarmos de forma hierárquica. ${ }^{540}$

Ao reconhecer a diferenciação funcional como característica da sociedade moderna “sem vértice nem centro", o sistema político para Luhmann é encarado como um sistema parcial da sociedade (mundial) como qualquer outro. O fato dos sistemas políticos apresentarem uma vinculação territorial não é uma contradição na teoria, uma vez que ela é encarada como uma segunda diferenciação interna da política da sociedade, ou seja, uma diferenciação territorial. ${ }^{541}$

O operar do sistema político, portanto, é orientado por seus próprios critérios e não pode ser dirigido operacionalmente por lógicas externas a ele. Sendo autopoiético, ele apenas pode reagir às irritações de seu ambiente, mas essa reação será feita por meio de seus próprios elementos, uma vez que não há troca de informações "prontas" entre sistemas. Um sistema não pode também operar fora de suas fronteiras definidas na distinção sistema/ambiente. Isso não impede que ela observe outros sistemas, o que é garantido pela abertura cognitiva.

${ }^{537}$ Coloquei o termo traduzido do inglês por julgar que auxilia na compreensão.

${ }^{538}$ LUHMANN, 1990. 47.

${ }^{539}$ LUHMANN, 1990, p. 48

${ }^{540}$ LUHMANN, 1990, pp. 46-49.

541 Luhmann, 2000a, p. 222. Vermos no capítulo 01 uma explanação sobre o funcionamento dos sistemas jurídico e político segundo o autor. O reconhecimento deste ponto será importante para as discussões sobre sociedade civil mundial, política mundial e esfera pública mundial. 


\subsection{Os espelhos da sociedade e da política: esfera pública e opinião pública}

Portanto, ao "contrário da tradição", Luhmann não descreve a esfera pública como um tipo de "seleção racional" (Vernunftsauslese) que permite obrigar o sistema político a operar de forma diferente. Luhmann trabalha a ideia da esfera pública como um âmbito de "reflexão" do sistema (na observação de observação - der Beobachtung der Beobachtung, ), funcionando como um ambiente interno da sociedade - isto é , "de todas as suas interações e de suas organizações -, mas também dos subsistemas sociais de função e dos movimentos sociais" ${ }^{\prime 542}$. Afirma-se que nenhum sistema pode atravessar sua fronteira de forma a agir operativamente em seu ambiente. Ele opera, portanto, "em um lado interno das fronteiras sistêmica" (Innerseite der Systemgrenzen). ${ }^{543}$ Entretanto, o lado interno pressupõe um lado externo. Caso contrário, o sistema não poderia ter capacidade de abertura cognitiva e de reconhecer a existência da própria fronteira em questão. É a partir desse lado externo que o sistema, após ser irritado de maneiras repetidas e da mesma forma, "identifica” outros sistemas. Enfim, Luhmann afirma: "é exatamente este outro lado generalizado que todos os sistemas sociais internos à sociedade (aller innergesellschaftlichen Sozialsysteme) podem chamar de esfera pública". ${ }^{544}$ Nota-se, com efeito, que Luhmann não atribui um caráter político para o conceito de esfera pública, mas antes o conceitua de forma muito restrita, como um âmbito de autorreflexão de toda a sociedade.

Luhmann realiza uma mudança radical das descrições comuns de esfera pública ligadas a grupos de interesse ou a associações "espontâneas". Para fazer isso, ele aponta para um conceito de observação entre sistemas sociais. Este conceito muito amplo de esfera pública, contudo, faz sentido em nosso estudo quando ligado ao meio da opinião pública (öffentlichen Meinung), que ganha relevância política, pois permite observações de segunda ordem tanto para a política mesma, quanto para os outros sistemas que a

${ }^{542}$ LUHMANN, 2005c, pp. 168-169.

543 Ainda que a metáfora do espelho não seja expressamente utilizada por Luhmann para o caso específico da esfera pública, é seguro vincular essa metáfora ao conceito, uma vez que - por sua análise funcional - Luhmann trabalha com conceitos "equivalentes funcionais". Daí porque o "espelho" da economia é seu ambiente interno do mercado, o "espelho" da política é seu ambiente interno da opinião pública. LUHMANN, 2005c, p. 169-170. (para uma conceituação expressa da esfera pública como o "espelho" de segunda ordem da sociedade, ver. e) STICHWEH, 2005, p. 87.

${ }^{544}$ LUHMANN, 2000a, pp. 284-285 (ênfase adicionada). 
observam. A singularidade do conceito está em reconhecer que a opinião pública é um meio para a observação de segunda ordem e serve como um meio de formação de opiniões (Meinungsbildung). ${ }^{545}$ Este caráter de observação é trabalhado por Luhmann pela metáfora do espelho. ${ }^{546}$ Possibilitando uma observação de segunda ordem, o próprio observador (no caso a política) pode observar-se e observar os outros na maneira pela qual eles são representados na opinião pública: "para além, disso, nas nossas costas vemos outros que também actuam em frente do espelho [sic]: outras pessoas, grupos, partidos políticos e versões do mesmo tema. ${ }^{547} \mathrm{O}$ espelho torna possível uma observação dos observadores. Isso não contradiz o fechamento operacional do sistema, uma vez que a opinião pública não serve para estabelecer contatos externos. O resultado desta alteração de pensamento são visíveis: "[n]o contexto de uma teoria do sistema político esta transformação do conceito de opinião pública tem um importante significado. Em primeiro lugar força à renúncia, certamente dolorosa, às expectativas de racionalidade e espera de uma revitalização da "vida" republicana civil. Por outro lado, indica claramente que o sistema político da sociedade moderna não pode ser entendido em termos de uma autoridade central cuja adequação (virtus) ou desadequação pode ser observada pelas pessoas". ${ }^{548}$ As críticas ao modelo habermasiano são, aqui, evidentes.

\subsection{O problema do consenso}

Com efeito, Luhmann critica o modelo da "ética discursiva" apresentado por Habermas em 1992 em seu "Zwischen Faktizität und Geltung” e sua proposta de decisões de controvérsias pela formação e institucionalização de consensos racionais (vernünfitgen Konsens). Mesmo reconhecendo o caráter "reconstrutivo" da empreitada habermasiana, Luhmann argumenta que Habermas não procede a uma separação precisa entre direito e política, mas se baseia em um conceito de Estado de Direito (rechtsstaatlichen Konzept)

${ }^{545}$ LUHMANN, 2000a, p. 286-287.

${ }^{546}$ LUHMANN, 2000a, p. 286 e 1999d, p. 86 e ss. Luhmann afirma que esta metáfora poderia ser utilizada também para o caso do Mercado na economia.

${ }^{547}$ LUHMANN ,1999d, p. 86. Para uma análise do desenvolvimento teórico do conceito luhmanniano de opinião pública em várias formulações ao longo de suas obras, ver SALVADOR, 2011.

${ }^{548}$ LUHMANN, 1999d, 87 
para buscar fundamentos de legitimação comuns (gemeinsame Legitimationsgrundlage) para o direito e para a política. ${ }^{549}$

Ademais, Luhmann rejeita o conceito de integração para a caracterização do sistema político, afirmando que a integração social não se realiza nem pela política nem pelo Estado. O conceito de tradicional de integração recairia na conservação de identidade entre política e sociedade, algo problemático de se afirmar no contexto da sociedade moderna. Segundo ele, "o conceito de integração pressupõe que, em casos de conflitos, as propostas políticas conseguem obter concordância e entendimento". Entretanto, ele se afasta desta concepção e abandona o conceito de integração, o que lhe permite uma "análise mais diferenciada" dos conflitos políticos. O autor sustenta que os conflitos políticos seriam aqueles que se reproduzem no campo esquemático do código governo/oposição e se prostram frente ao sistema político que, por sua vez, tem que decidir sobre conflitos de opiniões sociais ou conflitos de interesses. Esse seu conceito de conflito político corresponde à preferência dos meios de comunicação em massa por informar conflitos, assim como o faz a opinião pública. Neste sentido, consegue-se que a atenção pública (öffentliche Aufmerksamkeit) se centre em conflitos políticos.

De acordo com a perspectiva luhmanniana, os conflitos poderiam até exercer certo grau de integração, mas o fazem de forma muito mais complexa e distinta daquele conceito de integração proposto pela "teoria clássica". Conflitos são compreendidos como "sistemas hiperintegrados" que se desenvolvem de forma parasitária em todos os sistemas sociais e cuja tendência básica é a "busca pela obtenção da vitória". Entretanto, no transcurso da diferenciação funcional, o sistema político faz com que os conflitos se especifiquem tematicamente como conflitos políticos, evitando que eles se solidifiquem na sociedade. Assim, do ponto de vista da vinculação coletiva, a política se dirige em primeiro lugar aos conflitos que ela mesma tematiza e aos critérios que ela tem que desenvolver para resolvêlos. Dessa forma, a política trata apenas de conflitos que consigam ser tematizados politicamente, ou seja, que consistam em comunicação controversa que circula unicamente dentro do sistema político. Isto necessariamente leva à exageração e à dramatização de temas cotidianos que não seriam notados caso não sejam politizados. ${ }^{550}$

Luhmann se opõe frontalmente à pretensão da formação de consensos e de comunicação orientada pelo entendimento da teoria habermasiana. Ao contrário, como já

\footnotetext{
${ }^{549}$ LUHMANN, 2000, p. 125.

${ }^{550}$ Parafraseado de LUHMANN, 2000, pp. 131 e ss.
} 
tínhamos visto no contexto de sua teoria geral, o autor não trabalha com conceitos carregados de integração social. Ao invés do consenso, Luhmann discorre sobre os conflitos formulados politicamente dentro do sistema político. Com isso, o autor afirma poder desenvolver melhor os mecanismos de funcionamento do sistema político moderno, compreendendo de forma relativamente distinta da "tradição Europeia".

Esse é um ponto muito importante de ser destacado. Isso, pois, como tentei demonstrar no Capítulo 2, o a formação do projeto teórico Habermasiano desenvolve um grande esforço teórico para inserir a (auto?)concepção normativa da sociedade moderna para aplicá-la à sociedade moderna. Para fazê-lo, o autor se vala de sua teoria do discurso e das condições ideais para o agir comunicativo orientado pelo entendimento, cujo resultado é o consenso. Esse me parece ser o ponto mais fraco da teoria habermasiana quando encarado do ponto de vista sociológico (seja qual for seu nível de abstração). A partir desse conceito "filosófico" da ética discursiva, Habermas imputa no mundo uma divisão que me parece muito rígida e idealizada de âmbitos de integração social que são indissociáveis. A partir dessa "idealização", Habermas apresenta uma análise, a meu ver, muito restrita do conceito de sistema, considerando-os de forma "tecnicista", por não conceber que os sistemas parciais de função, ainda que operacionalmente fechados, apresentam forte relação entre si. Talvez essa seja uma decorrência da tradição que ainda vê a política e a economia como conceitos fundamentais para se explicar a sociedade. Com efeito, Habermas considera haver apenas dois sistemas, sem precisar bem do ponto de vista de sua consistência teórica inter como ficam outros âmbitos da reprodução social, como a mídia e o direito (em sua ambiguidade de "tradutor" entre sistemas e mundo da vida; mas que poderia também servir "aos imperativos sistêmicos" por meio da juridificação); além de outros como arte e medicina, por exemplo.

Enfim, Luhmann reconhece essa questão em uma entrevista publicada na obra "Protest", onde argumenta que a diferença entre sistemas e mundo da vida seria muito "grosseira" (grob). Em suas palavras: "[é] extremamente improvável dizer que um sistema opere fora do mundo da vida. Ele é também cotidiano em todos os lugares, em cada burocracia, em cada bolsa de valores, em cada compra de ações". ${ }^{551}$

Assim, ao se afastar das estilizações da noção de integração e do "consenso", Luhmann pode tanto considerar que o conflito não é "privilégio" do sistema político existindo em diversos âmbitos da sociedade - quanto especificar, por meio do seu

${ }^{551}$ LUHMANN, 1996b, p. 71 
funcionalismo radical, como os conflitos políticos são processados dentro da sociedade moderna. Neste sentido, em outra entrevista, ele argumenta: “[eu] não parto de um modelo de teoria dual do tipo 'conflito ou consenso', 'cooperação ou conflito', 'sistema ou conflito', mas considero em um nível geral também os conflitos como sistemas sociais (...). O conflito se constitui também sistematicamente, por assim dizer. ${ }^{552}$

Cumpre notar que a "confiança" (vertraut) habermasiana na orientação pelo consenso pode ser criticada, inclusive, dentro da perspectiva de teorias da democracia. Isso pode ser depreendido de concepções "agonistas" da democracia que argumentam que a insistência na orientação pelo consenso acabaria por fazer que a teoria deliberativa habermasiana incorresse precisamente no erro fundamental que ela acusa o liberalismo: o afastamento do âmbito "do político" ("The Political” - com maiúscula) por desconsiderar o elemento do conflito como característico dos processos políticos. ${ }^{553}$ Luhmann não desenvolve precisamente um conceito "agonista" da democracia, por considerar, inclusive, elementos de formação de consenso no âmbito parlamentar e partidário. Isso, contudo, não é feito de modo "idealizado".

Note-se, por fim, que mesmo autores que desenvolvem modelos robustos de esfera pública tendem a reconhecer esse problema na teoria habermasiana, como é o caso da obra de Marcelo Neves, que reconhece um problema "sociológico" na ênfase no consenso. Neves acompanha a teoria dos sistemas ao negar "radicalmente que o consenso possa ser condição da validade jurídica". ${ }^{554}$ Veremos o conteúdo do modelo de Neves com mais vagar quando tratarmos de seu modelo de legitimidade do Estado Constitucional de direito em sua relação com "um consenso procedimental e um "dissenso conteudístico" na esfera pública pluralista". 555

552 LUHMANN, 1987, p. 2.. Além disso, em outro texto, Luhmann argumenta que Habermas desenvolve uma concepção ,utópica“ de consenso que não parte de comunicações que efetivamente acontecem na realidade, apresentando um problema "sociológico". Para o autor, "afirmar que essas condições poderiam acontecer na realidade" não é suficiente. Ademais, Habermas não conseguiria explicar como isso poderia acontecer, como o potencial poderia se tornar atualidade. (LUHMANN, 1998c, p 160 e ss.)

${ }^{553}$ Ver, a titulo ilustrativo, MOUFFE, 2002.

${ }^{554}$ NEVES, 2006, p. 147.

555 NEVES, 2006, 2009a.. Veremos seu conceito de "esfera pública" como "a arena do dissenso" (2006, p. 132). 


\subsection{A função de "alarme" e de "caixa de ressonância"}

Ainda que Luhmann tenha um conceito "muito restrito" de esfera pública, ele considera que é pela opinião pública que temas vinculados na sociedade adquirem relevância política, como vimos acima. Nota-se que isso vai ao encontro daquilo que Habermas chamou de "caixa de ressonância" ou função de "alarme" da esfera pública. Aqui, o que pode ser relacionado entre o conceito dos autores, é o reconhecimento da "apresentação de temas" ao sistema político, ou, em outras palavras, o elemento de “formação de agenda" possibilitado na periferia desse sistema.

Contudo, vale ressaltar, os modelos são muito diferentes. Para Habermas, é a esfera pública política mobilizada localizada "fora" do sistema político que oferece estes temas que "rompem" as comportas do núcleo do sistema administrativo. Por outro lado, Luhmann atribui essa faceta à opinião pública, formulada politicamente. Ela é entendida como o ambiente interno da política (que parece estar fora dela, mas não está). Mais importante que isso, a opinião pública tem um papel bem determinado em sua teoria da circulação e contracirculação do poder, uma vez que ela se vincula ao público ${ }^{556}$ e à política (politics), aproximando-se dos partidos políticos em sua atuação. Note-se, entretanto, que não há em Luhmann uma concepção "ativa" do público, ou distinções normativas tais como propôs Habermas em seu conceito de "público aproveitador" e "público nativo".

Habermas parece fazer uma restrição injustificada quando afirma que a esfera pública, ao desempenhar sua função de "alarme", poderia ecoar as pretensões da opinião pública formada discursivamente e em relação com "as biografias da esfera privada" para, com isso, "capacitar" as rotinas do sistema administrativo com elementos de variabilidade. Isso, pois além dos elementos internos ao sistema político que lhe garantem variabilidade como a circulação e a contracirculação do poder - me parece injustificado que Habermas tenha excluído dessa "função" também grupos auto-interessados, pretensões vinculadas a outros sistemas sociais e a seus "públicos específicos" dessa função. Além disso, desenvolvimentos já conhecidos por teorias de médio alcance afirmam que o processo de "formação da agenda" política é muito complexo e perpassa diversos âmbitos ou "múltiplos fluxos" que não podem ser encarados como "formações espontâneas". Apenas a título ilustrativo, podemos citar o modelo de Kingdom que encara a "formação e a

${ }^{556}$ Ver LUHMANN, 1990, p. 178-9 e p. 183. 
mudança" da agenda política como o resultado da convergência entre três fluxos independentes que permeiam toda organização: (i) o fluxo dos problemas (problems), (ii) das soluções ou alternativas (policies), e (iii) da política (politics). ${ }^{557}$

Novamente, e em relação com o item anterior, isso parece ser uma decorrência do modelo de oposição "grosseira" entre âmbitos da integração da sociedade na teoria de Habermas. Mais importante do que isso, essa questão aponta para um problema interno da teoria habermasiana. Ainda que o autor coloque a esfera pública e a opinião publica nela formada como estando fora do sistema político (tese da auto-contenção), Habermas parece se contradizer quando afirma que, a partir da esfera pública, seria possível realizar um movimento "centrípeto" que parta da periferia do sistema político para o seu centro (tese do rompimento das comportas). Como vimos no capítulo anterior a partir dos comentários de Lubenow, não está claro como a esfera pública "defensiva" ou auto-contida se relaciona com a esfera pública "ofensiva", que visa a influenciar o poder administrativo. Ainda que considerássemos que Habermas teria substituído completamente o modelo defensivo pelo ofensivo - o que me parece incorreto, uma vez que seu modelo necessita ainda de conceitos vinculados à sociedade civil organizada e "livre" e de associações voluntárias em cultura política ativa -, o problema de consistência teórica se mantém, já que Habermas, ao colocar a esfera pública como atuando também "dentro da periferia do sistema político", estaria incorrendo em um argumento que contribui para a autolegitimação desse sistema.

Esse problema teórico é bastante mais claro em Luhmann, que encara a opinião pública como uma comunicação política. Reconhecer que ela está na periferia do sistema não a torna menos ou mais importante, seja ela sociológica ou normativamente considerada. Na verdade, Luhmann afirma que o centro dos sistemas parciais é o "âmbito" mais próximo de seu fechamento operacional, enquanto a periferia dos sistemas é o "âmbito" mais próximo da abertura cognitiva, no qual as pressões e irritações de sistemas e comunicações de seu ambiente são mais fortes. Com isso, a opinião pública parece ser um elemento caro à abertura cognitiva do sistema político, "filtrando" irritações de seu ambiente que não vêm apenas de uma opinião de um "público nativo" da esfera pública, mas de pretensões, valores, interesses, discursos de diversos sistemas sociais de seu ambiente. $^{558}$

\footnotetext{
${ }^{557}$ Cf. exposto por CAPELLA, 2006, pp. 4-6 e p. 26.

558 Ver, e m sentido semelhante, NEVES 2006, pp. 124 e ss., esp. p. 133.
} 


\subsection{Implicações da “despolitização” da esfera pública}

Quando da introdução dessa dissertação, afirmei que o "caráter político" da esfera pública é um dos elementos centrais das discussões sobre o conceito. Nota-se, entretanto, que Luhmann realiza uma considerável "despolitização" ao tratar a esfera pública como o ambiente interno de toda a sociedade e não apenas do sistema político. Isso parece apontar para um elemento novo no campo das discussões sobre a esfera pública, uma vez que ela não é definida em relação aos sistemas político nem econômico.

Tal despolitização apresenta consequências importantes para a discussão. Ao desvincular a esfera pública do seu contexto especificamente político, poderíamos que considerar que circulam nela discursos, valores e pretensões não apenas de "públicos mobilizados", mas também provenientes de outros âmbitos sociais - inclusive de sistemas parciais; mas que com eles não se confundem. Isso pode ser formulado se concebermos a esfera pública como "fórum de comunicação" pública em um contexto de linguagem não organizada sistemicamente, ${ }^{559}$ no qual a função de autorreflexão de todos os sistemas sociais é possível.

Neste sentido, não seria necessário que a esfera pública fosse caracterizada apenas por associações voluntárias ou públicos ativos, o que possibilitaria relativizar as fortes exigências normativas que Habermas impõe à sociedade civil e à cultura política associativa em sua "produção espontânea". Mais importante ainda, ao não se ligar necessariamente apenas à política - por ser o ambiente interno de toda a sociedade - seria possível incluir na esfera pública discussões ou processos comunicativos que se voltem não apenas para o centro do sistema político e para a tomada de decisões vinculantes, mas também para outros âmbitos sistêmicos.

Seria possível imaginar, por exemplo, situações em que questões vinculadas na esfera pública se dirijam a questões como o tratamento humano de paciente em hospitais, discussões sobre ética e conduta de profissionais dos meios de comunicação de massa, discussões sobre modelos pedagógicos de ensino, sobre a função social da universidade, sobre formas de vida e "reconhecimento" de formas "alternativas" de conduta amorosa, etc. Nos casos em que sistemas complexos podem se observar a si mesmos, não seria necessário haver o requisito habermasiano do "público leigo", uma vez que é possível

${ }^{559}$ Stichweh afirma que a esfera pública não é um sistema (STICHWEH, 2005, p. 87). Em sentido parecido, a leitura que Marcelo Neves faz do mundo da vida por meio da teoria dos sistemas o encara como espaço de comunicação não estruturada sistemicamente (NEVES, 2006, p. 125). 
conceber discussões que, ainda que não estruturadas sistemicamente, possam se dar em públicos especializados vinculados a certos sistemas sociais. Poder-se-ia até falar em esfera públicas que se vinculam a públicos especializadas, como uma esfera pública do esporte, por exemplo; onde "fóruns de comunicação" se ligariam a públicos especializados. ${ }^{560}$ Reforce-se que reconhecer que esferas públicas podem se tornar referidas a públicos especializados não implica, de forma alguma que elas se constituam em um sistema funcional. Por isso, nada impediria a formação de esferas públicas vinculadas a sistemas organizacionais, por exemplo, como tribunais, bancos ou universidades. Aliás, o conceito de esfera pública, como âmbito social de comunicações não organizadas sistemicamente apresenta um âmbito a partir do qual diversos sistemas sociais (interações, organizações e sistemas parciais) podem se observar e observar aos outros. Esta caracterização levou Rudolf Stichweh a afirmar que a esfera pública seria um "meio" através do qual poderiam ser realizadas observações mútuas entre os sistemas. ${ }^{561}$

É claro, muitas das comunicações, valores e pretensões vinculadas nas "esferas públicas especializadas" podem passar a exigir regulação e se direcionar ao sistema político. Contudo, para assim fazer, elas precisam passar pelo meio da opinião pública e formar temas com os quais seja possível adotar um posicionamento do tipo “favorável/contrário" para, então, se constituírem como comunicações políticas passíveis de adentrarem o processo de circulação e contracirculação do poder.

Ademais, essa esfera pública compreendida como o "espelho" do sistema-sociedade é potencializada com a existência de um sistema dos meios de comunicação em massa diferenciado $^{562}$ que tem alta capacidade de se acoplar estruturalmente com qualquer outro sistema social por meio dos "temas" de suas notícias. ${ }^{563}$

${ }^{560}$ Stichweh afirma que o público é o destinatário (Adressat) de uma esfera pública determinada, sendo por ela constituído. Por esse motivo, o autor concebe a existência de esferas públicas "especializadas", como uma esfera pública dos tribunais (Gerichtöffentlichkeit), esfera pública política e esfera pública do esporte. (STICHWEH, 2005, p. 86).

${ }^{561}$ SITICHWEH, 2005, p. 86.

562 Luhmann prefere esse termo ao popular "mídia” para ressaltar o caráter mais abrangente desse sistema social.

${ }^{563}$ No tocante ao sistema político, é precisamente por tratar de temas que os meios de comunicação em massa irritam a formação da opinião pública lidando com a "tendência" de ambos para tematizar o conflito e chamar a atenção pública para ele. 


\subsection{Legitimidade como fórmula de contingência da política e uma "questão desconfortável"}

A tese da autolegitimação do sistema político sustentada na circulação e contra circulação do poder, tão criticada por Habermas, merece alguns comentários. Cabe ressaltar que, para Luhmann, a "legitimidade" é também a "fórmula de contingência da política". ${ }^{564}$ Desse modo, não haveria como se trabalhar com o conceito de "crise de legitimação" habermasiano, uma vez que a legitimidade política como fórmula de contingência é sempre deficitária, obrigando o sistema a funcionar paradoxalmente, buscando algo inalcançável. Note-se, apenas, que Luhmann afirma que as fórmulas de contingência podem servir para orientar a "autodescrição" do sistema ao qual se vinculam. Como vimos na introdução, isso ocorre da mesma forma com o direito que se descreve na "busca pela justiça". Da mesma forma o conceito de legitimidade pode ser utilizado como um autodescrição interna da política e de comunicações políticas de observação de primeira ordem. ${ }^{565}$

Nota-se uma relação de "equivalência funcional" entre legitimidade e justiça na sociologia luhmanniana. Cabe tratar da "função" desse instituo teórico. Luhmann argumenta que a diferenciação de sistemas funcionais na sociedade faz com que surjam "fórmulas de contingência" que podem afirmar "o que para cada sistema constitui o especificamente indiscutível". ${ }^{566}$ As fórmulas de contingência substituem a função do sistema funcional para a observação do sistema de modo que as autodescrições deste sistema encontrem ali um ponto de referência. ${ }^{567}$ Elas representam o "valor" ("Wert" mais compreensivo do sistema funcional, funcionando como um "termo divino" ( "godterm”) que possibilita uma unidade na autodescrição do sistema: "[a] forma, com a

${ }^{564564}$ Por uma história dos conceitos, Luhmann afirma não ser mais possível vincular a fórmula da contingência da política ao "bem comum".

${ }^{565}$ LUHMANN, 2000, pp. 122-126.

566 LUHMANN, 2007a, 371, onde o autor nota que "o fato de que estas fórmulas estão ligadas a sistemas de função particulares deixa em aberto o significado delas para o conjunto da sociedade”.

${ }^{567}$ LUHMANN, 2007b, 130.

568 Sobre a fórmula de contingência da política - a legitimidade -, Luhmann afirma não ser ela meramente um "valor", uma vez que "ela é muito mais coordenada pela autopoiese do sistema político e pela contingência estrutural desse sistema". O valor, por uma perspectiva funcional, é encarado como uma "forma vazia" ("Leerformel”) (LUHMANN, 2000a, p.125). O tratamento funcional que Luhmann dá ao "valor" da fórmula de contingência fica mais claro em seu tratamento da justiça como forma de contingência do sistema jurídico, que está para o plano da auto-observação do sistema na forma de norma, mas apenas em um plano muito abstrato que não se confunde com os critérios e programas do sistema, pois não pode orientar decisões sobre lícito/ilícito diretamente. (LUHMANN, 2005a, p.279 e 282-83). 
qual o sistema introduz auto-limitação (selbst Limitationalität), denominamos de fórmula de contingência". ${ }^{59}$ Note-se que "[m]ediante estas fórmulas contingentes sempre apresentar-se-á uma semântica propícia com a qual sempre se 'pode-se fazer algo andar' ( 'puede echar a andar algo')" no contexto do sistema funcional em questão. ${ }^{570}$ Assim, as fórmulas de contingência podem ser consideradas geradoras de diversidade ("generation of diversity" - g.o.d ${ }^{571}$ ), algo que gera circularidade reflexiva e dá as "condições de possibilidade" (Bedingungen der Möglichkeit) para que o sistema continue operando na busca por esta fórmula de contingência. Isso vale para todos os sistemas, uma vez que se houvesse justiça plena não haveria necessidade de um sistema jurídico, se não houvesse escassez não haveria necessidade de um sistema econômico ${ }^{572}$, se houvesse legitimidade total na política não haveria motivos para votações ou constituição do sistema político.

$\mathrm{Na}$ introdução, tentei traçar uma relação de equivalência funcional entre a dogmática e a teoria democrática, referidas ao sistema jurídico e político respectivamente. Por ora, cabe uma análise mais detida do conceito luhmanniano de legitimidade como fórmula de contingência do sistema político, especificamente. Legitimidade política é questão formulada e buscada pelo sistema parcial político, ou seja, buscada e operacionalizada pelas comunicações políticas e conflitos esquematizados politicamente, como, por exemplo, pela posição governo/oposição; esquerda/direita em programas partidários, posicionamentos a favor/contra pela opinião, ou em manifestações "na sociedade, mas que negam essa mesma sociedade" em movimentos de protesto.

Luhmann apresenta as dificuldades que uma teoria que busca descrever a sociedade enfrenta caso não se diferencia de pretensões políticas de legitimação de ordens ou modelos institucionais - ainda que muito abstratamente. ${ }^{573}$ Nesse caso, parece não haver diferenciação clara de uma teoria social e das pretensões que poderiam ser formadas no sistema político.

${ }^{569}$ LUHMANN, 2000a, p. 119-120. Luhmann afirma também que "as formulas de contingência têm a capacidade de orientar as autodescrições dos sistemas funcionais” (idem p. 126).

${ }^{570}$ LUHMANN, 1996c, p. 285.

${ }^{571}$ Luhmann cita o termo em inglês (LUHMANN, 2005a, pp. 283-285). Interessante notar que "Deus" é a fórmula de contingência da religião (LUHMANN, 2007b, pp 129 e ss).

572 Agradeço a Marcelo Neves pela exposição deste argumento (comunicação pessoal). Neves também atenta para o fato de que Karl Marx já havia notado esta questão para a questão da economia. Em um mundo comunista de abundância, não apenas o Estado não seria mais necessário, mas também a própria economia (capitalista).

${ }^{573}$ Alguns desses argumentos são formulados de forma tangencial por Luhmann (LUHMANN, 1998c). 
Talvez seja por esse motivo que a teoria habermasiana tenha tamanha dificuldade para enquadrar em sua teoria associações "espontâneas", livres, que surgem para defender finalidades totalitárias, ${ }^{574}$ contrariar direitos civis ou exercer "opressão" pura e simples. Ao reconhecer estes casos, a oposição entre sistema e mundo da vida parece não ajudar, mas não deixa de haver certo desconforto da teoria em reconhecer tais fenômenos, o que a leva a subestimá-los consideravelmente.

\section{A sombra da exclusão social: o outro lado de uma esfera pública universalista em relação a discursos}

A questão da inclusão de "pessoas",575 em processos sociais (e políticos) é um tema extremamente frutífero na teoria sociológica e na teoria política. Com o advento da sociedade moderna, hipercomplexa e diferenciada funcionalmente, esta questão se intensifica, uma vez reconhecido que os sistemas parciais da sociedade aumentam seu âmbito de inclusão: um maior contingente populacional é incluído nos sistemas sociais, na economia de massa, na arte, no direito, na política, nos meios de comunicação em massa, etc. Seja esta inclusão entendida como for, o essencial é notar que os sistemas parciais da sociedade parecem ter aumentado consideravelmente seus âmbitos de reprodução, referindo-se a contingentes maiores de pessoas. Além disso, como vimos, a sociedade moderna passa a ser entendida como uma sociedade mundial, ou seja, que se reproduz por operações que vão além das fronteiras políticas. Contudo, nem todos os sistemas sociais parciais têm a mesma "capacidade" de internacionalização. Enquanto sistemas sociais parciais vinculados "a estruturas primariamente cognitivas da sociedade mundial” (como a ciência, técnica e a economia) tendem a se reproduzir com maior independência de contextos territoriais ou "nacionais"; sistemas sociais vinculados a estruturas "primariamente normativas", como é o caso do sistema jurídico e do sistema político, tendem a se reproduzir de maneira mais vinculada ao contexto nacional. É precisamente

574 Trabalhos que vinculam a queda da República de Weimar e o crescimento do nazismo a uma sociedade civil organizada e com associações livres (BERMAN, 1997), por exemplo, apresentam um problema sério para a teoria deliberativa tal como formulada por Habermas. No mesmo sentido, Luhmann argumenta que Habermas não consegue ser consistente entre sua teoria deliberativa (procedimental) de presunção de racionalidade de discursos, por um lado, e realizar o afastamento de premissas morais substantivas, por outro, e dá um exemplo: "quando ele [Habermas] se engaja em condenações morais de ataques criminosos feitos por jovens estrangeiros em busca de asilo político, ele substitui tacitamente uma perspectiva demo-crática por uma demo-crítica. Ainda que se concorde sinceramente com ele, isso é um desastre para sua teoria. Grosso modo, aqueles que se sentem afetados pela demora em procedimentos de expedição de asilo político deveriam ser convidados para o discurso" (LUHMANN, 1998c, p. 159).

575 cf. LUHMANN, 1998b. 
nestes sistemas que o tema da "inclusão" de pessoas ganha maior relevância na discussão moderna: a inclusão de pessoas nos sistemas jurídico e político ganha o título de cidadania.

Todavia, a "ampliação da cidadania", quando descrita como um fenômeno apenas de aumento progressivo da "inclusão" nestes sistemas, deixa de evidenciar paradoxos da inclusão e, principalmente, sua "sombra": a exclusão. Neste sentido, argumento que a teoria dos sistemas de Niklas Luhmann, ao abordar a diferença "inclusão/exclusão" como uma "forma de dois lados", permite tanto uma explicação sociológica inovadora para a questão da cidadania, quanto apresenta um problema teórico sociológico para a teoria habermasiana de esfera pública.

\subsection{Dois modelos de cidadania: status de direitos ou atitude política?}

A questão da cidadania (citzenship, Staatsbürgerschaft) desenvolve-se no contexto da inclusão no Estado Nacional. Mas este não é o único elemento atribuído às caracterizações da cidadania. Podemos selecionar, para os fins das discussões deste capítulo, duas correntes: (A) cidadania institucionalizada por direitos e (B) cidadania "ativa".

A primeira corrente - $(A)$ - aponta para um conceito de cidadania vinculado à inclusão em sistemas de direitos. A formulação clássica é a de T. H. Marshall em sua formulação da cidadania como status ${ }^{576}$ de "cavalheiro" concedido por direitos civis, políticos e sociais; de forma a considerar a cidadania como "princípio de igualdade social". Nesta linha, Talcott Parsons adiciona um elemento "cultural" aos três anteriores, desenvolvendo uma teoria mais compreensiva ou abrangente da sociedade. Por outro lado, (B) a segunda corrente, que podemos atribuir a uma "inspiração republicana" e um caráter normativo tende a enfatizar o caráter político e ativo da cidadania em uma inclusão mais abrangente do que jurídica (inclusão pela democracia procedimental deliberativa ou pelo reconhecimento intersubjetivo). Com Jürgen Habermas, temos uma tradição que concebe a cidadania não como uma "passividade" receptora de direitos, mas como um exercício de autogoverno. Além disso, a posição de Axel Honneth que traz a questão da "luta por

576 Sustentei em outra oportunidade que a teoria de Marshall é uma teoria da cidadania como status, que se refere a uma condição "efetiva" de confluência de direitos (RIBEIRO, 2009). Em sentido semelhante, Jürgen Habermas afirma que "Marshall defende a tese segundo a qual o status de cidadão foi sucessivamente ampliado e fortalecido nas sociedades modernas" (HABEMAS, 2003c, p.293). 
reconhecimento" também parece caminhar no sentido de argumentar nesta linha teórica que conceitua a cidadania como algo além da inclusão jurídica.

T. H. Marshall descreve a cidadania como status concedido a "membros integrais de uma comunidade", que teriam iguais direitos e obrigações. Isso implica uma redução na desigualdade (ou um "aumento no mínimo daqueles a quem é conferido o status) ${ }^{577}$. Além disso, a cidadania em Marshall também adquire um conceito de "princípio de igualdade social" que pode conviver com o princípio da desigualdade das classes sociais no sistema capitalista. A saída para a convivência destes dois princípios opostos ("crescimento e florescimento conjunto") ocorreria na condição de civilizado (cidadão) composta por três elementos: direitos civis, direitos políticos e direitos sociais. Ou seja, para o autor, a condição de cidadania só estará completa (trata-se de um processo) quando estes três elementos estiverem presentes ao mesmo tempo ${ }^{578}$. A condição de cidadania pressupõe todos os elementos em conjunto. ${ }^{579}$ Em suma, podemos reconhecer que Marshall conceitua a cidadania como um fenômeno referente a direitos, além de ser um princípio de "combate" a desigualdade (e aqui a importância dos direitos sociais é essencial). A cidadania e sua ampliação trata-se de um progressivo aumento da inclusão no direito. ${ }^{580}$

Ainda nesta primeira corrente, cabe uma breve e superficial citação da contribuição de Talcott Parsons. Este autor reconhece que apesar do "interesse sociológico" focar a questão da iniqüidade (inequality) e suas formas existiria uma "tendência para a institucionalização de bases continuamente crescentes de equidade (equality)" na sociedade moderna, na qual uma nova definição normativa da sociedade com os direitos naturais e humanos gerou um "foco igualitário de um sistema de 'direitos' inegável” que se relacionava com o conceito de cidadania (citzenship) proveniente da Revolução Francesa. Parsons reconhece que na modernidade duas das mais profundas bases de atribuição de iniqüidades (deep-seated ascriptive bases of inequality), religião e etnia, perderam muito de sua força em uma sociedade que se tornou notavelmente pluralística em sua

${ }^{577}$ MARSHALL, T. H.. 1967, p. 76.

${ }^{578}$.MARSHALL, T. H, 1967, p.63.

579 “A igualdade implícita no conceito de cidadania, embora limitada em conteúdo, limitou a desigualdade do sistema de classe, que era, em princípio, uma desigualdade total” (MARSHALL, 1967, p. 77).

580 Marshall acredita nesta "progressiva" inclusão (ou concessão de status por meio de direitos de cidadania) e coaduna com a afirmação de Alfred Marshall de que o problema "não é se, em última análise, todos os homens serão iguais - certamente eles não o serão - mas se o progresso não pode prosseguir firmemente, mesmo que vagarosamente, até que, devido à ocupação ao menos, todo homem será um cavalheiro. Afirmo que pode e que isso acontecerá (MARSHALL, 1967, p. 58). 
composição. ${ }^{581}$ Isso ocorreu devido à mudança dos focos de atribuição de iniqüidades (foci of ascription) que se centralizaram em uma "comunidade societal" da "sociedade nacional". ${ }^{582}$ Partindo do reconhecimento de valores da sociedade, Parsons argumenta no sentido de que "os princípios igualitários da sociedade moderna se encontrariam em uma tendência de institucionalização": com a ruptura com estruturas "ascriptivas" hierárquicas da sociedade pré-moderna, ocorre uma nova institucionalização do equilíbrio entre a iniqüidade-equidade (equality-inequality) em todas as sociedades modernas. Em suma, o valor da equidade passa e ser a regra e inserções de iniqüidade necessitam de justificação. ${ }^{583}$

Este equilíbrio entre desigualdade e equidade prostra-se como um "problema integrativo" da sociedade ${ }^{584}$. Parsons associa a função integrativa da sociedade com o "direito". ${ }^{585}$ É pela noção de direitos com função social integrativa que o "valor" moderno da equidade ganha institucionalização. ${ }^{586}$ Contudo, para Parsons, a questão da equidade como "cidadania" não lida apenas com a função, integrativa da sociedade; mas também com a função de manutenção de padrões (pattern-maintenance) relacionada à cultura. ${ }^{587} \mathrm{E}$ por este motivo que Parsons adiciona um elemento cultural aos elementos civil, político e social da cidadania propostos por T. H. Marshall. A conclusão de Parsons é que os “principais componentes igualitários estão ancorados nos subsistemas 'internos' da sociedade, precisamente os de manutenção de padrões [pattern maintanence] e integração (ou a comunidade societal)". Portanto, do lado da equidade, isso implicou a institucionalização de direitos fundamentais e de um "sistema básico de igualdade de status da qualidade de membros" [membership status]. Do ponto de vista da iniquiidades, estas teriam de ser justificadas por "necessidades adaptativas" seja por questões de poder e autoridade, por um lado, ou por questões econômicas de alocação de recursos.

${ }^{581}$ PARSONS, 1970, pp. 14-15.

582 Parsons reconhece que esta centralização tanto das bases que atribuem desigualdades quando da própria solidariedade foi um fenômeno complexo que oscilou entre religião e bases governamentais. Mas o "nacionalismo" e a "concentração territorial de funções" foram elementos importantes. Aqui, a "sociedade nacional" ou o sistema da "comunidade societal" coloca-se como central. (PARSONS, 1970, pp.14-18)

${ }^{583}$ PARSONS, 1970, pp.19 e ss.

${ }^{584}$ PARSONS, 1970, pp.20-26

${ }^{585}$ Ver o esquema “AGIL” das funções “estruturais” da sociedade em PARSONS,1970, pp.57 e ss.

${ }^{586}$ PARSONS, 1970, p 28 e ss. Aqui, Parsons refere-se diretamente à Marshall.

${ }^{587}$ Esta base valorativa de direitos "constitui a especificação do sistema geral de valores da sociedade ao nível da estrutura normativa da comunidade societal”. (minha trad. grifos originais. PARSONS, 1970, p.33). 
Além desta concepção de cidadania que implica a "inclusão" de pessoas no contexto nacional por meio da institucionalização por direitos; encontramos uma concepção normativa da cidadania - $(B)$ - que resulta em uma análise que vai além da mera referência à inclusão jurídica, implica antes uma concepção "ativa" da cidadania. No Capítulo 2, vimos o desenho geral da teoria de Jürgen Habermas. É possível sustentar que o autor formula um conceito de cidadania "ativa", referindo-se ao "procedimento deliberativo legítimo" concretizado em "esfera pública plural” enraizada em uma cultura política e em uma sociedade civil associativa no contexto de "um mundo da vida racionalizado".

Ademais, o conceito de cidadania habermasiano não se restringe à mera inclusão jurídica. Do ponto de vista histórico, Habermas reconhece a passagem da noção de “inclusão" de uma identidade nacional de "origem homogênea" para uma ancoragem "político-cultural" em sociedades pluralistas que se caracteriza como "patriotismo constitucional". ${ }^{588}$ Seu conceito de cidadania está, pois, mais próximo a uma concepção republicana, "ativa" 589 , fundada na prática de uma cultura “política libertária”. Habermas é categórico: "não é necessário amarrar a cidadania democrática à identidade nacional de um povo; porém, prescindindo da variedade de diferentes formas de vida culturais, ela exige a socialização de todos os cidadãos numa cultura política comum". ${ }^{590}$ Isso seria generalizado pelo médium do direito e por procedimentos juridicamente institucionalizados para a formação de vontades públicas. ${ }^{591}$

Além de Habermas, Honneth também pode ser considerado um teórico desta corrente relativa a uma cidadania "ativa" que não se reduz à mera inclusão jurídica.Honneth reconstrói o que chamou de "vestígios de uma tradição" filosófica social

${ }^{588}$ HABERMAS, 2003c, pp.281 e ss.

${ }^{589}$ HABEMRAS, 2003, c, p.286 e p.293.

590 HABERMAS, 2003c, p. 289. Em outro texto Habermas fala de "uma cultura política compartilhada por todos os cidadãos", se é que dentro desta comunidade política podem coexistir uma multiplicidade de culturas; e cita o caso dos Estados Unidos (HABERMAS, 1998, p. 190).

591 HABERMAS, 2003, c, p. 295. No texto em que o autor busca responder à pergunta entre a “inclusão e o confinamento" na inserção política ("Inklusion - Einbeziehen oder Einschließen?”) o autor desenvolve um conceito de inclusão política sensível às diferenças, com possibilidade de haver "solidariedade de estranhos" mesmo para além de âmbitos de identidade cultural ou de mero "patriotismo constitucional" em contextos de Estados nacionais. Para sustentar essa tese, mais uma vez, Habermas reconhece que uma concepção intersubjetivista da soberania popular procedimentalizada permite ver como a "formação da vontade política se realiza por meio dos discursos públicos que visam a aceitabilidade racional das regras, à luz de interesses generalizados, de orientações de valor compartidas e de princípios fundamentados. Desse modo, esse conceito não-instrumental de política apoia-se no conceito da pessoa que age comunicativamente" (HABERMAS, 2007, p. 164 - ver pp. 153-178). 
que - a partir de Hegel - teria trabalhado a noção de luta por reconhecimento como central no diagnóstico de época e, mais importante ainda; na elaboração de teorias normativas (ou críticas). Honneth sustenta a existência de uma "luta pelo reconhecimento de pretensões de identidade" ${ }^{, 592}$ e, portanto, ao analisar o conflito e os movimentos sociais afastando-se da noção de "interesse" para incluir como motivo da mobilização: "experiências morais de desrespeito". 593 Logo, a luta social ganha contornos morais (sentimentos morais de injustiça) e adquire a feição de uma luta por reconhecimento. Para isso, implica notar que esta "luta" é necessariamente social, pois coletiva, por "relações ampliadas de reconhecimento". O que é central perceber é que Honneth relaciona a noção de formação de identidade coletiva como uma ponte semântica entre as experiências individuais. ${ }^{594}$ Por fim, Honneth sustenta uma versão da evolução de um processo moral "universal". Para ele, além do modelo de conflito como reconhecimento ser um quadro de explicação do surgimento dos movimentos sociais, ele também é um quadro interpretativo de um progresso moral de uma "lógica universal da ampliação das relações de reconhecimento". 595

Vimos, portanto, duas “correntes" ou abordagens sobre o fenômeno da cidadania com referência à inclusão social no âmbito de direitos e da política. Uma delas vê esta inclusão como uma inclusão referente a direitos; a segunda associa a ela um âmbito de "atitude política", de cultura político-democrática e de "reconhecimento intersubjetivo". Todavia, o que podermos afirmar de comum entre estas abordagens é que ambas apresentam uma visão de progressiva inclusão na sociedade.

\subsection{A diferença "Inclusão/Exclusão" e suas implicações para o conceito de cidadania}

Em um primeiro momento, em 1981, Luhmann conceituou a inclusão como "a incorporação da população global às prestações dos distintos sistemas funcionais da sociedade. Ela faz referência, por um lado, ao acesso a estas prestações e, por outro, à

${ }^{592}$ HONNETH, 2003, p.229.

${ }^{593}$ HONNETH, 2003, p. 254.

${ }^{594} \mathrm{Em}$ outras palavras, na luta social, a identidade coletiva conecta as experiências privadas e possibilita uma semântica coletiva que resulta em uma articulação de um "quadro interpretativo". Isso tudo gera um horizonte subcultural de interpretação dentro do qual as experiências de desrespeito vividas privadamente podem se unir em uma "luta por reconhecimento" (coletiva) (HONNETH, 2003, p. 258-9).

${ }^{595}$ HONNETH, 2003, p. 265. 
dependência que estas virão a ter dos distintos modos de vida individuais". 596 A "inclusão" para este autor independe, portanto, de identidades coletivas e de reconhecimento intersubjetivo.

O que nos interessa propriamente, porém, é a segunda consideração de Luhmann sobre a inclusão; posição que ele alterou em 1995. Partindo de seu conceito de diferenciação funcional, Luhmann afirma que a integração da sociedade só pode ser realizada por meio de sistemas sociais parciais. Por integração entende-se "a limitação dos graus de liberdade que se proporcionam de forma recíproca os sistemas estruturalmente acoplados". ${ }^{597}$ Portanto, a ideia de integração proposta por Parsons (que vimos no item acima), é lida por Luhmann como subcomplexa, pois pressupõe a integração referente a toda a sociedade indistintamente. Parsons compreende um "sistema social solidário maior", 598 que implica compartilhamento de normas e consensos sociais - algo impossível para Luhmann. Portanto, Luhmann critica o conceito parsonianno de inclusão uma vez que ele faz referência a este contexto maior, além do fato de que Parsons recairia em uma "lógica de desenvolvimento" 599 , como se uma inclusão progressiva fosse possível até alcançar, no limite, uma inclusão total. Luhmann deixa claro que "a inclusão na sociedade moderna ocorre por meio dos sistemas funcionais, para cujas relações já não existe de qualquer modo uma fórmula geral" ${ }^{600}$ Acreditar em uma inclusão generalizada implica desconhecer o outro lado da questão, ou seja, a exclusão, que acaba sendo vista pela teoria sociológica apenas como "sombra lógica". ${ }^{601}$ Luhmann propõe que conceituemos a diferença inclusão/exclusão como uma "forma de dois lados", sendo a inclusão a face interna e a exclusão a externa. Inclusão, portanto, relaciona-se com "seres humanos tratados como pessoas". 602

Para Luhmann, a sociedade moderna funcionalmente diferenciada não pode regular a inclusão de forma uniforme: a inclusão é regulada internamente pelos diversos sistemas

\footnotetext{
${ }^{596}$ LUHMANN, 1990, p. 34.

${ }^{597}$ LUHMANN, 1998d, p. 168.

${ }^{598}$ LUHMANN, 1998d, p. 169.

${ }^{599}$ LUHMANN, 1998d, p. 169-170.

${ }^{600}$ LUHMANN, 2007 b, p.260.

${ }^{601}$ LUHMANN, 1998d, p.193.

${ }^{602}$ LUHMANN, 1998d, p.172 e 1998, b.
} 
sociais separadamente. ${ }^{603}$ Portanto, não se pode falar em uma inclusão sem exclusão ou em uma inclusão "coordenada".

O ponto central é que Luhmann critica frontalmente a ideia habermasuana de que “a inclusão na sociedade global deve ser alcançada através de uma esfera pública que, mediante a discussão há de selecionar aquilo que lhes parece razoável a todos que são capazes de razão. A fascinação exercida por esta proposta somente pode explicar-se, provavelmente, porque parte da constatação de que a opinião pública consiste de indivíduos. E quiçá também devido a que não se contempla de modo algum a exclusão". ${ }^{604}$

Enfim, podemos argumentar que a teoria luhmanniana pode servir decrítica tanto à abordagem da cidadania que a concebe como "progressiva inclusão político-jurídica" quanto à abordagem da "cidadania ativa" pelo mesmo motivo: nenhuma delas aborda a questão da exclusão nestes âmbitos.

Baseados nestas reflexões, podemos sustentar uma compreensão da cidadania como inclusão nos sistemas jurídico e político que não necessita de pressupostos "intersubjetivos" de "reconhecimento mútuo", ou de cultura política; muito menos de "patriotismo constitucional" em uma identidade coletiva; mas também não implica um “desenvolvimentismo" ou inclusão em um "sistema solidário maior". Do ponto de vista analítico parece-me mais frutífero delimitar o fenômeno da cidadania desta forma mais restrita, retirando-lhe a sobrecarga normativa de pesados pressupostos "intersubjetivos" e “identitários" para sua caracterização. Com isso me parece ser possível delimitar o conceito de cidadania de maneira analiticamente mais precisa, de modo que a descrição funcional dos sistemas jurídico e político em sua regulação seja mais frutífera.

\subsection{Dois problemas "sociológicos": generalização de direitos e a falta da abordagem da "exclusão"}

Esses argumentos da "cidadania ativa", por diferentes formas, deixam margem para uma aposta de que o direito poderia "generalizar" também formas de "solidariedade entre estranhos" em um horizonte de uma cultura política comum, ainda que deliberativa e processualmente determinada (Habermas), por um lado, e lutas que resultariam na lógica universal da generalização das "relações ampliadas de reconhecimento" (Honneth), por

\footnotetext{
${ }^{603}$ LUHMANN, 1998d, p.176.

${ }^{604}$ LUHMANN, 1998d, p 178. Ênfase adicionada.
} 
outro. Considero que isso apresenta problemas sociológicos no contexto de uma teoria que vise a trabalhar a sociedade moderna mundial complexa e funcionalmente diferenciada. Ao "carregam normativamente" o caráter generalizador do direito - incluindo nele fortes pretensões integrativas, “identitárias” e de legitimação -, os autores argumentam encontrar um meio para generalizar suas pretensões normativas: a saber, o direito. ${ }^{605}$

Entretanto, considero que Luhmann apresentou diversas "boas razões" para enquadrar a evolução do direito como um sistema autopoiético cuja evolução - assim como toda a evolução da sociedade na diferenciação de seus sistemas parciais de função não seria passível de ser explicada por conceitos de integração. No processo de aumento da complexidade social, os sistemas parciais ganham maior capacidade de desenvolvimento e de generalização precisamente por não ser necessário que eles se vinculem a questões integrativas, pautando-se, antes, por meios de comunicação simbolicamente generalizados.

Isso dito, a mim me parece que um conceito mais restrito de cidadania tal como exposto aqui é defensável do ponto de vista sociológico. Cabe trazer algumas reflexões que, ainda que tenham certo caráter "ensaístico" e careçam de maior fundamentação teórica e empírica, podem auxiliar a formulação do argumento. Em primeiro lugar, do ponto de vista analítico, parece-me que diversas situações históricas apontam para um contexto claramente classificável como "expansão da cidadania" que, não obstante, ocorre mesmo RAM sem nenhum correlato de "ampliação de reconhecimento intersubjetivo". Este seria o caso, por exemplo, da conquista de direitos civis por negros nos EUA na década de 1960. Isso, pois o contexto social "intersubjetivo" da época era de elevado grau de dissenso e de forte desprezo e desconsideração pelo "outro", havendo discriminação contra negros inclusive no âmbito institucional. A violência contra negros era comum, inclusive com grupos organizados promovendo enforcamentos e assassinatos principalmente no sul dos EUA. A segregação física e espacial e o racismo institucionalizado pressupunham o não reconhecimento do outro. $\mathrm{O}$ conflito foi pautado pelo dissenso, inclusive por setores da opinião pública que propagavam a ideia da demarcação de diferenças (doutrina do "separate but equal").

É claro que o movimento social de protesto que culminou nos direitos civis pode ser encarado como uma "luta por reconhecimento" - e consequentemente há méritos na

${ }^{605} \mathrm{O}$ posicionamento de Honneth enxerga que as lutas por reconhecimento que geram identidade coletiva ocorreria dentro dos grupos em luta. Essa constatação não parece ter problemas. A questão se mostra mais problemática quando pensamos em uma "evolução de amplas relações de reconhecimento" generalizada por mecanismos do direito. 
teoria de Honneth. Entretanto, parece-me que a noção de "identidade coletiva"606 e a ampliação do "reconhecimento intersubjetivo" não se generalizou para além da própria ação coletiva e da formação do movimento em si. Carregar a generalização de direitos da cidadania - como direitos civis, por exemplo - com pretensões de formação de identidades coletivas implica desconhecer os mecanismos de generalização de direito, que podem se generalizar precisamente por atravessar a necessidade da formação de identidades coletivas amplas. Neste sentido, é possível trabalhar com a referência à institucionalização de direitos de cidadania prescindindo de um pressuposto intersubjetivo entre "todos os afetados" - discriminados e opressores. É neste contexto que uma estratégia de separação dissensual pode ser feita. Isso demonstra como a "cidadania como referência a direitos" pôde servir como ponto de referência para um movimento social em um contexto de impossibilidade quase total de seu reconhecimento. A inclusão jurídica veio antes do reconhecimento; uma vez que o racismo norte-americano, inclusive em formas violentas, continuou - e continua - por muito tempo.

Esse argumento encontra apoio e ganha maior especificação teórica quando partilhamos da formulação de Marcelo Neves - em seu texto "A Constituição e a esfera pública: entre diferenciação sistêmica, inclusão e reconhecimento" - de que o reconhecimento ocorre no plano das interações, enquanto a inclusão ocorre no plano sistêmico. Neves argumenta que é evidente haver uma circulação positiva entre reconhecimento (entendido como problema de "dupla contingência") e inclusão; contudo haveria uma assimetria entre eles: é impossível reconhecimento sem inclusão. O reconhecimento ou a sua falta, quando ocorre nas relações de interação concreta, não pode ser tematizado em termos de direitos e, assim, generalizado. Ele se limita a contextos interacionais restritos. A falta de reconhecimento social somente entrará como uma questão de cidadania a partir do momento em que ela se generalizar de tal forma a ponto de gerar exclusão social de um determinado sistema. ${ }^{607}$

Além disso, esta sobrecarga normativa que prevê a necessidade de "uma cultura política comum” para o conceito de cidadania pode tornar invisíveis movimentos de protesto minoritários que optem por adotar uma estratégia de dissenso ou embate frente a um "ambiente" hostil. Ora, podemos citar o mesmo exemplo. Frente a um contexto social

606 Para a importância de identidades coletivas na formação de movimentos sociais, ver: dentre muitos. COHEN e ARATO, 1992 e MELUCCI, 1989 e 1994.

${ }^{607}$ NEVES, 2009 a, p.681. 
racista e extremamente violento nos EUA a estratégia de alguns grupos de protesto foi precisamente a de apoiar-se em direitos em detrimento de reconhecimento mútuo ou cultura política comum. Não obstante, parece ser possível atribuir boas razões para afirmar que estes movimentos contribuíram de diversas formas para que o tema da segregação e da falta de direitos civis fosse formulado em termos de opinião pública e, com isso, ao adentrar o esquema de circulação e contra circulação do poder, e se institucionalizar.

\subsection{A exclusão na esfera pública política}

Considero que a questão da exclusão na esfera pública ainda apresenta problemas para Habermas, mesmo após a década de 1990. Sua ideia de "contextos discursivos de uma esfera pública plural universalista aberta a todos os discursos", por ser normativamente carregada, deixa de reconhecer outros tipos de exclusão fática, a saber, que ocorrem no nível das prestações de sistemas sociais. Essa parece ser uma grande consequência da "virtualização" da esfera pública conforme busquei discutir aqui a partir das considerações de Adrian Gurza Lavalle. Com efeito, o movimento de se apoiar em condições "utópicas" ideais da formação de discursos é aquele que mais afasta Habermas do caráter "sociológico" de suas análises sobre a esfera pública. ${ }^{608}$

Tanto a questão de "racionalização da dominação", tal como formulado em 1961, quanto a problemática da "legitimação" em Estados Democráticos de Direito de 1992 não acessam a questão da exclusão social presente em grande parte da sociedade mundial. Assim, ainda que Habermas delimite a esfera pública a um contexto político de legitimação, a questão da existência fática de severas restrições ao princípio da inclusão “de todos os potencialmente atingidos" na esfera pública não parece ter sido bem resolvida dentro da teoria do autor.

É forçoso reconhecer que Habermas tentou enfrentar essa questão. Toda a sua crítica da "ideologia" da esfera pública burguesa se pautou no sentido de levar em conta a questão da "dominação". Mesmo após se afastar do contexto da teoria de classes e da crítica ideológica na década de 1990, Habermas se viu novamente forçado a enfrentar a questão da exclusão na esfera pública. Contudo, sua solução ainda me parece insatisfatória, uma vez que ele insiste que a esfera pública pluralista não rejeitaria - a princípio - nenhum

${ }^{608}$ Ademais, parece-me ser possível atribuir às suas análises um forte caráter "eurocêntrico", uma vez que ele apresenta o postulado da exigência - ainda que latente - de "padrões de sociabilidade", "cultura política comum" e "patriotismo constitucional" que são muito ligados ao contexto europeu. 
outro discurso. Em outras palavras, seu reconhecimento de haverem "esferas públicas plurais" - que não se constituem como discurso hegemônico, pois seriam abertas a outros discursos em sua pretensão universalista - não parece suficiente para dar conta de amplos setores de exclusão da sociedade que não podem constituir ou tomar parte em discursos hegemônicos ou "contra-hegemônicos", se assim quisermos, uma vez que não contam nem com inclusão da cidadania ativa nem com inclusão por acesso e dependência em relação às prestações de sistemas sociais (como o jurídico e político).

Luhmann, de certa maneira, atribui essa "ingenuidade"609 da teoria habermasiana ao caráter contrafactual de sua teoria e pela tentativa do autor de apresentar uma crítica que pressuponha argumentos "transcendentais" em relação à sociedade. ${ }^{610}$ Luhmann afirma que o princípio básico trabalhado por Habermas é que "todos os afetados devem ser ouvidos e concordar". Contudo, a pergunta central seria saber como isso seria plausível na sociedade contemporânea. Luhmann reconhece que Habermas não localiza o problema no nível de comunicações que realmente ocorrem, e, ao contrário, "ele emprega uma teoria de como a coordenação racional" pode ocorrer em situações específicas e "ideais" de discurso. Com isso, Habermas se valeria de sua distinção entre facticidade e validade para basear suas conclusões, mas não conseguiria resolver a questão de ser esta distinção uma de oposição ou dialética, chegando ao resultado "insatisfatório" de considerá-las como uma relação mútua de "relações de tensão". Luhmann interpreta essa distinção como um postulado "autotranscendente das condições discursivas" idealizadas que realizariam uma "duplicação" da realidade ${ }^{611}$ e serviriam de "contraste com o mundo".

${ }^{609} \mathrm{O}$ termo e utilizado por Luhmann para indicar as inconsistências de uma teoria que, descolada da realidade social, não consegue enfrentar o problema de exclusão em suas considerações - ainda mais sabendo de suas pretensões críticas (LUHMANN, 1998c, p. 166 e ss.) Ainda que Luhmann atribua à teoria habermasiana um alto grau de "utopia", o autor argumenta não ser necessário abandoná-la só por isso (apesar de haver justificações para tal), uma vez que ela trabalharia com problemas também trabalhados pela teoria dos sistemas - como a questão dos "conflitos de validade e legitimidade- que, por sua vez, estariam "escondidos" sob termos tais como autorreferência, fechamento operacional, autopoiese, etc. Contudo, Habermas enfrentaria a questão de forma inadequada e normativa - não sendo a diferença metodológica mera coincidência. Luhmann afirma, não sem certa ironia, que a abordagem normativa de Habermas não seria adequada para a descrição da sociedade moderna, uma vez que a "frieza do banimento para um futuro incerto seria difícil de ser acalentada pelo aconchego da terminologia tradicional (p.ex. democracia, racionalidade, entendimento, consenso e até Lebenswelt)" (LUHMANN, 1998c, p.160-161).

${ }^{610}$ Vimos no Capítulo 1 o longo percurso que Luhmann faz para construir um conceito autológico de sociedade que evite conceitos exteriores a ela como racionalidade e moral, por exemplo.

${ }^{611}$ Segundo o autor, a "duplicação da realidade" separa um "mundo real e um mundo imaginário". Esse mecanismo seria evidente em outras distinções como "jogo/seriedade", "imanência/transcendência" (religião), "ficção/mundo real" (arte), etc. Todas elas "serviriam para tornar suportável a dureza da "realidade real" (real reality) (LUHMANN, 1998c, p.162). 
Isso ficaria claro na formação do postulado habermasiano que sustenta: "são válidas todas aquelas normas da ação com as quais todas as pessoas afetadas poderiam concordar como participantes de um discurso racional". "Poderiam” - ressalta Luhmann. Não haveria no modelo habermasiano a resposta de como isso poderia ocorrer: "como essa operação decisiva da qual a era pós-metafísica depende pode se tornar juridificada", "como o potencial vira realidade" e como o poder "surge" de "de uma sociedade civil que discute livremente - a qual, é claro, não existe". 612

Luhmann desenvolve, então, um argumento que é central para demonstrar como a teoria de Habermas não levou em conta a questão da exclusão na sociedade moderna - e como isso traria problemas consideráveis pra uma "teoria que se autodescreve como crítica”. Luhmann sustenta que Habermas utiliza a teoria do discurso para reformular questões do liberalismo clássico de acesso livre e igualitário de experiência e, portanto, não apresenta nenhuma proposta de reformas amplas ou revoluções. Assim, Habermas estaria muito próximo do projeto do "idealismo alemão" e do "romantismo poético", ao que Luhmann lamenta a falta "de um traço qualquer de ironia e, portanto, de distância do projeto em questão". Referindo-se implicitamente à teoria marxista, Luhmann argumenta: “em uma tradição crítica consideravelmente diferente, ficou evidente que ao tornar a liberdade e a igualdade absolutas, ou seja, pelo mundo de ideias políticas das classes médias, algo estava excluído", a saber: "um lado sombrio, não-iluminado (...) uma realidade diferente que não podia participar na positividade de tal sociedade. Atualmente, isso não precisa mais ser compreendido em termos da análise de classes, que era baseada, em grande parte, numa cópia do modelo fabril de organização do século XIX. Todavia, a questão que concerne a "liberdade e igualdade" por seu outro lado da fórmula, é atual mais do que nunca. Se todos podem tomar posições de um modo livre e igual, parece não haver mais exclusão - nenhuma escravidão jurídica, nenhuma impossibilidade de fala (speechlessness) estruturalmente determinada, nenhum efeito sistêmico pelo qual muitos são excluídos do trabalho e renda. Tais efeitos de exclusão (...) são impossíveis de se negligenciar. Os princípios de igualdade e liberdade dependem de uma auto-seletividade de participantes (...). Contudo, existem aqueles muitos que simplesmente não querem, não podem querer, que sofrem de depressão, (...) que querem ser deixados em paz, que têm que

${ }^{612}$ LUHMANN, 1998c, p. 165. Interessante notar que além de reconhecer essa fragilidade da tese da "espontaneidade" do argumento habermasiano, Luhmann também critica que sua teoria da esfera pública daria muita ênfase ao processo legislativo, evitando abordar outros âmbitos do poder político. Ambas as questões são levantadas por teorias de médio alcance para criticar os estudos do campo da chamada "nova sociedade civil". 
lutar para sua sobrevivência física em um grau tamanho que não deixa sobrar energia para nada mais". 613

Neste sentido, aqueles "pensadores racionais" que participam dos discursos poderiam até chegar a algum consenso, mas isso é feito com por uma forma que tem outro lado, um lado de exclusão. Luhmann reitera que, ao apontar tal questão da exclusão, não se trata de negar a gravidade dos problemas com os quais a teoria habermasiana se ocupa, mas, ao contrário, "reconhecer que os problemas são de escala tão grande que, em comparação, a referência a discursos poderia ser interpretada como escárnio (mockery)". 614

Importante notar que o tema da "inclusão/exclusão" na teoria luhmanniana ganhou muita força em seus últimos escritos. No âmbito destes "últimos escritos" (após 1993), essa questão foi muito central nas obras do autor, de modo que diversas de suas obras tratam dela, muitas em seus capítulos finais, deixando diversas perguntas em aberto. ${ }^{615}$ As consequências de lidar com o tema foram grandes para sua teoria, de modo que o autor a tratou de forma consideravelmente "ambígua".

Em um primeiro momento, Luhmann circunscreveu a existência de "amplos setores de exclusão" primeiro como "situações típicas de países localizados na modernidade periférica", ${ }^{616}$ afirmando que, nestes contextos, a diferença "inclusão/exclusão" poderia chegar a se constituir como um "metacódigo" a ponto de fazer com que a exclusão seja de tal natureza que as "pessoas" passem a contar apenas como "corpos". 617 Aqui o autor parece circunscrever os setores de exclusão ao contexto de países periféricos e ao âmbito regional da sociedade mundial. Contudo, em outros momentos, a questão parece ficar mais forte e comprometer o elemento central da diferenciação funcional da sociedade moderna em sua teoria. Luhmann chega a afirmar que, "talvez" a importância dos códigos funcionalmente diferenciados do direito e da política (que são responsáveis pela inclusão político-jurídica na forma da cidadania) "não sejam outra coisa senão uma anomalia europeia que irá perder paulatinamente força no curso da evolução da sociedade

${ }^{613}$ LUHMANN, 1998c, p. 170.

${ }^{614}$ LUHMANN, 1998c, pp. 169-172.

${ }^{615}$ Ver, por Exemplo, LUHMANN, 1998d; 2007a, pp. 490 e ss, 639-442; 2005, p. 660 e ss; 1998c, e 2000, pp. 427 e ss.

${ }^{616}$ LUHMANN, 1998d, p. 176.

${ }^{617}$ LUHMANN, 1998d, pp.181 e ss. Essa posição exagerada, contudo, deve ser entendida apenas como caso limite da cadeia de exclusão, havendo situações intermediárias diversas. 
mundial", ${ }^{618}$ de modo que a diferença "inclusão/exclusão" se torne a diferença-guia do próximo século. ${ }^{619}$

Conclui-se dessa discussão, portanto, que o fenômeno da exclusão apontado por Luhmann é um forte contraponto às pretensões "críticas" do modelo habermasiano de legitimação de Estados Constitucionais de Direito por meio de uma transformação de poder comunicativo em administrativo por uma esfera pública que rompa as "comportas" do poder político. Ao analisá-lo, é possível trazer à luz a questão de que os conceitos de "cidadania ativa" e a crença habermasiana em uma sociedade civil associada em "redes complexas" seriam não apenas implausíveis do ponto de vista sociológico, como também demasiado excludentes e, com isso, apresentariam um sério problema de formulação interna - problema esse que afetaria, inclusive, suas próprias pretensões normativas do "projeto inconcluso da modernidade".

\section{O modelo de Marcelo Neves: a esfera pública como arena do dissenso e a heterolegitimação do Estado Constitucional de Direito}

\subsection{Diferença de abordagens ${ }^{620}$}

Até agora abordamos a questão da esfera pública “entre eclusas e espelhos" apenas pela ótica da contraposição das teorias dos dois autores, com exceção de breves comentários aos argumentos de Rudolf Stichweh. Cumpre discutir, ainda que brevemente, um outro modelo de esfera pública que é trabalhado a partir da mesma tensão entre os referenciais teóricos abordados neste trabalho.

Note-se que a análise desenvolvida nessa dissertação se diferencia do modelo de Marcelo Neves por dois motivos: em primeiro lugar, no nível analítico, meus objetivos nesse trabalho são antes o de apresentar as tensões entre dois modelos da sociologia abrangente da esfera pública, bem como seus limites e possibilidades quando analisados comparativamente. Com efeito, a teoria-guia fundamental para os argumentos aqui desenvolvidos, é a teoria dos sistemas de Niklas Luhmann. Em oposição à minha

${ }^{618}$ LUHMANN, 2005a, p.

${ }^{619}$ LUHMANN, p. 1995c, p. 147.

620 Agradeço o parecerista "ad hoc" anônimo da FAPESP - Fundação de Amparo á Pesquisa do Estado de São Paulo - e ao Professor Orlando Villas Bôas Filho por chamarem minha atenção para esse ponto e para a necessidade de sua especificação quando da análise de meu relatório parcial e do trabalho entregue para a banca de qualificação. 
abordagem mais exegética e investigativa, Marcelo Neves analisa o conceito esfera pública a partir de uma discussão com as teorias do discurso e dos sistemas que, entretanto, resulta em um modelo próprio do autor. Ademais, tal "confronto teórico" é levado a cabo por Neves pela ótica dos Estados Constitucionais de Direito. Seu modelo, portanto, não é redutível a nenhuma das duas teorias, mas apresenta desenvolvimentos próprios realizados com mediações teóricas adequadas. Neste sentido, a abordagem e os objetivos da análise são diversos - e, assim, também o são as respectivas conclusões.

Em segundo lugar, Marcelo Neves desenvolve em suas análises um modelo específico de Estado Constitucional de Direito, o que lhe possibilita desenvolver a tese de que a esfera pública poderia prestar funções de "heterolegitimação" a esse tipo de Estado. Nesta dissertação, além de não tratar do conceito de Estado Constitucional de direito em nenhum dos autores referência desse estudo e carecer de um modelo próprio do conceito de esfera pública, fico restrito às formulações dos autores alemães e não considero conceitos como "heterolegitimação do Estado Democrático de Direito". Isso, pois ao proceder de forma exegética, fico apenas com o conceito de legitimidade como fórmula de contingência do sistema político.

Entretanto, é evidente que o modelo proposto por Neves exerceu grande influência na formulação dessa dissertação e que tratar dele aqui não consiste apenas em uma apresentação despropositada. Com efeito, Marcelo Neves, ao se deslocar criticamente no âmbito da teoria dos sistemas de Luhmann e exercer diálogos com a teoria habermasiana, desenvolveu críticas a ambos os modelos. Nota-se, com efeito, que um dos principais pontos que o autor discute em sua obra concerne os problemas levantados pela questão da "inclusão/exclusão" na sociedade moderna. ${ }^{621}$ Contudo, ao fazê-lo, o autor se volta para a discussão do que poderíamos chamar de "mecanismos de inclusão" da sociedade moderna, como cidadania, Estado de Bem estar social e Estado Constitucional de Direito. Suas teses e argumentos se pautam dentro desses contextos. É por isso que o núcleo temático de suas análises se volta para a discussão das "condições" e "perspectivas" dessas formas de organização política. Assim, Neves trabalha com um conceito de esfera pública pluralista vinculado aos procedimentos constitucionais dessa forma estatal, algo que não está presente em minhas análises, pois, como ficou claro no item anterior, reconheço também "aspectos positivos" da posição restrita que Luhmann adota acerca da esfera pública. Com isso, foi possível trabalhar a importância que o conceito "enxuto" de Luhmann teve para o

\footnotetext{
${ }^{621}$ Ver anexo dessa dissertação.
} 
desenvolvimento de análises de "esfera públicas específicas" e "públicos específicos" (cf. analises de Stichweh analisadas acima)

Além disso, como vimos no item anterior, pretendo trabalhar como uma abordagem que encare a questão da "inclusão/exclusão" na teoria luhmanniana de forma ainda mais "radical", por assim dizer, e com isso vinculá-la a contextos mais amplos. Com isso, pode ocorrer que outras problemáticas internas à teoria dos sistemas possam ser levantadas.

Enfim, a relação com o modelo de Neves não é uma de oposição, mas antes uma de forte influência sem haver total aderência, uma vez que tento estender o rico debate entre Habermas e Luhmann sobre a esfera pública para outros contextos e por meio de outras abordagens. Com isso, pode ser possível que novas questões sejam levantadas.

\subsection{Esfera pública como arena do dissenso}

Marcelo Neves apresenta modelos teóricos de Estado de Direito e de esfera pública construídos a partir (e para além) de Habermas e Luhmann ao reinterpretar criticamente, por meio de uma leitura de teoria dos sistemas, conceitos habermasianos como esfera pública pluralista e mundo da vida. ${ }^{622} \mathrm{O}$ autor descreve a relação entre esfera pública e Constituição no contexto do Estado Constitucional, propondo um modelo que não "sobrecarregue" normativamente a esfera pública com a pretensão de consensos conteudísticos nem deixe de considerar a influência do mundo da vida como base da construção sistêmica. ${ }^{623}$ Dessa forma, o Estado de Direito é encarado como a relação entre, por um lado, o acoplamento estrutural entre os sistemas político e jurídico (a Constituição moderna) e, por outro, a esfera pública pluralista com as diversas influências que recebe tanto de outros sistemas como de outras esferas sócias. ${ }^{624}$ Esta relação é pautada por procedimentos consensuais de mediação do dissenso ${ }^{625}$, que se relacionam com uma esfera pública pluralista onde discursos dissensuais de valores, interesses, expectativas e discursos emergem tanto de outros sistemas sociais, como do mundo da vida encarado

${ }^{622}$ NEVES, 2006, pp. 126 e seguintes.

${ }^{623}$ NEVES, 2006. p126 e ss.

${ }^{624}$ Por conseguinte, “assim compreendida, a esfera pública é uma área de tensão entre direito e política como sistemas funcionais acoplados estruturalmente pela Constituição, por um lado, e os demais sistemas funcionais e o mundo da vida, por outro". (NEVES, 2006, p.133. e 2009a, p. 670).

${ }^{625}$ NEVES, 2006, p 128 e ss. 
como lócus da linguagem não-especializada; além de outras estruturas sociais nãoestruturadas sistemicamente, como a moral e a família.

Neves concebe a esfera pública como um conceito moderno e, portanto, diferente da distinção entre público e privado proveniente tanto da Grécia Antiga como de algumas concepções de "privado" modernas no contexto de diferenciação funcional. Dessa forma, a esfera pública pluralista se relaciona com a Constituição moderna compreendida como uma aquisição evolutiva da modernidade que funciona como acoplamento estrutural entre a política e o direito ${ }^{626}$.

Vemos que Neves, de maneira distinta a Luhmann, considera a esfera pública como um espaço não organizado sistemicamente que provê heterolegitimação para os sistemas político e jurídico em uma arena conflitiva na qual se dá a relação (permanentemente) paradoxal entre consistência jurídica e adequação social. ${ }^{627}$ Ainda assim, Marcelo Neves se distancia também da ideia habermasiana "normativamente sobrecarregada" de esfera pública política que a localiza em um mundo da vida no qual agentes do agir comunicativo se movimentam orientados pelo consenso. ${ }^{628} \mathrm{Em}$ seu modelo, Neves reputa que "é discutível se o sentido da esfera pública do Estado constitucional, inclusive do ponto de vista 'normativo', consiste em alcançar resultados racionais, ou seja, consensuais". ${ }^{229}$ Para ele, o conceito de mundo da vida deveria ser entendido como 'espaço não-organizado da reprodução da sociedade'; o que permite que seja formulada a seguinte conceituação de esfera pública: “a esfera pública é formada pelo conjunto de valores, interesses, expectativas e discursos que emergem dos diversos sistemas funcionais e do chamado 'mundo da vida' (...) e perdem sua pertinência de sentido específica às respectivas conexões sistêmicas de comunicações e às referências concretas do mundo da vida, com pretensão e a exigência de influenciar os procedimentos de produção e concretização

626 NEVES, 2009a, p.660.

627 O autor afirma "embora a teoria sistêmica luhmanniana admita, tanto para a sociedade em geral quanto para a política e o direito acoplados constitucionalmente, a relevância da moral e do protesto como formas não estruturadas sistemicamente de comunicação, ela não aceita o conceito de esfera pública como âmbito de comunicações não estruturado sistemicamente, mas apenas o conceito 'público' como dimensão funcional do sistema político. Essa ortodoxia sistêmica dificulta certas análises mais apuradas da sociedade supercomplexa do presente. Negar a esfera pública como conexão de comunicações não estruturadas sistemicamente, mas relevante para a heterolegitimação da política e do direito como sistemas acoplados constitucionalmente, parece-me decorrer de um preconceito da teoria dos sistemas" (NEVES, 2009a ,p.667).

${ }^{628}$ NEVES, 2009a, p.668.

${ }^{629}$ NEVES, 2009a, p.669. 
normativa, bem como os de tomada e execução de decisões políticas no Estado Constitucional". 630

Somado a isso, Neves sustenta que a esfera pública pluralista pressupõe inclusão e reconhecimento. ${ }^{631}$ Portanto, reforça-se a necessidade de que procedimentos constitucionais mantenham a esfera pública pluralista como "arena do dissenso", paradoxalmente incentivando este lócus conflitivo que gera legitimidade para os sistemas jurídico e político se ele se encontrar em um contexto de inclusão. Daí o motivo pelo qual Marcelo Neves utiliza-se do termo "pluralista" para qualificar a esfera pública moderna: existe uma pretensão (obviamente nunca plenamente atualizada) de inclusão generalizada para a participação na esfera pública.

Uma discussão é importante, aqui. Ainda que haja um "contexto de inclusão" na esfera pública pluralista tal como proposta por Neves, poderíamos perguntar pelo alcance dessa legitimidade em um contexto mundial de grande exclusão social. Importante notar, contudo, que o conceito de "heterolegitimação de procedimentos constitucionais" proposto por Neves não se assemelha ao conceito habermasiano "normativamente carregado" de legitimação, pois, como vimos, Neves afasta completamente o elemento da formação de “consensos" para encarar como central o caráter dissensual da esfera pública.

Perguntar pelo "alcance" da heterolegitimação de Estados Constitucionais de Direito parece fazer sentido em uma época em que se reconhece que estes Estados Constitucionais ou Estados de bem estar considerados "mais consolidados" ou "integrantes da modernidade central" estão em crise na Europa. Neves discute essa questão a partir de seu conceito de "periferização paradoxal do centro". Ao fazê-lo, em um primeiro momento, o autor parece apresentar poucas alternativas que não aquela que vise a reforçar ou fortalecer os Estados Constitucionais de Direito. ${ }^{632}$ Apesar de relevante, isso parece ser restrito quanto contraposto a um amplo contingente de exclusão social na sociedade mundial. Contudo, posteriormente, o autor desenvolve a tese do "transconstitucionalismo" e passa a enfrentar problemas de legitimação e de condições sociológicas não mais vinculados apenas aos Estados Constitucionais de Direito. ${ }^{633}$

${ }^{630}$ NEVES, 2009a, p.669-670.

631 Afirma o autor: “a esfera pública pressupõe inclusão das pessoas nos sistemas funcionais e reconhecimento recíproco no âmbito das interações" (NEVES, 2009a, p p.674). Importante notar que Neves diferencia seu conceito de "inclusão" e "reconhecimento" se afastando da concepção que Axel Honneth desenvolve e buscando interpretações mais próximas a conceitos da sociologia luhmanniana.

${ }^{632}$ NEVES, 2007a, pp. 191 e ss.

${ }^{633}$ NEVES, 2009b, esp. pp. 279 e ss. 
Seja como for, uma conclusão parece ser clara: a esfera pública não parece poder desempenhar um grande papel seja no enfrentamento da "crise" do Estado de Bem estar na Europa, seja para apresentar alguma alternativa ao problema da exclusão em massa que marca a sociedade contemporânea. ${ }^{634}$

\section{Problemas abertos levantados por teorias de médio alcance. Um exemplo das críticas aos modelos da sociedade civil}

A teoria habermasiana influenciou diversos debates e pautou o campo de estudos de médio alcance no âmbito das teorias democráticas, de representação e do que se convencionou chamar de "modelo da nova sociedade civil". Esse parece ser um ponto no qual a teoria de Habermas se destaca positivamente. Ao lidar com conceitos mais próximos de atores sociais, no âmbito de teorias da democracia, a teoria habermasiana parece ter maior potencial de diálogo com teorias interessadas em compreender fenômenos político institucionais. Esse parece ser um ponto cego da teoria de Luhmann, devido ao seu elevado grau de abstração.

Teorias influenciadas, em certa medida, pelo modelo habermasiano encontraram no conceito de sociedade civil um local privilegiado onde seria possível ancorar a ideia de uma esfera pública livre e mais próxima do mundo da vida. Diversos estudos empíricos e de médio alcance, sobre modelos institucionais e processos deliberativos seguiram a trilha da teoria em suas análises.

A explosão de estudos e de teorizações que seguiram experiências democráticas no Leste Europeu e na América Latina foi marcada pelas semânticas ${ }^{635}$ da "crise" ${ }^{636}$ e da "novidade". Em grossas linhas, tratava-se de afirmar ao mesmo tempo uma crise da democracia, de suas instituições, de seus objetivos e de sua legitimidade, para reconhecer, então, a possibilidade de toda uma nova forma legítima de se "aprofundar a democracia", dando a ela mais legitimidade e garantindo maior autonomia para os cidadãos. Termos

\footnotetext{
${ }^{634}$ Essa questão é abordada tangencialmente no final do Capítulo 5.

635 "Semântica", aqui, é utilizada em sua conotação comum, diferente do termo luhmanniano de "semântica social", que abordaremos mais a frente.

636 Neste sentido, Lavalle, Houtzager e Castello (2006a, p.67) sustentam no tocante à teoria da representação política, que as transformações pelas quais passou a democracia tornaram de difícil correspondência de alguns conceitos clássicos. Reputam a este fenômeno a multiplicação (não muito rigorosa conceitualmente) do vocábulo "crise". "dos partidos, da política, da democracia". Isso é relacionado com a dificuldade da literatura atual de se explicar o contexto contemporâneo das transformações democráticas pós1980.
} 
como "nova cidadania", "novos movimentos sociais", "novos atores da sociedade civil", "aprofundamento da democracia", "legitimidade democrática pelo processo deliberativo" (ou comunicativo) etc., tornaram-se comuns tanto nos discursos dos atores desta sociedade civil em ebulição, quanto na teoria democrática que buscava descrever este movimento. Tudo isso feito na esteira de uma "grande expectativa" 637 depositada na novidade e no "potencial democrático-legitimador" destas novas relações que pareciam ser capazes de gerar um "influxo legitimador" ou democrático nos mecanismos ${ }^{638}$ sistêmicos do Estado e da política. Quando estes "novos personagens entraram em cena", ${ }^{639}$ acompanhou-os uma concepção de sociedade civil carregada normativa e politicamente ${ }^{640}$ - na qual o contexto de esfera pública desempenhou um papel fundamental. ${ }^{641}$

Contudo, poder-se-ia afirmar, de forma um tanto simplista, que a "grande expectativa" anterior foi seguida de uma grande frustração. Uma vez que a formulação da "nova" sociedade civil como alicerce de uma esfera pública livre estaria carregada de normatividade, alguns comentadores afirmaram, com destaque para Lavalle, que o que se seguiu foi o reconhecimento de que diversas das pretensões nela depositada não foram satisfeitas. Isso teria levado a teoria democrática nos anos 2000 a deslocar o paradigma da "nova" sociedade civil com seus cidadãos ativos e sua cultura política comum para análises institucionais de "inovações democráticas" que se voltam menos para a questão da deliberação livre ou cidadania ativa e mais para maneiras novas de se exercer a representação política.

${ }^{637}$ Evelina Dagnino ressalta para a grande expectativa que a constituição de experiências associativas e participativas gerou, como o reducionismo da sociedade civil vista como 'pólo de virtude' e o Estado como 'encarnação do mal'. A autora associa a isso o fato de que grande parte dos diagnósticos da sociedade civil receberam os movimentos sociais (da sociedade civil) com grande entusiasmo, encarando-os, "em algumas versões, como os novos sujeitos da Revolução - esta, por sua vez, com o nome de Democracia". Desta forma, a atribuição de papel central na transformação social guiou os teóricos que as avaliavam à "inexorável constatação de seu fracasso.” (D’Agnino, 2002b P.371 e 388-9). No mesmo sentido, ver às críticas aos modelos com sobrecarga normativa de matriz Habermasiana in LAVALLE, 1999.

${ }^{638}$ O termo "mecanismos" é adotado no sentido das teorias de dupla integração da sociedade (como veremos a seguir). Denota-se um espaço de integração social não coordenado por ações humanas, pela "intenção" de agentes ou pela razão, consistindo ele por imperativos sistêmicos, especialmente os mecanismos administrativo e econômico (cf. Cohen \& Arato, 1992, p. viii).

${ }^{639}$ Paráfrase do título do famoso estudo de Eder Sader (1995).

${ }^{640}$ Adrian Gurza Lavalle (1999) denomina este enquadramento do debate, com forte carga normativa de "modelo da nova sociedade civil".

641 Os acontecimentos do final da década de 1980 são reconhecidos pelo próprio Habermas, que afirma "confirmarem", de certa forma, sua teoria, ao enfatizar os eventos ocorridos da Europa do Leste nessa época (HABERMAS, 1990, pp. 48 e 49). 
Ainda que Habermas não tenha propriamente um modelo de sociedade civil preciso e desenvolvido e que ele não seja, de forma alguma o único responsável pelo desenvolvimento deste campo; as críticas dirigidas à "grande expectativa" da sociedade civil podem ser dirigidas, também, ao modelo habermasiano. Isso, pois como bem demonstrou Lavalle, paradigma das teorias da sociedade civil teria perdido força sem realizar uma revisão "ponto-a-ponto" dos dilemas teóricos que elas enfrentaram. Assim, o autor conclui que debate da nova sociedade civil na América Latina enfraqueceu-se, sem "pena nem glória"642 por "infecundidade cognitiva" e que o debate acadêmico se encaminhou para direção diferente sem diálogo direto com esta teoria dos anos 1990. Agora, fala-se menos em emancipação pela sociedade civil, mas antes em controle cidadão, em cidadania responsiva ou democracia de accountability ${ }^{643}$ e Democracia de advocacy. ${ }^{644}$

Estes estudos aludem às "transformações da democracia",645 por uma ótica institucionalista, reconhecendo diversos fenômenos inovadores no relacionamento entre sociedade civil, esfera pública e Estado (que não poderiam ser explicados pela teoria habermasiana), pois teriam eles uma natureza diferente mais voltada à questão da representação política. Neste sentido, atualmente, a pesquisa no campo das associações civis- na confluência de abordagens sociológicas e de ciência política ${ }^{646}$ seria guiada pelo reconhecimento de inovações institucionais nas quais a relação entre Estado e sociedade civil é mais de sinergia do que de oposição. Nelas, as associações da sociedade civil agem em parceria com o poder político.

${ }^{642}$ Expressão mais comum na língua espanhola. Segundo o Diccionario Práctico Del Estudiante (Real Academia Española, 2007), "sin pena ni gloria" significa passar despercebido; sem destaque. Aqui a expressão parece-se referir-se a algo que não causa nem algo ruim (pena/dor) nem algo bom (glória).

${ }^{643}$ Lavalle, 2003.

${ }^{644}$ Dalton, Scarrow e Cain, 2006.

${ }^{645}$ Dalton, Scarrow e Cain (2006), sustentam que no último quarto do século XX teria ocorrido queda na confiança popular em instituições tradicionais como partidos e políticos, baixa no comparecimento em eleições em diversos países, bem como em varias formas de participação eleitoral, consonante com um aumento de demanda por participação popular. Segundo os autores, estaríamos presenciando a maior transformação do processo democrático desde o advento da democracia de massas (p.3). Para os autores, estaríamos na "terceira onda de reformas", apontando para novas formas de democracia mais atinadas a questões como transparência, acesso, participação e accountability; culminando, também, no que se chamou de democracia de estilo advocacy (p.10).

${ }^{646}$ Lavalle, 2003, p.109 
As críticas dirigidas às teorias da sociedade civil dirigidas ao seu caráter de "infecundidade cognitiva" são variadas, dentre as quais selecionei algumas que podem ser dirigidas ao modelo habermasiano aqui estudado.

(i) Ao tratar de uma separação "normativa" entre sociedade civil e Estado (tese da autocontenção), diversos contextos institucionais nos quais associações civis contribuem com a gestão pública e portanto participam do "poder" estatal não poderiam ser analisadas; ${ }^{647}$

(ii) $\mathrm{O}$ foco dado à tomada de decisões vinculantes - o centro do poder político administrativo com suas "comportas"- deixa de reconhecer a atividade de associações e de discussões da esfera pública em outros contextos como o da administração e implementação de políticas públicas e parcerias com o Estado;

(iii) A legitimidade automática atribuída às associações da sociedade civil ligava o conceito de esfera pública de maneira muito forte aos atores da sociedade civil, o que, por um lado, resultaria em numa tese do "espontaneísmo" do surgimento destes atores que não apenas deixava de explicar seu surgimento e formas de funcionamento; ${ }^{648}$

Ainda que tais críticas sejam feitas, a teoria do discurso habermasiano parece continuar a exercer muita influência em "estudos de médio alcance", sejam eles vinculados à teoria da nova sociedade civil ou não. Contudo, essas críticas apontam para "gargalos teóricos" que podem somar-se às considerações anteriores que fiz sobre os "problemas sociológicos" da teoria habermasiana da esfera pública. Isso levou diversos teóricos a abandonarem o referencial teórico habermasiano sem necessariamente desenvolver uma nova teoria abrangente da esfera pública em seu lugar. Talvez, outro elemento que tenha sido deixado "sem pena nem glória" tenha sido a pretensão de uma construção teórica compreensiva do conceito de esfera pública.

Isso justifica, de certa forma, o esforço deste trabalho em tentar trazer contribuições para o desenvolvimento do campo da sociologia abrangente da esfera pública a partir das contribuições da teoria dos sistemas. Isso desloca o problema de análise para questões de consistência teórica, que debatemos até agora nos itens anteriores. Aliás, diversas das críticas que eu selecionei foram tangencialmente tratadas nos itens deste capítulo.

\footnotetext{
${ }^{647}$ Lavalle, 2003, 2006. Ver também Lavalle e Vera, 2010b.

${ }^{648}$ Aqui a questão foi levanta por Cohen e Arato (1992, pp. 495 e ss).
} 
Contudo, muito embora o conceito luhmanniano de esfera pública possa "resistir" a diversas destas críticas por meio de seu conceito mais "enxuto" de esfera pública, ele também não parece "iluminar" o campo de estudos de médio alcance que se preocupe com questões concretas e institucionais na teoria democrática.

Essa conclusão "negativa" que demonstra "pontos cegos" que a teoria luhmanniana não consegue iluminar no tocante a estas teorias de médio alcance talvez possa ser melhor contrabalanceada, de certa forma, em análises de estudos de médio alcance em temáticas nas quais a teoria dos sistemas parece poder contribuir de forma mais significativa, a saber: a relevância da esfera pública para determinados sistemas sócias e para a sociedade mundial. É isso que se abordará nos Capítulos 4 e 5. 


\section{PARTE II}

\section{CAPÍTULO 4 - ESFERA PÚBLICA E SISTEMAS SOCIAIS: MEIOS DE COMUNICAÇÃO EM MASSA E A POLITIZAÇÃO DOS TRBUNAIS CONSTITUCIONAIS}

\section{Introdução}

O presente capítulo inaugura a segunda parte deste estudo. Com efeito, ela se diferencia profundamente dos capítulos anteriores, pois seu intuito é antes exploratório e ensaístico, visando buscar campos e questões nas quais o modelo luhmanniano de esfera pública possa ser mobilizado. Neste sentido, são apresentados problemas "livremente selecionados" que possam instigar tanto "estudos aplicados" que busquem compreender novas questões a partir da teoria luhmanniana por meio de seu conceito de esfera pública; quanto trazer problemas e questões em aberto "de volta" para a teoria, abrindo espaços para se discutir problemas de consistência interna da teoria.

Este capítulo se estrutura em dois momentos centrais. (i) Após esta introdução, (ii) a os meios de comunicação em massa são trazidos para o debate no tocante à sua relação com a esfera pública e com a opinião pública. Esse elemento é muito presente nas reflexões de Habermas sobre a esfera pública, mas parece ganhar novas possibilidades de abordagem dentro do contexto da teoria dos sistemas de Niklas Luhmann. (iii) Ao final, é apresentada uma formulação "exploratória" sobre a intrincada questão da "politização do judiciário", em suas diversas facetas, chamando-se a atenção para o estudo dos Tribunais Constitucionais como organização relevante para o acoplamento estrutural do sistema político e jurídico e, por isso, para discussões sobre o conceito de esfera pública política.

\section{Os meios de comunicação em massa e a esfera pública}

\subsection{Os meios de comunicação em massa pela teoria dos sistemas}

Luhmann inicia suas considerações sobre os meios de comunicação em massa de forma provocativa, atentando para seu caráter abrangente na autodescrição da sociedade 
moderna ao afirmar que "aquilo que sabemos sobre nossa sociedade, ou mesmo sobre o mundo no qual vivemos, o sabemos pelos meios de comunicação". ${ }^{649}$ Entretanto, mesmo que se admita que as informações provenientes desse sistema não são confiáveis, por serem determinadas por "lógica interna", o autor afirma não ser adequado trabalhar com "teorias da manipulação". Sua teoria visa a tratar desse objeto pela pergunta sobre o comportamento próprio desse sistema, analisando-o por meio da teoria da diferenciação funcional, sem incorrer nas teses de que "haveria alguém atrás da cena" ou coordenando intrigas.

Seu conceito dos meios de comunicação em massa é um consideravelmente mais amplo, uma vez que ele se afasta do conceito tradicional de "mídia" para tratar também de meios de comunicação que compreendem, em primeiro lugar, as instituições da sociedade que servem de "meio técnico de reprodução e difusão da comunicação voltadas a um público indeterminado". Assim, o "meio" da tecnologia de difusão em massa serviria à diferenciação de um sistema de "meios de comunicação em massa" da mesma forma que o dinheiro para economia ${ }^{650}$ - e o poder para a política.

Para o autor, os meios de comunicação em massa apresentariam uma "duplicação da realidade", isso, pois a "realidade real" dos meios de comunicação consistiria em suas próprias operações; no próprio processo de difusão de informação. ${ }^{651}$ Contudo, o sistema social dos meios de comunicação em massa funcionalmente diferenciado faria também uma segunda realidade que "aparece por meio deles como realidade para os outros". Esse sistema teria a capacidade de comunicar algo distinto de si mesmo - distinguindo autoreferência e hetero-referência-; uma vez que precisam construir uma "outra realidade, diferente deles mesmos". ${ }^{652}$ Isso teria grandes consequências para a geração de conhecimento disponível para outros sistemas.

Esse caráter de generalização dos meios de comunicação em massa, "onde tudo o que sabemos é disponibilizado por eles", se vincula com a forma pela qual esse sistema opera suas comunicações, a saber, por meio de "tópicos de comunicação" ou "temas". Os sistemas dos meios de comunicação de massa se valem de heterorreferência ao utilizar informações de outros sistemas sociais, mas as reproduzem a partir de seus

\footnotetext{
${ }^{649}$ LUHMANN, 2005c, p. 14.

${ }^{650}$ LUHMANN, 2005c, (op. cit), p.17-17.

${ }^{651}$ LUHMANN, 2005c, p.18-19.

${ }^{652}$ LUHMANN, 2005c, pp. 21 e ss.
} 
condicionamentos internos. Em outras palavras, desconsiderar que esse sistema opera de forma autopoiética - assim como todos os outros sistemas sociais - implicaria pensar um contexto no qual os temas e comunicações desse sistema seriam determinados externamente, tornando a mídia um mero "fórum" de discussões fragmentadas específicas políticas, econômicas, artísticas ou jurídicas. Para Luhmann, isso não é o que ocorre e a análise dos meios de comunicação em massa necessariamente deve passar pela abordagem de suas especificidades e de seu funcionamento interno. ${ }^{653}$

Ao se voltar para a peculiaridade como esse sistema se relaciona com os outros sistemas sociais da sociedade, Luhmann nota que os "temas" servem ao acoplamento estrutural dos meios de comunicação com todos os outros sistemas sociais, dando a este sistema grande capacidade de "descrição" e de "universalização". Com isso, o sistema dispõe de uma forma "elástica" e "diversificável”, podendo atingir "cada parte da sociedade". Luhmann, então, atribui uma grande capacidade dos meios de comunicação em massa em "irritar" os outros sistemas sociais pela imposição de seus temas. ${ }^{654}$

Reconhecer que os meios de comunicação em massa operam a partir de seus imperativos sistêmicos internos afasta a compreensão de que eles operariam pelo meio da verdade ou a partir do código "verdade/falsidade" tal qual a ciência. Como vimos, esse sistema parcial funciona vinculado aos "meios de difusão". A partir de sua teoria da evolução da sociedade, o sistema dos meios de comunicação em massa teria se diferenciado em grande parte pela decorrência de que o aumento da complexidade social teria levado a uma necessidade de maior generalização e rapidez no processo de produção de "novas informações". Uma sociedade moderna funcionalmente diferenciada altera sua relação com a temporalidade, necessitando de grande quantidade de informação nova, ao que Luhmann chamou de uma "compulsão por novidade" no âmbito das expectativas da sociedade. ${ }^{655}$ Ao exercer essa sua função social, esse sistema teria pautado seu

${ }^{653}$ LUHMANN, 2005c, pp. 29 e ss. Luhmann afirma que um tema tal como o da Aids, por exemplo, não é um produto próprio dos meios de comunicação. Ele é apenas aproveitado por eles, mas é tratado de tal forma e exposto a uma trajetória temática que não pode ser explicado nem com base nos diagnósticos médicos nem na comunicação entre médicos e pacientes".

${ }^{654}$ LUHMANN, 2005c, p. 31 e ss, e pp. 50-51. Note-se que, para o autor, os outros sistemas parciais, como "ciência, política e direito", teriam uma dificuldade de inserir seus temas nos meios de comunicação em massa e conseguir receptividade. Ademais, poder-se-ia pensar que os meios de comunicação em massa têm uma grande influência na formação da auto-descrição da sociedade moderna, exercendo grande influência no plano da semântica da sociedade (essa reflexão é baseada em discussões com o professor Marcelo Neves - comunicação pessoal).

${ }^{655}$ LUHMANN, 2005c, p 40 e ss. 
desenvolvimento ao possibilitar a existência de informações que pudessem transcender "a interação entre presentes". 656

O fechamento do sistema, portanto, se vincula ao código binário "informação/nãoinformação" ${ }^{657}$ É por meio dessa distinção binária que tal sistema se estrutura. Como qualquer outro sistema social, ao operar pela distinção tautológica de códigos binários, o sistema precisa de uma outra distinção "códigos/programas" para oferecer critérios para que o sistema possa se algo deve ser tratado como informativo ou não. ${ }^{658}$ Outra peculiaridade do sistemas de comunicação em massa é que seu núcleo seria formado por três programas consideravelmente independentes: os programas das notícias e reportagens; da publicidade e do entretenimento. ${ }^{659}$

O que diz respeito ao tema da esfera pública de forma mais direta para esta dissertação é o programa específico das notícias e reportagens. ${ }^{660}$ Esse programa seria pautado por "seletores" específicos do sistema para determinar o que seria passível de se tornar uma notícia ou reportagem. ${ }^{661}$ Sua relevância seria muito forte para os sistemas da política e do direito. Vimos no capítulo anterior como a formação da opinião pública se relaciona de forma próxima aos meios de comunicação em massa por utilizarem ambos da figura do "tema" (ainda que no caso da opinião pública isso deva ser formulado em termos políticos de uma opinião “favorável/desfavorável” e se formular politicamente). Além disso, diversos dos "seletores" do programa de notícias e reportagens também se

${ }^{656}$ LUHMANN, 2005c, p. 37.

${ }^{657}$ LUHMANN, 2005c, p. 38-39.

${ }^{658}$ LUHMANN, 2005c, p. 40.

${ }^{659}$ LUHMANN, 2005c, pp. 39 e ss.

${ }^{660}$ No tocante aos outros programas, Luhmann nota que a publicidade, acoplada ao sistema da economia, realiza manipulações do público ao mesmo temo que se pressupõe que isso tal manipulação seja conhecida. Seus interesses comerciais e econômicos de vendas de produtos estão claros e manifestos (LUHMANN, 2005c, p. 83 e ss.). Por sua vez, o programa do entretenimento realizaria o modelo já visto por nós da "duplicação da realidade”, a partir da distinção "jogo/seriedade” (2005c, pp. 93 e ss.).

${ }^{661}$ Luhmann se baseia em diversas pesquisas empíricas para apresentar 10 seletores, que podemos resumir rapidamente aqui: 1. Informação nova, seja eventos novos ou enquadrados dentro de padrões (catástrofes, eventos esportivos, encontros de cúpula), 2. Preferência por conflitos, que jogam com a incerteza e provocam tensão nos espectadores. 3. Informações que vinculam "quantidades e números" para passar ideia de objetividade. 4. Informações de relevância local e informações com relevância global. 5. Eventos de transgressão às normas, com jurídicas, morais ou contra o politicamente correto e que permitam ser formuladas pela forma do "escândalo". 6. Notícias que possam ser vinculadas de forma moral. 7. Notícias que atribuam ações a agentes e permitam a discussão de sua "culpabilidade". 8. Eventos chave da atualidade - como acidentes, distúrbios e desmoronamentos. 9. Manifestações e opiniões divulgadas como notícia. 10. Por fim, Luhmann atribui também às decisões interas das organizações do sistema de comunicação em massa, por seu caráter decisório, os seletores de tempo, espaço, e decisões; como, por exemplo, formação de pauta, espaço livre nas colunas, e moldes noticiários (LUHMANN, 2005c, pp. 57-69). 
aproximam da formação da opinião pública, como a preferência por conflitos, além da vinculação pelos meios de comunicação em massa de temas afeitos à moralização e à transgressão de normas, formulados por meio do "escândalo".

Luhmann afirma, ainda, que, por meio do acoplamento estrutural entre o sistema político e os programas de notícias e reportagens, a política "lucra" com as menções feitas nos meios de comunicação e, ao mesmo tempo, é fortemente irritada por elas. Os temas vinculados nos meios de comunicação em massa terminam por exigir reações por parte do sistema político. O autor argumenta que, "as mesmas comunicações têm ao mesmo tempo relevância medial e política. Mas isso vale exclusivamente para acontecimentos isolados e somente ad hoc. Pois o tratamento posterior segue, no sistema político, especialmente sob as condições da democracia, e quando a oposição estrutura-se na forma de partidos, caminhos totalmente diferentes do que nos meios de comunicação onde há uma espécie de história em capítulos", 662

\subsection{Meios de comunicação em massa e esfera pública}

Em seu livro sobre os meios de comunicação em massa, Luhmann reserva um capítulo intitulado "esfera pública" para analisar as relações desse sistema com os outros sistemas sociais. Nele, o autor ressalta que os meios de comunicação em massa "dão uma contribuição para a construção de realidade promovida pela sociedade". Essa construção "faz parte de uma contínua reatualização da autodescrição da sociedade e de seus horizontes cognitivos mundiais, seja na forma consensual, seja na forma dissensual $(\ldots)^{\prime \prime} \cdot 663$

Novamente, Luhmann discute o que caracterizaria o adjetivo "público" e se afasta da noção de "acessibilidade a todos", afirmando ser necessário fazer uma guinada da ação para a "observação". ${ }^{664}$ Assim, Luhmann ressalta o caráter de observação possibilitado pela esfera pública, "como a reflexão das fronteiras sistêmicas dos sistemas sociais": o

662 LUHMANN, 2005,c, pp. 116 e ss. No tocante ao caso do direito, o sistema dos meios de comunicação em massa irritaria o sistema jurídico principalmente pelo "julgamento antecipado" de casos isolados e por dar ao sistemas jurídico informações que não podem ser ignoradas pela "opinião jurídica".

${ }^{663}$ LUHMANN, 2005c, p. 168.

${ }^{664} \mathrm{O}$ autor afirma, com certa ironia, que o conceito da acessibilidade apresentaria problemas por deixar de lado grande parte do núcleo do conceito do adjetivo público ao afirmar que "toaletes públicas não são nem opiniões nem produto dos meios de comunicação", muito menos da política (LUHMANN, 2005c, p. 168). 
"ambiente social interno de todos os sistemas sociais", retomando seu conceito e reafirmando que os sistemas podem observar a si mesmos e aos outros sistemas pelo medium da esfera pública. Luhmann argumenta que "isso pode - mas não precisa - levar a que as opiniões sejam dirigidas a se orientarem de forma generalizável (e assim publicamente defensável). ${ }^{665}$

Com a necessidade de trânsito de informações contrária aos "segredos", ${ }^{666}$ surge no século XVIII a "exigência enfática" da esfera pública como meio de imposição da razão. Todavia, Luhmann argumenta que tal conceito de esfera pública é "reduzido" e seria, por assim dizer, "constitucionalista", sendo marcado por "exigências como, a liberdade de opinião, de imprensa, abolição da censura". Vale repisar que Luhmann reforça seu argumento pela análise mais geral da esfera pública, para além das liberdades constitucionais, encarando-a como "um medium social geral de reflexão que registra a intransponibilidade das fronteiras e, inspirado nisso, o observar das observações." Aqui, Luhmann reconhece que mesmo antes de se desenvolver claramente "um conceito enfático de opinião pública" no século XVIII, a imprensa foi utilizada para "obter ressonância pública para as comunicações politicamente ambiciosas e para expor com isso as instâncias de decisão a que fossem duplamente apanhadas: por meio dos escritos a elas dirigidos e de sua ressonância pública. (...) $\mathrm{O}$ acesso público à comunicação no aparelho político de dominação amplia-se assim com a ajuda da imprensa e só depois disso é que se chega à ideia de uma opinião pública como última instância do julgamento das questões políticas. Apesar ou pelo fato de a esfera pública não poder decidir politicamente e estar, de certa forma, fora dos limites do sistema da política, ela é explorada politicamente na política e será copiada no interior do sistema". 667

Para o autor, a "função dos meios de comunicação estaria assim não na produção, mas na representação da esfera pública. Aqui se trata de 'representação' no sentido 'contraído ou reduzido'. Exatamente pelo fato de a 'esfera pública' sempre descrever para todos os sistemas, até mesmo para os próprios meios de comunicação, o outro lado, inacessível, dos limites desses sistemas e não poder ser individualizada em sistemas

\footnotetext{
${ }^{665}$ LUHMANN, 2005c, p. 169.
}

${ }^{666} \mathrm{O}$ autor afirma que "o problema político da guarda do segredo está integrado nas regras gerais da moral das camadas superiores. Nessa medida, a crítica da política do segredo e a exigência de publicidade são ao mesmo tempo um indicador da diferenciação do sistema político, ela não pode ser naturalmente transferida para o comportamento daqueles que agora são tidos como "pessoas privadas" (LUHMANN, 2005c, p. 170).

${ }^{667}$ LUHMANN, 2005, p. 171. 
participantes determinados, é necessário representá-los na forma de construções de realidade nas quais todos os subsistemas, em que todos os homens podem participar, sem que disso nasça uma obrigação de proceder de uma determinada forma". 668

Nota-se, por fim, que ainda que os meios de comunicação de massa tenham essa peculiaridade de se acoplar com todos os outros sistemas da sociedade, eles também "têm" sua esfera pública; uma vez que sua diferenciação funcional estabelece fronteiras internas e externas. Assim, “[m]esmo eles refletem o seu lado externo como esfera pública, à medida que relações externas específicas, por exemplo, em relação à política ou aos anunciantes de publicidade, não estejam sendo questionadas. Contudo, esse reflexo tem para eles outro valor, pois aqui sua função torna-se reconhecível. O recurso a estratégias funcionalmente equivalentes da ocultação e da hipocrisia permanece por isso amplamente reservado, mesmo quando se fala fingindo que não se está fingindo. Isso pode ser complementado com uma redescrição metafórica - como, por exemplo, na forma de uma ética profissional que permite aos jornalistas encarar seus empenhos como serviço à esfera pública, concebêlos como justificativa das aspirações de autonomia e como base para a neutralidade de interesses, institucionalizando para isso um padrão crítico e um consenso profissional. A limitação jornalismo/profissão/ética tem boas razões quando se trata do autocontrole do sistema dos meios de comunicação. Ela oferece um ponto de partida para uma independência, como sempre utópica, dos desejos do público ou de determinados grupos de interesse. Mas esses resultados precisam ser conseguidos com um conceito fortemente limitado de autonomia. Aqui e somente aqui tem, portanto, sentido falar-se num sentido, em si paradoxal , de 'autonomia relativa",. 669

\subsection{Conclusão parcial: esfera pública e os meios de comunicação em massa}

Tanto Habermas quanto Luhmann deram forte importância para o relacionamento da "mídia" (ou meios de comunicação em massa) com a esfera pública. Ambos ressaltaram as "influências" e "irritações" que ocorrem entre a esfera pública, a formação de uma opinião pública e o sistema político. Vimos que Habermas, em 1961. apresenta uma análise dos comportamentos dos "clientes" frente ao desenvolvimento de uma mídia que os aliena

\footnotetext{
${ }^{668}$ LUHMANN, 2005c, p. 172.

${ }^{669}$ LUHMANN, 2005c, p. 172.
} 
de sua condição de cidadãos. Posteriormente, o autor atribui um papel "ambíguo" à mídia no tocante à formação de uma opinião pública de um público "nativo" da esfera pública. Ela poderia servir tanto positiva quanto negativamente para as pretensões democráticas estabelecidas pelo autor.

Com Niklas Luhmann, o enfoque não é mais voltado para a análise de comportamentos ou para medir o caráter de "incentivo ou de bloqueio" às opiniões públicas da mídia. Não obstante, nota-se que Luhmann desenvolve alguns argumentos no penúltimo capítulo de seu livro acerca do acoplamento estrutural entre meios de comunicação em massa e sistemas psíquicos ("pessoas", se tomarmos o ponto de vista do sistema). O autor afirma que conceitos psicológicos como "esquemas, mapas cognitivos, scripts e moldura (frame)" seriam progressivamente tratados para explicar comportamentos coletivos socialmente coordenados. Para Luhmann, esses conceitos poderiam ser aplicados frente o problema de que "ainda nos falta um conceito que, por exemplo, possa explicar (ou possa levar a hipóteses que consigam explicar) como o conhecimento do mundo que derivava da vida nos ambientes familiares da sociedade tradicional é desalojado ou fica sobremoldado pela participação nos programas dos meios de comunicação”. No processo circular do acoplamento entre sistemas psíquicos e os meios de comunicação em massa, estes últimos dariam ênfase à garantia de "compreensibilidade" que permitiriam um "ancoramento psíquico que se pressupõe como resultado do consumo de representações mediáticas".

Além disso, segundo Luhmann, os meios de comunicação também permitiriam que pessoas entrassem em contato com experiências inacessíveis a partir da experiência individual (utilizando o impacto da formulação midiática sobre a questão ambiental). Isso levaria a uma consequência importante, uma vez que as pessoas poderiam ser influenciadas por informações que não são acessíveis do ponto de vista de suas biografias e experiências individuais a partir dos "scripts" que lhes são oferecidos. Assim, elas poderiam se adaptar a isso associando eventualmente experiências próprias. ${ }^{670}$ Isso, contudo, não resulta em uma "reeducação" das pessoas, em uma mudança de valores positivas ou algo parecido; nem seria algo caracterizado como ideologia. O autor argumenta: [q]uem é afeiçoado a ideias como 'verdade objetiva' ou 'consenso' que vincula psiquicamente não está em condições de aceitar essa análise e acusa os meios de comunicação de superficialidade e mesmo de

${ }^{670}$ Luhmann dá o exemplo de associar a problemas ecológicos com "a camada de poluição no carro estacionado lá fora" (LUHMANN, 2005c, p. 179). 
manipulação. Se se considera seriamente, por outro lado, a individualidade e o fechamento operacional de sistemas autopoiétios, percebe-se que não dá para ser diferente. Visto pela perspectiva da sociedade, o acoplamento estrutural mediado pelo esquema tem a vantagem de acelerar as mudanças estruturais, quer dizer, promover uma aceleração que, se ela for bem sucedida, não permitirá o rompimento do acoplamento estrutural entre meios de comunicação e indivíduos, mas os transferirá a outros esquemas". ${ }^{671}$

Assim, a pergunta luhmanniana se desloca para uma análise do funcionamento interno dos meios de comunicação em massa. No tocante à sua relação com a esfera pública, Luhmann realiza um movimento no sentido da "observação" em seu modelo de espelho e argumenta que isso apresentaria a vantagem de transferir os debates para o âmbito dos sistemas parciais - e da relação entre eles. Portanto, é possível argumentar que a teoria dos sistemas apresenta a possibilidade de se colocarem algumas perguntas passíveis de incentivar estudos de médio alcance sobre relações entre sistemas sociais de função, meios de comunicação em massa e a formação de opiniões públicas. Isso ocorre em decorrência não apenas do "diálogo" luhmanniano com teorias de médio alcance sobre os meios de comunicação em massa (que o permitiram formar os conceitos de "seletores" das notícias e reportagens e de "scripts" de vinculação com sistemas psíquicos), mas também por levantar a questão de como sistemas parciais de função (ou organizações) poderiam "reagir" a temas formulados pelos meios de comunicação em massa que potencializam a formação de temas da opinião pública. Relações internas entre direito e mídia, política e mídia, e mídia e formação de opiniões públicas podem ser alguns exemplos.

Alguns desenvolvimentos neste sentido já podem ser pensados. Em primeiro lugar, destaca-se o trabalho de Marcelo Neves sobre a legislação simbólica (conceito desenvolvido com apoio em Harald Kindermann) a partir de uma perspectiva da teoria dos sistemas. Em especial, destaca-se o tipo denominado de "legislação-álibi". Esse tipo de legislação teria o objetivo de fortificar a confiança de cidadãos em governos, uma vez que

${ }^{671}$ LUHMANN, 2005c, pp. 173-180. A importância que o autor dá para esse acoplamento entre pessoas e meios de comunicação não é pequena e permitiria, inclusive, "mudanças estruturais". Em suas palavras, "[o]s acoplamentos estruturais entre indivíduos e a sociedade afetam a realidade total. Isso vale para todas as formações sociais. Contudo, os meios de comunicação variam as condições estruturais desses acoplamentos estruturais, pois eles alteram tanto a demanda por esquemas quanto sua oferta. Esquemas e scripts das necessidades ecológicas e a necessidade de uma esquematização da própria pessoa são apenas exemplos extremos escolhidos para isso. E não é talvez nenhum acaso que esses dois ambientes da comunicação social, a complexidade da natureza extra-humana e a dinâmica própria e a intransparência dos indivíduos humanos sejam dependentes, de forma especial, de esquemas e, com, isso dos acoplamentos estruturais dos meios de comunicação" (LUHMANN, 2005c, pp. 185-186). 
o poder legislativo, sobre a pressão direta do público elabore leis para satisfazer a expectativa dos cidadãos e "descarregar-se de pressões políticas" ou apresentar o Estado como "sensível" à expectativa popular. Esse tipo de legislação seria típico em casos nos quais haveria a insatisfação popular perante problemas determinados e urgentes que geram muita insatisfação popular. ${ }^{672}$ As relações, aqui, de "reação" de sistemas sociais a pressões vinculadas por notícias e reportagens midiáticas as quais se segue pressão pública, é evidente.

Isso parece ser possibilitado uma vez que Luhmann não recorre a uma "teoria da cultura de massas" ou "teria da ideologia"; nem a uma teoria deliberativa da democracia para explicar a relação entre mídia, opinião pública e esfera pública - tal como fez Habermas em 1961 e na década de 1990, respectivamente. Ao revés o autor parece apresentar algumas possibilidades de se trabalhar com os mecanismos internos do sistema dos meios de comunicação e, com isso, apresentar algumas possibilidades de novos diálogos.

A título de reflexão, uma questão se mostra relevante. A existência dos chamados "novos mídias" e redes sociais, cuja utilização tem sido declarada como um papel fundamental em movimentos de protestos e na derrubada de regimes autocráticos na chamada "primavera árabe", por exemplo, poderiam se tornar um objeto de estudo nos quais a teoria dos sistemas de Luhmann serviria de contexto para teorias de médio alcance que abordassem como estas novas mídias se relacionam com os meios de comunicação em massa, com a esfera pública e com a formação da opinião pública.

\section{Politização do judiciário: para além da panaceia e da barbárie}

Ao conceituar a esfera pública de maneira mais ampla, como o âmbito de reflexão dos sistemas sociais, a análise desse conceito parece ser interessante quando em referência ao sistema jurídico ou, mais precisamente, aos Tribunais Constitucionais, organização relevante tanto para o sistema político quanto para o sistema jurídico. Utilizar a teoria dos

${ }^{672}$ NEVES, 2007a, pp. 36 e ss. Vale citar uma passagem de Neves: "Kindermann refere-se ao caos de peixes acometidos por nematódeos que, conforme uma reportagem da TV alemã (1987), estariam sendo comercializados, provocando doenças intestinais nos consumidores. Os problemas econômicos socais resultantes da redução do consumo provocado pela reportagem levaram o Governo Federal da Alemanha a expedir um Decreto muito abrangente e detalhado, eu deveria garantir o não-acesso ao comércio de todo e qualquer peixe acometido". No mesmo sentido, Priscilla Soares de Oliveira analisa, também por uma ótica da teoria dos sistemas, como a vinculação midiática do caso "pílulas anticoncepcionais de farinha" no Brasil pílulas essas, portanto, ineficazes - teria passado pelo Congresso Nacional brasileiro em "regime de urgência urgentíssima" e resultado em uma legislação com pena consideravelmente alta (OLIVEIRA, 2010). 
sistemas para analisar esses embates pode ser um instrumento interessante para propor novas formas para o debate que, atualmente, é muito pautado pela teoria da separação dos poderes e por propostas normativas que encaram a politização do judiciário de formas muito estilizadas: ou como algo positivo e capaz de concretizar direitos, ou como algo negativo, com forte nota anti-democrática. Dessa discussão plural, vale discutir a atribuição de grande parte da literatura a um crescente de aumento de relevância dos Tribunais Constitucionais e da inserção de "programas finalísticos" no sistema do direito.

O "ativismo judicial" e a entrada do Judiciário como um player relevante na arena política foi encarado, por um lado, com grande entusiasmo ("uma panacéia") nos anos 60 e 70 pela a esperança que ele pudesse auxiliar no acesso da justiça dos mais pobres; ${ }^{673}$ fazer funcionar um direito reflexivo que implique cidadania ativa ${ }^{674}$; ou garantir efetividade de direitos, inclusive por políticas públicas ${ }^{675}$. Por outro, a politização do judiciário foi encarada com um grande pessimismo, em argumentos que sustentam ter ele uma nota marcadamente autoritária ${ }^{676}$. Neste contexto, além das "questões democráticas", já tão debatidas, a literatura parece apontar para o diagnóstico de "intrusão" de elementos políticos "finalísticos" - como, por exemplo, a influência recíproca entre judiciário e políticas públicas; ${ }^{677}$ - que "desnaturalizariam" a neutralidade do sistema jurídico. Esse debate, contudo parece ser pautado antes por modelos políticos de separação de poderes e de teorias democráticas.

\subsection{O judiciário entre a política e o direito - por meio da Constituição}

O Poder Judiciário foi concebido por dois modelos teóricos e constitucionais distintos no surgimento dos Estados Liberais modernos, seguindo duas funções diferentes, a saber: (i) o modelo dos EUA, de inspiração madisoniana e que ressaltava o controle constitucional e as formas de se controlar o poder político, vinculando o judiciário a esta

${ }^{673}$ Estes autores, em si, não concebiam o judiciário como uma panacéia para problemas sociais, mas deram algumas bases para um "pensamento otimista" em relação à atuação judicial mais proativa visando a implementação e efetivação de direitos. Cappelletti e Garth não deixam de reconhecer que existem limites ao alcance das reformas e do acesso à justiça (CAPPELLETTI E GARTH, 1988).

${ }^{674}$ VIANNA et all, 1997.

675 (dentre muitos, CAPPELLETTI E GARTH, 1988; ZAFFARONI, 1995 e COMPARATO, 1988. Esta "visão otimista" é muito encontrada no discurso de direitos - principalmente dos direitos humanos - e na linguagem de atores sociais, como juízes e movimentos sociais.

${ }^{676}$ Dentre muitos, MAUS, 2000; HIRSCHL, 2004; TUSHNET, 2000; FERRAZ JR, 1994.

${ }^{677}$ Cf. TAYLOR, 2007; para uma defes normativa, ver: Comparato, 1988 
esfera; e (ii) o modelo da França, de inspiração republicana e democrática, onde o embate contra a monarquia absoluta gerou um modelo de esvaziamento do executivo e supremacia do legislativo em um contexto no qual o judiciário tinha quase ou nenhuma função política. ${ }^{678}$ Assim, enquanto nos EUA a Suprema Corte possuía a tarefa madisoniana de controle do poder e controle das maiorias ${ }^{679}$; na França o Judiciário não obteve o status de poder político, seguindo o modelo de não intervir no Legislativo como fonte da "Vontade Geral" e da soberania popular.

Esta "tensão" do Judiciário entre "justiça e política" ressaltada por Arantes, que se desdobra na tensão de dois modelos político constitucionais de judiciário - um mais voltado para o "controle das maiorias" para se evitar a tirania (liberal constitucional), outro voltado para anulação política para não interferência na soberania popular que expressa sua vontade por meio do legislativo (republicano democrático) - parece ser a tensão central que todo modelo constitucional deve enfrentar. Em linhas muito gerais, existem visões mais "otimistas", que visam dar maior centralidade e agência para este órgão em seus modelos constitucionais; enquanto visões mais pessimistas tendem a depositar elevados graus de desconfiança atribuindo-lhe caráter de ilegitimidade democrática.

Nota-se a tensão entre uma concepção de um Judiciário ativo, transformador, que efetiva direitos de forma consequencialista; (no limite: uma visão otimista de uma nova panaceia para os problemas democráticos); e uma concepção de Judiciário passivo, instrumental, que não atue de forma paternalista ou tecnicista e não ameace nem a soberania popular expressa no legislativo nem invada a esfera de ação social dos movimentos populares. (no limite: uma ameaça tirânica à democracia). Essa configuração da "tensão" presente no judiciário, contudo, apenas pôde ser possível na segunda metade do século XX e depois que uma série de elementos levaram a uma reorientação do judiciário e suas funções.

Contudo, esta mesma tensão se manifesta ainda em outros níveis que permeiam as "expectativas" frente à constituição e à democracia (e não apenas o judiciário especificamente). Portanto, antes de adentrarmos a questão do judiciário, vejamos

678 (ARANTES, 2004, p.81 e ss)Arantes afirma que estas experiências constitutivas influenciaram a formação do Judiciário nos demais Estados Liberais democráticos nos séculos XIX e XX: “a experiência francesa, mais republicana do que liberal, modernizou a função de justiça comum do Judiciário, mas não lhe conferiu poder político; a americana, mais liberal do que republicana, não só atribuiu à magistratura a importante função de prestação de justiça nos conflitos entre particulares, como elevou o judiciário à condição de poder político". (ARANTES, 2004, p.80)

${ }^{679}$ Ver sobre a defesa de Madison ao pré-compromisso, HOLMES, 1988 p. 215 e ss. 
rapidamente outras formas de manifestação desta tensão em níveis mais abrangentes que se despontam na teoria política: (i) instituição e ação, por um lado, e (ii) constitucionalismo e democracia, por outro.

Em primeiro lugar, temos a tensão entre (i) as instituições políticas, que visam o plano das regras e convenções sociais de conservação da ordem e a ação política que visa sua transformação. Isso fica muito claramente definido quando formulado nos termos de Hannah Arendt, que reconhece o "paradoxo da liberdade". Para a autora, a liberdade se realiza politicamente no momento da revolução, ou seja, na "instauração do novo". Porém, feita a revolução (ou "fundada a liberdade"), é necessário um movimento no sentido de conservá-la por meio de instituições, o que gera um paradoxo inevitável. Ora, no limite, em um conceito normativo de política pautado apenas no plano da ação, como é o de Arendt, se a liberdade é a instauração da novidade e coincide com a ação política, atingir a liberdade, paradoxalmente, resultaria no fim da liberdade. Este paradoxo é reconhecido e enfrentado de maneira arguta por Arendt em "On Revolution" juntamente com o que podemos chamar de problema da "regressão infinita do fundamento de validade do Estado Moderno"; ou seja: não havendo mais um elemento externo de justificação (como "Deus" ou o paradigma do contratualismo hipotético-jusnaturalista); a relação dos governos Constitucionais modernos de busca por legalidade e legitimidade recai numa regressão infinita. Hannah Arendt lê este problema como "perplexidades da fundação"(perplexities of foundation) na tentativa de se fundar; ao mesmo tempo; um novo direito e um novo corpo político, uma vez que o direito se fundamenta no poder que o instituiu; e o poder do Estado se fundamenta no direito constitucional que o regula. ${ }^{680}$

Este paradoxo entre instituições (preservação, regras e direito) e ação (poder constituinte, política e auto-determinação) pode ser lido também pela (ii) tensão entre constitucionalismo e democracia. Stephen Holmes formula bem esta questão por meio do paradoxo democrático do pré-compromisso ${ }^{681}$ : o conflito entre política majoritária (ao lado

680 . (ARENDT, 1963, p.163 e ss )Isso leva Arendt a reconhecer a importância de "revoluções espontâneas" como a americana, mas ao mesmo tempo a importância de seu Senado e seu modelo institucional que visa preservar as conquistas desta revuloção. A forma pela qual Arendt tenta "solucionar" este paradoxo (pela adoção de uma política das townships) não é do interesse deste nosso estudo.

681 Para Holmes, “existe uma profunda, quase irreconciliável tensão entre constitucionalismo e democracia", estilizando o debate, Holmes fala que esta oposição pode ser bem reconhecida "entre os democratas que pensam ser a constituição um dano (nuisance) e os constitucionalistas que percebem a democracia como uma ameaça". (Holmes, 1988, p.197). Holmes apresenta uma interessante análise ao final de seu artigo, que de certa forma vai ao encontro de minha conclusão no item 6. Para o autor, esta "tensão" entre constitucionalismo e democracia não deve ser encarada de forma dramática. Existem restrições que são “democracy-enforcing”. Além disso, o processo de aprendizado e de alterações futuras não implica em uma 
da soberania popular, da autodeterminação e do autogoverno da concepção democrática) e restrições constitucionais (do lado da proteção constitucional, das cartas de direitos e das políticas contra-majoritárias liberais de controle). A questão dos motivos pelos quais se criam pré-compromissos que vinculam a vida social futura (why commit?) implica várias questões, a que nos interessa mais de perto é formulada diretamente por Holmes: "é a análise de constitucionalidade das leis pela Suprema Corte, quando baseada em uma fidelidade supersticiosa na intenção dos Constituintes, compatível com a soberania popular?". ${ }^{682}$ Vale a pena reconhecer que Holmes afirma ser o constitucionalismo essencialmente anti-democrático, pois "retira certas decisões do processo democrático, ou seja, amarra as mãos da comunidade" e protege a comunidade contra formações de maiorias apaixonadas no futuro. Ele vale-se da metáfora de "Peter sóbrio se protegendo de Peter bêbado" e de Ulisses se amarrando ao mastro para não ceder à tentação do canto das Sereias. ${ }^{683}$

Por sua vez, em obra recente que revê algumas de suas posições, John Elster apresenta um quadro mais complexo. Dentre outros temas discutidos na obra, é interessante notar que o pré-compromisso pode não ser desejável não apenas da "ótica da democracia”, mas também pela ótica da eficiência. Isso é importante, pois como veremos abaixo nos itens 3 , eficiência e efetividade são "novas" atribuições do Judiciário quando a ele se atribui um papel ativo em políticas públicas, principalmente em contexto de “judicialização da política”. Ao formular esta questão, Elster volta-se para suas referências metafóricas: mesmo que as auto-restrições constitucionais sejam "correntes com as quais os homens se amarram em seus momentos de sanidade para que não morram por uma mão suicida em seu dia de frensi", elas podem se tornar ineficientes, pois "as auto-restrições constitucionais fortes podem ser incompatíveis com a flexibilidade de ação exigida em uma crise" ${ }^{684} \mathrm{O}$ reconhecimento deste problema para Elster o afirmar que "a constituição é similar ao superego, no sentido de consistir em regras rígidas e inflexíveis que podem impedir o comportamento sensato mais adequado em ocasiões específicas". ${ }^{685}$ Isso é muito

\footnotetext{
“dominação dos mortos sobre os vivos". Holmes reconhece que a determinação de certas restrições não "fecha" completamente a capacidade de mudança e aprendizado das regras, e arremata: "The dead should not govern the living; but they can make it easier for the living to govern themselves" (HOLMES, 2009, p. 240).

${ }^{682}$ No original, "Is judicial review, when based on a superstitious fealty to the intent of the Framers, compatible with popular sovereignty?” (HOLMES, 1988, p. 195).

${ }^{683}$ HOLMES, 1988, p.196.

${ }^{684}$ ELSTER, 2009, p.207.

${ }^{685}$ ELSTER, 2009, p. 220.
} 
interessante, pois Elster atribui à (inflexibilidade da) Constituição o caráter de "superego" e; de forma oposta, Ingeborg Mauss ${ }^{686}$ atribui ao Judiciário (ativo) o caráter paternalista de "superego" de uma sociedade órfã.

Estas "tensões e paradoxos" mais gerais constitutivos da democracia moderna em seu relacionamento com o constitucionalismo liberal se manifestam de forma específica nos modelos constitucionais de Judiciário "entre a política e a justiça”. Mas começamos a ver com Elster que existe também uma tensão específica à questão eficiência quando contraposta ao constitucionalismo. Veremos abaixo, também, que esta tensão da eficiência pode também ser atribuída ao judiciário; principalmente quando este órgão passa a agir de forma mais "ativa", no que se convencionou chamar de judicialização da política. Ainda mais, quando ele passa a influenciar políticas públicas e a chamar a responsabilidade para si da efetivação de direitos.

O diagnóstico da "judicialização da política", do "ativismo judicial" e de seu correlato "politização do judiciário" já foi bastante trabalhado pela literatura de forma muito diversificada e sob intensos debates. Para nossos propósitos cabe apenas apontar alguns conceitos e algumas "causas estruturais" usualmente atrelados a estes fenômenos para contextualizar o debate, de forma mais ou menos estilizada, buscando alguns elementos consensuais usualmente levantados pela literatura. Depois, portanto, cabe apresentar as duas visões opostas sobre este fenômeno.

Com efeito, o fenômeno da predominância dos tribunais em decidir questões tradicionalmente relegadas à esfera legislativa parece ter começado já com o fenômeno do fim da segunda Guerra-Mundial com a constitucionalização de direitos para serem protegidos "além do processo decisório" político majoritário ${ }^{687}$ mas a literatura tende a precisar o momento mais proeminente deste fenômeno nas últimas quatro décadas.

Por um lado, algumas explicações mais gerais e de caráter mais sociológico ${ }^{688}$ buscaram explicar o fenômeno como uma questão da evolutiva, resultando da divisão de

686 MAUSS, 2000.

${ }^{687}$ HIRSCHL, 2004, p 2 e 32.

${ }^{688}$ Arantes divide as explicações sobre a expansão do Judiciário entre dois enfoques complementares: um mais sociológico sobre a crise do Estado de Bem Estar social e outro mais jurídico sobre a expansão do acesso à justiça para direitos coletivos principalmente a partir da década de 1970. (ARANTES, 2004, p. 96). De forma semelhante, divido neste item explicações "sociológicas" e explicações mais "vinculadas à ciência política"; faço isso para tentar incluir algumas explicações mais recentes que aplicam análises de ciência política neoinstitucionalista ao judiciário e à análises da constituição para se abordar o fenômeno (nesta corrente, incluo Couto e Arantes, 2006 Taylor 2007 e também a tentativa de Hischl, 2004, dentre outros). 
poderes e da constitucionalização de direitos no desenvolvimento da democracia ${ }^{689}$. Outras por uma ótica "funcionalista" tentaram relacionar o fenômeno às respostas internas do sistema político a pressões para se regular diversos níveis de governo que proliferaram com a crise do Estado de bem-estar social, fazendo o judiciário precisar funcionar como policy-making; ${ }^{690}$ além daqueles que afirmam que a judicialização da política seria um resposta à complexificação social e à crise do Estado de Direito, acompanhada por uma crise da representação política tradicional. ${ }^{691}$

Dentre muitos, Tércio Sampaio Ferraz Jr. (1994) associa este fenômeno às novidades trazidas com o advento do Estado de Bem-Estar social que trouxe consigo a regulação da cidadania social - e não mais apenas a cidadania formal do Estado Liberal. Assim, novos direitos difusos e coletivos (class actions) trouxeram consigo uma maior responsabilização do judiciário em questões coletivamente vinculantes, inclusive em "ações corretivas de desvios na consecução das finalidades a serem atingidas por uma política legislativa. Tal responsabilidade, que, pela clássica divisão dos poderes, que cabia exclusivamente ao Legislativo e ao Executivo, passa a ser imputada também à Justiça". ${ }^{692}$ Neste mesmo sentido, Cappeletti e Garth sustentam que a "nova estrutura de direitos" que passou a ser prevista Constitucionalmente em Estados Sociais reorientaram a justiça para questões de acesso e efetivação de direitos. Ou seja, para tornar estes direitos efetivos, o Estado deveria torná-los 'realmente acessíveis a todos' ${ }^{693}$

No tocante a explicações mais pertinentes à ciência política, Rogério Arantes demonstra como a "expansão do judiciário" ocorreu no século XX em suas duas funções principais: prestação da justiça comum e controle de constitucionalidade das leis. Nesta dimensão política, Arantes apresenta um panorama da experiência norte-americana de como a jurisprudência da Suprema Corte dos EUA (modelo de controle descentralizado ou difuso), da Áustria (com modelo de controle centralizado) e do Brasil de 1988 (de modelo misto); foram ganhando ares de maior ativismo judicial. ${ }^{694}$ Ainda, Arantes relaciona uma questão trabalhada pelas teses da politização do judiciário: o judiciário também se expande

\footnotetext{
${ }^{689}$ HIRSCHL, p. 33.

${ }^{690}$ Para uma análise da proliferação de esferas normativas e a consequente inflação legislativa neste contexto, ver ZOLO, 2007, p.86; HIRSCHL, 2004, p. 35.

${ }^{691}$ ZOLO, 2007, p. 82. Ver também, sobre isso, ARANTES, 2004, p 97-8.

${ }^{692}$ FERRAZ JR, 1994, p. 18-19.

${ }^{693}$ CAPPELLETTI \& GARTH, 1988, p.10-11.

${ }^{694}$ ARANTES, 2004, pp. 87 e ss.
} 
consideravelmente nos números de casos e em seu acesso. Neste último ponto, Arantes ressalta a importância da questão dos direitos coletivos constitucionalizados e a da influência da legislação social, além da função do Judiciário como um veto player. Por sua vez, Matthew Taylor ${ }^{695}$ argumenta que o Supremo Tribunal Federal pode ser utilizado estrategicamente como veto player de políticas públicas; com interpelação de diversos recursos e, principalmente, pela interposição de Ações Direitas de Constitucionalidade. ${ }^{696}$ De maneira interessante, Taylor afirma ao final do artigo, que deixar o Judiciário de fora das análises das escolhas políticas em políticas públicas pode deixar estas análises incompletas.

Por sua vez, Ran Hirschl apresenta uma crítica à falta de estudos empíricos nestas abordagens que - mesmo quando opostas ao fenômeno da judicialização - ficariam sempre e apenas no plano normativo da natureza contra-majoritária e do déficit decrático deste fenômeno. Ao invés disso, o autor sugere uma abordagem empírica que vise analisar os resultados substantivos. ${ }^{697}$ Assim, o autor analisa as "origens políticas" da judicialização em quatro países a partir de uma abordagem da "tese da preservação hegemônica", com a qual Hirschl "traz de volta” os vetores políticos para a explicação, afirmando que o poder judicial é construído politicamente. Ele analisa a influencia das elites políticas como fator chave no empoderamento (empowerment) judicial. Dessa forma, o autor tenta fornecer explicações mais específicas sobre as variações de tempo, escopo e natureza de cada fenômeno específico de constitucionalização e judicialização: “a tese da preservação hegemônica pode nos ajudar a entender o empoderamento judicial através do constitucionalismo como parte de uma tendência mais ampla pela qual funções cruciais de policy-making são crescentemente insuladas do controle majoritário". Não obstante as críticas que esta proposta pode receber, é interessante notar que Hirschl aponta para a necessidade de estudos empíricos na área mesmo que de forma mais abrangente incluindo experiências de países em análises comparativas.

Contudo, o reconhecimento de quais dessas variáveis são as mais corretas para se explicar este fenômeno não é tanto a questão, aqui. Antes nos interessa debate acerca das tensões que a judicialização da política apresenta para as abordagens democráticas. Neste sentido Gisele Citadino apresenta bem os dois primeiros âmbitos da discussão atual acerca

\footnotetext{
${ }^{695}$ TAYLOR, 2006 (Mímeo)

${ }^{696}$ (principalmente pp. 15 e seguintes)

${ }^{697}$ HIRSCHL, 2004 p.3-4.
} 
da judicialização da política. A autora afirma que "o protagonismo recente dos tribunais constitucionais e cortes supremas não apenas transforma em questões problemáticas os princípios da separação dos poderes e da neutralidade política do Poder Judiciário, como inaugura um tipo inédito de espaço público, desvinculado das clássicas instituições político-representativas". 698

Podemos, portanto afirmar, que este fenômeno de 'ativismo judicial', portanto, apresenta diversos eixos de discussão. Assim, (i) além de apresentar o problema da discussão acerca da função do Judiciário no Estado ${ }^{699}$, o judiciário ativo (ii) apresenta um risco de constituir-se como um espaço político que tome conta da democracia representativa e instaure um tecnicismo paternalista contrário à cultura democrática. Este fenômeno judiciário como uma arena de decisões coletivamente vinculantes que não passam pelo processo democrático pode se configurar, como afirmou Ingeborg Maus, em uma "delegação de superego" à administração judicial das decisões coletivas e da moral, constituindo-se como um "obstáculo para uma política constitucional libertadora" ${ }^{700}$ De maneira oposta; este mesmo novo "espaço político" que o Judiciário parece ocupar em detrimento de instituições clássicas de representatividade pode também ser visto com extremo otimismo. Isso fica evidente na Análise de Werneck Vianna et all sobre este novo espaço do Judiciário no Brasil, que apresentar-se-ia como uma esfera na qual a cidadania ativa poderia apreender com um direito reflexivo. ${ }^{701}$ Ainda, a questão da (iii) eficiência,

${ }^{698}$ CITTADINO, 2002, p. 17 (ênfase adicionada).

699 Ou pela teoria da divisão dos três poderes, que já vimos no item 2 na tensão entre constitucionalismo e democracia. Não faltam análises neste que reputam este excesso e 'hipertrofia' de um Judiciário que não é eleito. Neste sentido, a soberania popular e a decisão democrática ficam prejudicadas. A literatura é grande, dentre muitos e os já vistos, ver o clássico TATE e VALLINDER, 1997, especialmente introdução no qual os autores afirmam que o crescimento do poder de "policy-making" dos juízes e a judicialização da política "saem dos EUA" e ganham o caráter de "expansão global do poder judicial". Os autores apresentam um panorama do debate, mas afirmam que muitos analistas da judicialização da política não são necessariamente seus "fãs", exatamente por suspeitarem de um processo que substitui o julgamento e decisões de policies da política majoritária (politics) por um julgamento de elites não-eleitas e nãorepresentativas de Cortes de Justiça. Para uma concepção "radical” que prevê um "constitucionalismo populista" em oposição à interpretação constitucional das Cortes, ver TUSHNET, 2000. Ainda, Hischl fala de um poder judiciário que - ao afastar o decision-making do legislativo - favorece as elites que mais acesso tem a ele, caminhando para uma tendência à uma verdadeira juristocracia (HIRSCHL, 2004, p.213).

${ }^{700}$ MAUSS, 2000.

${ }^{701}$ Nas palavras dos autores: "Mais uma vez, e agora no território inédito da democracia política, o direito, seus procedimentos e instituições passam a ser mobilizados em favor da agregação e da solidarização social, como campo de exercício de uma pedagogia para o civismo. A expansão do direito e do Poder Judiciário, em uma sociedade [brasileira] que jamais conheceu, de fato, a liberdade, se reveste, portanto de uma dupla inspiração. De um lado, nasce, como em outros contextos nacionais contemporâneos, da ocupação de um vazio deixado pela crise das ideologias, da família, do Estado e do sistema da representação; de outro, reitera uma prática com raízes profundas na história brasileira, em que o direito, como instrumento de ação 
efetivação e governamentalidade também se apresentam como um eixo de posições conflitantes. Pelo lado otimista, vemos autores que afirmam que este novo protagonismo do Judiciário é uma nova forma de se garantir a efetifidade de direitos sociais a qual seria impossível de ser garantida pelas estruturas tradicionais principalmente em países da America Latina. ${ }^{702}$ Além disso, existem propostas de se aumentar a capacidade de controle de constitucionalidade judicial para políticas públicas, sob argumentação de que o poder Judiciário seria mais eficaz e mais rápido que o Legislativo. ${ }^{703}$ Por fim, essa “expansão judiciária" levaria ao acesso dos mais pobres que poderiam se valer do recurso do judiciário para fazer valer seus direitos. ${ }^{704}$

Pelo lado negativo, algumas análises afirmam que a judicialização da política pode ser indesejável, pois interfere até na governabilidade democrática e na consistência do sistema político, abrindo demais o judiciário para decisões que sejam pautadas pelos interesses momentâneos e movimentos de massa. ${ }^{705}$ Além disso, vimos com Elster que uma "constitucionalização excessiva" (de pré-compromissos) pode levar a problemas de decisões eficientes devido à "inflexibilidade" das regras (as amarras de Ulisses podem ter sido apertadas demais, podemos dizer).

Neste apertado panorama vimos que a judicialização da política, em diversos eixos, pode ser vista por meio de duas semânticas normativas. Se "estilizarmos" e radicalizarmos estes argumentos podemos vê-las por um ângulo interessante: por um lado, ela ocorre como uma "panecéia", uma saída para a "crise" da representação, da democracia e do Estado Social. Por meio dessa panacéia, encontrar-se-ia não apenas uma garantia de efetividade de direitos velhos e novos; mas um espaço de aprendizado e de exercício de uma civilidade democrática que - além de impulsionar ações Estatais de políticas públicas - incentiva uma cultura democrática ajudando a transformação do status quo e o acesso dos pobres à Corte. Por outro lado, ela ocorre como a ameaça da tirania; tirania que retira o poder de decisão do povo; afeta a legitimidade democrática, viola o

de um intelligentzia jurídica, se põe a serviço da construção da cidadania e da animação da vida republicana". (VIANNA, CARVALHO, MELO, BURGOS, 1999, p.153).

702 Para Eugenio Raúl Zaffaroni, “a justiça moderna não pode ser apolítica neste sentido, e hoje mais do que nunca deve-se re conhecer que o poder judiciário é governo. Sua definição não pode ser encontrada na afirmação de que não estabelece regras erga omnes, de que não é "co-legislador", para reconhecer de imediato que igualmente não lhe resta às vezes outro recurso do que sê-lo, como o demonstra nossa realidade" (ZAFFARONI, 1995, p.24).

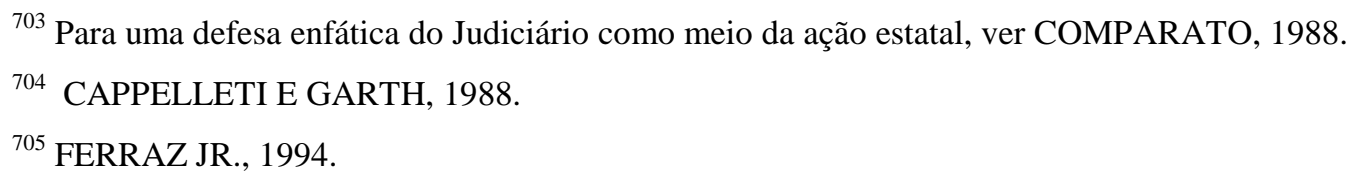


princípio dos três poderes, gera problemas de inconsistência política, sufoca a cultura democrática e o auto-governo de grupos sociais por "transferência de superego" à esferas "tecnocêntricas" de decisão judicial e, ao ser permeável por aqueles que têm maiores condições de acesso, funciona antes como uma conservação do status quo, servindo principalmente ao interesses de elites.

\subsection{Discussão e Conclusões parciais: a questão dos Tribunais Constitucionais}

A discussão que Habermas apresenta da jurisdição constitucional ${ }^{706}$ é voltada para sua teoria da deliberativa da democracia. ${ }^{707}$ Com efeito, ela pode influenciar diversos debates e questões através de formulações de sua teoria deliberativa da democracia, uma vez que Habermas poderia se posicionar no sentido de uma teoria radical da democracia e influenciar debates pautados pela discussão da divisão dos três poderes.

Por outro lado, se olharmos a questão pela ótica da teoria dos sistemas de Niklas Luhmann, outras questões se tornam relevantes, como as formas de "abertura" que sistemas como a política, o direito, e o sistema organizacional do Tribunal Constitucional poderiam ter frente à opinião pública.

Há alguns estudos dentro da teoria dos sistemas que trabalham a questão da politização do judiciário por uma outra ótica, a saber: da inserção de programas políticos ou programáticos no interior do sistema jurídico. Nota-se que Luhmann já discorreu sobre o tema da pretensão de influências externas no interior do direito quando tratou de doutrinas que pregavam uma dogmática sociológica para o direito. $\mathrm{O}$ autor afirma que fazer tais pretensões implicaria em desconhecer a função que a dogmática exerce para o sistema jurídico, principalmente no que toca sua importância em mediar a adequação social do direito com sua consistência jurídica interna; consistindo a dogmática no nível mais elevado de auto-observação do sistema jurídico. ${ }^{708}$

Além disso, Celso Fernandes Campilongo aborda a politização do judiciário a partir da tese de que haveria uma inserção de "programas finalísticos" (típicos da política) dentro do direito. Eles se oporiam aos "programas condicionais" típicos do sistema jurídico e

\footnotetext{
${ }^{706}$ Ver, por exemplo, HABERMAS, 2003b, pp. 330 e ss.

${ }^{707}$ CITAR HABERMAS, 2003c, pp.

${ }^{708}$ Ver, neste sentido LUHMANN, 1983c, e CORREIA e RIBEIRO, 2010.
} 
operariam uma sobrecarga política ao sistema jurídico que, por não conseguir filtrar em sua periferia as comunicações políticas de seu ambiente, incorreria em problemas de consistência interna. Pela tese do "hipercontato intrasistêmico", a periferia não conseguiria filtrar as irritações provenientes do ambiente jurídico e, os tribunais localizados no centro do sistema não conseguiriam agir de forma juridicamente consistente, adotando programas finalísticos. $^{709}$

Nessa mesma linha, Orlando Villas Bôas Filho, apoiado em Tércio Sampaio Ferraz Jr., traça um diagnóstico parecido trabalhando a questão da "desneutralização" do judiciário vinculando-o a uma "crítica pública e pressão política" com efeitos potencialmente destrutivas. O autor afirma que problemas de consistência do direito (problemas entre redundância e variação) não seriam apenas característicos de países integrantes da modernidade periférica, ${ }^{710}$ mas afetariam todos os tribunais. Ele argumenta tratar-se de um "fenômeno que acompanha o aumento de complexidade da sociedade moderna em escala mundial e que, como consequência, afeta a clássica divisão dos poderes tradicionalmente assentada na pressuposição de uma neutralidade do Poder Judiciário, consistente, como bem nota Tércio Sampaio Ferraz Jr., não numa indiferença generalizada, mas sim numa indiferença controlada, que se traduz na independência e imparcialidade do juiz. Como corolário da perda de neutralidade, há uma tendência à repolitização do Judiciário que transforma a responsabilidade outrora condicional do juiz neutro numa responsabilidade finalística de um juiz que passa a estar investido de uma função socioterapêutica. Ora, essa desneutralização política do Judiciário o submete à crítica pública e à pressão política de forma muito mais contundente e potencialmente destrutiva. Ou seja, nota-se que a desneutralização do Judiciário revela uma irritação crescente do subsistema jurídico, sobretudo pelo subsistema político, irritação essa que precisa ser devidamente filtrada a fim de que não se perca a especificidade funcional que caracteriza cada um desses subsistemas sociais. ${ }^{711}$

\footnotetext{
${ }^{709}$ Ver, especialmente. CAMPILONGO, 2002, esp. pp 93 e ss.

${ }^{710}$ Ver artigo anexo para uma discussão sobre o assunto. Sobre a questão específica da modernidade periférica, Marcelo Neves apresenta um argumento contrário ao argumento o do pluralismo jurídico, que visaria se atentar para a "abertura" do direito a outras formas de regulação não-jurídicas de comunidade e, assim evitar a "juridificação"; por afirmar que esta corrente seria mais adequada para países da modernidade central, desconhecendo os problemas de consistência e autonomia do direito em países integrantes da modernidade periférica. (NEVES, 2003c).
}

${ }^{711}$ VILLAS BÔAS FILHO, 2009, pp 392-394. Ênfases adicionadas. 
A questão de se apontar para a politização do judiciário a partir da inserção de programas finalísticos no sistema, principalmente a se referir a uma "opinião pública com potencial destrutivo" parece também poder ser analisada por uma ótica que leve o postulado da diferenciação funcional de uma forma menos "normativa", por assim dizer, e se volte antes para análises de como ocorrem relações entre a opinião pública e o sistema jurídico. Além disso, seguindo as formulações de Rudolf Stichweh, poder-se-ia pensar em se abordar a existência de uma "esfera pública do direito", além de se problematizar a relação entre o centro e a periferia desse sistema.

Nestes debates, contudo, uma questão parece passar despercebida, a saber: a questão dos Tribunais Constitucionais. Os Tribunais Constitucionais parecem ser o centro de grande atenção desse debate, mas seu enquadramento teórico na teoria de Luhmann me parece ser pouco explorado, tanto pelo autor quanto por seus comentadores. Não obstante, ao ser encarado como uma organização que se vincula ao sistema político e ao sistema político, simultaneamente, sua análise pode abrir diversas questões para o debate. Além disso, a politização do judiciário levanta questões relevantes de como uma "hipertrofia" de uma organização decisória tal como são os tribunais constitucionais pode interferir no contexto dos processos políticos e, com isso, tornar-se relevante para a esfera pública política e para a opinião pública.

Note-se que, para Luhmann, os Tribunais são "organizações" que decidem no sistema jurídico. Contudo, como vimos no Capítulo 1, as organizações são sistemas autopoiéticos que podem se ligar com outros sistemas da mesma sorte, uma peculiaridade entre os sistemas sociais. Isso nos leva a um problema interessante, uma vez que os Tribunais Constitucionais, por meio da jurisdição constitucional, estão intimamente ligados à Constituição, forma do acoplamento estrutural entre política e direito.

Alias, ao tratar dos acoplamento estrutural da política com o direito pela Constituição, Luhmann chama a atenção para os acoplamentos realizados pelos sistemas organizacionais entre os dois sistemas. Neste sentido, as organizações do acoplamento estrutural de sistemas sociais servem para que ele possa gerar uma hipertrofia das possibilidades de decisão (Hypertrophie von Entscheidungsmöglichkeiten)", 712 É precisamente aqui que Luhmann chama a atenção para os Tribunais constitucionais

${ }^{712}$ LUHMANN, 2000, p. 400. 
(Bundesverfassungsgerichts) como organizações que servem ao acoplamento do direito com a política. ${ }^{713}$

Com isso em mente, seria possível tratar, a partir da teoria dos sistemas de Luhmann, da questão dos Tribunais Constitucionais a partir de suas relações com o direito por meio da Constituição, mas, além disso, de abordagens que tratem de questões acerca da esfera pública. Poderíamos pensar que, uma vez que a literatura reconhece uma "hipertrofia" dessa organização que se vincula tanto à política (portanto à tomada de decisões vinculantes) quanto ao direito, seu funcionamento pode ser encarado dentro do contexto do conceito de esfera pública de Luhmann ou até de opinião pública, uma vez que ele se relaciona estritamente com o sistema político. Ademais, a importância que essa organização tem ganhado na mídia, com vinculação de pautas sobre suas decisões, reproduções televisivas imediatas de suas sessões, etc. podem abrir espaço para estudos que analisem sua relação com os meios de comunicação em massa, e a inter-relação mútua entre os dois.

${ }^{713}$ LUHMANN, 2000, p. 401. 


\section{CAPÌTULO 5 - MOVIMENTOS DE PROTESTO, ESFERA PÚBLICA MUNDIAL E DIREITOS HUMANOS}

\section{Introdução}

Este capítulo, também com caráter panorâmico e "ensaístico", busca apresentar algumas possibilidades de se estender o conceito luhmanniano para "iluminar" novas possibilidades de discussão por teorias de médio alcance que visem estudar fenômenos contemporâneos vinculados à questão da esfera pública de forma mais completa. Portanto, (i) após esta introdução, são apresentados aqui comentadores da teoria dos sistemas de Luhmann que desenvolvem, criticam e aplicam suas teses (ii) ao conceito de movimentos sociais, e (iii) ao diagnóstico da formação de uma esfera pública mundial.

\section{Movimentos de protesto}

A teoria sociológica - seja ela "positiva" (focada primariamente na explicação da ordem pelos "fatos sociais"- "qual é o caso?”), seja ela "crítica" (pautada primariamente no conflito, na latência oculta e na emancipação - "o que se esconde atrás?”) - enfrenta o problema da "negação da sociedade", questionando-se sobre os movimentos de protesto. A questão da "negação da sociedade" - na qual se insere a questão dos movimentos de protesto - é, portanto, questão central à teoria sociológica principalmente no tocante à questão de se definir o que é sociedade. ${ }^{714}$

Portanto, de maneira provocativa, Luhmann refere-se à tentativa do mundo antigo de se traçar um limite para a observação (do mundo) a partir de Deus e do "Anjo caído Satanás" e afirma que "no mundo moderno isso é assunto dos movimentos de protesto; com a diferença de que estes não caem, senão se elevam". ${ }^{715}$ Vemos aqui a questão da "afirmação/negação" da sociedade em termos de metáfora. A maneira pela qual esta mesma questão é tratada pela sociologia é de extrema relevância. Luhmann - ao (re)problematizar a questão de como a sociedade é possível (ou se afirma) ao mesmo

${ }^{714}$ Luhmann sustenta que a definição do que é sociedade é questão central para ser debatida na teoria sociológica, sendo ela uma de suas principais metas teóricas (LUHMANN, 2007a, p. 10 e pp 51 e ss.).

${ }^{715}$ LUHMANN, 2007a, p. 672 
tempo que visa explicar como opera sua negação dentro da própria sociedade ${ }^{716}$ - leva a questão da "afirmação/negação da sociedade" para novos terrenos da sociologia.

\subsection{Elementos do debate contemporâneo sobre movimentos sociais}

Sem pretender uma análise exaustiva, mas antes apenas para exemplo de ilustração, vejamos algumas considerações sobre o desenvolvimento de teorias acerca dos movimentos sociais (que Luhmann denominará de movimentos de protesto).

Usualmente $^{717}$ aponta-se o início do debate (i) pela perspectiva das teorias de massa e do comportamento coletivo (collective-behavior approaches), baseadas na abordagem smelserniana, na qual os movimentos sociais eram vistos como irracionais; funcionando como "multidões" ou "hordas" espontâneas (esponteneous crowds), ${ }^{718}$ muitas vezes entendidos como ações pautadas por "reações" resultantes de mudanças estruturais na sociedade (breakdown thesis ${ }^{719}$ ) que levam a condições de "anomia social"720 no sentido de Émile Durkheim. Por outro lado, (ii) a teoria marxista ofereceu uma explicação da sociedade a partir de uma ontologia de "bases reais" determinada por "produção de modos de vida" ${ }^{, 721}$, em que a partir do materialismo histórico dialético se pôde pensar a sociedade moderna por um conflito e por uma contradição estruturais entre burguesia e proletariado. ${ }^{722}$ Por ela, existe $u m$ conflito material homogêneo estrutural da sociedade e a figura do proletariado aparece como "sujeito da história"; ou seja, como movimento social homogêneo ou material.

\footnotetext{
${ }^{716}$ Luhmann faz isso de maneira interessante ao enfrentar temas clássicos como a "contradição" e o “conflito" (cf. LUHMANN, 1995b, cap. 9.), afirmando que a contradição lógica não é suficiente para explicar a sociedade. (esp. pp 359-361). Isso, contudo, não implica concordarmos com a interessante e controversa tese de Bachur de que este reconhecimento de Luhmann da contradição social seja necessariamente um elemento da "materialidade da comunicação", próximo até da idéia de "contradições reais”, em Karl Marx. (BACHUR, 2010, esp. pp. 197 e ss.)

${ }^{717}$ Este "desenvolvimento" da teoria é já clássico na literatura. (ver esp. COHEN \& ARATO, 1992, cap. 10 pp. 493-563; COHEN, 1985; além de ALONSO, 2009.)

${ }^{718}$ COHEN, 1985 e COHEN e ARATO, 1992, pp. 496

${ }^{719}$ Cf. COHEN \& ARATO, 1992, p. 510, dentre muitas.

${ }^{720}$ Para este conceito, dentre muitas obras, ver DURKHEIM, 2004. Pp. 311 e ss.

${ }^{721}$ MARX e ENGELS, 2002, p 18-19, onde se encontra a célebre frase: "partimos dos homens em sua atividade real, é a partir de seu processo de vida real que representamos também o desenvolvimento dos reflexos e das repercussões ideológicas desse processo vital”.
}

${ }^{722}$ MARX e ENGELS, 1982, esp. pp 93 e ss. 
Posteriormente, "teorias de médio alcance" orientadas para a pesquisa empírica ganharam espaço ao mesmo tempo em que a cunha de "irracionalidade" dos movimentos sociais perdeu força. Aqui, (iii) surgem teorias que buscam explicar "a lógica da ação coletiva" por meio de elementos da "análise racional". (iv) Mais importante foram os estudos de "microssociologia organizacional" da teoria da mobilização de recursos; que entendiam os movimentos sociais como organizações latentes e manifestas; afirmando que eles devem mobilizar recursos para continuar atuando e atingir objetivos. ${ }^{723}$ (v) Então, principalmente sob com o advento do "neoinstitucionalismo" na ciência política - que "trouxe o Estado de volta" -, os movimentos sociais deixaram de serem compreendidos por sua organização e passaram a ser entendidos por sua relação com o Estado e com a Política (com maiúscula). Não apenas devido ao fato de o Estado ser "alvo" dos movimentos sociais, mas também devido às possibilidades explicativas que contextos políticos podem ter para a questão do surgimento de movimentos sociais. Neste contexto, as "estruturas de oportunidades políticas" de Charles Tilly foram extremamente influentes ${ }^{724}$.

Mas o que nos interessa mais aqui são (vi) as "teorias dos novos movimentos sociais", que retomaram o debate na sociologia "de grande alcance" realizando um movimento de retorno "à dimensão da integração social na ação coletiva sem, contudo, reproduzir a confiança durkheimniana na breakdown thesis ou os modelos smerlserianos de comportamento coletivo". ${ }^{725}$ Aqui, podemos indicar duas correntes: (vi.1) a corrente que analisa a questão da formação de identidades e (vi.2) a corrente que analisa os movimentos sociais na sociedade civil. Veremos esta última no item 3, abaixo.

O reconhecimento básico deste paradigma dos novos movimentos sociais é o de que a sociedade "pós-industrial” (Alain Tourraine) ou "da informação" (Alberto Melucci) não comporta mais movimentos sociais como o do proletariado. Os "novos" movimentos sociais seriam pautados pela "pluralização dos locais de conflito", por uma estrutura "transclassista", por demandas imateriais, por organização difusa e por objetivos que não implicam a tomada de poder ou a participação do Estado. Este reconhecimento tem

${ }^{723}$ Dentre muitos, ver a exposição desta teoria in COHEN \& ARATO, pp. 497 e ss.

724 Cf. TILLY, 1994. Apesar de muitos considerarem a perspectiva da estrutura de oportunidades políticas independente (cf. ALONSO, 2009); outros a consideram compatível (ou mesmo parte) da teoria de mobilização de recursos, cf. COHEN \& ARATO, 1992, p. 496-497; além do livro organizado especificamente com o intuito de trabalhar as duas teorias: McADAM, McCarthy \& ZALD, 1999.

${ }^{725}$ COHEN \& ARATO, 1992, p. 510 
importantes consequências: ora, quando "novos personagens entram em cena",726 as teorias "espontaneístas" de massa não dão mais conta de explicar como estes movimentos plurais surgem; além disso a teoria marxista não permite um enquadramento analítico destes movimentos; e, portanto, torna-se necessário uma nova teoria dos novos movimentos sociais que leve em consideração o "lócus" destes movimentos sociais. Aqui ganham força os elementos explicativos de "cultura", "identidade", "solidariedade" e de "sociedade civil".

Alberto Melucci trabalha os movimentos sociais também por suas "funções simbólicas" ${ }^{, 727}$ chegando a afirmar que até a forma de organização dos movimentos sociais teria mudado, sendo ela agora mais voltada para "identidades coletivas", "cultura de identidades" e "imersão na vida cotidiana". Isso, além de tornar obsoletas as teorias da mobilização de recursos que não explicam os motivos do surgimento dos movimentos, é importante, pois demonstra a criação de um espaço próprio para a ação coletiva nas sociedades complexas - o que vai contra a proposta de Charles Tilly de relacionar os movimentos sociais com uma orientação primordial ao Estado. ${ }^{728}$ Isso é essencial para a questão do loccus, dos movimentos sociais; que agora passa a ser explicado por variantes culturais de produção de solidariedade e identidades coletivas, principalmente na sociedade civil. Isso implicou toda uma construção teórica da questão clássica da sociologia da integração social: os movimentos sociais não seriam explicáveis por variantes estruturais, organizacionais nem políticas - os novos movimentos sociais não apenas entram em cena, como também levam o debate para outro lugar, a saber, o lugar do "simbólico e da significação"; da formação da cultura e da solidariedade; da sociedade civil e, em última análise, do "mundo da vida".

Antes de ver análise, é importante que se diga que a "teoria de médio alcance" do subcampo específico da sociologia que estuda movimentos sociais orientando pesquisas empíricas desenvolve-se muito além desta pequena revisão. Um exemplo interessante é como esta explicação do surgimento e do modo de funcionamento de movimentos sociais a partir de "identidades" foi relida de modo não-normativo pela teoria dos framing processes por David Snow, que afirma que os movimentos sociais apresentam um "enquadramento" de simplificação da realidade que constituem identidades (como laços

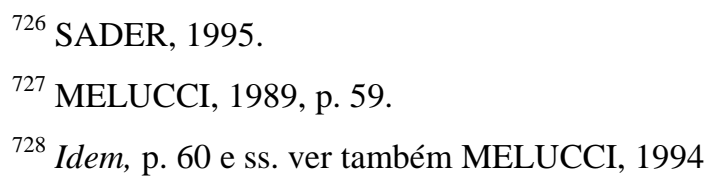


organizativos) e simplificam a visão de mundo para orientar a ação. ${ }^{729}$ Isso não apenas foi lido de maneira mais normativa pelo clássico conceito de "matrizes discursivas" de Eder $\operatorname{Sader}^{730}$, mas também - se lido como em David Snow, de maneira descritiva - é congruente com o conceito de scripts simplificadores, que Luhmann apresenta (abaixo).

Como vimos, Cohen e Arato afirmam que o paradigma dos "novos movimentos sociais" recolocaram a questão da integração social e o locus da sociedade civil de volta na pauta. Ora, como a sociedade se mantém integrada (e quem é incluído nesta integração) é uma questão importante. Abordagens normativas que viram um "papel exagerado" do direito na integração total da sociedade não faltaram. A ideia básica é que a sociedade moderna se integra por base em direitos; ou ainda, podemos pensar que a integração da sociedade e a inclusão de pessoas ocorrem por meio da inclusão nos sistemas jurídicos e políticos pela cidadania (e pela luta de ampliação de direitos). ${ }^{731}$

Em suma, vimos até aqui como o debate sociológico dos movimentos sociais realizou um movimento grande saindo de grandes determinantes "estruturais" (Smelser e Marx), passando por análises organizativas e relacionadas com a política, para chegar ao contexto da sociedade civil e cultura. Dessa forma, os movimentos sociais passam a se localizar na sociedade civil e a serem explicados com base na formação de solidariedade e identidade próprias do "mundo da vida", que engloba a sociedade civil.

\subsection{Luhmann e os movimentos de protesto}

Por sua vez, onde Luhmann "localiza" em sua teoria os movimentos de protesto? Já podemos perceber que eles não podem estar em uma "posição privilegiada" em um "mundo da vida" de solidariedade. Pela teoria dos sistemas, eles não podem estar fora da sociedade. Para Luhmann a tipologia "sociedade, organização e interação" não é suficiente para compreender o fenômeno dos movimentos de protesto", 732 que teriam um status próprio na teoria. Eles não são organizações, pois para não lidam com decisões, mas com

\footnotetext{
${ }^{729}$ SNOW, 1988.

${ }^{730}$ SADER, 1995, esp. p. 143

731 Vimos essa questão no Capítulo 3 quando tratei das teorias de Habermas e Honneth sobre a "cidadania ativa"

${ }^{732}$ LUHMANN, 2007a, p. 672
} 
vínculos de motivação de status de membros (membrecía); e não são interações, pois não são apenas momentâneos. ${ }^{733}$

Para Luhmann, como vimos, a questão improvável de aceitação da comunicação social ocorre por meio dos meios de comunicação simbolicamente generalizados. Quando estes meios não conseguem se generalizar na sociedade diferenciada, os movimentos de protesto surgem para dar uma resposta a este problema. Os movimentos de protesto constituem-se, pois, paradoxalmente, como uma comunicação na sociedade contra a sociedade. $^{734}$ Luhmann reconhece, em consonância com o debate que vimos anteriormente, que os "novos" movimentos de protesto não são homogêneos, não podem ser explicados pela teoria de classe - por terem temas diversificados - e não podem ser explicados nem pelo behavorismo da Escola de Chicago nem pela noção individualista de racionalidade. $^{735}$

Ainda, os movimentos de protesto não teriam a sua unidade dada por um código binário, mas pela forma do protesto. ${ }^{736}$ Nesta forma de protesto, a tensão "tema/protesto" é essencial; ou seja, "o protesto vive da seleção de um tema". ${ }^{737}$ Ao selecionar um tema, a forma do protesto prevê que ele coloque-se em um (pseudo) "auto-exílio",738 da sociedade dirigindo-se contra ela. (isso apenas vale para a auto-observação de primeira ordem dos movimentos sociais). Isso, pois o protesto foca apenas a questão do "problema", não havendo a pretensão de sua "solução"; que deverá (ou não) ser processada por um sistema funcional específico (o protesto não visa virar governo; ou seja, não participa da distinção governo/oposição do sistema político). ${ }^{739}$ Descrevendo-se como "auto-exilado"; o protesto pauta-se por questões "éticas" (e portanto nada relacionadas pela regra da maioria) e

\footnotetext{
${ }^{733}$ L LUHMANN, 2007a, p.673 e 675

${ }^{734}$ LUHMANN, 2007a, p. 685 e 676.

${ }^{735}$ LUHMANN, 2007a, p.675
}

736 Para Luhmann, os códigos binários do tipo "sim"/“não" fecham um sistema social autopoiético internamente. Isso se dá a exemplo do código "lícito/ilícito" no direito; "ter/não ter" na economia; "belo/feio" na arte; etc. Para o conceito de forma como uma forma de dois lados, dentre muitos, ver LUHMANN, 2007a, pp 145 e ss.

${ }^{737}$ LUHMANN, 2007a, p.680

738 BACHUR, 2010, p.253 afirma que os movimentos de protesto "[t]êm de se auto-exilar na sociedade, têm de se converter a uma espécie de autismo deliberado". É claro que isso não implica "sair da sociedade": "o paradoxo dos movimentos de protesto está no fato de que eles tentam mobilizar a sociedade contra ela mesma, mas como se estivessem fora ou acima da sociedade” (BACHUR, 2010, p.251)

${ }^{739}$ LUHMANN, 2007a, p.679 
descreve o mundo por 'scripts' que simplificam o mundo em descrições em forma de "escândalo". 740

Luhmann não desconhece que os protestos irritam os centros dos sistemas, principalmente do jurídico e político, que chegam a "absorver" alguns deles. O autor dá o exemplo de que protestos valem-se da constituição como acoplamento estrutural entre o direito e a política como "provocação para provocar". Além disso, Luhmann concebe a possibilidade de um acoplamento estrutural entre movimentos de protestos e meios de comunicação em massa pelos temas específicos afirmando que os protestos se adéquam à disposição de reportagem dos meios de comunicação em massa. ${ }^{741}$

Enfim, o que Luhmann contribui para o debate anterior que vimos? Ora, em primeiro lugar, Luhmann supera as teses "espontaneístas" e "marxistas" sem cair em questões "microssociológicas" e sem localizar os movimentos de protesto na "sociedade civil" ou em qualquer instância crítica de legitimação dos sistemas. Luhmann demonstra que os movimentos de protesto são uma forma social de processamento de contradições e conflitos. Isso é extremamente relevante para a teoria sociológica de grande alcance que desde a metade da década de 1990 parece não mais se manter com teorias do consenso, da sociedade civil e de "crises de legitimidade". A teoria dos sistemas sociais parece apontar para uma teoria complexa o suficiente para dar conta de problemáticas sociais e sociológicas as mais diversas em uma sociedade funcionalmente diferenciada. E melhor que isso, ela o faz em um nível alto de abstração teórico cada vez menos prestigiado na pesquisa sociológica. Em segundo lugar, Luhmann apresenta uma descrição dos movimentos de protestos que não coloca o direito como uma "instância salvadora", ou abarcadora dos movimentos sociais. Mesmo reconhecendo que estes podem dirigir-se ao centro dos sistemas político e jurídico para serem ouvidos.

Algo também digno de nota é que Luhmann apresenta uma teoria interessante da contradição e do conflito que vai além da "pergunta pelo sujeito" de movimentos de protesto. Na teoria dos sistemas a sociedade moderna não processa conflitos apenas por movimentos de protesto; mas também por procedimentos. O tema da contradição e do

${ }^{740}$ LUHMANN, 2007a, p.683. Aqui é evidente o paralelo com a função dos framing processes reconhecidos pela "teoria de médio alcance" de David Snow. Luhmann chega a falar, quando tratando de teorias psicológicas, que frames, schematas e scripts seriam sinônimos. LUHMANN, 2007a, p. 81.

${ }^{741}$ LUHMANN, 2007a, p. 684. Desta forma, seria exatamente uma adequação a estes seletores que o acoplamento entre estes meios e os protestos por meio de temas específicos ocorreria. Luhmann afirma que a exposição midiática e televisiva dos movimentos de protestos visa "chamar a atenção para o tema" (LUHMANN, 2007, p. 683-4) 
conflito não é monopólio de movimentos sociais, havendo diversos conflitos entre os próprios sistemas (como por exemplo, entre direito e economia; entre política e economia e até entre pedagogia e ciência acoplados estruturalmente pela universidade). Na verdade, a sociedade contemporânea cria uma espécie de "sistema imunológico" que processa conflitos sem que eles interrompam a reprodução autopoiética da sociedade. (protegendo, pois, a sociedade). ${ }^{742}$ Neste contexto, Bachur demonstra que a sociedade processa conflitos se reproduzindo como movimentos de protesto e procedimentos. (que não se confundem com processos jurídicos). Os procedimentos, entendidos em seu funcionamento comunicativo, designam "o processo social de reestruturação comunicativa de expectativas"; mas o procedimento não elimina o descontentamento nem o inconformismo, mas procura minimizá-los tanto quanto possível. ${ }^{743}$

Com Luhmann, parece que a questão da "síntese" que transcende a afirmação/negação da sociedade não é possível; visto que não há um ponto de vista externo na sociedade; nem um "sujeito histórico" localizado fora dela (ou na sociedade civil). A relação "Deus/Diabo" parece antes ser processada socialmente (com comunicação) por meio dos procedimentos e dos movimentos de protesto.

Contudo, e isso é importante que se diga, isso não quer dizer que Luhmann tem uma visão negativa dos movimentos de protestos. A metáfora "demoníaca” é apenas para indicar o caráter de negação destes movimentos, e não desprezá-los valorativamente.

\subsection{Conclusões parciais: movimentos de protesto na sociedade moderna}

Luhmann vincula sua análise da esfera pública também ao âmbito dos movimentos de protesto, afirmando que ela serviria para que eles tomassem posicionamentos e observassem a si próprios e aos outros sistemas da sociedade. ${ }^{744}$ Por também lidarem com "temas", isso os torna vinculados aos meios de comunicação em massa e à opinião pública. Sua teoria parece não se contrapor aos principais desenvolvimentos das teorias de médio alcance que reconhecem serem os "novos" movimentos sociais transclassistas, heterogêneos e não vinculados à tomada do poder político. Todavia, ainda que sua teoria não postule um conceito normativo de movimentos de protesto e evite recair em teses da

742 ver LUHMANN, 1995b, Capítulo 9. Para o conceito de "sistema imunológico" ver também, E BACHUR, 2010, p.241 e ss.

\footnotetext{
${ }^{743}$ BACHUR, 2010, p. 246 e ss.

744 Como vimos em LUHMANN, 2005c, p. 169
} 
"espontaneidade" dos movimentos sociais, Luhmann parece não apresentar grandes contribuições para o campo de estudos desses movimentos. Suas análises não oferecem abordagem detalhada sobre como esses movimentos se formam ou sobre a maneira pela qual eles se organizam.

Entretanto, a partir do conceito luhmanniano de esfera pública, é possível analisar como movimentos sociais se observam e observam os sistemas sociais da sociedade. A partir de uma esfera pública entendida como o âmbito de reflexão da sociedade, os movimentos sociais podem ser observados por (e observar os) meios de comunicação em massa, sistemas políticos, sistema educacional, família, sistema de relações íntimas (amor) etc. Isso parece ser uma decorrência positiva do modelo. Com isso, ao se retirar a "politização" e a "idealização" excessivas do conceito de esfera pública habermasiano, parece que o conceito de movimentos de protesto que pode ser desenvolvido a partir de Luhmann - ainda que revisto e trabalhado por comentadores - pode fornecer elementos que compreendam protestos contemporâneos em sua vinculação com outros sistemas funcionais que não apenas política e o direito.

Além disso, Luhmann parece apresentar certo "preconceito", por assim dizer, ao lidar com a relação entre os movimentos de protesto e a sociedade moderna funcionalmente diferenciada. Ao exigir desses movimentos que eles reconheçam que se encontram num contexto de diferenciação funcional, Luhmann parece recair em um problema interno de sua teoria. Isso, pois essa exigência não é feita para nenhum outro sistema social que, no plano de suas observações de primeira ordem, se autodescrevem como se exercessem influência direta em toda a sociedade, não tomando a sociedade como funcionalmente diferenciada em suas observações. Ora, citando o próprio autor em sua famosa frase: "eles não podem ver que não podem ver o que não podem ver". 745

Mais importante que isso, Luhmann deixa de reconhecer diversos movimentos sociais contemporâneos que, nas palavras de Hans-Georg Moeller, estariam mais conscientes da diferenciação funcional e dos limites que ela impõe. O autor dá o exemplo de movimentos ativistas na América do Norte que clamam por direitos para minorias, direitos feministas e direitos homoafetivos - todos eles com notável tendência de orientação funcional, demandando, pois, acesso a determinados sistemas. Isso se expressaria por "demandas por maior representação nos sistemas jurídico e político (mais

745 Essa frase é utilizada por Luhmann para demonstrar os "pontos cegos" inerentes a todos os sistemas sociais. No Capítulo 1 vimos essa questão com a metáfora do "sol nascendo". Não há como escapar da observação de primeira ordem. 
políticas mulheres, mais juízes afrodescendentes), igual tratamento na educação e na economia (acesso igualitário à universidades para minorias, igualdade de renda entre gêneros). Estes tipos de ativismo parecem aceitar a diferenciação funcional com muita boa vontade". Suas metas e suas semânticas se harmonizariam com o princípio de inclusão igualitária nos sistemas ("uma das metas da diferenciação funcional”). Segundo Moeller, tal adaptação desses ativistas parece garantir-lhes maior sucesso - ou pelo menos sucesso mais imediato - uma vez que "suas demandas podem ser realmente satisfeitas pelos sistemas funcionais e traduzidas por eles". Esse "ativismo socialmente adaptado" falaria a "língua" de sistemas funcionais e pediria pela mesma coisa que os sistemas fazem: inclusão generalizada (all-inclusion). Ademais, esses sistemas chegariam a cooperar com a diferenciação funcional, ajudando-a a se estabilizar e se perpetuar. A inserção desses movimentos nos meios de comunicação em massa seria uma decorrência dessa adaptação social. Com efeito, Moeller apresenta o exemplo de movimentos por direitos humanos que não seriam antagonistas da sociedade, de modo que sua semântica "seria compartilhada por diversos políticos, pela mídia de massas, e até pela economia". Mesmo admitindo que Luhmann tenha refletido sobre essas questões, Moeller afirma que tais movimentos dificilmente poderiam ser chamados de movimentos de protesto. ${ }^{746}$

Por sua vez, Celso Fernandes Campilongo apresenta argumentação semelhante ao tratar da relação entre movimentos sociais e o direito, afirmando que existiriam três tipos de movimentos sociais em relação a esse subsistema: (i) movimentos "contra o direito", no qual haveria luta por sua revogação ou por nova interpretação do direito, buscando-se a modificação do direito vigente por meio do próprio sistema jurídico; (ii) movimentos pelo "direito", na luta pelo reconhecimento e afirmação de direitos ainda não estabelecidos e pela conquista de novos direitos na lei ou na justiça; e (iii) movimentos "após o direito", que se caracterizariam pela busca da eficácia de direitos, pela adoção de políticas, pela reorientação da jurisprudência, etc. $\mathrm{O}$ autor considera também movimentos que sejam contrários ao direito estruturado como sistema social diferenciado. Tais movimentos não pretenderiam pleitear sua melhora, mas antes "violá-lo, transgredi-lo ou submetê-lo a testes que desvelem seus limites operativos e sua incapacidade decisória, isto é tornem manifestas suas latências. Uma estratégia para despir e ridicularizar a Justiça”. Contudo, Campilongo argumenta que "[m]esmo quando atuam desse modo, ainda que de maneira não prevista ou indesejada, eles contribuem para o aguçamento da autorreflexão do direito,

\footnotetext{
${ }^{746}$ MOELLER, 2006, pp. 106-108
} 
para [a] expansão de sua capacidade de auto-observação e autocorreção de suas operações e, por fim, introdução de variabilidade no sistema jurídico". ${ }^{747}$ Assim como Moeller, Campilongo também argumenta que movimentos de protesto podem se organizar contra a produção de exclusões na sociedade moderna. ${ }^{748}$

Uma outra questão se coloca. Mesmo se admitirmos a tese - cujo peso terminológico me parece ser discutível - de que os movimentos sociais "socialmente adaptados" à diferenciação funcional com pretensões de inclusão generalizada nos sistemas sociais seriam mais "conscientes", com grandes possibilidades de sucesso e cooperativos com os sistemas sociais parciais de função; ainda não é possível acessar a questão já aceita por Luhmann em seus últimos trabalhos de que a "inclusão generalizada" trazida pelos sistemas funcionais de função não pode ser cumprida. Ainda que seja importante reconhecer que a exclusão possa gerar movimentos sociais que consigam grandes conquistas por meio de prestações de acesso a sistemas sociais diversos, não me parece adequado associar a isso um caráter normativo de que estes processos seriam mais "adequados" ou conscientes, uma vez que o próprio Luhmann reconhece que os amplos setores de exclusão da sociedade mundial são produzidos precisamente pela diferenciação funcional da sociedade. Além disso, tal estratégia exclui da análise movimentos de protestos que são identificáveis na sociedade os movimentos de protesto "radicais", por assim dizer. Tratar tais protestos como "inconscientes", "inadequados”, “inadaptados” ou "em certa medida reacionários" parece ser antes um posicionamento normativo que não coaduna com a teoria luhmanniana - ainda que este eventual "postulado normativo" seja o reconhecimento da sociedade moderna como funcionalmente diferenciada e seja apenas inferido das análises acima relacionadas.

${ }^{747}$ CAMPILONGO, 2012, p. 34-35. Apesar de apontar de maneira interessante para contextos de movimentos sociais ou de protesto orientados para sistemas funcionais, Campilongo parece tomar o postulado da diferenciação funcional de forma muito forte, quase normativa, quando afirma: “[d]a perspectiva dos movimentos de protesto, lutar contra a sociedade significa, geralmente, aspirar à substituição e superação da forma de organização social. Nesse sentido, buscam suplantar a diferenciação funcional. As condições para que esse objetivo seja atingido não estão dadas na atualidade. Se a diferenciação funcional for tomada como etapa contemporânea da diferenciação funcional, movimentos contrários a ela também podem ser considerados reacionários, ainda que não necessariamente”. (CAMPILONGO, 2012, p. 35 - nota de rodapé 45$)$.

${ }^{748}$ CAMPILONGO, 2012, p. 61. O autor argumenta também que a ideia luhmanniana de que pessoas sejam tratadas em alguns contextos apenas como corpos seria discutível, uma vez que "algum tipo de inclusão sempre existe”. (CAMPILONGO, 2012, p. 66). Isso parece ser correto. Todavia, parece-me que Luhmann desenvolve tal conceito de exclusão como "conceito-limite". Apesar da estilização exagerada que o autor faz de suas visitas às favelas brasileiras e latino americanas, Luhmann procura enfrentar outros modos de inclusão em contextos de exclusão sistêmica, como no caso de seu estudo sobre "redes de inclusão" (LUHMANN, 1998d). Sobre o conceito de exclusão em Luhmann e a importância que as suas visitas às favelas da cidade do Recife, ver o artigo anexo dessa dissertação. 


\section{Esfera pública mundial: um novo espaço dos debates}

Vimos que a teoria dos sistemas de Niklas Luhmann apresenta uma instigante formulação de se pensar a sociedade para além das fronteiras nacionais, a partir de um conceito de sociedade mundial. Nesse sentido, caberia falar de existência de uma esfera pública mundial? Em caso positivo, como ela se relacionaria com organizações nacionais e internacionais, sistemas sociais e com os meios de comunicação em massa? Esse item, que finaliza a dissertação, procura enfrentar essas questões a partir de comentadores da teoria dos sistemas de Luhmann que desenvolvem suas análises para pensar a configuração de uma esfera pública mundial. Note-se, que a desvinculação do conceito de esfera pública de sua orientação apenas para "romper as portas do poder administrativoburocrático", especialmente no âmbito do poder legislativo, parece abrir portas para uma formulação mais abstrata do conceito que permita trabalha-lo no contexto da sociedade mundial.

Rudolf Stichweh trata da questão da formação da esfera pública mundial (Weltöffentlichkeit) como fenômeno simultâneo à constituição da noção de esfera pública tal como foi formulada na Europa no século XVII. Ambas teriam o caráter de se orientarem por um público abstrato. Para o autor, esse processo paralelo entre a formação da esfera pública europeia (europäischer Öffentlichkeit) e esfera pública mundial não seria caracterizado pela concorrência, mas pela co-evolução. ${ }^{749}$ Ao correlacionar o conceito de esfera pública para a esfera pública mundial - pensada no âmbito global - Stichweh se pergunta: a esfera pública mundial seria o ambiente interno, o "espelho" de qual sistema? Sua resposta é: o sistema da política mundial (das System der Weltpolitik). A esfera pública mundial operaria juntamente com atores e organizações internacionais governamentais e não-governamentais. Além disso, haveriam "indícios" de que existiria a possibilidade da formação de uma opinião pública com efeitos globais, mas isso dependeria ainda de "pesquisas empíricas". 750

Ademais, o autor dá grande importância ao papel desempenhado pelos meios de comunicação em massa ao afirmar que a esfera pública - a partir do século XX - deixou de ser uma "história" de abertura para se tornar uma história de "comunicações públicas"

\footnotetext{
${ }^{749}$ STICHWEH, 2005, p. 84.

${ }^{750}$ STICHWEH, 2005, pp. 88-89.
} 
que podem ser endereçadas a públicos locais, regionais ou globais. Por sua vez, os meios de comunicação em massa teriam o efeito de fazer avançar a globalização da esfera pública. ${ }^{751}$ Stichweh destaca a importância que a internet desempenha neste processo, uma vez que ela funcionaria como um meio de disseminação para as comunicações (Verbreitungsmedium für Kommunikationen) servindo à formação da esfera pública mundial. E esfera pública da internet seria um sistema distributivo, em rede de formação de opiniões que refletiria a diversidade da sociedade mundial. Ela possibilita que a esfera pública mundial possa se organizar quase que como um sistema de interação, colocando em contato públicos, opiniões e pessoas ao redor do mundo. ${ }^{752}$ Por fim, o autor afirma que mesmo essa esfera pública heterogênea e diversificada poderia ser endereçada para a obtenção de efeitos políticos. ${ }^{753}$

\subsection{A questão dos direitos humanos}

É possível afirmar que o direito contemporâneo passa por um fenômeno de "transnacionalização", por assim dizer, acompanhando o desenvolvimento da sociedade mundial. Não se trata apenas da economia globalizada (hoje em crise regulatória, diga-se de passagem), mas de um processo de toda a sociedade moderna que tem chamado a atenção da sociologia jurídica contemporânea. Com efeito, é possível acompanhar Marcelo Neves em sua formulação de que os sistemas sociais de função primariamente cognitivos (tais como a economia e a ciência) têm maior capacidade de expansão, enquanto sistemas primariamente normativos (como o direito e política) apresentam maior lentidão ${ }^{754}$, por se vincularem às organizações territorialmente delimitadas (como tribunais $^{755}$ e Estado ${ }^{756}$ ). É precisamente por ser um sistema normativo que o direito internacional - e com ele os direitos humanos, especificamente - se mostra como uma arena frutífera para o debate da teoria luhmanniana com a institucionalização de uma esfera pública mundial.

${ }^{751}$ STICHWEH, 2005, pp. 89-91.

752 STICHWEH, 2005, pp. 91-93.

753 STICHWEH, 2005, p. 94. Aqui podemos ver algumas aberturas que a proposta de Stichweh apresenta para se pensar as inovações que "novos mídias" e redes sociais podem apresentar para o tema da esfera pública.

${ }^{754}$ NEVES, 2009, p.290

${ }^{755}$ LUHMANN, 2005a, p. 383 e ss.

${ }^{756}$ LUHMANN, 2000, p. 243. 
Neste contexto, destaca-se o debate sobre direitos humanos em uma sociedade em que parece enfrentar um deslocamento do papel do Estado na política mundial. Antigos debates de sociologia política que tinham como objeto o Estado ou sistemas políticos determinados ganham âmbito internacional. Diversos estudos e teorias têm reconhecido (e se entusiasmado com) uma maior "abertura" do direito nas últimas décadas com maior porosidade entre âmbitos "locais" e "globais" no sistema jurídico, ${ }^{757}$ a proteção dos direitos humanos, a relação com a política e movimentos de protesto cada vez mais internacionalizados. ${ }^{758}$ A noção de democracia de "accountability mundial", por exemplo, se refere a uma política (também ela) mundial, que parece contar com uma opinião pública e movimentos de protesto em uma esfera pública mundializada, ligada aos meios de comunicação em massa para se posicionar perante temas políticos.

Para adentrarmos a questão de como seria possível uma esfera pública mundial, cabe tratar, antes, de um de seus principais correlatos: os direitos humanos e o problema de sua "identificação" e de sua capacidade "inclusão". Nota-se, que a tese luhmanniana da "terceira forma do paradoxo dos direitos humanos" desempenhou grande influência nos debates de comentadores de sua teoria que buscam analisar a formação dessa esfera pública mundial.

Já Hannah Arendt havia notado que só “conseguimos perceber a existência de um direito a ter direitos e de um direito de pertencer a algum tipo de comunidade organizada, quando surgiram milhões de pessoas que haviam perdido esses direitos e não podiam recuperá-los devido à nova situação da política global." 759 Esta noção de "reconhecimento de direitos através de sua violação", também trabalhada - ainda que de forma diferente por Luhmann, ${ }^{760}$ é uma tese central para os desenvolvimentos da ideia da constituição de uma esfera pública mundial.

Luhmann reconhece três paradoxos dos direitos humanos e três formas de desenvolvê-los. A primeira forma deste paradoxo ocorreria na (i) teoria do contrato social,

${ }^{757}$ A noção de "pluralismo jurídico" retorna, com novas roupagens. SANTOS $(2009, \mathrm{p} 58)$ reconhece, com bons olhos, uma diminuição da "burocracia" no "direito que se globaliza" (idem, p.72) e um aumento da "retórica" social e participação da sociedade civil na determnação do direito, seja no âmbito local (citando o exemplo da favela brasileira de Pasárgada), seja o âmbito global (citando a lex mercatoria). Isso o leva a cunhar o termo "glocalismo". O pluralismo clássico já foi enfrentado com elementos da teoria dos sistemas (NEVES, 2003). Contudo, nota-se que o fenômeno da "transnacionalização" ou "globalização jurídica" coloca novas questões em debate. (cf já notado em NEVES, 2009)

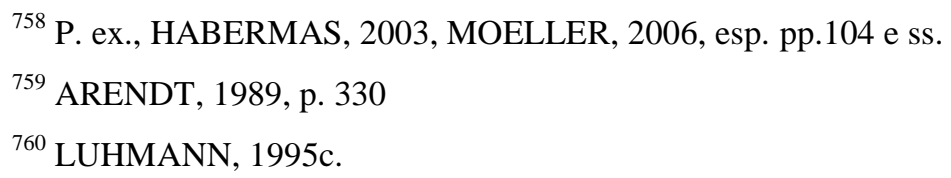


pelo problema da determinação da anterioridade dos indivíduos ou do contrato. Ou seja: "que acontecerá aos indivíduos após terem concluído o contrato? A este problema do antes/depois responde a doutrina dos direitos humanos, diferenciando os direitos humanos dos direitos estabelecidos convencionalmente. E isto não pelo modelo de "estado da natureza/estado civil", mas sim pela forma paradoxal da unidade dessa diferença. Direitos humanos são os direitos que podem se passar do estado de natureza para o estado civil justamente quando o contrato não pode ser denunciado". Na segunda, (ii) o problema dos direitos humanos prossegue na "textualização, e por fim na positivação desses direitos prépositivos". Inicialmente, este processo se dá através de textos meramente declaratórios (como Bill of Rights ou Déclaration francesa), para, depois, incluir tais textos na Constituição no sentido de dar-lhes a estabilidade do Direito Constitucional e normalizálos juridicamente: trata-se do "paradoxo como necessidade de positivação do direito prepositivo". Por fim, e esse é o argumnto mais importante aqui, (iii) a terceira forma do paradoxo ocorre de maneira semelhante ao argumento de Arendt acerca dos apátridas: as normas de Direitos humanos são reconhecidas por meio de suas violações e na medida de seu descumprimento. Luhmann argumenta que assim como as "expectativas" muitas vezes se tornam conscientes por via de sua frustração, também as normas o fazem pela frequente ofensa a elas. Segundo ele, “[p]arece que a atualização dos direitos humanos, hoje, utilizase em nível mundial primariamente deste mecanismo". ${ }^{761}$ Neste sentido, manifestações de "escândalo", de "cólera pública" ou de indignação podem servir para tornar normas de direitos humanos identificáveis.

\subsection{Conclusões parciais: a esfera pública mundial e escândalos na sociedade mundial}

Andreas Fischer-Lescano apresenta uma análise interessante para nossos propósitos, pois trabalha com diversos elementos discutidos por essa dissertação acerca do conceito de esfera pública, ligando-os, contudo, ao âmbito da esfera pública mundial. O autor analisa o casos do surgimento de um sistema mundial emergente de direito transnacional que não se resume ao âmbito das relações entre Estados, mas concebe também um âmbito de normas de direitos humanos. Ele analisa o caso das "Madres de La Plaza de Mayo" na Argentina como um "processo de escandalização global” que teria

\footnotetext{
${ }^{761}$ LUHMANN, 1995c.
} 
resultado na instauração de um regime de direitos humanos que reconhece o caso do desaparecimento político como um crime contra a humanidade. Isso teria ocorrido, pois, em primeiro lugar, o movimento de protesto levado à cabo pelas Mães da Praça de Maio chamou a atenção da imprensa internacional - uma vez que elas protestavam sempre que estrangeiros visitavam a argentina. Assim, inda que tenha havido forte repressão por parte do governo, o autor afirma que isso já bastava para considerar esse evento como uma “mundialização" decisiva do protesto. ${ }^{762}$ À essa atenção dada pela imprensa internacional se seguiram protestos em diversos países como França, Estados Unidos e Alemanha, cada qual com a mobilização de associações e organizações governamentais e nãogovernamentais atuantes atuantes em seus países. O autor argumenta que isso "é de especial relevância no contexto do processo de globalização do protesto, de uma ação global de afetados, atuantes espontâneos e organizados, governamentais ou não, que foi tornada pública pelos meios de comunicação". ${ }^{763}$ O autor aplica aqui a ideia do terceiro paradoxo dos direitos humanos desenvolvida por Luhmann e afirma que, "atualmente, a instauração do direito mundial se leva a cabo em primeira linha por esse mecanismo". Assim, o direito internacional público teria evoluído para incluir regras gerais de direitos humanos, atentando para órgãos como tribunais regionais de direitos humanos e tribunais penais internacionais. ${ }^{764}$ Segundo Fischer-Lescano, esse "processo de escandalização representou uma pressão político-jurídica e foi condição sine qua non para a condenação de crimes e criminosos. Contudo, por outro lado, o processo de escandalização também é, em um âmbito mais direto, a manifestação de uma nova forma de expectativa normativa de expectativas normativas [sic] a nível mundial: o protesto fez valer uma nova norma de direito mundial ao formular que 'o desaparecimento [político] é uma injúria mundial". Essa conclusão o leva a reconhecer que "[a] perspectiva de que o direito internacional, ainda que centrado no Estado, possa evoluir como direito mundial da sociedade civil mundial, adaptando-se estruturalmente às mudanças de condições básicas da sociedade mundial, não é uma utopia". 765

Por sua vez, Marcelo Neves desenvolve, a partir da teoria de Niklas Luhmann, um conceito de direitos humanos como "expectativas normativas de inclusão jurídica de toda

\footnotetext{
${ }^{762}$ FISCHER-LESCANO, 2007, p. 437

${ }^{763}$ FISCHER-LESCANO, 2007, p. 438

${ }^{764}$ FISCHER-LESCANO, 2007, pp. 438-441

${ }^{765}$ FISCHER-LESCANO, 2007, p. 441-442
} 
e qualquer pessoa na sociedade (mundial) e, portanto, de acesso universal ao direito enquanto subsistema social (autônomo)". ${ }^{766}$ Neste sentido, o autor argumenta que o "novo artefato" a que denominamos de direitos humanos foi construído na busca de força normativa e, emergindo com a modernidade, diferenciou-se do 'direito natural' em seu desenvolvimento, o que culminou com a sua positivação em textos constitucionais e internacionais. A decadência do direito natural pré-moderno deixou uma estrutura de expectativas normativas que, com o advento da sociedade moderna e complexa, desenvolveu a noção de direitos humanos e sua consequente relação com uma sociedade "aberta para o futuro". 767

Neves discorda da assertiva luhmanniana de que a terceira forma de desenvolvimento do paradoxo dos direitos humanos seria a melhor forma de reconhecêlos. Luhmann sustenta que o reconhecimento das normas ocorre na medida em que as violações - "chocantes e escandalosas à dignidade humana - determinarem paradoxalmente as normas as quais estão violando, trazendo-as à tona. Neves, no entanto, sustenta que a percepção do "chocante e do escandaloso" varia amplamente na situação de complexidade sistêmica. Isso aponta para a exigência premente do desenvolvimento deste paradoxo "mediante formas complexas de institucionalização de procedimentos no plano global ou internacional, que, no entanto, não poderão ter o caráter centralizado que marcou a positivação dos direitos humanos como direitos fundamentais na experiência do Estado Democrático de Direito. Exige-se, portanto, aqui, (...) a emergência de procedimentos, que, além de atuarem seletivamente perante a pluralidade de definições das ofensas chocantes e escandalosas que dariam ensejo à transformação das expectativas normativas correspondentes em norma jurídica válida referente aos direitos humanos, com força sancionadora, permaneçam abertos ("democraticamente") a essa mesma pluralidade (...)" ${ }^{768}$ Neves atenta, então para a questão da legitimidade democrática dos órgãos e instituições transnacionais de proteção aos direitos humanos.

O autor ressalta a imensa dificuldade de tal institucionalização procedimental dos direitos humanos no plano internacional, tendo em vista que os direitos humanos se inserem no contexto de grande pluralidade de expectativas, contexto esse característico de uma sociedade heterogênea e complexa como a sociedade moderna. Por conseguinte,

\footnotetext{
${ }^{766}$ NEVES, 2003a, p. 146

${ }^{767}$ NEVES, 2003a, p. 146-147

${ }^{768}$ NEVES, 2003a, p. 155
} 
assim como ocorre com seu conceito de esfera pública (política nacional), Neves dissocia a ideia de "consenso" da noção de direitos humanos para encarar estes direitos no contexto do "dissenso estrutural". Desta forma, os "direitos humanos servem, antes, para permitir a convivência nas condições reais de dissenso estrutural. Se quisermos falar de uma moral universalista moderna que estaria suposta na ideia de direitos humanos, essa moral deveria ser entendida como moral do dissenso", de modo que "a inclusão jurídica universal e a autonomia discursiva constituem a moldura dentro da qual as divergências podem ser suportadas". 769

O ponto ao qual Neves atenta é para a falta de institucionalização dos direitos humanos que lhes desse uma base consensual própria permitindo inclusive a possibilidade da crítica reflexiva. Esta "base consensual" que ocorreria pela noção de "respeito a procedimentos democráticos" e é encontrada, segundo Neves, no "âmbito muito restrito de alguns Estados Democráticos e Sociais de Direito", onde esta institucionalização de “consenso procedimental e dissenso conteudístico" resultou, em maior ou menor grau, sua institucionalização. ${ }^{770}$

É possível retirar desse panorama algumas conclusões. Enquanto Fischer-Lescano apresenta um modelo pelo qual movimentos de protesto, por meio de relações com o sistema dos meios de comunicação em massa, pode influenciar e institucionalizar direitos em um espaço público mundial ligado a associações e organizações de defesa de direitos humanos, Neves apresenta o caráter duplo da força simbólica dos direitos humanos, que pode tanto ser utilizada para o reconhecimento de novos direitos, quanto utilizada de forma instrumental na retórica de "intervenções humanitárias" por parte de Estados em suas políticas militares. Daí por que o autor perguntar pelo controle democrático dos procedimentos internacionais ligados à efetivação de direitos humanos.

Seja como for, fica claro que esse debate reproduz diversas linhas dos debates levados a cabo no âmbito do conceito de esfera pública (política) no contexto dos

\footnotetext{
${ }^{769}$ NEVES, 2003a, p. 147
}

${ }^{770}$ NEVES, 2003a, pp. 147-151. Neves alerta para a questão da força simbólica dos direitos humanos. Ele afirma que a "semântica dos direitos humanos" importa um agir simbólico, que se caracteriza como um discurso em que há um deslocamento de sentido para outra esfera de significações. O ponto a se ressaltar aqui é que este contexto do caráter simbólico dos direitos é fundamentalmente vinculado por este autor à falta de normatividade (baixo grau de "força normativa") destes direitos, ou ainda, à sua inefetividade. Desta forma, a semântica dos direitos humanos pode ser utilizada por outros interesses e discursos que não o jurídico, importando no esvaziamento normativo da noção e reforçando sua inefetividade. Contudo, é importante notar, a "força simbólica" é um conceito com duas facetas. Ele importa um lado também positivo, ou seja, "a dimensão simbólica do normativo pode servir à superação de situações de negação concretas dos direitos". 
Estaados Nacionais. Daí porque, com a transferência da discussão para o âmbito da sistemas normativos na sociedade mundial, as discussões passam a ser pautadas por conceitos como solidariedade global cosmopolita, cidadania universal, sistema internacional de direitos humanos, democratização da ONU, a consolidação de uma esfera pública mundial e o combate ao "direito hegemônico" encampado pelas empresas multinacionais. Estes debates parecem trazer para o âmbito global os debates que antes circundavam os Estados Nacionais. ${ }^{771}$

Seja como for, o conceito de esfera pública de Luhmann parece permitir, como tentou propor Stichweh, a concepção de uma esfera pública mundial. Os debates obre o tema parecem, novamente, acentuar o caráter político dessa esfera pública. Esse caráter, contudo, não se vincula ao rompimento de comportas de sistemas políticos em seus processos circulares de circulação e contracirculação do poder. O debate parece caminhar mais para uma discussão sobre protestos e formas amplas de expressão da "escandalização" do público que busquem institucionalização no âmbito da ordem emergente de direitos humanos na sociedade mundial. O conceito "enxuto" de esfera pública de Luhmann e sua caracterização do "terceiro paradoxo dos direitos humanos" parece ter contribuído consideravelmente para a formulação destes debates.

${ }^{771}$ cf. BRUNKHORST, 2005, p. 114 e ss 


\section{CONCLUSÕES}

Textos e estudos acerca do conceito de esfera pública, como vimos na introdução, são plurais, interdisciplinares e remetem a uma longa tradição filosófica e teórica. No âmbito específico da sociologia de grande alcance, no qual este estudo pretendeu se inserir, parece ter ocorrido um movimento no sentido de se trabalhar o conceito de forma cada vez mais distante de contextos vinculados a grupos e a atores; ideais, formas de sociabilidade ou formação de vontades, para o reconhecimento de um contexto social no qual impera a complexidade e a pluralidade de sistemas sociais independentes da ação e da vontade dos "homens" e de seus ideias. Partiu-se para o reconhecimento de intrincados processos comunicativos de uma sociedade complexa que parece fugir ao controle de qualquer tentativa de racionalização. Isso vale não só para Luhmann, mas também para Habermas, que foi muito influenciado pela sociologia luhmanniana. Ao acompanharmos o percurso de Habermas em suas obras da década de 1960 para a década de 1990, nota-se também aí um progressivo caminho de retirada dos sujeitos e de grupos sociais para a análise de processos comunicativos e procedimentos do Estado de Direito - mesmo que se tratem de processos intersubjetivos e "traduzidos" por procedimentos democráticos. A pretensão mais forte de "racionalização" do poder também foi substituída por um procedimento de legitimação de Estados democráticos de direito.

Enfim, trabalhar dois modelos de esfera pública que vinculam teorias sociais complexas, com diversos pressupostos teóricos imbricados, parece apontar que o conceito é amplo demais para ser abordado de forma concreta por teorias de médio alcance. Conceitos como ação, atores, grupos e interações concretas não podem fornecer elementos para dar conta de uma estrutura social de sistemas autorreferenciais nem dos intrincados mecanismos de funcionamento da sociedade moderna. Nesse sentido, as teorias de médio alcance que trabalham com conceitos relacionados ao de esfera pública tendem a se especializar em campos específicos de análise que possibilitam melhor compreensão de fenômenos contemporâneos mais delimitados. Parece-me que teorias e estudos que pretendam entender contextos mais concretos de fenômenos vinculados à esfera pública, principalmente aqueles que se vinculam a análises de institucionais, podem aproveitar pouco do debate abstrato que tem caracterizado a sociologia abrangente da esfera pública, hoje marcado pela presença tanto de Habermas quanto de Luhmann. A questão de se abordar o conceito de esfera pública no nível de abstração de teorias sociais de grande 
alcance, contudo, não perde com isso sua importância. Neste sentido, ainda que a teoria habermasiana da esfera pública tenha sido muito criticada por diversas perspectivas, a questão de se formular teoricamente uma resposta a elas continua em aberto. A teoria habermasiana parece ter fornecido um modelo robusto do conceito de esfera pública, com diversas consequências. Assim, abordar os problemas que ela enfrenta só pode ser feito com uma teoria que se desloque no mesmo grau de abstração, como é o caso da teoria de Niklas Luhmann.

Contrapor dois modelos de sociedade tão diferentes como os desses autores, implica mobilizar pesados pressupostos teóricos, sem o qual a análise teórica não se completa. Isso foi enfrentado nos Capítulos 1 e 2 do trabalho, por meio da argumentação de que os conceitos de esfera pública desenvolvidos tanto por Luhmann quanto por Habermas apresenta são indissociáveis de suas teorias da sociedade. Entretanto, além de diferenças consideráveis de perspectivas teóricas, o "status teórico" que o conceito desempenha na teoria dos dois autores é muito diverso. Enquanto Habermas deposita uma grande esperança normativa no conceito de esfera pública, essencial para a concretização de seus pressupostos normativos; Luhmann desenvolve um conceito quase que negativo, muito restrito, de esfera pública. Não obstante, existem diversos pontos de diálogo - ainda que de crítica e oposição - entre os dois conceitos.

No "embate mútuo" entre os modelos de esfera pública de Habermas e Luhmann diversos pontos de limites e possibilidades puderam ser ressaltados. Como especificado na introdução, um dos argumentos principais dessa dissertação é que a teoria sociológica luhmanniana apresenta explicações teóricas mais plausíveis e adequadas para a explicação do funcionamento da sociedade contemporânea, resistindo a muitas das críticas recebidas pelo modelo habermasiano de esfera pública. $\mathrm{O}$ modelo habermasiano, ao lidar com uma oposição demasiado forte entre sistemas e mundo da vida, carrega seu modelo com pesados conceitos normativos que o impedem de acessar elementos relevantes da esfera pública moderna. Por realizar uma "politização excessiva" e uma "idealização excessiva", Habermas vincula o conceito de esfera pública a condições muito delimitadas no âmbito de sua teoria deliberativa da democracia. $\mathrm{O}$ caráter forte que o autor atribui a uma esfera pública que, ancorada em um mundo da vida "racionalizado", se estrutura no sentido de romper as comportas do sistema político administrativo, "engessa" analiticamente o conceito e o impede de conceber outros aspectos sociologicamente relevantes do conceito. 
Ainda assim, o "caráter espacial" que o autor atribui à esfera pública como fórum que pode servir "alarme" e como "caixa de ressonância" parece se coadunar com a pergunta pelas funções da esfera pública na sociedade contemporânea. Retirando-se o caráter normativo do autor, com a pretensão de consenso e com divisões normativas tais como a separação entre "público nativo" e "público aproveitador", parece que as discussões sobre a esfera pública podem se voltar para ressaltar o caráter conflitivo, dissensual e plural de uma esfera pública encarada como um espaço, um fórum, ou uma arena na qual as comunicações públicas da sociedade ocorrem e pela qual os sistemas podem se observar e observar outros sistemas. Com o afastamento de postulados normativos sobre o conceito, as questões trabalhadas pela teoria dos sistemas não se pautam pela busca de elementos que garantam plausibilidade de um modelo ideal de esfera pública, mas se deslocam para a pergunta de como as comunicações processadas nesse forma podem irritar (e serem irritadas) por outros sistemas sociais, pela opinião pública e pelos movimentos de protesto. A redução e a despolitização do conceito de esfera pública realizada por Luhmann parece ter aberto maiores possibilidades de análise deste conceito.

Contudo, ainda que o "modelo das eclusas" apresente problemas sociológicos de consistência teórica, ele parece ter tido maior capacidade de influenciar estudos e autoobservações de atores na sociedade civil. Mesmo ao considerar o modelo habermasiano como "insatisfatório" tanto do ponto de vista de suas análises mais sociológicas quanto do ponto de vista da fundamentação de seus pressupostos normativos, é forçoso notar que sua teoria foi muito influente para deitar as bases do campo de estudos da sociologia abrangente da esfera pública. Isso ainda parece ser uma dificuldade para Luhmann, cuja teoria não conseguiu ainda muita inserção.

Ainda assim, ao trabalhar com um modelo de esfera pública como espelho da sociedade, Luhmann pode oferecer um referencial teórico capaz de analisá-la de forma mais ampla, em suas relações com outros sistemas sociais. Isso, contudo, não parece ser uma "conclusão tautológica" quando abordamos as diversas questões que sua teoria pode levantar para se pensar a esfera pública (capítulos 4 e 5). Além disso, a partir do modelo luhmanniano do conceito, é possível se chegar à conclusão de que os ganhos analíticos da despolitização da esfera pública, em seu enfoque a voltado ao âmbito da reflexão dos sistemas sociais, demonstram que as pretensões de inclusão efetivada pela esfera pública são demasiadamente restritas; uma vez que as condições de acesso e dependência dos sistemas sociais são reguladas e prestadas por cada um deles. Nesse sentido, ainda que 
movimentos de protesto que se manifestem na esfera pública e na opinião pública busquem inclusão em sistemas sociais, as condições de uma "inclusão generalizada" (tão presente nas formulações iniciais do conceito) não pode ser garantida em uma sociedade funcionalmente diferenciada. Por esse motivo, a ênfase que dei aos trabalhos tardios de Luhmann parece reforçar que o que caracteriza a esfera pública é menos a "inclusão de discursos", o caráter público da "acessibilidade", mas antes seu funcionamento como meio possibilitador de observações mútuas.

Desvincular a esfera de suas pretensões de inclusão generalizada é muito diferente de se postular normativamente que se deva censurar, contrair ou se postar de forma contrária ao conceito. Como vimos, o próprio Luhmann reconhece que a evolução da sociedade funcionalmente diferenciada resulta na semântica da opinião pública e na operação de comunicações heterárquicas na sociedade moderna. Luhmann não desconhece também a necessidade de direitos fundamentais e liberdades públicas para que a esfera pública política - essencial para a constituição do Estado Constitucional de Direito moderno - se constitua.

O que uma leitura mais radical da questão da exclusão desse autor pode trazer para o debate, é que a pretensão de inclusão da esfera pública, quando olhada a partir do reconhecimento de sua ampla exclusão fática, perde consideravelmente seus contornos normativos e ideologizados. Reforce-se que as conclusões dessa dissertação, de modo algum, servem para refutar movimentos de "aprofundamento da democracia" ou qualquer tipo de incentivo institucional para a florescimento de uma esfera pública política vigorosa. Muito menos se trata aqui de apresentar considerações "reacionárias" ou "conservadoras" contra o desenvolvimento da esfera pública; mas reconhecer limites em seu discurso e apontar para problemas mais profundos que não parecem ser solucionáveis por meio de uma esfera pública ativa. Ao reconhecer que Luhmann radicaliza a questão da exclusão como algo "indescritível”, que "poderia dominar a diferença da sociedade moderna nos próximos séculos" faz ruir com as pretensões políticas de enfrentá-las. Ainda assim, as considerações sobre a esfera pública desenvolvidas nos capítulos 4 e 5 permitem apontar para possibilidades de novas formulações possíveis na esfera pública que vinculem suas pretensões a movimentos de protesto nos âmbitos nacional e internacional.

Ainda que, com Luhmann, tenha havido uma "despolitização" do conceito, a importância da esfera pública política ainda é forte nos debatedores do conceito, e sua relevância é manifesta. Na esfera pública são vinculados aspectos normativos, valores, 
dissenso, pretensões, reclamos, etc. Ainda que não se busque mais um "sujeito" (autônomo ou não) para atuar nessa esfera, existe ainda uma pretensão, ainda que fraca de generalização normativa. Mesmo que fiquemos com o conceito luhmanniano da esfera pública como âmbito de reflexão de todos os sistemas sociais, existe também um caráter muito fraco de "eclusa" no conceito que, mesmo não sendo mais vinculado tão estritamente ao sistema e às pretensões da política, parece ter algum grau de expectativa por generalização. O que Luhmann nos traz é que, para haver qualquer tipo de institucionalização dessas pretensões, as pretensões políticas vinculadas na esfera pública devem tomar a forma de opiniões pública e serem comunicadas de modo político. 


\section{REFERÊNCIAS BIBLIOGRÁFICAS}

ALONSO, Ângela (2009) "As teorias dos movimentos sociais: um balanço do debate." Lua Nova: revista de cultura e política, 2009, n .76, pp. 49-86

ARATO, Andrew (2002) . "Representação, soberania popular e accountability" Lua Nova : Revista de Cultura e Política. N. 55-56. 2002

AVRITZER, Leonardo (1996) A Moralidade da Democracia: ensaios em teoria habermasiana e teoria democrática. São Paulo-Belo Horizonte : Perspectiva e Ed. da UFMG, 1996 (Coleção Debates;272)

BACHUR, João Paulo (2010) Às portas do Labirinto: para uma recepção crítica da teoria social de Niklas Luhmann. Rio de Janeiro : Beco do Azougue.

BENFORD, Robert d. \& SNOW, A. David. (2000) "Framing processes and Social Movements: Na Overview and Assessment" Annual Review of Sociology 26.2000), dentre diversas outras teorias e conceitos. Quer-se demonstrar aqui que a especificidade de um

BERMAN, Sheri (1997) "Civil Society and the collapse of the Weimar Republic" New World Politics. N.49. April 1997 pp. 401-29

BOBBIO, Norberto (2007) Da estrutura à função: novos estudos de teoria do direito. [trad. Daniela Beccaria Versiani. Barueri-SP : Manole, 2007

BRUNKHORST, Hauke (2005) Solidarity: From Civic Friendship to a Global Legal Community [translated from german by Jeffrey Fynn]. Cambridge : The MIT Press, 2005.

CALHOUN, Craig (ed.) (1993) Habermas and the Public Sphere. Cambridge : The MIT Press.

CAMPILONGO, Celso Fernandes (2002) Política, sistema jurídica e decisão judicial. São Paulo: Max Limonad, 2002

CAPELLA, A. (2006) "Formação da Agenda Governamental : Perspectivas Teóricas". In: Revista IB, No 61., 2006 (Mimeo)

CARO, José M. Sauca; y SIMON, María I. Wences. (2007)“Un mapa contemporáneo de las teorías de la sociedad civil". In: José M. S. Cano y Maria I W. Simon (orgs) Lecturas de la sociedad civil. Un mapa contemporáneo de sus teorías. Madrid : Editorial Trotta, 2007.

CHALMERS, MARTIN and PIESTER. (1994) "Associative Networks: New Structures of Representation for the Popular Sectors?”. In Douglas Chalmers and Carlos Vilas. (eds) The New Politic of Inequality in Latin America. Oxford University Press, 1994. Pp.544-580)

CLIVE THOMAS (org.) (2004) - Research guide to U.S. and international interest groups - Westport: Praeger Publishers, 2004

COELHO, Vera e Nobre, Marcos (orgs) (2004). Participação e Deliberação: teoria democrática e experiências institucionais no Brasil contemporâneo. São Paulo : Editora 34, 2004. 
COHEN, Jean \& ARATO, Andrew (1992) Civil Society and Political Theory. Cambridge : MIT Press. 1992

COHEN, Jean L. (1985) Strategy or identity: new theoretical paradigms and contemporary social movements. Social research, New York, v. 52, n. 4, p. 671-673, oct./dic. 1985.

COHEN, Jean L. (2003). "Sociedade Civil e globalização: repensando categorias". In DADOS - Revista de Ciências Sociais, Rio de Janeiro, Vol. 46, no 3, 2003, pp. 419 a 459

COHEN, Joshua and ROGERS, Joel (1992) "Secondary associations and democratic governance" - Politics \& Society, Vol. 20, No. 4, 1992

COHEN, Joshua and ROGERS, Joel. (2003) Associations and Democracy: The Real Utopias Project.Volume 1. New York - London : Verso, 2003.

COHN, Gabriel (1998) “As diferenças finas: de Simmel a Luhmann. Revista Brasileira de Ciências Sociais, São Paulo, v. 13, p. 53-62, 1998 - disponível on line na base de dados do SciELO).

COHN, Gabriel (2003) Crítica e Resignação: Max Weber e a teoria social. São Paulo : Martins Fontes, 2003.

CORREIA, José Gladston Viana e RIBEIRO, Pedro Henrique (2011). "Por que Luhmann? A função da dogmática jurídica para o direito e sua (má) utilização da teoria dos sistemas." Artigo apresentado no XX Encontro Nacional do CONPEDI, disponível no site $[\ldots]$

CORSI, Giancarlo; ESPOSITO, Elena; e BARALDI, Claudio. (1996) Glosario sobre La teoría Social de Niklas Luhmann. [trad. Miguel Romero Pérez y Carlos Villalobos, coord.. Javier Torres Nafarrate] Ciudad de México / Guadalajara: Universidad Iberoamericana y Instituto Tecnológico y de Estudios Superiores de Occidente (ITESO)., 1996

COSTA, Pietro (2006) "O Estado de Direito: uma introdução histórica” in ZOLO, Danilo e COSTA, Pietro (orgs). O Estado de Direito: história, teoria, crítica. São Paulo : Martins Fontes, 2006 - (Justiça e Direito).

COSTA, Sérgio (1997) "Categoria analítica ou passe-partout político-normativo: notas bibliográficas sobre o conceito de sociedade civil". BIB, 43, 1997.

DAGININO, Evelina (2002a) "Sociedad Civil, Espacios Públicos y Reconstrucción Democrática em Brasil: Límites y Possibilidades" in Evelina Dagnino (org). Sociedad Civil, Esfera Pública y Democratización en América Latina: Brasil. Fondo de Cultura - Editora Unicamp - Campinas/Catarrera(México), 2002.

DAGNINO, Evelina (2002b). "Introducción". in Evelina Dagnino (org). Sociedad Civil, Esfera Pública y Democratización en América Latina: Brasil. Fondo de Cultura Editora Unicamp - Campinas/Catarrera(México), 2002.

DAHL, Robert (1992) Los dilemas Del pluralismo democrático. Autonomía versus control. México, Alianza Editorial/CONACULTA, 1992.

DALTON, Russell J; SCARROW, Susan E. and CAIN, Bruce E. (2006) "New forms of Democracy? Reform and Transformation of Democratic Institutions." In. Bruce CAIN, Russell DALTON and Susan SCARROW (eds.) Democracy Transformed? Expanding Political Opportunities in Advanced Industrial Democracies. Oxford : Oxford University Press, 2006. 
Don E. EBERLY (ed.) The Essential Civil Society Reader: Classic Essays in the American Civil Society Debate. New York - Oxford : Roman \& Littlefield Publishers, INC, 2000.

DOWNS, Anthony ([1957]1999). Uma teoria econômica da democracia -São Paulo : EDUSP.

EBERLY, Don E. (2000) The Essential Civil Society Reader. Lanham, Maryland : Rowman \& Littlefield Publishers, INC.

EISENSTADT, Shmuel (2000) "Multiple Modernities" Daedalus, Vol. 129, No. 1, Multiple Modernities (Winter, 2000), pp. 1-29

FERRAZ JR., Tércio Sampaio (1994) “O Judiciário frente à divisão dos poderes: um princípio em decadência?” in REVISTA USP n.21, 1994 pp. 12-22.

FERRAZ JR., Tércio Sampaio (1999a) Função Social da Dogmática. São Paulo : Max Limonad, 1999.

GOHN, Maria da Glória. (2010) Movimentos sociais e redes de mobilizações civis no Brasil contemporâneo. Petrópolis: Editora Vozes.

HABERMAS, Jürgen. (1983) Para a Reconstrução do Materialismo Histórico. São Paulo : Ed.Brasiliense.

HABERMAS, Jürgen (1987) Teoría de La acción comunicativa. II: crítica de da razón funcionalista. Madrid : Taurus Ediciones. 1987.

HABERMAS, Jürgen (1990). "Vorwort zur Neuauflage 1990" in Jürgen Habermas: Strukturwandel der Öffentlichkeit: Untersuchungen zu einer Kategorie der bürgerlichen Gesellschaft. Frankfurt sobre o Meno : Suhrkamp. [lido comparativamente com a versão publicada em inglês em 1992: HABERMAS, Jürgen. "Further Reflections on the Pulic Sphere" in Craig Calhoun (org). Habermas and the Public Sphere. The MIT Press, Cambridge, 1992, pp. 421-461]

HABERMAS, Jürgen (1994). "Concluding Remarks" in Craig Calhoun (ed.) Habermas and the Public Sphere. Terceira reimpressão. Cambridge : The MIT Press, pp 462479.

HABERMAS, Jürgen (1996) “O que é Pragmática Universal?” in Racionalidade $e$ Comunicação. [tradução Paulo Rodrigues, revisão Pedro Bernardo]/ Lisboa : Edições 70.

HABERMAS, Jürgen (1995) Reconciliation Throught the Public use of Reason: Remarks on John Rawls`s Political Liberalism”. The Journal of Philosophy, Vol. 92, No. 3. (mar., 1995).

HABERMAS, Jürgen. (1998) Más Allá Del Estado Nacional. Catarrera Picacho-Ajusco México : Fondo de Cultura Económica. [Originalmente publicado como Die Normalität einer Berliner Rupublik. Kleine Politische Schriften VIII. Surkamp Verlag: Frankfurt am Main, 1995].

HABERMAS, Jürgen (2000) O Discurso Filosófico da Modernidade: doze lições. Trad. Luiz Sérgio Repa, Rodnei Nascimento - São Paulo: Martins Fontes.

HABERMAS, Jürgen (2002) A crise de legitimação do capitalismo tardio. Trad. Vamireh Chacon. Rio de Janeiro: Tempo Brasileiro Coleção Biblioteca Tempo Universitário. $N^{\circ} 60,2002$ 
HABERMAS, Jürgen (2003a [1962]) Mudança Estrutural da Esfera Pública: investigações quanto a uma categoria da sociedade burguesa. Trad. Flávio R. Kothe Rio de Janeiro: Tempo Brasileiro, 2003.

HABERMAS, Jürgen (2003b [1992]) Direito e Democracia: entre facticidade e validade. Vol 1 Trad. Flávio Beno Siebeneichler - Rio de Janeiro : Tempo Brasileiro, 2003 (Biblioteca Tempo Universitário 101). [Lido comparativamente com o original Faktizität und Geltung: Beiträgre zur Diskurstheorie des Rechts und des demokratischen Rechtsstaats. Frakfurt sobre o Meno : Suhrkamp, pp. 1- 348]

HABERMAS, Jürgen (2003c [1992]) Direito e Democracia: entre facticidade e validade. Vol 2. Trad. Flávio Beno Siebeneichler - Rio de Janeiro : Tempo Brasileiro, 2003 (Biblioteca Tempo Universitário 102). [Lido comparativamente com o original Faktizität und Geltung: Beiträgre zur Diskurstheorie des Rechts und des demokratischen Rechtsstaats. Frakfurt sobre o Meno : Suhrkamp, pp. 349-660]

HABERMAS, Jürgen. (2003d) Consciência Moral e o Agir Comunicativo. $2^{\mathrm{a}}$ edição. Rio de Janeiro : Tempo Brasileiro,

HABERMAS, Jürgen (2007) A Inclusão do Outro: estudos de teoria política. Edições Loyola : São Paulo, 2007

HOFSTADTER, Douglas R. (1979). Gödel, Escher, Bach: an Eternal Golden Braid. Hassocks: The Harvester Press

HONNETH, Axel (2003) A Luta por Reconhecimento. Tradução de Luis Repa. São Paul : Editora 34.

IZAIAS, Rafael Silva. (2009) “A Legitimação do Estado de Direito na Modernidade Periférica" Tese de mestrado apresentada à Faculdade de Direito da Universidade de São Paulo

IZUZQUIZA, Ignacio. (2008). La sociedad sin hombres. Niklas Luhmann o La teoria como escândalo. $2^{\mathrm{a}}$ edição. Rubí (Barcelona): Anthropos Editorial.

KANT, Immanuel. (1784) "Resposta à pergunta: O que é o Esclarecimento?" 1784(Mímeo) tradução de Luiz Paulo Rouanet. [material didático encontrado na Faculdade de Filosofia da FFLCH USP].

LAVALLE, Adrian Gurza (1999) "Crítica ao modelo da nova sociedade civil" in Lua Nova - Revista de Cultura e Política. N.47, 1999. (pp.121-135)

LAVALLE, Adrian Gurza (2002) "Habermas: a virtualização da publicidade". (2002) Margem (PUCSP), São Paulo, v. 16, n. 16, p. 65-82, 2002.

LAVALLE, Adrian Gurza (2003) "Sem Pena nem Glória: o debate sobre sociedade civil nos anos 1990" in Revista Novos Estudos - CEBRAP, julho 2003 pp. 91-109.

LAVALLE, Adrian Gurza (2004) Vida pública e identidade nacional: Leituras Brasileiras. São Paulo: Editora Globo., 2004.

LAVALlE, Adrian Gurza; HOUTZAGER, Peter P. e CASTELlO, Graziela. (2006a) “Democracia, Pluralização da representação e Sociedade Civil". Lua Nova revista de cultura e política, São Paulo, No.. 67, 2006 (pp. 49-103).

LAVALLE, Adrian Gurza e VERA, Ernesto Isunza (coords) (2010a) La innovación democrática en América Latina. Tramas y nudos de la representación, la 
participación y el control social. Veracruz e México, DF : Centro de Investigaciones y Estudios Superiores en Antropologís Social, Universidad Veracruzana.

LIPSKY, M. (1995) Street Level Bureaucracy: Dilemmas o the Individual in Public Services. New York : Russel Sage Foundation , 1995.

LUBENOW, Jorge Adriano (2007). “A categoria de esfera pública em Jürgen Habermas: para uma reconstrução da autocrítica". Cadernos de Ética e Filosofia Política 10, 1/2007, p.103-123.

LUHMANN, Niklas \& NAFARRATE, Javier Torres (2004). La Política como Sistema. (organização de textos por Javier Torres Nafarrate). México: Universidad Iberoamericana; Faculdad de Ciencias Politicas y Sociales, UNAM, FCE, 2004.

LUHMANN, Niklas (1980a) Gesellschaftsstruktur und Semantik: Studien zur Wissenssoziologie der modernen Gesellschaft. Band 01. Frankfurt sobre o Meno : Suhrkamp Verlag. Vol. 1

LUHMANN, Niklas (1980b) Legitimação pelo Procedimento, Trad. de Maria da Conceição Côrte-Real. Brasília, Editora Universidade de Brasília, 1980. ( Coleção Pensamento Político,15).

LUHMANN, Niklas (1981a) Gesellschaftsstruktur und Semantik: Studien zur Wissenssoziologie der modernen Gesellschaft. Band 02. Frankfurt sobre o Meno : Suhrkamp Verlag. Vol. 2

LUHMANN, Niklas (1981b) „Wie ist soziale Ordnung möglich?“ in LUHMANN, 1981a.

LUHMANN, Niklas (1980) Legitimação pelo Procedimento, Trad. de Maria da Conceição Côrte-Real. Brasília, Editora Universidade de Brasília, 1980. ( Coleção Pensamento Político,15).

LUHMANN, Niklas (1983a) Sociologia do Direito I. Vol. I. Trad. Gustavo Bayer. Rio de Janeiro: Edições Tempo Brasileiro - Coleção Biblioteca Tempo Uniiversitário No 75, 1983.

LUHMANN, Niklas (1983b) Sociologia do Direito II. Vol. I. Trad. Gustavo Bayer. Rio de Janeiro: Edições Tempo Brasileiro - Coleção Biblioteca Tempo Universitário No 75, 1983.

LUHMANN, Niklas (1983c) Sistema Jurídico y dogmatica jurídica. Madrid: Centro de Estudios Constitucionalesm 1983

LUHMANN, Niklas (1985) Poder. [trad. Martine Creusot de Rezende Martins] Brasília : Editora Universidade de Brasília UNB, 1985.

LUHMANN, Niklas (1985) Sociologia do Direito II. Vol. II. Trad. Gustavo Bayer. Rio de Janeiro: Edições Tempo Brasileiro Coleção Biblioteca Tempo Universitário No 80, 1985.

LUHMANN, Niklas (1987). Archimedes und wir-Interviews. Berlin : Merve Verlag.

LUHMANN, Niklas (1989) Gesellschaftsstruktur und Semantik: Studien zur Wissenssoziologie der modernen Gesellschaft. Band 03. Frankfurt sobre o Meno : Suhrkamp Verlag. Vol. 3

LUHMANN, Niklas (1990) Political Theory in the Welfare State. Translated by John Bednarz Jr - Berlin; New York : De Gruyer. 
LUHMANN, Niklas (1991) "Am Ende der kritischen Soziologie“. Zeitschrift für Soziologie,Jg. 20, Heft 2, April 1991, S. 147-152

LUHMANN, Niklas (1992a) "Operational Closure and Structural Coupling: the differentiation of the legal system". CARDOZO LAW REVIEW, vol. 13, Number 5, March, 1992, pp. 1419-1443

LUHMANN, Niklas (1992b) “The coding of the Legal System" in TEUBNER, Gunter \& FEBBRAJO, Alberto. State, Law, and Economy as autopoietic Systems: regulation and autonomy in a new perspective. Milan : Dott. A. Giuffrè Editore, 1992. Pp.145185

LUHMANN, Niklas (1994 [1993]) "'What is the Case?' and 'What Lies behind It?' The Two Sociologies and the Theory of Society." Sociological Theory, Vol. 12, No. 2. (Jul., 1994), pp. 126-139.

LUHMANN, Niklas (1995a) Soziologische Aufklärung 6: Die Soziologie ind der Mensch. Opladen: Westdeutscher Verlag

LUHMANN, Niklas (1995b) Social Systems. Translated by John Bednarz Jr. Stanford: Stanford University Press, 1995

LUHMANN, Niklas (1995c mímeo) "O paradoxo dos direitos humanos e três formas de seu desdobramento"(Mímeo. Tradução de Ricardo Henrique Arruda de Paula e Paulo Antônio de Menezes Albuquerque). Originalmente publicado como: "Das Paradox der Menschenrechte und drei Formen seiner Entfaltung", tendo sido publicado na série Soziologische Aufklärung 6, Westdeutscher Verlag, Opladen 1995, S. 229-236

LUHMANN, Niklas (1995e) Gesellschaftsstruktur und Semantik: Studien zur Wissenssoziologie der modernen Gesellschaft. Band 04. Frankfurt sobre o Meno : Suhrkamp Verlag. Vol. 4

LUHMANN, Niklas (1996a) „, Systhemtheorie und Protestbewegungen. Ein Interview“. In Niklas Luhmann Protest: Systemtheorie und soziale Bewegungen. Org. Kai-Uwe Hellmann. Frankfurt sobre o Meno: Surkamp.

LUHMANN, Niklas (1996b). „Das trojanische Pferd. Ein Interview”. In Protest: Systemtheorie und soziale Bewegungen. Org. Kai-Uwe Hellmann. Frankfurt sobre o Meno: Surkamp.

LUHMANN, Niklas. (1996c) La Ciencia de la Sociedad. [trad. coord. por Javier Torres Nafarrate]. Guadalajara, México. Itesco, Anthropos y Universidad Iberoamericana.

LUHMANN, Niklas (1997a) "O Conceito de sociedade" in Niklas Luhmann A Nova Teoria dos Sistemas. (organizado por Clarissa Eckert Baeta Neves e Eva Machado Barbosa Samkios) Porto Alegre : Ed. UNIVERSIDADE/UFRGS, GoetheInstitut/ICBA, 1997.

LUHMANN, Niklas. (1997b) "Sobre os fundamentos teórico-sistêmicos da teoria da sociedade". In Clarissa Eckert Baeta Neves; e Eva Machado Barbosa Samios (Orgs.). Niklas Luhmann: a nova teoria dos sistemas. [tradução dos textos de Luhmann por Eva Machado B. Samios]. Porto Alegre/São Paulo : Editora da Universidade Federal do Riogrande do Sul / Goethe-Institut, Instituto Cultural Brasileiro Alemão, 1997

LUHMANN, Niklas (1997c) "Globalization or World Society: How to Conceive of Modern Society?" International Review of Sociology Mar97, Vol. 7 Issue 1. [trad brasileira: LUHMANN, Niklas. "A Sociedade Mundial como Sistema Social”. in 
ARAÚJO, Cícero \& WAIZBORT, Leopoldo. "Sistema e Evolução na Teoria de Luhmann" (mais - Um texto de Niklas Luhmann: "A Sociedade Mundial como Sistema Social"). Lua Nova - Revista de Cultura e Política. N. 47, 1999, pp. 179200]

LUHMANN, Niklas. (1998a) "La astucia del sujeto y la pregunta por el hombre". In. LUHMANN, Niklas. Complejidad y diferencia: De la unidad a la diferencia. [Edição - seleção de textos -e tradução para o espanhol de Josetxo Berian y José María García Blanco]. Madrid : Editorial Trotta, 1998

LUHMANN, Niklas (1998b)“La forma 'persona'”. In. LUHMANN, Niklas. Complejidad y diferencia: De la unidad a la diferencia. [Edição - seleção de textos -e tradução para o espanhol de Josetxo Berian y José María García Blanco]. Madrid : Editorial Trotta, 1998; pp 231-244.

LUHMANN, Niklas (1998c) “Quod Omnes Tangit. Remarks on Jürgen Habermas's Legal Theory in ROSENFELD, Michel e ARATO, Andrew (ed.) Habermas on law and Democracy: critical Exchanges. Berkeley : University of California Press.

LUHMANN, Niklas (1998d) "Inclusión y Exclusión" in Complejidad y diferencia: De la unidad a la diferencia. [Edição - seleção de textos -e tradução para o espanhol de Josetxo Berian y José María García Blanco]. Madrid : Editorial Trotta, 1998; pp $167-$ 196. [originalmente publicado como "Inklusion und Exclusion" in Soziologische Aufklärung 6. Westdeutcher Verlag Opladen, 1995, pp. 169-188)

LUHMANN, Niklas (1999a) "Globalization or World Society: How to Conceive of Modern Society?" International Review of Sociology Mar97, Vol. 7 Issue 1. [trad brasileira: LUHMANN, Niklas. "A Sociedade Mundial como Sistema Social". in ARAÚJO, Cícero \& WAIZBORT, Leopoldo. "Sistema e Evolução na Teoria de Luhmann" (mais - Um texto de Niklas Luhmann: "A Sociedade Mundial como Sistema Social"). Lua Nova - Revista de Cultura e Política. N. 47, 1999, pp. 179200]

LUHMANN, Niklas (1999b) “Complexidade social e opinião pública”. In Niklas Luhmann A Improbabilidade da comunicação. [tradução Anabela Carvalho]. Almerin : Editora Vega.

LUHMANN, Niklas (2000a) Die Politik der Gesellschaft. Frankfurt : Suhrkamp.

LUHMANN, Niklas (2000b) Art as a Social System. [trad. Eva Knot]. Stanford : Stanford University Press and Werner Hamacher \& David Wellbery editors.

LUHMANN, Niklas (2002a) Das Erziehungssystem der Gesellschaft. Frankfurt am Main : Suhrkamp Verlag.

LUHMANN, Niklas (2002b [1979]) “Ciência incompreensível: problemas de uma linguagem própria à teoria" [tradução de Leopoldo Waizbort] in Revista Novos Estudos n. 63, julho de 2002, pp.51-59. [originalmente publicado como "Unverständliche Wissenchaft. Probleme einer theorieigenen Sprache" in LUHMANN, Niklas. Soziologische Aufklärung 3. Soziales System, Gesellschaft, Organization, $3^{\text {a }}$ Ed. Opladen Westdeutscher, 1993(1a edição de 1979)].

LUHMANN, Niklas (2005a) El derecho de la sociedad. [trad. Javier Torres Nafarrate et all.] Ciudad de México: Editorial Herder; Universidad Iberoamericana, 2005.

LUHMANN, Niklas (2005b) Einführung in die Theorie der Gesellschaft. Heidelberg : Carl-Auer Verlag. 
LUHMANN, Niklas (2005c) A realidade dos meios de comunicação. [tradução de ]Ciro Marcondes Filho] São Paulo : Paulus, 2005.

LUHMANN, Niklas (2006). Einführung in die Systemtheorie. (terceira edição). Heiderberg : Carl-Auer-Verlag.

LUHMANN, Niklas (2007a) La sociedad de la sociedad. . [trad. Javier Torres Nafarrate y Dario Rodrígues Mansilla] Ciudad de México : Editorial Herder; Universidad Iberoamericana; DAAD - Deutscher Akademischer Austausch Dienst.

LUHMANN, Niklas (2007b) La Religión de la Sociedad. Editorial Trotta : Madrid.

LUHMANN, Niklas. (2009 [1995]) „That's not my problem. Niklas Luhmann im Interview mit Klaus Tascher" in Wolfgang Hagen (org). Was tun, Herr Luhmann? Vorletzte Gespräche mit Niklas Luhmann. Kadmos Verlag.

LUKES, Steven (1992) - Power: A Radical View - Londres: The Macmillan Press, 1992

MARCONDES FILHO, Ciro (2005) “Apresentação". In LUHMANN, Niklas. A realidade dos meios de comunicação. [trad. Ciro Marcondes Filho] São Paulo : Paulus, 2005,

MARCONDES FILHO, Ciro (2005) "Prefácio à edição brasileira: Niklas Luhmann, a comunicação vista por um novo olhar" in LUHMANN, Niklas. A realidade dos meios de comunicação. [trad. Ciro Marcondes Filho] São Paulo : Paulus, 2005

MARSHALL, T. H. (1967) Cidadania, Classe Social e Status. Zahar editores. Rio de Janeiro: 1967

MATURANA, Humberto and VARELA, Francisco (1980) Autopoiesis and Cognition: The Realization of the Living. Dordrecht-Holland / Boston-USA / London-England : D. Reidel Publishing Company, [Boston studies in the philosophy of science; v. 42].

MAUS, Ingeborg (2000) "Judiciário como superego da sociedade: o papel da atividade jurisprudencial na 'sociedade órfã'”. In Revista Novos Estudos - CEBRAP, n.58 Novembro de 2000, pp.183-202.

McCARTHY, Thomas. (1981) The Critical Theory of Jürgen Habermas. Cambridge, Massachusetts, and London, England : The MIT Press.

McADAM, Doug; McCARTHY, John D.; ZALD, Mayer D. (orgs.) (1996)Comparative perspectives on social movements. Political Opportunities, mobilizing structures and cultural framings. Cambridge: Cambridge University Press, 1996.

MELUCCI, Alberto (1988). "Getting involved: identity and mobilization in social movemens".international Social Movement Research. Vol. I, 1988

MELUCCI, Alberto (1989) "Um objetivo para os movimentos sociais?" Lua Nova: revista de cultura e política n. 17. julho de 1989.

MELUCCI, Alberto (1994) . Movimentos sociais, renovação cultural e o papel do conhecimento. Entrevista de Alberto Melucci a Leonardo Avritzer e Timo Lyyra. Novos estúdios, n. 40. Nov. 1994.

MERTON, Robert (1968) Sociologia: Teoria e Estrutura. São Paulo : Editora Mestre Jou.

MOELLER, Hans-Georg (2006). Luhmann Explained: from souls to systems. Chicago and La Salle: Open Court Publishing Company, 2006

MOELLER, Hans-Georg (2011). "Preface". In MOELLER, Hans-Georg. The Radical Luhmann. Columbia : Columbia University Press. (disponível em: 
http://cup.columbia.edu/book/978-0-231-15378-2/the-radical-luhmann/excerpt .Último acesso em 23.01.2012)

MOUFFE, Chantal (2002) Politics and passions. The stakes of democracy. Centre for the Study of Democracy, University of Westminister.

NAFARRATE, Javier Torres (2004) Luhmann: La Politica Como Sistema. México: Universidad Iberoamericana; Facultad de Ciencias Políticas y sociales, UNAM, FCE, 2004

NEIDHARDT, Friedhelm. (1994) “Öffentlichkeit, Öffentliche Meinung, soziale Bewegungen - Einleitung“ . In Jürgen Friedrichs, M. Rainer Lepsius e Friedhelm Neidhardt (eds.). Öffentlichkeit, Öffentliche Meinung, soziale Bewegungen.( Kölner Zeitschrift für Soziologie und Sozialpsychologie, Sonderheft n. 34) Opladen: Westdeutscher Verlag.

NEVES, Marcelo (1988) Teoria da inconstitucionalidade das leis. São Paulo : Saraiva, 1988

NEVES, Marcelo (1992). Verfassung und Positivität des Rechts in der peripheren Moderne: Eine theoretische Betrachtung und eine Interpretation des Falls Brasilien. Berlim: Duncker und Humblot.

NEVES, Marcelo (1994). "Entre Subintegração e Sobreintegração: a cidadania inexistente”.In: DADOS - Revista de Ciências Sociais, vol. 37, $\mathrm{n}^{\mathbf{o}}$ 2. Rio de Janeiro: Iuperj, pp. 253-276.

NEVES, Marcelo (1995) "Do pluralismo jurídico à miscelânea social: o problema da falta de identidade da(s) esferas de juridicidade na modernidade periférica e suas implicações na América Latina". In Direito e Debate, ano V, n 15. Ijuí: Universidade de Ijuí, PP 7-37. 1995

NEVES, Marcelo (1996) “Luhmann, Habermas e o Estado de Direito". Lua Nova: Revista de Cultura e Política, São Paulo, v. 37, 1996 (pp. 93-106)

NEVES, Marcelo (2001) From the Autopoiesis to the Allopoiesis of Law. Journal of Law and Society, v. 28, p. 242-264, 2001.

NEVES, Marcelo (2003a) A Força Simbólica dos Direitos Humanos. Revista Brasileira de Direito Público, Belo Horizonte, v. 03, p. 139-174, 2003.

NEVES, Marcelo (2003b) "Del Pluralismo jurídico a la miscelánea social: el problema de la falta de identidad de la(s) esferas(s) de juridicidad en la modernidad periférica y sus implicaciones en América Latina". In VILLEGAS, Maurício García; y RODRIGUEZ, César A. (eds.) Derecho y Sociedad en América Latina: un debate sobre los estudios jurídicos críticos. Bogotá : Ediciones Antropos, 2003. Pp.261-290

NEVES, Marcelo (2004) "E se Faltar o Décimo Segundo "Camelo? Do Direito Expropriador ao Direito Invadido". In ARNAUD, André-Jean e LOPES JR., Dalmir (orgs.) Niklas Luhmann: Do Sistema Social à Sociologia Jurídica. Rio de Janeiro : Lumen Juris, 2004, pp. 145-173

NEVES, Marcelo (2005a) A Constituição e a Esfera Pública Pluralista. In: XIX Conferência Nacional dos Advogados, 2005, Florianópolis. Anais da XIX Conferência Nacional dos Advogados. Brasília: OAB, 2005. v. 1. p. 223-228. 
NEVES, Marcelo (2005b) "Pesquisa interdisciplinar no Brasil: o paradoxo da interdisciplinariedade. In Crítica à dogmática: dos bancos acadêmicos à prática dos tribunais. Porto Alegre: Instituto de hermenêutica Jurídica, 2005, pp. 207-214.

NEVES, Marcelo (2006) Entre Têmis e Leviatã: uma relação difícil. O Estado Democrático de Direito a partir e além de Luhmann e Habermas. [tradução do autor] Martins Fontes: São Paulo.

NEVES, Marcelo (2007a) A Constitucionalização Simbólica. São Paulo: Martins Fontes.

NEVES, Marcelo (2007b) "Die Staaten im Zentrum und die Staaten an der Peripherie: Einige Probleme mit Niklas Luhmanns Auffassung von den Staaten der Weltgesellschaft“". In NEVES, Marcelo e VOIGT, Rüdiger, 2007a.

NEVES, Marcelo (2009a) “A Constituição e a esfera pública: entre diferenciação sistêmica, inclusão e reconhecimento". In BENEVIDES, Maria Victória de Mesquita; BERCOVICI, Gilberto; MELO, Claudineu de. Direitos Humanos, Democracia e República: homenagem a Fábio Konder Comaparato. São Paulo : Quartir Latin.

NEVES, Marcelo (2009b) Transconstitucionalismo. São Paulo : WMF Martins Fontes.

NEVES, Marcelo (2009c). "Niklas Luhmann: "Eu vejo o que tu não vês"”. In Jorge de Almeida e Wolfgang Bader (orgs). Pensamento Alemão no Século XX. São Paulo : Cosac Naif e Goethe Institut São Paulo. Pp 257-274

NEVES, Marcelo. (2011) Entre Hidra e Hércules: princípios e regras constitucionais como diferença paradoxal do sistema jurídico. São Paulo : Martins Fontes

NEVES, Marcelo e VOIGT, Rüdiger. (2007) "Einleitung: Die Staaten der Weltgesellschaft“. in Marcelo Neves e Rüdiger Voigt (orgs) Die Staaten der Weltgesellschaft: Niklas Luhmanns Staatsvertändnis. Baden-Baden, Nomos Verlagsgesellschaft.

NOBRE, Marcos. (2008) "Introdução". In NOBRE, Marcos e TERRA, Ricardo. Direito e Democracia: um guia de leitura de Habermas. São Paulo : Malheiros Editores.

O`DONNELL, Guilhermo \& SCHMITTER, Philippe (1988). Transições do Regime Autoritário: primeiras conclusões. Vértice : São Paulo, 1988

O'DONNELL, Guilhermo (2004) "Why The Rule of Law Matters". Journal of Democracy. Baltimore : Oct 2004. Vol 15, Iss. 4; pg 32, 15 pgs.

OLIVERA, Alberto G. (org) (2003). Sociedad Civil, Esfera Pública y Democratización en América Latina: México. Catarrena : Fondo de Cultura e Universidad Veracruzana, 2003.

OLIVEIRA, Priscilla Soares de. (2010) "Legislação Reativa e Inconsistência do Direito:Uma Análise Sistêmica da Lei [Penal] como Critério de Decisão dos Tribunais". Iniciação científica apresentada à Faculdade de Direito da Pontifícia Universidade Católica de São Paulo.

OLIVEIRA FILHO, José Jeremias de Oliveira (1995). "Patologias e regras metodológicas". Estudos Avançados [IEA-USP]. Vol. 9, n.23, Jan/abril 1995, pp. 263268.

PARSONS, Talcott (1970) "Equality and inequality in Modern Society, or Social Stratification Revisited". In Sociological Inquiry N. 40. Spring.Social Systems and the olution of Action Theory. New York and London, p.13-72. 
POPPER, Karl. (2006) A Lógica da Pesquisa Científica. 12aedição. Trad Leonidas Hegenberg e Octanny Silveira da Mota. São Paulo: Cultrix.

RENNÓ, Lucio (1998) “Teoria da cultura política: vícios e virtudes” Revista Brasileira de informação bibliográfica em Ciências Sociais (BIB). Rio de Janeiro, n. 45, $1^{\circ}$ semestre de 1998, pp.71-97.

RIBEIRO, Pedro Henrique (2009a). “A (in)efetividade dos direitos sociais na modernidade periférica: um diálogo brasileiro com as teorias do discurso e dos sistemas." Iniciação Científica PIBIC-CEPE apresentada à PUC-SP em Julho de 2009 e no $18^{\circ}$ Encontro de Iniciação Científica da PUC-SP (2009), além do $62^{\circ}$ Encontro da Sociedade Brasileira para o Progresso da Ciência (SBPC) em Natal-RN, 2010.

RIBEIRO, Pedro Henrique (2009b) "Processos de subjetivação em Michel Foucault e Jürgen Habermas: é possível um diálogo entre "atitude crítica" e "agir comunicativo" no vislumbrar de um "direito novo"?" Monografia de conclusão de curso entregue à Faculdade de Direito da Pontifícia Universidade Católica de São Paulo.

RIBEIRO, Pedro Henrique (2011) "Niklas Luhmann 'fora do lugar'? Desafios atuais da teoria dos sistemas vistos pelo debate brasileiro". Trabalho que será apresentado no $35^{\circ}$ encontro nacional da ANPOCS em Outubro de 2011.

RINGER, Fritz. (2004). A Metodologia de Max Weber. [trad. de Gilson César Cardoso de Sousa]. - São Paulo : Editora da Universidade de São Paulo.

SADER, Eder (1995) Quando novos personagens entraram em cena. Experiências e lutas dos trabalhadores da grande São Paulo 1970-1980. $2^{a}$ ed. Paz e Terra, 1995.

SALVADOR, Felipe de Souza (2011). “Opinião pública e sistema político na obra de Niklas Luhmann" Iniciação científica apresentada no Departamento de Ciência Política da FFLCH-USP. São Paulo.

SCHMITTER, Philippe (1992) "The consolidation of Democracy and Representation of Social Groups", American Behavoral Scientist, Vol. 35, Nos. 4-5, March/June 1992, (pp.422-449).

SCHMITTER, Philippe (2010) "Twenty-Five Years, Fifteen Findings" in Journal of Democracy. Volume 21, number 1. Pp17-28.

SHAPIRO, Ian. (2002) "Problems, Methods, and Theories in the Study of Politics - or what's wrong with political science and what to do about it". In. Political Theory, Vol 30. No 4, agosto de 2002, pp596-619

SNOW, David A.; BENDFORD, Robert D. (1988) Ideology, frame resonance, and participant mobilization. International social movement research, Stamford, v. 1, p.197, 1988.

STICHWEH, Rudolf (1997) "Inklusion/Exklusion, funktionale Differenziung und die Theorie der Weltgesellschaft", in Soziale Systeme: Zeitschrift für soziologische Theorie 3. Opladen : Leske und Budrich, pp.123-36.

STICHWEH, Rudolf (2000a) Die Weltgesellschaft: Soziologische Analysen. Frankfurt sobre o Meno : Suhrkamp.

STICHWEH, Rudolf. (2000b) "Systems Theory as an Alternative to Action Theory? The Rise of 'Communication' as a Theoretical Option" in Acta Sociologica, Vol. 43, No. 1 (2000), pp. 5-13 
STICHWEH, Rudolf (2004) "Strangers in World Society - Indifference and Minimal Sympathy". pp. 111-123 in: Between Nanoworlds and Global Culture. Science + Fiction. Berlin: Jovis. (citado conforme cópia mimiografada disponível em: http://www.uni-bielefeld.de/(de)/soz/iw/pdf/stichweh_9.pdf (último acesso em 05.06.2012).

STICHWEH, Rudolf (2005) Inklusion und Exklusion: Studien zur Gesellschafttheorie. Bielefeld : Transcript Verlag

STRUM, Arthur. (1994) "A Bibliography of the Concept Öffentlichkeit" New German Critique, No. 61, Special Issue on Niklas Luhmann (Winter, 1994), pp.161-202

TEUBNER, Gunther (1989). "How the Law Thinks: Toward a Constructivist Epistemology of Law”; Law and Society Review, Vol. 23, No. 5, 1989

URBINATI, Nadia e WARREN, Mark. (2008) "The Concept of Representation in Contemporary Democratic Theory". Annual Review of Political Science. 2008.11, pp. 387-412.

VILLAS BÔAS FILHO, Orlando (2006) O Direito na Teoria dos Sistemas de Niklas Luhmann. Ed. Max Lominad. São Paulo.

VILLAS BÔAS FILHO, Orlando (2008) “A esfera pública levada a sério". Revista Brasileira de Ciências Sociais, vol.23 no.68 São Paulo. Outubro de 2008.

VILLAS BÔAS FILHO, Orlando (2009) Teoria dos sistemas e o direito brasileiro. São Paulo : Saraiva, 2009

VOIROL, Olivier. (2006) “Critique généalogique et critique normative". In CUSSET, Yves et HABER, Stéphane (dir), Habermas et Foucault: Parcours croisés, confrontations critiques. CNRS ÉDITIONS, Paris.

WEBER, Max (2004). Economía y Sociedad: Esbozo de sociología comprensiva. Trad. José Medina Echavarría, Juan Roupa Parella, Eugênio Ímaz, Eduardo Carcía Máynez y José Ferrater Mora.México: Fondo de Cultura Económica. 2a edición, 1964, 15a reimpresión, 2004.

ZOLO, Danilo. "Teoria e crítica do Estado de Direito" in ZOLO, Danilo e COSTA, Pietro (orgs). O Estado de Direito: história, teoria, crítica. São Paulo : Martins Fontes, 2006 - (Justiça e Direito) 


\section{ANEXO - LUHMANN "FORA DO LUGAR”? COMO A "CONDIÇÃO PERIFÉRICA” DA AMÉRICA LATINA IMPULSIONOU DESLOCAMENTOS E APRENDIZADOS NA TEORIA DOS SISTEMAS}

\section{RESUMO:}

O artigo objetiva (I) demonstrar uma guinada teórica na sociologia de Niklas Luhmann (após 1992) em resposta as críticas que levavam em conta "contextos sociais periféricos". Argumenta-se ter ocorrido (a) revisão da teoria da diferenciação funcional como faceta caracterizadora da modernidade, (b) um deslocamento de interesse para temas de integração social (e inclusão/exclusão), e (c) um aprofundamento do conceito de sociedade mundial. (II) Utiliza-se o conceito de "modernidade periférica" (Neves) e as críticas que ele recebeu para abordar descrições (inclusive do próprio Luhmann) da sociedade mundial moderna, desvelando debates e tendências atuais no campo. (III) Sustenta-se que a tensão (paradoxal) entre "teorias "estrangeiras' universalistas" e "casos de exceção" é frutífera para o desenvolvimento do debate sociológico. Aqui parece ser interessante deslocar o usual foco da "explicação de contextos sociais "exóticos"” para os desenvolvimentos e aprendizados da teoria em si e das análises sobre a sociedade mundial moderna.

"A face da Modernidade é uma paisagem de luszes e sombras" Hauke Brunkhorst ${ }^{772}$

\section{I) Introdução: teoria dos sistemas e "os lugares" d $a$ sociedade mundial}

Já disse Roberto Schwarz que "[a]o longo de sua reprodução social, incansavelmente o Brasil põe e repõe idéias européias, sempre em sentido impróprio”, que, "[s]ubmetidas à influência do lugar, sem perderem as pretensões de origem, gravitavam segundo uma regra nova, cujas graças, desgraças, ambigüidades e ilusões eram também singulares. Conhecer o Brasil era saber destes deslocamentos, vividos e praticados por todos como uma espécie de fatalidade, para os quais, entretanto, não havia nome, pois a utilização imprópria dos nomes era a sua natureza”. (SCHWARZ, 2005, pp.29 e 26).

772 2001, p 614; 2005, p. 13 
O reconhecimento de "idéias fora do lugar" - "fora de centro, em relação ao seu uso europeu" - como algo constitutivo do "caráter nacional" brasileiro é uma argumentação que recebeu diversas críticas por (supostamente) desconsiderar questões vinculadas à estrutura social da "sociedade brasileira" (VILLAS BÔAS FILHO 2009, esp. pp. 195 e ss). Seja como for, a questão da "especificidade brasileira" ou de regiões como a América Latina, como quer que sejam elas elaboradas, continuam pautando discussões sociológicas atuais, ainda que de maneira renovada e com outros objetivos.

As grandes "explicações do Brasil", principalmente pela grande influência dos ensaios sociológicos da década de 1930, preocuparam-se com as especificidades do país e se caracterizaram pela reapropriação de "temas e problemas" que levaram autores a "explorar determinadas perspectivas de leituras do passado" na busca pela identidade nacional. (LAVALLE, 2004, esp. pp. 69-70). Muitas explicações do Brasil são caracterizadas por remeter a resquícios cristalizados do passado, em continuidades históricas de grande explicação.

Nelas se destaca o caráter anômalo, pré-moderno e atrasado do Brasil, apontando óbices para sua a caracterização moderna. Estes óbices estruturais de "fardo do passado" são encontrados em formulações de resquícios pré-modernos, como evidenciam as análises do caráter nacional do ethos ibérico, (VILLAS BOAS FILHO, 2009, esp. pp. 187 e ss.) e do ethos público para explicar a falta de possibilidade de constituição de um espaço público no país. (LAVALLE, 2004,).

O "pensamento político brasileiro" (BRANDÃO, 2005) tinha uma agenda manifestamente política e normativa: fundar a Nação brasileira moderna ou demonstrar seus entraves e indicar suas possibilidades de superação para sua modernização. Ou seja, parte-se de uma descrição universalista da modernidade e se explica porque o Brasil não seria moderno por faltar-lhe algo, quando comparado com países ditos centrais.

Mobilizava-se, pois, um projeto político ou de desenvolvimento para a nação. $\mathrm{O}$ problema de fundo não era apenas a caracterização teórica (explicação) do Brasil, mas também a descrição politicamente orientada de uma nação visando o problema de enfrentar o atraso e inseri-la na modernidade. Posteriormente, a problemática se espraiou para um "amplo espectro de perspectivas da pesquisa acadêmica (...) realizada pela escola de sociologia paulista, capitaneada por Florestan Fernandes, chegando ao marxismo e à pesquisa engajada, passando por liberais de cores diversas e pelo, hoje, massivo estudo do 
'pensamento social brasileiro'." Isso implicaria, em síntese, em um viés "nacionalista metodológico". (DOMINGUES, 2011, p 8 e p.89).

Para além da questão dos projetos políticos ou desenvolvimentistas para o país e das posteriores teorias da modernização e do progresso (que hoje todos parecem querer evitar), é possível extrair deste debate um outro ponto: "existe uma tensão subjacente a todas estas explicações que pode ser pensada como a tensão "estrangeiro/autêntico", ou ainda "explicação pela regra/explicação pela exceção" (RIBEIRO, 2009, esp. p.67 e ss). Essa parece ser uma constante não apenas do pensamento social brasileiro, mas de toda uma tradição do pensamento social "periférico" em tematizar sua "condição periférica" na modernidade global.

Cabe destacar, portanto, que este tema é constitutivo não apenas do pensamento político brasileiro, mas também da sociologia latino americana. Chernilo e Mascareño (2010, p. 15) chamam a atenção para a busca por aquilo que faria a América Latina ser simultaneamente universal (moderna) $e$ Latino-americana (particular). Ao analisar a tensão entre "universalismo e particularismo", os autores discorrem sobre como a sociologia latinoamericana lidou com a questão da modernidade de forma ambivalente, associando sua identidade às fronteiras nacionais e aos "ethos culturais imutáveis", por um lado, e adotando as teorias sociológicas mais abstratas e gerais de diferentes conjunturas, criadas e pensadas para tempos e contextos sociais muito diferentes. Como admitem os autores, não se trata de afirmar uma total impossibilidade da sociologia latino americana de levar em conta suas especificidades empíricas com das demandas de conhecimento "universalmente orientado do cânone sociológico", mas antes reconhecer que tanto uma posição que foque apenas os particularismos quanto uma posição abstrata ahistórica que não leve em conta contextos específicos são ambas inatingíveis.

Neste sentido, é possível argumentar que, por um lado, uma explicação apenas centrada em contextos específicos da sociedade perde seu caráter de explicação e generalização mais abrangente, ficando na descrição pontual sem capacidade de comunicação com as teorias sociológicas existentes; por outro lado, uma aplicação sem mediação de teorias construídas em contextos sociais diferentes pode levar a análises que desconsiderem a "realidade" do objeto que pretendem descrever, resultando em descrições que artificiais sem levar em conta o contexto e a história de determinadas regiões. ${ }^{773}$

773 Em momento anterior, eu formulei esta questão com a infeliz analogia com uma espécie de “autismo" comunicacional (recorrentemente utilizada por diversos autores luhmannianos) - uma descrição particularista fechada de sentido, por um lado, e com a rara síndrome neurológica conhecida como "agnosia 
Esta tensão paradoxal que mobiliza teorias universalistas para explicar sua própria negação em contextos determinados (sua "exceção" particularista) parece ser um elemento de produtividade no pensamento social em contextos periféricos. A comparação das "ideias fora de lugar" gerou muita discussão sobre formas de se compreender a "periferia" da modernidade e sua identidade. A mim me parece, contudo, que o outro lado da mesma discussão está subaproveitado: ao invés de focar apenas o entendimento da periferia por si só ou por comparação, cumpre também indagarmos pela consistência interna de teorias generalizantes que se julgam adequadas para descrever a sociedade moderna de maneira abrangente.

Atentar para a condição periférica de certos contextos sociais tem a vantagem crítica de demonstrar a inadequação de teorias ditas universalistas para a compreensão de determinadas regiões da sociedade moderna. Isso tem suas vantagens e suas dificuldades (como veremos no "perigo" de se "valorizar o centro"). Entretanto, o "lado externo" da mesma indagação também é passível de enfrentamento: como as teorias universalistas podem ser refinadas, em sua pretensão generalizante, ao levar em conta contextos nos quais que elas se mostram inadequadas? A pergunta se transfere, então, do potencial explicativo de contextos regionais para a consistência interna de uma teoria que se pretende macrossociológica ou "superteórica", como é o caso da teoria luhmanniana. De maneira simplista, sem desmerecer o valor de tais pesquisas, cabe somar ao debate uma pergunta contraintuitiva: não focar os contextos de "inautenticidade", "excentricidade" ou "excepcionalidade" da(s) "modernidade(s)-desvio" per se, mas perguntar se não é a teoria dita universal, ela sim, quem está fora de lugar na sociedade moderna. Ou seja, cabe indagar se ela consegue dar conta dos diversos lugares ou regiões dessa sociedade (e quais os ajustes e melhoramentos que ela pode oferecer).

Como pretendo demonstrar a seguir, essa é precisamente a questão e o "valor" da teoria social de Niklas Luhmann - que visa construir uma teoria macrossociológica adequada da sociedade mundial moderna - motivo pelo qual argumento que o autor respondeu ativamente às críticas de que sua teoria sofreria de um "provincianismo empírico" (NEVES, 1992, p.9; 2004, p. 167, VILLAS BÔAS FILHO, 2009, p.269) e seria

visual", "object recognition disorder", por outro (RIBEIRO, 2009, p. 73 e ss). A analogia é infeliz, pois desnecessária para fins heurísticos e pode incorrer em uma imagem negativa de síndromes neurológicas mesmo que não seja essa a intenção. Deixo a referência para marcar o aprendizado e agradeço Maurício Palma Resende pela discussão do assunto. 
inadequada para explicar os "lugares/regiões da sociedade mundial" realizando adequações e "aprendizados" teóricos em seu arcabouço conceitual.

É claro, não se trata, aqui, de inferir a resolução do paradoxo em uma "teoria panaceia", mas, como sustenta Luhmann, é o caso de tornar o paradoxo produtivo precisamente por ser impossível resolvê-lo. Formulando de maneira não rigorosa, não me parece ser possível um momento último de síntese (ou supra-sunção -Aufhebung ${ }^{774}$ ) que seja tanto individualizante (descoberta de singularidades) quanto universalizante (reconhecimento de propriedades comuns). Nem me parece interessante do ponto de vista heurístico rejeitar qualquer possibilidade de comparação entre contextos sociais diversos da sociedade moderna, como se isso necessariamente implicasse em valorações do "núcleo da modernidade". ${ }^{775}$ Isso, mesmo porque, nas palavras de Luhmann: "uma teoria deve tornar comparações possíveis" (1995b, p. xlv). Se teorias têm uma função de dar sentido ao mundo que descrevem, cabe perguntar por sua consistência interna, por sua utilidade para a formulação de hipóteses e por sua capacidade heurística para enfrentar de problemas.

Por esse motivo, cumpre também ressaltar que não é o caso de se desconsiderar a importância de contextos históricos, mas de formular a questão de forma diferente. Luhmann é consistente em sua busca uma teoria sociológica abstrata para a sociedade moderna. E isso, ao contrário do que alguns os críticos de Luhmann por vezes tentam sustentar, não implica em desconsideração pela pesquisa empírica nem por histórias regionais. Aliás, após a "virada" que argumento ter ocorrido, o autor reconhece que a diferenciação funcional da sociedade moderna assume efeitos específicos que só podem ser acessados do ponto de vista regional (2007, p. 639 e ss), afirmando não apenas que a existência generalizada setores de exclusão na sociedade moderna é "sem dúvida" uma decorrência da diferenciação funcional, mas que essa diferença da inclusão/exclusão "apresenta variação extraordinariamente forte por regiões, o que exige uma investigação detalhada de cada caso”, com forte aporte histórico e empírico. (1995a, p. 244. Ênfase adicionada). É possível inferir, portanto, que a explicação de contextos regionais específicos demanda estudos empíricos massivos e narrativas históricas elaboradas. A

${ }^{774}$ Ver a interessante análise das noções de "paradoxo" e diferença "sistema/ambiente" na teoria luhmanniana que, em oposição (manifesta) à tradição dialética hegeliana marxista, abandonaria a pretensão de supra-sunção (Aufhebung) em BACHUR, 2010, esp pp 33 e 259 e ss, culminando na proposta crítica de desenvolver uma "dialética da diferenciação funcional" a partir de - e contra(?) - Luhmann.

${ }^{775}$ Tal é a proposta de uma "teoria crítica da (semi)periferia" universalizante e generalizante que não parte de comparações (DOMINGUES, 2011, p. 49) 
teoria do sistemas de Niklas Luhmann - sem a realização de mediações específicas (como fizeram NEVES, 1992, 2006 e 2007 e VILLAS BÔAS FILHO, 2009) parece ser mais útil para "questões generalizantes". A pergunta de Luhmann se volta mais para a "estrutura da exclusão" na sociedade moderna, ou seja, para a comparação de contextos de exclusão diversos e variados na sociedade moderna.

Assim, ao demonstrar que o pensamento luhmanniano realizou um "movimento de revisão" da teoria da diferenciação funcional e o reconheceu a não-homogeneidade da sociedade mundial (Weltgesellschaft) no nível regional, apresento argumentos no sentido de apontar que não apenas o reconhecimento da "condição periférica" foi essencial para desenvolvimentos tardios da teoria luhmanniana em geral (item II), como também que tais mudanças apresentam novas possibilidades de debates e desafios dentro da própria teoria (item III). Com isso, de forma secundária, pretendo apresentar uma faceta da teoria social de Niklas Luhmann que julgo ser mal compreendida por diversos críticos que afirmam ser sua teoria necessariamente cínica e "sintomática de nossa época" (DOMINGUES, 2011, p. 100); que ele prega por valores liberais da diferenciação funcional ou pelo status quo ${ }^{776}$, ou que sua teoria seria demasiada e inutilmente hermética (BOBBIO, 2007, p. 112).

Luhmann pode ser considerado excêntrico do ponto de vista de suas bases teóricas, mas me parece incorreto aferir que sua teoria não dialoga com questões clássicas da teoria sociológica, como a questão da integração social e da exclusão social, por exemplo, como veremos no item III. Aliás, essa "virada" luhmanniana no reconhecimento de "limites da teoria da diferenciação funcional" parece ter aproximado a teoria de Luhmann de debates mais próximos de teorias críticas, como a exclusão na sociedade mundial, a legitimação democrática da política internacional e até o vislumbre de um "subsistema de ajuda social". Interessante notar que é no contexto dessa discussão o (dito) "cético e irônico" Luhmann afirma que até aqueles que pretendem fazer teoria crítica deveriam atentar para sua teoria (1993, p. 550) admitindo, portanto a possibilidade de tal diálogo.

É possível argumentar que esta revisão conceitual - e a importância da América Latina e "do pensamento social periférico" em impulsioná-la - podem ser remetidas a dois momentos: (i) ao ano de 1992, quando o autor entrou em contato com as críticas de Marcelo Neves à amplitude dada pela teoria luhmanniana ao conceito de diferenciação funcional e (ii) à incorporação do autor da realidade "além de descrição" das favelas sul-

776 João Paulo Bachur, (2010, p. 275) refuta este argumento de maneira clara e precisa, demonstrando porque a teoria luhmanniana não pode ser considerada uma teoria de preferência ao status quo. 
americanas nos dois anos seguintes (LUHMANN, 1995c. ver BALKE, 2002 para um interessante comentário desse texto obra).

Tal argumento apoia-se na constatação de que o prefácio (Zur Einführung) de Luhmann à obra de Neves (LUHMANN, 1992) foi, até onde pude constatar, o primeiro texto em que o autor enfrenta a questão dos limites da teoria da diferenciação funcional de forma central, ${ }^{777}$ de modo a esboçar de forma embrionária teses sustentadas em obras posteriores. ${ }^{778}$ Neste texto, Niklas Luhmann provocativamente pergunta quais seriam as implicações teóricas de tal "interpretação do caso brasileiro" para a teoria da sociedade, o que permite uma citação mais longa:

"Isso [crítica de Neves] aponta para problemas que nem a teoria de classe de proveniência marxista ou pós-marxista nem o conceito usual de diferenciação funcional da sociedade sabem dar uma resposta. Essas teorias estão, por isso, refutadas? Mas como, se não mediante uma outra teoria?

Talvez os fatos descritos já permitam perceber que outras diferenças sobrepõem-se às teorias de nossa tradição, construídas de maneira demasiadamente simples. Talvez a realização da diferenciação funcional no nível da sociedade mundial, com alta dinâmica interna da economia, da ciência, dos meios de comunicação de massas e da política, não queira dizer, por muito tempo, que as correspondentes condições possam realizar-se também no plano regional. E talvez já haja, entrementes, indícios de diferença pré-ordenada, primordial, que regule o acesso às vantagens da diferenciação funcional, a saber, a diferença de inclusão e exclusão, (...). Isso significaria que a sociedade no Brasil é integrada de maneira dupla, a saber, positivamente através da rede de favores, de gratidões, de relações patrão/cliente, da corrupção, e negativamente mediante a exclusão prática de muitos da participação em todos os sistemas funcionais, situação em que uma exclusão (falta de documento, de trabalho, de alimentação regular, de educação, de seguro de saúde, da segurança do corpo e da vida) que forçosamente traz consigo, cada vez mais, outras exclusões.

\footnotetext{
777 A exceção de LUHMANN, 1989 (publicado originalmente em 1986) e LUHMANN, 1990, esp. p. 34 e ss (originalmente em 1981). No entanto, em ambas as obras, a teoria da diferenciação funcional não é revista pelo debate sobre os conceitos de inclusão e exclusão, nem há discussões sobre integração social.

778 Das quais destaco: LUHMANN, 1993, 1995a, 1995c, e 2007 [originalmente publicada em 1997], esp p. 490 e ss e 639 e ss.. Em todas as obras, a condição periférica e o trabalho de Neves são abordados.
} 
Espera-se que o trabalho de Marcelo Neves não seja lido apenas como se fosse apenas um conjunto de informações sobre relações jurídicas exóticas em um país da modernidade periférica, mas antes também para estimular $o$ pensamento sobre a sociedade na qual nós vivemos hoje”. (LUHMANN, 1992, PP. 3-4, ênfases adicionadas)

Para isso, após esta introdução (I), o presente estudo irá (II) expor brevemente a caracterização da sociedade moderna em termos de uma sociedade mundial baseada no primado da diferenciação funcional por Niklas Luhmann e demonstrar as alterações que estes conceitos sofreram após a "virada teórica" do enfrentamento da condição "periférica" da sociedade mundial. Por fim, (III) discutem-se críticas e vantagens da distinção centro/periferia da sociedade mundial para abordar alguns "desafios em aberto" ainda no campo da teoria luhmanniana para se pensar temas relevantes para contextos de regionalização da sociedade mundial, manifestamente o tema da "inclusão/exclusão" na sociedade mundial.

\section{II) Luhmann e aprendizados da teoria da modernidade: uma releitura da teoria pela tematização da periferia}

Para demonstrar o argumento é necessário (II.1) apresentar de maneira muito breve alguns elementos da teoria da sociedade moderna de Luhmann, (II.2) e o conceito da bifurcação centro/periferia na sociedade mundial, para, então, (II.3) expor a "virada teórica" realizada tardiamente na sociologia luhmanniana.

(II.1)

Em seu curso Einführung in die Theorie der Gesellschaft, Luhmann apresenta um "mapa dual" de sua teoria da sociedade moderna combinando dois aspectos: (i) uma perspectiva "histórica", na descrição da sociedade como "moderna" (em oposição às sociedades tradicionais - 2005, pp.11-12) e (ii) uma perspectiva interdisciplinar abstrata, usualmente marcada com a palavra-chave "teoria dos sistemas".

Para entender a empreitada luhmanniana, nota-se que o autor pretende desenvolver uma "teoria universal" do social, mesmo que não seja ela exclusiva (1995b, p.xlvii e ss). 
Assim, para trabalhar a teoria sociológica "em crise" (1995b, p.xlv; 1996b, p.27) e dar-lhe unidade em um nível de abstração elevado (1981, p. 195-196), Luhmann desenvolve uma teoria complexa que visa a refletir a complexidade da sociedade moderna que ela busca descrever (1995b, pp. xlix-1) A teoria social de Luhmann parte, pois, de pressupostos epistemológicos da teoria geral dos sistemas ${ }^{779}$ para criar uma descrição da sociedade moderna como um sistema social autopoiético cujo elemento é a comunicação. A sociedade é o sistema social mais abrangente (omniabarcador, na tradução mexicana) e conta com diversos sistemas sociais "parciais" também autopoiéticos como religião, ciência, arte, direito, política, economia, etc. (2007a, pp 55 e ss). Cada sistema é compreendido não como um "objeto", mas como uma "forma de dois lados", ou seja, uma distinção: sistema/ambiente (dentre muitos, 2007, p. 40 e ss).

O que é mais interessante para nossa discussão é que Luhmann apresenta uma "teoria da evolução" não ontológica e não linear da sociedade (sem direção ou finalidade). O autor descreve como processos de "variação, seleção e (re)estabilização" ocorrem na diferenciação da sociedade (2007a, p. 335; pp 380 e ss). Ressalte-se, com efeito, que sua teoria da evolução não é linear, teleológica e nem se confunde com “progresso", mas é marcada pela contingência. (1983, p. 173 e ss.) Sem adentrarmos questões específicas da teoria, temos que Luhmann aponta como característica distintiva da sociedade moderna a diferenciação funcional. Com o advento da modernidade a sociedade torna-se supercomplexa e descentralizada (heterárquica e multicêntrica, ou seja, sem nenhum "sistema central"). Isso gera uma pressão seletiva (Selektionszwang) impulsionando a diferenciação por funções que geram sistemas funcionalmente diferenciados - os sistemas parciais (2007, p.473).

Portanto, para Luhmann, a sociedade moderna torna-se "inacessível" do ponto de vista de sua totalidade: "uma sociedade organizada em subsistemas não dispõe de nenhum órgão central. É uma sociedade sem vértice e sem centro” (1990, p.31). A organização é pautada pela diferenciação funcional, sem a prevalência de nenhum sistema social na “direção da sociedade". Portanto, por meio de seu conceito de diferenciação funcional, Luhmann afirma que a integração da sociedade só pode ser realizada por meio de sistemas sociais parciais, ou melhor: por integração entende-se "a limitação dos graus de liberdade que se proporcionam de forma recíproca os sistemas estruturalmente acoplados” (1995a, p.

${ }^{779}$ LUHMANN, 1997b e 2007a, esp. pp. 40 e ss e 66 e ss. Além do conceito base de autopoiese como sistemas fechados operacionalmente que se reproduzem a partir de seus próprios elementos (MATURANA e VARELA, 1980, p. xvii). Por isso, auto (próprio) + poiesis (produção) = autopoiesis. 
227, 2007, p. 476-478). A diferenciação funcional é a aquilo que primariamente caracteriza a sociedade moderna em contraposição de sociedades pré-modernas ou tradicionais que se diferenciavam primacialmente por outros princípios, como em sociedades segmentárias e estratificadas (2007, pp. 482 e ss).

Contudo, para a descrição da sociedade moderna, falta ainda o conceito de sociedade mundial (Weltgesellschaft - LUHMANN, 1975, 1997c e 2007 p 108 e ss). e. Luhmann afirma, baseando-se em Gaston Bachelard, que haveria quatro obstáculos epistemológicos para uma compreensão adequada do conceito de sociedade: (i) que a sociedade estaria constituída por homens concretos e por relações entre seres humanos; (ii) que a sociedade se estabeleceria por consenso destes seres humanos; (iii) que as sociedade seriam unidades regionais, territorialmente delimitadas ("pelo qual, por exemplo, o Brasil seria uma sociedade distinta da Tailândia",), e (iv) que portanto as sociedades podem se observar do exterior como humanos ou territórios (2007, p.12). Ora, é precisamente o terceiro obstáculo que impediria reconhecer, segundo o autor, que a sociedade moderna um sistema social de comunicação - seria caracterizada por ser uma sociedade mundial uma vez que as comunicações não mais respeitariam fronteiras territoriais na reprodução da sociedade . Para o autor, a sociedade moderna é encarada ela mesma como um sistema global, um horizonte de comunicação possível.

Nota-se, por fim, que o caráter "complexo" ou hermético de sua teoria social policêntrica (e conseqüentemente policontextural) busca se adequar a uma sociedade concebida acentricamente. Portanto, sua teoria não é apenas uma estrita correspondência ponto-a-ponto entre "conceito e realidade", de modo que ela desenvolve complexidade própria precisamente para fins heurísticos. Neste processo, "por um lado, uma referência à realidade precisa ser salvaguardada. Por outro, entretanto, a ciência, especialmente a sociologia, não deve permitir ser enganada (duped) pela realidade. Visto dessa forma, a abstração é uma necessidade epistemológica". (1995b, p. li) Portanto, sua teoria é marcadamente não-linear e sem centro (2005 :14). Luhmann compara seu desenho a um labirinto, em detrimento de uma "estrada para o pôr do sol". (1995b, p. lii). ${ }^{780}$

O ganho de abstração da teoria luhmanniana já foi reconhecido por diversos comentadores - críticos ou não. Contudo, vimos que Luhmann advertiu: "alguma referência à realidade precisa ser salvaguardada”. Essa é precisamente a entrada que teve

${ }^{780}$ Sobre o perigo de se perder no labirinto em interpretações estritas e dogmáticas, ver BACHUR, 2010. p. 28-29, além do "labirinto de cristal" de IZUZQUIZA, 2008, p. 313 e ss. Para uma análise da teoria luhmanniana como uma "construção chanfrada”, VILLAS-BÔAS FILHO, 2006, p. 257-258. 
a crítica de Marcelo Neves e de outros pensadores da "condição periférica", a saber: forçar o pensamento luhmanniano a dar conta do reconhecimento de seu "provincianismo empírico" e a mobilizar sua rede abstrata de conceitos para tematizar uma sociedade mundial muito menos homogênea, onde o princípio da diferenciação funcional não se espraiou sem conflitos e variações. Afinal, não é tudo reconhecer que "há luzes e sombras na paisagem da modernidade" (BRUNKHORST, 2005, p.113), é necessário também explicar a constituição dessa paisagem e como as luzes se relacionam com as sombras.

Há vinte anos, Marcelo Neves apresentou uma "análise do caso brasileiro" por meio de uma análise crítica dos conceitos de positividade do direito e de eficácia da Constituição, demonstrando os limites de seu uso no contexto da modernidade periférica. Intentou-se realizar uma "irritação" do modelo luhmanniano de diferenciação sistêmica como princípio característico da modernidade, apontando diferenças estruturais em seu desenvolvimento e aplicação na sociedade mundial. (NEVES, 1992, p 9).

Segundo Neves, "o terceiro mundo" era tratado de maneira inadequada tanto por teorias europeias e norte-americanas que o concebiam como um conjunto de sociedades tradicionais, quanto por teorias da modernização e da dependência que utilizavam o esquema conceitual "antes/depois" na aplicação de uma política desenvolvimentista ou baseavam-se centralmente apenas na estrutura do capitalismo. O autor reconhece, então, duas dimensões sincrônicas da sociedade mundial, sustentando ter ocorrido uma bifurcação entre centro e periferia da modernidade (1992, p. 72-75; 2004. p.146). Esta bifurcação é relacionada com a profunda desigualdade econômica no desenvolvimento inter-regional, trazendo consequências significativas na reprodução de todos os sistemas sociais, principalmente no político e no jurídico. (1992, p. 75 e 2006, p 226-227).

Sua análise da subintegração de regiões na sociedade mundial parte de um caráter primariamente econômico (força do código da economia), o que o levou a reconhecer que a "mundialização" (expansão da sociedade mundial) era guiada por uma preferência por seus sistemas sociais baseados em expectativas cognitivas, dispostas ao aprendizado, como economia, ciência e técnica. Por outro lado, os sistemas jurídico e político, vinculados a expectativas normativas, teriam menor capacidade de expansão, contanto com uma segunda diferenciação no plano dos territórios (1992, p.75). Aliás, essa já foi a posição de 
Luhmann (1975, p.68), que posteriormente teria radicalizado sua teoria da diferenciação horizontal (cf. reconhece NEVES, 2006, p.218).

Com isso, a sociedade teria uma divisão dicotômica e "hierárquica" estruturada em um centro e periferia (1992, p. 75). Neves chama a atenção para fatores e especificidades locais e regionais que funcionariam como fatores de desenvolvimento, gerando níveis prestacionais diferentes no âmbito regional.

Posteriormente, Neves atenta para o fato de que a teoria luhmanniana vincula a emergência da sociedade moderna em sua teoria da evolução a partir da noção de complexidade, tida como o elemento impulsionador da modernidade (LUHMANN, 1983, p. 45 e 172). Além de diferenciar conceitualmente os "tipos ideais" do centro e periferia da sociedade mundial apresentando a relação assimétrica entre eles, Neves caracteriza a modernidade periférica por lidar com a hipercomplexidade do ambiente de forma desestruturada ou desorganizada. Com isso, a autonomia autopoiética do direito e da política ficaria prejudicada e o funcionamento desses subsistemas sociais e do Estado de Direito seriam bloqueados generalizadamente na sua autoprodução por injunções heterônomas de outros códigos e critérios sistêmicos (NEVES, 1992, e 2006, p 239 e ss). À desintegração moral da sociedade tradicional não teriam sucedidos sistemas autopoiéticos autônomos gerando complexidade desestruturada. Daí porque, em sua primeira formulação, Neves a concebia como modernidade "negativa" (1994, p. 264), conceito que depois parece abandonar.

Tal situação é trabalhada a partir do conceito de "corrupção sistêmica". Nota-se ele se refere ao bloqueio do funcionamento operativamente fechado de um sistema determinado e em tese pode ser aplicado a qualquer subsistema social. Por isso, não obstante Neves reconheça a corrupção sistêmica no direito e na política - sistemas sociais segmentados territorialmente - ele não se resume de forma alguma ao termo vulgar da "corrupção política" por interesses particulares. O núcleo do conceito é o reconhecimento uma corrupção sistêmica generalizada e não meramente pontual, principalmente do sistema jurídico. Trata-se de uma questão estrutural que afeta as expectativas perante este sistema social no âmbito das expectativas sociais e do "agir e vivenciar" (LUHMANN, 2007, p. 258 e ss) ${ }^{781}$

${ }^{781}$ MASCAREÑO (2003), de maneira diferente, afirma que a não generalização do direito ocorreria na América Latina (em seus regimes autoritários de modernização pelo Estado) por meio de indifenciação entre política/direito, por um lado, e economia/política, por outro. Isso obstaria o funcionamento por meios de comunicação simbolicamente generalizados. O autor fala também em "alopoiése" do direito. 
Portanto, a seleção jurídica não ocorre de forma autônoma, ou seja, pelo código "lícito/ilícito" (Recht/Unrecht). Outros códigos sociais e outros interesses bloqueiam esta reprodução. A política e a economia "invadem" ou "superexploram" o direito, que não consegue se reproduzir. Desta forma, ao invés das comunicações jurídicas operarem por seu código, elas são transpassadas por códigos como "ter/não-ter" (propriedade/nãopropriedade) e "poder/não-poder" ou ainda por seleções de redes particularistas, como "amigo/não-amigo" ou "patrão/cliente" (relações de patronagem), além de "redes de favores".

$\mathrm{O}$ argumento da corrupção sistêmica não deve ser confundido, de forma alguma, com um elogio do liberalismo ou com um argumento formalista de legalidade. Isso, pois a corrupção sistêmica em "direito alopoiético" (ou que teria momentos de alopoiese) obstariam consideravelmente a capacidade de prestação de mecanismos sociais modernos de inclusão de forma generalizada. É por esse motivo que Neves analisa a positividade do direito e a efetividade da Constituição e dos direitos sociais. A análise não recai na "sociedade brasileira", mas no reconhecimento de que mecanismos de inclusão social (como cidadania, Estado de bem estar social, Estado Constitucional de Direito, direitos sociais, inclusão política, etc) em determinadas regiões do globo apresentam "déficits" em relação à sua formulação.

É por esse motivo que a análise de Neves caminha para reconhecer a seletividade da ordem jurídica, o que o levou a uma redescrição do conceito de Constituições nominalistas de Lowenstein (1992, p. 65 e ss.) e o posterior desenvolvimento do conceito de constitucionalização simbólica (2007). Assim, à questão da exclusão social soma-se uma outra problemática: quando o direito não é autônomo (nem a política) seus mecanismos de inclusão não se generalizam de forma homogênea e passam a funcionar seletivamente, não ocorrendo a generalização da cidadania. Sobre o assunto, Jürgen Habermas afirma que em tais contextos "a letra imaculada do texto constitucional não é mais do que a fachada simbólica de uma ordem jurídica altamente seletiva" (HABERMAS, 1999, p. 229). Em sentido semelhante, Guilhermo O’Donnell - ao tratar em estudo com aportes empíricos da (in)efetividade da lei ((un)rule of law) em alguns países ou "novas poliarquias" da Amérca Latina - também se refere a Neves ao falar do sentimento dos privilegiados de desprezo pelo direito e da submissão a procedimentos regulares em contextos em que alta violência estatal e de "agentes privados poderosos" pode conviver com “escandalosa impunidade criminal”. (O’DONNELL, 2000, p. 346). 
A base do argumento é a formulação luhmanniana do Estado de bem-estar social como a realização de inclusão política em decorrência do "princípio sociológico da inclusão". O conceito luhmanniano "antigo" de inclusão, desenvolvido em 1981, era definido pela abrangência de toda a população nas performances de sistemas funcionais individuais: isso se relaciona, por um lado, com o acesso aos benefícios de um sistema e, por outro, com a dependência aos modos de vida que determinado sistema impõe. (LUHMANN, 1990, p 34). A marginalização de segmentos populacionais de prestações sistêmicas configuraria o conceito de "exclusão". 782

Por sua vez, Neves argumenta que em contextos de modernidade periférica - mais extensa em território e população que o chamado centro europeu-norte americano da modernidade - caberia antes reconhecer a dominância de um princípio da exclusão, de modo que não seria possível afirmar que os direitos fundamentais estariam generalizados no âmbito do agir e vivenciar da população nem serviriam como orientação de suas expectativas normativas. (1992, p. 215). Assim, o autor parte da heterogeneidade estrutural da sociedade mundial e da "marginalização das massas" para discorrer sobre relações de subintegração e sobreintegração ${ }^{783}$ como típicas de contextos periféricos, principalmente no tocante à generalização da cidadania. Portanto, não seria suficiente apenas a análise dos “marginalizados”, pois "a subintegração das massas é inseparável da sobreintegração de grupos privilegiados". (1992, p. 95).

Neste contexto, os "marginalizados" são encarados como subcidadãos subintegrados ao sistema jurídico, para quem os direitos fundamentais não têm efetividade e não são concretizados. Para os subintegrados, "os dispositivos constitucionais têm relevância quase exclusivamente em seus efeitos restritivos das liberdades. Eles são integrados ao sistema, "em regra, como devedores, indiciados, denunciados, réus, condenados, etc., não como detentores de direitos, credores ou autores.” (1994, p 261, ver 1992, p.79) Aqui o "legalismo" é imposto de forma dura, principalmente pela atividade repressiva do aparelho estatal. Em termos da teoria da inclusão inicialmente desenvolvida por Luhmann, caberia falar que sua relação com o sistema jurídico é de dependência sem acesso.

\footnotetext{
${ }^{782}$ Luhmann não deixa de reconhecer, contudo, que a "Europa também não seria completamente isenta de exclusão".

${ }^{783}$ Poderíamos também considerar - com base nas formulações posteriores de Luhmann sobre a forma inclusão/exclusão - denominar essas relações como "subinclusão e sobreinclusão". No presente artigo, contudo, manterei o conceito tal como desenvolvido por Neves em 1992.
} 
Por sua vez, os sobreintegrados constituiriam grupos privilegiados que, muitas vezes com o apoio da burocracia estatal, desenvolveriam ações bloqueantes da reprodução autônoma do direito, de forma a manter privilégios. Tratar-se-ia de acesso sem dependência, configurando a utilização corrompida de privilégios e ilegalidades, sendo a impunidade sua marca distintiva. (NEVES, 1992, 1994)

A generalização de relações de subintegração e sobreintegração típica de contextos periféricos onde impera o princípio da exclusão, obstaria a configuração da cidadania pensada como princípio de inclusão, tornando-a ineficaz. Seria possível reconhecer o paradoxo do legalismo e da impunidade, operando de forma seletiva. Neves argumenta que a cidadania como conquista da modernidade pressuporia como condições de sua realização um contexto positivo de juridificação e a autonomia do sistema jurídico. (1992, 1994, p.256).

Com isso, o autor pode formular críticas ao pluralismo jurídico de Santos (NEVES, 1992, p.102 e 1995) e àqueles que transporiam de forma acrítica modelos europeus críticos à juridificação e expansão do direito. Para o autor, o problema da modernidade periférica é menos a invasão de formas autônomas do "mundo da vida" por um direito hipertrofiado, e antes, precisamente seu oposto: dificuldade de generalização de um sistema jurídico autônomo e da construção de um "espaço público de legalidade generalizada" (NEVES, 1994, p. 268).

Enfim, a crítica formulada por Marcelo Neves, para os fins deste artigo, deve ser abordada na medida em que ela formulou problemas para a teoria da diferenciação funcional luhmanniana e apontou suas limitações "empíricas", demonstrando não apenas que a sociedade moderna é assimétrica, mas também que a própria definição de modernidade na teoria luhmanniana fica prejudicada quando olhamos para o contingente de exclusão de amplos setores da sociedade onde os sistemas jurídico e político não parecem funcionar nem de forma autopoiética nem como mera "superestrutura", tal como a teoria marxista afirma ser o seu funcionamento no capitalismo.

(II.3)

Sustento ter havido uma "guinada de interesse" na teoria luhmanniana para questões vinculadas à integração social e à diferença inclusão/exclusão no reconhecimento de assimetrias na sociedade mundial. Esse deslocamento parte de temas que "seriam mais 
visíveis em contextos de modernidade periférica" (LUHMANN, 1995a), o que nos permite reconhecer a importância desses debates para o pensamento luhmanniano. A propor isso, não parto de análises meramente biográficas do autor alemão, ${ }^{784}$ mas do reconhecimento do enfrentamento de sua teoria às questões acima expostas. Aliás, o enfrentamento da teoria dos sistemas da "questão periférica" parece se descolar das discussões originais no âmbito jurídico e político e se espraiar para a sociedade mundial como um todo, em uma ampliação que, talvez, até seus críticos não contavam - pelo menos em um primeiro momento.

As "teses embrionárias" que vimos no prefácio de Luhmann (1992) à tese de Marcelo Neves foram aprofundadas e desenvolvidas em textos posteriores. Já no ano seguinte, na parte final de seu "O Direito da Sociedade", Luhmann discorre sobre o direito na sociedade mundial e é expresso em reafirmá-la. Ao fazê-lo, o autor não desconhece as diferenças regionais, mas considera que nem a mera comparação entre normas de diferentes países nem a referência a suas "culturas jurídicas" são suficientes para uma sociologia comparativa do direito, voltando sua atenção para estruturas de inclusão jurídica como dificuldades de concretização do Estado de bem-estar social, problema da dependência de organizações e problemas de economias regionais. O ponto central é reforçar a ideia de uma sociedade mundial, de um direito que mantém semelhanças reconhecíveis frente a extraordinárias dimensões e diversidade regional de formas de sua violação. Luhmann argumenta, inclusive, que o "lamento generalizado acerca da exploração pós-colonial dos países da periferia por parte de nações industriais e teorias como a da dependência e da marginalidade constituem antes uma evidência a favor da sociedade mundial - e não contra ela." (1993, p 570-573).

$\mathrm{O}$ reconhecimento da assimetria da sociedade mundial nessa obra é manifesto. Luhmann afirma:

“A sociedade mundial se caracteriza pelo primado da diferenciação funcional. (...) Contudo, diferenciação funcional não quer dizer, de forma alguma, que haja uma simetria regional do desenvolvimento e muito menos uma evolução convergente. (...) Uma sociedade funcionalmente diferenciada é tudo menos uma sociedade harmônica dotada de garantias inerentes de estabilidade. (...) (1993, p, 572-573).

${ }^{784}$ Para uma advertência nesse sentido, LUHMANN, 1987, p. 19 
Nas páginas seguintes Luhmann esboça o que explicaria essa diferença regional, trabalhando argumentos que ele desenvolverá com maiores detalhes a partir de 1995, a saber: a diferença inclusão/exclusão. Para o autor, a simples constatação de que não existiria um equivalente funcional "mundial" para a Constituição - acoplamento estrutural entre os sistemas jurídico e político no plano regional - não seria suficiente para explicar como são possíveis desenvolvimentos regionais tão diversos que podem ir tão longe a ponto de se questionar a capacidade funcional e a diferenciação da orientação ao direito:

"É possível supor que o ponto de partida do problema se encontra na inclusão defeituosa de grandes contingentes de população na comunicação dos sistemas funcionais, ou, dito de outra maneira: o problema se encontraria em uma diferenciação aguda entre inclusão e exclusão, produzida sem dúvida pela diferenciação funcional, mas que não apenas é incompatível com ela, mas que também mina sua concretização. (sie untergräbt)" (1993, p. 582).

Segundo Luhmann, os sociólogos tendem a abordar este fenômeno como uma estratificação social claramente conformada ou como "uma dominação de classe (sustentada internacionalmente)". Estes conceitos seriam insuficientes, pois remeteriam a ordens de inclusão não mais dominantes, como famílias ou relações de classe fabris do século XIX. Para o autor, sob o regime de diferenciação funcional, cada sistema opera seus modos de inclusão e, com a acelerada urbanização e monetarização, "os afetados passam a depender da economia do dinheiro, sem poder, contudo, participar dela". Com isso, a diferença entre inclusão e exclusão torna-se mais aguda e com efeitos mais amplos. Não se trata de sustentar que sob tais condições direito deixe de existir, mas sim que:

"[a] descrição desses fenômenos deve ser feita conceitualmente de maneira muito mais diferenciada. Possivelmente, a melhor via de acesso a eles seja obtida com a tese de que a diferença entre inclusão e exclusão serva como uma espécie de metacódigo mediadora de todos os demais códigos”. (1993, p.583)

Então, em referência à obra de Marcelo Neves, Luhmann afirma que, nestas situações, sem dúvida, existe um sistema jurídico funcionando pela diferença lícito/ilícito e por seus programas. Entretanto, tal diferença teria pouca relevância para tanto para os 
grupos populacionais excluídos, premidos pelas estruturas de oportunidades e pela necessidade de modo que oportunidades de inclusão possam se transformar em possibilidades de corrupção, quanto para os grupos incluídos - especialmente os políticos e aqueles que fazem parte da burocracia. Ambos os lados poderiam escolher agir de acordo (ou não) com o direito. O código jurídico e seus programas funcionariam de modo débil, pois existiriam outras preferências - como a econômica, por exemplo - que teriam preferência. Isto levaria a generalização no âmbito das expectativas, levando-se em conta que em casos extremos - que não são raros - até a política e a polícia operariam sem relevância perante o direito, ou melhor, saber se o código jurídico será ou não utilizado se orienta por outra distinção: inclusão/exclusão. (1993, pp. 583-585). Luhmann afirma que estas questões devem ser trabalhadas com o conceito de integração social, usualmente utilizada por teóricos como oposta à diferenciação social. Na verdade, Luhmann é mais radical. Ele pretende "substituir o tema da integração social pela distinção inclusão/exclusão" (2007, p. 491).

Antes de tratar deste conceito, mais detalhado em obras posteriores, cabe atentar para a importância que estas considerações tiveram para a teoria da diferenciação funcional luhmanniana: Luhmann já postula de forma pessimista a pergunta pela inclusão geral, ou seja, que todos participem das "vantagens da sociedade". Não se trataria de uma condição passageira ou desenvolvimentista - tal qual proposto pelas teorias da modernização, podemos dizer. Para ele, subsiste o problema de saber se seria possível realizar no âmbito mundial o grau atual de bem-estar de alguns países industrializados, algo que seria improvável "por razões puramente ecológicas". A isso se soma a dependência histórica de todos os sistemas autopoiéticos - nas especificidades existentes em seus níveis regionais, podemos acrescentar. Sua obra termina de maneira surpreendente:

"Diferentemente da teoria parsoniana do sistema geral de ação, vemos a diferenciação funcional como um produto da evolução e não como uma consequência lógica da análise do conceito de ação. Pode muito bem ocorrer que a importância atual do sistema jurídico e o fato de que a sociedade mesma e a maioria de seus sistemas funcionais dependam do funcionamento de um código do direito não seja nada mais que uma anomalia europeia que irá perdendo paulatinamente sua força no curso da evolução da sociedade mundial" (1993, pp 585-586) 
Ao levar em conta este problema, Luhmann sustenta ser necessária uma ampliação e complementação da teoria da diferenciação social, dominante na sociologia desde os clássicos. Para isso, é necessário levar em conta a covariação diferenciação/integração, voltando-se para a integração social, ainda pouco clara na teoria sociológica. A teoria da diferenciação funcional apresentaria limitações explicativas e seus limites ganhariam relevo nos contextos de países ditos em vias de desenvolvimento ou subdesenvolvidos. (1995a, pp. 226-7), ou melhor, partindo de "situações típicas de países localizados na modernidade periférica" para abordar "problemas estruturais da sociedade funcionalmente diferenciada". (1995a, p. 231-232).

Luhmann define a integração da sociedade como "a limitação dos graus de liberdade que se proporcionam de forma recíproca os sistemas estruturalmente acoplados" (1995a, p 227, 1993, p584). O autor se afasta, portanto, de "teorias positivas" da integração social que partem de conceitos de integração por valores ou consenso moral (tal como Parsons e Durkheim) - que trabalhariam na "lógica desenvolvimentista" visando a uma total inclusão - e aborda a questão da exclusão, tida como "sombra lógica" do debate sociológico. Luhmann trata da questão como uma forma de dois lados, sendo a face interna a inclusão e a externa a exclusão. Portanto, a inclusão (e analogamente a exclusão) se referem às "pessoas" no contexto comunicativo. (1995a, p. 228-229)

Após tratar de formas de inclusão nas sociedades segmentárias e estratificadas, Luhmann discorre sobre sua conformação na sociedade moderna, ligada à diferenciação funcional. Nela não seria possível regular a inclusão de forma uniforme: a inclusão é regulada internamente pelos diversos sistemas sociais separadamente. (1995a, p. 235, 2007, p.499) Nesta nossa sociedade contemporânea, reconhecer apenas problemas de adaptação de economias locais ao contexto global não seria suficiente. Isso implicaria confiar na capacidade dos sistemas funcionais em se desenvolver e na esperança de sua realização em um caminho único no sentido de uma modernização que se autoimpulsiona. Tal confiança esperançosa é colocada sobre sérias críticas de Luhmann, que afirma ser decorrência de teorias da modernização, que o autor manifestamente rejeita (1995a, p. 235236), considerando também problemáticos os "projetos políticos de modernização" (2007, p. 858 e ss.) Luhmann reconhece que, vistos da perspectiva dos centros da modernidade, tal ordem poderia parecer como resultado de uma modernização fracassada. Entretanto, o autor desenvolve uma "explicação um pouco mais exata" ao reconhecer uma sociedade intensamente integrada em tais setores de exclusão, o que acarretaria em imobilização da 
política, economia, direito, da mobilidade social e até do sistema universitário (1995a, p. 240).

Antes, caberia olhar para os modos de exclusão modernos. Isso seria evidenciado no contexto periférico em que haveria tamanho abismo entre os âmbitos ou setores de inclusão e exclusão que esta tenderia a assumir a posição de diferenciação primária. Neste cenário, grande parte da população fica privada das prestações dos sistemas funcionais e são introduzidas "formas imprevistas de estabilização que, aproveitando de forma parasitária as oportunidades oferecidas por estes âmbitos de prestação, criam mecanismos próprios de inclusão e exclusão" e de sua própria manutenção. (1995a, p.235).

Portanto, o conceito de redes de inclusão, operando no plano das interações ou sistemas de contato, se refere a cadeias de reciprocidade - tais como amizades interessadas e relações patrão/cliente - em que os recursos dos subsistemas funcionais são "alienados" para conexões transversais. (1995a, p 236 e GONÇALVES, 2006, p.250-251) Em tais contextos Luhmann admite uma explicação pela noção de corrupção, mas tende a adotar uma explicação mais voltada à prevalência das redes como "integração transversal" (LUHMANN, 1995a, p.237-238)

Em interessante tese, Luhmann conclui que a integração da sociedade é frouxa no plano da inclusão - pois os sistemas parciais operam cada qual de forma independente ao incluir pessoas a suas prestações. Por exemplo, alguém que tenha um alto nível científico não necessariamente terá boa condição econômica. Contudo, a sociedade se integra de forma muito mais intensa do ponto de vista da exclusão: exclusão gera mais exclusão. Ou seja, existiria uma "espiral de exclusão": um sistema funcional implica a exclusão de outros. Isso assume caráter "dramático" para Luhmann que reconhece que os sistemas só tem capacidade de controlar internamente a inclusão e, quanto maior a exclusão de sistemas funcionais, menor a capacidade de inclusão sistêmica em outros (1995a, p. 148, 2007, p.500).

Nota-se que o conceito de inclusão/exclusão na sociologia de Luhmann não se restringe ao âmbito jurídico e político de amplas regiões da sociedade como a América Latina. O autor aplica o conceito ao nível regional (2007, p.639 e ss.) em setores de exclusão, inclusive de guetos urbanos em grandes cidades de qualquer região do globo. Mesmo reconhecendo que cada âmbito de exclusão têm suas especificidades históricas e empíricas, Luhmann afirma ser possível acessar, do ponto de vista de sua teoria da sociedade, suas estruturas comuns ou seu efeito “equifinal” (̈̈quifinal).(1995a, 243) 
Nestes setores de exclusão, a diferença inclusão/exclusão chegaria a funcionar como um metacódigo, como vimos, e, neles, as "pessoas" passariam a contar apenas como meros "corpos", separados e aglomerados, em um contexto em que tudo que concebemos como "pessoa" retrocede. (1995a, o. 245 e ss) No âmbito da exclusão os meios de comunicação perdem seu sentido específico e impera a violência física e as necessidades básicas em orientações de satisfação de curta temporalidade (2007, p. 501).

Luhmann reconhece que contextos tão extremos de exclusão não são a regra, e existe algum grau de inclusão até em setores tidos como excluídos, sendo este caso-limite utilizado para a argumentação. ${ }^{785} \mathrm{O}$ autor dá o exemplo da vacinação nas favelas (1995a, p. 260). Enfim, o que cabe ressaltar, é a afirmação do autor de que a teoria da diferenciação funcional seria demasiadamente simples para explicar a sociedade, necessitando ser enriquecida com novos deslocamentos teóricos de modo a abandonar a esperança de que a sociedade possa ser descrita suficientemente bem desde a perspectiva da forma típica predominante de uma diferenciação estratificatória ou funcional. (ibidem)

Em outro texto, Jenseits Von Barbarei (Além da Barbárie), Luhmann chega ainda mais longe e afirma que o modo moderno de exclusão é peculiar e a "estratificação se torna um mero subproduto dos sistemas funcionais, especialmente o econômico e educacional (1995c, p 141). Este texto parte também de análise de favelas sulamericanas. Balke (2002, p 33 e ss) compara a observação exterior de Luhmann, em uma breve visita, àquela que Levi-Strauss relata em seus Tristes Trópicos. A fala de Luhmann é direta e questiona frontalmente a diferenciação funcional da sociedade moderna

"Para a surpresa dos bem intencionados, devemos reconhecer que a exclusão ainda existe, e existe em uma escala massiva e em tamanhas formas de miséria que elas estão para além da descrição. Qualquer pessoa que ouse visitar as favelas das cidades da América do Sul (...) pode falar sobre isso. (...) Nenhuma pesquisa empírica é necessária. Quem quer que confie em seus olhos pode ver, e ver de forma tão impressionante que todas as explicações disponíveis irão falhar."

"Sabemos que há discursos sobre exploração, opressão, marginalidade e sobre uma intensificação na contradição entre centro e periferia. Entretanto, todas essas teorias ainda são governadas pelo desejo da inclusão total e, assim,

785 Esse "exagero" despertou críticas (NEVES 2006, p. 251-252, CORREIA, 2010, p.11). Vale destacar o alerta para que não caiamos no ontologismo da explicação pela marginalização, uma vez que os excluídos “não estão desintegrados nem são marginais”. (RODRIGUEZ, 2010 : 44) 
buscam bodes expiatórios: capitalismo, a aliança dominante entre o capital financeiro e industrial com as forças armadas ou as poderosas famílias de um país. Mas se uma análise mais cuidadosa é feita, não se encontra nada que possa ser explorado ou oprimido. Encontram-se existências reduzidas ao âmbito corporal em sua autodescrição e heterodescrição, tentando apenas sobreviver ao dia seguinte. (...) Se o que é visto é levado em conta, pode-se conceber a ideia do que poderá ser a diferença guia (Leitdifferenz) do próximo século: inclusão e exclusão" (1995c, p. 147)

Enfim, Luhmann parece ter levado a sério o desafio e questionado (radicalmente?) sua teoria da diferenciação funcional trazendo novos desenvolvimentos e deslocando a discussão dos contextos periféricos para o âmbito da sociedade mundial. Além disso, ele deslocou os debates centrados nos sistemas jurídico e político destes contextos para âmbitos mais abrangentes de sua teoria social. Ele trouxe o debate de volta para sua macrossociologia que não encara a sociedade moderna com base em descrição política. Isso parece ainda mais relevante no contexto atual da chamada "crise europeia" em que se discute a crise do Estado democrático de direito e emerge a questão das ondas imigratórias para "países centrais".

\section{III) Exclusão na sociedade mundial: Periferização do centro ou problemas estruturais da sociedade?}

Como relacionar, então, esse movimento dentro da teoria luhmanniana (item II) com a tensão trabalhada anteriormente (item I)? Mais precisamente, quais são os ganhos que retiramos desse debate e como eles podem contribuir para a análise de problemas contemporâneos? Nesse sentido, cabe primeiramente (III.1) discutir as vantagens e desvantagens da distinção "centro/periferia" da sociedade mundial moderna para posteriormente (III.2) propor uma agenda de pesquisa que sustenta ser possível valer-se dos desenvolvimentos tardios da teoria luhmanniana para acessar problemas estruturais da sociedade mundial contemporânea, manifestamente ao adentrar os debates do alto contingente de exclusão social no contexto da chamada crise do Estado Democrático de Direito ou do Estado de Bem Estar, bem como na busca por uma inclusão geral em um 
sistema político democrático mundial, tal como os debates da esfera pública mundial e do direito mundial, manifestamente os direitos humanos.

\section{(III.1)}

Demonstrado como a condição periférica impulsionou um deslocamento na sociologia luhmanniana, cabe aprofundar quais são seus ganhos analíticos e quais são seus pontos cegos à luz da discussão esboçada no item I, onde argumentei que a tensão entre teorias universalistas e teorias explicativas de contextos regionais é uma maneira frutífera de se formular hipóteses e avançar no debate da teoria sociológica. Para isso, é necessário abordar algumas críticas que o conceito de modernidade periférica recebeu e explicitar o caráter "típico ideal" do conceito, bem como os ganhos heurísticos que a distinção comparativa centro/periferia pode gerar.

Como vimos no item I, a oposição entre teorias universalistas e contextos periféricos é essencial para este debate. Neste sentido, cumpre notar que os conceitos de "especificidade", de "autenticidade" ou de "peculiaridade" são conceitos necessariamente relacionais: aqui, é impossível não comparar. É claro, não se desconhece que comparações podem ser feitas de maneira "normativa" ou teleológica, tomando um lado como hierarquicamente superior ao outro. Isso seria equivalente aos pares-oposição por antinomias assimétricas (asymmetrischer Gegenbegriffe - Kosselleck) ou ao englobamento do contrário ("englobement du contraire" - Luis Dumon). Estas são oposições formais de conceitos que, contudo, mais abstratamente, operam como distinções que resultam "da tentativa de continuar uma arquitetura de mundo hierárquica em face da crescente complexidade social": a avaliação positiva de um lado (o lado "melhor" ou "superior") não apenas demarca a oposição, como também postula, ao mesmo tempo, uma ordem hierárquica entre essas distinções, em uma dupla função - horizontal e vertical -, que não apenas distingue, mas postula uma relação hierárquica. Niklas Luhmann aborda estes conceitos em sua análise da distinção entre Helenos e Bárbaros (1995c, p.139).

Por ora, cabe indagar se a busca pela descrição da "modernidade periférica" em oposição conceitual à "modernidade central" é necessariamente uma oposição valorativa em qualquer de suas formulações- ou, como afirmam os críticos dessa distinção - se se trataria de uma oposição teológica, normativa, (VILLAS BÔAS FILHO, 2009, esp. p. 340 e 383 e ss. e DOMINGUES, 2011, p.28 e ss) caracterizadora do desvio (TAVOLARO, 
2011, esp. p. 91 e ss) ou proveniente de uma submissão neocolonialista - contra a qual a crítica pós-colonialista apresentaria alternativas (GONÇALVES, 2010 esp. p. 314-315). Ora, isso nos leva à pergunta da utilidade dessa distinção.

Para isso, cumpre notar que Marcelo Neves a concebe como um tipo ideal weberiano, que é uma "utopia" (um "sem lugar"), ou seja, tipos que "nunca são encontrados em forma pura na realidade social, servindo antes como esquemas de sua interpretação com ênfase unilateral em determinados elementos mais relevantes à abordagem". (NEVES, 2006, p. 227) A esta caracterização do tipo ideal por Marcelo Neves, podemos acrescentar que Weber também afirma que, no "que se refere à investigação, o conceito do tipo ideal propõe-se a formar o juízo da atribuição. Não é uma "hipótese", mas pretende conferir a ela meios expressivos unívocos". (WEBER, 2006, p. 72).

A escolha desta ferramenta heurística, portanto, visou a iluminar questões abrangentes da sociedade mundial, especificamente em notar que os mecanismos de inclusão - tais como Estado de bem estar, a garantia de direitos fundamentais e a cidadania, todos ligados à segmentação territorial - não se espraiaram de forma homogenia. Ao assim proceder, Neves possibilita uma comparação que se volta precisamente para as assimetrias dos instrumentos de inclusão da sociedade moderna e questiona a utilidade e abrangência do conceito de diferenciação funcional na sociedade moderna.

A noção de modernidade periférica parece ser frutífera mais para discussões voltadas à generalização da teoria do que necessariamente para desenvolver uma "teoria explicativa do direito brasileiro", ${ }^{786}$ como vimos nos desenvolvimentos da teoria luhmanniana. Com efeito, um caminho diverso que busque uma "redução da escala de análise" (VILLAS BÔAS FILHO, 2009, p. 375 e ss), que dê conta de especificidades de contextos regionais é possível e necessário. Contudo, resta saber até que ponto análises abrangentes - e comparativas como a de Neves - estariam, com isso, enviesadas. Pareceme que a "redução de escala de análise" é necessária para a compreensão dos contextos regionais, necessitando forte aporte empírico e histórico (como vimos admitir o próprio Luhmann). Contudo, cabe indagar quais seriam as vantagens de se utilizar a teoria

${ }^{786}$ Para desenvolver uma análise assim, Orlando Villas Bôas Filho trabalha com o conceito de "sociedade brasileira" como capaz de autodescrição (Semântica da sociedade brasileira), o que apresenta diferenças com o modo de Luhmann analisar a semântica de sociedades pré-modernas (no plural) e da sociedade moderna (no singular). Luhmann não aplica o conceito de sociedade contextos sociais delimitados por fronteiras territoriais. (dentre vários, ver Luhmann, 2007a, pp. 11 e ss.). De maneira semelhante, Aldo Mascareño também fala em sociedades Latino-Americanas tendo "diferenciação funcional concêntrica" (MASCAREÑO, 2003). 
luhmanniana para tal projeto, uma vez que reconhecemos que ela tem méritos na construção de uma teria abrangente da sociedade, parecendo-me pouco útil para explicar contextos mais específicos. Vimos que a preocupação luhmanniana é consistente em procurar "estruturas comparáveis" por meio de uma teoria abrangente da sociedade e que, inclusive, sua pergunta teórica se volta para as estruturas de exclusão moderna (seus efeitos “equifinais"), ainda que elas apresentem feições diferentes nas diversas regiões da sociedade moderna.

Neste sentido, a mim me parece que a distinção centro/periferia da modernidade é construída no sentido de possibilitar a tematização destes problemas regionais sem recair em questões de "antropologia cultural” (NEVES, 2006, p 247-248) ou em óbices estruturais como os já mencionados "ethos ibérico e ethos público", não incorrendo em interpretações estanques do "fardo do passado" por retirar a pecha de uma região "prémoderna". Neste percurso, busca-se desenvolver um conceito que seja compatível com a importância dada por Luhmann à sociedade mundial, evitando-se conceitos como "sociedade brasileira", mas abordando de forma abrangente como sistemas jurídicos e políticos em regiões diversas apresentam problemas ao lidar com a questão da inclusão/inclusão.

A modernidade periférica aponta para "estruturas comparáveis" de um fenômeno pelo qual a autonomia do direito e a efetivação da cidadania como forma de inclusão podem ser reconhecidas em contextos tão diversos quanto a América Latina e países africanos que incorreriam no conceito de failed States. O ganho desta distinção, como bem notou Luhmann, é reconhecer que não se trata de mera marginalização econômica ou da afirmação de que o direito e a política seriam apenas "superestruturais" no capitalismo. Trata-se de reconhecer um funcionamento prestacional assimétrico de mecanismos de inclusão na sociedade moderna, cuja forma ("conquista evolutiva") encontrada para combater a exclusão se baseou em subsistemas funcionais territorialmente segmentados como o direito e a política. Pior que isso, nota-se que essa conquista evolutiva parece ter sido algo muito restrito, "uma anomalia europeia" - se quisermos ficar com a formulação provocativa de Luhmann.

Isso aponta para uma questão grave da sociedade mundial contemporânea, que exige novas formulações teóricas, uma vez que nem o conceito de exploração nem a teoria da diferenciação funcional, por si só, dão conta de explicá-lo. 
A questão mais delicada persiste: saber se a distinção centro/periferia da modernidade implicaria necessariamente em um "programa desenvolvimentista" para regiões periféricas, ainda que isso seja uma decorrência trazida "sub-repticiamente" pela teoria, que incorreria no erro que ela mesma buscava combater. Não desconhecendo este "perigo" apontado por Orlando Villas Bôas Filho em importante obra de teoria dos sistemas (2009), parece-me possível interpretar o conceito de maneira diversa. Não se trata da busca de implantação de um "programa político para a nação", tal como podemos reconhecer, grosso modo, no pensamento político brasileiro (cf. item I, acima). Não é o caso de se fazer uma apologia do centro ou "copiar" seu percurso institucional em uma espécie de apologia do liberalismo ou do "fim da história", nem apontar soluções políticas para o "caso brasileiro" ou latino americano. Se "calibrarmos" o conceito a partir das posteriores obras luhmannianas, reconhecendo a multiplicidade histórica de contextos regionais, mas abordando apenas suas estruturas comparáveis, o conceito de modernidade periférica parece não incidir em qualquer valorização do centro.

Nota-se, portanto, que ele parece menos frutífero para realizar uma "teoria da periferia" e tratar de suas especificidades. Este talvez seja um de seus "pontos cegos". Sua utilidade é baixa também para explicar setores de exclusão no interior de "Estados democráticos de direito consolidados", como os guetos norte-americanos, tal como Luhmann os descreve. Contudo, essa não parece ter sido a intenção da formulação, voltada para apontar assimetrias na sociedade mundial. Antes, ela me parece mais frutífera quando olhada pela ótica da crítica teórica e do reconhecimento de estruturas comparáveis da sociedade mundial no âmbito dos sistemas jurídico e político.

Além disso, talvez fosse possível aplicar de maneira diversa o argumento do póscolonialismo, que concebe a importação de ideias e modelos do centro hegemônico por parte de uma periferia que desconhece suas particularidades, estendendo-o para análises de uma estrutura de dominação na sociedade mundial, de "externalização da exclusão" por meio de uma divisão hierárquica excludente da sociedade mundial por meio dos Estados de direito territoriais, que, por razões históricas, puderam prestar benefícios sociais extensos aos seus membros (cidadãos). Contudo, essas análises vão mais além e chegam a questionar, inclusive, se a descrição "positiva" que Luhmann faz destes Estados centrais não seria nada mais que uma "ideologia liberal" que não atentaria para os problemas de inclusão nestes mesmos Estados, que não funcionariam tão bem quanto Luhmann os descreve (Guilherme Leite Gonçalves, comunicação pessoal). Neste sentido, reconhecer o 
"déficit da cidadania" das regiões periféricas (VILLAS BÔAS FILHO, 2009, p.356) não implicaria em uma "sobrevaloração do centro", mas antes em apontar para uma estrutura desigual e assimétrica de inclusão na sociedade mundial a partir de seus sistemas territorialmente segmentados.

De qualquer maneira, os desenvolvimentos posteriores realizados pela teoria de Luhmann abordaram a exclusão como uma decorrência da diferenciação funcional de forma abrangente na teoria moderna. Para isso, o autor desenvolveu uma "sociologia da exclusão" que implicou rever sua teoria da diferenciação funcional. Os contextos de exclusão seriam mais visíveis em contextos periféricos, mas não se restringem a eles. Evitando tratar da questão no estilo de teorias da modernização, Luhmann parte para a análise de conceitos como redes de inclusão e exclusão, setores de exclusão e guetificação, analisando o caso-limite da exclusão em que pessoas passam a contar como corpos. A questão não se encerra aí. O crescente reconhecimento da exclusão e a "perda da inocência" da sociologia em basear-se apenas em uma teoria da diferenciação, (LUHMANN, 1995a) levaram o autor a questionar se a sociedade moderna não passaria a operar "no próximo século" por esta diferença guia. Isso nos leva a debates atuais no contexto da sociedade mundial.

\section{(III.2)}

O debate desenvolvido por Neves em 1992 se enquadrava em um contexto histórico diferente do atual. Poucos anos após a "redemocratização" de países da América Latina, da queda do muro de Berlin e da dissolução da URSS, os debates se pautavam pelo cenário dos desafios da "consolidação democrática" (cf. ODONNEL, 1988, esp. p. 42 e ss) nos países da chamada "terceira onda de democratização", voltando-se para a efetividade de direitos que essas "novas democracias" prometiam.

Hoje, contudo, o debate parece ter se deslocado. Mesmo que estilizemos um pouco o debate - e talvez o enquadremos (ainda) de forma eurocêntrica - o interesse da academia parece apontar para uma crise dos Estados de bem-estar e dos chamados Estados democráticos de Direito em todo o globo. Com isso, o interesse se transfere para a integração de sistemas normativos na sociedade mundial, em discussões pautadas por conceito como solidariedade global cosmopolita (Habermas), cidadania universal, sistema internacional de direitos humanos, democratização da ONU, a consolidação de uma esfera 
pública mundial e o combate ao "direito hegemônico" encampado pelas empresas multinacionais. Estes debates parecem trazer para o âmbito global os debates que antes circundavam os Estados Nacionais (cf. BRUNKHORST, 2005, p. 114 e ss).

O âmbito global da sociedade parece ganhar relevância. Podemos argumentar, com Brunkhorst, que, a sociedade mundial funcionalmente diferenciada surgiu como um projeto europeu, mas hoje ela não mais o é" (2005, p. 111). Com isso, não se desconhece os diversos caminhos históricos e regionais possíveis, tal como evidenciado pelo conceito de modernidades múltiplas de Eisenstadt (2000), nem se parte de uma análise do "choque de civilizações", mas antes aponta para um nível de integração inegável da sociedade em escala mundial.

Isso levou alguns autores a uma busca de integração global "positiva", principalmente a partir do reconhecimento do aumento da aceitação da "ideia de humanidade". Neste sentido, Rudolf Stichweh analisa o "princípio da indiferença" na sociedade global - cujo elemento moderno supera as estruturas de confiança interacionais e baseadas em amizade - e afirma que "algum nível de solidariedade global existe em uma sociedade que se estrutura de forma global, na qual ninguém poderia ser considerado um estranho dentro dela" (2004 : 9). No mesmo sentido, Hauke Brunkhorst (2005) investe em uma "solidariedade global", influenciado por Habermas.

A questão que está em pauta é o reconhecimento que não haveria sistemas normativos no âmbito global para contrapor a globalização econômica (LUHMANN, 1993, p. 593 e ss) tal qual o Estado de Direito o faz no âmbito regional. Poder-se-ia considerar, como o fez Stichweh (2000, p. 85 e ss) de maneira mais ampla, de um conflito entre a estatalidade de bem estar e a globalização de sistemas funcionais (Konflikt von Wohlfahrtsstaatlichkeit und Globalisierung der Funktionssysteme)

Marcelo Neves se refere a esta questão como uma paradoxal "periferização do centro", em que duvida dos intentos de regulação da sociedade mundial por uma política transnacional baseada em uma solidariedade cosmopolita. Seu ponto (e sua aposta) se volta para análise do Estado democrático de Direito. Nesse sentido, o autor afirma que a “orientação includente do Estado de bem-estar no Ocidente desenvolvido não surgiu isolada da ampla exclusão na periferia da sociedade mundial. O problema que se apresenta na atualidade é exatamente a propagação de ondas de exclusão aos países centrais no contexto da globalização econômica" (2007, p. 193). Seu diagnóstico é de que uma periferização paradoxal do centro na sociedade mundial moderna estaria "relacionada com 
o desmonte ou superação do clássico welfare state, sem que novos mecanismos de inclusão sejam esboçados clara e seriamente para a construção de uma sociedade de bem-estar fundada nos diversos subsistemas sociais, mesmo apenas nas respectivas regiões do tradicional Estado de bem-estar. O problema redunda na iminente possibilidade de que as formas de exclusão até o presente típicas dos países periféricos propaguem-se sobre a modernidade central (2007, p. 197). Neves é cético quanto a possibilidade de uma solução global desta questão e afirma que saídas poderiam ser encontradas antes no plano regional pelos Estados de direito. (2007, p. 199).Por esse motivo, a aposta de Neves no Estado democrático de Direito é mais bem desenvolvida a partir de um modelo de legitimação que enfrente as dificuldades de sua implementação no âmbito da modernidade periférica e central (ver, NEVES, 2006, esp. p. 123 e ss).

Todos estes debates, contudo, implicam em duas soluções baseadas em formas de inclusão política: ou (i) a saída se encontraria na maior integração social no plano de uma "política internacional democrática" legítima que implique em democratização do âmbito global, com "públicos fortes" e uma esfera pública mundial (Weltöffentlichkeit) (STICHWEH, 2005, p 83 e ss) que pressiona o sistema político mundial através de "movimentos de escandalização", ou (ii) ela se daria por uma fortificação e ampliação do conceito de Estado democrático de direito (NEVES, 2006, 2007, e RODRIGUEZ, 2010, p. 44), acreditando que organizações territoriais como o Estado podem combater a exclusão.

Entretanto, se voltarmos para a análise luhmanniana da exclusão social (e a radicalizarmos), as conclusões a que chegamos parecem ser mais sombrias. Luhmann rejeita - no desenvolvimento tardio de sua obra - a possibilidade de "inclusão total", reconhecendo que as formas de inclusão até hoje encontradas sempre implicam alguma forma de exclusão. A aposta no Estado de bem estar como forma de inclusão política é desacreditada, de forma que Luhmann a encara como tendo sido uma "anomalia europeia". Por outro lado, (ii) Luhmann afirma que reconhecer que não há equivalente funcional para a Constituição no nível global e recair na escandalização da sociedade mundial (1993, p. 580) também não seria suficiente. O autor chega a admitir que esforços nesse sentido são positivos, mas continua cético com a possibilidade da formação de um sistema global de inclusão política e traz duras críticas ao "discurso intelectual do século XX" que postula que a inclusão na sociedade global deveria ser alcançada por meio da esfera pública. (LUHMANN, 1995a, p. 233). 
Enfim, Luhmann parece ter radicalizado de tal forma o problema estrutural da sociedade moderna que parece ser até difícil falar em "periferização do centro" frente a uma exclusão massiva dentro - e produzida pela - estrutura da sociedade moderna funcionalmente diferenciada. Mais do que isso, o problema parece tão grave que não poderia ser solucionado por pretensões regulatórias da política (seja ela global ou regional). O contingente de exclusão seria tamanho, e beiraria o "indiscritível", que não haveria saída possível pela via da política. De maneira insipiente, o autor chega a esboçar algo como a necessidade de um "subsistema diferenciado de ajuda social" que se ocuparia dos efeitos da exclusão da diferenciação funcional (2007, p. 502), que, por sua vez, nada se assemelharia com "solidariedade", mas antes deveria ser um sistema social diferenciado. Isso, contudo, parece antes um vislumbre do que o reconhecimento preciso de um sistema social em formação.

De todo este debate, é possível concluir que Luhmann não poderia ter chegado a conclusões tão surpreendentes e contraintuitivas com os desenvolvimentos iniciais de sua teoria sem levar em consideração a condição periférica. Contudo, este movimento da teoria sistêmica parece ter ocorrido no sentido inverso daquele ao qual estamos acostumados no pensamento social brasileiro e latino americano: não somos nós que utilizamos a teoria de Luhmann de maneira inadequada - "fora do lugar" -; mas antes foi o caso de reconhecer que era a teoria de Luhmann que estava fora dos lugares da sociedade mundial.

\section{Referências (data da publicação original de obras de Luhmann entre colchetes)}

BACHUR, João Paulo (2010) Às portas do Labirinto: para uma recepção crítica da teoria social de Niklas Luhmann. Rio de Janeiro : Beco do Azougue.

BALKE, Friedrich. (2002) "Tristes Tropiques: Systems Theory and the Literary Scene. Soziale Systeme 8 (2002), Heft 1, S. 27-37

BOBBIO, Norberto (2007) Da estrutura à função: novos estudos de teoria do direito. [trad. Daniela Beccaria Versiani. Barueri-SP : Manole, 2007

BRANDÃO, Gildo Marçal. (2005) "Linhagens do Pensamento Político Brasileiro". DADOS - Revista de Ciências Sociais, Rio de Janeiro, Vol. 48, no. 2, 2005

BRUNKHORST, Hauke. (2001) "Globale Solidarität. Inklusionsprobleme der modernen Gesellschaft" In Lutz Wingert und Klaus Günther (orgs). Die Öffentlichkeit der Vernunft und die Vernunft der Öffentlichkeit. Frankfurt sobre o Meno : Suhrkamp Verlag, 2001.

BRUNKHORST, Hauke (2005) Solidarity: From Civic Friendship to a Global Legal Community [translated from german by Jeffrey Fynn]. Cambridge : The MIT Press, 2005. 
CHERNILO, Daniel e MASCAREÑO, Aldo (2009) "Obstacles and Perspectives of Latin American Sociology: Normative Universalism and Functional Differentiation", Soziale Systeme 15 (1): 72-96. [aqui citado conforme cópia mimeografada em manuscrito em documento do programa Microsoft Word em páginas 1-20]

CORREIA, José Gladston Viana. (2010) "Inclusão, exclusão e políticas públicas: uma análise a partir doprograma Bolsa Família”. Trabalho Apresentado nos seminários da Disciplina de Pós-Graduação do Departamento de Ciência Política da USP: "Inclusão/Exclusão"Um paradigma novo da pesquisa da desigualdade social? Abordagens teóricas e análises empíricas. Ministrados pelos Profs. Rainer Schmidt e Marurizio Bach.

DOMINGUES, José Maurício. (2011) Teoria Crítica e (Semi)Periferia. Belo Horizonte : Editora UFMG, 2011

EISENSTADT, Shmuel. (2000). "Multiple Modernities". Daedalus, Vol. 129, No. 1 (Winter, 2000), pp. 1-29

GONÇALVES, Guilherme Leite. (2006). „Redes de Inclusão“ verbete. In André-Jean Arnaud e Eliane Bothelho Junqueira. Dicionário da Globalização. Rio de Janeiro : Lumen Juris

GONÇALVES, Guilerme Leite. (2010) "Rechtssoziologische Interpretationen des Rechtsdiskurses in Lateinamerika: eine postkoloniale Kritik". Juridikum - Zeitschrift für Kritik, Recht und Gesellschaft. [Thema: Recht (de)kolonisiert] N.3, 2010. pp. 311320

HABERMAS, Jürgen (1999) Wahrheit und Rechtfetigung: philosophische Aufsätze. Frankturt sobre o Meno :Surhkamp

IZUZQUIZA, Ignacio. (2008) La sociedad sin hombres. Niklas Luhmann o la teoria como escândalo. $2^{a}$ Edição. Barcelona : Anthropos Editorial.

LAVALLE, Adrian Gurza (2004) Vida pública e identidade nacional: Leituras Brasileiras. São Paulo: Editora Globo.

LUHMANN, Niklas (1975). „Die Weltgesellschaft“. In Niklas Luhmann. Soziologische Aufklärung 2: Aufsätze zur theorie der Gesellschaft. (6a edição de 2009). Wiesbaden : VS -Verlag

LUHMANN, Niklas (1980) Gesellschaftsstruktur und Semantik: Studien zur Wissenssoziologie der modernen Gesellschaft. Band 01. Frankfurt sobre o Meno : Suhrkamp Verlag. Vol. 1

LUHMANN, Niklas (1981) „Wie ist soziale Ordnung möglich?“ in Niklas Luhmann Gesellschaftsstruktur und Semantik: Studien zur Wissenssoziologie der modernen Gesellschaft. Band 02. Frankfurt sobre o Meno : Suhrkamp Verlag. Vol. 2

LUHMANN, Niklas (1983 [1972]) Sociologia do Direito 1. Tradução de Gustavo Bayer. Rio de Janeiro : Tempo Brasiliense

LUHMANN, Niklas (1987). Archimedes und wir - Interviews. Berlin : Merve Verlag.

LUHMANN, Niklas (1989 [1986]). Ecological Communication. trad. John Bednarz Jr. Chicago: University of Chicago Press,

LUHMANN, Niklas. (1990 [1981]) Political Theory in the Welfare State. Trad. De

LUHMANN, Niklas (1992) "Zur Einführung” In Marcelo Neves: Verfassung und Positivität des Rechts in der peripheren Moderne: Eine theoretische Betrachtung und eine Interpretation des Falls Brasilien. Berlim: Duncker und Humblot. 
LUHMANN, Niklas (1993) Das Recht der Gesellschaft. Frankfurt am Main : Suhrkamp Verlag.

LUHMANN, Niklas (1995a) „Inklusion und Exklusion“ in: Niklas Luhmann. Soziologische Aufklärung 6: Die Soziologie ind der Mensch. Opladen: Westdeutscher Verlag. pp. 226-251

LUHMANN, Niklas (1995b) Social Systems. Translated by John Bednarz Jr. Stanford: Stanford University Press, 1995

LUHMANN, Niklas (1995c): „Jenseits von Barbarei“. in: N. Luhmann, Gesellschaftsstruktur und Semantik. Studien zur Wissenssoziologie der modernen Gesellschaft,Vol. 4. Frankfurt a.M.: Suhrkamp. pp. 138-150

LUHMANN, Niklas (1996b) Introducción a la Teoria de Sistemas. México: Universidad Iberoamericana, 1996.

LUHMANN, Niklas (1997a) A Nova Teoria dos Sistemas. (organizado por Clarissa Eckert Baeta Neves e Eva Machado Barbosa Samkios) [tradução dos textos de Luhmann por Eva Machado B. Samios] Porto Alegre : Ed. UNIVERSIDADE/UFRGS, GoetheInstitut/ICBA, 1997.

LUHMANN, Niklas. (1997 b) "Sobre os fundamentos teórico-sistêmicos da teoria da sociedade". In LUHMANN, Niklas. (1997a)

LUHMANN, Niklas (1997c) "Globalization or World Society: How to Conceive of Modern Society?" International Review of Sociology Mar97, Vol. 7 Issue 1. [trad brasileira: LUHMANN, Niklas. "A Sociedade Mundial como Sistema Social". in ARAÚJO, Cícero \& WAIZBORT, Leopoldo. "Sistema e Evolução na Teoria de Luhmann" (mais - Um texto de Niklas Luhmann: "A Sociedade Mundial como Sistema Social”). Lua Nova - Revista de Cultura e Política. N. 47, 1999, pp. 179-200]

LUHMANN, Niklas (2005) Einführung in die Theorie der Gesellschaft. Heidelberg : CarlAuer. (publicação póstuma)

LUHMANN, Niklas (2007 [1997[) La sociedad de la sociedad. . [trad. Javier Torres Nafarrate y Dario Rodrígues Mansilla] Ciudad de México : Editorial Herder; Universidad Iberoamericana; DAAD - Deutscher Akademischer Austausch Dienst.

MATURANA, Humberto and VARELA, Francisco (1980) Autopoiesis and Cognition: The Realization of the Living. Dordrecht-Holland / Boston-USA / London-England : D. Reidel Publishing Company, [Boston studies in the philosophy of science; v. 42].

MASCAREÑO, Aldo (2003) . Teoría de sistemas de América Latina. Conceptos fundamentales para la descripción de una diferenciación funcional concéntrica. Persona y Sociedad [en línea]. 2003, vol. XVII, no. 2 [citado 2012-05-03], pp. 9-26. Disponible en Internet: Http://Www.Personaysociedad.Cl/Teoria-De-Sistemas-DeAmerica-Latina-Conceptos-Fundamentales-Para-La-Descripcion-De-UnaDiferenciacion-Funcional-Concentrica/. ISNN 0716-730X

NEVES, Marcelo (1992). Verfassung und Positivität des Rechts in der peripheren Moderne: Eine theoretische Betrachtung und eine Interpretation des Falls Brasilien. Berlim: Duncker und Humblot.

NEVES, Marcelo (1994). "Entre Subintegração e Sobreintegração: a cidadania inexistente".In: DADOS - Revista de Ciências Sociais, vol. 37, nº 2. Rio de Janeiro: Iuperj, pp. 253-276.

NEVES, Marcelo (1995) "Do pluralismo jurídico à miscelânea social: o problema da falta de identidade da(s) esferas de juridicidade na modernidade periférica e suas 
implicações na América Latina". In Direito e Debate, ano V, n 15. Ijuí: Universidade de Ijuí, PP 7-37. 1995 Política, São Paulo, v. 37, 1996 (pp. 93-106)

NEVES, Marcelo (2004) "E se Faltar o Décimo Segundo "Camelo? Do Direito Expropriador ao Direito Invadido". In ARNAUD, André-Jean e LOPES JR., Dalmir (orgs.) Niklas Luhmann: Do Sistema Social à Sociologia Jurídica. Rio de Janeiro : Lumen Juris, 2004, pp. 145-173

NEVES, Marcelo (2006) Entre Têmis e Leviatã: uma relação difícil. O Estado Democrático de Direito a partir e além de Luhmann e Habermas. [tradução do autor] Martins Fontes: São Paulo.

NEVES, Marcelo (2007) A Constitucionalização Simbólica. São Paulo: Martins Fontes.

O’DONNELL, Guilhermo. (1988) A Democracia no Brasil: dilemas e perspectivas. São Paulo : Vértice

O’DONNELL, Guilhermo (2000). "Poliarquias e a (in)efetividade da Lei na América Latina: uma conclusão parcial". Tradução de Otacilio Nunes. In Juan E. Mendes, Guilhermo O’donnell e Paulo Sérgio Pinheiro. Democracia, Violência e Injustiça: o não-Estado de Direito na América Latina. São Paulo : Paz e Terra.

RIBEIRO, Pedro Henrique (2009). "A (in)efetividade dos direitos sociais na modernidade periférica: um diálogo brasileiro com as teorias do discurso e dos sistemas." Iniciação Científica PIBIC-CEPE apresentada à PUC-SP em Julho de 2009 e no $18^{\circ}$ Encontro de Iniciação Científica da PUC-SP (2009), além do $62^{\circ}$ Encontro da Sociedade Brasileira para o Progresso da Ciência (SBPC) em Natal-RN, 2010.

RODRIGUEZ, Darío M. (2010) "Los Limites del Estado em la Sociedad Mundial: De la Política al Derecho" in Marcelo Neves Transconstitucionalidade do Direito: novas perspectivas dos conflitos entre ordens jurídicas. São Paulo : Quartier Latin/ DAAD.

SCHWARZ, Roberto (2005) “As idéias Fora do lugar" in Roberto Schwarz Ao Vencedor as Batatas. $5^{\text {a }}$ Ed. São Paulo : Editora 34

STICHWEH, Rudolf (2000) Die Weltgesellschaft. Soziologische Analysen. Frankfurt sobre o meno : Suhrkamp.

STICHWEH, Rudolf (2004) "Strangers in World Society - Indifference and Minimal Sympathy". pp. 111-123 in: Between Nanoworlds and Global Culture. Science + Fiction. Berlin: Jovis. (citado conforme cópia mimiografada disponível em: http://www.uni-bielefeld.de/(de)/soz/iw/pdf/stichweh_9.pdf (último acesso em 05.06.2012).

STICHWEH, Rudolf (2005) Inklusion und Exklusion: Studien zur Gesellschaftstheorie. Bielefeld: Transcript-Verlag

TAVOLARO, Sérgio Barreira de Faria. (2011). Cidadania e Modernidade no Brasil (19301945): uma crítica a um discurso hegemônico. São Paulo : Annablume

VILLAS BÔAS FILHO, Orlando (2006) O Direito na Teoria dos Sistemas de Niklas Luhmann. Ed. Max Lominad. São Paulo.

VILLAS BÔAS FILHO, Orlando (2009) Teoria dos sistemas e o direito brasileiro. São Paulo : Saraiva, 2009

WEBER, Max (2006) A “objetividade” do conhecimento em ciências sociais. [tradução e comentários Gabriel Cohn] São Paulo : Ática. 